\title{
Het nationaliteitsrecht in de Oosteuropese landen : een vergelijkend onderzoek naar de regelingen van verkrijging en verlies van de nationaliteit in de Oosteuropese landen
}

Citation for published version (APA):

Tratnik, M. (1989). Het nationaliteitsrecht in de Oosteuropese landen : een vergelijkend onderzoek naar de regelingen van verkrijging en verlies van de nationaliteit in de Oosteuropese landen. [Doctoral Thesis, Maastricht University]. Kluwer. https://doi.org/10.26481/dis.19890908mt

Document status and date:

Published: 01/01/1989

DOI:

10.26481/dis.19890908mt

Document Version:

Publisher's PDF, also known as Version of record

Please check the document version of this publication:

- A submitted manuscript is the version of the article upon submission and before peer-review. There can be important differences between the submitted version and the official published version of record. People interested in the research are advised to contact the author for the final version of the publication, or visit the DOI to the publisher's website.

- The final author version and the galley proof are versions of the publication after peer review.

- The final published version features the final layout of the paper including the volume, issue and page numbers.

Link to publication

\footnotetext{
General rights rights.

- You may freely distribute the URL identifying the publication in the public portal. please follow below link for the End User Agreement:

www.umlib.nl/taverne-license

Take down policy

If you believe that this document breaches copyright please contact us at:

repository@maastrichtuniversity.nl

providing details and we will investigate your claim.
}

Copyright and moral rights for the publications made accessible in the public portal are retained by the authors and/or other copyright owners and it is a condition of accessing publications that users recognise and abide by the legal requirements associated with these

- Users may download and print one copy of any publication from the public portal for the purpose of private study or research.

- You may not further distribute the material or use it for any profit-making activity or commercial gain

If the publication is distributed under the terms of Article $25 \mathrm{fa}$ of the Dutch Copyright Act, indicated by the "Taverne" license above, 
HET NATIONALITEITSRECHT IN DE OOSTEUROPESE LANDEN 


\section{HET NATIONALITEITSRECHT IN DE OOSTEUROPESE LANDEN}

Een vergelijkend onderzoek naar de regelingen van verkrijging en verlies van de nationaliteit in de Oosteuropese landen

\section{PROEFSCHRIFT}

ter verkrijging van de graad van doctor aan de Rijksuniversiteit Limburg te Maastricht, op gezag van de Rector Magnificus, Prof. Dr. F.I.M. Bonke, volgens het besluit van het College van Dekanen, in het openbaar te verdedigen op vrijdag 8 september 1989 om 16.00 uur

door

\section{Matjaž Tratnik}

geboren te Ljubljana in 1957

Kluwer - Deventer - 1989 


\title{
Promotores:
}

\author{
Prof. Mr. G.R. de Groot \\ Prof. Mr. F.J.M. Feldbrugge
}

Beoordelingscommissie:

Prof. Mr. C. Flinterman LL.M.

Prof. Mr. J.L.M. Elders

Prof. Dr. Ko Swan Sik

De handelseditie van dit proefschrift is verschenen in de serie Wetenschappelijke reeks Faculteit der Rechisgeleerdleid Rijksuniversiteit Limburg, ISBN 9026819404

(․) 1989, M. Tratnik, Mstastricht

Behoudtens uitzonderingen door de Wet gesteld mag zonder schriftelijke toestemming van de rechthebende( $n$ ) op het auteursrecht, $c_{\text {. }}$. de uitgeefster van deze uitgave, door de rechthebber. $\mathrm{de}(\mathrm{n})$ gemachtigd namens hem (hen) op te treden, niets uit deze uitgave worden verveelwoudigd en/of openbaar gemankt door middel van druk, fotocopie, microfilm of anderszins, hetgeen ook van toepassing is op de gehele of gedeeltelijke bewerking.

De uitgeefster is met uitsluiting van ieder ander gerechtigd de door derden verschuldigde vergoedingen voor copiëren, als bedoeld in artikel 17 lid 2, Auteurswet 1912 en in het $\mathbb{K}$. B. wan 20 juni 1974 (Stb. 351) ex artikel 16b Auteurswet 1912, te innen en/of daartoe in of buiten rechte op te treden. 
"Eigentlich weiss man nur, werin man wenig weiss;

mit dem Wissen wächst der Zweifel".

J.W. Goethe (in: Maximen und Reflexionen) 


\section{VOORWOORD}

Toen ik vier jaar geleden als Joegoslavisch jurist samen met Prof. Mr. Gerard Rene de Groot een boek over het Nederlandse nationaliteitsrecht aan het schrijven was, werd het idee geboren om ook over het nationaliteitsrecht in Joegoslavie en andere zogenaamde "socialistische" landen te gaan schrijven. Het aanvankelijke ambitieuze plan om ook buiteneuropese landen te behandelen, werd echter reeds bij het eerste literatuuronderzoek tot Europa teruggebracht. Ook na deze beperking bleef het onderwerp echter omvangrijker dan ik aanvankelijk had gedacht. Het nationaliteitsrecht is op zichzelf weliswaar een relatief beperkt rechtsgebied, maar men kan er niet over schrijven zonder ook aan andere onderwerpen zoals staatsen administratief recht, het personen- en familierecht en het internationaal recht aandacht te besteden.

Bij het verzamelen van de literatuur verkeerde ik in de gelukkige omstandigheid dat de heer Privatdozent Dr. Hellmut Hecker van het Institut für internationale Angelegenheiten van de Universiteit Hamburg zijn verzamelde bibliografische gegevens aan mij ter beschikking stelde. Ik bedank hem hartelijk voor zijn gastvrijheid. Voorts dank ik de heer Dr. Günther H. Tontsch en zijn medewerkers van de Seminarabteilung für Ostrechtsforschung, eveneens van de Universiteit Hamburg, voor het feit dat zij mij voor verschillende dagen in hun instituut hebben opgenomen, waar ik gebruik kon maken van hun voortreffelijke collectie Oosteuropese juridische literatuur. Mijn dank gaat ook uit naar de medewerkers van het Documentatiebureau woor het Oosteuropees Recht te Leiden voor hun behulpzaamheid tijdens mijn bezoeken aldaar.

Ik ben eveneens dank verschuldigd aan Prof. Mr. F.J.M. Feldbrugge voor zijn bereidheid mijn manuscript te lezen en voor zijn waardevolle suggesties, alsmede aan Prof. Mr. Cees Flinterman, Prof. Mr. Jacques Elders en Prof. Dr. Ko Swan Sik.

Te denken dat een proefschrift voltooid is op het moment waarop het manuscript door de leescommissie goedgekeurd wordt, is bij een niet-commercieel onderwerp een grote dwalling. Om de publicatiekosten enigszins beperkt te houden moet de auteur zelf van het manuscript een boek maken. Dit was mij zonder de bijzonder sterke inzet van Mr. Réjean Pinckaers, assistent in opleiding aan de Rijksuniversiteit Limburg zeker nooit gelukt. Daarvoor mijn hartelijk dank. Bij de grootste "crash" tijdens mijn kennisneming met de mogelijkheden van een personal computer was het Peggy Lieben, secretaresse bij de vakgroep Privaatrecht aan de Rijksuniversiteit Limburg, die mij door een dieptepunt heeft geholpen, door 40 verdwenen pagina's van het manuscript opnieuw te typen.

Aangezien dit boek in een voor mij vreemde taal is geschreven was het nodig mijn Nederlands op verschillende plaatsen te verbeteren. Mijn dank gaat uit naar Jean Dohmen, student-assistent aan de Rijksuniversiteit Limburg, door wie het leeuwendeel van deze werkzaamheden werd verricht. Ik ben blij dat ass. iur. Hildegard Schneider, Wies Rayar, Stafford Wadsworth en Peter Grilc, dipl. iur. de vertaling, respectievelijk de taalkundige correctie van de samenvattingen in het Duits, Engels en Sloveens op zich op zich hebben genomen.

Bijzondere dank ben ik verschuldigd aan Mr. Roel Mertens, assistent in opleiding aan de Rijksuniversiteit Limburg, tevens mijn "kamergenoot", die, ondanks dat hij zelf ook een proefschrift aan het schrijven was, bereid was 
verschillende delen van mijn boek te lezen en met mij over diverse nationaliteitsrechtelijke problemen "moest" discussiëren. Zonder zijn stimulerende aanwezigheid was het manuscript zeker niet op dit tijdstip voltdooid.

Tenslotte wil ik mijn dank betuigen aan Prof. Mr. Gerard Rene de Groot. Hij draagt de "schuld" dat ik mij voor het nationaliteitsrecht ging interesseren en heeft mij aangespoord om het onderhavige onderzoek te verrichten. Ofschoon hij zelf een dissertatie over het nationaliteitsrecht aan het schrijven was, was hij bereid het gehele manuscript te lezen, verschillende delen zelfs meermalen. Ik heb dankbaar gebruik gemaakt van zijn interessante opmerkingen in de discussies die ik over het nationaliteitsrecht met hem heb gevoerd. Bovendien bood mij zijn eigen boek over dit onderwerp een belangrijke bron van informatie en een mogelijkheid om over de daarin verdedigde standpunten met hem in discussie te treden.

Maastricht, 1 mei 1989 


\section{INHOUD}

Voorwoord

Inhoud

Lijst van afkortingen

I.

ALGEMEEN DEEL

HOOFDSTUK 1. INLEIDING

HOOFDSTUK 2. ENKELE ALGEMENE THEORETISCHE BESCHOUWINGEN

Theoretische beschouwingen met betrekking tot de nationaliteit in West-Europa

2.1 .1

2.1 .2

De inhoud van het begrip nationaliteit

De functie van de nationaliteit

Theoretische beschouwingen met betrekking tot de nationaliteit in Oost-Europa

Grondlijnen van de marxistische rechtsopvatting

De termen "Staatsbürgerschaft" en "Staatsangehörigkeit"

De inhoud van het begrip nationaliteit

De functie van de nationaliteit

Enkele beschouwingen met betrekking tot de vergelijkbaarheid van rechtsinstituten Inleiding

Intersystemaire rechtsvergelijking

Intersystemaire rechtsvergelijking op het gebied van het nationaliteitsrecht

HOOFDSTUK 3. ALGEMENE OPMERKINGEN MET BETREKKING TOT VERKRIJGING EN VERLIES VAN DE NATIONALITEIT

Inleiding

Verkrijging van de nationaliteit

Verkrijging van rechtswege

Het begrip

Gronden voor verkrijging van rechtswege

Naturalisatie

Het begrip

Gronden voor naturalisatie

Optie 
II.

BESCHRIJVING VAN HET NATIONALITEITSRECHT IN DE OOSTEUROPESE LANDEN

HOOFDSTUK 1. OVERZICHT VAN DE VOOR OOSTEUROPESE LANDEN GELDENDE VOLKENRECHTELIJKE VERPLICHTINGEN OP HET GEBIED VAN HET NATIONALITEITSRECHT

Inleiding

Algemene volkenrechtelijke verplichtingen 37 Specifieke nationaliteitsrechtelijke verdragen 37

Haagse nationaliteitenverdrag van 1930 met protocollen 37 Verdrag betreffende de nationaliteit van de gehuwde vrouw

Nationaliteit in mensenrechtenverdragen

Art. 15 van de Universele verklaring van de rechten van de mens

Verbod van willekeurige ontneming van de nationaliteit

Art. 34 van het verdrag betreffende de status van vluchtelingen en art. 32 van het verdrag betreffende de status van staatlozen

Art. 24 lid 3 BUPO-verdrag

Art. 5 van het verdrag inzake uitbanning van alle vormen van rassendiscriminatie

Art. 9 van het verdrag betreffende uitbanning van vrouwendiscriminatie

Bilaterale verdragen strekkende tot beperking van gevallen van meervoudige nationaliteit Inleiding 45 Inhoud 46

Bestaande gevallen van bipatridie $\quad 46$ 
1.3.2.2 Toekomstige gevallen van bipatridie

Lijst van verdragen, strekkende tot beperking van bipatridie

HOOFDSTUK 2. RUSLAND/SOVIETUNIE

2.1

2.1.1

2.1 .2

2.1.2.1

2.1.2.2

2.1.2.2.1

2.1.2.2.2

2.1.2.2.3

2.1 .3

2.1.3.1

2.1.3.2

2.1.3.3

2.1.3.4

2.1.3.5

2.1.4

2.1.4.1

2.1.4.1.1

2.1.4.2

2.1.4.2.1

2.1.4.2.2

2.1.4.3

2.1.4.3.1

2.1 .5

2.1.5.1

2.1.5.1.1

2.1.5.2

2.1.5.2.1

2.1.5.2.2

2.1.5.3

2.1.5.3.1

2.1.5.3.2

2.1.5.3.3

2.1.6

2.1 .7

2.1 .8

2.1 .9

2.1.9.1

Geschiedenis $\quad 50$

Inleiding $\quad 50$

Het nationaliteitsrecht tot 1918

Algemeen $\quad 53$

De nationaliteitsrechtelijke regeling in de Svod van $1876 \quad 53$

Algemeen 53

Verkrijging van de nationaliteit 54

Verlies van de nationaliteit $\quad 58$

Het nationaliteitsrecht tot 1924

Algemeen $\quad 59$

Het decreet van 5 april $1918 \quad 62$

Het familiewetboek van 16 september 1918

De verordening van 22 augustus 1921

De verordening van 28 oktober $/ 15$ december 1921

De verordening van 29 oktober 192466

Algemeen $\quad 66$

De verhouding tussen de federale en de deelstaatnationaliteit $\quad 67$

Verkrijging van de nationaliteit 68

Verkrijging van rechtswege $\quad 68$

Naturalisatie $\quad 69$

Verlies van de nationaliteit $\quad 70$

Ontslag 71

De verordening van 28 juni $1930 \quad 72$

Algemeen $\quad 72$

De verhouding tussen de federale en de deelstaat- 72 $\begin{array}{ll}\text { nationaliteit } & 72 \\ & 73\end{array}$

Verkrijging van de nationaliteit $\quad 73$

Geboorte uit Sovjet-ouder(s) 73

Naturalisatie $\quad 73$

Verlies van de nationaliteit $\quad 74$

$\begin{array}{ll}\text { Ontslag } & 74\end{array}$

Ontneming $\quad 74$

Invloed op de nationaliteit van gezinsleden van 74 betrokkene $\quad 74$

De verordening van 23 november 1930

De verordening van 5 mei 1931

De ontwikkelingen tot $1938 \quad 75$

De wet van $1938 \quad 76$

$\begin{array}{ll}\text { Algemeen } & 76\end{array}$ 
De verhouding tussen de federale en de deelstaatnationaliteit

Verkrijging van de nationaliteit

2.1.9.2.2

Verkrijging van rechtswege

Naturalisatie

2.1.9.3

Verlies van de nationaliteit

Ontslag

Ontneming

2.1.10

2.1.10.1

2.1.10.2

2.1.10.2.1

2.1.10.2.2

2.1.10.2.3

De ontwikkelingen tussen 1938 en 1978

80

Algemeen

81

Uitbreidingen van het territorium van de USSR

Baltische staten

Duitsland

Finland

82

2.1.10.2.4

Polen

82

2.1.10.2.5

Roemenië

82

2.1.10.2.6

2.1.10.2.7

Tsjechoslowakije

Azië

2.1.10.3

2.1.10.4

2.1.10.4.1

2.1.10.4.2

2.2

2.2 .1

2.2.1.1

2.2.2

2.2.2.1

2.2.2.1.1

2.2.2.1.2

2.2.2.1.3

2.2.2.2

2.2.2.2.1

2.2.3

2.2.3.1

2.2.3.1.1

Wijzigingen van de wet van 1938

83

Andere regelingen tot 1978

83

Het decreet van 1954

De "basisbeginselenwet" van 1968

84

84

Het positieve nationaliteitsrecht

Algetieve nationaliteitsrecht

Algemeen

De verhouding tussen de federale en de deelstaatnationaliteit

Verkrijging van de nationaliteit

Verkrijging van rechtswege

89

Geboorte uit Sovjet-ouder(s)

Geboorte op het grondgebied van de USSR en vondelingen

Adoptie door Sovjet-ouder(s)

91

Naturalisatie

Invloed op de nationaliteit van de gezinsleden

van de verzoeker

91

Verlies van de nationaliteit

93

Ontslag

Invloed op de nationaliteit van de gezinsleden 
Verlies van de nationaliteit

Algemeen

Verkrijging van de nationaliteit

Verkrijging van rechtswege

Naturalisatie

Verlies van de nationaliteit $\quad 110$

Afstand

Ontslag

111

Ontneming

Het positieve nationaliteitsrecht

Naturalisatie

Invloed op de nationaliteit van de gezinsleden van de verzoeker

Verlies van de nationaliteit

Ontslag

Invloed op de nationaliteit van de gezinsleden van de verzoeker

Invloed op de nationaliteit van gezinsleden van

4.1

4.1.1

4.1.2

4.1.2.1

4.1 .2 .2

4.1.2.2.1

4.1.2.2.2

4.1.2.2.3

4.1 .3

4.1.3.1

4.1.3.2

4.1 .4

4.1.4.1

4.1.4.2
Geschiedenis

Inleiding

Het nationaliteitsrecht voor 1944

Algemeen

De wet van 1940

Algemeen

Verkrijging van de nationalliteit

Verlies van de nationaliteit

Het nationaliteitsrecht tussen 1944 en 1948

De verordening van 27 november 1944

Andere regelingen

De wet van 1948

118

118

119

119

120

120

121

124

127

127

128

128

128

Algemeen

128 
4.1.4.2.1

4.1.4.2.2

4.1.4.3

4.1.4.3.1

4.1.4.3.2

4.1 .5

4.2

4.2 .1

4.2 .2

4.2 .2 .1

4.2.2.1.1

4.2.2.1.2

4.2 .2 .2

4.2.2.2.1

4.2.2.2.2

4.2 .3

4.2.3.1

4.2.3.1.1

4.2 .3 .2

4.2.3.2.1

4.2 .3 .2 .2
Verkrijging van rechtswege

Naturalisatie

Verlies van de nationaliteit

131

Ontslag

Ontneming

Bijzondere regelingen tot 1968

131

131

132

134

Het positieve nationaliteitsrecht

134

134

135

135

135

136

137

Hernaturalisatie

Invloed op de nationaliteit van de gezinsleden

van de verzoeker

138

138

138

Ontslag

Invloed op de nationaliteit van de gezinsleden

van de verzoeker

140

140

Ontneming en herroeping van naturalisatie

142

Invloed op de nationaliteit van gezinsleden van betrokkene

142

143

HOOFDSTUK 5. DUITSLAND/DDR

143

Geschiedenis

143

145

145

145

146

149

Verlies van de nationaliteit

Het nationaliteitsrecht in door Duitsland bezette

152

152

152

153

154

154

5.1 .3

5.1 .4

5.1 .4 .1

5.1.4.1.1

5.1 .4 .2 en ingelijfde gebieden

Algemeen

Verkrijging en verlies van de nationaliteit van de

DDR tot 1967 
5.1.4.2.1

5.1.4.2.2

5.2

5.2 .1

5.2 .2

5.2 .2 .1

5.2.2.1.1

5.2 .2 .1 .2

5.2 .2 .2

5.2.2.2.1

\section{2 .3}

5.2 .3 .1

5.2.3.1.1

5.2.3.2

5.2.3.2.1

5.2.3.2.2
Verkrijging van de nationaliteit

Verlies van de nationaliteit

Het positieve nationaliteitsrecht

Algemeen

Verkrijging van de nationaliteit

Verkrijging van rechtswege

Geboorte uit DDR-ouder(s)

Geboorte op het grondgebied en vondelingen

Naturalisatie

Invloed op de nationaliteit van de gezinsleden

van de verzoeker

Verlies van de nationaliteit

Ontslag

Invloed op de nationaliteit van de gezinsleden

van de verzoeker

Ontneming en herroeping van een naturalisatiebesluit

Herroeping van naturalisatie

Invloed op de nationaliteit van de gezinsleden van

betrokkene
158

160

161

161

162

162

162

163

163

164

164

165

166

166

168

168

169

HOOFDSTUK 6. HONGARIJE

$\begin{array}{ll}\text { Geschiedenis } & 169\end{array}$

6.1

Inleiding

169

Het nationaliteitsrecht tot 1945

6.1 .2

6.1.2.1

Algemeen

171

172

172

Algemeen

Verkrijging van de nationaliteit

172

175

179

180

180

180

181

182

184

184

185

185

186

186

186

186

187

Geboorte uit Hongaarse ouder(s)

Geboorte op het Hongaarse grondgebied en vondelingen 
Invloed op de nationaliteit van de gezinsleden

6.2 .3

6.2 .3 .1

6.2.3.1.1

6.2 .3 .2

6.2.3.2.1 van de verzoeker

Verlies van de nationaliteit

Ontslag

Invloed op de nationaliteit van de gezinsleden

van de verzoeker

Ontneming

betrokkene
Invloed op de nationaliteit van gezinsleden van

188

189

189

190

190

190

191

HOOFDSTUK 7. JOEGOSLAVIË

191

Geschiedenis

191

7.1 .1

7.1 .2

7.1 .2 .1

Inleiding

Het nationaliteitsrecht tot 1941

193

Algemeen

De wet van 1928

193

196

Algemeen

196

Verkrijging van de nationaliteit

196

Verlies van de nationaliteit

201

Het nationaliteitsrecht tijdens de tweede wereldoorlog

205

De "Onafhankelijke staat Kroatië" (NDH)

205

Duitsland

Hongarije

205

205

Bulgarije

206

Itallië

De wet van 1945

206

206

Algemeen

De verhoudling tussen de federale en de deelstaatnationaliteit

7.1.4.2

7.1 .4 .2 .1

7.1.4.2.2

7.1.4.2.3

7.1.4.3

7.1.4.3.1

7.1.4.3.2

7.1.4.3.3

7.2

7.2.1

7.2.1.1

7.2 .2

7.2 .2 .1

7.2.2.1.1

Verkrijging van de nationaliteit

208

Verkrijging van rechtswege

Optie

Naturalisatie

Verlies van de nationaliteit

206

Afstand

Ontslag

Ontneming

209

209

210

211

213

213

213

Het positieve nationaliteitsrecht

214

Algemeen

217

217

De verhouding tussen de federale en de deelstaat-

nationaliteit

217

Verkrijging van de nationaliteit 219

Verkrijging van rechtswege

219

Geboorte uit Joegoslavische ouder(s)

219 
Geboorte op het Joegoslavische grondgebied en vondelingen

Naturalisatie

Invloed op de nationaliteit van de gezinsleden van de verzoeker

Invloed op de nationaliteit van gezinsleden van betrokkene

Ontslag

Invloed op de nationaliteit van de gezinsleden

Invloed op de nationaliteit van gezinsleden van betrokkene

8.1

8.1 .1

8.1.2

8.1.2.1

8.1.2.2

8.1.2.2.1

8.1.2.2.2

8.1.2.2.3

8.1 .3

8.1.3.1

8.1.3.2

8.1 .4

8.1 .5

8.1.5.1

8.1.5.2

8.1.5.2.1

8.1.5.2.2

8.1.5.3

8.1.5.3.1

8.1.5.3.2

8.2

8.2 .1

8.2 .2

8.2.2.1

8.2.2.1.1

8.2.2.1.2

8.2.2.2
Geschiedenis

229

Inleiding 229

Het nationaliteitsrecht voor $1939 \quad 232$

Algemeen 232

De wet van 1920

Algemeen 233

Verkrijging van de nationaliteit 233

Verlies van de nationaliteit 237

Het nationaliteitsrecht tijdens de tweede wereldoorlog 240

Sovjetunie 241

Duitsland 241

Het nationaliteitsrecht tussen 1945 en 1951

De wet van 1951

Algemeen 243

Verkrijging van de nationaliteit 244

Verkrijging van rechtswege 244

Naturalisatie 245

Verlies van de nationaliteit $\quad 247$

$\begin{array}{ll}\text { Ontslag } & 247\end{array}$

Ontneming 247

Het positieve nationaliteitsrecht 248

Algemeen 248

Verkrijging van de nationaliteit 249

Verkrijging van rechtswege 249

Geboorte uit Poolse ouder(s) 249

Geboorte op het grondgebied en vondelingen 250

Naturalisatie 
Invloed op de nationaliteit van de gezinsleden

8.2 .2 .2 .2

8.2 .3

8.2.3.1

8.2.3.1.1

8.2.3.1.2

8.2 .3 .2

8.2.3.2.1

van de verzoeker

Verlichte naturalisatie

251

Verlies van de nationaliteit

254

Ontslag

254

Invloed op de nationaliteit van de gezinsleden van de verzoeker

255

Ontslag in verband met huwelijk

256

Ontneming

256

Invloed op de nationaliteit van gezinsleden van

betrokkene

Geschiedenis

Het nationaliteitsrecht tot 1944

Algemeen

260

9.1.2.2

De wet van 1939

262

9.1.2.2.1

Algemeen

262

9.1.2.2.2

Verkrijging van de nationaliteit

263

9.1:2.2.3

Verlies van de nationaliteit

267

9.1 .3

Het nationaliteitsrecht tussen 1940 en 1948

271

9.1 .4

Het decreet van 1948

272

Algemeen

272

9.1 .4 .1

Verkrijging van de nationaliteit

273

9.1.4.2.1

9.1.4.2.2

Verkrijging van rechtswege

273

Naturalisatie

274

9.1.4.3

Verlies van de nationaliteit

275

Ontslag

Ontneming

275

9.1.4.3.2

Het decreet van 1952

276

9.1.5

9.1.5.1

Algemeen

277

Verkrijging van de nationaliteit

9.1.5.2

9.1.5.2.1

9.1.5.2.2

Verkrijging van rechtswege

277

Naturalisatie

277

Verlies van de nationaliteit

278

Ontslag

279

9.1.5.3.1

9.1.5.3.2

Ontneming

279

Het positieve nationaliteitsrecht

280

9.2

9.2.1

9.2 .2

Algemeen

280

Verkrijging van de nationaliteit

280

Verkrijging van rechtswege

280

Geboorte uit Roemeense ouder(s)

280

9.2.2.1.1

9.2.2.1.2

9.2 .2 .1 .3

Geboorte op het Roemeense grondgebied

281

Adoptie door een Roemeen(se)

281

Naturalisatie 
Invloed op de nationaliteit van de gezinsleden van de verzoeker

Verlies van de nationaliteit

Ontslag

Invloed op de nationaliteit van de gezinsleden

Ontslag in verband met adoptie door vreemdelingen

Invloed op de nationaliteit van gezinsleden van

10.1

10.1.1

10.1 .2

10.1.2.1

10.1.2.2

10.1.2.2.1

10.1.2.2.2

10.1.2.2.3

10.1.3

10.1.3.1

10.1.3.2

10.1.3.3

10.1.3.4

10.1 .4

10.1 .4 .1

10.1.4.2

10.1.4.3

10.1 .5

10.1.5.1

10.1.5.2

10.1.5.2.1

10.1.5.2.2

10.1.5.3

10.1.5.3.1

10.1.5.3.2

10.1 .5 .3 .3

10.1 .6

10.1.6.1

10.1.6.2

10.1.6.3
Geschiedenis

288

Inleiding

Het nationaliteitsrecht tot 1939

288

290

Algemeen

De regelingen van het $\mathrm{ABGB}$ en van de Hongaarse nationaliteitswet van 1879

Algemeen

Verkrijging van de nationaliteit

Verlies van de nationaliteit

Het nationaliteitsrecht tussen 1939 en 1945

Slowakije

Karpatho-Oekraïne

290

293

293

293

296

299

299

299

Bohemen en Moravië

300

Het Sudetengebied

De regelingen tussen 1945 en 1949

301

301

De politiek ten opzichte van de Duitse en de

Hongaarse minderheid

301

De wet betreffende verkrijging en verlies van de

303

nationaliteit door huwelijk

303

De IPR-wet van 1948

De wet van 1949

304

304

Algemeen

Verkrijging van de nationaliteit

304

Verkrijging van rechtswege

304

305

Naturalisatie

307

Verlies van de nationaliteit

307

Verlies van rechtswege

307

308

Ontneming

309

309

Gehuwde vrouwen

310

De Hongaarse minderheid

310

xix 
De verhouding tussen de federale en de deelstaat-

10.2 .2

10.2.2.1

10.2.2.1.1

10.2.2.1.2

10.2 .2 .2

10.2.2.2.1

10.2.2.2.2

10.2 .3

10.2.3.1

10.2.3.1.1

10.2.3.2

10.2.3.2.1 nationalliteit

Verkrijging van de nationaliteit

Verkrijging van rechtswege

Geboorte uit CSSR-ouder(s)

Vondelingen

Naturalisatie

Invloed op de nationaliteit van de gezinsleden

van de verzoeker

Verlichte naturalisatie

Verlies van de nationaliteit

Ontslag

Invloed op de nationaliteit van de gezinsleden

van de verzoeker

Ontneming

Invloed op de nationaliteit van gezinsleden

van betrokkene

III.

VERGELIJKENDE SAMENVATTING

HOOFDSTUK 1. HET "OUDE" NATIONALITEITSRECHT IN DE OOSTEUROPESE LANDEN

1.1

1.1 .1

1.1.1.1

1.1 .1 .2

1.1.1.3

1.1.1.4

1.1 .2

1.1 .3

1.1.3.1

1.1.3.1.1

1.1 .3 .2

1.1 .3 .3

1.2

1.2 .1

1.2 .1 .1

1.2 .1 .2

1.2 .1 .3

1.2 .1 .4

1.2.1.4.1
Verkrijging van de nationaliteit

321

Ius sanguinis

321

Geboorte op het grondgebied en vondelingen

322

Ius matrimonii

322

Andere gronden voor verkrijging van het staatsburgerschap ipso iure

Optie

324

Verlichte naturalisatie

325

"Erkenning"

326

Hernaturalisatie

326

Invloed op de nationaliteit van de gezinsleden

van de verzoeker

328

Verlies van de nationaliteit

328

Verlies van rechtswege

328

Wettiging of erkenning door een vreemdeling

328

Huwelijk met een vreemdeling

Vreemde militaire of staatsdienst

Invloed op de nationaliteit van de gezinsleden van betrokkene
Verkrijging van rechtswege

Naturalisatie 
1.2.1.5

1.2 .1 .6

1.2 .2

1.2 .3

1.2.3.1

1.2 .4

1.2.4.1
Langdurig verblijf of vestiging in het buitenland

Het niet vervullen van militaire dienstplicht

Afstand

Ontslag

Invloed op de nationaliteit van de gezinsleden

van de verzoeker

Ontneming van nationaliteit en herroeping van

naturalisatie

Invloed op de nationaliteit van gezinsleden van

betrokkene
329

330

330

330

331

331

333

334

"NOUVEAUX REGIMES"

334

334

334

335

336

336

337

337

339

339

340

340

342

342

342

342

343

344

346

Invloed op de nationaliteit van gezinsleden van

betrokkene

HOOFDSTUK 3. DE ONTWIKKELINGEN TOT OP HEDEN

Ius soli

Optie

Naturalisatie 
3.1.3.1.1

3.1.3.1.2

3.1.3.2

3.1.3.3

3.2

3.2 .1

3.2 .1 .1

3.2 .2

3.2 .2 .1

3.2 .3

3.2.3.1
Ius matrimonii

"Repatriëring"

Hernaturalisatie

Invloed op de nationaliteit van de gezinsleden

van de verzoeker

Verlies van de nationaliteit

Afstand

Invloed op de nationaliteit van gezinsleden van. betrokkene

Ontslag

Invloed op de nationaliteit van de gezinsleden

van de verzoeker

Ontneming van nationaliteit en herroeping van

naturalisatie

Invloed op de nationaliteit van gezinsleden van

betrokkene

CONCLUSIES

HOOFDSTUK 1. CONCLUSIES MET BETREKKING TOT VERKRIJGING EN VERLIES VAN DE NATIONALITEIT

1.1

1.2

1.2.1

1.2.1.1

1.2.1.1.1

1.2.1.1.2

1.2.1.1.3

1.2 .2

1.3

1.3 .1

1.3.2

1.4

1.4 .1

1.4 .2

1.4.2.1

1.4 .3

1.4.3.1

1.4 .3 .2
Algemene opmerkingen

Verkrijging van de nationaliteit

Verkrijging van rechtswege

Ius sanguinis

Inleiding

Ius sanguinis a patre et a matre, versus:

meervoudige nationaliteit

Onwettige kinderen

Naturalisatie en optie

Verlies van de nationaliteit

Ontslag en afstand

Ontneming

Invloed van verandering van nationaliteit wan ouders

op het staatsburgerschap van hun minderjarige kinderen 378

Inleiding

Naturalisatie, optie, ontslag en afstand

Medenaturalisatie

Enige voorstellen tot wijziging van het Nederlands

recht

Inleiding

Kinderen van naturalisandi en optanten
361

363

351

353

354

354

355

355

357

357

359

363

364

365

365

365

365

370

373

375

375

376

378

379

379

380

380

381

xxiii 
HOOFDSTUK 2. HOE "ANDERS" IS HET NATIONALITEITSRECHT IN OOST-EUROPA?

2.1

2.2

Inleiding

384

Beslissingsmacht in nationaliteitsaangelegenheden

384

Medenaturalisatie en medeontslag van minderjarige kinderen

Slot

SAMENVATTINGEN

Nederlandse samenvatting

Deutsche zusammenfassung

396

English summary

401

Povzetek v slovenščini

406

Literatuur

411

Curriculum vitae

439 


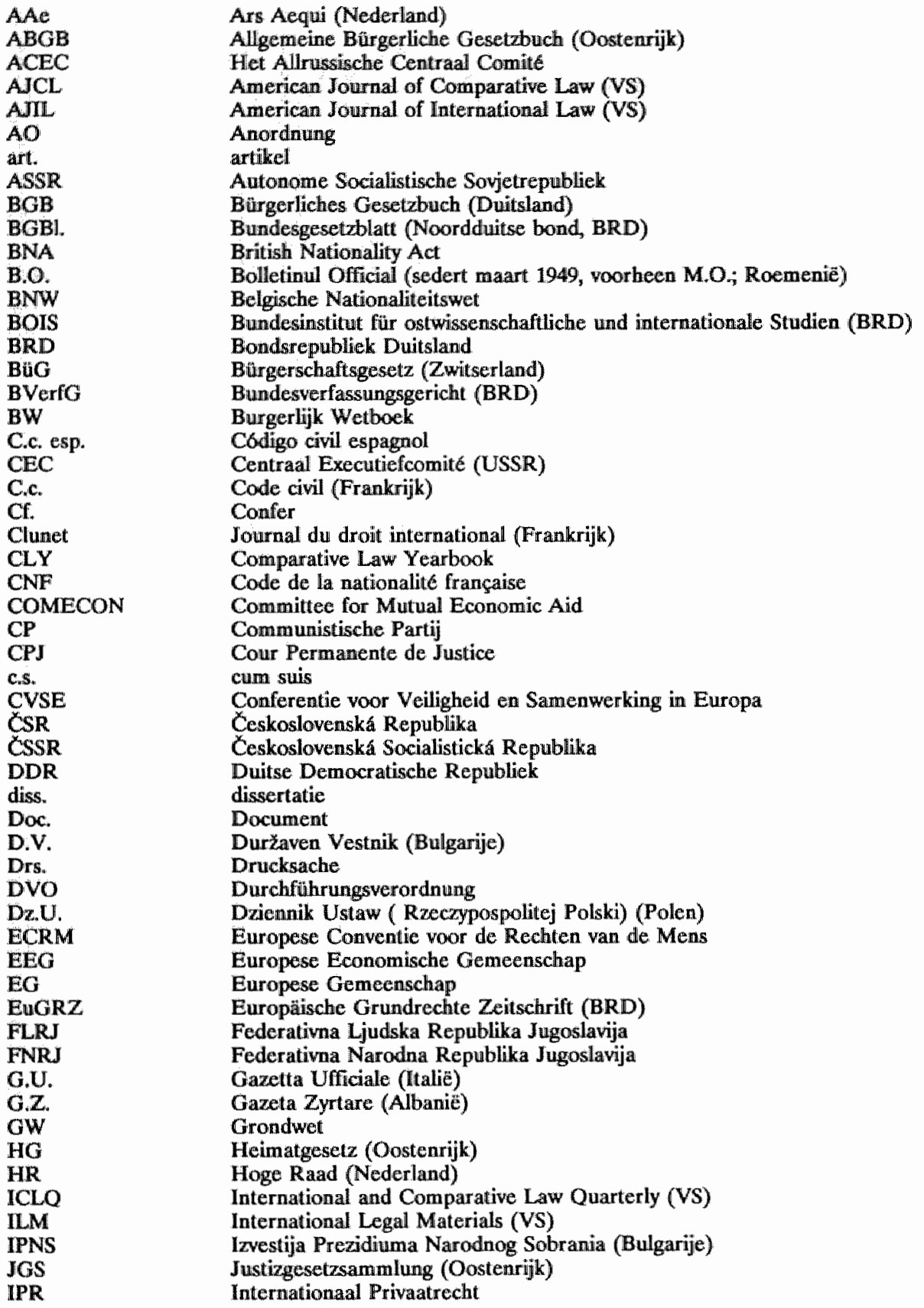




\begin{tabular}{|c|c|}
\hline JOR & Jahrbuch für Ostrecht (BRD) \\
\hline JöR & Jahrbuch für das öffentliche Recht (BRD) \\
\hline JRMP & Jugoslovenska Revija za Medjunarodno Pravo (Joegoslaviè) \\
\hline $\mathbf{J Z}$ & Juristenzeitung (BRD) \\
\hline LCN & Legge sulla cittadinanza (Italie) \\
\hline LDG & Lesebuch zur deutschen Geschichte \\
\hline LNTS & League of Nations Treaty Series \\
\hline Losbl. ed. & Losbladige editie \\
\hline MBHE & Ministerialblatt \\
\hline m.b.t. & met betrekking tot \\
\hline m.i. & mijns inziens \\
\hline M.K. & Magyar Kozlony (Hongarije) \\
\hline m.m.v. & met noot van \\
\hline MP & Mednarodne pogodbe (Joegoslavië) \\
\hline M.O. & Monitorul Official (tot maart 1949, daarna B.O.; Roemeniē) \\
\hline M.T. & Magyar Törvenytár (Hongarije) \\
\hline NDH & Nezavisna Drzava Hrvatska \\
\hline NJ & Nederlandse Jurisprudentie \\
\hline NJB & Nederlands Juristenblad \\
\hline NJW & Neue Juristische Wachenschrift (BRD) \\
\hline NKVD & Narodni Kommisariat Vnutrennih Djel (USSR) \\
\hline nr. & nummer \\
\hline NRC & Nieuwe Rotterdamsche Courant (Nederland) \\
\hline NISDAP & Nazionalsozialistische Deutsche Arbeiterpartei \\
\hline NWG & Nationaliteisswetgering (losbladige editie; Nederland) \\
\hline OEA & Organización de Estados Americanos \\
\hline OER & Osteuropa Recht (BRD) \\
\hline opm. & opmerking \\
\hline ORGBI. & ästerreichisches Reichsgesetzblatt \\
\hline OStBG & österreichisches Staatsbürgerschaftsgesetz \\
\hline p. & pagina \\
\hline PiP & Panstwo i Prawo (Polen) \\
\hline PNS & Prezidium Narodnog sobranija (Bulgarije) \\
\hline POS & Presidium van het Opperste sovjet (USSR) \\
\hline pos. & positie \\
\hline ProtBM & Protektorat Böhmen und Mähren \\
\hline RabelsZ & Rabels Zeitschrift für das ausländisches und Internationales Priwatrecht (BRD) \\
\hline RCDIP & Revue critique de droit international privé (Frankrijk) \\
\hline RdErl. & Runderlass \\
\hline RDIP & Revwe de droit international privé (Frankrijk) \\
\hline red. & redactic \\
\hline resp. & respectievelijk \\
\hline Rev. & Review \\
\hline RGBl. & Reichsgesetzblatt (Duitsland 1871-1945) \\
\hline RMBliV & Ministerialblatt des Reichs- und Preussisches Minister des Innern \\
\hline RMdI & Reichsminister des Innern \\
\hline ROW & Recht in Ost und West (BRD) \\
\hline RSFSR & Russische Socialistische Federatieve Sovjetrepubliek \\
\hline RuStAG & Reichs- und Staatsangehörigkeitsgesetz (Duitsland) \\
\hline RwNed & Rijkswet op het Nederlanderschap \\
\hline Sb. & $\begin{array}{l}\text { Sbirka zákonu (a narizeni republiky Ceskoslovenske) Tsjechoslowakije. Tot } \\
\text { 4. april } 1945 \text { verscheen er steeds tevens cen officiele Duitse versie: Slg. }\end{array}$ \\
\hline SBZ & Sowjetische Biesatzungszone \\
\hline SED & Sozialdemokratische Einheitspartei Deutschlands \\
\hline Ser. & Series \\
\hline SFRJ & Socialistična Federativna Republika Jugoslavija \\
\hline SGiP & Sovetskoe Gosudarstvo i Pravo (USSR) \\
\hline SGS & Sammlung Geltender Staatsangehörigkeitsgesetze \\
\hline
\end{tabular}


slg.

SHS

SI.].

slin.

Soc. pr.

\section{SSD.}

SUAZ

Stb.

StBG

StuR

SU

$\mathrm{SZ}$

La.y.

T.K.

TK

Trb.

U.I.

UNTS

Ur.l.

USSR

UV

VBIRProt

VS

VVS

WC'SR

WGO

WPNR

WSSR

ZaöRV

ZFoR
Sammilung der Gesetze und Verordinumgen des Protektorates Böhmen und Mähren tot 1939 (tot 4 apiril 1945)

(Kraljevina) Srbov Hrvatov in Slovencev (Joegoslavië)

Sluzbeni list (Joegoslaviē na 1945)

Sluzbene novine (Joegoslavie 1918-1941)

Socialističeskoe pravo (Bulgarije)

Soviet Statutes and Decisions

Das Standesamt, tot 1949 Zeitschrift für Standesamtwesen (BRD)

Staatsblad (Nederland)

Staatsbürgerschaftsgesetz (DDR)

Staat und Recht (DDR)

Sbornik Uloženij (RSFSR)

Sobranie Zakonov (i razporjaứenil pravitel'stva) (RSFSR)

ten aanzien van

Tanácköotấrsäg (Hongaarse "radenrepubliek" in 1919)

Tweede Kamer (Nederland)

Tractatenblad (Nederland)

Uredni list (CSSR)

United Nations Treaty Series

Uradni list (Joegoslavië)

Unie van de Socialistische Sovjetrepublieken

Uitwoeringsverordening

Verordnungsblatt des Protektorats Böbmen und Mähren

Verenigde Staten (van Amerika)

Vedomosti Verchovnog soveta (USSR)

Tsjechische nationaliteitswet van 1969

Monatshefte für osteuropäisches Recht (BRD)

Weekblad voor Privaatrecht, Notariaat en Registratie (Nederland)

Slowaakse nationaliteitswet van 1968

Zeitschrift für ausländisches öffentliches Recht und Völkerrecht (BRD)

Zeilschrift für osteuropaisches Recht (BRD) 
I. ALGEMEEN DEEL 
Bij het verrichten van het voorliggende onderzoek stonden mij verschillende doeleinden voor ogen. In de eerste plaats heb ik getracht een systematisch overzicht van de regelingen van verkrijging en verlies van de nationaliteit in de Oosteuropese landen te geven. De term "Oosteuropees" wordt in dit verband gebezigd in de "politieke" zin, als aanduiding voor alle Europese landen die door communistische partijen worden geregeerd ${ }^{1}$. De term "Westeuropees" zal voor alle overige landen in Europa worden gebruikt. In de tweede plaats wilde ik nagaan in hoeverre de regelingen van verkrijging en verlies van de nationaliteit in de Oosteuropese landen verschillen en overeenkomsten vertonen met de regelingen van hetzelfde onderwerp in Nederland en enkele andere Westeuropese landen. Daar deze studie in het Nederlands verschijnt, zal bovendien worden nagegaan of uit het Oosteuropees nationaliteitsrecht inspiratie voor verbetering van het Nederlandse recht kan worden geput.

De tot nog toe in Oost-Europa verschenen publicaties op het gebied van het Oosteuropees nationaliteitsrecht beperken zich steeds tot beschrijvingen van het recht van een bepaald land, waarbij soms naar bepalingen van de nationaliteitswetten van andere (Oosteuropese) landen wordt verwezen. Vele van deze werken worden bovendien in de voor het Westeuropees publiek weinig toegankelijke slavische talen geschreven. De publicaties in het Westen beperken zich voor een groot gedeelte tot de serie "Sammlung geltender Staatsangehörigkeitsgesetze" (SGS), die echter met betrekking tot vele landen sterk gedateerd is ${ }^{2}$. Belangrijke uitzonderingen vormen hierbij het werk van Ginsburgs over het nationaliteitsrecht van de Sovjetunie en de recente dissertatie van Wolloch over het Roemeense nationaliteitsrecht ${ }^{3}$. Een systematische vergelijking van het nationaliteitsrecht van alle Oosteuropese landen ontbreekt echter volkomen.

Gezien het feit dat de slavische talen voor de meeste Westeuropese juristen niet of nauwelijks toegankelijk zijn, wordt ernaar gestreefd zoveel mogelijk verwijzingen naar vertalingen van wetteksten in het Duits, Engels en Frans, alsmede naar de literatuur die in deze talen verschenen is, op te nemen.

Aangezien in de Sovjetunie, Bulgarije en in een gedeelte van Joegoslavië het cyrillische schrift wordt gebruikt, ontstaat het probleem van transcriptie naar het Latijnse alfabet. In dit boek wordt voor de zogenaamde wetenschappelijke transcriptie in Tsjechische letters gekozen. Slechts de in Nederland ingeburgerde Russische woorden zoals "tsaar", "bolsjeviek", alsmede de geografische namen, worden in de in Nederland gebruikelijke transcriptie weergegeven. Op deze wijze kan de tevens eenheid van spelling van woorden in de Tsjechische, Slowaakse, Sloveense en Servo-Kroatische taal, die de van oorsprong Tsjechische lettertekens $\check{c}$, š en $\check{z}$ kennen, worden bewaard.

1. Reeds door Loeber, RabelsZ 1961, p. 209 werd ingegaan op de vraag welke benaming voor deze landen juist zou zijn. Ook door hem wordt voor hetzelfde criterium gekozen.

2. In deze serie wordt slechts het positieve nationaliteitsrecht van Albanie, Hongarije en Tsjechoslowakije behandeld.

3. G. Ginsburgs, The Citizenship Law of the USSR, The Hague/Boston/Lancaster 1983 en E. Wolloch, Die geschichtliche Entwicklung des Staatsangehörigkeitsrechts in Rumänien, Frankfurt am Main/Bern/New York/Paris 1988. 
In de literatuur van de Oosteuropese landen, met name in die van de DDR, wordt de opvatting verdedigd dat de nationaliteit in socialistische landen een geheel andere inhoud en functie heeft dan het "burgerlijke instituut" met dezelfde naam. Deze opvatting wordt niet zelden ook door Westeuropese auteurs overgenomen ${ }^{4}$. In dit werk zal op de in Oost-Europa verschenen literatuur over de nationaliteit nader worden ingegaan en zal deze tegen de meningen die in West-Europa met betrekking tot dit rechtsinstituut heersen, worden afgezet. Een belangrijke vraag die in het kader van dit onderzoek wordt gesteld is, of de nationaliteit in de socialistische landen inderdaad een geheel andere inhoud en functie heeft en met de "Westerse" nationaliteit eventueel slechts de naam gemeenschappelijk heeft. Deze vraag kan uiteraard niet worden beantwoord door slechts met de Oosteuropese theoretici op dit gebied in discussie te treden en voor hun argumenten betere tegenargumenten te zoeken. De enige mogelijke wijze om deze vraag te beantwoorden, is bestudering van het nationaliteitsrecht in de Oosteuropese landen zowel in de "burgerlijke" periode, als de ontwikkeling in de tijd waarin de nationaliteitswetgeving door de "nouveaux régimes" tot stand werd gebracht. Slechts op deze wijze kan worden nagegaan in hoeverre het nationaliteitsrecht nadat de communistische partijen aan de macht kwamen werkelijk principieel veranderde en in hoeverre het slechts om een aanpassing van het bestaande recht aan nieuwe denkbeelden zoals het verbod van discriminatie van vrouwen en van onwettige kinderen ging. Indien de inhoud en functie van de nationaliteit inderdaad geheel anders is, zou men logischerwijs verwachten dat de gronden voor verkrijging en verlies van de nationaliteit in Oost-Europa duidelijk afwijken van die in het Westen.

Het nationaliteitsrecht van Oosteuropese landen wordt tewens met het recht van Nederland en incidenteel met het recht van andere Westerse landen vergeleken. Verwijzingen naar Westeuropese landen hebben tot doel na te gaan of bepaalde wijzen en gronden van verwerving en verlies van het staatsburgerschap ook in West-Europa bestaan. Van een voor een dergelijke vergelijking wellicht noodzakelijke beschrijving van het Nederlandse nationaliteitsrecht wordt bewust afgezien. In de eerste plaats is het voorliggende werk een boek over het Oosteuropees recht en bovendien bestaan er reeds diverse systematische beschrijvingen van het Nederlandse nationaliteitsrecht, waarvan één mede van mijn hands.

Als Nederlandse jurist voel ik me niet geroepen om voorstellen tot wijziging van het recht van andere landen te doen. Dit geldt uiteraard niet ten aanzien van Joegoslavië ${ }^{6}$ maar daar dit boek in het Nederlands wordt geschreven, zou dat weinig zinvol zijn. Wel zal aan de hand van het recht van de Oosteuropese landen worden nagegaan of er eventueel voorstellen tot verbetering van het Nederlandse nationaliteitsrecht kunnen worden gedaan.

4. Zie bijwoorbeeld De Groot diss., p. 3 .

5. G.R. de Groot Staatsangehörigkeitsrecht im Wandel, diss., Maastricht, 's- Gravenhage 1988; G.R. de Groot en M. Tratnik, Nationaliteitsrecht, Zwolle 1986; Losbladige editie Personen- en familierecht, gedeelte Nationaliteitsrecht, bewerkt door G.R. de Groot; Nationaliteitswetgeving, thans bewerkt door F.Th. Zilverentant, med medewerking van C.J. Brinkman, J. Dekker en R.M. Pruimers; C.J. Brinkman, Het Nederlandse Nationaliteitsrecht in de praktijk, Alphen a/d Rijn/'sGravenhage 1985 .

6. De auteur is zowel afgestudeerd aan de juridische faculteit van de Universiteit van Ljubljana, Joegoslavië, als aan de Rijksuniversiteit Limburg te Maastricht. 
Het onderhavige boek bevat vier delen. In het eerste deel zullen in hoofdstuk 2 de theoretische opvattingen omtrent de nationaliteit in West- en Oost-Europa worden uiteengezet. Aangezien in dit boek het recht van landen met verschillende politieke stelsels wordt vergeleken, kan riet worden nagelaten om tevens enige woorden aan de problematiek van deze zogenaamde "intersystemaire rechtsvergelijking" ${ }^{7}$ te wijden. Voorts zal in het derde hoofdstuk de bij de landenbeschrijvingen gevolgde structuur worden verantwoord en terminologische opmerkingen in verband met de verkrijging en verlies van de nationaliteit worden gemaakt. In het tweede deel wordt het nationaliteitsrecht van alle Oosteuropese landen beschreven. In het eerste hoofdstuk zullen de voor deze landen geldende volkenrechtelijke verplichtingen op het gebied van het nationaliteitsrecht worden besproken. Bijzondere aandacht zal hierbij worden besteed aan art. 15 van de rechten van de mens en aan de vele tot beperking van meervoudige nationaliteit strekkende verdragen die de Oosteuropese landen onderling hebben gesloten. De landenbeschrijvingen worden beperkt tot de bespreking van regelingen van verkrijging en verlies van de nationaliteit in algemene nationaliteitsrechtelijke voorschriften. $\mathrm{De}$ regels betreffende verkrijging en verlies van de nationaliteit in internationale verdragen, die betrekking hebben op de talrijke grondgebiedsweranderingen die zich in deze eeuw in Oost-Europa hebben voorgedaan, zullen buiten beschouwing worden gelaten. Aangezien het recht van de USSR als "moederrecht" ten opzichte van de andere Oosteuropese rechtsstelsels wordt beschouwd, zal met de bespreking van het nationaliteitsrecht van dit land worden aangevangen. Beschrijving van het recht van andere Oosteuropese landen volgt in alfabetische volgorde. In het derde deel zullen de regelingen van verkrijging en verlies van de nationaliteit samenvattend met elkaar worden vergeleken. In het vierde deel zullen allereerst conclusies ten aanzien van bepaalde verkrijgings- en verliesgronden worden getrokken. Vervolgens zal worden nagegaan welke specifieke karakteristieken uit het "Oosteuropees nationaliteitsrecht" kunnen worden gedestilleerd om uiteindelijk de vraag te beantwoorden of nationaliteit in Oost-Europa werkelijk (zo) anders is. Het boek wordt afgesloten met samenvattingen in de Nederlandse, Duitse, Engelse en Sloveense taal.

7. Deze term ontleen ik aan $\mathbf{H}_{0}$-J. Bartels, Methode und Gegenstand intersystiemarer Rechtsvergleichung, Tübingen 1982. 


\subsection{THEORETISCHE BESCHOUWWNGEN MET BETRHKKING TOT DE NATTONALTTETr IN West-EuRop'A}

\subsubsection{De inhoud" van het begrip nationaliteit}

Het begrip "nationaliteit" heeft zijn oorsprong in de Engelse, respectievelijk Franse taal (nationality, nationalite) ${ }^{1}$. Taalkundig beeft dit begrip twee betekenissen. De eerste geeft het behoren tot een bepaalde staat aan (staatsburgerschap, Staatsangehörigkeit, citoyenneté, citizenship) en ziet derhalve op een juridische relatie tussen een persoon en een staat ${ }^{2}$. De tweede betekenis van dit begrip is de nationaliteit in etnische zin, die niet het behoren tot een bepaalde staat weergeeft, doch het behoren tot een bepaald volk, een volksstam of een volksgroep. Dikwijis komen beide begrippen met elkaar overeen; de meeste (juridische) Nederlanders behoren ook etnisch tot het Nederlandse "volk". Het komt echter voor dat bijvoorbeeld een Nederlander naar de Verenigde Staten emigreert en zich daar laat naturaliseren, waardoor hij de juridische Nederlandse nationaliteit op grond van art. 15 sub a RwNed automatisch verliest, terwijl hij echter etnisch nog steeds als Nederlander moet worden beschouwd. Ook het omgekeerde komt voor: een Italiaan, Fransman of Pool verkrijgt door naturalisatie hier ter lande de juridische Nederlandse nationaliteit, doch voor zijn etnische nationaliteit is een naturalisatie zonder betekenis. Het is van belang om beide betekenissen van het begrip nationaliteit goed te onderscheiden. De reden daarvoor is, dat in verschillende Oosteuropese landen de tweede, etnische nationaliteit ook een juridische categorie is en aan het bezit van deze nationaliteit ook rechtsgevolgen worden gekoppeld. Tenzij uitdrukkelijk anders wordt aangegeven, zal met de term nationaliteit in dit boek steeds de juridische nationaliteit worden aangeduid.

Naast de begrippen juridische en etnische nationaliteit komen we in de literatuur ook begrippen tegen als algemene, functionele, "sächllich beschränkte", morele, psychologische, sociologische en effectieve nationaliteit. Het zou echter te ver voeren om ten behoeve van dit werk al deze verschillende begrippen te beschrijven ${ }^{3}$.

De inhoud van het begrip nationaliteit laat zich in abstracto niet exact omschrijven, evenmin als bijvoorbeeld het zijn van ambtenaar, huurder, werknemer, etc. Het gaat om abstracte begrippen, waaraan zeer werschillende rechtsgevolgen kunnen worden verbonden. Men kan bijvoorbeeld huurder van een riant kasteel zijn, of slechts van een rammelende fiets. Pas indien we spreken over het bezit van de nationaliteit van een bepaalde staat op een bepaald tijdstip, bijvoorbeeld over de Nederlandse nationaliteit op 8 september 1989, staat exact vast welke rechten en plichten het bezit van deze nationaliteit op dit tijdstip met zich meebrengt.

1. De Groot diss., p. 11, met bijzonder vitvoerige verwijzingen naar het gebruik van deze term in het verleden op p. 372 , noot 84.

2. Verschillende schrijvers voerden een discussie of het over een band, dan wel status gaat. Zie voor een overzicht van de verschillende meningen De Groot diss., p. 12-13.

3. Zie voor een korte verklaring van deze begrippen De Groot diss., p. 10-11; De Groot/Tratnik, p. 6-9. 
Hoewel door de diverse staten dikwijls dezelfde rechten en verplichtingen aan het bezit van hun nationaliteit worden gekoppeld (bijvoorbeeld het kiesrecht en de militaire dienstplicht), betekent dit niet dat deze rechten en plichten begripsmatig met de nationaliteit verbonden zijn. De staten zijn in beginsel vrij om in plaats van de nationaliteit een ander criterium voor de toedeling van deze rechten en plichten te kiezen, bijwoorbeeld de woonplaats. Het is wel zo, dat in enkele internationale verdragen de lidstaten de verplichting op zich hebben genomen om bepaalde rechten aan het bezit van hun nationaliteit te koppelen, hoewel de staten ook in dit geval aan deze rechten zeer verschillende inhoud (kumnen) geven (zie ook p. 40). Dit belet echter niet dat in de toekomst deze rechten niet aan een ander aanknopingspunt, bijvoorbeeld de woonplaats, kunnen worden gekoppeld.

De opvatting dat de nationaliteit juridisch-technisch gezien een koppelbegrip is, waaraan verschillende rechtsgevolgen kunnen worden verbonden, wordt door vele andere auteurs gedeeld. Makarov zegt hierover het volgende:

"Welche Rechte und welche Pflichten den Staatsangehörigkeitsstatus zur Voraussetzung haben, ist für Begriff der Staatsangehörigkeit irrelevant... Es wäre aber verfehlt, eines dieser Rechte oder eine dieser Pflichten als zum Wesen der Staatsangehörigkeit miteinzuschliessen. Jedes neue Gesetz, das in einem Staate erscheint, kann eine Änderung des Inhalts der an die Staatsangehörigkeit angeknüpften Rechte und Pflichten mitsichbringen ${ }^{4 . "}$

Een goede illustratie van de betrekkelijke betekenis van de nationaliteit is de situatie in federale staten, die zowel de federale nationaliteit, als de nationaliteit van de deelstaten kennens. Terwijl zich de nationaliteit in andere gevallen bij uitstek ervoor leent om onderscheid tussen eigen onderdanen en vreemdelingen te maken, is de deelstaatnationaliteit voor dit doel vaak onbruikbaar. In de grondwetten van de meeste federaties wordt immers juist bepaald dat tussen staatsburgers van verschillende deelstaten geen onderscheid op grond van de deelstaatnationaliteit mag worden gemaakt. Aan de nationaliteit van de deelstaten kumnen in de regel niet de voor de nationaliteit "typische" rechten zoals het kiesrecht, recht op verblijf, recht op toelating, recht op arbeid en vestiging van een onderneming en recht op (kosteloos) onderwijs worden verbonden. Indien we Joegoslavië als voorbeeld nemen zien we dat al deze rechten voor alle Joegoslavische onderdanen, ongeacht hun deelstaatnationaliteit, gelden (artt. 153-200 van de federale $\mathrm{GW}$ ).

\subsubsection{De functie van de nationaliteit}

Iedere staat heeft naast een min of meer bepaald grondgebied ook een zekere kring van onderdanen, waarover hij zijn gezag uitoefent ${ }^{6}$. Deze kring van onderdanen wordt in alle landen aan de hand van de nationaliteit bepaald. De

4. Makarov, p. 30-31; ongeveer dezelfde mening huldigen woorts: De Groot diss., p. 13; Ko Swan Sik, p. 13; Koessler, Yale Law Journal 1946-47, p. 70.

5. In Oost-Europa zijn dat de USSR, Joegoslavië en Tsjechoslowakije.

6. In dit verband wordt door Jellinek, p. 179-180, gesproken van de drie wezenskenmerken van elke staat: het staatsgezag, een bepaald grondgebied en een kring van onderdanen. 
nationaliteit dient derhalve in de eerste plaats als een soort "hekwerk" om het personenbereik van het gezag van een bepaalde staat af te grenzen. Deze afgrenzing is om tweeërlei redenen noodzakelijk. In de eerste plaats verblijven op het grondgebied van nagenoeg elke staat ook vreemdelingen, dat wil zeggen personen, die de staat niet als zijn eigen onderdanen beschouwt. Door de snelle ontwikkeling van verkeersmiddelen, de mobiliteit van werknemers, studenten, toerisme, etc. komt het vandaag de dag steeds vaker voor dat in vele landen grote aantallen vreemdelingen verblijven. Zou iedere staat aan vreemdelingen exact dezelfde rechten en plichten als aan zijn eigen onderdanen willen toekennen, dan zou de nationaliteil geheel overbodig zijn. Alleen al om praktische redenen zou iets dergelijks in de praktijk nauwelijks voorstelbaar zijn. Om tijdens een vakantieverblijf op bijwoorbeeld Nauru een oproep voor de verkiezingen te ontvangen zou voor de betrokkene waarschijnlijk nog amusant zijn. Indien hij wegens het geen gehoor geven aan een dergelijk oproep strafrechtelijk zou worden vervolgd, is dat niet meer het geval.

De nationaliteit zou eveneens overbodig zijn, indien een staat in plaats van bet staatsburgerschap een ander aanknopingspunt voor toekenning van rechten en plichten zou kiezen. Zo zou de nationale wetgever van een bepaalde staat kunnen bepalen dat iedereen na vijf jaar woonplaats in die staat te hebben gehad alle rechten en plichten zou hebben. Van dergelijke afschaffing van de nationaliteit kunnen geen werkelijke voorbeelden worden gevonden. Wel komt het voor dat in bepaalde landen ten aanzien van enkele traditioneel aan het staatsburgerschap gekoppelde rechten de nationaliteit niet als aanknopingspunt werd gebruikt. Zo werd tijdens de Parijse Commune (1870-1871) aan buitenlanders actief en passief kiesrecht toegekend ${ }^{7}$. In de Sovjetunie hadden buitenlandse boeren en arbeiders tot 1936 eveneens kiesrecht. Hetzelfde geldt sedert 1985 ten aanzien van de gemeenteraadsverkiezingen voor vreemdelingen die reeds meer dan vijf jaar in Nederland verblijven. Ook het EEG-verdrag heeft in de functie van de nationaliteit in de lidstaten van deze organisatie enige veranderingen aangebracht. De lidstaten mogen namelijk geen onderscheid meer maken tussen werknemers die eigen onderdanen zijn en werknemers, die de nationaliteit van een andere lidstaat bezitten (art. 48 lid 2). Enerzijds heeft hierdoor het staatsburgerschap van de afzonderlijke EG-staten binnen het EG-verband aan betekenis ingeboet. Het kan niet meer als onderscheidend criterium tussen de werknemers dienen, voorzover het om onderdanen van andere lidstaten van de Europese Gemeenschap gaat. Anderzijds werd door deze ontwikkeling naar buiten toe een nieuw onderscheidend criterium in het leven geroepen, namelijk het bezit van de nationaliteit van een willekeurige EG-lidstaat, tegenover het staatsburgerschap van landen, die niet tot de EG behoren. Door verschillende schrijvers wordt in dit verband ingegaan op de mogelijke ontwikkeling van een nieuwe nationaliteit, namelijk die van de EG als een geheel ${ }^{8}$.

7. Ricge, p. 99, met verwijzing naar W. Wippold, Pariser Kommune, Berlijn(Oost) 1961, p. 94 .

8. Zie De Groot diss., p. 23-29, met verdere literatuurverwijzingen. 


\subsubsection{Grondlijnen van de marxistische rechtsopvatting}

Alvorens tot bespreking van de opvattingen omtrent de nationaliteit in OostEuropa over te gaan zullen in het kort de grondlijnen van de marxistische opvatting van het recht worden geschetst. De marxistische opvatting van het recht wordt gebaseerd op de leer van het zogenaamde historisch en dialectisch materialisme". Het uitgangspunt van deze leer is, dat de oorzaak van alles in het materiêle, uiterlijk waarneembare ligt. Al het immateriële zoals filosofie, religie, recht, etc. is slechts een weerspiegeling van het materiële en wordt geheel daardoor bepaald. Zo worden ook politieke en economische systemen niet bepaald door in het bewustzijn van mensen levende opvattingen, maar door de socialeconomische werkelijkheid in een bepaalde maatschappij, of met de woorden van Marx te spreken:

"Es ist nicht das Bewusstsein der Menschen, das ihr Sein, sondern umgekehrt ihr gesellschaftliches Sein, das ihr Bewusstsein bestimmt". ${ }^{10}$

Er wordt een onderscheild gemaakt tussen de economische basis en de "bovenbouw", waartoe religie, filosofie, kunst en ook recht behoren. Bepalend voor de economische basis zijn de zogenaamde "productieverhoudingen"; dat zijn de verhoudingen tussen de productiekrachten (arbeid, grond, grondstoffen, technologie, machines, etc) ${ }^{11}$. In wezen gaat het hierbij om het eigendom van productiemiddelen ${ }^{12}$.

Bij elke ontwikkelingsfase van de productiemiddelen, productiewijze genoemd, behoort een apart type van deze productie- (= eigendoms-)verhoudingen. Zo wordt een onderscheid gemaakt tussen de klassenloze maatschappij die geen eigendom kende, de slavenhoudersmaatschappij van de Antieke oudheid, de feodale maatschappij in de middeleeuwen, de kapitalistische maatschappij en uiteindelijk de socialistische. Deze laatste zou de overgangsfase naar een nieuwe hoog ontwikkelde klassenloze maatschappij zijn. Elke fase betekent een kwalitatief hogere fase van ontwikkeling. Terwijl het bij de eerste drie steeds om een tegenstelling tussen de eigenaars van productiemiddelen en degenen die werkelijk produceren gaat, komt in het socialisme dit eigendom in handen van de producenten zelf ${ }^{13}$.

De bovenbouw in elke van deze ontwikkelingsfases wordt door de economische basis, derhalve door eigendom van productiemiddelen bepaald. Het recht en de staat worden niet als zelfstandig gezien, maar uitsluitend als een instrument in handen van de klassen van eigenaars van productiemiddelen om de status quo met

9. David, p. 171; Zweigert/Kötz I, p. 333.

10. Marx in zijn voorwoord bij: Zur Kritik der Polltischen Ökonomie, uit: Marx/Engells deel II, p. 503. Zie ook Iglï̌r, p. 41; Zweigert/Kötz I, p. 333.

11. Marx, o.c. (noof 10), p. 503; Iglizar, p. 41; Zweigert/Kötz I, p. 334.

12. "Produktionsverhältnüssen oder, was nur ein juristischer Ausdruck dafür ist...Eigentumsverhälttnissen". Marx, o.c. (noot 10), p. 503.

13. Zie uitwoerig daarover Engels, Die Ursprung der Familie, des Privateigentums und des Staats in Marx/Engels deel IV, p. 15-197). Zie ook bijw. Kusej e.a., p. 43-57; Zwweigert/Kötz 1, p. 335. 
betrekking tot de eigendomsverhoudingen te handhaven ${ }^{14}$. Het "kapitalistische" recht is derhalve een middel in de handen van kapitalisten en ook afzonderlijke rechtsregels mogen niet los van hun klassekarakter worden gezien. Het "socialistische" recht echter, zou in de eerste (overgangs)fase na de revolutie dienen om de positie van de arbeiders tegen de resten van het kapitalisme te handhaven. Nadat dit gebeurd is, kan het eenvoudig worden afgeschaft aangezien het geen functie meer heeft ${ }^{15}$.

De marxistische opvattingen met betrekking tot het recht kunnen treffend worden geillustreerd met de woorden van Kyšinskij:

"Das Recht ist die Gesamtheit der Verhaltensregeln die den Willen der herrschenden Klasse ausdrücken und auf gesetzgeberischem Wege festgelegt sind." 16

Volgens het marxisme staat de socialistische maatschappij derhalve op een hoger niveau van ontwikkeling dan de kapitalistische, aangezien de productiewijze in het socialisme hoger is ontwikkeld. Het recht wordt dientengevolge uiteraard ook als recht van hogere orde dan het "kapitalistische" recht beschouwd. Bovendien zou het in beide systemen een ander klassekarakter en een andere functie hebben. Deze opvattingen leiden dan inderdaad noodzakelijkerwijs tot de visie dat een rechtsinstituut dat eventueel in beide systemen dezelfde naam heeft, toch geheel anders is zonder dat men zich daarbij mag afvragen of het inderdaad zo is. Dit betekent dat de Oosteuropese juristen zich in een "ideologische kooi" bevinden. Ze moeten ook het nationalliteitsrecht in hun landen als hoger ontwikkeld dan het nationalliteitsrecht in het Westen beschouwen ${ }^{17}$. Zouden ze toegeven dat beide rechtsinstituten gelijk zijn, dan zouden ze "hoogverraad" tegenover de marxistische rechtsopvatting plegen.

\subsubsection{De termen "Staatsbürgerschaft" en "Staatsangehörigkeit"}

Om het verschil tussen de nationaliteit in West- en Oost-Europa te onderschrijven, wordt in de literatuur van de DDR sedert ongeveer 1955 steeds van de "sozialistische Staatsbürgerschaft" en van de Westerse "Staatsangehörigkeit" gesproken. De eerste term zou doelen op de burger als drager wan souvereiniteit, terwijl bij de tweede de gezagsverhouding tussen de staat en zijn onderdaan op de voorgrond zou staan. Dit verschil in de benaming werd overigens niet door de nationaliteitsrechtelijke literatuur van de DDR geïntroduceerd, maar dateert reeds uit de tijd van de Franse "bourgeoise" revolutie ${ }^{18}$. In de "Declaration des droits de l'homme et du citoyen" van 1789 wordt in plaats van de voorheen gebruikelijke term "sujet"

14. Kušej e.a.n p. 84; David, p. 172.

15. David, p. 175; Kusej e.a., p. 81; Zweigert/Kötz I, p. 335.

16. Vysinskij, p. 76, in Die Hauptaufgaben der Wissenschaftler vorm sozialistischen Sowjetrecht 1938, afgedrukt in: Sowjetische Beiträge zur Staats- und Rechtslehre, Gesellschaft für deutschsowjetische Freundschaft 1955 , p. 55 e.v. Gicciteerd bij Zweigert/Kötz I, p. 337. Zie woor een gelijkstrekkende definitie ook Kusej e.a., p. 75.

17. Krav'uk, p. 88.

18. Dit wordt ook in de DDR niet ontkend, echter met de toevoeging dat het "staatsburgerschap" later door de bourgeoisie uitgehold werd. Riege, p. 29-32. 
het begrip "citoyen" gebezigd. De verklaring voor dit terminologieonderscheid was overigens dezelfde als die welke onder meer door Riege 130 jaar later wordt gegeven. Voorts is de term "Staatsbürgerschaft" ook in Oostenrijk ${ }^{19}$ en Zwitserland gebruikelijk en kan derhalve ook om deze reden niet als een typisch "socialistische" term dienen. Ook door Ćerny en Ćenvenka in de CSSR wordt uitdrukkelijk ge iteld dat het socialisme geen eigen term voor de nationaliteit heeft ingevverd ${ }^{20}$. Tenslotte dient er op te worden gewezen dat een dergelijk terminologisch onderscheid slechts mogelijk is, indien de taal van het desbetreffende land dat toelaat.

We zien dat het door Riege gehanteerde onderscheid tussen "Staatsangehörigkeit" en "Staatsbürgerschaft" zowel gezien zijn historische oorsprong als taalkundig op zeer wankele voeten staat. In dit boek zullen derhalve beide termen als elkaars synoniemen worden gebruikt. Het is overigens bijzonder interessant dat ook in het "Rechtslexikon" van de Staatsuitgeverij van de DDR van 1988 beide termen als synoniemen worden gezien ${ }^{21}$.

\subsubsection{De inhoud van het begrip nationaliteit}

Met betrekking tot de inhoud van het begrip nationaliteit zijn de opvattingen in Oost-Europa niet unaniem ${ }^{22}$. In de literatuur van de DDR werd door Riege het zogenaamde "materielle Staatsbürgerschaftsbegriff" ontwikkeld ${ }^{23}$. Hij geeft de volgende definitie van dit begrip:

"Die Staatsbürgerschaft ist ein rechtlich relevantes, zumeist rechtlich geregeltes Realverhältnis zwischen Staat und Burger..." 24

Tot dusverre komt zijn definitie derhalve overeen met de in het Westen gehanteerde begripsomschrijving van de nationaliteit als een relatie tussen staat en burger. Het essentiële verschil ten opzichte van Westeuropese opvattingen ligt in het tweede deel van zijn definitie:

"...Es bildet nicht nur die Grundlage für die vielfältige Beziehungen zwischen ihnen (nationaliteit als aanknopingspunt, MT), sondern schliesst diese Beziehungen selbst ein." ${ }^{25}$

Volgens de bovenstaande definitie is de nationaliteit derhalve niet slechts een aanknopingspunt, dat door de staat voor verschillende rechten en plichten van de burger wordt gebruikt, maar maken de rechten en plichten begripsmatig deel uit van de nationaliteit. Dit zou betekenen, dat alle socialistische staten precies dezelfde rechten en plichten aan hun burgers toekennen. Het zou derhalve onmogelijk zijn dat bijvoorbeeld het kiesrecht, dat bij uitstek een recht is dat aan

19. Zie bijwoorbeeld $\$ 30$ van de ABGB van 1811 .

20. Cerny/Cervenka, p. 17.

21. Rechtslexikon, p. 5, 338.

22. Riege, p. 55.

23. Deze opvatting wordt ook gedeeld door Kulke diss., p. 2.

24. Riege, p. 16.

25. Riege, p. 9. 
de hand van de nationaliteit wordt bepaald, uitsluitend aan eigen onderdanen en niet aan alle ingezetenen van een socialistische staat, los van het staatsburgerschap, kan worden toegekend.

Voorts wordt door verschillende Oosteuropese schrijvers met betrekking tot de "hogere kwaliteit" van het socialistische staatsburgerschap verwezen naar het op de marxistische rechtsopvatting gegronde klassekarakter van de nationaliteit en op het "feit" dat het recht van socialistische landen en derhalve ook zijn rechtsinstituten op een kwalitatief hoger niveau staan dan het recht in het Westen ${ }^{26}$. Ten aanzien van het socialistische staatsburgerschap wordt betoogd dat dit recht actieve deelname van de burgers aan de uitoefening van de staatsmacht betekent, terwijl het in het Westen voornamelijk om gezagsverhouding ("Angehörigkeit") zou gaan, waarbij de burger geen subject maar object van de staatsmacht is. Met betrekking tot het nationaliteitsrecht van Westerse landen wordt er aan de hand van historische voorbeelden uit het recht van koloniale mogendheden of uit het nationaliteitsrecht in Duitsland onder de nazi's op gewezen dat men door hantering van verschillende categorieën van onderdanen de nationaliteit voor discriminatiedoeleinden gebruikt ${ }^{27}$. Hierbij wordt echter vergeten te vermelden dat in vele Westeuropese landen dergelijke voorbeelden inmiddels tot de rechtsgeschiedenis behoren ${ }^{28}$. Ironisch genoeg wordt de door Riege zo benadrukte gelijkheid van alle DDR-staatsburgers door de DDR-nationaliteitswet van 1967 zelf tegengesproken. Blijkens $\$ 12$ StBG kan de nationaliteit aan een genaturaliseerde niet alleen wegens fraude bij de naturalisatieprocedure worden ontnomen, maar ook indien:

"....sich der Bürger der Staatsbürgerschaft der Deutschen Demokratischen Republik durch grobe Missachtung der mit ihrer Verleihung übernomenen Verpflichtungen nicht würdig erweist".

Het bestaan van een aparte mogelijkheid van ontneming van de nationaliteit aan genaturaliseerden buiten gevallen van fraude bij de naturalisatieprocedure impliceert immers dat aan het gedrag van dergelijke staatsburgers zwaardere eisen worden gesteld dan aan het gedrag van degenen, die de nationaliteit van de DDR van rechtswege verwierven. Uit het feit dat deze mogelijkheid naast de algemene ontneming wegens grove veronachtzaming van "staatsbürgerschaftliche Pflichten" ( $\$ 13)$ bestaat, kan worden afgeleid dat bij een genaturaliseerde sneller een dergelijke veronachtzaming wordt aangenomen. Bovendien kan aan een genaturali-

26. Zie bijwoorbeeld Tunkin, SGiP $1979 / 7$, p. 23, in de Sovjetunie.

27. Riege, p. 50 en 38-42. Verschillende andere schrijwers nemen niet eens de moeite om hun stellingen met voorbeelden te onderbouwen, maar schrijwen zoals bijvoorbeeld Vulkanov, p. 45 : "De naturalisatievereisten in socialistische landen zijn noodzakelijk anders dan die in kapitalistische landen. Naturalisatievereisten in kapitalistische landen kunnen niet anders dan discriminatoir zjjn." (Vertaling door mij, MT) "Ook het volgende "bloempje" van Kulik is een vermelding warard: "In de bourgeoise staten komt staatloosheid meestal woor bij het armere gedeelte van de bevolking." (vertaling van mij, MT). Zie voor meer voorbeelden van dit soort "wetenschapsbeoefening" ook Cerny/Cervenka, p. 18 -19.

28. Onderscheid tussen werschillende categorieên van staatsburgers kennen in West-Europa thans bijwoorbeeld nog Belgie (grote en kleine naturalisatie) en Groot Britannië met betrekking tot de bewoners van kolonice èn. Ook de ruimere mogelijkheden om aan genaturaliseerde Britten de nationaliteit te ontnemen zijn een voorbeeld wan onderscheid tussen verschillende categorieën burgers (Section 40 BNA 1981). Cf. De Groot diss., p. 112. 
seerde het staatsburgerschap ook worden ontnomen indien hij zich binnen de DDR bevindt, terwijl de algemene ontneming ex $\$ 13$ in een dergelijk geval niet mogelijk is. Een genaturaliseerde DDR- staatsburger moet zich in ieder geval binnen vijf jaren ${ }^{29}$ na de naturalisatie "beter" gedragen dan degene, die deze nationaliteit van rechtswege verwierf.

Door Riege wordt echter ten aanzien van de inhoud van de nationaliteit niet van een abstract nationaliteitsbegrip uitgegaan, maar van "het socialistische staatsburgerschap" of zelfs specifieker, van de nationaliteit van de DDR. Het gaat derhalve steeds om de inhoud die in die landen aan het begrip "staatsburgerschap" wordt gegeven. Hij betoogt in dat verband dat de nationaliteit in de socialistische landen een andere inhoud heeft dan de nationaliteit in het Westen. Dit is inderdaad tot op zekere hoogte juist; er zijn rechten en plichten aan te wijzen die de burgers in het Westen wel hebben en in het Oosten niet en omgekeerd ${ }^{30}$. De consequentie die daaraan moet worden verbonden is echter niet, dat de nationaliteit als rechtsinstituut anders is, maar slechts precies hetgeen ik op p. 6-7 heb betoogd, namelijk dat de nationaliteit op zichzelf een koppelbegrip is waaraan door afzonderlijke staten, of een groep staten met bepaalde gemeenschappelijk kenmerken telkens andere rechtsgevolgen (kunnen) worden verbonden.

In de literatuur van de USSR wordt het begrip "nationaliteit" doorgaans in het algemeen omschreven als het "behoren" (prinadležnost) van een individu tot een staat, of als een juridische band (svjaz') ${ }^{31}$ tussen een individu en een staat. Cerničenko ${ }^{32}$ zegt hierover, dat de omschrijving als band wellicht wat preciezer is doch dat er tussen beide definities nauwelijks verschil bestaat. Door sommigen wordt de nationaliteit voorts ook als status, respectievelijk rechtstoestand ${ }^{33}$ omschreven. Door Rusinova ${ }^{34}$ tenslotte, wordt zelfs betoogd, dat de nationaliteit een objectief recht is. Indien we aan de hand van het staatsrechtelijk leerboek van Kravčuk een van de "standaardomschrijvingen" van de nationaliteit nader gaan beschouwen, kunnen we concluderen dat deze definitie evengoed in elk Westeuropees handboek zou kunnen wordlen gevonden:

"In der Staatsrechtwissenschaft wird unter die Staatsbürgerschaft gewöhnlich die rechtliche oder politisch- rechtliche Zugehörigkeit zu einem bestimmten Staate verstanden."135.

29. Herroeping van een naturalisatie is mogelijk binnen vijf jaren na de naturalisatie.

30. De mogellijkheid van vervangendle dienstplicht en het recht om het land te verlaten zajn twee rechten die de meeste Oosteuropese landen niet kennen. Aan de andere kant wordt recht op arbeid in Oost-Europa dikwijls grondwettelijk gewaarborgd, of bijvoorbeeld het recht op arbeiderszelfbestuur in Joegoslavië. Vele zogenaamde klassieke grondrechten die men in beide typen landen kent, hebben in Oost-Europa een andere (veel beperktere) inhoud. Zie bijvoorbeeld Van Rijn, De functic van de vrijheid vain meningsuiting in beide Duitse staten, diss, Maastricht 1985 .

31. Bojars, p. 24; Kulik, p. 3; Kozlova/Sevcov, p. 149; Kokevnikov, p. 272; Prochorov, p. 334; Zlatopol"skij, p. 245.

32. Cernicenko, p. 6 .

33. Zie bijwoorbeeld Lepeskin, p. 457.

34. Rusinova, Pravovedenie, $1962 / 4$ p. 47.

35. Kraviuk, p. 88. Zie ook: Tunkin, SGiP 1979/7, p. 22; Lomonosova, p. 174; Machnenko, p. 170; Safronov, p. 8; Vojevodin in Barabasev e.a, p. 155; Cernitenko, p. 5. 
Hier wordt derhalve uitgegaan wan een abstract algemeen nationaliteitsbegrip, waardoor het staatsburgerschap van elke willekeurige staat kan worden omschreven. In het vervolg van de definitie wordt er vervolgens op gewezen, dat een nadere concretisering van de mationaliteit afhankelijk is van het karakter van de staat:

"...Diese Charakteristik umreisst den allgemeinen Inhalt des Instituts der Staatsbürgerschaft. "Die soziale Natur und konkrete Inhalt des Instituts der Staatsbürgerschaft werden jedoch vom historischen Typ des jeweiligen Staates bestimmt."

Met het historisch type van een staat wordt bij Kravcuk uiteraard gedoeld op p. 9-10 beschreven, op de eigendom van productiemiddelen gebaseerde marxistische classificatie. Een gewolg hiervan is uiteraard, dat in de USSR evenals door Riege het "klassekarakter" van het nationaliteitsrecht wordt benadrukt.

De vralag of de rechten en verplichtingen van de burgers tot de inhoud van het begrip nationaliteit behoren, wordt in de USSR in het allgemeen niet met zoveel nadruk gesteld als door Riege in de DDR. Door sommigen wordt deze vraag zelfs uitdrukkelijk ontkennend beantwoord, zoals door Zlatopol'skij, die de nationaliteit duidelijk als voorwaarde ${ }^{36}$ voor de toekenning van rechten en plichten beschouwt:

"Het staatsburgerschap is geen recht of complex van rechten. Het staatsburgerschap is een noodzakelijke voorwaarde voor de bepaling van de juridische status van de burger, die de rechtsregels van een bepaalde staat naar hem toe trekt." ${ }^{37}$

In andere Oosteuropese landen wordt in de regel minder aandacht aan theoretische aspecten van de nationaliteit besteed dan in de DDR en de USSR. Door de auteurs worden veelal de in de USSR gangbare opvattingen gevolgd, waarin enige nuanceringen worden aangebracht ${ }^{38}$. In Roemenië heeft zich voorts tussen Draganu en Prisca een hevige discussie ontwikkeld over de "oude" vraag of de nationaliteit status of band is ${ }^{39}$. Interessant zijn de opvattingen van Blagojevic ${ }^{40}$ in Joegoslavië, die in zijn leerboek over het nationaliteitsrecht in 1947 bij de theoretische

36. De opvatting van Zlatopol'skij dat de mationaliteit een voorwaarde woor de toekenning van rechten en plichten is, komen we ook bij verschillende andere auteurs tegen. Kučcinskij, p. 7576; Procloorow, p. 334; Rusinova, Pravovedenie, p. 1962/4 p. 47; Sevcow, p. 22.

37. Zlatopol'skij, p. 244 , vertaling door mij, MT. Dat de rechten en plichten niet tot het begrip "nationaliteit" behoren wordt ook uitdrukkelijk gezegd door Kucinskij, p. 76: Lepeskin, p.. 457; Jampolskaja, p. 156; Kozlova/Sevcov, p. 183; Sevcov, p. 22. Anders echter Bojars, p. 27; Cernicenko, SGiP $1964 / 1$, p. 111.

38. Zie Spasov/Angelow, p. 450-451 (ook door then wordt de nationaliteit ook als aanknopingspunt beschouwd, zie p. 451) en Vulkanov, p. 187 voor Bulgarije; Bajăki, SGiP 1976/11, p. 80-86 en Social isticeskoe grazdanstvo-aktualnyje teoreticeskije " praktǐ̌skije problemy, Referaat gehouden in 1977 in Moskou, geciteerd naar Riege, p. 59, voor Hongarije; Ramus, p. 35-36; Ramus 1980, p. 9-24 en Seniuta, p. 36-75 voor Polen.

39. Draganu, Studlia Universitatis Babes Bolyai Series iurisprudentia 1968, p. 13-26; Prisca, Analele Universitatii Bucuresti, Stiinte Juridice 1970/1, p. 47-55.

40. Blagojevic, Drzavljanstwo s naroxitim obzirom na pravo FNRJ, 2e druk, Beograd 1947. 
beschouwingen in het geheel geen aandacht besteedt aan de vraag of de nationaliteit van een "socialistisch" land een aparte categorie is. De wijzigingen die de nieuwe machthebbers in 1945 in het bestaande nationaliteitsrecht hadden aangebracht ziet hij als een ontwikkeling van reeds bestaand recht zonder een duidelijke scheidslijn. Het is weliswaar zo dat Joegoslavië een aparte plaats tussen de Oosteuropese landen inneemt, maar in 1947 was dit land even orthodox communistisch als de USSR onder Stalin. In latere Joegoslavische literatuur wordt evenmin van een bijzonder "socialistisch" staatsburgerschap gesproken.

Resumerend kan worden gesteld dat de door Riege c.s. verdedigde opvatting dat de nationaliteit in het socialisme een geheel ander rechtsinstituut is dan in het kapitalisme (Staatsbürgerschaft versus Staatsangehörigkeit) door vele auteurs in Oost-Europa niet wordt gevolgd. Men gaat wan het bestaan van een abstract nationaliteitsbegrip uit, dat door verschillende groepen van staten op uiteenlopende wijze wordt ingevuld. Conform de marxistische rechtsopvatting wordt wel over het algemeen aangenomen, dat het nationaliteitsrecht in socialistische landen andere klasseninteresses dient dan in kapitalistische en dat het telkens door de belangen van de in een bepaald type maatschappij heersende klasse wordt bepaald.

De verklaring voor het feit dat in de DDR in vergelijking met de andere Oosteuropese landen buitengewoon veel aandacht wordt besteed aan de theoretische aspecten van de nationaliteit en dat Riege met zijn "materieller Staatsbürgerschaftsbegriff" zelfs een "nieuw" rechtsinstituut wil introduceren, moet worden gezocht in de specifieke positie waarin de nationaliteitsrechtswetenschap in de DDR zicht bevindt. De theorie van Riege moet naar mijn mening voornamelijk worden gezien als een middel in de strijd tussen het in de DDR verdedigde aparte bestaan van de nationaliteit van dit land en de in de BRD nagestreefde "gesamtdeutsche Staatsangehörigkeit" ${ }^{4}$. In de overige landen heeft men een dergelijke theoretische "oorlog" niet nodig.

\subsubsection{De functie van de nationaliteit}

Het is opvallend dat door Riege c.s. veel aandacht aan de bijzondere inhoud van de nationaliteit wordt besteed, terwijl over de functie van dit rechtsinstituut in socialistische landen nauwelijks wordt gesproken. Dit kan naar mijn mening worden verklaard door het feit dat de functie van de nationaliteit in Oost-Europa ook naar de opvatting van vele Oosteuropese auteurs in hoofdzaak op de afgrenzing van de kring onderdanen en een grond voor onderscheid tussen eigen staatsburgers en vreemdelingen neerkomt ${ }^{42}$. Daarnaast wordt in sommige Oosteuropese landen ${ }^{43}$ op de psychologische functie van de nationaliteit als "bindmiddel" tussen de staat en de burger zeer veel nadruk gelegd. Bijzonder ver is hierbij de Roemeense wetgever gegaan. De nationaliteitswet van dit land staat bol van hoogdravende pathetische frasen die- om met woorden van Luchterhandt ${ }^{44}$ te spreken- in een nationaalsocia-

41. Zo ook Luchterhandt, OER 1984, p. 133.

42. Zie Blagojevic 1947, p. 13; Cerny/Cervenka, p. 17; Kozlova/Ševeov, p. 149; Tunkin, SGiP 1979/7, p. 23.

43. Voornamelijk in de DDR, Roemeniê en de USSR.

44. Luchterhandt, OER 1984, p. 132. 
listische staatsverheerlijking zijn ontaard. Illustratief voor de tot het absurde gedreven psychologische functie van de nationaliteit is ook het "pleidooi" van Riege voor uiterste terughoudendheid met betrekking tot het ontslag uit de nationaliteit van de DDR:
"Wer aus der sozialistischen Staatsbürgerschaft aussscheidet, verlåsst damit das Kollektiv unserer Bürger. Diesem aber sind der Einzelne und sein Geschick durchaus nieht gleichgültig. Der Satz 'Wir sind ihn los, mag aus ihm werden, was will' hat in unserem Moralkodex keinen Platz. Es gilt die Antithese. Die sozialistische Gesellschaft verantwortet für ihre Mitglie- der". ${ }^{45}$

Een ander aspect van de psychologische functie van de nationaliteit komt tot uitdrukking in de opvatting dat het bezit, respectievelijk verlening van de nationaliteit als een "eer" dient te worden beschouwd. Zo bepaalt bijvoorbeeld art. 19 van de Roemeense nationaliteitswet van 1971:

"Jener, der sich vom Land lostrennt, seine Verpflichtung der Treue zum Vaterland verletzt, die Interessen des Volkes verrät, ... wird unwürdig den hohen Titel eines rumänischen Staatsbürgers zu tragen" ${ }^{46}$.

In de nationaliteitswet van de USSR van 1978 (art. 18) vinden we voorts de woorden:

"...den guten Ruf des Begriffes eines UdSSR Bürgers".

In de nationaliteitswet van de DDR wordt als voorwaarde voor naturalisatie gesteld dat de verzoeker zich:

" der Verleihung der Staatsbürgerschaft der DDR würdig erweist" ( $\$ 7$ lid 1).

Aangetekend dient te worden dat ook in sommige Westerse landen het bezit, respectievelijk verlening van een nationaliteit als een "eer" wordt beschouwd ${ }^{47}$. Zo werd bij de totstandkoming van de Rijkswet op het Nederlanderschap de oorspronkelijk voorgestelde naturalisatie bij ministerieel besluit vervangen door verlening van de nationaliteit bij koninklijk besluit. De motivering voor deze wijziging was, dat de naturalisandi het meer op prijs zouden stellen indien het Nederlanderschap hen door de Koning(in) zou worden verleend ${ }^{48}$.

Art. 18 van het uit 1986 daterende voorontwerp voor een ingrijpende herziening van de Zwitserse nationaliteitswet ${ }^{49}$ bepaalt, dat een verzoeker kan worden gehernaturaliseerd indien hij:

45. Riege, Wissenschaftliche Zeilschrift Jena 1965, p. 568. Ook geciteerd door Luchterhandt, OER 1984 , p. 141.

46. Vertaling ontleend aan Bergmann/Ferid, p. 9.

47. Anders De Groot diss, p.14, die deze opvatting in West-Europa reeds tot het verleden rekent.

48. Bijlagen Handelingen TK 1981-82, 16947, nr. 7, p. 22. Zie daarower De Groot/Tratnik, p. 82-83.

49. Voorontwerp van 21 april 1986 , geciteerd bij De Groot diss., p. 173. 
"...nicht die Wiedereinbürgerung offensichtlich unwürdig ist".

In Section 40 van de British Nationality Act (BNA) van $1981^{50}$ wordt bepaald dat aan een genaturaliseerde Brit de nationaliteit kan worden ontnomen indien hij binnen 5 jaar na de naturalisatie tot een vrijheidsstraf van meer dan én jaar wordt veroordeeld. Het Spaanse nationaliteitsrecht kent voorts ten aanzien van Spanjaarden die van niet Spaanse afstamming zijn, ontneming van de nationaliteit door de rechter als strafsanctie ${ }^{51}$.

De opvatting dat het bezit van de nationaliteit van een socialistisch land een onderscheiding is, zou zich logischerwijs moeten weerspiegelen in zeer selectieve gronden voor verkrijging van de nationaliteit en in vele mogelijkheden om deze nationaliteit te verliezen. Ook zou men kunnen verwachten dat bij strafrechtelijke veroordelingen wegens zware misdrijven de nationaliteit in de regel zou kunnen worden ontnomen. Door Riege ${ }^{52}$ wordt kennelijk met het oog op het feilt dat de regelingen van verkrijging en verlies van de nationaliteit in de DDR niet aan deze verwachting beantwoorden, er op gewezen dat niet slechts diegene staatsburger kan worden, respectievelijk blijven, die aan de verwachtingen die de socialistische maatschappij stelt, beantwoordt. Ook diegenen kunnen staatsburgers zijn die zulks niet waard zijn. De nationaliteit zou met betrekking tot hen een educatieve functie hebben. Consequent is hij hierbij echter niet. Op een andere plaats in hetzelfde boek ${ }^{53}$ betoogt hij namelijk, dat slechts diegenen voor naturalisatie in aanmerking kunnen komen, die zich: "die Verleihung würdig erweisen". Op dezelfde plaats spreekt hij voorts over de "Status" die verlening van de (DDR-) nationaliteit zou hebben.

\subsection{ENIKELE BESCHOUWINGEN MET BETREKKING TOT DE VERGELIJBAARHEID VAN RECHTSINSTTIUTEN}

\subsubsection{Inleiding}

De vraag van vergelijkbaarheid van twee rechtsinstituten of rechtsstelsels is het eerste methodologisch vereiste voor rechtsvergelijkend onderzoek ${ }^{54}$. De vergelijkbaarheid ligt in de aanwezigheid van tenminste éen gemeenschappelijke noemer van de te vergelijken objecten, die het "tertium comparationis" wordt genoemd ${ }^{55}$. Wanneer we van deze voorwaarde uitgaan, zal vrijwel steeds kunnen worden geconstateerd dat er vergelijkbaarheid aanwezig is. Deze vergelijkbaarheid in abstracto mag niet worden verward met de tweede methodologische vraag die naar mijn mening steeds moet worden gesteld: is een vergelijking in concreto zinvol? Men kan bijvoorbeeld een boek met een appel vergelijken maar verder dan de constatering dat beide roerende goederen ziji (als de appel tenminste reeds geplukt is), kan het zoeken naar overeenkomsten tussen beide voorwerpen niet komen. Of een vergelijking zinvol is moet aan de hand van het doel van de

50. British Nationality Act 1981 (Commencement) Order 1982, Statutory Instrument 1982/933.

51. Art. 24 Código civil (C.c. esp.) jo. artt. 27, 34, en 141 Código penal.

52. Riege, p. 99.

53. Riege, p. 305 .

54. Kokkini-Iatridou, p. 129.

55. Kokkini-Iatridou, p. 129. 
vergelijking worden bepaald. Het doel van een vergelijking $k$ an zeer verschillend zijn. Zo kan bijvoorbeeld het doel zijn aan te tonen dat in twee landen een rechtsinstituut met dezelfde naam een geheel andere inhoud heeft. Doel van een vergelijking kan ook zijn verschillen tussen bepaalde rechtsstelsels op een rechtsgebied te inventariseren. Ook kan doel van een rechtsvergelijking zijn inspiratie voor verbetering van het eigen rechtsstelsel te vinden. Met betrekking tot de twee eerstgenoemde doelstellingen kan vrijwel steeds worden gezegd dat een vergelijking zinvol is, tenzij de verwachte verschillen uiteraard miniem blijken te zijn. De zwaarste vereisten gelden echter voor een vergelijking tussen twee rechtsinstituten met het doel het eigen recht te verbeteren. De vraag of de voorgenomen vergelijking zinvol is, is dan in de eerste plaats afhankelijk van de functie van de te vergelijken rechtsinstituten in beide rechtsstelsels ${ }^{56}$. Voorts is het van belang of de wetgevers in de te vergelijken landen bij de regeling van het desbetreffende onderwerp dezelfde doelen voor ogen stonden. Een regeling van verwijzingsregels met betrekking tot het huwelijksgoederenregime in het IPR heeft in alle landen de functie collisies tussen verschillende stelsels op te lossen. Het doel van de wetgever in het ene land kan daarbij zijn de partijen zoveel mogelijk keuzevrijheid te geven, terwijl in een ander land men bijvoorbeeld zo vaak mogelijk het eigen recht van toepassing wil verklaren. Zou een jurist van het eerste land zijn eigen regeling willen verbeteren, dan zou het weinig zinvol zijn dit aan de hand van het recht van het andere land te doen.

\subsubsection{Intersystemaire rechtsvergelijking}

De vraag of het mogelijk is het recht van landen met verschillende politieke en economische systemen te vergelijken werd in West-Europa voor de eerste keer aan de orde gesteld door Loeber in $1961^{57}$. Zijn conclusie was dat een dergelijke vergelijking mogelijk is en dat deze zelfs vruchtbaar kan zijn. Dit is echter volgens hem sterk afhankelijk van de "Systembezogenheit" van het te vergelijken rechtsinstituut. Daaronder verstaat hij gebondenheid van een rechtsinstituut aan het politieke en economische systeem in dat land. Zo maakt hij onderscheid tussen "systembezogen, systemneutrale en pseudosystembezogen" rechtsinstituten ${ }^{58}$. De vergelijkbaarheid is naar zijn opvatting omgekeerd evenredig met de mate van systeemafhankelijkheid van het te vergelijken rechtsinstituut. Later hebben zich ook vele andere Westerse comparatisten met de onderhavige problematiek bezig gehouden. De meningen van verschillende schrijvers komen op tenminste éen punt overeen. Vergelijking tussen rechtsstelsels met verschillende politieke en economische systemen is in beginsel mogelijk. Ten aanzien van de vraag op welke niveaus en in

56. Bogdlan, CLY 1978, p. 93; Zweigert/Kötz I, p. 48; Drobnig, RabelsZ 1984, p. 240.

57. Loeber, RabelsZ 1961, p. 201-229.

58. Als voorbeelden van "systemberogen" rechtsinstituten geeft hij de eigendom en overeenkomsten; als "systemneutral" ziet hij bijvoorbeeld het verkeersrecht. Tot "pseudosystembezogen" rekent hij het personen-, familie-- en erfrecht. De regelingen van deze laatste rechtsgebiedem vertonen namelijk vele overeenkomsten met het "westerse" recht hoewel dit door de doctrine in OostEuropa met klem wordt ontkend. Loeber, RabelsZ 1961, p. 226. 
hoeverre een zinvolle vergelijking mogelijk is, zijn de meningen echter sterk verdeeld ${ }^{59}$.

In de oudere Oosteuropese literatuur werd de vergelijkbaarheid echter consequent afgewezen. Eén van de belangrijkste vertegenwoordigers van deze opvatting is Knapp ${ }^{60}$ die van op de marxistische rechtsleer steunende kwalitatieve onderscheid tussen "kapitalistisch" en "socialistisch" recht uitgaande elke vergelijkbaarheid uitsloot. Later "ontdekten" verschillende Oosteuropese schrijvers dat de intersystemaire rechtsvergelijking een geschikt middel kan zijn, om de door hen verdedigde superioriteit van het "socialistische" recht aan de hand van voorbeelden uit het "kapitalistische" recht te onderbouwen. Dit kan treffend worden geilllustreerd met de woorden van Romaškin:

"Die sowjetischen Juristen, die... an der Arbeit von Organisationen auf dem Gebiet der vergleichende Rechtswissenschaft teilnehmen, müssen die sowjetischen Konzeptionen äussern und vertreten, den Vorzug des Sowjetrechts als das Recht des höchsten historischen Typus aufzeichnen, nicht aber Gemeinsamheiten im sozialistischen und bourgeoisen Recht feststellen (was bei uns leider mitunter vorgekommen ist) ${ }^{461}$.

Conform deze "Opgave" gaan Čikvadze en Zivs in de Sovjetunie en Szabó in Hongarije weliswaar van vergelijkbaarheid uit, echter met het doel om de verschillen en superioriteit van het eigen recht aan te tonen ${ }^{62}$. Met betrekking tot het nationaliteitsrecht wordt deze, zogenaamde "präjudizierte Rechtsvergleichung" voornamelijk door Riege bedreven ${ }^{63}$.

Door verschillende Oosteuropese juristen en zelfs door $S z a b 6$ in zijn latere publicaties wordt de vraag van vergelijkbaarheid echter bevestigend beantwoord. De intersystemaire rechtsvergelijking wordt door hen niet slechts als middel voor ideologische doeleinden misbruikt ${ }^{64}$. Dikwijls komt het echter ook voor dat Oosteuropese schrijvers die hun eigen recht met het recht van Westerse landen gaan vergelijken de theoretische "gewetensvraag" van vergelijkbaarheid omzeilen door deze gewoon niet te stellen. Voorts komt het voor dat men in Oost-Europa bij de voorbereiding van een nieuwe codificatie ook het recht van de Westerse landen "stiekem" als voorbeeld neemt, maar dit wordt in de regel dan niet

59. Zie voor verwijzingen naar verschillende meningen Kokkini-latridou preadvies, p. 22-23; Drobnig, RabelsZ 1984, p. $234-235$.

60. Knapp, RabelsZ 1962/63, p. 495-518. Zo ook Luby, Právni obzor 1970, p. 3-21; Bystricky, Právnik 1962 , p. 634; Stargardt, p. 25.

61. Romaśkin, referaat over de opgaven van het Juridische instituut van de Academie van Wetenschappen van de USSR in het licht van besluiten van het 2liste congres van de CP der USSR, gehouden voor de wetenschappelijke raad van dit instituut in maart 1959 (vertaling van Loeber, RabelsZ 1961, p. 201). Zie ook het bericht van Pankratov in SGiP 1959/7, p. 144.

62. Cikvadze/Zivs in SGiP 1966/2, p. 12-20; Zivs in SGiP 1964/3, p. 23-35; Szab6, Acta juridica 1977, p. 177. Zie voorts ook Grahn, p. 31 en iets relativerend Arlt, p. $48-49$ voor de DDR.

63. Riege, Die Staatsbürgerschaft der DDR, 2e druk, Jena 1986.

64. Blagojevic methode, p. 36; Grzybowsky, p. 331; Popescu, Revue Roumaine 1974, p. 70; Scab6, Acta juridica 1973, p. 131-141 en Szab6/Péteri (red.) A Socialist. Approach to Comparative Law, Leiden/Budapest 1977. Zo cok Cadere, RIDC 1971, p. 852; Eörsy, RIDC 1967, p. 410; Neumann, p. 65 ; Péteri, p. 22. 
toegegeven ${ }^{65}$. In Hongarije werd ten aanzien van de civielrechtelijke codex van 1959 zelfs uitdrukkelijk toegegeven, dat men ook in de Westerse codificaties inspiratie had gezocht ${ }^{66}$. Illustratief in dit verband zijn ook de woorden van Cigoj in Joegoslavie in zijn handboek van verbintenissenrecht, waar zeer vele werwijzingen naar het recht wan andere, ook Westeuropese landen worden opgenomen:

\begin{abstract}
"This book was written at a time in which a new civil code for Yugoslavia was in preparation. Therefore the author looked for the best possible way to regulate... the particular branches of the law of obiigations. In order to achieve these goals the systems of other countries are compared in particular respects to the Western European (including the anglo-saxon) codes as well as codes from Eastern Europe..." ${ }^{67}$.
\end{abstract}

Uitgaande van de hierboven, op p. 17 omschreven eerste voorwaarde voor vergelijkbaarheid kan zonder meer worden vastgesteld dat indien men een rechtsinstituut in een kapitalistisch en in een socialistisch land wil vergelijken, er steeds een gemeenschappelijk noemer, een "tertium comparationis" kan worden gevonden. Anders is het met de vraag of een dergelijke vergelijking zinvol is. Men moet gaan onderzoeken of de functie van de te vergelijken rechtsinstituten dezelfde is. Dit is reeds de eerste moeilijkheid die bij intersystemaire rechtsvergelijking optreedt. In de Oosteuropese landen wordt dikwijls met betrekking tot rechtsinstituten die ze uit de "burgerlijke periode" hebben geërfd, betoogd dat ze een geheel andere inhoud en functie hebben. Ter ondersteuning van dit standpunt worden zelfs de meest absurde voorbeelden gegeven. Zo werd door Luby in Tsjechoslowakije betoogd dat verkeersregels in socialistische landen andere klasseninteresses dienen dan in het Westen en derhalve niet vergelijkbaar zijn ${ }^{68}$. Een goed voorbeeld van een rechtsgebied dat in de Oosteuropese landen niet wezenlijk anders is, maar dat in Oost-Europa kunstmatig ideologisch geladen wordt, is het familierecht ${ }^{69}$. Een leuke illustratie is de reactie van David hierop:

"Quand j'ai vu des familles socialistes- car on m'a fait l'honneur et le plaisir de m'inviter dans des familles socialistes- j'avoue qu'a certains moments, je me ne suis senti dans un milieu tellement étranger et je n'ai pas observé des comportements qui opposent, d'une maniere très nette, la famille socialiste aux familles françaises et dites capitalistes qui me sont plus familières!" 70

Deze opvatting kan ik zonder meer onderschrijven en ik heb "des familles socialistes" niet slechts bezocht. Zo zijn er ook vele andere onderwerpen aan te wijzen waarop het recht in het Oosten en het Westen vele gemeenschappelijke kenmerken vertoont.

65. Loeber, RabelsZ 1961, p. 212.

66. Revue de droit hongrois $1960 / 2$, p. 169.

67. Cigoj, p. 1227.

68. Luby, Pränny obzor 1970, p. 16-17.

69. Zo ook Loeber, RabelsZ 1961, p. 226; Bogdan, CLY 1978, p. 97.

70. David in Livre, p. 155. Ook geciteerd bij Bogdan, CLY 1978, p. 97. 
Het zou derhalve niet juist zijn aan de hand van de opvattingen van Oosteuropese auteurs a priori van vergelijking af te zien. We moeten namelijk niet uit het oog verliezen dat Oosteuropese juristen in de reeds genoemde "ideologische kooi" zitten. Het toegeven dat een bepaald rechtsinstituut in een socialistisch land niet anders is, zou namelijk onvermijdelijk negatie van superioriteit van hun rechtsstelsel impliceren ${ }^{71}$. Er zijn weinige Oosteuropese juristen die zich een dergelijke stelling kunnen permitteren. De inhoud en functie van een te onderzoeken rechtsinstituut kan zeer dikwijls pas na de bestudering van dat instituut worden vastgesteld, derhalve op het ogenblik dat de rechtsvergelijker al halverwege zijn studie is. Voorts is het mogelijk dat een bepaald rechtsinstituut verschillende functies heeft. Voor een zinvolle vergelijking is het geenszins vereist dat alle functies van het rechtsinstituut overeenstemmen. Verschillen met name ten opzichte van nevenfuncties, kunnen gemakkelijk worden verwaarloosd.

Concluderend kan worden gesteld dat intersystemaire rechtsvergelijking naar mijn mening zeer zeker mogelijk en niet zelden zinvol is. Het ware derhalve wenselijk dat zich meer Westerse juristen daarmee bezig zouden houden. Het feit dat vele Oosteuropese juristen zich om ideologische redenen alle mogelijke moeite troosten om totaal verschillende uitgangspunten van het recht van beide politieke systemen te accentueren, heeft echter het uitzicht op het recht van de landen vanuit West-Europa vertroebeld. De slechte toegankelijkheid van slavische talen heeft hen hierbij veel geholpen. De volgende woorden die ik van Bogdan leen zouden naar mijn mening bij de intersystemaire rechtsvergelijking als richtsnoer moeten dienen:

"The question whether there are common principles of socialist and Western law cannot in my view be answered on the basis of theoretical dogmas but only on the basis of factual comparison between socialist and Western legal systems. Such comparison shows many amazing similarities, at least in the fields of law which in the Romano-Germanic legal systems are called private law. It would, sometimes, be fruitful for the comparatists to confront their theoretical conclusions with the common sense of the legally uneducated tourists." 72

\subsubsection{Intersystemaire rechtswergelijking op het gebied van het nationaliteitsrecht}

Met betrekking tot het nationaliteitsrecht, in het bijzonder tot regels betreffende verkrijging en verlies van de nationaliteit is naar mijn mening een intersystemaire rechtsvergelijking zonder meer mogelijk en kan ook zinvol zijn ${ }^{73}$. Is intersystemaire rechtsvergelijking op het gebied van nationaliteitsrecht zinvol indien het doel daarvan is inspiratie voor verbetering van Nederlands recht te zoeken? Deze vraag wordt door De Groot met verwijzing naar de andere functie die de nationaliteit in Oost-Europa zou hebben, ontkennend beantwoord ${ }^{74}$. Deze stelling is naar mijn

71. Zie ook Bogdan, CLY 1978, p. 98.

72. Bogdan, CLY 1978, p. 109-110.

73. Zo ook De Groot diss., p. 5 .

74. De Groot diss., p. 3-4, 5. Deze stelling wordt hoofdzakelijk gesteund op een passage uit art. 18 van de nationaliteitswet van de USSR. Zie p. 369 , noot 24 . 
mening echter veel te ongenuanceerd. Het moge zo zijn dat in enkele Oosteuropese landen op de psychologische functie van de nationaliteit meer nadruk wordt gelegd dan in het Westen ${ }^{75}$, doch in de Westerse landen zijn evengoed voorbeelden van de "onderscheidende" functie van het staatsburgerschap te vinden ${ }^{76}$. De primaire functie van de nationaliteit is echter het maken van een afgrenzing tussen eigen onderdanen en vreemdelingen. Deze functie heeft de nationaliteit zowel in Oost- als in West-Europa. Een eventuele nevenfunctie, bijvoorbeeld dat de staat de burger probeert te overtuigen dat verlening van de desbetreffende nationaliteit een eer is, maakt een vergelijking echter niet bij voorbaat onzinnig. Het zou echter anders zijn, indien men een regeling van verlening van de nationaliteit "honoris causa" die uitsluitend de functie van een eretitel heeft, met een regeling van "gewone naturalisatie" zou gaan vergelijken. In een dergelijk geval is de functie inderdaad verschillend en zou een vergelijking weinig vruchten opleveren. Echter het feit dat de functie van de nationaliteit in Nederland en in de Oosteuropese landen grosso modo dezelfde is, betekent niet dat vergelijking met het doel het eigen recht te verbeteren altijd zinvol is. Om deze vraag te beantwoorden, moet nagegaan worden inhoeverre de doelstellingen die door de wetgever met betrekking tot het object van vergelijking in het te bestuderen Oosteuropese land dezelfde zijn als men in Nederland bij het ontwerpen van de regeling van hetzelfde onderwerp voor ogen had. Indien bijvoorbeeld vastgesteld wordt dat bij de regeling van verkrijging van nationaliteit iure sanguinis in het te vergelijken land evenals in Nederland gelijkstelling van mannen en vrouwen en het voorkomen van meervoudige nationaliteit de doelstellingen van de wetgever waren ${ }^{n}$, dan moet geconcludeerd worden dat een dergelijke vergelijking zinvol is. Indien we in beschouwing nemen dat deze doelstellingen in de Sovjetunie reeds sedert 1918 en in de rest van OostEuropa sedert ongeveer 1950 in de nationaliteitswetgeving worden nagestreefd, terwijl men in Nederland dit pas sedert $1976^{78}$ doet, moet gezien de grote ervaring die men in Oost-Europa op dit gebied heeft, een dergelijke vergelijking zelfs een hoge prioriteit genieten. Geheel anders zou het zijn indien men met hetzelfde doel de regellingen van de naturalisatie in Oost-Europa met die in Nederland zou willen gaan vergelijken. Terwijl men hier te lande ernaar gestreefd ${ }^{79}$ heeft om naturalisatie als een recht van de verzoeker te kwalificeren, wordt in Oost-Europa een dergelijk recht met de grootste stelligheid ontkend. Vergelijking zou dan uitsluitend zinvol zijn om vast te stellen hoe de Nederlandse regeling van de naturalisatie in ieder geval niet mag zijn.

75. Dit geldt zeer zeker woor Roemenië, de DDR en de USSR. Mij werd echter nooit verteld dat het bezit van de Joegoslavische nationaliteit een eer is, hoewel ik tot mijn 25 ste jaar daar heb gewoond.

76. Zie voor voorbeelden p. 15-16. Het heffen van naturalisatiegelden (zie bijvoorbeeld art. 13 RwNed) wordt trouwens door De Groot diss, p. 269, ook gezien als een mamifestatie van de functie van verlening van de nationaliteit als een onderscheiding.

77. Zie de MvT, Bijlagen Handelingen TK 1981-82, 16947 nr. 3-4. Zie ook De Groot/Tratnik, p. 6062; De Groot diss, p. 127.

78. Zie de mededeling in Stert. 1976,256 , betreffende een voorontwerp voor het huidige RwNed. Gepubliceerd als bijlage van Het Personeel Statuut (HPS) 1977. De tekst werd eveneens afgedrukt bij De Groot preadvies, p. 100-107. Zie ook De Groot, NJB 1975, p. 782-787.

79. Het is overigens bij cen streven gebleven. Zile voor een kritisch commentaar De Groot/Tratnik p. 107. 
Reeds in de inleiding werd gesteld dat het doel van het voorliggend onderzoek onder meer is, de overeenkomsten en verschillen tussen de regelingen van verkrijging en verlies van de nationaliteit in Nederland en de andere Westeuropese landen enerzijds en in de Oosteuropese landen anderzijds te inventariseren, alsmede incidenteel inspiratie voor verbetering van het Nederiands recht te zoeken. Ten aanzien van deze doelstellingen kan gezien het bovenstaande worden geconcludeerd, dat aan beide methodologische voorwaarden is voldaan. De regelingen van verkrijging en verlies van de nationaliteit hebben reeds op grond van hun functie voldoende gemeenschappelijke kenmerken om vergelijkbaarheid aan te nemen en tevens te constateren dat een vergelijking zinvol is. 


\subsection{INLEIDING}

In dit boek worden de regelingen van verkrijging en verlies van de nationaliteit van negen verschillende Oosteuropese landen besproken. Een eerste voorwaarde voor een overzichtelijke bespreking van het recht van zoveel landen is dat in al deze regelingen bepaalde "gemene delers" kunnen worden gevonden, die de structuur van de landenbeschrijvingen zullen dragen. Aan de andere kant moeten deze "structurele pijlers" ook voor het Nederlandse publiek voldoende houvast bieden om de beschrijvingen te kunnen volgen. Met het oog op deze doeleinden werd voor de indeling van de stof in "wijzen" van verkrijging en verlies gekozen. Deze indeling is ten aanzien van verkrijging van de nationaliteit dezelfde als de Nederlandse wetgever met betrekking tot de RwNed hanteert. De besprekingen van de afzonderlijke nationaliteitswetten wordt zo onderverdeeld in: verkrijging van rechtswege, verkrijging door optie en verkrijging door naturalisatie. Met betrekking tot het verlies van de nationaliteit wijkt mijn indeling van de stof van de RwNed af. De reden daarvoor is dat de Nederlandse wetgever zijn tot art. 13 gevolgde systematiek losliet ${ }^{1}$. Gezien het feit dat de afwijking in RwNed naar mijn mening niet consequent en systematisch is ${ }^{2}$, worden besprekingen van de nationaliteit in het voorliggend werk onderverdeeld in verlies van rechtswege, door afstand, ontslag en ontneming. Deze keuze lijkt mij des te meer voor de hand liggend aangezien de wijzen van verkrijging en verlies van de nationaliteit voor een zeer groot gedeelte elkaars spiegelbeelden vormen.

Wie zou verwachten dat de termen verkrijging en verlies van rechtswege, optie, afstand, naturalisatie, ontslag en ontneming in alle nationaliteitswetten van de besproken rechtsstelsels dezelfde betekenis hebben, komt bedrogen uit. Om deze reden is het noodzakelijk om een verklaring voor de in dit werk gehanteerde terminologie te geven, alsmede alle wijzen van verkrijging en verlies van de nationaliteit die in de verschillende landen uiteenlopende etiketten dragen, in de in dit boek gehanteerde "hokjes" te plaatsen.

Allereerst zullen enkele algemene opmerkingen worden gemaakt ten aanzien van de termen "wijze" en "grond" voor verkrijging, respectievelijk verlies van de nationaliteit. In de literatuur wordt tussen beide begrippen dikwijls geen scherp onderscheid gemaakt. Het verschil tussen beide termen kan aan de hand van art. 3 lid 1 van de Nederlandse nationaliteitswet (RwNed) worden verklaard. Daarin wordt bepaald, dat een kind van hetzij een Nederlandse moeder, hetzij een Nederlandse vader Nederlander is. De nationaliteit wordt in dat geval van rechtswege, enkel en alleen vanwege het feit dat de RwNed aan geboorte uit tenminste éen Nederlandse ouder verwerving van de nationaliteit koppelt, verkregen. Verkrijging van rechtswege is derhalve een wijze waarop het Nederlan-

1. In de RwNed wordt in hoofdstukken 2,3 en 4 verkrijging van rechtswege, door optie en naturalisatie geregeld, terwijl de gehele regeling van verlies van het Nederlanderschap in hoofdstuk 5 staat.

2. En derhalve wordt een nevenschikking tussen verkrijging van rechtswege, door optie en naturalisatie en het verlies wan de nationaliteit gemaakt. 
derschap wordt verkregen. De grond voor deze verkrijging, de reden waarom de wetgever dit heeft bepaald, is het feit dat het kind in ons voorbeeld van een Nederlandse ouder afstamt, het zogenaamde ius sanguinis (a patre et a matre). Afstamming van een Nederlandse ouder is derhalve een grond voor verkrijging van het staatsburgerschap.

\subsection{VERKRUGING VAN DE NATIONALTTET}

Indien we nationaliteitsrechtelijke regelingen van verschillende landen onder de loep nemen, kunnen verschillende wijzen van verkrijging van de nationaliteit worden geconstateerd. Elk land kent in ieder geval twee wijzen, namelijk de verkrijging van rechtswege en door verlening, ook wel naturalisatie genoemd. Daarnaast komt men nog verschillende andere wijzen tegen die in wezen steeds een hybride vorm tussen de twee "hoofdwijzen" van de verkrijging van de nationaliteit betekenen. Meestal wordt dan over verkrijging door optie gesproken. Reeds op deze plaats zij er op gewezen dat aan het begrip "optie" in verschillende landen diverse inhoud wordt gegeven. Vanwege het hybride karakter van optie zal deze wijze van verkrijging in afwijking van de structuur die bij beschrijving van het nationaliteitsrecht van afzonderlijke landen wordt gevolgd, in dit hoofdstuk achter verkrijging van de nationaliteit van rechtswege en door naturalisatie worden besproken.

\subsubsection{Verkrijging van rechtswege}

\subsubsection{Het begrip}

Van verkrijging van de nationaliteit van rechtswege is sprake, wanneer aan bepaalde rechtsfeiten die zich in het leven van een persoon voordoen, automatisch verkrijging van de nationaliteit van een staat wordt gekoppeld. Kenmerkend voor deze verkrijging van de nationaliteit in haar zuiverste vorm is, dat de nationaliteit geheel onafhankelijk van de wil van de betrokkene en van de staat waarvan de nationaliteit wordt verkregen, wordt verworven. Meestal wordt verkrijging van de nationaliteit van rechtswege gekoppeld aan geboorte uit onderdanen van een staat (ius sanguinis) of aan geboorte op het grondgebied van een staat (ius soli). Ook aan andere feiten kan verkrijging van de nationaliteit van rechtswege worden verbonden, bijvoorbeeld aan een verblijf in een land van een bepaalde duur ${ }^{3}$ of aan het feit dat een vrouw niet binnen een bepaalde tijd na het sluiten van een huwelijk met een onderdaan van het desbetreffende land verklaart dat ze die nationaliteit niet wil verwerven ${ }^{4}$. Door sommigen wordt in dergelijke gevallen verdedigd dat het om een verkrijging door de wil van betrokkene gaat aangezien deze een uiterst minieme mogelijkheid heeft de verkrijging van die nationaliteit te voorkomen ${ }^{5}$. In dergelijke gevallen wordt ook gesproken van een "negatieve optie" ${ }^{\text {". Naar mijn }}$

3. Art. 5 lid 2 van de Toescheidingsovereenkomst tussen Nederland en Suriname, Trb. 1975, 132; \$2 29 van het Oostenrijkse ABGB van 1811 .

4. Zie bijvoorbeeld art, 4 van de Belgische nationaliteilswet (BNW) van 1932.

5. Brinkman, p. 66.

6. Zie bijvoorbeeld Geilke, in SGS deel 9, p. 35, met betrekking tot een vergelijkbaar geval, geregeld in art. 8 van de Poolse nationaliteitswet van 1951. Zie daarover ook boofdstuk Polen, p. 245. 
mening wordt in deze gevallen het staatsburgerschap van rechtswege verworven? In de eerste plaats is de wil van betrokkene in een dergelijk geval gericht op een ander rechtsfeit: het sluiten van een huwelijk, woonplaats in een bepaald land, etc. Van de nationaliteitsrechtelijke gevolgen van een dergelijke stap is men zich in de regel niet bewust. In de tweede plaats gaat het in dergelijke gevallen om uiterst korte, objectief gestelde wervaltermijnen ${ }^{8}$, zodat het zeer dikwijls voorkomt dat de betrokkene pas op de hoogte van zijn weigeringsmogelijkheid wordt gesteld indien deze termijn reeds verstreken is.

Strikt genomen is van verkrijging van rechtswege eveneens sprake, in geval dat een ouder in een land wordt genaturaliseerd en zijn minderjarige kinderen automatisch in die naturalisatie worden inbegrepen (art. $11 \mathrm{RwNed}$ ). Om wille van de overzichtelijkheid zullen deze gevallen echter steeds bij de naturalisatie worden besproken.

\subsubsection{Gronden voor verkrijging van rechtswege}

De in de continentale rechtsstelsels het voorkomende grond voor verkrijging van de nationaliteit van rechtswege, het feit dat een kind van een onderdaan van het desbetreffende land afstamt, werd reeds in $\$ 1$ van dit hoofdstuk genoemd. In verreweg de meeste gevallen wordt de nationaliteit op deze grond reeds op het tijdstip van de geboorte van het kind verkregen. Noodzakelijk is dit echter niet. Zo verkrijgt een kind van een vreemdelinge, dat door een Nederlander wordt erkend, de Nederlandse nationaliteit pas op het moment van erkenning en dat slechts indien het op dat tijdstip nog minderjarig is (art. 4 lid 1 RwNed). Was de vader van het kind echter met de moeder gehuwd, dan zou hetzelfde kind op grond van art. 3 lid 1 reeds bij zijn geboorte Nederlander worden. In beide gevallen is de grond voor verkrijging het feit dat het kind van een Nederlandse ouder afstamt. Anders is het bij adoptie. Terwijl degene die een kind erkent in de regel ook de (biologische) vader van het kind is, gaat het bij adoptie om vestiging van familierechtelijke betrekkingen tussen ouders en kinderen buiten de afstamming om. Dit is ook de reden dat nationaliteitswetten van vele landen aan adoptie geen nationaliteitsrechtelijke gevolgen van rechtswege toekennen?

Aangetekend zij dat er aan een regeling met betrekking tot verkrijging van de nationaliteit van rechtswege dikwijls niet slechts éen maar een combinatie van verschillende gronden ten grondslag ligt. Dit kan worden geillustreerd aan de hand van een tweede, zeer dikwijls voorkomende grond voor verkrijging van de nationaliteit, namelijk het feit dat het kind op het grondgebied van de desbetreffende staat werd geboren, het zogenaamde ius soli. Deze grond impliceert in de regel tevens toepassing van een andere grond, namelijk het feit dat tenminste de moeder

7. In ongeveer dezelfde richting dienkt ook De Groot, die op verschillende plaatsen betoogt dat in een dergelijk geval niet van wrijwillige verkrijging van de nationaliteit kan worden gesproken. De Groot losbl. ed., commentaar bij art. 15 sub a RwNed; noot onder HR van 5 juni 1987, NJ 1988, 134.

8. Zes maanden in het reeds genoende voorbeeld van de Belgische nationaliteitswet van 1932; Cén maand in art. 8 van de Poolse nationaliteitswet van 1951. Thans bedraagt deze termijn in Polen 3 maanden (art. 6 van de wet van 1962).

9. Door Hecker, StAZ 1985, p. 153-163 werd een overzicht van de adoptie betreffende nationaliteitsrechtelijke regelingen van 175 landen gegeven. 
van het kind in het desbetreffende land woont, het ius domicilii. De meeste moeders bevallen immers in het land waarin ze woonachtig zijn. Typerend voor hedendaagse continentale rechtsstelsels is, dat het feit van geboorte in het land op zichzelf niet als een toereikende grond voor verkrijging van de nationaliteit ipso iure wordt beschouwd. Het kind verkrijgt in de regel slechts de nationaliteit indien het anders staatloos zou zijn ${ }^{10}$. Het gaat hierbij derhalve tevens om een andere grond voor de verkrijging van de nationaliteit, namelijk de wens van een wetgever om in het algemeen ongewenste apatridie te voorkomen. De Franse nationaliteitswet bijvoorbeeld, combineert in een bepaald geval het ius soli met het inschrijven van betrokkene voor de militaire dienst (art. 48).

Het raadplegen van nationaliteitswetten van verschillende landen levert nog verschillende andere gronden voor verkrijging van de nationaliteit van rechtswege op, bijvoorbeeld huwelijk met een onderdaan van Monaco ${ }^{11}$, benoeming tot hoogleraar in Oostenrijk ${ }^{12}$.

\subsubsection{Naturalisatie}

\subsubsection{Het begrip}

Naturalisatie is een wijze van verkrijging van de nationaliteit, waarbij aan degenen, die aan bepaalde vereisten voldoen, door een overheidsorgaan op hun eigen verzoek de nationaliteit wordt verleend. Anders dan bij een zuivere optie werkt de beschikking van het overheidsorgaan constitutief. In de literatuur wordt onderscheid gemaakt tussen de gewone, uitzonderings-, verlichte, vereenvoudigde, en geprivilegieerde (bevoorrechte) naturalisatie. Dit onderscheid maakt men op grond van het feit dat aan bepaalde groepen naturalisandi hetzij vrijstelling van bepaalde vereisten wordt verleend, hetzij dat voor hen (tevens) andere, lichtere, of zwaardere procedurele eisen gelden dan bij de gewone naturalisatie het geval is. In dit boek worden de regels betreffende verlichte naturalisatie slechts in gevallen waarin de procedure anders is, in een aparte subparagraaf besproken.

Voorts kennen sommige nationaliteitswetten aparte regelingen voor de zogenaamde (her)naturalisatie van personen, die in het verleden reeds de desbetreffende nationaliteit bezaten. Deze regels worden in de nationaliteitswetten hetzij bij de regelingen van verlichte naturalisatie geplaatst, hetzij in een aparte regeling. In dit boek wordt hernaturalisatie uitsluitend in een aparte subparagraaf besproken, indien aan deze groep naturalisandi wezenlijk andere vereisten worden gesteld, of indien de procedure anders is.

\subsubsection{Gronden voor naturalisatie}

De gronden voor verkrijging van de nationaliteit door naturalisatie komen dikwijls overeen met de naturalisatievereisten, die tot op een zekere hoogte een indicator van aanwezigheid van deze gronden zijn. Zo bepaalt art. 8 RwNed dat degene die om naturalisatie verzoekt reeds sedert vijf jaren hier ter lande moet wonen, dat hij

10. Art. 3 lid 2 RwNed; art. 10 van de Belgische nationalliteitswet van 1985.

11. Art. 8 C.c. van Monaco.

12. \& 25 aStBG (österreichisches Staatsbürgerschafisgesetz) van 1965 . 
"ingeburgerd" moet zijn en dat hij ến van de in het koninkrijk gebruikelijk talen moet spreken. Dit zijn enkele vereisten voor naturalisatie, terwijl als voornaamste grond het feit moet worden genoemd dat de wetgever vindt, dat een vreemdeling die in het koninkrijk woont en zich in de samenleving heeft ingeburgerd het recht moet hebben om ook de iure Nederlander te worden. De genoemde vereisten zijn slechts enkele objectieve toetsingscriteria die helpen aan te geven of ten aanzien van een verzoeker inderdaad de grond voor verlening van de nationaliteit bestaat.

Daarnaast kan als grond voor naturalisatie ook worden genoemd het in art. 15 lid 2 van de Universele declaratie van de rechten van de mens ${ }^{13}$ neergelegde recht om van nationaliteit te veranderen. Men kan immers slechts van nationaliteit veranderen, indien de mogelijkheid bestaat om een andere nationaliteit te werwerven. Ook in de overweging dat personen die reeds geruime tijd in een bepaald land verblijven de mogelijkheid moeten hebben om politieke rechten in het desbetreffende land te verwerven, kan een grond voor naturalisatie worden gezien.

De gronden voor de toekenning van mogelijkheden van verlichte naturalisatie blijken in de regel reeds uit de wettelijke opsommingen van degenen, aan wie een dergelijke mogelijkheid wordt toegekend. Dat zijn bijvoorbeeld degenen, die etnisch tot één der in een bepaald land wonende volkeren behoren ${ }^{14}$, degenen die met een onderdaan van een land gehuwd zijn ${ }^{15}$, adoptiefkinderen van onderdanen van een land ${ }^{16}$. Niet zelden is ook een staatsbelang een grond voor verlichte naturalisatie. Deze bestaat uit de wil om bekende wetenschappers, kunstenaars of sportlieden snel de nationaliteit te verlenen ${ }^{17}$. Ook snelle naturalisatie van echtgenoten van troonopvolg(st)ers is in de regel in het belang van de staat ${ }^{18}$.

\subsubsection{Optie}

\subsubsection{Het begrip}

Reeds hiervoor werd benadrukt dat in verschillende landen de term "optie" een uiteenlopende inhoud heeft. Hierbij kan worden gedacht aan gevallen, waarin aan een bepaalde kring personen de mogelijkheid wordt geboden om door een wilsverklaring in combinatie met een "toestemming" of "bekrachtiging" van overheidswege de nationaliteit van een land te verkrijgen. We kunnen hier niet spreken van een optie pur sang en evenmin van een gewone naturalisatie. Het gaat hierbij om een spectrum van verschillende mogelijkheden; van een zuiver declaratoire "toestemming", respectievelijk "bekrachtiging" tot de zeer breed uitgemeten mogelijkheid om de nationaliteitsverkrijging te weigeren, ondanks het feit dat betrokkene aan alle in de wet gestelde "optievereisten" voldoet. De

13. Trb. 1969,99 . Zie daarover p. 42-43.

14. Zie bijvoorbeeld art. 7 sub 1 van de Joegoslavische nationaliteitswet van 1964 in de versie van 1976; art. 10 van de Bulgaarse nationaliteitswet van 1968.

15. Art. 8 lid 2 RwNed; ant. 12 van de Bulgaarse nationaliteitswet wan 1968.

16. art. 11 van de Bulgaarse nationaliteitswet van 1968.

17. Een dergelijke mogelijkheid wordt geopend in art. $10 \mathrm{RwNed.}$

18. Zo werd van de mogelijkheid van uitzonderingsnaturalisatie in de wet op het Nederlanderschap en het ingezetenschap slechts drie keer gebruik gemaakt. Bij wetten van 26 juni 1901, Stb. 1903, 38); 24 nowember 1936, Stb. 1936, 2 en van 8 december 1965, Stb. 1965, 526 werden telkens de (Duitse) echtgenoten van Nederlandse kroonprinsessen genaturaliseerd. 
nationaliteitsverkrijging werkt soms vanaf het moment van de "toestemming" of zelfs vanaf een later tijdstip, en soms weer ex tunc, vanaf het moment waarop het feit dat de grond voor de nationaliteitsverkrijging wormt, zich heeft voorgedaan ${ }^{19}$.

Door De Groot ${ }^{30}$ wordt onderscheid tussen "reine" en "kontrollierte" optierechten gemaakt. Als onderscheidend criterium neemt hij de vraag of de overheid de mogelijkheid heeft om een "optieverklaring" te weigeren, indien betrokkene aan alle objectief gestelde vereiste voldoet ${ }^{21}$.

In dit boek worden slechts "zuivere optierechten" met de term "optie" aangeduid en zullen deze in een aparte paragraaf worden besproken. Onder dit begrip versta ik een wijze van verkrijging van de nationaliteit waarbij de beslissing omtrent verwerving uitsluitend afhankelijk is van de wil van betrokkene. Deze wil moet worden geuit door een uitdrukkelijke, uitsluitend op verwerving van de nationaliteit gerichte werklaring van betrokkene zelf. Indien aan de objectieve optievereisten is voldaan, mag de overheild niet de vrijheid hebben om een optie te weigeren. Een eventuele "acceptatieverklaring" moet slechts een declaratoir karakter hebben. In alle andere gevallen wordt de nationaliteit door de overheid verleend en wordt derhalve gesproken van (verlichte, vereenvoudigde) naturalisatie.

Toegegeven moet echter worden dat de grens tussen beide wijzen van verkrijging in de praktijk dikwijls vervaagt. Zo zijn er ook gevallen die volgens de bovenstaande definitie als naturalisatie moeten worden beschouwd, maar die in feite niet van optie verschillen. Hierbij kan worden gedacht aan gevallen waarin de "toestemming" van het overheidsorgaan weliswaar constitutief werkt, terwijl het in de praktijk zelden of nooit voorkomt dat een verkrijging van de nationaliteit wordt geweigerd. Aan de andere kant kan het gebeuren dat een overheidsorgaan in het geheel niet bevoegd is een "echte" optieverklaring te weigeren en dat dit desalniettemin wordt gedaan. Ook indien de optievereisten enige interpretatieruimte openlaten, kan een dergelijke optie in praktijk tot een verlening van de nationaliteit leiden. Desalniettemin lijkt het mij voornamelijk ter wille van de overzichtelijkheid zinvol om bij de bespreking van de regelingen van verkrijging van de nationaliteit een grens tussen optie en naturalisatie te trekken.

\subsubsection{Gronden voor optie}

Reeds hierwoor werd gesteld dat optie eigenlijk een hybride wijze van verkrijging is, die tussen verwerving van de nationaliteit van rechtswege en de naturalisatie moet worden geplaatst. Ook is het gebleken dat de grenzen tussen deze drie wijzen nogal vaag zijn. Reeds op grond hiervan kan worden geconcludeerd dat ook de gronden voor verkrijging van de nationaliteit door optie grosso modo dezelfde zijn als bij de overige twee wijzen van verkrijging. Meestal gaat het om degenen die door omstandigheden zoals afstamming, geboorte op het grondgebied, langdurige

19. Volgens 2 wan de Tsjechoslowaakse nationaliteitswet wan 1949 kon een buitenlandse vrouw, die met een CSR-onderdaan in het buwelijk trad, binnen 6 maanden ma de huwelijkssluiting om de Tsjechoslowaakse nationaliteit werzoeken. De verlening van de nationaliteit werkte hierbij vanaf het moment van de huwelijkssluiting, die grond voor de verkrijging van de nationaliteit was.

20. De Groot diss., p. 211,217 en 227.

21. Bijvoorbeeld op gronden van openbare orde, staatsbelang of onvoldoende assimilatie vam betrokkene. De Groot diss., p. 211. 
woonplaats, opleiding, etc. met een land zo sterk verbonden zijn dat de beslissing omtrent de verkrijging van de nationaliteit van dat land niet mede aan de overheid, zoals bij de naturalisatie, maar uitsluitend aan de betrokkene zelf wordt overgelaten. Naast deze overwegingen speelt ook een grote rol bij de keuze van een nationale wetgever tussen optie en naturalisatie de vraag, in hoeverre de staat zich de mogelijkheid wil voorbehouden een beslissende controle over de verkrijging van zijn nationaliteit uit te oefenen.

\subsubsection{Overige wijzen van verkrijging}

Naast de reeds genoemde drie wijzen van verkrijging van de nationaliteit komt men in sommige nationaliteitswetten nog enige aparte wijzen tegen, die door hun bijzondere naam ten onrechte de indruk wekken dat het om wijzen van verkrijging sui generis gaat. Zo kent men in Polen en Roemenië verkrijging door "repatriëring" die tot 1951, respectievelijk 1948 "erkenning" werd genoemd. Uiteraard ging het niet om erkenning in familierechtelijke zin, maar om een erkenning als burger door een constitutieve beschikking van overheidswege en derhalve om een soort verlichte naturalisatie. Verwarrend is ook de constructie die hierbij wordt gehanteerd, namelijk dat betrokkene door het feit van vestiging in het land van rechtswege die nationaliteit zou verwerven. Het staatsburgerschap wordt echter slechts verkregen, indien aan betrokkene op grond van een onderzoek naar de voorwaarden voor deze "wijze" van verkrijging een vestigingsvergunning wordt verleend. De grond voor verkrijging is overigens in beide landen het bezit van de Poolse, respectievelijk Roemeense etnische nationaliteit, alsmede de wens van beide overheden om (kinderen) van emigranten tot terugkeer te bewegen.

\subsection{VeruIES VAN DE NATTONALITETT}

De nationaliteit van een land kan worden verloren van rechtswege, door het afleggen van een verklaring van afstand, door ontslag of door ontneming. Terwijl de eerste drie wijzen van verlies spiegelbeelden van verkrijging van rechtswege, door optie en door naturalisatie zijn, is ontneming een aparte rechtsfiguur, die echter tot een bepaalde hoogte sterke overeenkomsten met verlies van rechtswege vertoont (zie p. 34).

\subsubsection{Verlies van rechtswege}

\subsubsection{Het begrip}

De nationaliteit wordt van rechtswege verloren, indien het verlies automatisch wordt gekoppeld aan bepaalde feiten en omstandigheden, ongeacht de wil van de betrokkene. Zo bepaalt art. 15 sub a RwNed, dat een Nederllander zijn nationaliteit verliest door vrijwillige verkrijging van een andere. 


\subsubsection{Gronden voor verlies van rechtswege}

De grond voor verlies in het zojuist genoemde voorbeeld is de wens van de Nederlandse wetgever gevallen van meervoudige nationaliteit zoveel mogelijk te beperken. Een andere niet zelden voorkomende grond voor verlies van de nationaliteit van rechtswege is het feit dat betrokkene reeds langdurig in een ander land woont en de nationaliteit daarvan bezit waardoor de band met zijn andere nationale staat tot het enkele formele bezit van de nationaliteit wordt gereduceerd. Een voorbeeld van verlies van het staatsburgerschap op deze grond is te vinden in art. 15 sub $\mathrm{c}$ RwNed. In de geschiedenis kunnen nog verdere voorbeelden worden gevonden van het verlies van de nationaliteit van rechtswege, zoals ten aanzien van vrouwen een huwelijk met een buitenlander en legitimatie door een vreemdeling 22 .

\subsubsection{Ontslag}

\subsubsection{Het begrip}

Ontslag is een wijze van verlies van de nationaliteit, waarbij het staatsburgerschap wordt verloren door een beschikking van een overheidsinstantie nadat betrokkene een daartoe strekkend verzoek heeft ingediend. De beschikking werkt constitutief. Het ontslag wordt conform art. 7 van het Haagse nationaliteitenverdrag van $1930^{23}$ in de regel verleend onder de voorwaarde van verkrijging van een andere nationaliteit.

Sommige nationaliteitswetten gebruiken bij verlies van de nationaliteit door ontslag verwarrende, in nuances verschillende constructies, die ten onrechte de indruk wekken dat het om verlies van de nationaliteit van rechtswege zou gaan. Meestal spreken de wetten en in navolging daarvan ook verschillende commentaren van "toestemming voor verkrijging van een andere nationaliteit" 24 of van verlies van de nationaliteit "door verkrijging van een andere" ${ }^{\text {"25. }}$. Deze constructies berusten in wezen op een énzijdige uitleg van het zogenaamde "exclusiviteitsbeginsel" in het nationaliteitsrecht. Dit beginsel is gecodificeerd in art. 3 van het Haagse nationaliteitenverdrag van 1930:

"Onder voorbehoud van de bepalingen van dit Verdrag zal een persoon die, twee of meer nationaliteiten bezit, door ieder van de Staten, waarvan hij de nationaliteit heeft, als zijn onderdaan kunnen worden beschouwd."

Deze bepaling wordt dan zo uïtgelegd dat onderdanen van een staat geen andere nationaliteit kumnen bezitten, of verkrijgen zonder de toestemming van die eerste staat. Deze interpretatie staat echter op gespannen voet met art. 2 van hetzelfde verdrag, waarin uitdrukkelijk wordl bepaald, dat de vraag of een persoon de nationaliteit van een staat bezit, aan de hand van het recht van die staat moet

22. Art. 5 van de Nederlandse nationaliteitswet van 1892, ingetrokken bij wet van 14 november 1963 , Stb. 1963, 467; art. 2 ter van dexelfde wet ten aanzien van wettiging.

23. Stb. $1937,17$.

24. Art. 11 van het Albanese BW van 1928 .

25. Zie bijwoorbeeld art. 11 van de Poolse nationaliteitswet van 1951. 
worden bepaald. Deze regel, ook het beginsel van nationale autonomie in het nationaliteitsrecht genoemd, werd reeds in 1923 bevestigd in een uitspraak van de CPJ:

"La question de savoir si une certaine matière rentre ou ne rentre pas dans la domaine exclusif d"un Etat est une question essentiellement relative: elle dépend du developpement des rapports internationaux. C'est ainsi que, dans l'état actuel du droit international, les questions de nationalité sont, en principe, de l'avis de la Cour, comprises dans ce domaine réservé." 25

Het ontslag wordt dan geconstrueerd als toestemming voor verkrijging van een andere nationaliteit, waarbij de nationaliteit formeel "door verkrijging van die andere van rechtswege" wordt verloren. Bezit men de andere nationaliteit reeds, dan gaat de eerste nationaliteit met het verlenen van die "toestemming" verloren.

\subsubsection{De gronden voor ontslag}

De grond voor ontslag is de overweging dat men de mogelijkheid moet hebben om van nationaliteit te veranderen. Zo wordt van de verzoeker in de regel geëist dat hij reeds een andere nationaliteit bezit, of althans kan bewijzen dat hij deze na het ontslag zal verkrijgen. Een dikwijls gesteld vereiste is voorts dat de verzoeker aan verplichtingen tegenover de staat, met name de militaire dienstplicht en het betalen van belastingen, heeft voldaan. Ook niet vervulde verplichtingen ten opzichte van private en rechtspersonen vormen dikwijls een beletsel voor ontslag. Reeds in de uiteenzettingen met betrekking tot naturalisatie en optie werd geconcludeerd, dat de keuze die de wetgever tussen beide wijzen van verkrijging maakt, in belangrijke mate wordt bepaald door de vraag in hoeverre zich een staat de mogelijkheid wil voorbehouden om daar nog "een stokje voor te steken". Hetzelfde geldt voor de keuze tussen ontslag en het hierna te bespreken verlies door het afleggen van een verklaring van afstand.

\subsubsection{Afstand}

\subsubsection{Het begrip}

In dit boek wordt met het begrip "afstand" slechts een wijze van verlies van de nationaliteit aangeduid, waarbij het verlies uitsluitend door een uitdrukkelijke, daarop gerichte willsverklaring van betrokkene intreedt. Indien betrokkene aan de wettelijke vereisten voor afstand voldoet, heeft de overheid geen recht om een afstandsverklaring te weigeren. Ten aanzien van de afgrenzing tussen verlies door afstand enerzijds en door ontslag anderzijds, geldt precies hetzelfde als met betrekking tot de grens tussen optie en naturalisatie (zie p. 28-29).

26. Tumis and Morocco Nationality Decrees case, CPJ van 7 februari 1923, CPJ Serie B, nr. 4 (1923); daarover Ko Swan Sik preadvies, p. 5; Weis, p. 71-75. Zie ook De Groot, diss. p. 17. 


\subsubsection{Gronden voor afstand}

De grond voor de mogelijkheid van verlies door afstand ligt m.i. voornamelijk in het in art. 15 lid 2 van de Universele Verklaring van de rechten van de mens neergelegde recht om van nationaliteit te kunnen veranderen. Voorts kan worden genoemd de overweging dat een persoon die geen reële banden met een van zijn nationale staten heeft, de mogelijkheid behoort te hebben om zich van zijn "papieren nationaliteit" te ontdoen. De toekenning van een mogellijkheid van afstand kan (mede) zijn grond hebben in de wens om gevallen van meervoudige nationaliteit zoveel mogelijk te beperken.

De mogelijkheid van afstand wordt in de regel slechts geboden aan personen, die tevens een andere nationaliteit bezitten. Anders zou betrokkene immers staatloos worden. Dit is bijvoorbeeld naast meerderjarigheid de enige voorwaarde die de Nederlandse wet met betrekking tot afstand stelt (art. 15 sub b RwNed). Ook komt het voor dat betrokkene naast het enkele bezit van een vreemde nationaliteit een sterkere band met een andere staat moet hebben. Deze kan zijn gelegen in het feit dat betrokkene in zo'n land is geboren, daar langdurig woont, etc. 27 .

\subsubsection{Ontneming}

\subsubsection{Het begrip}

Ontneming is een wijze van verlies van de nationaliteit waarbij deze tegen de wil van betrokkene wordt verloren door een constitutieve individuele beschikking van een overheidsorgaan. Ontneming heeft meestal het karakter van een sanctie en wordt voorzien voor gevallen van (althans in de ogen van de wetgever) laakbaar gedrag van betrokkene. Er zijn ook voorbeelden bekend, waarin de strafwetgeving van een land ontneming van de nationaliteit als én van de (bijkomende) straffen kent ${ }^{23}$. Dan wordt de beslissing door de rechter genomen. Ontneming van de nationaliteit is een rechtsfiguur met zeer ingrijpende gevolgen, met name wanneer het staatsburgerschap zelfs kan worden ontnomen, indien betrokkene daardoor staatloos wordt. Deze wijze van verlies van de nationaliteit komt niet in alle nationaliteitswetten voor ${ }^{29}$. In de $\mathrm{BRD}$ bijvoorbeeld, is ontneming zelfs grondwettelijk verboden (art. 16).

Sommige landen kennen (tevens) een bijzondere vorm van ontneming, namelijk herroeping van een naturalisatiebesluit, die in dit werk steeds samen met ontneming zal worden besproken. Herroeping, soms ook intrekking genoemd, is in de regel slechts mogelijk wegens fraude of andere onregelmatigheden bij de naturalisatieprocedure. Het komt echter woor dat ook in andere gevallen mogelijkheden voor herroeping bestaan, die niet zelden een uitbreiding van ontnemingsmogelijkheden met betrekking tot genaturaliseerden betekenen. Zo bepaalt $\$ 12$ van

27. Zie bijvoorbeeld art. 17 van de Joegoslavische nationaliteitswet van 1964.

28. Voorbeelden daarwan zijn te vinden in Tsjechoslowakije tussen 1948 en 1956 en in Sovjetunie tussen 1927 en 1958.

29. Geen ontneming kenden bijwoorbeeld het Russische nationaliteitsrecht tot 1921, het Albanese BW van 1926 en de mationaliteitsrechtelijke regeling van het Oostenrijkse ABGB. 
de nationaliteitswet van de DDR, en art. 18 van het voorontwerp tot herziening van de Zwitserse nationaliteitswet, dat een naturalisatie kan worden herroepen, indien betrokkene de verlening van de nationaliteit "onwaardig" blijkt te zijn.

Ontneming van de mationaliteit en verlies van rechtswege zijn eigenlijk nauw met elkaar verwant. In beide gevallen wordt de nationaliteit buiten de wil van betrokkene om, dikwijls zelfs tegen zijn wil in verloren. De verschillen zijn echter dat het bij de ontneming in de regel om een strafsanctie gaat en dat ontneming bij een individueel gericht besluit van een staatsorgaan of een rechter geschiedt. Er zijn echter niet steeds scherpe grenzen te trekken. Zo kan de nationaliteit bij] een algemeen voorschrift aan een bepaalde categorie personen worden ontnomen. Een voorbeeld daarvan is het Nederlandse koninklijk besluit van 17 november $1945^{30}$. Strikt genomen wordt in dergelijke regelingen het nationaliteitsverlies van rechtswege gekoppeld aan bepaalde feiten, i.c. huwelijk met een Duitser, doch de ratio van die regelingen komt neer op een collectieve ontneming. Een ander woorbeeld is het treden in de militaire of staatsdienst van een vreemde staat, welke dikwijls als een grond voor verlies van de mationaliteit wordt beschouwd. In sommige landen kiest de wetgever in dit geval voor verlies van rechtswege ${ }^{31}$, terwijl in andere landen een dergelijke schending van de loyaliteitsplicht tegenover het vaderland een grond voor ontneming van de nationaliteit is ${ }^{32}$.

\subsubsection{Gronden voor ontneming}

Zojuist werd reeds gezegd dat de grond voor ontneming in de regel een laakbare gedraging van betrokkene is. Meestal gaat het om schending van de loyaliteitsplicht, handelingen die de staatsveiligheid of andere belangen van de staat (kunnen) schaden ${ }^{33}$, het ontwijken van militaire dienstplicht ${ }^{34}$, of zelfs het enkele bezit van een vreemde nationaliteit ${ }^{35}$.

30. Stb. F 278.

31. Zie bijwoorbeeld art. 7 sub 4 van de Nederlandse nationaliteitswet van 1892 .

32. Zie bijwoorbeeld $\$ 14 \mathrm{a}$ sub $\mathrm{b}$ van de Tsjechische natiomaliteitswet van 1968 .

33. Zie bijwoorbeeld art. 15 sub 1,2 van de Poolse nationaliteitswet van 1962; Section 40 van de BNA 1981; art. 8 van de Italiaanse wet nationaliteitswet (LCN) van 1912 sedert de wijziging van 31 januari 1926; G.U. 1926, nr. 28.

34. Zie bijvoorbeeld art. 15 sub 5 van de Poolse nationaliteitswet van 1962.

35. Zie bijvoorbeeld $\$ 7$ lid 2 Van de Tsjechoslowaakse nationaliteitswet van 1949. 
II. BESCHRIJVING VAN HET NATIONALITEITSRECHT IN DE OOSTEUROPESE LANDEN 
HOOFDSTUK 1. OVERZICHT VAN DE VOOR OOSTEUROPESE LANDEN GELDENDE VOLKENRECHTELIJKE VERPLICHTINGEN OP HET GEBIED VAN HET NATIONALITEITSRECHT

\subsection{INLEIDING}

In het onderstaande hoofdstuk zal worden ingegaan op de thans voor de Oosteuropese staten geldende volkenrechtelijke verplichtingen op het gebied van de nationaliteit. Allereerst zal kort aandacht worden besteed aan enkele bepalingen van verschillende multilaterale verdragen, waar tenminste én van de Oosteuropese landen partij bij is ${ }^{1}$. Ook zal worden stilgestaan bij art. 15 van de Universele verklaring van de rechten van de mens. Voorts hebben de meeste Oosteuropese landen onderlinge bilaterale verdragen gesloten. De strekking van deze regelingen is gevallen van dubbele nationaliteit zoveel mogelijk te beperken. Aangezien vele Oosteuropese landen dergelijke verdragen met elkaar hebben gesloten, vormen de regelingen daarvan een belangrijke wijziging van de nationale regels met betrekking tot verkrijging en verlies van de nationaliteit.

Voorts werden tussen de Verenigde Staten en enkele Oosteuropese landen billaterale verdragen gesloten die eveneens (gedeeltelijk) betrekking hebben op de nationaliteit. Ook daarop zal kort worden ingegaan.

\subsection{ALGEMENE VOLKENRECHTELUKE VERPLICHTTNGEN}

\subsubsection{Specifieke nationaliteitsrechtelijke verdragen}

\subsubsection{Haagse nationaliteitenverdrag van 1930 met protocollen}

In het verdrag van 's-Gravenhage van 12 april $1930^{2}$ nopens zekere vragen betreffende wetsconflicten in zake nationaliteit, werden enkele algemene regels met betrekking tot de nationaliteit neergelegd. Deze regels hebben zoals de naam van het verdrag reeds aangeeft, hoofdzakelijk betrekking op conflictsituaties die door meervoudige nationaliteit (positief conflict) of door apatridie (negatief conflict) kunnen ontstaan ${ }^{3}$.

In artt. 1 en 2 werd het zogenaamde beginsel van de nationale autonomie in het nationaliteitsrecht neergelegd; iedere staat is in beginsel uitsluitend bevoegd te bepalen, wie zijn onderdanen zijn. In artt. 3 en $4 \mathrm{komt}$ voorts het zogenaamde "exclusiviteitsbeginsel" tot uitdrukking: iedere staat heeft het recht om polypatriden die tevens zijn nationaliteit bezitten, uitsluitend als zijn eigen onderdanen te behandelen. Een zeer belangrijke consequentie van deze regel vinden we voorts in art. 4: een staat is niet bevoegd een onderdaan diplomatiek te beschermen tegenover een staat waarvan betrokkene eveneens de nationaliteit bezit. Al met al

1. Volgens de stand van ratificaties per 1 januari 1988 , gepubliceerd in Human Rights Law Journal 1988.

2. LNTS CVXXIX, 89; Stb. 1937, 4, 54. Zie daarover De Lapradelle/Niboyet, p. 307-319; De Groot diss, p. 30-32.

3. Zie De Lapradelle/Niboyet, p. 285-286, 312 , 
betekent dit dat een staat bevoegd is, het feit dat éen van zijn onderdanen tevens een vreemde nationaliteit bezit, in het geheel te negeren.

Art. 5 van het verdrag heeft voorts betrekking op gevallen dat een polypatride zich in een staat bevindt, waarvan hij geen nationaliteit bezit. In een dergelijke geval moet hij geacht worden slechts de nationaliteit van die staat te bezitten waarin hij woont, of anderszins het nauwst mee verbonden is.

Interessant is art. 6 warin een soort recht op afstand, respectievelijk ontslag wordt neergelegd ten behoeve van bipatriden, die hun beide nationaliteiten zonder hun wil hebben verworven. Dit recht betreft verlies van de nationaliteit van de staat waarin zij niet woonachtig zijn, doch blijkens het tweede lid mag de nationale wet voorwaarden voor ontslag of afstand stellen.

In art. 7 worden regels met betrekking tot het ontslag uit de nationaliteit geformuleerd. Ontslag mag volgens deze bepaling slechts zijn werking hebben, indien betrokkene reeds een andere nationaliteit bezit. In andere gevallen mag het ontslag slecht onder de voorwaarde dat de verzoeker een andere nationaliteit verwerft, worden verleend.

Artt. 8-11 hebben voorts betrekking op een vrouw, die door huwelijk haar oorspronkelijke nationaliteit verliest, en niet die van haar bruidegom verwerft. Volgens de regeling van het verdrag zou de oorspronkelijke nationaliteit door een huwelijk slechts moeten kumnen worden verloren onder de voorwaarde dat betrokkene door of in verband met het huwelijk het staatsburgerschap van haar echtgenoot verwerft.

Artt. 12-16 hebben tenslotte betrekking op de nationaliteit van kinderen. De strekking daarvan is voornamelijk staatloosheid van kinderen in bepaalde gevallen te woorkomen.

Van de Oosteuropese landen is slechts Polen partij bij dit verdrag, terwijl het nog door de volgende landen werd ondertekend en niet geratificeerd: Estland, Joegoslavië, Letland, Tsjechoslowakije, en Hongarije 4 . Desalniettemin kunnen in de nationaliteitswetgeving van Oosteuropese landen vele in dit verdrag geformuleerde regels terug worden gevonden.

Bij het verdrag van 's-Gravenhage behoren ook drie protocollen. Het eerste protocol betreft militaire verplichtingen van polypatriden en werd door geen van de Oosteuropese landen ondertekend. Bij het tweede protocol, betreffende vermindering van een bepaald geval van staatloosheid zijn slechts Polen en Joegoslavie partij. Interessant is, dat Joegoslavië dit protocol pas in 1959 ratificeerde. Wel ondertekend, doch niet geratificeerd hebben dit protocal ook Estland, Letland en Tsjechoslowakije ${ }^{5}$. Bij het derde protocol, dat in het algemeen betrekking op het bestrijden van staatloosheid betrekking heeft, is echter geen van de Oosteuropese landen partij ${ }^{6}$.

4. SGS deel 30, p. 13-14.

5. SGS deel 30 , p. $24-25$.

6. Dit protocol is vanwege cen onvoldoende aantal ratificaties overigens nooit in werking getreden.

De Groot diss., p. 31. 


\subsubsection{Verdrag betreffende de nationaliteit van de geluuwde vrouw}

In het verdrag van New York van 20 februari $1957^{\top}$ werden enkele regels neergelegd, die de strekking hebben aan een gehuwde vrouw een zelfstandige nationaliteitsrechtelijke positie te verschaffen. In de artt. 1 en 2 wordt bepaald dat een huwelijk met een vreemdeling, echtscheiding, of verandering van de nationaliteit van de echtgenoot geen automatische gevolgen voor de nationaliteit van een vrouw mogen hebben. Volgens art. 3 zou de vrouw echter de mogelijkheid moeten hebben om op vereenvoudigde wijze de nationaliteit van haar man te verwerven. Beperkingen van deze mogelijkheid die verband houden met openbare orde of staatsveiligheid worden echter uitdrukkelijk toegelaten.

Alle Oosteuropese staten zijn partij bij dit verdrag.

\subsubsection{Nationaliteit in mensenrechtenverdragen}

\subsubsection{Art. 15 van de Universele verklaring van de rechten van de mens}

De Universele verklaring van de rechten van de mens van $1948^{8}$ is geen verdrag, hetgeen betekent dat de verbindendheid van de bepalingen daarvan door velen wordt bestreden ${ }^{9}$. Naar mijn mening kan echter afgezien van de vraag of deze verklaring volkenrechtelijke verplichtingen inhoudt, aan een verklaring van de Algemene Vergadering van de Verenigde Naties grote waarde worden gehecht. De bepalingen daarvan kunnen in ieder geval worden beschouwd als een soort richtlijnen voor de wetgeving van de nationale staten, waarvan het wenselijk zou zijn dat ze zouden worden nageleefd ${ }^{10}$. Ook zou kunnen worden gesteld dat de Universele Verklaring een aantal voorwaarden bevat, waaraan een behoorlijke wetgeving zou moeten voldoen ${ }^{11}$.

Op de nationaliteit heeft art. 15 van de Universele verklaring betrekking:

"1. Een ieder heeft recht op een nationaliteit.

2. Aan niemand mag willekeurig zijn nationaliteit worden ontnomen, noch het recht worden ontzegd om van nationaliteit te veranderen."

7. UNTS 309, 65; Trb. 1965, 218. Zie hierover De Groot diss. p. 32; De Groot/Tratnik, p. 91-94; Jessurun d'Oliveira, AAe 1985, p. 212; en NJB 1985, p. 52-53; Maresceaux, p. 57-62.

8. Resolutie 217A (III) van de Algemene vergadering van de VN; United Nations General Assembly Official Records 3rd Session, Resolution part $\mathbb{I}_{\text {., }}$ 71. Trb. 1969, 99. Zie daarover Cassin, Recueil des Cours 1951, 1, p. 271-296; Maresceaux, p. 18-24; De Groot diss, p. 15 en 28; Kanger, p. 110111; Lauterpacht, p. 745; Robinson, p. 123-124; Verdoodt, p. 156-161.

9. Zie bijwoorbeeld Verdross, ${ }_{*}$ p. 313, die stelt dat deze declaratie slechts een aanbeveling is. Zo ook Blatova, p. 285-286; Kozevnikov, p. 262. Door Humphrey, p. 28-37, wordt echter betoogd, dat de Declaratie volkenrechtelijk gewoonterecht is geworden. Zie over de verschillende meningen met betrekking tot de juridische status van de declaratie ool Ansbach/Mohr, Neue Justiz 1988, p. 480481; Kanger, p. 27-33; Robinson, p. 33-63; Verdoodt, p. 315-331; Uibopuu, Israel Yearbook of Human Rights 1977, p. 55-57.

10. In die zin ook Lauterpacht, p. 745; Verdoodt, p. 321; Verdross/Simma, p. 405; Uibopuu, Israed Yearbook of Human Rights 1977 , p. 55.

11. Zie ook Humphrey, p. 28. 
Het m.i. in beginsel weinig zinvol dat het recht op "een nationaliteit" in de zojuist omschreven bewoordingen in de Universele verklaring is opgenomen. Een zo geformuleerde "garantie" brengt de justitiabele niets, zolang er niet wordt gezegd op welke nationaliteit hij recht zou moeten hebben. Iedere staat kan een dergelijk "recht" immers negeren met de motivering dat het feit dat een bepaalde persoon recht heeft op "een nationaliteit" niet inhoudt dat betrokkene recht op de nationaliteit van juist die staat zou hebben. Het zou iets anders zijn indien art. 15 zou bepalen dat iedereen recht heeft op hetzij de nationaliteit die tenminste én van zijn ouders bezit, hetzij op het staatsburgerschap van het land waar hij wordt geboren ${ }^{12}$. Interessant is dat in het voorontwerp van de Universele verklaring van het VN-secretariaat het recht op de nationaliteit op basis van een ontwerp van het Interamericaans Juridisch Comité inderdaad nader werd gedefinieerd:

"Tout individu a droit à une nationalité. Tout individu a droit à la nationalité du pays sur le territoire duquel il est né, à moins qu’à sa majorité, il n"opte pas pour la nationalité à laquelle sa filiation lui donnerait droit." ${ }^{13}$

Helaas was bij de vertegenwoordigers van de lidstaten geen meerderheid voor een dergelijk concreet recht op de nationaliteit te vinden. In dit verband dient ook te worden gewezen op art. 20 van het Pact van San Jose ${ }^{14}$. In het tweede lid van dit artikel wordt namelijk bepaald, dat een kind dat door geboorte geen andere nationaliteit verwerft, recht heeft op de nationaliteit van het land waarin het wordt geboren. Een recht op een op deze wijze bepaalde nationaliteit zou dan indirect het recht op de aan de nationaliteit gekoppelde rechten betekenen. Voorwaarde daarvoor is wel, dat de staten verplicht zijn bepaalde rechten aan het bezit van de nationaliteit te verbinden. Dergelijke verplichtingen zijn inderdaad opgenomen in art. 12 lid 4 en art. 25 van het BUPO-verdrag. Volgens de eerste bepaling zijn de lidstaten verplicht aan hun onderdanen een voorwaardelijk recht op verblijf in hun land te waarborgen. Deze garantie is echter zwak, aangezien dit recht slechts niet willekeurig mag worden ontzegd. Een sterkere waarborg biedt art. 3 van het Vierde protocol bij de ECRM ${ }^{15}$. In deze bepaling werd wèl een absoluut verbod van uitzetting van eigen onderdanen opgenomen, alsmede het recht tot toelating tot een staat waarvan men de nationaliteit bezit. Het is echter wel zo, dat deze verplichting slechts voor een zeer beperkt aantal staten geldt.

In art. 25 van het BUPO-verdrag wordt voorts door de lidstaten aan hun onderdanen ${ }^{16}$ het recht op participatie in het politieke leven in die landen gewaarborgd (o.m. het actief en passief kiesrecht). We mogen evenwel niet vergeten dat deze rechten in verschillende landen een zeer uiteenlopende inhoud hebben (éenpartijstelsel versus meerpartijenstelsel).

12. Ci. Jessurun d'Oliveira in het bundel Internationaal recht en vrouwen deel 1, p. 282 .

13. Geciteerd bij Verdoodt, p. 157. Zie ower de totstandkoming van art. 15 ook p. 156-159.

14. Pact van 22 november 1969; Organisation of American States, Official Records OEA/Ser. K/XV1/1.1, Doc. 65, Rev. 1, Corr. 2. Zie voor cen Duitse vertaling EuGRZ 1980, 435 .

15. Protocol van Straatsburg van 16 september 1963, Trb. 1969, 241.

16. Uiteraard zijn de staten vrij aan een bredere kring van personen deze rechten toe te kennen, zoalls met betrekking tot de gemeenteraadswerkiezingen in Nederland. 
Wellicht kan in art. 15 lid 1 een vaag verbod van ontneming van de nationaliteit worden gelezen, voor het geval dat betrokkene daardoor staatloos wordt. Het is namelijk logisch dat indien men over het recht op bezit van een nationaliteit spreekt, en betrokkene reeds eén bezit het recht van art. 15 lid 1 als recht op bezit van die nationaliteit kan worden beschouwd. Ook dit recht wordt echter reeds door het hierna te bespreken tweede lid van art. 15 gerelativeerd. Daarin wordt ontneming van de nationaliteit slechts verboden, indien deze willekeurig is ${ }^{17}$.

Gezien het bovenstaande concludeer ik dat pas indien vaststaat op welke nationaliteit men recht heeft het echt mogelijk is om ten behoeve van iedere mens het recht op een nationaliteit te garanderen. Een dergelijke garantie zou voor justitiabele dan indirect de (mensen)rechten die in die staat soms conform een volkenrechtelijke verplichting aan de nationaliteit worden gekoppeld, waarborgen.

Het feit dat art. 15 eerste lid van de Universele verklaring geen juridische garantie van de nationaliteit met de daaraan verbonden rechten en plichten inhoudt, betekent niet automatisch dat het niet zinvol was om deze bepaling in de Universele verklaring op te nemen. In ieder geval heeft het daarin geformuleerde recht op een nationaliteit een hoge morele waarde en kan bij het ontwerpen van een nieuwe nationaliteitswet door de nationale wetgevers daarom niet eenvoudig worden genegeerd. Bovendien heeft het inmiddels nader gestalte gekregen in de daarna tot stand gekomen internationale verdragen tot beperking van staatloosheid. De waarde van art. 15 lid 1 dient naar mijn mening niet te worden gezocht in zijn juridische kwaliteiten. Het gaat om een symbolische bepaling die moet worden gezien tegen de achtergrond van de tijd waarin de Universele declaratie tot stand $\mathrm{kwam}$. In de jaren veertig dreigde staatloosheid als gevolg van massale ontnemingen van de nationaliteit door totalitaire regimes van werschillende signatuur een groot probleem te worden. Het opnemen van art. 15 getuigt van een wereldwijde consensus omtrent de onwenselijkheid daarvan en is daardoor een belangrijke mijlpaal in de ontwikkeling van de bestrijding van apatridie geworden.

\subsection{Verbod van willekeurige ontneming van de nationaliteit}

In het tweede lid staat o.m. het verbod van willekeurige ontneming van de nationaliteit ${ }^{18}$. De vraag is uiteraard wanneer ontneming van een nationaliteit willekeurig is. Daaromtrent heerste onder de vertegenwoordigers van verschillende landen bij de totstandkoming van de Verklaring grote onenigheid ${ }^{19}$. Door Verdoodt wordt een willekeurige ontneming in ieder geval gezien in het geval, dat deze in strijd met de wet geschiedt ${ }^{20}$. M.i. is deze opvatting echter te beperkt. Indien een nationale wetgeving aan een staatsorgaan onbeperkte discretionaire bevoegdheid verleent en de gronden voor ontneming in het geheel niet, of uiterst vaag in de wet worden geformuleerd, dan zal de ontneming weliswaar zelden of nooit in strijd met de wet zijn, aangezien de wet zelf willekeurig is. Zo werd reeds

17. Op deze inconsistentie werd reeds gewezen door Lauterpacht, p. 674.

18. Verdross, p. 313, ziet in art. 15 lid 2 een toepassing van het algemene volkenrechtelijke verbod van rechtsmisbruik.

19. Zie voor overzicht van verschillende meningen Kanger, p. 93-94; Verdoodt, p. 159-160.

20. Verdoodt, p. 160. 
tijdens de discussie bij totstandkoming van de Universele declaratie door Cassin ${ }^{21}$ gesteld, dat de wet ook niet willekeurig mag zijn.

Naar mijn mening gaat het om een willekeurige ontneming van het staatsburgerschap indien ingeval van dezelfde althans een redelijkerwijs als gelijksoortig te beoordelen handeling aan én persoon den nationaliteit wel wordt ontnomen en aan een andere niet. Een nationaliteitsrechtelijke regeling maakt derhalve in ieder geval theoretisch willekeurige ontnemingen mogelijk indien aan éen van de volgende voorwaarden is voldaan:

- indien het bevoegde orgaan discretionaire bevoegdheid heeft, die dikwijls wordt uitgedrukt met de zinsnede: "de nationaliteit kan worden ontnomen";

- indien de gronden voor ontneming enige interpretatieruimte laten;

In al deze gevallen is het mogelijk dat ingeval van dezelfde (eerste geval) althans een redelijkerwijs als gelijksoortig te beoordelen handeling (tweede geval) aan eén persoon de nationaliteit wel te ontnemen en aan een andere niet. De mogelijkheid van willekeurige beslissingen werken ook de volgende omstandigheden in de hand: het ontbreken van de motiveringsplicht dat een wellicht theoretisch bestaande beroepsmogelijkheid illusoir maakt, of zelfs het in het geheel ontbreken van een beroepsmogelijkheid. In het feit dat in sommige landen voor ontneming de hoogste staatsorganen bevoegd zijn, zie ik geen voldoende garantie tegen willekeur. Het zou zelfs een indicatie van het tegenovergestelde kunnen zijn: er is in het geheel geen mogelijkheid voor beroep. Het zojuist gestelde wil uiteraard niet zeggen dat in elk land dat een regeling kent die aan de bovenstaande voorwaarden voldoet, de nationaliteit inderdaad willekeurig wordt ontnomen. Het is wel zo dat een dergelijke nationaliteitswet, in ieder geval theoretisch, de mogelijkheid van willekeurige ontneming toelaat. Zulks is uit het oogpunt van rechtszekerheid onwenselijk en strookt niet met art. 15 lid 2 van de Universele verklaring. Gezien het onduidelijke juridische karakter van de Verklaring en de restrictieve gangbare interpretatie van het begrip "willekeurig" zou het te ver voeren om een wettelijke regeling die aan bovengeformuleerde criteria voldoet, in strijd met het volkenrecht te achten. Wel kan worden gezegd, dat een dergelijke regeling uit het oogpunt van bescherming van mensenrechten, voor verbetering vatbaar is.

\subsection{Recht om van nationaliteit te veranderen}

Art. 15 lid 2 verbiedt bovendien aan iemand willekeurig het recht te ontzeggen om van zijn nationaliteit te veranderen. Het recht om van nationaliteit te veranderen kan an de hand van twee verschillende situaties wordt toegelicht. In het eerste geval gaat het om een persoon die de nationaliteit van een bepaald land bezit en vervolgens door optie of naturalisatie het staatsburgerschap van een ander land verwerft, of wil verwerven. Zijn eerste nationale recht moet hem in een dergelijk geval een recht op vrijwillig verlies van de eerste nationaliteit toekennen. In het tweede geval moet worden gedacht een de situatie dat betrokkene reeds twee of meer nationaliteiten, bijvoorbeeld reeds sedert zijn 
geboorte, bezit. In dit geval houdt recht op verandering van de nationaliteit in, dat betrokkene het recht moet hebben om slechts én wan deze nationaliteiten te behouden, door alle andere door zijn eigen wil te verliezen.

We zien dat het recht op verandering van de nationaliteit welbeschouwd op het recht op eigenwillig verlies van een nationaliteit neerkomt. Iedereen zou derhalve het recht moeten hebben om op voorwaarde van bezit of verkrijgi...g van een ander staatsburgerschap afstand van zijn nationaliteit te kunnen doen. Het gaat hierbij niet om een absoluwt recht, maar om een recht dat aan bepaalde voorwaarden mag worden gebonden. Door Weis ${ }^{22}$ wordt aan de hand van het volkenrecht een aantal voorwaarden opgesomd, die tot weigering van een afstandsverklaring mogen leiden, namelijk:

- de verkrijging van een andere nationaliteit mag niet in strijd met het volkenrecht zijn en betrokkene moet deze bona fide verkrijgen;

- betrokkene moet zijn gewoon verblijf buiten de staat hebben waarvan hij de nationaliteit wil verliezen;

- betrokkene moet handelingsbekwaam zijn;

- betrokkene moet aan al zijn verplichtingen tegenover de staat waarvan hij de nationaliteit wenst te verliezen, hebben voldaan.

- de staat waarvan de nationaliteit zou worden verloren mag niet in oorlog zijn.

Het zou echter wenselijk zijn, om aan deze vereisten de eis toe te voegen, dat ze in de nationale wetgevingen scherp dienen te zijn geformuleerd en het staatsorgaan dat een afstandsverklaring moet "accepteren" uitsluitend bevoegd is om na te gaan of aan alle objectief gestelde vereisten is voldaan en indien dat het geval is, een afstandsverklaring niet mag weigeren.

Het bovenstaande zou mutatis mutandis ook moeten gelden voor een regeling, die het ontslag uit het staatsburgerschap, als de enige wijze van vrijwillig verlies van de nationaliteit kent.

1.2.2.2 Art. 34 van het verdrag betreffende de status van vluchtelingen en art. 32 van het verdrag betreffende de status van staatlozen

In art. 34 van het verdrag van Genève van 28 juli $1951^{23}$ betreffende de status van vluchtelingen en in art. 32 van het verdrag van New York van 28 september $1954^{24}$ betreffende de status van staatlozen hebben zich de verdragsluitende partijen verplicht de naturalisatie van staatlozen zoveel mogelijk te vergemakkelijken. Beide verdragsbepalingen zijn nagenoeg gelijkluidend.

Van de Oosteuropese landen is uitsluitend Joegoslavië partij bij deze twee verdragen.

22. Weis, p. 133-134.

23. UNTS 189, 137; Trb. 1966, 197. Daarover De Groot diss., P. 29; Maresceaux, p. 35-46.

24. UNTS 360, 117; Trb. 1955, 42 (1967, 22); Daarover De Groot diss., p. 29; Maresceaux, p. 46-51. 


\subsubsection{Art. 24 lid 3 BUPO-verdrag}

Art. 24 lid 3 van het BUPO-verdrag ${ }^{25}$ bepaalt:

"Elk kind heeft het recht een nationaliteit te verwerven".

Deze bepaling is een concretisering van het reeds in art. 3 van de VN-Verklaring van de rechten van het kind ${ }^{26}$ neergelegde recht op nationaliteit. Evenals bij het eerste lid van art. 15 van de Universele verklaring is ook hier het voornaamste gebrek van deze bepaling, dat er niet geregeld wordt welke nationaliteit door het kind zou moeten worden verworven ${ }^{27}$. Het zou derhalve wenselijk zijn om deze bepaling bijvoorbeeld zo te redigeren, dat elk kind het recht zou hebben hetzij op de nationaliteit vain zijn ouders, indien zij beiden dezelfde bezitten of één staatloos of reeds overleden is, hetzij op de nationaliteit van het land waarin het wordt geboren. Albanië.

Partij bij dit verdrag zijn alle Oosteuropese landen met uitzondering van

\subsubsection{Ant. 5 van het verdrag inzake uitbarning van alle vormen van rassendiscriminatie}

Art. 5 aanhef van het $\mathrm{VN}$-verdrag betreffende uitbanning van rassendiscriminatie van 7 maart $1966^{28}$ verbiedt discriminatie op grond van ras, huidskleur, nationale of etnische afstamming. In sub d onder IIII werd uitdrukkelijk een verbod van rassendiscriminatie met betrekking tot het recht op nationaliteit opgenomen.

Met betrekking tot dit verdrag kan de vraag worden gesteld, of een regeling die bijwoorbeeld op grond van etnische nationaliteit aan bepaalde groepen verzoekers de mogelijkheid van verlichte naturalisatie geeft, in strijd moet worden geacht met dit verdrag. Naar mijn mening moet deze vraag ontkennend worden beantwoord. Dit kan worden verduidelijkt door het feit dat verkrijging van de nationaliteit van een land in de regel zelfs aan afstamming wordt verbonden. $\mathrm{Er}$ wordt derhalve onderscheid gemaakt tussen kinderen die van ouders, onderdanen van een bepaald land afstammen en kinderen die vanuit het standpunt van dat land afstammelingen van vreemdelingen zijn. Weliswaar gaat het hier om de juridische en niet etnische afstamming, doch zoals reeds op p. 6 werd gezegd komen beide begrippen heden dikwijls met elkaar overeen. Het gaat ook om dezelfde achterliggende gedachte. Dit onderscheid op grond van afstamming wordt algemeen aanvaard; afstamming is éen van de voornaamste gronden voor verkrijging van de nationaliteit wan rechtswege. I $k$ zie derhalve geen beletselen dat afstamming dan

25. Het verdrag van New York van 19 december 1966; UNTS 999, 171; Trb. 1975, 60. Daarover Maresceau, p. 24-30; Verwilghen, p. 4; De Groot diss., p. 28; Blatova, p. 287-288; Ko tevnikow, p. $262-264$.

26. Resolutie 1386 (XIV) van de Algemene vergadering van de VN van 20 november 1959; Daarover Maresceaux, p. 30-33; Verwilghen, p. 3-4; De Groot diss., p. 28.

27. C. Jessurun d'Oliveira, in het bundel Internationaal recht en vrouwen deel 1, p. 282: "Ook aan kinderen...is het recht op een nationaliteit beloofd, zonder dat er een staat wordt aangewezen die zich dit recht moet aantrekken".

28. UNTS 660; 195; Trb 1966, 237. Daarover De Groot diss., p. 28. 
niet een grond voor bevoorrechte naturalisatie zou kunnen zijn. Het zou slechts anders zijn indien een nationaliteitswet van een bepaald land naturalisatie van bepaalde volksgroepen zou uitsluiten of beperken ${ }^{*}$.

Partij bij dit verdrag zijn alle Oosteuropese لanden met uitzondering van Albaniè.

\subsubsection{Ant. 9 van het verdrag betreffende uitbanning van vrouwendiscriminatie}

In art. 9 van het verdrag van New York van 18 december $1979^{30}$ werd het verbod van discriminatie van vrouwen op grond van de nationaliteit opgenomen. In het eerste lid wordt bepaald, dat de vrouwen gelijke rechten met betrekking tot verkrijging, verandering en behoud van een nationaliteit moeten hebben als mannen. Voorts worden ook de reeds in het verdrag van 20 februari 1957 neergelegde regels met betrekking tot een zelfstandige nationaliteitsrechtelijke positie van een gehuwde wrouw herhaald: huwelijk met een buitenlander en wijziging van de nationaliteit van de echtgenoot mogen geen automatische verandering van de nationaliteit van de vrouw, of haar staatloosheid veroorzaken. Bovendien mag ze niet gedwongen worden de nationaliteit van haar man aan te nemen. In het tweede lid van art. 9 wordt voorts bepaald, dat de vrouwen gelijke rechten als mannen met betrekking tot het doorgeven van de nationaliteit aan hun kinderen dienen te hebben.

Partij bij dit verdrag zijn alle Oosteuropese landen met uitzondering van Albanië.

\subsection{BILATERALIE VERDRAGEN STREKKENIDE TOT BEPERKING VAN GEVALLEN VAN MEERVOUdIGE NATIONALTTEIT}

\subsubsection{Inleiding}

In de loop der jaren hebben de Oosteuropese landen met uitzondering van Albanië en Joegoslavië onderling een netwerk van bilaterale verdragen gesloten, die strekken tot beperking van gevallen van dubbele nationaliteit van landen die met elkaar een dergelijk verdrag hebben gesloten. Albanië en Joegoslavië sloten uitsluitend verdragen met de USSR, terwijl er ook nog verdragen van Roemenië met Polen en met de ČSSR ontbreken. De USSR heeft inmiddels met alle Oosteuropese landen, behalve Albanië, de DDR en Joegoslavië reeds een tweede verdrag gesloten. Aangezien volgens de nationale regelingen van verkrijging van de nationaliteit van bijna alle Oosteuropese landen een kind reeds het staatsburgerschap van een land verwerft, indien één van zijn ouders de desbetreffende nationaliteit bezit, zouden de nationale regelingen van deze landen in bijna alle gevallen, waarin de ouders van een kind verschillende nationaliteiten bezitten tot bipatridie leiden. Door deze verdragen worden echter vele gevallen van dubbele Oosteuropese nationaliteit efficiënt uitgesloten.

29. Een voorbeeld hiervan zijn de beperkingen van naturalisatie van Joden in het tsaristische Rusland. Zie dlaarover p. 57.

30. Trb. 1981, 61. Zie hierover Jessurun d" Oliveira in het bundell Internationaal recht en vrouwen, deel 1, p. 279-291. 


\subsubsection{Inhoud}

De genoemde antibipatridieverdragen vertonen inhoudelijk vele overeenkomsten. Door de verdragsregels worden zowell de op het tijdstip van inwerkingtreding van elk verdrag bestaande gevallen van bipatridie beperkt, evenals mogelijke toekomstige gevallen van dubbele nationaliteit. De hoofdregels van de verdragen laten zich als volgt samenvatten: ${ }^{31}$

\subsubsection{Bestaande gevallen van bipatridie}

Met betrekking tot personen, die ten tijde van de inwerkingtreding van de respectievelijke verdragen de nationaliteit van telkens beide verdragstaten bezaten, wordt onderscheid gemaakt tussen meerderjarigen en minderjarigen.

\section{Meerderjarigen}

Alle meerderjarigen, die de nationaliteit van beide verdragsluitende partijen bezaten, moesten binnen een termijn van één jaar na de inwerkingtreding van de verdragen voor één van beide nationaliteiten kiezen, dat wil zeggen afstand van één van hun staatsburgerschappen te doen. Indien betrokkene geen keuze maakte, verloor hij van rechtswege één van beide nationaliteiten, namelijk die van het land waarin hij niet tevens woonachtig was ${ }^{32}$.

\section{Minderjarigen (tot 18 jaar)}

Met betrekking tot minderjarigen wordt onderscheid gemaakt tussen gevallen waarin hun ouders dezelfde nationaliteit bezaten en gevallen waarin de nationaliteit van de ouders verschillend was.

Bezaten de ouders dezelfde nationaliteit, dan behield in sommige verdragen het kind uitsluitend die nationaliteit. In andere mochten de ouders binnen éen jaar na de inwerkingtreding van het desbetreffende verdrag de nationaliteit van het kind kiezen.

Voor het geval dat de nationaliteit van de ouders verschillend was (en beide ouders de nationaliteiten van beide verdragstaten bezaten), werden weer diverse oplossingen gekozen.

- het kind behield de nationaliteit van het land waarin het woonde, waarbij het kind na zijn 16de of 14de levensjaar het recht kreeg om voor de andere nationaliteit te kiezen; of

31. Zie voor een gedetailleerde bespreking van de verdragsregels Hecker, WGO 1986, p. 273-283 en over de eerste verdragen Sipkov, AJIL 1962, p. 1010-1019.

32. Volgens de verdragen van de USSR met Hongarije, Joegoslavië en Roemenie hadden betrokkenen geen keuzemogelijkheid en behielden uitsluitend de nationaliteit van het land waarin ze woonden. 
de ouders moesten binnen én jaar na de inwerkingtreding van het verdrag gezamenlijk éen van beide nationaliteiten kiezen en kinderen boven 14 of 16 jaar moesten zelf met de keuze van hun ouders instemmen.

\subsubsection{Toekomstige gevallen van bipatridie}

Bij de bovenbeschreven overgangsregeling werden de ten tijde van inwerkingtreding van de verdragen bestaande gevallen van bipatridie geëlimineerd. De overige regels van de verdragen hebben betrekking op gevallen, waarin na de inwerkingtreding van de verdragen bipatridie zou kunnen ontstaan. Het gaat hierbij om de nationaliteit van kinderen, die na de inwerkingtreding van de verdragen worden geboren en om onderdanen van een Oosteuropees land, die in een ander Oosteuropees land worden genaturaliseerd.

\section{Kinderen, geboren na de inwerkingtreding van de verdragen}

Door de antibipatridiewerdragen wordt een regeling getroffen met betrekking tot de nationaliteit van kinderen, waarvan de ouders telkens de nationaliteiten van beide verdragspartijen bezitten. De ouders van het kind moeten steeds binnen een bepaalde termijn ( 3 maanden, 6 maanden of éen jaar) na de geboorte van het kind kiezen, welke van zijn van beide nationaliteiten het kind zal behouden. Indien er geen keuze wordt gemaakt, dan behoudt het kind automatisch de nationaliteit van het land waar hij na het verloop van de gestelde termijn woont. De andere nationaliteit wordt steeds ex tunc verloren.

Door deze verdragen wordt meervoudige nationaliteit van kinderen van Oosteuropeanen nagenoeg uitgesloten, tenzij de ouders de volgende combinaties van nationaliteiteiten bezitten:

- de Joegoslavische en Één van de andere Oosteuropese landen m.u.v. de USSR, - de Albanese en van één van de andere Oosteuropese landen m.u.v. de USSR,

- de Roemeense en de Poolse,

- de Roemeense en de Tsjechoslowaakse.

\section{Potentiële naturalisandi}

Interessant is dat niet in alle verdragen regels met betrekking tot onderdanen van één staat, die zich in de andere verdragstaat laten naturaliseren, werden opgenomen. De eis van verlies van de oude nationaliteit bij naturalisatie wordt in de verdragen evenmin scherp geformuleerd. Slechts in de notawisseling tussen Bulgarije en Hongarije wordt bepaald, dat naturalisatie van onderdanen van de andere partij uitsluitend na ontslag uit de oude nationaliteit geldig is, ongeacht de nationale wetgevingen ${ }^{33}$. De regelingen van de verdragen kunnen in drie groepen worden verdeeld. In de eerste zeven verdragen ${ }^{34}$ worden geen eisen met betrekking

33. Hecker, WGO 1986 , p. 281 .

34. De verdragen van de USSR met Joegoslavië, Hongarije, Roemenie (het eerste verdrag"), Albanie, Tsjechoslowakije (het eerste verdrag), Bulgarije (het eerste verdrag) en Polen (het eerste verdrag). Hecker, WGO 1986 , p. 281. 
tot het verlies van de oude nationaliteit door de naturalisandi gesteld. In sommige verdragen ${ }^{35}$ wordt voorts de mogelijkheid van behoud wan de oude nationaliteit door de naturalisandus aan de staat van afkomst van betrokkene uitdrukkelijk voorbehouden. Tot de derde groep tenslotte, behoren verdragen, waarin de staten zich verplichten om de naturalisatie van het ontslag uit de oude nationaliteit afhankelijk te maken ${ }^{36}$.

\subsubsection{Lijst van verdragen, strekkende tot beperking van bipatridie}

Hieronder is een lijst van de antibipatridieverdragen die de Oosteuropese landen onderling hebben gesloten, opgenomen ${ }^{37}$. Telkens wordt de datum van inwerkingtreding, alsmede de vindplaats van het verdrag in UNTS (voorzover geregistreerd) vermeld.

$\begin{array}{lcll}\text { USSR-Joegoslavië } & 31 \text { juli } & 1956^{38} & \text { UNTS 259, 155 } \\ \text { USSR-Hongarije } & 15 \text { januari } & 1958 & \text { UNTS 318, 35 } \\ \text { USSR-Roemenië } & 3 \text { maart } & 1958 & \text { UNTS 318, 89 } \\ \text { USSR-Albanië } & 29 \text { april } & 1958 & \text { UNTS 307, 251 } \\ \text { USSR-Tsjechoslowakije } & 21 \text { juli } & 1958 & \text { UNTS 320, 111 } \\ \text { USSR-Bulgarije } & 28 \text { maart } & 1958 & \text { UNTS 302, 3 } \\ \text { USSR-Polen } & 8 \text { mei } & 1958 & \text { UNTS 319, 277 } \\ \text { Bulgarije-Hongarije } & 3 \text { juli } & 195939 & \text { UNTS 477, 321 } \\ \text { Bulgarije-Roemenië } & 24 \text { december } & 1959 & \text { UNTS 387, 61 } \\ \text { CSSR-Hongarije } & 19 \text { maart } & 1961 & \text { UNTS 397, 227 } \\ \text { Polen-Hongarije } & 3 \text { februari } & 1961 & \text { UNTS 437, 3 } \\ \text { USSR-Hongarije II } & 19 \text { augustus } & 1963 & \text { UNTS 577, 201 } \\ \text { USSR-Polen II } & 13 \text { januari } & 1966 & \text { UNTS 571, 217 } \\ \text { Polen-CSSR } & 20 \text { mei } & 1966 & \text { UNTS 572, 181 } \\ \text { USSR-Bulgarije II } & 19 \text { januari } & 1967 & \text { UNTS 596, 177 } \\ \text { USSR-DDR } & 13 \text { februari } & 1970 & \text { UNTS 777, 143 } \\ \text { DDR-Hongarije } & 8 \text { juli } & 1970 & \text { UNTS 986, 59 } \\ \text { DDR-Bulgarije } & 11 \text { mei } & 1972 & \\ \text { Bulgarije-Polen } & 5 \text { september } 1972 & \\ \text { CSSK-DDK } & 31 \text { maart } & 1974 & \\ \text { Bulgarije-CSSR } & 4 \text { mei } & 1975 & \\ \text { DDR-Polen } & 25 \text { april } & 1976 & \\ \text { USSR-Roemenië II } & 16 \text { juni } & 1979 & \\ \text { DDR-Roemenië } & 17 \text { februari } & 1980 & \\ \text { Roem-Hongarije } & 24 \text { februari } & 1980 & \\ \text { USSR-CSSR II } & 5 \text { juli } & 1981 & \end{array}$

35. De verdragen vain de USSR met Polen (het tweede verdrag), Bulgarije (het tweede verdrag) en de DDR. Hecker, WGO 1986, p. 281-282.

36. De verdragen van de DDR met Hongarije, Bulgarije, CSSR, Roemenië en $\mathbb{P o l e n .}$ De verdragen van de USSR met Roemenië en CSSR (tweede verdragen), voorts tussen Bulgarije en Hongarije, Bulgarije en CSSR en tussen Roemenië en Hongarije. Hecker, WGO 1986, p. 281.

37. Dit overzicht is ontleend aan Hecker, WGO 1986, p. 283.

38. Met notawisseling van $22 / 29$ augustus 1958.

39. Met notawisseling betreffende naturalisatie, UNTS 477,340 . 


\subsection{Bilaterale verdragen met Westerse landen}

Hieronder zal aandacht worden besteed aan bilaterale verdragen die tussen de VS en enkele Oosteuropese landen werden gesloten en die eveneens althans gedeeltelijk betrekking hebben op de nationaliteit. Van de Westeuropese landen heeft slechts Oostenrijk met de DDR een dergelijk verdrag gesloten. Het gaat hierbij om verdragen, die betrekking hebben op emigranten uit Oost Europa en hun kinderen. De VS sloten reeds in de jaren twintig en dertig van deze eeuw naturalisatieverdragen met Albanië, Bulgarije en Tsjechoslowakije ${ }^{40}$. De regelingen van deze verdragen komen er op neer, dat een onderdaan van deze landen door naturalisatie in de VS van rechtswege zijn oude nationaliteit verloor. Deze verdragen werden ook door communistische regeringen in die landen niet opgezegd.

Zeer interessant zijn de consulaire verdragen en de bijbehorende notawisselingen die de VS met een aantal communistische landen hebben gesloten, namelijk met Joegoslavië, Bulgarije, de DDR en Polen ${ }^{41}$. Het eerste verdrag werd gesloten bij notawisseling van 23-25 maart 1950 met Joegoslavië, derhalve in de tijd direct na de breuk tussen dit land en de andere Oosteuropese landen. Verdragen met andere landen volgden pas iets meer dan twintig jaar later.In deze verdragen wordt een regeling ten gunste van polypatriden die zowel de VS- als één van de Oosteuropese nationaliteiten bezitten, opgenomen. Deze regelingen komen er op neer, dat de Oosteuropese staten met betrekking tot dergelijke personen die met een VS-paspoort het land bezoeken, afstand wordt gedaan van het reeds genoemde recht om dergelijke personen uitsluitend als eigen onderdanen te behandelen (exclusiviteitsbeginsel). Betrokkenen worden uitsluitend gezien als Amerikaanse staatsburgers, hetgeen betekent dat ze hun VS-paspoort mogen gebruiken, dat hen niet de uitreis kan worden geweigerd, dat zij in militaire dienst worden opgeroepen, of dat zij zelfs als tegenstanders van het regime worden vervolgd ${ }^{42}$.

Door de VS werden ook consulaire verdragen met Hongarije en Roemenië gesloten, echter zonder de bepalingen ten gunste van bipatriden ${ }^{43}$. Geen verdragen werden gesloten met de USSR, Albanië en Tsjechoslowakije ${ }^{44}$.

40. LNTS CLX, 31; XXV, 238 en XCVI, 301.

41. Notawisseling van 23/25 maart 1950 met Joegoslavié, in werking getreden op 1 april 1950 UNTS 98, 195. Notawisseling en consulair verdrag van 31 mei 1972 met Polen; in werking getreden op 6 juli 1973 UNTS $925 / 6 ; 31$. Notawisseling en consulair verdrag van 14 aprill 1974 met Bulgarije ILM 1974, p. 1416; in werking getreden op 28 mei 1975. Het consulair verdrag van 4 september 1979 met DDR, GBI. 1981 II, p. 1 ; in werking getreden op 18 februari 1981. Zie over deze verdragen Hecker, WGO 1986 , p. 31-33.

42. Hecker, WGO 1986 , p. 32 .

43. Hecker WGO 1986, p. 7 .

44. Tussen de CSSR en de VS werd weliswaar een consulair verdrag gesloten, maar is nog niet geratificeerd. Hecker, WGO 1986, p. 32. Zie voor het verdrag ILM 1974, p. 1416. 


\subsection{GesCHIEDENIS}

\subsubsection{Inleiding}

Tegen het einde van de eerste wereldoorlog kwam het in Rusland tot zeer ingrijpende veranderingen. Een sterke economische crisis, militaire nederlagen en groeiende ontevredenheid met de regering van tsaar Nikolaj II leidden in 1917 tot

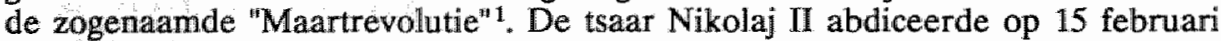
ten gunste vain zijn broer Michail, die op zijn beurt reeds op 16 maart gedwongen werd de troon op te geven, waarna een republiek werd uitgeroepen ${ }^{2}$. Op 13 maart 1917 werd een woorlopige parlementair-democratische regering gevormd met prins Lvov als minister-president en Kerenskij als minister van oorlog en marine ${ }^{3}$. Sedert 21 juli 1917 was de belangrijkste man van deze regering, A.F. Kerenskij, ook zelf minister-president ${ }^{4}$. Dit regime bleef echter slecht tot 7 november 1917 aan de macht. Op die dag pleegden de bolsjevieken ${ }^{5}$ een nieuwe staatsgreep ${ }^{6}$. De nieuwe regering sloot vervolgens reeds op 5 december een wapenstilstand met Duitsland en op 3 maart 1918 het vredesverdrag van Brest-Litowsk, om de oorlog met Duitsland zo snel mogelijk tot een einde te brengen. De bolsjevieken ontmoetten evenwel zowel in het binnen- als in het buitenland sterke tegenstand, hetgeen tot een bloedige burgeroorlog leidde, waaraan ook enige andere landen ${ }^{7}$ deel hebben genomen. Pas in 1921 werd de "overwinning" van de bolsjevieken een $\mathrm{feit}^{8}$.

Staatsrechtelijk werd Rusland in 1917 eerst republiek en na de oktoberrevolutie een socialistische sovjetrepubliek (de Russische Socialistische Federatieve Sovjet Republiek, de RSFSR). De uitgangspunten voor een nieuwe constitutie werden geformuleerd in de Declaratie van de rechten van het werkende en uitgebuite volk van 25 janwari $1918^{\circ}$. Deze nieuwe staat, met Moskou als hoofdstad ${ }^{10}$, werd gevestigd op het grondgebied van het vroegere keizerrijk, met uitzondering van Finland, Polen, Estland, Letland en Litouwen, die onafhankelij-

1. Zweigert/Kötr, I., p. 347; Bergmann/Ferid, p. 2b; Geilke 1983, p. 43. De regering van tsaar Nilikolaj II viel wolgens de Gregoriaanse kalender op 8 maart 1917 en volgens de Russische op 22 februari. Vandaar ook de naam "Februarirevolutie". De data worden in dit werk steeds volgens de Gregoriaanse kalender weergegeven.

2. Enciklopedija, p. 249; Geilke 1983, p. 44.

3. Geilke 1983, p. 44; Zaitzeff, p. 275; Enciklopedija, p. 248-249.

4. Enciklopedija, p. 252; Geilke 1983, p. 44; Prochorov, p. 569.

5. De linkervleugel van de Russische sociaaldemocratische partij onder leiding van Lenin, die zich op het partijcongres van 1903 in Brussel afscheidde. David, p. 182; Geilke 1983, p. 45; Malaja enciklopedija I, p. 1127; Maurach 1955, p. 16-17.

6. Enciklopedija, p. 255-256; Geilke 1983, p. 46.

7. Groot-Brittannië, Japan, Roemeniè en de Verenigde Staten. Zie over deze periode Enciklopedija, p. $261-269$.

8. Zwengert/Kötz I. p. 349; David p. 184.

9. SU (Sbornik Uzakonenij i Rasporjaženij Rabočego i Krest'janskogo pravitel'stva) RSFSR 1918, nr. 15 , pos. 215 . Geilke 1983 , p. 50.

10. Voor de revolutie was de hoofdstad Petrograd (St. Petersburg), het huidige Leningrad. 
ke staten vormden ${ }^{11}$. De eerste grondwet van de RSFSR werd vervolgens op 10 juli $1918^{12}$ afgekondigd.

Nadat het "Nouveau régime" bij de declaratie van 15 november $1917^{13}$ het recht van in Rusland wonende volkeren tot zelfbeschikking en afscheiding erkende, ontstonden er verschillende min of meer zelfstandige republieken, waarvan de meeste weer gauw verdwenen ${ }^{14}$. Dit gebeurde met name in gebieden, waarin etnisch niet-Russische bevolkingsgroepen de meerderheid vormden. Zo werd het grondgebied van de RSFSR langzamerhand gereduceerd tot de omvang van de huidige deelstaat met dezelfde naam.

$\mathrm{Na}$ de burgeroorlog werd op 30 december 1922 tussen de RSFSR en de daarvan afgescheiden republieken Oekraïne, Transkaukasie en Witrusland een verdrag gesloten ${ }^{15}$. Deze overeenkomst vormde de grondslag voor hereniging op federale basis, zodat op 6 juli 1923 de Unie van Socialistische Sovjet Republieken (USSR) werd geproclameerd ${ }^{16}$. Later traden ook andere republieken tot het federale verband toe. Op 2 februari 1924 was het de regering van Groot-Brittannië die als eerste de USSR erkende. De eerste grondwet van de USSR werd op 31 december $1924^{17}$ afgekondigd. Deze constitutie werd op 5 december 1936 vervolgens grondig gewijzigd ${ }^{18}$.

Op 23 augustus 1939 sloot de USSR met Duitsland een niet-aanvalsverdrag en een geheim verdrag betreffende de verdeling van interessesferen in OostEuropa ${ }^{19}$. Volgens dit verdrag zouden Finland, de Baltische staten behalve Litouwen, een gedeelte van Polen en het Roemeense Bessarabië aan de Sovjetunie toekomen. Na de Duitse aanval op Polen marcheerden de Sovjettroepen op 17 september 1939 eveneens over de Poolse grens. Het Poolse grondgebied werd vervolgens bij het Grens- en vriendschapsverdrag van 28 september $1939^{20}$ verdeeld. Het door de Sovjetunie bezette gedeelte werd deels aan Litouwen en gedeeltelijk aan de USSR (Oekraïne en Witrusland) toegevoegd ${ }^{21}$. In de eerste

11. Daartoe werd De RSFSR gedwongen volgens de bepalingen wan het vredeswerdrag met Duitsland van 3 maart 1918 in Brest-Litowsk en de aanvulling daarop het verdrag van Berlijn van 27 augustus 1918. Cr. Sandifer AJIL 1936, pk 614; Taracouzio p. 22.

12. SU RSFSR 1918,nr. 51, pos. 582; Enciklopedija, p. 261. Duitse vertaling bij Grünberg, p. 4-16; Engelse bij Rothstein, p. 11-31.

13. SU RSFSR 1917-18, nr. 2, pos. 18. Geilke, p. $49-50$.

14. Sandifer, AJIL 1936, p. 614-615; SGS deel 25, p. 22; Dennis, Political Science Quarterly 1923, p. 544-545; Korovine, RGDIP 1925, p. 296.

15. Dennis, Political Science Quarterly 1923, p. 548; Bergmann/Ferid, p. 2b; Geilke 1983, p. 62-63; Maurach 1955, p. 91 . Enciklopedija, p. 273.

16. Engelse vertaling van de proclamatie bij Taracouzio, p. 355-369.

17. Vestnik van het Centraal Executiefcomité, Raad van de volkscommissarissen en van de Raad voor de Arbeid en Defensie USSR 1924, nr. 2, pos. 24. Zie Geillke 1983, p. 63.

18. Lzvestija 1936, nr. 136. Zie Lesage, p. 7; Enciklopedija, p. 286 en uitvoerig Maurach, Handbuch der Sowjetverfassung, München 1955.

19. VVS (Vedomosti Verchovnog Soveta) USSR $1939 \mathrm{nr}$. 37, in werking getreden op 24 september 1939; Enciklopedija, p. 287; Geilke 1983, p. 91.

20. VVS USSR 1940, nr. 10, in werking getreden op 14 december 1939; Duitse RGBI. 1940, I, p. 40; SGS deel 9, p. 15. Zie ook het aanvullend protocol van 4 oktober 1940, VVS 1940, nir. 10; RGBI. II, p. 5; ZfoR 1939, p. 303-304.

21. SGS deel 3, p. 56. Het ging om de gebieden: Wilna, Westoekraïne en Westwitrusland. Wilna werd op grond van een verdrag van 11 oktober 1939, VVS USSR 1939, nr. 37; in werking getreden op 16 oktober 1939, aan Litouwen afgestaan, terwijl de twee andere bij de wetten van 14 en 15 november 1939, Izwestija 1939, nr.. 256, bij de USSR werden ingellijfd. 
dagen van augustus 1940 werden vervolgens de Baltische staten na een ongeveer twintigjarige zelfstandigheid, als socialistische sovjetrepublieken, bij de USSR ingelijf 2 . Deze annexatie werd echter door verschillende Westerse landen een lange tijd niet (of slechts de facto) erkend. In november $1940 \mathrm{kwam}$ het ook tot een korte oorlog tussen de USSR en Finland, warma bij het vredesverdrag van 12 maart 1940 kleine grenscorrecties werden wastgesteld ${ }^{23}$ "Roemenie moest aan de Sovjetunie bij een notawisseling van 26-28 juni 1940 de gebieden Noord-Boekowina en Bessarabië $\operatorname{afstan}^{24}$

Op 22 juni 1941 werd de USSR door Duitsland aangevallen, waarna een gedeelte van de Sovjetunie door de Duitsers werd bezet ${ }^{25}$. Tot mei 1945 werd het grondgebied van de Sovjetunie, met geheel Oost Europa en een gedeelte van Duitsland, Oostenrijk en Joegoslavië door het Rode Leger van de Duitse bezetting bevrijd. Op 9 augustus 1945 verklaarde de USSR de oorlog aan Japan dat dan weer op 2 september 1945 capituleerde ${ }^{26}$. Na de tweede wereldoorlog bleven verschillende gebieden die de USSR kort voor de oorlog inlijfde, onderdeel van de Sovjetunie. Dit waren de roormalige Baltische staten, Bessarabië en Noord-Boekowina. Voorts werd het Sovjet-grondgebied tevens ten koste van een aantal andere landen. uitgebreid. Zo werd op grond van het verdrag van Moskou van 29 juni 1945 het voormalige Tsjechoslowaakse gebied Karpatho-Oekraïne een onderdeel van de USSR $^{27}$. Ook Duitsland moest een gedeelte van zijn grondgebied aan de Sovjetunie afstaan. Bij het verdrag van Potsdam van 2 augustus 1945 werden de door de USSR bezette gebieden Noord-Oostpruisen (Königsberg, Kaliningrad) en Memelland in afwachting van een definitieve beslissing aan de USSR toegekend ${ }^{28}$ "Het eerste gebied werd bij de RSFSR en het tweede bij Litouwen ingelijfd ${ }^{29}$ "Ook de grenzen tussen de Sovjetunie en een aantal Aziatische landen werden in de tijd rond de tweede wereldoorlog veranderd. Het ging daarbij om de grenzen met Afghanistan, China, Iran, Japan, Mongolië en Turkije ${ }^{30}$.

In de tijd na de tweede oorlog heeft de Sovjetunie haar invloed in de door haar bevrijde Oosteuropese staten behouden. In al deze landen werden in de tweede helft van de jaren veertig volksrepublieken uitgeroepen. In september 1947 werd een "Informatiebureau van communistische en arbeiderspartijen" (Comin-

22. Enciklopedija p. 287; Darrover Meder, ZfoR 1940-41 p. 124-147; Makarov, ZaöRV 1940-41, p. 682-707; SCS deel 3, p. 60-62. Zie de wetten wan resp. 3 augustus 1940 (Litouwen), 5 augustus 1940 (Letland) en 6 augustus 1940 (Estlland), alle gepubliceerd in VVS USSR 1940, na. 28; Duitse vertaling: ZfoR 1940-41, p. 182-183.

23. VVS $1940_{4}$ nr. 14, in we rking getreden op 20 maart 1940; Enciklopedija, p. $288_{*}^{*}$ Duitse vertaling in ZaöRV 1940-41, p. 331-333. Zue over het conflict tussen de USSR en Finland Makarov, Zaó RV $1940-41, p=294-330$.

24. Bessarabiè werd grotendeels ingelijfd bij de ASSR Moldavie en Noord-Boekowina en de rest wan Bessarabie bij de Ockraine. VVS 1940, nr. 28, ZfoR 1940-41 p. 181. Zie daarover SGS deel 3, p. 59; SGS deel 5 p. 67; Sugga, diss. p. 22; Zic daarover uitvoerig Makarov, ZaöRV 1940-41, p. $336-359$.

25. Enciklopeddijal, p. 288.

26. Einciklopedija, p. 294.

27. VVS USSR 1945, tr 79; Algedrukt bij Vilkov, p. 61-62. Daarover Beuer, p. 179-182; Schmid, p. 38 ; $S \mathrm{CS}$ deel $25, \mathrm{p}, 281-283$. 2 ie ook het aanvillend protocol van 29 juni 1945

28. SOS deell 3, p. 65-66.

29. Enciklopedija, p. 294 .

30. Zie daarover SGS deel 25, p. 199-201 (Afghanistan), 203-218 (China), 242-247 (Japan), 250-253 (Iran), 248-249 (Mongolicic) en 283-286 (Turkije). 
form), opgericht ${ }^{31}$. Door dit orgaan kon de Communistische partij van de USSR haar invloed op andere communistische partijen "institutionaliseren". In de eerste helft van $1948 \mathrm{kwam}$ het tot escalatie van een conflict tussen de Sovjetunie en Joegoslavië, hetgeen leidde tot een economisch en politiek isolement van het tweede land dat tot na de dood van Stalin in 1953 duurde ${ }^{32}$. De integratie in Oost Europa onder leiding van de Sovjetunie, zette zich ook op economisch en militair gebied door. Zo werd op 25 januari 1949 de Raad voor wederzijdse economische hulp (COMECON) opgericht en op 14 mei 1955 het Warschaupact ${ }^{33}$.

Op 7 oktober 1977 werd in de Sovjetunie een nieuwe grondwet afgekondigd ${ }^{34}$, waardoor enkele staatsrechtelijke wijzigingen werden doorgevoerd. In de laatste jaren komt het in de USSR onder invloed van de secretaris-generaal van de communistische partij $\mathrm{M}$. Gorbacëv tot ingrijpende veranderingen in zowel de binnen- en de buitenlandse politiek, alsmede in de wetgeving van de USSR ${ }^{35}$.

\subsubsection{Het nationaliteitsrecht tot 1918}

\subsubsection{Algemeen}

Het Russische keizerrijk kende geen algemene nationaliteitswet. Regels met betrekking tot verkrijging en verlies van de nationaliteit waren te vinden in de vreemdelingenwetgeving die (evenals de rest van het Russische recht) zeer onoverzichtelijk was. De vreemdelingenwetgeving bevatte hoofdzakelijk regels betreffende naturalisatie en optie, terwijl verkrijging van de nationaliteit door geboorte in het geheel niet wettelijk was geregeld.

\subsubsection{De mationaliteitsrechtelijke regeling in de Svod van 1876}

\subsection{Algemeen}

In de eerste helft van de $19 \mathrm{de}$ eeuw kreeg de belangrijkste Russische codificatiespecialist Speranskij ${ }^{36}$ van tsaar Nikolaj I de opdracht, de uitermate onoverzichtelijk geworden Russische wetgeving te systematiseren ${ }^{37}$. Het werk van Speranskij resulteerde in een verzameling van 15 banden, Svod Zakonov Rossijskoj Imperii

31. Lid daarvan werden alle Oosteuropese communistische partijen, alsmede die van Frankrijk en Italiê. In juni 1948 werd de Joegoslavische communistische partij uitgeslloten en werd de zetel wan Belgrado naar Boekarest verplaalst.

32. In 1955 hadden de betrekkingen tussen beide landen zich genormaliseerd, waarbij Joegoslaviè een rellatief onafhankelijke positie behield. Enciklopedijis, p. 298; Tratnik, p. 421.

33. Enciklopedija, p. 299.

34. VVS USSR 1977, nr. 4, pos. 18/19; Duitse vertaling; Roggemann, p. 395-453; Osteuropa 1978, p. A 3 e.v. ; Engelse: Feldbrugge, The Constitutions of the USSR and the Union Republics, Alphen aan den Rijn/Germantown 1979; Nederlandse: Constitutie(grondwet) van de Unie van socialistische sowjet-republieken, Moskou 1980 . Zie over de totstandkoming van deze grondwet Lesage, p. 7-17. Zie ook Schultz, ROW 1978, p. $207-213$.

35. Feldbrugge 1988 , p. 494.

36. Speranskij ontwierp in de jaren 1809 -1810 reeds cen constitutie en een burgerlijk wetboek. Het ontwerp-BW werd overigens zeer sterk door de Franse Code Civil geïnspireerd. Zweigert/Kötz I, p. 345; Constitutions, p. 1; Geilke 1983, p. 39.

37. Gorlé, JOR 1/1981, p. 9-35; Polizei Hamburg, p. 174. 
(wettenverzameling van het Russische Imperium) genoemd, die in 1832 voor de eerste keer verscheen en ongeveer 42.000 artikelen bevatte ${ }^{38}$. De laatste integrale publicatie van de Svod dateert uit 1857, daarna werden slechts afzonderlijke (delen van) banden gereviseerd en uitgegeven ${ }^{39}$.

Regels met betrekking tot vreemdelingen en de verkrijging van het Russische "onderdaanschap" 40 werden voor het eerst gesystematiseerd in deel 6 van het eerste boek van band IX (artt. 1538-1558) van de Svod in de versie van 1857. Vervolgens werd op 10 februari $1864^{41}$ een naturalisatiewet afgekondigd, die aan artt. 15381558 Svod derogeerde ${ }^{42}$. Band IX verscheen daarna in 1876 weer in zijn geheel en werd nog in $1881,1883,1886,1887$ en 1889 aangevuld. De na 1876 verschenen versies van de Svod bevatten geen nationaliteitsrechtelijke wijzigingen van betekenis.

In band IX van de Svod van 1876 vinden we in de artt. 990-1031 bepalingen betreffende vreemdelingen, waarvan de artt. 1010-1031 regels omtrent verkrijging van de Russische nationaliteit bevatten ${ }^{43}$. De bepalingen met betrekking tot naturalisatie werden in nagenoeg ongewijzigde vorm uit de naturalisatiewet van 1864 overgenomen ${ }^{44}$. Er zij overigens op gewezen, dat in Polen, Finland en de Baltische landen iets afwijkende regelingen golden ${ }^{45}$.

\subsection{Verkrijging van de nationaliteit}

De nationaliteit van het Russische keizerrijk kon worden verkregen van rechtswege, door optie en door naturalisatie.

\section{a. Verkrijging van rechtswege}

Verkrijging van de Russische nationaliteit werd van rechtswege gekoppeld aan:

- geboorte uit Russische ouder(s);

- geboorte in Rusland in combinatie met het treden in staatsdienst (art. 998);

- huwelijk met een Russische man (art. 1028);

Adoptie door een Rus had geen verkrijging van de nationaliteit ipso iure tot gevolg ${ }^{45}$.

38. David p. 164; Zweigert/Kötz I., p. 346; Constitutions p. 2.

39. Policei Hamburg, p. 174.

40. Russisch: "Poddanstvo". In de literatuur werd echter reeds destijds ook de huidige term "grazdanstwo" (staats)burgerschap gebezigd. Zie Polizei Hamburg, p. 177, voetnoot 2.

41. State Papers 63,920. Clunet 1903, p. 436-441.

42. Zie woor een Engelse vertaling State Papers 63, p. 920; Franse: Clunet 1903 p. 436.

43. Polizei Hamburg, p. 175.

44. Zie voor een overzicht van verschillen tussen de wet van 1864 en de Svod van 1876: Polizei Hamburg, p. 175, voetnoot.

45. Kazansky, Clunet 1898 , p. 227.

46. Polizei Hamburg, p. 180-181. 
Verkrijging van het Russische staatsburgerschap iure sanguinis werd in de Svod in het geheel niet geregeld. De wetgever ging stilzwijgend van dit beginsel uit ${ }^{47}$. Een wettig kind was Rus, indien het uit een Russische vader werd geboren ${ }^{48}$. Een onwettig kind volgde de Russische nationaliteit van zijn moeder ${ }^{49}$.

Ondanks het ontbreken van een wettelijke bepaling werd in het algemeen aangenomen, dat een kind van een vreemdelinge dat door een Rus werd gewettigd, eveneens de Russische nationaliteit verwierf ${ }^{50}$.

\section{ii. Geboorte op het Russische grondgebied}

Uitsluitend iure soli kon het staatsburgerschap van het keizerrijk niet worden verworven $^{51}$. Wel verkreeg degene die op Russisch grondgebied werd geboren en vervolgens in staatsdienst trad, deze nationaliteit (art. 998). Tevens werd vereist dat betrokkene een eed van trouw had afgelegd ${ }^{52}$. Ten aanzien van vondelingen bestond er geen wettelijk regeling.

\section{iii. Huwelijk met een Rus}

Een vreemdelinge verwierf door huwelijk met een Rus diens nationaliteit. Deze behield zij ook in het geval, dat het huwelijk door dood van de man of door echtscheiding eindigde (art. 1028) ${ }^{53}$. De nationaliteit werd verkregen ongeacht of ze haar oude nationaliteit door of in verband met het huwelijk verloor.

\section{b. Optie}

De optie werd in de nationaliteitsrechtelijke regeling van de Svod niet als een aparte wijze van verkrijging van de Russische nationaliteit genoemd. De bepalingen, die "optierechten" verleenden werden "officieel" als verlichte naturalisaties gezien. Een (verkapt) optierecht- de wet sprak van een recht om tot het afleggen van een eed van trouw te worden toegelaten- op de Russische nationaliteit werd toegekend aan de volgende categorieën personen:

degenen, die in Rusland geboren en opgevoed waren, of althans daar een middelbare of hogere opleiding hadden gevolgd en tussen 21 en 22 jaar oud waren (art. 1023) $)^{54}$;

47. Maurach, p. 6 met verdere literatuurverwijzingen.

48. Maurach, p. 6; Polizei Hamburg, p. 177.

49. Polizei Hamburg, p. 177; SGS deel 3, p. 11-12.

50. Maurach, p. 6.

51. Cr, Kowal-Wolk, p. 37.

52. Kazansky, Clunet 1898, p. 229.

53. Polizei Hamburg, p. 178 ; Kazansky, Clunet 1898 , p. $228-229$.

54. Ten onrechte wordt in Polizei Hamburg, p. 180 gestell, dat voor de verkrijging van de Russische nationaliteit in dit geval tevens toestemming van de regering werd vereïst. Cf. Kazansky, Clunet 1898, p. 229: "... sans aucune formalité..." en de Duitse vertaling van art. 1023 in Polizei Hamburg, p. 184: "... erlangen... das Recht zur Leistung russischen Unterthaneneides wenn sie solches wünschen...zugelassen zu werden". Zie ook Maurach, p.9. 
- personen, die in Russische militaire of civiele dienst traden en aan geestelijken van "vreemde" (niet-Russisch-orthodoxe) godsdienst, die door het Ministerie van binnenlandse zaken naar Rusland werden geroepen (art. 1025) ${ }^{55}$;

gewezen Russische vrouwen, die hun nationaliteit door of in verband met een huwelijk met een vreemdeling hadden verloren, alsmede de uit die huwelijken geboren kinderen, nadat die huwelijken werden ontbonden (artt. 1026 en 1027) ${ }^{56}$. Terwijl de kinderen een eed van trouw dienden af te leggen, werd bij hun moeders het overleggen van een bewijs van beëindiging van het huwelijk aan het hoofd van het gouvernement van hun (nieuwe) woonplaats voldoende geacht (art. 1026).

\section{Invloed op de nationaliteit van gezinsleden van betrokkene}

Een optie was in het tsaristische Rusland persoonlijk en omvatte niet eventuele kinderen van betrokkene(art. 1015) ${ }^{57}$. Slechts de vrouw van de optant, die nationaliteitsrechtelijk geheel onzelfstandig was, deelde in de verkrijging van de nationaliteit door haar man (art. 1028). Door deze regeling ontstond er een merkwaardige situatie: terwijl een meerderjarig kind van een optant bij wijze van uitzondering tegelijkertijd met zijn ouder(s), of althans binnen éen jaar daarna kon worden genaturaliseerd (zie daarover p. 58), moesten minderjarigen wachten, totdat zij zelf aan de optie- of naturalisatievereisten hadden voldaan ${ }^{58}$.

\section{c. Naturalisatie}

In artt. $1010 \mathrm{t} / \mathrm{m} 1031$ werd een uitvoerige, doch weinig systematische regeling van de naturalisatie (vstuplenie v poddanstwo) ${ }^{59}$ opgenomen. Het naturalisatieverzoek moest worden ingediend bij de Minister van binnenlandse zaken. Deze was ook in het geval dat de verzoeker aan alle vereisten voldeed, vrij de naturalisatie te weigeren (art. 1020). Een afwijzende beschikking hoefde niet te worden gemotiveerd ${ }^{60}$.

Als enig algemeen naturalisatievereiste gold de eis van vijfjarig legaal verblijf in Rusland (art. 1013) ${ }^{61}$. Het vereiste van legaal verblijf hield in dat eenn naturalisandus in het bezit moest zijn van een "vestigingsvergunning" afgegeven door het hoofd van het gouvernement van zijn woonplaats (art. 1011). Daarbij moet worden aangetekend, dat aan een vreemdeling, die eenmaal een Russisch inreisvisum had gekregen $^{62}$, in de regel steeds een vestigingsvergunning werd verleend. Deze

55. Polizei Hamburg, p. 180.

56. Polizei Hamburg, p. 179 en 180.

57. Polizei Hamburg, p. 179; Kazansky, Clunet 1898, p. 229.

58. Cf. Polizei Hamburg, p. 179; Kazansky; Clunet $1898_{n}$ p. 229.

59. Letterlijk: het treden in het onderdaanschap.

60. Kazansky, Clunet 1898, p. 229.

61. Polizei Hamburg, p. 178; Kazansky, Clunet 1898, p. 228-229.

62. Kazansky, Clunet 1898, p. 227 noemt categorieën personen, aan wie het inreisvisum niet kon worden verleend. Daaronder: " ...aux bohémiens, joueurs d’orgue de barbarie et aux autres vagabonds...juifs roumains sans resources... jésuites....". 
vergunning bevatte in beginsel geen beperkingen ten aanzien van plaats en duur van de vestiging ${ }^{63}$.

Art. 1017 sub 1 bepaalde voorts, dat betrokkene bewijsstukken omtrent zijn (beroeps)bezigheden en zijn leefwijze aan het naturalisatieverzoek moest toevoegen. Deze bepaling doet vermoeden, dat er in feite ook een zeker vereiste van "goed gedrag" gold.

Naturalisandi moesten een eed van trouw afleggen (art. 1022). Interessant hierbij is, dat deze zowel in hun moedertaal, als in iedere andere taal die betrokkene sprak, kon worden afgelegd. Kennis van het Russisch werd dus blijkbaar niet vereist.

Aan bepaalde categorieën personen werd de mogelijkheid van naturalisatie zonder meer onthouden. Dat waren:

- gehuwde vrouwen, tenzij hun mannen tegelijkertijd werden genaturaliseerd (art. 1014);

- minderjarigen (onder 21 jaar) (artt. 1023, 1024 en 1027);

- Jaden, die niet uit Middenazië afkomstig waren (art. 992) en

- Derwisjen ${ }^{64}$.

Het verblijf van vijf jaar was evenwel geen absoluut vereiste. Voor verschillende categorieën verzoekers werd naturalisatie na een verblijf van kortere duur, of zelfs zonder een verblijf in Rusland, mogelijk gemaakt.

Een verkorte verblijfseis gold ten aanzien van volgende categorieën personen:

- degenen, die Rusland bijzondere diensten hadden bewezen, of die vanwege hun bijzondere begaafdheid of bekwaamheid bekend waren, of aanzienlijk kapitaal in Russische bedrijven van algemeen nut hadden geïnvesteerd. Hoe lang betrokkene in deze gevallen wel in Rusland moest wonen, werd telkens ad hoc door de minister van binnenlandse zaken beslist (art. 1016) ${ }^{65}$;

- onderdanen van landen, met wie Rusland verdragen omtrent verkorting van de verblijfseis ten behoeve van naturalisandi had gesloten (art. 1013, opm. ${ }^{66}$ ) ${ }^{67}$;

63. Uitzonderingen golden echter ten aanzien van (niet vermogende) Joden, Chinezen en Koreanen. Kazansky, Clunet 1898 , p. 228.

64. Kazansky, Clunet 1898, p. 229; Maurach, p. 7.

65. Polizei Hamburg, p. 179-180; Kazansky, Clunet 1898, p. 229; Maurach. p. 8.

66. Het was en het is nog steeds in de Russische/USSR-wetgevingstechmiek gebruikelijk, dat kleinere veranderingen van wetten als "opmerkingen " aan de wettekst worden toegevoegd. Deze opmerkingen hebben kracht van wet. Zie Rzepka, ROW 1961, p. 177-180; SGS deel 25, p. 148, voetnoot 7 .

67. Polizei Hamburg, 179. 
- ten aanzien van buitenlandse boeren en arbeiders en met betrekking tot immigranten van Slavische afkomst bestonden er bijzondere regelingen, die naast de nationaliteitsrechtelijke regeling van de Svod golden ${ }^{68}$;

- meerderjarige kinderen van naturalisandi en van optanten konden zowel tegelijkertijd met hun ouder(s), als binnen een termijn van een jaar daarna, zelfstandig worden genaturaliseerd, zonder aan de vijfjarige verblijfseis te hebben voldaan (art. 1024) ${ }^{69}$.

\section{i. Invloed op de nationaliteit van de gezinsleden van de verzoeker}

Ten aanzien van de medenaturalisatie van de echtgenote en de kinderen van naturalisandi golden dezelfde regels als bij optie (zie p. 56).

\subsection{Verlies van de nationaliteit}

De nationaliteitsrechtelijke regeling van de Svod bevatte slechts een zeer summiere regeling van het verlies van het Russische staatsburgerschap. De Russische nationaliteit kon worden verloren van rechtswege en door ontslag uit het staatsverband. De regeling van de Swod kende geen verlies van de nationaliteit door het afleggen van een verklaring van afstand of door ontneming ${ }^{70}$.

\section{a. Verlies van rechtswege}

Van rechtswege werd de Russische nationaliteit verloren door een vrouw, die met een vreemdeling in het huwelijk trad (art. 1026) ${ }^{71}$. De nationaliteit ging verloren, ongeacht of betrokkene door of in verband met haar huwelijk de nationaliteit van haar man verwierf. Deze bepaling was geheel in overeenstemming met het in die tijd absoluut geldende beginsel dat een gehuwde vrouw dezelfde nationaliteit als haar man moest bezitten, het zogeheten "système unitaire". Gesteld kan worden dat een gehuwde vrouw nationaliteitsrechtelijk in het geheel niet bestond ${ }^{72}$.

68. De positie van kolonisten was geregeld in "Ustav o kolonijach inostrancev $v$ imperii" (wet betreffende kolonieën wan vreemdelingen in het keizerrijk) die opgenomen werd in band XII wan de Svod van 1857. Zie art. 1029 van de nationaliteitsrechtelijke regeling van de Svod, alsook Polizei Hamburg, p. 176; Kazansky, Clunet 1898 p. 229.

69. Polizei Hamburg, p. 180; Kazansky, Clunet 1898 p. 229.

70. Maurach, p. 11; Kowal-Wolk, p. 39.

71. Polizei Hamburg, p. 181; Clumet 1898, p. 229.

72. De aan het systeme unitaire ten grondslag liggende gedachte kan treffend worden geillustreerd door de woorden van het Nederlandse parlementslid Nicolai, de "geestelijke vader" van het Nederlandse BW van 1838, tijdens de parlementaire behandeling van het ontwerp voor het Nederlandse BW van 1838: "Partout il a été statué que le mari serait le chef de la societé conjugale; et la femme, des le moment de son mariage, n'est plus été considerée generalement comme une personne separée et distincte, mais comme un être identifié avec son mari". Zie Voorduin, p. 32 . 


\section{b. Ontslag}

De bevoegdheid ten aanzien van de verlening van het ontslag uit de Russische nationaliteit, lag bij de minister van binnenlandse zaken. De nationaliteitsrechtelijke regeling van band IX Svod gaf nergens aan welke vereisten betrokkene diende te voldoen om uit het Russische staatsburgerschap te kunnen worJen ontslagen. De maturalisatiewet van 1864 kende een ontslagvereiste echter wel. Een genaturaliseerde Rus $^{\text {T3 }}$ kon het ontslag krijgen, indien hij al zijn schulden aan natuurlijke en rechtspersonen, alsmede zijn publiekrechtelijke had voldaan (afd. 2). Het onderhavige voorschrift werd niet in de Svod van 1876 overgenomen ${ }^{74}$. Aangezien de discretionaire bevoegdheid van de administratie op dit punt vrijwel onbeperkt was, is aannemelijk dat de onderhavige ontslagvoorwaarde ook na 1876 een rol speelde. Voorts bepaalde art. 3 van de dienstplichtwet van 1886, dat jongens van 15 jaar en ouder niet vóor de vervulling van de militaire dienstplicht uit het Russische staatsverband konden worden ontslagen. Voor het overige werd de beslissing omtrent een ontslagverzoek geheel ter discretie van het beoordelende orgaan overgelaten. In de regel werd op een verzoek positief beslist, tenzij politieke redenen of militaire verplichtingen aan een dergelijke beslissing in de weg stonden 75 .

\subsubsection{Het nationaliteitsrecht tot 1924}

\subsubsection{Algemeen}

In de periode tussen 7 november 1917 en 29 oktober 1924, toen de eerste federale nationaliteitsrechtelijke regeling in werking trad, was de situatie op het gebied van de nationaliteit erg chaotisch en onoverzichtelijk ${ }^{76}$. De regeling van band IX Svod bleef althans formeel gelden tot het decreet van 12 december 1918, waardoor alle wetgeving van het keizerrijk en van de interim regering (maart-november 1917) werd opgeheven ${ }^{n}$. Deze voorlopige regering schafte echter reedis bij de wet van 20 maart $1917^{78}$ alle beperkingen van rechten, die op een religieuze, nationale of andere status waren gebaseerd, af. Hierdoor kwamen beperkingen bij de verkrijging van de Russische nationaliteit ten aanzien van Joden en andere achtergestelde bevolkingsgroepen te vervallen ${ }^{79}$.

De nieuwe machthebbers in zowel de RSFSR als in de andere republieken voerden in de periode na 7 november 1917 verschillende regelingen in, die (althans) gedeeltelijk betrekking hadden op de nationaliteit. Deze regels waren

73. Mijns inziens kan deze bepaling analoog worden toegepast op personen, die anders dan door naturalisatie de Russische nationaliteit badden werworven. Het feit dat in de tekst van de bepaling slechts sprake was van genaturaliseerde Russen laat zich verklaren door de omstandigheid dat die wet met het oog op naturalisandi was geschreven. Door sommigen werd echter aangenomen dat ontslag van degenen die de Russische nationaliteit door geboorte bezaten, nier mogelijk was. Zie De Lapradelle/Niboyet, p. 744.

74. Polizei Hamburg, p. 181 .

75. Polizei Hamburg, p. 181; Kazansky Clunet 1898, p. 229; Maurach, p. 11.

76. Sandifer, AJIL 1936, p. 6.

77. SU RSFSR 1918, mr. 85, pos. 898. Cf. Maurach, p. 14.

78. Zaitzeff, p. 276-277.

79. Maurach, p. 12; SGS deel 3, p. 15. 
echter zonder uitzondering uiterst summier, onvolledig en soms zelfs onderling tegenstrijdig ${ }^{80}$. Voor het feit dat men tot 1924 geen duidelijke nationaliteitsrechtelijke regeling kende, kunnen verschillende redenen worden aangevoerd. De belangrijkste lijkt mij het feit dat de Sovjetstaat de nationaliteit niet echt nodig had. De nationaliteit is immers een rechtsinstituut dat als onderscheidend criterium voor de toekenning van bepaalde (voornamelijk politieke) rechten wordt gebruikt. Een staat heeft de nationaliteit nodig, om dergelijke rechten alleen voor een bepaalde bevolkingsgroep, in de regel haar eigen onderdanen, te reserveren. In plaats wan de nationaliteit kan echter ook een ander criterium worden gebruikt, zoals bijwoorbeeld de woonplaats. In de RSFSR had men echter een derde criterium "uitgevonden", namelijk het behoren tot een bepaalde sociale klasse. De nieuwe machthebbers hadden reeds op 13 januari $1918^{81}$ een declaratie omtrent de "Rechten van het werkende uitgebuite volk" uitgevaardigd, die de grond vormde voor de verdeling van de bevolking in twee klassen: die van de geprivilegieerde arbeiders en boeren en die van hun vroegere "uitbuiters". Deze verdeling werd verder geïnstitutionaliseerd in art. 20 van de constitutie van de RSFSR van 10 juli 1918:

"Entsprechend der Solidarität der Werktätigen aller Nationen gewärleistet die Russische Sozialistische Föderative Sovjetrepublik die vollen politischen Rechte der russischen Staatsbürger allen Ausländern, die in der russischen Republik, ihrer Arbeitstätigkeit nachgehen und der Klasse der Arbeiter oder der keine fremde Arbeitskraft ausbeutenden Bauernschaft angehören und ermächtigt die örtlichen Sowjets diesen Ausländern unter Ausserachtung aller beschwerlichen Formalitäten die russischen Staatsbürgerschaftsrechte (lees: "juridische nationaliteit", opm. van mij, MT) zu verleihen"'. ${ }^{82}$

Voorts bepaalde art. 23:

"Als Garantin der Interessen der gesamten Arbeiterklasse entzieht die RSFSR einzelnen Personen und einzelnen Gruppen ihre Rechte, deren sie sich zum Nachteil der Interessen der sozialistischen Revolution bedienen". ${ }^{\prime 3}$

Aan buitenlandse arbeiders en boeren die niet Sovjet staatsburgers waren geworden, werden politieke rechten, waaronder het stemrecht toegekend (art. 64, opm. 2 van dezelfde grondwet $)^{84}$.

Het moge aan de hand van het hier voorafgaande duidelijk geworden zijn dat niet de nationaliteit (in juridische zin), maar het behoren tot de klasse vam arbeiders en boeren het onderscheidende criterium voor toekenning van politieke

80. Maurach p. 14.

81. Enciklopedija, p. 259.

82. SU RSFSR 1918, nr. 51, pos. 582; Enciklopedija, p. 261. Duitse vertaling bij Grünberg, p. 4-16; Engelse bij Rothstein, p. 11-31.

83. Vertaling ontleend aan SGS deel 25, p. 288.

84. Zie Sandifer, AIIL 1936, p. 615; alsook Durdenevskij, ZfoR 1931, p. 333; Gajdukov, p. 33. 
rechten was. Niet de "Staatsangehörigkeit", maar de "Klassenzugehörigkeit" \&s was relevant ${ }^{86}$. In dit licht is het niet verbazingwekkend dat de Sovjets geen haast hadden om een duidelijke nationaliteitsrechtelijke regeling te produceren, te meer als we voor ogen houden dat tussen 1917 en 1922 de burgeroorlog en de economische chaos bijna alle aandacht van het "nouveau régime" opeisten ${ }^{87}$.

Aan dit nieuwe verschijnsel van "Klassenzugehörigkeit" werd ook in de Sovjetliteratuur veel aandacht besteed. Durdenevskij ${ }^{88}$ sprak bijwoorbeeld over "Zugehörigkeit zum Staate der Werktätigen". Hij wees er echter op, dat de "Klassenzugehörigen" miet dienstplichtig waren en dat hun bijzondere status slechts bestond, zolang zij zich in de RSFSR bevonden. Illustratief voor de positie van buitenlandse proletariërs zijn ook de woorden van Plotkin:

"The Soviet State... does not recognize any material difference between the status of a foreign worker, who is resident in the USSR and is performing work therein, and the status of a worker who is a citizen of the USSR.... We observe here an almost complete elimination of a system of law rellating to the status of foreigners." 89

De verhouding tussen de nationaliteit van de RSFSR en andere sovjetrepublieken was eveneens onduidelijk. De RSFSR omvatte eerst het grondgebied van het voormalige keizerrijk (met uitzondering van Polen, de Baltische staten en Finland). Dit betekent dat de voormalige onderdanen van de keizer volgens een ongeschreven overgangsregel in eerste instantie als RSFSR-staatsburgers dienen te worden beschouwd. Door de afscheiding van enkele republieken van de RSFSR kunnen de bewoners daarvan voorts als onderdanen van die entiteiten worden gezien ${ }^{90}$. Niet duidelijk is echter, of de RSFSR hen na de afscheiding tevens als eigen onderdanen beschouwde. In ieder geval staat vast, dat er geen duidelijke regels omtrent de afgrenzing tussen de nationaliteit van de RSFSR en die van andere entiteilen op het grondgebied van het voormalige keizerrijk bestonden ${ }^{91}$.

Terwijl de RSFSR om hierbovenstaande redenen geen dringende behoefte voelde om de nationaliteit van binnen haar grenzen verblijvende personen te regelen, moest zij op het internationale vlak met de nieuwe staten die op het grondgebied van het vroegere keizerrijk ontstonden, nolens volens nationaliteitsrechtelijke vraagstukken oplossen. Het ging daarbij om (vredes)verdragen met Finland, Polen en de Baltische landen Estland, Letland en Litouwen, waarin de toescheiding van staatsburgers en in bepaalde gevallen wederzijdse optierechten waren geregeld ${ }^{92}$.

85. Deze term werd eveneen gebezigd door Maurach, p. 28.

86. Cf. Sandifer, AJIL 1936, p. 615; Pusylewitsch, OER 1979, p. 248; Rzepka, ROW 1964, p. 41

87. Cf. Maurach, p. 14.

88. Plotkin, p. 26; Durdenevskij, ZfoR 1931, p. 332-332. Zie ook zijn weergave van de meningen van Kixkin, Krylow en Hoichbarg.

89. Plotkin, p. 8.

90. SGS deel 25 , p. 22.

91. Zie over dit onderwerp ook Makarov, Ostrecht 1926 , p. 4-14.

92. Zie voor Finland arte. 3 en 9 van de verdragen van 14 oktober 1920 en vam 12 augustus 1922, LNTS III, 1, 6. Voor Estland art. 4 van het wredesverdrag van 2 februari 1920, LNTS XI, 30; 103-105. Voor Litouwen art. 6 van het wredesverdrag van 12 juli 1918, LNTS III, 2, 106; SSD, p. 167-168. Voor Letland art. 8 van het wredesverdrag van 11 august us 1920, LNTS II, 3, 196; SSD, 
Hieronder zullen de nationaliteitsrechtelijke regelingen die de RSFSR tot de inwerkingtreding van de eerste federale verordening met betrekking tot de nationaliteit had "geproduceerd", de revue passeren. Hierbij zullen de regelingen van de andere republieken om tweeërlei redenen buiten beschouwing blijwen. In de eerste plaats zou het te ver voeren om bij dit korte historische overzicht al deze regelingen die zoals gezegd zeer summier, onsystematisch en onoverzichtelijk waren te bespreken ${ }^{93}$. Bovendien was de RSFSR verreweg de grootste en de belangrijkste republiek en de enige, wier volledige souvereiniteit in die periode niet in twijfel kan worden getrokken ${ }^{4}$. Bovendien waren de nationaliteitsrechtelijke regelingen die in andere republieken werden getroffen zeer sterk door de RSFSR-regels geïnspireerd ${ }^{95}$. Ook werd er reeds hierboven op gewezen, dat het onduidelijk is of de RSFSR tot 1924 de burgers van de andere republieken niet tevens als eigen onderdanen beschouwde.

Typerend is dat in de RSFSR, evenals overigens in het keizerrijk Rusland geen algemene nationaliteitsrechtelijke regeling tot stand kwam. Verkrijging en verlies van de nationaliteit werd gedeeltelijk geregeld in het familiewetboek, in de grondwet en in aparte naturalisatie- en ontnemingsregelingen. Zo bestond er in het geheel geen regeling van verlies van de nationaliteit door ontslag, of door afstand. Interessant is \$106 van een door Levin ${ }^{\% 6}$ samengestelde "restatement" van de op 1 mei 1923 geldende vreemdelingenwetgeving, waarin wordt gezegd, dat aangezien er geen regeling van ontslag bestond, ontslagverzoeken niet in behandeling werden genomen.

\subsubsection{Het decreet van 5 april 1918}

De eerste nationaliteitsrechtelijke regeling die de nieuwe machthebbers in Moskou uitvaardigden was, het decreet van 5 april $1918^{97}$. Er waren echter slechts bepalingen omtrent de naturalisatie in opgenomen. Zeer opvallend is het feit, dat daarin anders dan in de grondwet van 10 juli 1918 geen onderscheid tussen de naturalisandi op grond van hun "Klassenzugehörigkeit" werd gemaakt ${ }^{98}$.

Als enige naturalisatievereiste werd woonplaats in de RSFSR voorgeschreven, zonder daarbij te bepalen hoe lang de verzoeker aldaar woonachtig had moeten zijn (art. 1). Betrokkene moest aan zijn verzoek tevens een verklaring omtrent zijn beroep toevoegen. Voorts was het van belang of tegen de verzoeker een strafrechtelijke procedure aanhangig was (geweest) (art. 2). Volgens verschillende schrijvers verleende de onderhavige regeling aan naturalisandi die aan de vereisten voldeden,

157-158. Voor Polen art. 6 van het verdrag vam Riga van 18 maart 1921, LNTS I, 52; SSD, p. 179 181. Daarnaast werden met al deze landen ook verdragen betreffende repatriëring en optierechten gesloten.

93. Deze regelingen worden uitvoerig besproken in SGS deel 25, p. 45-143. Zie ook Durdenevskij, ZfoR 1931, p. 336-339.

94. Zie Sandifer AJIL 1936 p. 615; uitwoerig Maurach 1955, p. 87-91.

95. Sevcov, p. 134.

96. Levin, p. 34.

97. SU RSFSR $1918 \mathrm{nr}$. 31, pos. 405; SSD, p. 11-12. Zie daarower Makarov, Ostrecht 1926, p. 4; Durdenevskij, ZfoR 1931, p. 336; SGS deel 3, p. 16; Gajdukov, p. 28-29.

98. Cr. Sevcov, p. 133. 
een recht op naturalisatie ${ }^{99}$. De bevoegdheid om naturalisaties aan in de $\mathrm{RSFSR}$ wonende verzoekers te verlenen lag bij de plaatselijke overheden (art. 4).

Naturalisatie van in het buiteniand wonende personen was mogelijk. In die gevallen was het Alrussiche Centraal Executiefcomité (ACEC) bevoegd om de beslissing te nemen (art. 5).

Deze regeling werd reeds op 10 juli 1918 doorkruist door het hierboven geciteerde art. 20 van de grondwet, dat een nieuwe regeling ten aanzien van de naturalisatie van in de RSFSR wonende personen, die tot de klasse van arbeliders en boeren behoorden, met zich mee bracht ${ }^{100}$. Ten aanzien van in het buitenland wonende naturalisandi bleef de verordening van 5 april nog steeds van kracht ${ }^{101}$.

\subsubsection{Het familiewetboek van 16 september 1918}

Het familiewetboek van 16 september $1918^{102}$ bevatte tevens enkelle nieuwe regels ten aamzien van de nationaliteit in het geval van internationale hwwelijken en ten aanzien van de nationaliteit van kinderen, die uit nationaliteitsrechtelijk gemengde huwelijken werden geboren ${ }^{103}$. Van groot belang is in dit verband art. 103 waarin met het beginsel van énheid van de nationaliteit in een gezin (systeme unitaire) ten aanzien van de nationaliteit van de gehuwde vrouw werd gebroken ${ }^{104}$. Volgens deze bepaling bracht het huwelijk geen automatische verandering van de nationaliteit met zich mee.

Volgens een circulaire van het NKVD (Ministerie van binnenlandse zaken) van 1 juli $1921^{105}$ betreffende de interpretatie van art. 103 van de wet, had een vreemdelinge, die met een RSFSR-staatsburger in het huwelijk trad, bij de huwelijkssluiting een optierecht op de RSFSR-nationaliteit. Een man had een dergelijk optierecht niet.

De nationaliteit van kinderen uit gemengde huwelijken waarvan althans een van de ouders de RSFSR-nationaliteit bezat, werd bij overeenstemming van de ouders bepaald ${ }^{106}$. Indien er geen overeenstemming kon worden bereikt, werd het kind RSFSR-onderdaan, met dien verstande, dat het na het bereiken van de meerderjarigheidsgrens die op 18 jaar werd gesteld ${ }^{107}$, voor de nationaliteit van de andere ouder mocht "kiezen" (art. 147, opmerking). Hierbij moet in beschouwing

99. Maurach, p. 15; Geilke, SGS deel 25, p. 24; Durdenevskij, ZfoR 1931, p. 336, met verwijzing naar Russakow en Pokrovskij. Kowal-Wolk, p. 40. Zie ook art. 4 van de verordening. Makarov, Ostrecht 1926 , p. 4, laat zich daar echter niet uitdrukkelijk over wit.

100. Zlatopol'skij, p. 250.

101. SGS deel 25 , p. 24.

102. SU RSFSR 1918 , nr. 76/77, pos. 818; SSD, p. 19. Zie ook SGS deel 25, p. 24, i.h.b. voetnoot 2.

103. Zie voor een Duitse vertaling van de desbetreffende bepalingen SGS deel 25, p. 289.

104. Art. 103 van de wet gold blijkens een instructie van het wolksconmmissariaat van justitie van 12 mei 1924 nr. 630/III; SSD, p. 280 echter niet ten aanzien van personen die in die jaren 1917. 1920 op door het "witte leger" gecontroleerde gebieden in het huwelijk traden. In deze gevallen werd de nationaliteit door het huwelijk automatisch. werworven, respectievelijk werloren.

105. Circulaire nr. 263, 1921; ook opgenomen in 110 van de restatement van Levin, p. 34-35; SSD, p. 21.

106. Een beslissing daaromtrent diende reeds bij de huwelliksluitting worden genomen. Taracouzio, p. 84.

107. Zie de circulaire van het Volkscommissariaat voor buitenlandse zaken van 8 mei 1922 . Taracouzio, p. 85 . 
worden genomen, dat de ouders, respectievelijk thet meerderjarig geworden kind slechts over de verkrijging en verlies wan de RSFSR-nationaliteit konden beslissen. De verkrijging van de nationaliteit van de andere ouder was uiteraard uitsluitend afhankelijk van de regels van het nationale recht van de desbetreffende ouder ${ }^{103}$.

\subsubsection{De verordening van 22 augustus 1921}

Op 22 augustus $1921^{109}$ werd een nieuwe nationaliteitsrechtelijke verordening afgekondigd. Deze regeling werd gepresenteerd als "aanvulling" op de reeds genoemde verordening van 5 april 1918. Ook daarin werden slechts voorschriften met betrekking tot naturalisatie opgenomen. De vernieuwingen ten opzichte van de verordening van 1918 waren de volgende:

In art. 5 werd bepaald, dat een negatieve beslissing omtrent het naturalisatieverzoek onaanvechtbaar was. Daardoor werd aan de verzoeker een recht op naturalisatie impliciet ontzegd ${ }^{110}$.

Nieuw waren ook bepalingen omtrent de inwloed van de naturalisatie van ouders op hun kinderen. Deze regelling was gebaseerd op ongeveer dezelfde beginselen als de op de nationaliteit betrekking hebbende bepalingen van het familiewetboek van $1918^{11}$. Indien een echtpaar werd genaturaliseerd werden minderjarige kinderen (onder 18 jaar) automatisch in de naturalisatie inbegrepen. Werd slechts eén van de ouders genaturaliseerd, dan konden de ouders gezamenlijk beslissen over de medenaturalisatie van minderjarige kinderen. Indien overeenstemming ontbrak, verkregen hun kinderen onder 14 jaar geen RSFSRnationaliteit ${ }^{112}$. $\mathrm{Na}$ het bereiken van deze leeftijd konden ze echter voor het staatsburgerschap van de RSFSR opteren (art. 7).

Art. 8 had betrekking op personen die door naturalisatie in de RSFSR bipatriden waren geworden. Volgens deze bepaling "verloren de naturalisandi het recht om bescherming van hun andere nationale staat in te roepen". Dat wil zeggen: de RSFSR weigerde dergelijke bescherming van (tevens) eigen staatsburgers binnen eigen grenzen toe te laten.

Bij de naturalisatie moest betrokkene tevens schriftelijk verklaren dat hij bereid was de grondwettelijke orde van de RSFSR te respecteren en te verdedigen (art. 3).

De verhouding tussen deze verordening en art. 20 van de grondwet van 1918 is onduidelijk. De vraag is bijvoorbeeld of buitenlandse boeren en arbeiders ook na de inwerkingtreding van de verordening nog steeds krachtens art. 20 grondwet konden worden genaturaliseerd. Bovendien is het onduidelijk of de regeling van

108. Indien het bijwoorbeeld on een RSFSR-vader en een (ex-) Nederlandse moeder ging, dan verloor de moeder bij het sluiten van het huwelijk haar Nederlandse nationaliteit op grond van art. 6 WNed 1892. Het kind kon derhalve niet Nederlander worden.

109. SU RSFSR 1921, nr. 62, pos. 437; SSD, p. 22-24. Zie voor een Duitse vertaling SGS deel 25, p. 290-291. Daarover Gajdukov, p. 29-30.

110. Cf. Kowal-Wolk, p. 40.

111. Zlatopol'skij, p. 250-251; Maurach, p. 20.

112. De verordening sprak van het behoud van de oorspronkelijke nationaliteit. Deze kon echter slechts worden behouden, indien het nationale recht van het kind die mogelijkheid toeliet. 
22 augustus 1921 ook ten aanzien van onderdanen van de afgescheiden sovjetrepublieken (bijv. Oekraïne, Georgië, Witrusland) werd toegepast ${ }^{113}$.

Op 8 december 1921 vaardigde het Volkscommissariaat voor buitenlandse zaken een circulaire uit, die enkele nadere voorschriften ten aanzien van de naturalisatieprocedure bevatte. Interessant is art. 4 , dat in geval van een negatieve beschikking motivering van de weigering voorschreef ${ }^{114}$.

\subsubsection{De verordening van 28 oktober $/ 15$ december 1921}

In de eerste jaren na de revolutie waren velen uit de RSFSR en uit de andere Sovjetrepublieken verbannen of gevlucht naar het buitenland. Met name de emigratie naar Duitsland, Frankrijk en Joegoslavië kan bijzonder sterk worden genoemd. Om deze reden is het begrijpelijk dat het "nouveau régime" in Moskou een regeling omtrent de nationaliteit van emigranten moest treffen.

Op 28 oktober $1921^{115}$ werd een verordening afgekondigd, die het verlies van de RSFSR-nationaliteit door bepaalde groepen emigranten regelde. Deze verordening werd vervolgens vervangen door de verordening van 15 december 1921 116, die echter inhoudelijk niets nieuws bevatte. Alleen de termijn voor registratie werd verlengd ${ }^{117}$. Het verlies van de nationaliteit betrof:

emigranten die tot 1 juni 1922 minstens vijf jaar ononderbroken in het buitenland verbleven en niet vór de genoemde datum bij buitenlandse vertegenwoordigingen van de RSFSR nieuwe Sovjet-paspoorten hadden afgehaald (art. 1 sub a) ${ }^{118}$;

- allen, die na 7 november 1917 de RSFSR illegaal hadden verlaten (art. 1 sub b);

- personen die in de burgeroorlog vrijwillig aan de "andere zijde" hadden gevochten, of aan andere "anti-sovjet" activiteiten hadden deelgenomen (art. 1 sub c) en zich in het buitenland bevonden ${ }^{119}$;

- personen, die van het optierecht op de RSFSR-nationaliteit niet binnen de gestelde termijnen gebruik hadden gemaakt (art. 1 sub d). Deze bepaling was

113. Maurach, p. 20 en Makarow, Ostrecht 1926 , p. 15 en 17 neigen ertoe om de tweede vraag ontkennend te beantwoorden.

114. Zie voor Engelse vertaling Taracouzio, p. 337-338.

115. SU RSFSR 1921, nr. 72, pos. 578. Duitse vertaling: SGS deel 25, p. 292; Engellse vertaling: SSD, p. 26-27; Taracouzio, p. 375. Daarover Gajdukov, p. 31-32; Zlatopol'skij p. 251.

116. SU RSFSR 1922, nr. 1 pos. 11. Duitse wertaling: SGS deel 25, p. 292-293.

117. SSD, p. 27; SGS deel 25, p. 181.

118. Dit gold krachtens de opmerking bij art. 1 sub a nict voor enigranten in landen waarin de RSFSR (nog) geen vertegewoordigingen had, zoals bijvoorbeeld Joegoslavie.. Zie de tekst, afgedrukt bij Vilkov, p. 18.

119. Aan gewone soldaten van het witte leger werd echter bij decreet van het ACEC RSFSR van 3 nowember 1921, SU RSFSR 1921, nr. 74, pos. 611; SSD, p. 27-28 amnestie verleend. Zile ook de circulaire van het NKVD van 1 december 1921 nr. 507; SSD, p. 28-29 volgens welke betrokkenen een petitie moesten indienen om de nationaliteit te herkrijgen. Andere vereisten werden aan hen niet gesteld. 
onlogisch en overbodig. Bedoelde personen waren gezien het optierecht niet eens onderdanen van de RSFSR, daarom konden zij deze nationaliteit ook niet verliezen ${ }^{120}$;

- alle andere in het buitenland verblijvende personen, die niet sub a-c vielen en verzuimden zich tot 1 juni 1922 bij buitenlandse vertegenwoordigingen van de RSFSR te laten registreren (art. 1 sub e) ${ }^{121}$.

Deze verordening had echter slechts betrekking op personen, die de RSFSR vóor haar inwerkingtreding (15 december 1921) verlieten ${ }^{122}$. De nationaliteit van latere emigranten bleef onduidelijk. Volgens Ginsburgs ${ }^{123}$ hadden ze juridisch wel de RSFSR-nationaliteit, terwijl ze als "de facto" echter als staatlozen moeten worden beschouwd.

\subsubsection{De verordening van 29 oktober 1924}

\subsubsection{Algemeen}

Op 31 december $1924^{124}$ werd de eerste grondwet van de Unie van de Socialistische Sovjetrepublieken (USSR) afgekondigd. In art. 7 werd bepaald, dat de burgers van de USSR een "algemene" federale nationaliteit hadden ${ }^{125}$. Deze grondwettelijke bepaling vormde de basis voor de verordening van 29 oktober $1924^{126}$ die de verkrijging en het verlies van de nationaliteit van de federatie regelde. Naast de nationaliteit van de USSR bezaten de Sovjet-burgers in de regel ${ }^{127}$ ook het staatsburgerschap van een van de deelstaten.

Om een goed beeld van de eerste regeling van de nationaliteit van de Sovjetunie te krijgen, is het noodzakelijk om nog enkele andere bepalingen van de verordening van 1924 die niet direct op de verkrijging en verlies van de Sovjetnationaliteit betrekking hadden, kort te belichten. In art. 2 van de verordening van 1924 vinden we een bepaling, die niet in het nationaliteitsrecht, maar in de grondwet of in het vreemdelingenrecht thuis hoorde. Daarin werd bepaald, dat vreemdelingen, die tot de klasse van arbeiders en boeren behoorden, dezelfde politieke rechten als de USSR-staatsburgers bezaten. Hierdoor had de nationaliteit als "het criterium" voor toedeling van politieke rechten slechts geringe betekenis. Het primaat van de "Klassenzugehörigkeit" dat reeds de RSFSR kende, werd ook in de USSR gehandhaafd.

120. Cf. Maurach, p. 4 en Makarov, Ostrecht 1926, p. 8.

121. Zie noot 118 .

122. SGS deel 25 , p. 182 ; Maurach, p. 19-20.

123. Ginsburgs, AJIL 1957, p. 330.

124. Vestnik van het Centraal Executiefcomitê, $R$ aad wan de volkscommissarissen en van de Raad voor de Arbeid en Defensie USSR 1924, nr. 2 , pos. 24.

125. Daarover Gajdukov, p. 34-35; Kiritenko Socialisticeskaja zakonnost 1972/11, p. 9.

126. SZ USSR 1924, nr. 23, pos. 201 en 202. Duitse vertaling: SGS deel 25, p. 295-297; Franse vertaling: Clunet 1925, p. 548-553. Zie daarover Gajdukov, p. 34-40; Zlatopol'skij, p. 251-254.

127. Slechts de federale nationaliteit bezaten degenen, die werden naturaliseerd terwijl ze (nog) in het buitenland woonden. 
Art. 3 van de verordening bevatte een praesumptio van het bezit van de USSR-nationaliteit voor iedereen, die zich op het grondgebied van de Sovjetunie bevond, zolang betrokkene ${ }^{128}$ niet bewees dat hij een andere nationaliteit bezat. Hoewel deze bepaling van een zekere ruimhartigheid ten aanzien van het toekennen van de Sovjet-nationaliteit blijk geeft, waren de overwegingen die tot opneming van art. 3 hadden gelleid andere, dan men op het eerste gezicht zou vermoeden. Gezien de chaos die in de jaren 1917-1924 in de USSR heerste, alsmede de gebreken en innerlijke tegenstrijdigheden van de verschillende op nationaliteit betrekking hebbende regels, was het onduidelijk en dikwijls onbewijsbaar of lemand die in USSR woonde tevens de Sovjet-nationaliteit bezat. Daardoor beweerde men niet zelden staatloos te zijn, om publieke lasten, met name de militaire dienstplicht, te ontkomen ${ }^{129}$. Door art. 3 op te nemen, had de wetgever de genoemde problemen op een handige manier omzeild.

Uit art. 11 blijkt het standpunt dat de wetgever in Moskou ten aanzien van de meervoudige nationaliteit innam. Art. 11 bepaalde, dat personen die naast de Sovjet- ook een andere nationaliteit bezaten, zich niet op de aan die vreemde nationaliteit verbonden rechten en plichten konden beroepen. Met andere worden: polypatriden werden in (en door) de USSR uitsluitend als eigen staatsburgers behandeld.

\subsection{De verhouding tussen de federale en de deelstaatnationaliteit}

De wettelijke basis voor de verhouding tussen beide Sovjet-nationaliteiten vormde art. 1 van de verordening van 1924:

"Für die Staatsbürger der Sozialistischen Sovjetrepubliken wird eine einheitliche Unionsbürgerschaft begründet (Art. 7, Verfassung UdSSR).

Der Bürger jeder Unionsrepublik, die dem Verband der UdSSR angehört besitzt hierdurch die Staatsbürgerschaft der UdSSR und hat alle Rechte bzw. trägt alle Pflichten, die nach der Verfassung und der Gesetzgebung derjenigen Unionsrepublik, in deren Gebiet er lebt, den Bürgern obliegen" ${ }^{\prime 130}$.

Iedere staatsburger van een van de republieken bezat derhalve tevens de federale mationaliteit. Of iemand uitsluitend in het bezit van het staatsburgerschap van de USSR kon zijn, werd niet in de wet bepaald. Uit art. 9 van de verordening van 1924 kan echter worden afgeleid, dat in het buitenland woonachtige naturalisandi, te wier aanzien tevens het CEC (Centraal Executiefcomité) van de USSR bevoegd was om de naturalisatie te verlenen, inderdaad slechts de federale nationaliteit konden bezitten. De federale organen waren namelijk uitsluitend bevoegd om de nationaliteit van de federatie te verlenen ${ }^{131}$.

128. Zie over de bewijslast Ginsburgs, ICLO, 1966 p. 2.

129. Maurach, p. 27-28; Durdenewskij, ZfoR 1931, p. 341 met verwijzing naar CiCerin. Zie over art. 3 ook Dufour, RGDIP 1930, p. 512-513.

130. Vertaling ontleend aan SGS deel 25, p. 295.

131. Makarow, Ostrecht 1926, p. 18. 


\subsubsection{Verkrijging van de nationaliteit}

De nationaliteit van de USSR kon van rechtswege en door naturalisatie worden verkregen. Verkrijging van het staatsburgerschap door optie was volgens de regeling van 1924 niet meer mogelijk.

\subsection{Verkrijging van rechtswege}

Volgens de werordening van 1924 was verkrijging van de Sovjet-nationaliteit van rechtswege gekoppeld aan geboorte uit USSR-ouders. De regeling van verkrijging van de nationaliteit bevatte geen bepalingen met betrekking tot kinderen van onbekende of statlloze ouders die in de USSR werden geboren, of gevonden. Dit was echter niet nodïg omdat krachtens het reeds op p. 67 besproken art. 3 toch ledereen die niet het bezit van een vieemde nationaliteit kon bewijzen, als USSRonderdaan werd aangezien.

Het sluiten van een huwelijk met een Sovjet-burger en adoptie hadden geen automatische gevolgen voor de nationaliteit van betrokkene. Ten aanzien van het huwelijk werd dat uitdrukkelijk in art. 5 van de verordening bepaald.

\section{a. Geboorte wit Sovjet-ouder(s)}

De Sovjet-wetgever ging bij de verkrijging van de nationaliteit principieel van het beginsel ius sanguinis a matre et a patre uit. Een kind kon de nationaliteit van de USSR op gelijke voet zowel aan zijn vader, als aan zijn moeder ontlenen. Het was ook niet van belang of het kind al dan niet wettig was ${ }^{132}$. Dit betekent dat een kind dat door een Sovjet-onderdaan werd erkend, of wiens afstamming van een USSRvader gerechtelijk werd vastgesteld, geacht werd kind van een USSR-ouder te zijn.

Indien beide ouders op het tijdstip van geboorte van het kind de USSRnationaliteit bezaten, verwierf ook hun kind dit staatsburgerschap, ongeacht waar het werd geboren (art. 4 lid 1).

Ten aanzien van verkrijging van de USSR-nationaliteit door kinderen waarvan slechts één van de ouders de Sovjet-nationaliteit bezat, stelde de verordening nog enkele additionele vereisten. Zo werd een kind automatisch burger van de USSR indien tenminste sen van de ouders op het tijdstip van de geboorte van het kind bimen de USSR woonde (art. 4 lid 2). Dit gold zelfs in geval dat de niet-Sovjetouder in de Sovjetunie woonachtig was. Het ging hierbij derhalve om een interessante combinatie tussen het ius sanguinis en het ius domicili. Woonden beide ouders op het tijdstip van de geboorte van het kind in het buitenland, dan verwierf het kind de nationaliteit van de USSR uitsluitend op grond van een gemeenschappelijke verklaring van zijn ouders. De verordening bevatte geen regeling voor het geval dat tussen de ouders van het kind geen overeenstemming kon worden bereikt. Makarov ${ }^{133}$ zag dat als een "ernstige lacune". Mijns inziens is zijn kritiek op deze plats niet geheel terecht. Art, 4 lid 3 van de verordening stelde als vereiste voor verkrijging van de nationaliteit door het kind een verklaring van zijn ouders. Indien deze ontbrak, is slechts eén conclusie mogelijk: de USSR-

132. Cl. Makarov, Ostrecht 1926, p. 19; De Lapradelle/Niboyet, p. 746 .

133. Makarov, Ostrecht 1926, p. 19-20. 
nationaliteit werd niet verkregen. Aan de hand van het land waarin het kind werd geboren en varu het nationale recht wan zijn niet-Sovjet-ouder moest worden vastgesteld welke nationaliteit het kind bezat. Deze regeling was derhalve voldoende duidelijk. Een andere vraag is of zij bevredigend werkte, aangezien het voor kon komen dat een dergelijk kind staatloos werd.

In gevallen waarin geen overeenstemming werd bereikt, of de ouders besloten dat het kind geen USSR onderdaan zou worden, kreeg het kind de mogelijkheid om na het bereiken van de meerderjarigheid via een vereenvoudigde naturalisatieprocedure te worden genaturaliseerd (art. 4 lid 3).

\subsection{Naturalisatie}

De verordening van 1924 kende zowel een gewone, als een vereenvoudigde naturalisatieprocedure. De bevoegdheid om de nationaliteit in de gewone procedure te verlenen, lag bij de CEC's van de afzonderlijke deelstaten. In de regel ging het daarbij om de deelstaat, waarin betrokkene woonde (art. 7). Indien de verzoeker in het buitenland woonde, was tevens het federale CEC bevoegd (art. 9). Een jaar na de afwijzing van een verzoek kon een nieuwe aanvraag worden ingediend, hetgeen als een soort "rechtsmiddel" kan worden beschouwd ${ }^{134}$ "

In de verordening van 1924 werd echter niet bepaald aan welke vereisten betrokkene moest voldoen, om voor de gewone naturalisatie in aanmerking te kunnen komen. Enige naturalisatievereisten zijn te vinden in een instructie van het NKVD aan het Presidium van het ACEC RSFSR van 11 augustus 1928 135 . De verzoeker moest 18 jaar oud zijn (art. 4) en verklaren dat hij zijn oude nationaliteit "opgaf" en dat hij bereid was het politieke systeem te verdedigen (art. 5). Voorts waren zijn motieven voor het indienen van het verzoek en zijn economische en sociale status van belang ${ }^{136}$.

\section{a. Vereenvoudigde naturalisatie}

De bevoegdheid om de nationaliteit van de USSR in een vereenvoudigde procedure te verlenen lag bij de executiefcomite's van lagere (plaatselijke) overheden ${ }^{137}$. De mogelijkheid van een vereenvoudigde naturalisatie hadden volgens de verordening van 1924 de volgende categorieën personen:

- de "klasse van arbeiders en boeren" en politieke immigranten (art 7);

- personen, die hun nationaliteit als gevolg van het verlies van het USSRstaatsburgerschap door hun ouders hadden verloren (art. 6 Opm. 2) en

134. Zlatopol'skij, p. 252 .

135. Instructie nir. 271, SSD, p. 288-292.

136. Bij Zlatopol'skij, p. 252 vinden we enige statistische gegevens met betrekking tot naturalisaties. Tussen januari en maart 1928 werden door het CEC USSR 2317 naturalisatieverzoeken in behandeling genomen en werden er slechts 893 gehonoreerd. In 200 gevallen ging het om een herhaald verzoek en daarvan werden er 30 gehonoreerd.

137. De deelstaten werden in de regel administratief onderverdeeld in gouvernementen en werder in gebieden. De structuur was echter niet voor alle deelstaten gelijk. 
- meerderjarig (18 jaar) geworden kinderen van én Sovjet-ouder, die deze nationaliteit niet reeds krachtens art. 4 lid 3 (iure sanguinis) bezaten.

In art. 8 van de verordening werd voorts verwezen naar een speciale mogelijkheid van naturalisatie van economische immigranten, remigranten en van personen die op grond van internationale verdragen werden gerepatrieerd. Deze groepen personen konden via een bij bijzondere federale wetten voorgeschreven procedure collectief worden genaturaliseerd. Blijkens art. 12 van de reeds genoemde instructie van het NKVD van 1928 was het mogelijk binnen éen maand na een afwijzende beschikking beroep bij het Presidium van het ACEC USSR in te dienen.

\section{b. Invloed op de nationaliteit van de gezinsleden van de verzoeker}

In geval dat beide ouders werden genaturaliseerd, werden hun kinderen, die jonger dan 14 jaar waren, automatisch in de naturalisatie inbegrepen. Waren de kinderen reeds ouder, dan had de naturalisatie van hun ouders geen invloed op hun nationaliteit (art. 6 opm. 1) ${ }^{139}$. Deze kinderen kwamen na het bereiken van de meerderjarigheid uiteraard wel voor een zelfstandige naturalisatie in aanmerking.

\section{1 .4 .3 Verlies van de nationaliteit}

De nationaliteit van de USSR kon volgens de verordening van 1924 worden verloren door ontslag. Verlies door ontneming werd in de verordening niet geregeld ${ }^{139}$. Verlies van de nationaliteit van rechtswege of door het afleggen van een verklaring van afstand kende de verordening niet. De regeling van het verlies van het staatsburgerschap was bijzonder slordig en onlogisch geredigeerd. Art. 12 dat als een overgangsbepaling werd geredigeerd ${ }^{140}$, spande in dit opzicht de kroon. Dit artikel bepaalde wie de nationaliteit van de USSR hadden verloren. In wezen kwam dit artikel inderdaad gedeeltelijk neer op een overgangsbepaling, gedeeltelijk op een verwijzing naar elders opgenomen verliesbepalingen en deels op een zelfstandige verliesbepaling. Het ging om het verlies van de nationaliteit door de volgende categorieën personen:

- degenen, aan wie de nationaliteit op grond van de wetgeving van de republieken voor 6 juli 1923 werd ontnomen, of die hun nationaliteit op grond van de federale wetgeving ${ }^{141}$ hadden verloren (art. 12 sub a);

138. Zie ook Makarov, Ostrecht 1926, p. 20-21; Gajdukov, p. 37.

139. Zlatopol'skij, p. 253.

140. De aanhef luidde in Duitse vertaling: "Die Staatsbïrgerschaft der USSR haben verloren...". Zie SGS deel 25, p. $2 \%$ in Franse vertaling: "Sont considerées comme dechués du droit de cité..." Clunet 1925, p. 551 .

141. Hierbij kan slechts worden gedacht aan de verordening van 13 november 1.925 , SZ USSR 1925 , nr. 77 , pos. 581 ; SSD, p. 240-241; betreffende het verlies van de nationaliteit door oudkrijgsgevangenen en geinterneerde soldaten wan het keizerlijk leger die in het buitenland woonden. Zie voor cen Duitse vertaling: SGS deel 25, p. 299. Het feit dat in art. 12 van de verordening van 1924 sprake is van personen die de USSR-nationaliteit hadden verloren, zou doen vermoeden dat de betreffende bepaling niet betrekking kon hebben op een voorschrift, dat pas in 1925 tot stand kwam. Uit de literatuur blijkt echter dat dit niet het geval was. De verordening van 1925 was overigens de enige federale regeling van ontmeming wan de nationaliteit. Daarover 
- degenen, die zonder toestemming het land hadden verlaten, respectievelijk niet op oproep van het bevoegde orgaan terugkeerden (sub b);

- personen, die op wettelijk voorgeschreven wijze wit het staatsverband werden ontslagen (sub c);

- degenen, aan wie de nationaliteit door een rechterlijk vonnis werd ontnomen (sub d) ${ }^{142}$;

- verdragsoptanten (sub e).

\subsection{Ontslag}

In art. 13 werd bepaald, dat de CEC's van de deelstaten, respectievelijk dat van de federatie, bevoegd waren om het ontslag uit het Sovjet-staatsburgerschap te verlenen. De vereisten om het ontslag te krijgen, werden niet in de verordening genoemd. Enige ontslagverboden bevatte een instructie van het NKVD aan het Presidium van het ACEC RSFSR van 23 januari $1928^{143}$. Er was geen ontslag mogelijk ten aanzien van minderjarigen, degenen die in een strafrechtelijke procedure waren verwikkeld, degenen, tegen wie een strafrechtelijke veroordeling nog niet ten uitvoer werd gelegd, alsmede ten aanzien van dienstplichtigen en leden van de militia.

\section{a. Invloed op de nationaliteit van de gezinsleden van de verzoeker}

Het verlies van de USSR-nationaliteit door een ouder kon slechts invloed hebben op de nationaliteit van zijn kinderen die jonger dan 14 jaar waren (art. 6 opm. 1). Automatisch verlies van het staatsburgerschap door deze kinderen trad slechts zonder meer in, indien beide ouders deze nationaliteit hadden verloren. Bij de regeling van gevallen, waarin slechts én van de ouders het Sovjet-staatsburgerschap verloor, had de wetgever voor de woonplaats als het maatgevende criterium gekozen ${ }^{144}$. Indien de ouder die de USSR-nationaliteit verloor op het grondgebied wan de Sovjetunie woonde, had zijn nationaliteitsverlies geen invloed op de nationaliteit van zijn kind(eren) (art. 6 lid 1). Bij de woonplaats van de ouders in het buitenland, werd de nationaliteit van de kinderen bij onderlinge overeenstemming van de ouders bepaald (art. 6 lid 2). De wet bepaalde niet, wat er gebeurde indien een dergelijke overeenstemming ontbrak. Naar mijn mening werd in een dergelijk geval de status quo gehandhaafd: het kind behield zijn Sovjet-nationaliteit.

Maurach, p. 29-30; Makarov, Ostrecht 1926, p. 26; Durdenevskij, ZfoR 1931, p. 342 .

142. De "Basisbeginselen van de strafwetgeving" van 31 oktober 1924, SZ USSR 1924, nr. 24, pos. 205, bevatten als een van de straffen ontneming van de USSR-nationaliteit. Zie Sevcov, p. 167. Zie bijvoorbeeld ook art. 20 wan het wetboek van strafrecht van de RSFSR wan 22 november 1926 , SSD, p. 285, krachtens welke betrokkene tot "vijand wan de arbeidersklasse" werd verklaard waarna ontmeming van de nationaliteit van de RSFSR en dientengevolge van de USSRnationaliteit volgde.

143. Instructie nr. 37; SSD, p. 286-288.

144. Cf. Gajdukov, p. 37; Makarov, Ostrecht 1926 , p. 21. 
Makaroy ${ }^{145}$ ziet in 1926 op deze plats echter wederom een "wesentliche Lücke" en betoogt, dat de nationaliteit van het kind dan aan de hand van het nieuwe nationale recht van zijn ouder moest worden bepaald. Daarbij zou in bepaalde gevallen blijkbaar aan de hand van een vreemd nationaliteitsrecht tot verlies van het USSR-staatsburgerschap moeten worden geconcludeerd! Mijns inziens kon aan de harid van vreemde wetgevingen echter slechts worden vastgesteld, of het kind, doordat het in de naturalisatie of optie van zijn ouder werd inbegrepen, tevens een andere nationaliteit had verworven.

Een decreet wan het CEC USSR van 21 maart $1928^{146}$ had betrekking op het geval dat een minderjarige sovjet-onderdaan door buitenlanders werd geadopteerd. In dat geval behield het geadopteerde kind de nationaliteit van de Sovjetunie en kreeg bij het bereiken van meerderjarigheid de mogelijkheid om via een vereenvoudigde procedure uit de nationaliteit van de USSR te worden ontslagen.

\subsubsection{De verordening van 28 juni 1930}

\subsubsection{Algemeen}

Op 28 juni $1930^{147}$ werd een nieuwe federale nationaliteitsrechtelijke regeling bekend gemaakt. Deze verordening bracht ten opzichte van die van 1924 enkele vernieuwingen, die hoofdzakelijk betrekking hadden op uitbreiding van de competenties van de federatie. Voorts was de Sovjet-wetgever ten aanzien van de toekenning van de USSR-nationaliteit aan kinderen van nationaliteitsrechtelijk gemengde ouders nog ruimhartiger geworden ${ }^{148}$. De belangrijkste wijzigingen zullen kort worden genoemd.

\subsection{De verhouding tussen de federale en de deelstaatnationaliteit}

Ten aanzien van de verhouding tussen de nationaliteit van de USSR en die van de deelstaten, heeft de verordening van 1930 enkele nieuwe regels met zich mee gebracht. Zo werd in art. 1 in fine uitdrukkelijk bepaald, dat iedere burger van een deelstaat tevens de nationaliteit van de federatie bezat. Volgens art. 2 werd de deelstaatnationaliteit aan de hand van het domicilie bepaald, en door verandering van de woonplaats werd vormeloos de nationaliteit veranderd ${ }^{149}$. Desalniettemin kon betrokkene blijkens art. 2 in fine, kiezen voor een andere nationaliteit dan die van de deelstaat van zijn woonplaats, "...mit der er sich nach seiner Volkszugehörigkeit und Abstammung verbunden fühlt" 150 .

145. Makarov, Ostrecht 1926 , p. 21-23.

146. SZ USSR 1928, 1, p. 357. Taracouzio, p. 89.

147. SZ USSR 1930, nr. 34, pos. 367; SSD, p. 245-247; zie daarover Gajdukov, p. 40-42; Zlatopol'skij, p. 254255 .

148. Zie Gajdukov, p. 40-41; SGS decl 25, p. 149-151; Freund, ZfoR 1930, p. 707; Maurach, p. 34.

149. Esajan, p. 83, met verwijzing naar Cicerin; Maurach, p. 34.

150. Vertaling ontleend aan SGS deel 25, p. 310 . 


\subsubsection{Werkrigiging wan de nationaliteit}

\subsubsection{Geboone uit Sovjet-ouder(s)}

Anders dan onder de vigeur wan de verordening van 1924 werd een kind USSRstaatsburger in alle gevallen, waarin ten minste éen wan zijn ouders op het tijdstüp van geboorte van het kind de nationaliteit van de USSR bezat (art. 7). Het vereiste van onderlinge overeenstemming bij in het butenland geboren kinderen verviel derhalve. Hoewel zulks niet uitdrukkelijk werd bepaald, kan als vanzelfsprekend worden aangenomen, dat het niet relevant was of het om wettige of onwettige kinderen ging ${ }^{151}$.

\subsection{Naturalisatie}

Gewone naturalisatie van personen, die in het buitenland woonachtig waren, kon volgens de verordening van 1930 slechts bij een beschikking van het presidium van het CEC USSR tot stand komen (art. 13). Ten aanzien van in de USSR wonende naturalisandi bleven de presidia van de CEC's van de deelstaten bevoegd (art. 12 lid 1), terwijl de verzoeker zich ook rechtstreeks tot het Presidium van het CEC USSR mocht wenden ${ }^{152}$. Nieuw was echter de mogelijkheid van beroep tegen een negatieve beslissing omtrent een naturalisatieverzoek bij het presidium van het CEC USSR (art. 12 lid 2). Naturalisatievereisten bevatte ook deze verordening niet.

\section{a. Vereenvoudigde naturalisatie}

De regeling van de vereenvoudigde naturalisatieprocedure werd in de verordening van 1930 aanzienlijk uitgebreid. De bevoegdheid om een dergelijke naturalisatie te verlenen, lag evenals onder de verordening van 1924 bij de plaatselijke overheden (art. 16 lid 1) ${ }^{\text {t53. }}$. De vereenvoudigde naturalisatie stond open voor de volgende categorieën personen:

- arbeiders, boeren en asielgerechtigden (art. 16 lid 2 sub a);

personen (zowel mannen als vrouwen), die met een Sovjet-burger in het huwelijk traden (art. 16 lid 2 sub b jo. art. 8).

\section{b. Invloed op de nationaliteit van de gezinsleden van de verzoeker}

In geval dat beidle ouders werden genaturaliseerd, werden hun kinderen, die jonger dan 14 jaar waren, automatisch in de naturalisatie inbegrepen (art. 9 lid 1). Werd slechts én van de ouders genaturaliseerd, dan werden zijn kinderen onder de 14 jaar op verzoek van die ouder in de naturalisatie inbegrepen (art. 10 lid 1).

151. Cf. Sandifer, AJL 1936, p. 620 .

152. Sevcov, p. 137.

153. De plaatselijke overheden waren echter bevoegd om de vereenvoudigde naturalisatie te weigeren en betrokkene naar de normale procedure te verwijzen (art. 16, opm.). 
Kinderen die reeds 14 jaar waren of ouder, moesten altijd zelf met hun medenaturalisatie instemmen (art. 9 lid 2 en art. 10 lid 1).

\subsubsection{Verlies van de nationaliteit}

Ten aanzien van het verlies van de Sovjet-nationaliteit waren de belangrijkste vernieuwingen de versterking van bevoegdheden van de federatie bij het ontslag en ontneming en bepalingen omtrent de invloed van het verlies van de nationaliteit van ouder(s) op die van minderjarige kinderen.

\subsection{Ontslag}

Evenals de naturalisatie, kon ook het ontslag uit de nationaliteit van de USSR zowel via een gewone als via een vereenvoudigde procedure worden bereikt. De tweede was mogelijk in gevallen, waarin Sovjet-burgers (zowel mannen, als vrouwen) huwelijken met buitenlanders hadden gesloten (art. 16 lid 2 sub b jo. art. 8).

Bij de gewone ontslagprocedure werd onderscheid gemaakt op grond van het feit of betrokkene binnen dan wel buiten de USSR woonde. Ten aanzien van in de Sovjetunie wonende personen waren de presidia van de CEC's van de deelstaten bevoegd, waarbij tegen een negatieve beschikking een beroep op het presidium van het CEC USSR open stond (art. 14). Over de vereisten voor het ontslag wordt in de verordening van 1930 niets bepaald. Ook de literatuur zwijgt op dit punt.

\subsection{Ontneming}

Beslissingen omtrent de ontneming konden slechts door het CEC USSR worden genomen, hetzij direct, hetzij door goedkeuring van een overeenkomstig besluit van de CEC's van de deelstaten (art. 17). De vereisten voor ontneming stonden niet in de wet geëxpliciteerd ${ }^{154}$.

\subsection{Invloed op de nationaliteit van gezinsleden van betrokkene}

De regeling van de gevolgen van het verlies van de nationaliteit door ouders op het staatsburgerschap van hun minderjarige kinderen, neergelegd in artt. 9 en 10 van de verordening van 1930 gold zowel bij ontslag als bij ontneming. Het verlies van de nationaliteit door een of beide ouders kon uitsluitend invloed hebben op de nationaliteit van kinderen die de leeftijd van 14 jaar nog niet hadden bereikt. Kinderen boven 14 jaar behielden in alle gevallen hun nationaliteit (art. 9 lid 3).

Het verlies van de Sovjet-nationaliteit door beide ouders strekte zich automatisch uit over hun kinderen jonger dan 14 jaar (art. 9 lid 1).

154. Zlatopol'skij, p. 253, spreekt van "antisovjetactiviteiten" in thet buitenland. Een voorbeeld van ontneming van de nationaliteit op grond van art. 17 is te vinden im een decreet van het Presidium van het CEC USSR vin 20 februari 1932, SZ USSR 1932, nr. 13, pos. 70; SSD, p. 253. Toen werd aan Lev Trockij en 36 andere emigranten de nationaliteit wegens "contrarevolutionaire activiteiten" ontnomen en werd hen verboden naar het land terug te keren. De beslissing was niet gemotiveerd. Zie ook Gajdukov, p. 43. 
Ten aanzien van kinderen van nationaliteitsrechtelijk gemengde ouders die niet bij elkaar woonden, bevatte art. 10 een ingewikkelde regeling. Belangrijk was bij welke ouder het kind verbleef. Indien het kind bij zijn buitenlandse ouder woonde, verloor het automatisch de USSR-nationaliteit doordat zijn Sovjet-ouder overleed of elk contact met het kind verloor (lid 2). Op de keper beschouwd ging het in dit geval niet om verlies van de nationaliteit door het kind ingevolge het verlies door zijn ouder. De onderhavige bepaling kan worden beschouwd als een apart geval van nationaliteitsverlies doordat de feitelijke band met zijn Sovjetouder kwam te vervallen.

Woonde het kind bij zijn USSR-ouder, terwijl de buitenlandse ouder overleden was of elk contact met het kind verloren had, dan deelde het kind in het verlies van de Sovjet-nationaliteit van zijn ouder. Het kind verloor de nationaliteit niet automatisch, maar op verzoek van die ouder (lid 3).

\subsubsection{De verordening van 23 november 1930}

De verordening van 23 november $1930^{155}$ had uitsluitend betrekking op art. 16 van de verordening van 13 juni 1930 . Het ging daarbij slechts om redactionele wijzigingen, die noodzakelijk waren geweest in verband met reorganisatie van het bestuur van lagere overheden, die bevoegd waren om de naturalisaties via een vereenvoudigde procedure te verlenen.

\subsubsection{De verordening van 5 mei 1931}

Nog geen jaar na de verordening van 28 juni 1930 werd op 5 mei $1931^{156}$ een nieuwe verordening afgekondigd, die ten opzichte van de oude hoofdzakelijk redactionele wijzigingen met zich mee had gebracht ${ }^{157}$. Als belangrijkste wijziging kan worden genoemd het wegvallen van de mogelijkheid om uitsluitend de federale nationaliteit te bezitten. Krachtens art. 13 jo. 12 lid 3 werden in het buitenland wonende naturalisandi verplicht om aan te geven welke deelstaatnationaliteit zij naast de federale wensten te verkrijgen ${ }^{158}$. Op deze verordening zal gezien het marginale karakter van vernieuwingen niet nader worden ingegaan.

\subsubsection{De ontwikkelingen tot 1938}

De verordening van 5 mei 1931 vormde de basis voor het nationaliteitsrecht van de Sovjetunie totdat in 1938 een nieuwe nationaliteitswet in werking trad. Tussentijds werden nog enkele andere nationaliteitsrechtelijke regelingen getroffen, zoals de verordening van 27 mei $1933^{159}$, die betrekking had op het verlies van de

155. SZ USSR 1930, ar. 58 , pos. 614.

156. SZ USSR 1931, nr. 24, pos. 196. Duitse vertaling: SGS deel 25, p. 313-316; Engelse Taracouzio, p. $379-382$.

157. Maurach, p. 36; SGS deel 25, p. 151; Durdenevskij, ZfoR 1931, p. 519. Zie voor een kort overzicht van wijzigingen ook Zlatopol'skij, p. 254.

158. Cf. Sevcov, p. 138; Maurach, p. 37, Durdenevskij, ZfoR 1931, p. 519.

159. SZ USSR 1933, nr. 34, pos. 200 . Zie voor Duitse vertaling: SGS deel 25 , p. 316 . Deze verordening werd ingetrokken bij de nationaliteitswet van 1938. Expliciet werd dat bekend gemaakt bij cen apart decreet van het POS USSR wan 2 juni 1939, VVS USSR 1939, nr. 22. Vilkov, p. 22. 
USSR-nationaliteit door personen, die voor 7 november 1917 Rusland hadden verlaten en een andere nationaliteit hadden verkregen, of althans daarom hadden gevraagd $^{160}$.

Voorts is van belang de "authentieke interpretatie" van het Opperste Gerechtshof van de USSR van 19 september $1934^{161}$ betreffende de nationaliteit van emigranten, die de USSR na de afkondiging van de op p. 64-65 besproken verordening van 15 december 1921 hadden verlaten ${ }^{162}$. Ten aanzien van deze groep werd namelijk nooit een uitdrukkelijke regeling getroffen. Volgens het Opperste Gerechtshof moesten deze personen als USSR-staatsburgers worden beschouwd, tenzij hen deze nationaliteit door een rechterlijk vonnis, of door een beschikking van de administratie uitdrukkelijk werd ontnomen ${ }^{163}$.

\subsubsection{De wet van 1938}

\subsubsection{Algemeen}

Op 18 augustus $1938^{164}$ werd een nieuwe nationaliteitswet afgekondigd. Een herziene regeling van de USSR-nationaliteit was nodig, omdat ingevolge de zogenaamde "Stalin-grondwet" van 1936 een reorganisatie van staatsorganen die bevoegdheden op het gebied van de nationaliteit bezaten, plaatsvond. Bovendien kende de nieuwe grondwet niet meer de verdeling in twee klassen, waarbij de proletariers bijzondere privileges bezaten ${ }^{165}$. Hoewel ook ten aanzien van eerdere nationaliteitswetgeving aan Moskou geen langdradigheid kan worden verweten, werd de wetgever in 1938 duidelijk door het adagium: "In der Beschränkung zeigt sich der Meister" geïnspireerd. Meesterlijk was de wet van 1938 overigens niet. De acht(!) artikelen korte regeling vertoonde zeer vele lacunes die slechts met vergaande interpretaties konden worden opgevuld.

Ook enkele bepalingen die niet direct betrekking hebben op de verkrijging, respectievelijk het verlies van de Sovjet-nationaliteit zijn een vermelding waard. Zo bevatte art. 2 een interessante overgangsregeling. Deze knoopte niet aan bij de inwerkingtreding van de wet van 1938 , maar bij de datum van de revolutie, namelijk 7 november 1917 . Volgens het bepaalde sub a bezaten alle personen, die tot 7 november 1917 onderdanen van de vroegere Russische staat waren en deze nationaliteit nadien niet verloren hadden, de nationaliteit van de Sovjetunie. Sub b breidde de kring varn Sovjet-onderdanen voorts uit tot degenen, die deze nationaliteit op wettelijk voorgeschreven wijze hadden verworven.

160. Illustratief zijn met betrekking tot de onderhavige verordening de woorden wan Sevcov, p. 166: "Apart from its chief purpose, which was tot get rid of persons not worthy of the name of Soviet citizens, the ordinance was also aimed at preventing dual citizenship,".

161. Sovetskaja justicia 1934, nr. 26; daarower Kowal-Wolk, p. 46-47. Zie voor Duitse wertaling ZfoR $1934-35$, p. 268 e.v.

162. Zoals we op p. 66 zagen, gold deze verordening slechts voor personen, die de RSFSR tussen 7 november 1917 en 15 december 1921 hadden verlaten.

163. Zile hierover ook SGS deel 3, p. 35-36.

164. VVS USSR 1938, nr. 11. Duitse vertaling: SGS deel 25, p. 319-320; Engelse: SSD, p. 258. Zie daarover Ginsburgs, The Citizenship Law of the USSR, The Hague/Boston/Lancaster 1983; Gajdukov, p. 44-52; Vondracek, RM Themis 1966, p. 71-84; Zlatopol'skij, p. 255-258.

165. SGS deel 3 ,p. 37. 
Het vermoeden van bezit van de Sovjet-nationaliteit ten aanzien van personen, die binnen de USSR woonden en niet konden bewijzen dat ze onderdanen van een andere staat of staatloos waren, die de regelingen van 1924 en van 1930/31 kenden, werd in 1938 opgeheven. In plaats daarvan bepaalde art. 8 juist het tegenovergestelde: inwoners van de USSR, die zich noch als Sovjet-burgers, noch als onderdanen wan andere landen konden legitimeren, werden als staatloos beschouwd. Zo kende men in de USSR drie groepen personen: USSR-staatsburgers, vreemdelingen (die het bezit van een andere nationaliteit konden bewijzen) en staatlozen ${ }^{166}$.

\subsection{De verhouding tussen de federale en de deelstaatnationaliteit}

De (grond)wettelijke basis voor de verhouding tussen de nationaliteit van de federatie en die van de deelstaten is te vinden in art. 21 van de grondwet van 1936 respectievelijk in art. 1 van de nationaliteitswet van 1938:

\footnotetext{
"Auf Grund des Art. 21 der Verfassung (des Grundgesetzes) der Union der sozialistischen Sovjetrepubliken wird für Bürger der UdSSR eine einheitliche Staatsbürgerschaft begründet.

Jeder Bürger einer Unionsrepublik besitzt die Staatsbürgerschaft der UdSSR" 167 .
}

In tegenstelling tot de verordeningen van 1930/31 werd in de nieuwe nationaliteitswet niet meer bepaald op welke grond de nationaliteit van een deelstaat kon worden vastgesteld. Bij het ontbreken van een dergelijke bepaling werd door Ginsburgs, Makarov en Meder aangenomen, dat het domicilie nog steeds als het beslissende criterium moest worden beschouwd ${ }^{168}$. Ook de vraag of het volgens de nieuwe wet opnieuw mogelijk was geworden om uitsluitend de federale nationaliteit te bezitten, laat zich niet met alle zekerheid beantwoorden. Terwijl Meder en Maurach voor gevallen, waarin betrokkene in het buitenland woonde en de naturalisatie door de federale organen werd verleend, geneigd zijn om een bevestigend antwoord te geven, vindt Makarov het twijfelachtig 169 .

\subsubsection{Verkrijging van de nationaliteit}

De nationaliteit van de Sovjetunie kon onder de vigeur van de wet van 1938 van rechtswege en door naturalisatie worden verkregen.

\subsubsection{Verkrijging van rechtswege}

Zoals gezegd was verkrijging van de USSR-nationaliteit van rechtswege in het geheel niet in de wet van 1938 geregeld. Desalniettemin werd verkrijging van de Sovjet-nationaliteit van rechtswege gekoppeld aan geboorte uit USSR ouder(s). Door enkele geboorte in de USSR, adoptie, of huwelijk kon het staatsburgerschap

166. Boguslavskij/Rubanov, p. 4; Gajdukov, p. 51-52; Rzepka, ROW 1962, p. 49.

167. Vertaling ontleend aan SGS deel 25, p. 319.

168. Ginsburgs, p. 20; Makarov, ZaöRV 1938, p. 802; Meder, SGS deel 3, p. 40.

169. Meder, SGS deel 3, p. 40-41; Maurach, p. 48; Makarov, ZaöRV 1938, p. 802. 
van de Sovjetunie niet worden verkregen. Ten aanzien van het huwelijk werd zulks in art. 5 uitdrukkelijk bepaald. Vondelingen werden op grond wan het reeds op p. 77 besproken art. 8 niet vermoed Sovjet-staatsburgers te zijn, maar apatriden.

\section{a. Geboorte uit USSR-ouder(s)}

Zoals reeds is opgemerkt, wordt over de verkrijging van de Sovjet-nationaliteit door geboorte in de wet van 1938 met geen woord gerept. Het is zeer opmerkelijk dat de wet slechts op een relatief klein gedeelte van de verkrijging van de nationaliteit van de USSR betrekking had. We mogen namelijk niet vergeten dat in meer dan $90 \%$ gevallen de nationaliteit van een land juist door geboorte wordt verkregen. Dat de Sovjet-nationaliteit ondanks het ontbreken van een wettelijke bepaling ook iure sanguinis kon worden verkregen, wordt ook in de Sovjetliteratuur door niemand ontkend. Veeleer wordt aangenomen, dat de verkrijging van de nationaliteit iure sanguinis zo vanzelfsprekend was, dat men het overbodig vond, om zulks expliciet in de wet te vermelden ${ }^{170}$. Om deze lacune op te vullen, werden in de literatuur verscheidene wegen ingeslagen. Makarov en Meder zochten een oplossing aan de hand van de regels die de wet wel bood ten aanzien van de invloed van een naturalisatie op minderjarige kinderen van betrokkene (art. 6) ${ }^{171}$. Geilke en Sevcov ${ }^{172}$ zijn evenwel van oordeel dat de regeling van de verkrijging van de USSR-nationaliteit door geboorte aan familiewetboeken van afzonderlijke deelstaten werd overgelaten. Argumenten voor deze interpretatie geven zij echter niet. De vraag is ook hoe deze opvatting zich met art. 14 sub 21 van de Sovjetgrondwet van 1936 verdraagt. Daarin werd de regeling van de federale nationaliteit uitdrukkelijk aan USSR-organen voorbehouden. Bovendien werd in art. 19 van de GW de absolute prioriteit van de federale wetgeving neergelegd ${ }^{173}$. Beide interpretaties leidden echter slechts tot verschillende uitkomsten in gevallen waarin een kind uit nationaliteitsrechtelijk gemengde ouders werd geboren.

Gezien de hiërarchische verhouding tussen de federale en de deelstaatwetgeving lijkt het mij juister om in het voetspoor van Makarov en Meder de regels betreffende de verkrijging van de Sovjet-nationaliteit iure sanguinis uit art. 6 af te leiden. Aangezien kinderen onder 14 jaar wier beide ouders werden genaturaliseerd automatisch de USSR nationaliteit verkregen (art. 16 lid 1) moet naar mijn mening een kind, dat uit Sovjet-ouders werd geboren ${ }_{n}$ a fortiori als onderdaan van de USSR worden beschouwd.

Naturalisatie van slechts een van de ouders had echter geen invloed op de nationaliteit van zijn kind. Een strikte interpretatie aan de hand van art. 6 zou dan waarschijnlijk leiden tot de conclusie dat indien slechts een van de ouders op het tijdstip van de geboorte van het kind de Sovjet-nationaliteit bezat, het kind deze nationaliteit niet iure sanguinis verkreeg. Aan de andere kant echter, wijst de ontwikkelingstendens in de wetsgeschiedenis in de tegenovergestelde richting. Terwijl in 1924 nog additionele vereisten van woonplaats, respectievelijk over-

170. Cf. Ginsburgs 1983, p. 193; Taracouzio AJIL 1939, p. 18; Durdenevskij Problemi socialistixeskogo prava 1938/6, p. 65: SGS dieel 3, p. 45. Zie ook Jakovenko, p. 16; Menžnskij/Koževnikow, p. 285.

171. Makarov, ZaöRV 1939, p. 803; Meder, SGS deel 3, p. 43-45. In dezelfde richting ook Maurach, p. $60-61$.

172. Geilke in SGS deel 25, p. 155 en in Bergmann/Ferid, p. 8; Sevcov, p. 121.

173. Ginsburgs, p. 27; Maurach 1955, p. 115-116. 
eenstemming tussen de ouders werden gesteld, breidden de verordeningen van 1930/31 de USSR-nationaliteit tot alle kinderen, die een Sovjet-ouder hadden, uit. Gezien het ontbreken van een andersluidende uitdrukkelijke wettelijke regeling, ben ik tezamen met verschillende schrijvers ${ }^{174}$ geneigd om te concluderen, dat een kind van tenminste één USSR-ouder, ook na 1938, iure sanguinis de Sovjetnationaliteit verkreeg. Daarbij is het niet wan belang, of het kind binnen, dan wel buiten de grenzen van de USSR werd geboren. Volgens de interpretatie van Geilke en $\breve{S}_{e v c o v}$, werd het kind slechts Sovjet-onderdaan, indien tenminste een van zijn ouders op het tijdstip van de geboorte van het kind in de USSR woonde, of op grond van gemeenschappelijke verklaring van zijn ouders (zie bijv. art. 35 van het familiewetboek van de RSFSR) ${ }^{17}$. Gezien de onduidelijkheden op dit punt ben ik met Ginsburgs ${ }^{176}$ geneigd te concluderen, dat in de praktijk zeer waarschijnlijk beide interpretaties werden toegepast.

Bij de verkrijging van de nationaliteit volgens de zojuist beschreven regels werd er aanvankelijk geen onderscheid tussen wettige en onwettige kinderen gemaakt. Een onwettig kind gold als kind van een Sovjet-vader, indien het werd erkend, of het vaderschap gerechtelijk werd vastgesteld. In 1944 werden echter zowel erkenning, als gerechtelijke vaststelling van vaderschap door wijzigingen in het afstammingsrecht verboden ${ }^{177}$. Deze, voor een communistisch land hoogst opmerkelijke regel had tot gevolg, dat onwettige kinderen uitsluitend iure sanguinis a matre de nationaliteit van de USSR konden verwerven.

\subsubsection{Naturalisatie}

Ten aanzien van de naturalisatie kunnen in de wet van 1938 enkele belangrijke vernieuwingen worden gesignaleerd. Zo werd de mogelijkheid van een vereenvoudigde naturalisatieprocedure afgeschaft ${ }^{178}$. Nieuw was ook de bepaling van art. 3 , die bij het verlenen van de Sovjet-nationaliteit elk onderscheid op grond van ras of etnische herkomst verbood. Hieraan kan de consequentie worden verbonden, dat de discretionaire bevoegdheid van de administratie in zoverre werd beperkt, dat een naturalisatie niet op de zojuist genoemde gronden kon worden geweigerd ${ }^{179}$. Op grond van religie mocht evenmin tussen naturalisandi onderscheid worden gemaakt ${ }^{180}$. Dat de nationaliteitsrechtelijke regelingen geen naturalisatievereisten noemden, was in de Sovjetunie inmiddels reeds traditie geworden.

Om naturalisatie te verlenen waren de Presidia van de Opperste Sovjets (POS) van de USSR en van de deelstaat waarin betrokkene woonde, bevoegd (art. 3). Uit de wet bleek niet in welke gevallen de federale en in welke het deelstaat-POS de

174. Meder, SGS deel 3, p. 44; Makarov, ZaöRV 1939, p. 803; Ginsburgs, p. 24; Taracouzio, AIIL 1939, p. 18.

175. Cf. ook Ginsburgs, p. 26-27.

176. Ginsburgs, p. 27.

177. Zie de decreten van 8 juli 1944, VVS USSR 1944, nr. 37; van 10 november 1944, VVS USSR 1944 , nr. 60 en van 14 maart 1945, VVS USSR 1945, nr. 15. Zie daarover Geilke 1983, p. 100; Vondracek, RM Themis 1966, p. 78.

178. Meder, p. 38; Osakwe, AJCL 1980, p. 626.

179. Cf. SGS deel 3 , p. 50 .

180. Volgens Meder, SGS deel 3, p. 50, werd de religie niet expliciet in de wet genoemd, omdat het vanzelfsprekend was, dat discriminatie ook op die grond uit den boze was. 
beslissing kon nemen. Bij gebreke aan een uitdrukkelijke regeling concludeert Meder dat naturalisandi die binnen de USSR woonden zelf konden kiezen of ze hun naturalisatieverzoek bij het POS USSR of bij het POS van de deelstaat van hun woonplaats indienden. In het buitenland woonachtige personen konden echter slechts bij een besluit van het Presidium van het federale Opperste Sovjet worden genaturaliseerd ${ }^{181}$.

\section{a. Invloed op de nationaliteit van de gezinsleden van de verzoeker}

Reeds hierboven werd zeer summier de essentie van de regeling van art. 6 weergegeven. Indien beide ouders genaturaliseerd werden, werden hun kinderen die nog geen 14 jaar oud waren, automatisch medegenaturaliseerd. Bij kinderen tussen 14 en 18 jaar werd hun eigen instemming vereist. In alle andere gevallen had de naturalisatie wan de ouder(s) geen invloed op verkrijging van de Sovjet-nationaliteit. Voor deze kinderen stond derhalve slechts een normale naturalisatieprocedure open.

\subsubsection{Verlies van de nationaliteit}

De nationaliteit van de USSR kon slechts door ontslag en ontneming worden verloren. Wijzigingen in de familierechtelijke status hadden geen invloed op de Sovjet-nationaliteit van betrokkene. Ten aanzien van het huwelijk werd zulks uitdrukkelijk bepaald in art. 5 .

\subsection{Ontslag}

Evenals bij de naturalisatie kunnen we ook bij het ontslag de vereisten ervoor tevergeefs zoeken. De bevoegdheid om thet ontslag te verlenen lag blijkens art. 4 uitsluitend bij het POS USSR.

\section{a. Invloed op de nationaliteit van de gezinsleden van de verzoeker}

In art. 6 van de wet van 1938 werden de gevolgen van het verlies van de nationaliteit van de USSR door ontslag op het staatsburgerschap van de minderjarige kinderen van betrokkene geregeld. Kinderen onder 14 jaar verloren hun nationaliteit slechts indien het verlies beide ouders had getroffen. Waren ze ouder dan 14 jaar dan was hun toestemming nodig. In alle andere gevallen behielden ze de nationaliteit van de Sovjetunie.

\subsection{Ontneming}

De nationaliteit van de USSR kon blijkens art. 7 zowel bij een rechterlijk vonnis, als bij een beschikking van het POS USSR worden ontnomen. De eerste mogelijkheid werd beperkt tot "in de wet voorziene gevallen", waarbij met name moet

181. SGS deel 3 , p. $46-48$. Maurach, p. 48 , is echter van mening dat de in de USSR wonende naturalisandi steeds bij de Opperste Sovjet van hun deelstaat een naturalisatieverzoek moesten indienen. 
worden gedacht aan een decreet betreffende politieke delicten van 25 februari $1927^{182}$ en aan afzonderlijke bepalingen van strafwetboeken van de deelstaten ${ }^{183}$, die bij sommige "contrarevolutionaire" tevens de ontneming van de nationaliteit als straf voorschreven. Deze sanctie bleek zelden of nooit te zijn toegepast ${ }^{184}$. Bij de "Basisbeginselenwet strafwetgeving" van 25 december $1958^{185}$ werd de ontneming van de nationaliteit als strafsanctie afgeschaft. Bij het decreet van 19 januari $1961^{186}$ werd de tekst van art. 7 van de wet van 1938 uiteindelijk daaraan aangepast ${ }^{187}$.

De ontneming van het staatsburgerschap bij een beschikking van het POS USSR werd nergens verder geregeld, hetgeen op een volledige discretionaire bevoegdheid van de beslissende instantie wijst.

\subsection{De ontwikkelingen tussen 1938 en 1978}

\subsubsection{Algemeen}

De Sovjet-nationaliteitswet van 1938 "overleefde" de tweede wereldoorlog en bleef van kracht tot 1 juli 1979 , toen een nieuwe algemene regeling van het Sovjetstaatsburgerschap in werking $\operatorname{trad}^{188}$. Hieronder zal eerst een kort overzicht van nationaliteitsrechtelijke regelingen, die betrekking hadden op de uitbreidingen van het grondgebied van de USSR rondom de tweede wereldoorlog, worden gegeven. Vervolgens zal aandacht worden besteed aan de wijzigingen van de nationaliteitswet van 1938 en aan enkele bijzondere regelingen die eveneens betrekking hadden op het staatsburgerschap.

\subsubsection{Uitbreidingen van het territorium van de USSR}

In de jaren kort vó́r en na de tweede wereldoorlog werd het grondgebied van de Sovjetunie en daardoor tevens het geldingsbereik van het Sovjet-nationaliteitsrecht aanzienlijk uitgebreid. Hierna zullen de belangrijkste wijzigingen worden genoemd.

\subsubsection{Baltische staten}

In de eerste dagen van augustus 1940 werden de Baltische staten na ongeveer twintigjarige zelfstandigheid als socialistische sovjetrepublieken, bij de USSR ingelijfd ${ }^{139}$. Krachtens het decreet van het POS USSR van 7 september $1940^{190}$

182. SZ USSR $1927 \mathrm{I}$, pos. 123 .

183. Zie SGS deel 3, p. 54 .

184. Mensagin, Ugolownoe pravo obšaja Cast 1948, p. 500. Geciteerd door Ginsburgs, p. 51.

185. VVS USSR 1959 , nr. 1 , pos. 6.

186. VVS USSR 1961, ar. 4 , pos. 35.

187. Ginsburgs 1983, p. 238-239; Pusylewitsch, OER 1979, p. 252-253.

188. Luchterhandt, OER 1981, p. 458.

189. SGS deel 3, p. 60-62. Zie de wetten van resp. 3 augustus 1940 (Litouwen), 5 augustus 1940 (Letland) en 6 augustus 1940 (Estland), VVS USSR 1940, nr. 28; Duitse vertaling: ZfoR 194041, p. 182-189. Daarover Makarov, ZaöRV 1940-41, p. 682-707.

190. VVS USSR 1940, nr. 31. Duitse vertaling in ZfoR 1940-41, p. 188. Daarover Makarov, ZfoR 1940-41, p. 184-187; SGS deel 3, p. 60-62; Bergmann/Ferid, p. 8. Zie voorts de wetten wan respectievelijk 3 augustus 1940 (Litouwen), 5 augustus 1940 (Letland) en 6 augustus 1940 (Estland), VVS USSR 1940, nr. 28. De USSR-nationaliteit werd ook verworven door degenen 
verwierven de onderdanen van deze nieuwe deelstaten de nationaliteit van de USSR (art. 1). De annexatie van de Baltische staten werd echter door verschillende Westerse landen een lange tijd niet (of slechts de facto) erkend. Het gevolg daarvan was, dat vluchtelingen uit deze landen door sommige landen als staatlozen, door andere als Sovjet-burgers, of zelfs als onderdanen van (niet meer bestaande) Baltische staten werden beschouwd ${ }^{191}$.

\subsection{Duitsland}

Bij het verdrag van Potsdam van 2 augustus 1945 werden de door de Sovjetunie bezette Duitse gebieden Noord-Oostpruisen (Königsberg, Kaliningrad) en Memelland voorlopig aan de USSR gegeven ${ }^{192}$. Het eerste gebied werd vervolgens bij de RSFSR en het tweede bij Litouwen ingelijfd. Terwijl de Duitse inwoners van het Königsberg-gebied niet de Sovjet-nationaliteit hadden verkregen en slechts als USSR-"Schutzangehörigen" ${ }^{193}$ moeten worden beschouwd, hebben de inwoners van Memelland echter wel de Litouwse en daardoor de USSR-nationaliteit verworven ${ }^{194}$.

\subsection{Finland}

Bij de vredesverdragen van 12 maart 1940 en 10 februari 1947 werden kleine grenscorrecties vastgesteld. Nationaliteitsrechtelijke bepalingen bevatten de verdragen echter niet ${ }^{195}$.

\subsection{Polen}

Ingevolge het verdrag tussen de USSR en Duitsland van 28 september 1939 werd Polen in twee interessesferen verdeeld, waarvan vervolgens die van de USSR gedeeltelijk aan Litouwen (Wilna) en gedeeltelijk aan de USSR (West-Oekraïne en Westwitrusland) werd toegevoegd ${ }^{196}$. Het POS USSR stelde voorts op 29 november 1939 vast, dat de inwoners van de nieuwe USSR-gebieden Sovjetstaatsburgers werden ${ }^{197}$. Na de Duitse aanval op de Sovjetunie sloot de laatste met de Poolse regering in Londen op 30 juli een nieuw verdrag, dat aan de bepalingen van het Sovjet-Duitse verdrag omtrent territoriale veranderingen derogeerde. $\mathrm{Na}$ verschillende meningsverschillen omtrent een nieuwe grens tussen Polen en de

die in het buitenland woonden. Makarov, ZfoR 1940-41, p. 185.

191. Zie daarower SGS deel 3, p. 63-64; Ginsburgs, p. 21, met verwijzingen naar de jurisprudentie in Zweden en in de BRD.

192. SGS deel 3 , p. 65-66.

193. Zie over dit begrip De Groot/Tratnik, p. 8 .

194. SGS deel 3, p. 65-66.

195. SGS deel 3, p. 58-59.

196. SGS deel 3, p. 56. Het ging om gebieden: Willna, Westoekraïne en Westwitruslland. Wilna werd op 10 oktober 1939, VVS USSR 1939, nr. 37 aan Litouwen afgestaan, terwijl de twee andere bij de wetten van 14 en 15 november 1939, lzvestija 1939, nr. 256 bij de USSR werden ingelijfd.

197. Bergmann/Ferid, p. 8. Duitse vertaling in SGS deel 25, p. 325 van de publicatie van de de Engelse vertaling in Polish-Soviet Relations 1918-1943. Official Documents, Issued by the Polish Embassy in Washington (1944). Dit decreet werd in de USSR niet officieel gepubliceerd. 
USSR, werd deze bij het verdrag van 16 augustus 1945 vastgesteld ${ }^{198}$. Ten aanzien van etnisch Poolse USSR-staatsburgers die tijdens de tweede wereldoorlog in het Poolse leger vochten en hun gezinsleden werden op 22 juni en 14 juli $1944^{\text {is }}$ twee decreten afgekondigd, die het recht van deze personen op afstand van de USSRnationaliteit regelden.

\subsection{Roemenië}

Roemenië had aan de Sovjetunie bij een notawisseling van 26-28 juni 1940 de gebieden Noord-Boekowina en Bessarabië afgestaan 200 . De nationaliteit van de inwoners van deze gebieden werd geregeld in een decreet van het POS USSR van 8 maart $1941^{201}$.

\subsection{Tsjechoslowakije}

Op grond van het verdrag van 29 juni $1945^{202}$ is het gebied Karpatho-Oekraïne onderdeel van de USSR geworden. De inwoners van dat gebied hadden op grond van dit verdrag de nationaliteit van de Sovjetrepubliek Oekraïne en daardoor van de USSR verkregen ${ }^{203}$.

\subsection{Azië}

Ook de grenzen tussen de Sovjetunie en een aantal Aziatische landen werden rond de tweede wereldoorlog veranderd. Het ging daarbij om Afghanistan, China, Iran, Japan, Mongolië en Turkije ${ }^{204}$.

\subsubsection{Wijzigingen van de wet van 1938}

De Sovjet-nationaliteitswet van 1938 werd slechts tweemaal gewijzigd. De eerste wijziging werd aangebracht bij decreet van 15 februari 1947, die bij wet van 4 februari $1948^{205}$ werd bevestigd. Volgens deze wet werd het de Sovjet-burgers verboden om met buitenlanders te trouwen. Als gevolg hiervan werd art. 5 van de wet van 1938 als overbodig ingetrokken ${ }^{206}$. Het verbod van gemengde huwelijken werd op 26 november 1953 weer opgeheven en art. 5 van de wet van 1938 weer "in ere hersteld" ${ }^{207}$. De tweede wijziging betrof het reeds op p. 81 vermelde decreet van 19 januari 1961, waardoor de mogelijkheid van ontneming van de nationaliteit door de rechter kwam te vervallen.

198. Geratificeerd door het POS USSR op 13 januari 1946. SGS deel 3, p. 58.

199. VWS USSR 1944, nr. 35 en 38 ; SSD, p. $264-266$.

200. SGS deel 3, p. 59; Makarov, in ZfoR 1940-41, p. 524-529 en in ZaöRV 1940-41, p. 336-359.

201. VVS USSR 1941, nr. 13, pos. 4; Duitse vertaling in ZfoR 1940-41, p. 529; SGS deel 3, p. 59-60.

202. VVS USSR $1945, \mathrm{nr}, 79$; Vilkov, p. 61-62.

203. SGS deel 3, p. 65.

204. Zie daarower SGS deel 25, p. 199-201 (Afganistan), 203-218 (China), 242-247 (Japan), 250-253 (Iran), 248-249 (Mongolië) en 283-286 (Turkije).

205. VVS USSR 1947, nr. 10 en VVS USSR 1948, nr. 6; SSD, p. 270 . Zie ook Vilkow, p. 28.

206. SGS deel 3, p. 52; Ginsburgs, ICLQ 1966, p. 29.

207. VVS USSR 1953, nr. 49. Luchterhandt, OER 1981, p. 461; Ginsburgs, ICLO 1966, p. 29-30. 
Alvorens tot de bespreking van de huidige nationaliteitswet van de Sovjetunie over te gaan zal aandacht worden besteed aan twee andere regelingen, die tevens betrekking hadden op de nationaliteit, namelijk een decreet uit 1954 en de "basisbeginselenwet" van 1968.

\subsection{Het decreet van 1954}

Op 16 december $1954^{2008}$ vervaardigde het POS USSR een decreet, dat nergens officieel werd gepubliceerd. Deze regeling verleende de nationaliteit van de Sovjetunie aan personen, die aldaar "langdurig" 209 woonden en niet het bezit van de nationaliteit van een andere staat konden aantonen, alsmede aan hun kinderen. Politieke immigranten werden echter uitgesloten. Dit decreet leek inhoudelijk veel op art. 3 van de verordening van 1931 dat een vermoeden van het USSRstaatsburgerschap bevatte en stond op gespannen voet met art. 8 van de wet van 1938 dat ten aanzien van ongeveer dezelfde personen een "praesumptio apatridiae" voorschreef. Uit het feit dat de oorspronkelijke tekst van de nationaliteitswet na 1954 nog herhaaldelijk in ongewijzigde vorm werd gepubliceerd, kan worden geconcludeerd, dat men met het decreet geen intrekking van art. 8 beoogde ${ }^{210}$. De regeling van 1954 lijkt meer bedoeld te zijn geweest als een eenmalige geste om aan het begin van het "post-Stalin tijdperk" het aantal van apatriden sterk te reduceren, of zoals Ginsburgs dat verwoordde:

"The 1954 decree was just one manifestation of this desire to erase the more objectionable traits of the ancient regime. However, all it was expected to do was to rectify a long-standing injustice, not introduce (or reintroduce) a daring legal formula that henceforward would operate as a general rule" 211 .

\subsection{De "basisbeginselenwet" van 1968}

Op 1 oktober $1968^{212}$ traden de zogenaamde "basisbeginselen van de wetgeving op het gebied van het huwelijks- en familierecht in werking. Dit federale wetboek bracht (eindelijk) een regeling van de verkrijging van de Sovjet-nationaliteit iure sanguinis met zich mee en vulde daardoor de lacune van de nationaliteitswet van 1938 op dit gebied op. De regeling wan art. 30, die betrekking op het staatsburgerschap had, zag er als volgt uit:

Een kind van Sovjet-ouders verkreeg steeds de nationaliteit van de USSR, ongeacht waar het werd geboren. Hetzelfde gold in het geval dat slechts een van de ouders een Sovjet-staatsburger was en het kind in de Sovjetunie werd geboren.

208. Zlatopol'skij, p. 258; Ginsburgs 1983, p. 175; SSD, p. 273.

209. Wat "langdurig" betekende, werd nergens bepaald.

210. Ginsburgs 1983 , p. 175.

211. Ginsburgs 1983 , p. 176.

212. VVS USSR 1968 , nr. 27 , pos, 241 ; SSD, p. 277 . Zie daarover Ginsburgs, University of Toronto Law Journal 1971, p. 71-80; Sevcov, p.. 121. 
Voorts was het ook mogelijk dat een in het buitenland geboren kind van slechts eén USSR-ouder de Sovjet-nationaliteit verkreeg. Voor dit geval bedacht men een ingewikkelde regeling. Voor de verkrijging werd vereist, dat de vader van het kind zich op het moment van de geboorte van het kind in de USSR bevond. Het ging hierbij niet om de woonplaats, maar om het feitelijk verblijf.

Was de vader op het tijdstip van geboorte van het kind in het buitenland, dan werd woor de verkrijging van de Sovjet-nationaliteit door het kind een gezamenlijke daartoe strekkende verklaring van beide ouders vereist ${ }^{213}$.

De discriminatie van onwettige kinderen die in 1944 werd ingevoerd, werd bij deze wet opgeheven. Bij de verkrijging van de nationaliteit volgens de zojuist beschreven regels werd namelijk geen onderscheid tussen wettige en onwettige kinderen meer gemaakt. Een onwettig kind gold als kind van een Sovjet-vader, indien het werd "erkend" ${ }^{\mathrm{214}}$, of het vaderschap gerechtelijk werd vastgesteld (art. 16 e.v.)

\subsection{Het POSTrIEVE NATIONALITEITSRECHT}

\subsubsection{Algemeen}

Op 1 juli 1979 trad de huidige nationaliteitswet van de Sovjetunie tezamen met het invoeringsdecreet van 15 juni $1979^{215}$ in werking. Er waren verschillende redenen om een nieuwe regeling van de USSR-nationaliteit uit te vaardigen. In de eerste plaats moet hier worden gedacht aan de nieuwe grondwet van 7 oktober $1977^{216}$, die enkele staatsrechtelijke veranderingen teweeg heeft gebracht. In de Sovjetunie is het namelijk in de loop der jaren traditie geworden om naar aanleiding van een nieuwe constitutie de nationaliteitswet te veranderen. De op de nationaliteit betrekking hebbende bepalingen van art. 33 verschillen inhoudelijk niet van hun pendanten in de grondwet van 1936:

213. Dit lijkt op het eerste gezicht een terugkeer naar het ius sanguinis a patre, maar dat was het nivet. In het onderhavige geval werd eigenijk wereist dat zich eén van de ouders op het beslissende tijdstip in de USSR bevond en aangezien het kind in het buitenland werd geboren, kon dat slechts de vader zijm. Zie voor een bespreking van alle mogelijke situaties Ginsburgss, p. 40-41.

214. Een "erkenning" geschiedt door een gemeenschappelijke verklaring van de ouders omtrent het vaderschap van het kind. M.b.t. kinderen, geboren ma 1 oktober 1968 was thet weer mogelijk on het vaderschap gerechtelijk vast te stellen. Bergmann/Ferid, p. 46.

215. VVS USSR 1978, nr. 49, pos. 816 en VVS USSR 1978, nr. 25, pos. 436; Luchterhandt, OER 1981, p. 458. Duitse vertaling: Bergmann/Ferid p. 14-17; Nederlandse vertaling: $N W G$, p. 1-9. Engelse vertaling: Sevcow, p. 272-279. Zie uitgebreid over deze wet Ginsburgs, The Citizenship Law of the USSR, The Hague/Boston/Lancaster 1983 en The New Soviet Citizenship Law and Human Rights, Camden 1979; Bojars, Grazdanstwo v mezdunarodnom i vnutrennem prave, Riga 1981; Kulik, Zakon o graždanstve SSSR, Moskva 1980; Safronov, Konstitucija SSSR i sovetskoe grazdanstvo, Moskva 1984; Sevcov, Citizenship of the USSR, Moscow 1979.

216. VVS USSR 1977 , nr. 4, pos. 18/19; Duitse vertaling: Osteuropa 1978, p. A 3 e.v.; Engelse: Feldbrugge, The Constitutions of the USSR and the Union Republics, Alphen aan den Rijn/Germantown 1979; Nederlandse: Constitutie (grondwet) van de Unie van socialistische sowjet-republieken, Moskou 1980. In werking getreden op 7 november 1978. Zie over deze grondwet Schultz, ROW 1978, p. 207 e.v. 
"In de USSR is een algemeen, voor de gehele unie geldend staatsburgerschap ingesteld. Iedere burger van een unierepubliek is een burger van de USSR.

De grondslagen en de wijze van verwerven en verliezen van het Sowjet-staatsburgerschap zijn vastgelegd in de wet op het staatsburgerschap der USSR.

De burgers der USSR genieten in het buitenland bescherming en steun van de Sowjet-staat"'.

Naast de herziene grondwet noemt Luchterhandt ${ }^{217}$ nog het voornemen van de stalats-en partijleiding om de belangrijkste wetgeving opnieuw in een "Svod Zakonov" te bundelen ${ }^{218}$ en de ontwikkelingen op het internationale vlak. USSR heeft na de tweede wereldoorlog een aantal verdragen gesloten, die tevens op de nationaliteit betrekking hadden. Bovendien heeft zij ook de Slotakte van Helsinki ondergetekend, met de daarin opgenomen bepalingen betreffende gezinshereniging en internationale huwelijken. Als wre hiernaast ook denken aan sterke emigratie in de jaren zeventig en aan het feit dat de bestaande nationaliteitswet niet alleen veertig jaar oud, maar tevens bijzonder beknopt en vol hiaaten ${ }^{219}$ was, dan ligt het voor de hand dat een nieuwe regeling noodzakellijk was.

Het is interessant kort stil te staan bij enkele algemene bepalingen van de wet van 1978, die niet direct op verkrijging en verlies van de nationaliteit betrekking hebben.

Een zuiver declaratoir karakter heeft art. 4 waarin wordt bepaald dat het sluiten van een huwelijk geen gevolgen voor de Sovjet-nationaliteit van betrokkene kan hebben. Hetzelfde kan reeds worden afgeleid uit het feit dat de verkrijgingsen verliesbepalingen van de wet aan het sluiten van het huwelijk geen nationaliteitsrechtelijke rechtsgevolgen verbinden. Dezelfde opmerking kan worden gemaakt ten aanzien van art. 5, waarin uitdrukkelijk wordt vermeld een woonplaats in het buitenland als zodanig geen verlies van de Sovjetnationaliteit teweeg kan brengen ${ }^{220}$. Het opnemen van beide artikelen in de wet kan worden verklaard door het feit, dat het in de wetgeving van de socialistische landen gebruikelijk is om uitgangspunten van een wet als inleidende artikelen van de desbetreffende wet op te nemen.

Art. 6 bepaalt voorts in overeenstemming met de grondwet (art. 33 lid 3) dat onderdanen van de USSR die zich in het buitenland bevinden, recht hebben op

21.7. Luchterhandt, OER 1981, p. 458-459.

21.8. Op grond van gezamenlijke besluiten van het Centraal comité van de CP USSR en van de Ministerraad wan 23 december 1970 (KPSS v rezoljucijach iv v rešenijach deel 10, 1969-1971; geciteerd door Gorle, JOR 1981/1, p. 12) begon men in de USSR aan cen nieuwe "Svod zakomov" De verzameling die in 1978 gereed kwam, is een keuze wit de rechtsvoorschriften die losbladig. wordt uitgegewen. Het gaat on een officiêle publicatie van het POS USSR en van de Ministerraad. Zie verder over deze nieuwe Svod Gorlé, JOR 1981/1, p. 9-35. Zie ook besluiten wan 2 september 1976, VVS USSR 1978, nr, 5, pos. 239 en van het Centraal comite CP USSR, POS en van de Ministerraad van 23 maart 1978, VVS USSR 1978, nr. 25, pos 239.

219. Dexe werden dikwijls provisorisch opgevuld door verschillende instructies van owerheidswege. Tunkin, SGiP $1979 / 7$, p. 22.

220. Anders is het bijwoorbeeld in de Nederlandse nationaliteitswet, waar in art. 15 sub d wordt bepaald, dat Nederlandlers door een tienjarig verblijf in een land, waar ze werden geboren en waarvan ze de nationaliteit bezitten, het Nederlanderschap verliezen. 
bescherming door de staat ${ }^{221}$. Ook art. 7 dat uitlevering van de Sovjet-staatsburgers verbiedt, is in de nationaliteitswet m.i. misplaatst. De grondwet en de strafwetgeving zouden de aangewezen plaatsen voor dit artikel zijn.

Interessant is verder art. 8 dat uitdrukkelijk bepaalt, dat het eventuele bezit van een vreemde nationaliteit door een Sovjet-burger niet wordt erkend ${ }^{222}$. Dit betekent, dat de Sovjetunie eventuele diplomatieke bescherming van een onderdaan van haar in de USSR a priori weigert toe te laten. Deze bepaling werd overigens reeds in de verordening van 1924 opgenomen (art. 11). Het feit dat een dergelijke bepaling in een nationaliteitswet wordt geplaatst is op zichzelf opmerkelijk. Inhoudelijk komt art. 8 echter overeen met het reeds op p. 31-32 besproken art. 3 van het Haagse nationaliteitenverdrag, waarbij de USSR overigens geen partij is.

Tenslotte zij opgemerkt dat de op p. 77 besproken "praesumptio apatridiae" van art. 8 van de wet van 1938 in art. 9 van de huidige wet wordt gehandhaafd.

\subsubsection{De verhouding tussen de federale en de deelstaatnationaliteit}

Naast de nationaliteit van de deelstaten en van de federatie, kent het nationaliteitsrecht van de Sovjetunie nog een derde "soort" staatsburgerschap, namelijk dat van de autonome republieken ${ }^{223}$. Een onderdaan van een autonome republiek kan tevens burger van een (gewone) republiek zijn en is steeds ipso iure burger van de USSR. Zo wordt in gevallen waarin een deelstaat-POS omtrent naturalisaties beslissingen nemen, de nationaliteit van een deelstaat verleend, waardoor men automatisch het USSR-staatsburgerschap verkrijgt (art. 26 lid 5). Het is evenwel ook mogelijk om uitsluitend de nationaliteit van de federatie te bezitten ${ }^{224}$. Dit gebeurt in de regel in gevallen, waarin aan in het buitenland wonende naturalisandi door het POS USSR de nationaliteit wordt verleend. De algemene (eenheids-) nationaliteit van de USSR staat overigens hoog in het vaandel geschreven ${ }^{225}$. Hoewel theoretisch de nationaliteit van de USSR uit die van de deelstaten wordt afgeleid, kan de federale nationaliteit zeker als de primaire worden beschouwd ${ }^{226}$.

De nieuwe nationaliteitswet bevat geen regels met betrekking tot verkrijging en verlies van de deelstaatnationaliteit en ook de republieken hebben geen algemene nationaliteitswetten "geproduceerd" 227 . Wel kwam in de deelstaten in 1981 een serie nagenoeg gelijkluidende regelingen van naturalisatie tot stand, waarin enige nadere regels met betrekking tot de naturalisatieprocedure worden

221. Poljanskij, SGiP 1980/5, p. 126; Sevcov, SGiP $1970 / 6$, p. 40.

222. Daarover Rubanov, SGiP 1979/7, p. 54; Poljanskij, SGiP 1980/5, p. 125.

223. Voigens art. 17 van de grondwet van Bashkirse Autonome Socialistische Sovjetrepubliek (ASSR) is iedere burger van de ASSR tewens burger van de RSFSR. Voorbeeld ontleend aan: Osakwe, AJCL 1980, p. 630. Heel treffend zegt hij voorts: "Ironically, however, ewen though an A.S.S.R. has both a constitution and citizenship of its own, it neither has the right to adopt its own constitution nor authority to accept petitions for admission to its citizenship. For all practical purpose therefore the citizenship of an autonomous-republic is meaningless".

224. Cf Osakwe, AJCL 1980, p. 6

225. Luchterhandt, OER 1981 , p. $459-460$.

226. Cf. Uibopur, OER 1979, p. 64. Zie bijwoorbeelde Bilinsky, OER 1979, p. 64" "Die Staatsangehörigkeit der Unionsrepublik ist seit $1930 \mathrm{zu}$ einer blossen Farce geworden".

227. Pusylewitsch, OER 1979 p. 248. 
gegeven ${ }^{228}$. De vraag of de nationaliteit van deelstaten nog steeds aan de hand van de woonplaats moet worden bepaald, wordt door verschillende schrijvers uiteenlopend beantwoord ${ }^{229}$. Daarbij lijkt het ook niet echt belangrijk welke deelstaatnationaliteit men bezit ${ }^{230}$. Reeds op verschillende plaatsen werd benadrukt, dat de nationaliteit van een (deel)staat slecht belangrijk is, indien op die grond onderscheid tussen personen die op het grondgebied van de desbetreffende (deel)staat wonen onderscheid wordt gemaakt. Uit de grondwetten van de (autonome) Sovjet republieken blijkt echter dat tussen de USSR-burgers op grond van de deelstaatnationaliteit geen onderscheid mag worden gemaakt ${ }^{231}$. Een typisch voorbeeld van een recht dat dikwijls aan de nationaliteit wordt gekoppeld is het kiesrecht. In de (autonome) sGvjetrepublieken wordt het kiesrecht echter niet aan de hand van de nationaliteit, doch aan de hand van woonplaats toegekend ${ }^{232}$.

Op deze plaats dient er op te worden gewezen, dat men in de Sovjetunie tussen de juridische deelstaatnationaliteit en het etnisch behoren tot één der in de USSR wonende volkeren een scherp onderscheid maakt ${ }^{233}$. Interessant hierbij is, dat ook de tweede, etnische mationaliteit (nacional'nost') een juridische categorie is. Zo stat op de interne paspoorten, die de Sovjet-Burgers verplicht zijn bij zich te hebben, niet de juridische, maar de etnische "nationaliteit" van betrokkene vermeld ${ }^{234}$.

In de huidige regeling van de nationaliteit van de Sovjetunie wordt de sterke positie van de federatie ten aanzien van bevoegdheden op het gebied van het nationaliteitsrecht grotendeels gehandhaafd. Dit is gebeurd ondanks pleidooien in de Sovjet-literatuur voor versterking van de rol van deelstaten ${ }^{235}$. Zo heeft het POS USSR in een aantal gevallen uitdrukkelijk exclusieve bevoegdheden toebedeeld gekregen.

228. Armenië: 26 augustus 1981, VVS 1988, nr. 16, pos. 174; Azerbaidjan 4 december 1981, VVS 1981, nr. 23, pos. 281; Estland 30 november 1981, VVS 1981, nr. 39, pos. 589; Kazachstan 28 augustus 1981, VVS 1981, nr. 36, 613; Kirgizische republiek 22 september 1981; Letland 4 december 1981, VVS 1981, nr. 50; Litouwen 29 december 1981, VVS 1981, nr. 36, pos. 450; Moldavië 13 juni 1981; Oekraine 27 november 1981, VVS 1981, nr. 49, pos. 837; Oezbekistan 27 augustus 1981; de RSFSR 29 juni 1981, VVS 1981, nr. 22, pos. 903 (Duilse vertaling in Bergmann/Ferid, p. 19); Tadjikistan 11 december 1981, VVS 1981, nr. 24, pos. 223; Toerkmenistan 1981, VVS 1981, nr. 33, pos. 152; Witrusland 26 november 1981, Sobranie zakonov 1981, nr. 33, pos. 676.

229. Volgens Osakwe, AJCL 1980, p. 630, is de woonplaats niet meer beslissend bij het bepalen van de deelstaatnationaliteit. Anders echter: Riege, StuR 1979, p. 894; Sevcov, p. 73.

230. Cf. Pusylewitsch, OER 1979 p. 248.

231. Cl. art. 31 lid 3 van de grondwet van RSFSR, alsook: Poljanskij, SGiP 1980, p. 127; Pusylewitsch, OER 1979 , p. 248 ; Riege, StuR 1979, p. 893.

232. Pusylewitsch, OER 1979, p. 248.

233. In de Nederlandse taal bestaat dit onderscheid niet, we gebruiken voor beiden het woord nationaliteit. Vergelijk echter de betekenis van termen: Staatsangehörigkeit en Nationalität; citizenship en nationality; citoyenneté en nationalitế; cittadimanza en nazionalita.

234. Feldbrugge Encyclopaedia, 463-464; Osakwe, AJCL 1980, p. 630; Vondraček, RM Themis 1966, p. 71 .

235. Zie bijwoorbeell Esajan, Nekotorye voprosy sovetskogo grazdanstva, Erevan 1966; Vitrjuk, Problemi pravoznanstva 1973. p. 49-59. 


\subsubsection{Verkrijging van de nationaliteit}

Volgens de regeling van de wet van 1978 kan de nationaliteit van de Sovjetunie worden verkregen van rechtswege en door naturalisatie.

\subsubsection{Verkrijging van rechtswege}

Na veertig jaar heeft de verkrijging van de Sovjet-nationaliteit van rechtswege opnieuw een plaats in de federale nationaliteitswet van de Sovjetunie gekregen. De wetgever heeft ditmaal zelfs een zeer uitgewerkte regeling van de verkrijging van het staatsburgerschap ipso iure, "geproduceerd". Van rechtswege wordt verkrijging van de USSR nationaliteit gekoppeld aan de volgende rechtsfeiten:

- geboorte uit USSR-ouder(s);

- geboorte, of het gevonden worden in de Sovjetunie;

- adoptie door een Sovjet-onderdaan.

Ius sanguinis a matre et a patre is ook in de huidige wet het uitgangspunt gebleven, hoewel er meer uitzonderingen ten gunste van het ius soli werden gemaakt ${ }^{236}$. Ook is de wetgever iets minder ruimhartig geworden met de toekenning van de nationaliteit van de USSR aan kinderen, die wit nationaliteitsrechtelijk gemengde ouders worden geboren. Daarbij heeft de wens om meervoudige nationaliteit van dergelijke kinderen te voorkomen, kennelijk op de voorgrond gestaan. Nieuw is verkrijging van de nationaliteit door adoptie in art. 23. Hoewel aan de hand van de literatuur reeds voor de periode vóór 1979 mag worden aangenomen dat het USSR- staatsburgerschap door adoptie kon worden verkregen ${ }^{237}$, is dit de eerste keer dat zulks uitdrukkelijk in een federale nationaliteitsrechtelijke regeling wordt bepaald.

\subsection{Geboorte uit Sovjet-ouder(s)}

Een kind is Sovjet-burger, indien zijn beide ouders op het tijdstip van zijn geboorte de nationaliteit van de USSR bezitten. Dit geldt ongeacht waar het kind wordt geboren (art. 11). De nationaliteit van de USSR wordt door het kind eveneens verkregen, indien slechts één van de ouders het Sovjet-staatsburgerschap bezit en het kind binnen de Sovjetunie wordt geboren (art. 12 lid 1 sub 1).

In geval dat slechts één van de ouders de nationaliteit van de USSR bezit en het kind bovendien in het buitenland wordt geboren, worden voor verkrijging van de nationaliteit door het kind in art 12 enkele additionele eisen gesteld, namelijk:

236. Cf. Scheetz, Ukraïnian Quarterly 1982, p. 274; Riege, StuR 1979, p. 895.

237. Zie Ginsburgs 1983 , p. 266-267 met verdere literatuurwerwijzingen. 
- vaste woonplaats ${ }^{238}$ van tenminste éen ouder in de USSR (art. 12 lid 1 sub 2);

- staatloosheid of onbekendheid van de andere ouder (art. 12 lid 3); of

- onderlinge overeenstemming van ouders omtrent verkrijging van de Sovjetnationaliteit door het kind (art. 12 lid 2) 239 .

De ouders van een in het buitenland geboren kind hebben derhalve de mogelijkheid om zelf omtrent de verkrijging van het Sovjet-staatsburgerschap door hun kind te beslissen. De wet bepaalt echter niet, in welke vorm en binnen welke termijn de gezamenlijke verklaring van de ouders moet geschieden. Deze lacune is echter opgevuld, namelijk door het decreet van het POS USSR van 15 juni 1979240 . De onderhavige verklaring dient in schriftelijke vorm te worden voorgelegd aan een diplomatieke of consulaire vertegenwoordiging van de USSR binnen een jaar na de geboorte van het kind ${ }^{241}$. In het geval dat een dergelijke overeenstemming niet tot stand komt, of de ouders beslissen dat het kind geen Sovjet-burger zal worden, heeft het kind na het bereiken van meerderjarigheid de mogelijkheid van vereenvoudigde naturalisatie ${ }^{242}$.

Bij de verkrijging van de nationaliteit volgens de zojuist beschreven regels wordt geen onderscheid tussen wettige en onwettige kinderen gemaakt. Een onwettig kind geldt als kind van een Sovjet-vader, indien het wordt erkend, of het vaderschap gerechtelijk wordt vastgesteld ${ }^{243}$.

\subsection{Geboorte op het grondgebied van de USSR en vondelingen}

Het ius soli beginsel heeft in het huidige nationaliteitsrecht van de Sovjetunie een veel grotere rol dan voorheen toebedeeld gekregen. In het kader van de bestrijding van apatridie wordt de USSR-nationaliteit toegekend aan kinderen van aldaar wonende staatlozen. Krachtens art. 13 verkrijgt een kind van apatride, in de Sovjetunie wonende ouders ipso iure de nationaliteit van de USSR ${ }^{244}$.

238. "Vaste woonplaats" is volgens de toenmalige voorzitter van het POS USSR, Kuznecow: "Ort, an dem der Bürger meistens wohnt und arbeitet". Interview voor de Frankfurter Allgemeime Zeitung van 4 april 1979. Geciteerd door Luchterhandt, OER 1981, p. 462. Volgens Ginsburgs 1983, p. 204 , is voor het aaninemen van "vaste woomplaats"' in USSR echter voldoende, dat men (nog) in een bevolkingsregister aldaar staat ingeschreven.

239. Cf. Riege, StuR 1979, p. 895-896; Tunkin, SGiP 1979/7, p. 26. Mijns inziens ten onrechte draail Pusylewitsch, OER 1979, p. 251, de onderhavige bepaling om en betoogt, dat in het buitenland geboren kind wan een Sovjet-ouder slechts dan geen nationaliteilt van de USSR verkrijgt, indien żj] beide ouders hun vaste woomplaats in het buitenland hebben en gezamenlijk beslissen dat het kind geen Soyjel-burger zou worden. Bij gebreke van een gezamenlijke verklaring, wordt de USSR-nationaliteit juist nief verkregen.

240. VVS USSR 1979, nr. 25, pos. 436; zie Kowal-Wolk, p. 67.

241. Ginsburgs 1983, p. $207-208$.

242. Sevcov, p. 120. Deze mogelijkheid wordt echter niet in de wet vermeld.

243. Artt. 16 e.v. van de basisbegenselenwet huwelijks-en familierecht; Bojars, p. 80 .

244. Pusylewitsch, ER 1979, p. 251; Riege, StuR 1979, p. 896; Tunkin SGiP 1979/7 p. 26. De automatische verkrijging geldt voor personen, geboren na 30 juni 1979. Aan in USSR geboren minderjarige staatlozen werd in de overgangsregeling wan het decreet van 15 juni 1979, VVS USSR 1979. nr. 25, pos. 436 een optierecht op de Sovjet-nationaliteit verleend. Cf. Ginsburgs 
Een regeling van verkrijging van de Sovjet-nationaliteit door vondelingen is in de wet van 1978 voor het eerst opgenomen. Een kind, dat in de Sovjet unie wordt gevonden en wiens ouders onbekend zijn, verkrijgt op grond van art. 14 de nationaliteit van de USSR. Volgens Riege gaat het hier niet om de gebruikelijke praesumptio van verwerving van de nationaliteit die kan worden weerlegd, doordat een of beide ouders van het kind bekend worden, of vastgesteld wordt dat het kind. door geboorte tevens een andere nationaliteit bezit. De verkrijging van de nationaliteit zou definitief zijn ${ }^{245}$.

\subsection{Adoptie door Sovjet-ouder(s)}

Anders dan zijn voorgangers, kent de wet van 1978 ook verkrijging van de nationaliteit van de Sovjetunie door adoptie. Een vreemdeling, die de leeftijd van 14 jaar nog niet heeft bereikt, verwerft in de volgende gevallen het Sovjetstaatsburgerschap door adoptie:

- indien zijn beide adoptïef-ouders de nationaliteit van de USSR bezitten (art. 23 lid 1);

- indien één van zijn adoptief-ouders staatsburger van de USSR en de andere staatloos is (art. 23 lid 2);

- indien één van de adoptanten de Sovjet- en de andere een vreemde nationaliteit bezit en beiden hun wil daartoe verklaren (art. 23 lid 3).

Kinderen tussen 14 en 18 jaar verwerven het USSR-staatsburgerschap door adoptie slechts indien ze uitdrukkelijk er mee instemmen (art. 25).

In beginsel kan de USSR-nationaliteit ook door een in het buitenland uitgesproken adoptie worden verkregen. De rechters in de Sovjetunie hebben echter de mogelijkheid om een dergelijke adoptie te vernietigen en daarbij te beslissen, of het kind in dit geval de Sovjet-nationaliteit al dan niet behoudt ${ }^{246}$.

\subsubsection{Naturalisatie}

De verkrijging van de nationaliteit van de Sovjetunie door naturalisatie wordt geregeld in artt. 15, 27 en 28 van de wet van 1978. Hoewel de Sovjet-wetgever op een aantal gebieden van het nationaliteitsrecht eindelijk relatief uitgebreide regelingen heeft getroffen, blifft de regeling van naturalisatie beperkt tot regels betreffende competentieverdeling tussen federale en deelstaatorganen. De

1983, P. 212.

245. Riege, StuR 1979, 1979, p. 896-897. 4. Sevcov, p. 122, kiest bij art. 14 echter voor de "praesumptio iuris sanguinis" constructie. Zo ook Ginsburgs 1983, p. 214; Kowal-Wolk, p. 73-74. Uit de tekst van art. 14 zelf blijktt echter niet of de verkrijging van de nationaliteit op het ius soli berust, of het om een presumptie wan geboorte uit Russische ouders, dus een "praesumptio iuris sanguimis" gaat. In de Nederlandse vertaling in de NWG, p. 4, wordt ten onrechte gesproken van geboorte in de USSR. Cf. de authentieke Russische tekst, respectievelijk de Engelse vertaling bij $\$$ evcov, p. 275 en de Duitse in Bergmann/Ferid, p. 15.

246. Seveov, p. 130; Ginsburgs 1983, p. 269. 
beslissing omtrent de naturalisatie kan worden genomen bij een decreet van het POS USSR of van een deelstaat op een daartoe strekkend verzoek van betrokkene, respectievelijk zijn wettelijke vertegenwoordiger, indien de naturalisandus nog minderjarig is (art. 27 lid 3) ${ }^{247}$. In art. 15 wordt het verzoek expliciet genoemd, waaruit kan worden afgeleid, dat niemand tegen zijn wil kan worden genaturaliseerd ${ }^{248}$. Een verzoeker, die in de Sovjetunie woonachtig is, kan zowel door een decreet van het POS van een van de deelstaten, als van het POS USSR worden genaturaliseerd. De wet geeft geen scherpe afgrenzing van de bevoegdheden tussen beide organen aan. Er wordt wel bepaald, wanneer het POS USSR exclusief bevoegd is, namelijk:

- ten aanzien van in het buitenland wonende naturalisandi (art. 26 lid 1),

- wanneer reeds in het verleden het POS USSR omtrent de nationaliteit van betrokkene beslissingen heeft genomen (lid 2) en

- bij de herverkrijging van de Sovjet-nationaliteit (lid 3) ${ }^{249}$.

Bovendien is het POS USSR steeds bevoegd om een beslissing omtrent een verzoek (ook als het tot een deelstaat-POS wordt gericht) tot zich te trekken (lid 4) ${ }^{250}$. De verzoeker heeft geen recht op naturalisatie; de beslissing daaromtrent wordt volledig ter discretie van het beoordelende orgaan overgelaten ${ }^{25 \%}$. Een recht op naturalisatie zou volgens de Sovjet-doctrine in strijd met de staatssouvereiniteit op het gebied van de nationaliteit zijn ${ }^{252}$.

Een genaturaliseerde Sovjet-burger heeft dezelfde rechten en plichten, als degenen, die deze nationaliteit door geboorte hebben verkregen, aldus uitdrukkelijk art. 1 lid 3 van de wet van 1978.

Naturalisatievereisten worden wederom buiten de wet gelaten. Er wordt slechts bepaald, wat niet als voorwaarde voor de verkrijging van de nationaliteit mag worden gesteld. Zo mag bij de naturalisatie geen onderscheid tussen verzoekers worden gemaakt op de volgende gronden:

- woonplaats $^{253}$,

- taal,

247. Bij minderjarigen van 14 jaar en ouder is tevens hun schriftelijke instemming noodzakelijk (art. 25). Riege, StuR 1979, p. 897.

248. Ginsburgs 1983 , p. 218-220, merkt terecht op, dat men in de USSR desalniettemin automatische (dwang)naturalisaties kent, met name als het gaat om de verlening van de mationaliteit aan een groep personen, zoals bijvoorbeeld bij het hierboven, op p. 84 besproken decreet van 1954 het geval was.

249. Het federale POS is bevoegd om met betrekking tot herverkrijging van de nationaliteit cen bijzondere procedure te hanteren. Tunkin, SGiP 1979/7, p. 29.

250. Cr. Pusylewitsch, OER 1979, p. 251.

251. Cr. Cernicenko, p. 59, Pusylewitsch, OER 1979, p. 251; Riege, StuR 1979, p. 879; Kowal-Wolk, p. 101.

252. CerniKenko p. 78; Poljanskij, SGiP 1980/5, p. 125, 128.

253. Een naturalisandus hoeft niet in de Sovjetunie te wonen, Cf. Osakwe, AjCL 1980, p. 637-638: "Under the new law one does not even have to be resident in the USSR or express a desire to take up permanent residence in the USSR in order to qualify admission to citizenship". Zie ook Pusylewitsch, OER 1979, p. 251 . 
- opleiding,

- geslacht, of

- nationaliteit (zowel etnische als juridische).

Voorts wordt volgens Kuznecov bij de beoordeling van een naturalisatieverzoek bijzonder gelet op de vraag, of betrokkene "door zijn gedrag bewijst dat hij een dergelijke onderscheiding verdient, zich eervol gedraagt en de autoriteit en

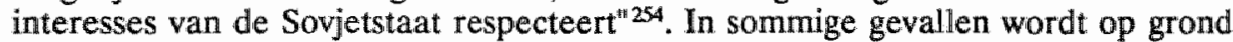
van internationale verdragen vereist, dat de nationale staat van betrokkene in de naturalisatie toestemt ${ }^{255}$, of zelfs uitdrukkelijk dat betrokkene uit zijn vorige nationaliteit moet zijn ontslagen ${ }^{256}$. Men vond het niet nodig een dergelijk vereiste expliciet in de nationaliteitswet op te nemen, aangezien reeds in art. 8 wordt bepaald, dat een vreemde nationaliteit van een USSR-onderdaan niet wordt erkend en bi- of polypatridie dus uit het Sovjetstandpunt "niet kan bestaan" 257 .

\subsection{Invloed op de nationaliteit van de gezinsleden van de verzoeker}

De regeling van medenaturalisatie van minderjarige kinderen van naturalisandi is geplaatst in de artt. 20,21 en 25 van de wet van 1978. Deze regeling is gebaseerd op de reeds voorheen geldende beginselen, en is met enkele varianten aangevuld:

Indien beide ouders worden genaturaliseerd, zijn hun kinderen, jonger dan 14 jaar, steeds automatisch bij de naturalisatie inbegrepen. (art. 20). In het geval dat slechts een van de ouders wordt genaturaliseerd, zijn ten aanzien van de medenaturalisatie van het kind verschillende mogelijkheden. Aan het kind kan op verzoek van de genaturaliseerde ouder ook de Sovjet-nationaliteit worden verleend, indien de andere ouder een vreemde nationaliteit heeft (art. 21 lid 1), of hij staatloos is en het kind zijn vaste woonplaats in het buitenland heeft (lid 3 ). Indien de andere ouder staatloos is en het kind binnen de Sovjetunie woont, dan wordt het- mits het nog geen 14 jaar oud is- automatisch meegenaturaliseerd (art. 21 lid 2).

Bij kinderen die tussen 14 en 18 jaar oud zijn, is voor hun naturalisatie in alle gevallen hun schriftelijke instemming noodzakelijk (art. 25).

\section{2 .3 Verlies van de nationaliteit}

De nationaliteit van de Sovjetunie kan worden verloren door ontslag en ontneming. Dit betekent dat een Sovjet-staatsburger niet door eigen wil(suiting) sec, zonder dat de overheid daarover beslist, zijn USSR-nationaliteit kan verliezen. Dit feit wordt in de Westerse literatuur sterk bekritiseerd ${ }^{258}$ wegens strijd met art. 15 lid

254. Kuznecor in de officiele toelichting wan de wet in Izvestija van 2 december 1978.

255. De reeds besproken antibipatridieverdragen van de USSR mel Bulgarije, DDR en Polen. Zie p. 48.

256. De reeds besproken antibipatridieverdragen van de USSR met Roemenie en Tsjechoslowakije, zie p. 48. Zie ook Vilkow, p. 49.

257. Bojars, p. 88 .

258. Scheetz, Ukrainian Quarterly 1982, p. 277; Pusylewitsch, OER 1979, p. 253; Luchterhandt OER 1979, p. 463-467; Kowal-Wolk, p. 135. In de USSR wordt in dit verband gesproken over het beginsel staatssouvereiniteit op het gebied van het nationaliteitsrecht. Zie Poljanskij, SGiP 1980/5, p. 128-129. 
2 van de Universele declaratie van de rechten van de mens van 1948, waarin het recht om van de nationaliteit te veranderen wordt gewaarborgd.

Adoptie door vreemdeling(en) heeft geen nationaliteitsrechtelijke gevolgen. Wel is het voor de adoptant(en) mogelijk om ten aanzien van het kind het ontslag uit de Sovjet-nationaliteit te krijgen. Deze mogelijkheid bestaat echter slechts indien het kind door twee onderdanen van een andere staat of een echtpaar waarwan één echtgenoot onderdaan van de USSR is en de andere een andere nationaliteit bezit, wordt geadopteerd (art. 24).

Als gevolg van de regell, dat niemand uitsluitend de nationaliteit van een (autonome) republiek kan bezitten, gaat met het USSR-staatsburgerschap ook de deelstaatnationaliteit ipso iure verloren (art. 16 lid 2).

\subsubsection{Ontslag}

Het ontslag is de enige mogelijkheid, dat betrokkene mede door zijn eigen wil het verlies van de Sovjet-nationaliteit kan bewerkstelligen. Het ontslagverzoek kan worden ingediend zowel door binnen, als buiten de Sovjetunie woonachtige personen, ongeacht of betrokkenen naast de Sovjet- een andere nationaliteit bezitten of niet. Met name indien betrokkene nog in de USSR woont, zal het verlenen van ontslag dikwijls apatridie tot gevolg hebben. Anders dan bij de naturalisatie, is bij het ontslag uit het staatsverband het federale POS uitsluitend bevoegd om omtrent een verzoek te beslissen (art. 17). De wet geeft in tegenstelling tot die van 1938 een aantal criteria aan, op grond waarvan het ontslag moet, respectievelijk kan worden geweigerd. Deze vereisten zijn evenals bij de naturalisatie (art. 15) negatief geformuleerd en kunnen in absolute en relatieve ontslagbeletselen worden onderverdeeld. Terwijl bij de eerste ontslag in het geheel niet mogelijk is, wordt bij de relatieve beletselen de beslissing ter discretie van het POS USSR overgelaten. Betrokkene heeft in het geheel geen recht op het ontslag en tegen een afwijzende beschikking wordt ook geen beroep toegelaten ${ }^{259}$.

3):

Van een absoluut ontslagbeletsel is sprake in de volgende gevallen (art. 17 lid

- indien tegen betrokkene een strafprocedure aanhangig is;

- in het geval dat tegen de verzoeker een rechterlijk vonnis dient te worden geëxecuteerd, of

- indien het ontslag de staatsveiligheid zou kunnen schaden.

Terwijl het bestaan van de eerste twee weigeringsgronden objectief vast te stellen is, kan de derde des te meer problemen veroorzaken. Aangezien in de Sovjetunie het begrip "staatsgeheim" zelfs tot de meest absurde situaties kan worden 
doorgevoerd, kan het onderhavige beletsel tot zeer willekeurige ontslagweigeringen leiden ${ }^{360}$.

Als relatieve beletselen noemt de wet van 1978 in art. 17 lid 2 de volgende omstandigheden:

- verplichtingen tegenover de staat en

vermogensrechtelijke verplichtingen tegenover andere burgers ${ }^{261}$ "de stat, coöperatieve en andere maatschappelijke organisaties ${ }^{262}$.

Onder de genoemde verplichtingen moeten worden verstaan schulden, die binnen een overzichtbare termijn kunnen worden betaald, zoals belastingen, verzekeringspremies, huurpenningen, kredieten en kosten van opleidingen ${ }^{263}$. Met name de laatste kunnen in de praktijk dikwijls problemen veroorzaken. In dit verband moet een geheim decreet van 3 augustus 1972 worden genoemd, waarin emigranten naar "kapitalistische" landen verplicht werden gesteld om de kosten van hun universitaire of hogeschool-opleidingen aan de staat terug te betalen. Deze maatregel werd genomen om emigratie van met name jonge Joodse intellectuelen onmogelijk te maken of althans af te remmen ${ }^{264}$.

De regeling van de weigeringsgronden met betrekking tot ontslag uit de nationaliteit komt in grote lijnen overeen met de regeling voor verkrijging van een uitreisvisum, die laatstelijk werd gewijzigd bij een verordening van de Ministerraad in $1986^{265}$. In vergelijking met de daarvoor geldende regels, kan worden geconstateerd, dat de discretionaire bevoegdheid van plaatselijke besturen, die deze toestemmingen verlenen, enigszins beperkter is geworden, doordat de weigeringsgronden veel uitvoeriger zijn geformuleerd ${ }^{266}$. Desalniettemin heeft betrokkene geen recht om het land te verlaten. Voor degenen die niet tot etnische minder-

260. Zie uitwoerig hierover het rapport Who may Leave: a Review of Soviet Practice Restricting Emigration on Grounds of Knowledge of "State Secrets", New York 1987. Als twee absurde voorbeelden noemt Luchterhandt, OER 1981, p. 465 het geval van iemand die aan een universiteit heeft gestudeerd, waar ook een leerstoel in "militaire wetenschappen" is en van een journaliste van een gewone krant, die door haar beroep ook als "geheimendrager" werd beschouwd. Ook aan personen, die de militaire dienstplicht reeds verwuld hebben, kan op grond van hun "kennis wan geheimen" gemakkelijk het ontslag worden geweigerd. Een ontslagverzoek voor de diensttijd leidt in de regel tot cen oproep voor de militaire dienst. Zie ook Kowal-Wolk, p. 112.

261. Hiver gaat het dikwijls on verplichtingen op het gebied van familierecht. Van betrokkene wordt vereist on de toestemming van de huwelijkspartner, of een echtscheidingsvonnis te overleggen. Voor emigratie is ook de toestemming van ouders nodlig, aangexien kinderen verplicht zijn hun ouders te onderhouden. Luchterhandt, OER 1981, p. 464; Kowal-Wolk, p. 112.

262. Sevcow, p. 171; Luchterhandt, OER 1981, p. 464.

263. Luchterhandt, OER 1981, p. 464-465. Of dric jaar werken in plaats van "vergoeding" van een universitaire of een hoge school-opleiding. Kowal-Wolk, p. 112.

264. Volgens het onderthavige decreet kon de "schadevergoeding" vastgesteld worden op een bedrag van 4.000-25,000 Roebels, hetgeen bij de lage inkomens in de Sovjetunie hat loon over verschillende jaren betekent. In 1985 bedroeg een gemiddeld maandloon 190 Roebells. Menschenrechte, p. 127; Zie ook Luchterhandt, OER 1981, p. 464.

265. Sobranie postanowlenij pravitel'stwa USSR 1986, nr. 31, pos. 163. In werking getreden op 1 januari 1987. Duitse vertaling in ROW 1987, p. 44-45; Engelse met een commentaar van Feldbrugge in Soviet Jewish Affairs 1987/9, p. 21-23. Zie daarover ook Kuss, EuGRZ 1987, p. 305.307; Restricting p. 96-105; Brunner, WGO 1988, p. 213-216; Ginsburgs 1988, p. 217-251.

266. Zie Kuss, EuGRZ 1987, p. 306. 
theden behoren zijn de mogelijkheden op een positieve beslissing minimaal ${ }^{267}$. In 1980 werd het woor het verkrijgen van een uitreiswisum te betalen bedrag op 221 Roebels vastgesteld en voor het ontslag 300 Roebels ${ }^{268}$.

Met betrekking tot Joden wordt het ontslag in de regel gehanteerd als voorwaarde om een uitreisvisum te kunnen krijgen ${ }^{269}$. Zo wordt een potentielle emigrant gedwongen om reeds voor zijn vertrek zijn Sovjet-nationaliteit op te geven, ongeacht of hij dat zelf wil of niet. Deze koppeling tussen een uitreisvisum en het ontslag wordt echter niet ten aanzien van alle groepen potentiële emigranten gehanteerd. Zo mochten bijwoorbeeld in het verleden etnische Duitsers dikwijls de Sovjet-nationaliteit behouden, terwijl dat bij Joden juist niet het geval was ${ }^{270}$. Emigratie van Joden uit de Sovjetunie is onder het Gorbacëv-bewind weer toegenomen ${ }^{271}$. Desalniettemin komt het thans nog voor dat op een verzoek ook meer dan 10 jaren niet positief wordt beslist, meestal in verband met kennis van "geheimen" 272.

\subsection{Invloed op de nationaliteit van de gezinsleden van de verzoeker}

Het ontslag van een of beide ouders uit het staatsverband van de USSR kan het verlies van de Sovjet-nationaliteit door hun minderjarige kinderen (tot 18 jaar) tot gevolg hebben. Ipso iure treedt volgens de wet het nationaliteitsverlies ten aanzien van het kind echter slechts in, indien zijn beide ouders het Sovjet-staatsburgerschap verliezen en het kind nog geen 14 jaar oud is (art. 20). Bij kinderen tussen 14 en 18 jaar wordt tevens een schriftelijke instemming van het kind vereist (art. 25).

In het geval dat slechts een van de ouders wordt ontslagen en de andere de Sovjet-nationaliteit behoudt, verliest het kind zijn staatsburgerschap niet (art. 24). De wetgever heeft echter vergeten om uitdrukkelijk gevallen te regelen, waarin slechts een van de ouders de nationaliteit van de Sovjetunie verliest en de andere:
a. onbekend is,
b. staatloos is,
c. een andere nationaliteit bezit,
d. als Sovjet-burger is overleden,
e. als staatloze is overleden
f. als onderdaan van een andere staat is overleden.

267. In de jaren 1971-1985 verlieten bijwoorbeeld legaal de USSR 264.500 Joden, 72, 000 etmische Duitsers, 40.000 Armeniêrs en 16.000 Grieken. Zie Menschenrechte, p. 109.

268. Menschenrechte, p. 127. Bij emigratie naar "socialistische landen zijn de bedragen voor het uitreiswisum, resp. ontslag, 20, resp. 30 Roebels.

269. Luchterhandt, OER 1981, p. 464; Scheet, Ukrainian Quarterly 1982, p. 276; Kowal-Wolk, p. 123.

270. Deze discriminatie van Joden wordt in de Sovjet-literatuur als volgt toegelicht: Een Sovjetonderdaan heeft het recht om in het buitenland diplomatieke bescherming van de USSR in te roepen. Dit is echter slecht mogelijk indien de Sovjetunie met de desbetreffende staat diplomatieke betrekkingen onderhoudt en dat is bij lsrael niet het geval. Luchterhandt, OER 1981, p. 464.

271. In september 1988 meldide het NRC-Handelsblad ongeveer 2000 emigrantem per maand. Zie ook de statistische gegevens met betrekking tot Joodse emigranten uit de USSR bij Mertens, Osteuropa 1987, p. 519-522.

272. Zie voor concrete voorbeelden de resolluties van het Europese parlement, gepubliceerd in EuGRZ 1987, p. 326 en 1988, p. 186. Zie ook Kuss, EuGRZ 1987, p. 305. 
Gezien de ratio van de regeling in artt. 20-25 moeten naar mijn mening de variaties onder $a, b, d$ en e gelijkgesteld worden met het geval dat de andere ouder Sovjet-onderdaan blijft (art. 24) en de mogelijkheden sub c en $f$ met de situatie waarin beide ouders de nationaliteit van de USSR verliezen (art. 20).

\subsubsection{Ontneming}

Ontneming van de nationaliteit kan worden gezien als sanctie voor niet loyaal of oneerbaar gedrag van betrokkene en wordt geregeld in art. 18 van de nationaliteitswet van 1978. Deze bepaling, die de ontneming als een uitzonderingsmaatregel betitelt, geeft in tegenstelling tot de wet van 1938 tenminste in de vorm van een vage "Generalklausel" aan, in welke gevallen de Sovjet-nationaliteit kan worden ontnomen. het moet daarbij gaan om handelingen, die:

"... den guten Ruf des Begriffes eines UdSSR Bürgers diskriminieren und dem Prestige oder der Staatssicherheit der UdSSR schaden." 273

Deze uiterst vage norm geeft aan het POS USSR een praktisch onbegrensde discretionaire bevoegdheid, die aan geen enkele rechterlijke controle wordt onderworpen ${ }^{274}$. Met het oog op de gevallen van ontneming van de nationaliteit onder de vigeur van de oude wet concludeert Scheetz ${ }^{275}$ dat men in de onderhavige bepaling de gebruikelijke praktijk ten aanzien wan "te lastige" dissidenten heeft neergelegd. De nationaliteit van de USSR kan overigens worden ontnomen ongeacht of betrokkene daardoor staatloos wordt en of hij binnen, dan wel buiten de Sovjetunie woont ${ }^{276}$. Ontneming van de nationaliteit wordt zeer zelden toegepast, in de regel met betrekking tot "te lastige" dissidenten ${ }^{27}$. In tegenstelling tot de andere Oosteuropese landen worden ontnemingsbesluiten in de regel wel in het staatsblad (VVS USSR) gepubliceerd ${ }^{278}$. Tussen 1 januari 1979 en 1 januari 1989 werden ontnemingen aan 53 personen op deze wijze bekend gemaakt ${ }^{279}$. In bijna alle gevallen ging het om in het buitenland woonachtigen. Bij het ontnemingsbesluit kan ook worden bepaald dat degene die in de USSR woont, het land moet verlaten (art. 5 verordening) ${ }^{280}$.

273. Vertaling ontleend aan Bergmann/Ferid, p. 16.

274. Cr. Luchterhandt, OER 1981, p. 466; Osakwe, AJCL 1980, p. 640; Scheetz, Ukrainian Quarterly 1982 , p. 277 ; Kowal-Wolk, p. 120.

275. Scheetz, Ukrainian Quarterly 1982, p. 277 . Reeds voor de wet van 1978 werd de onderhavige formule bijwoorbeeld gebruikt ten aamzien wan de ontmeming van nationaliteit aan: Pjotr Grigoreniko VVS USSR 1978 nr. 8 pos. 125, Mstislav Rostropovie VVS USSR nr. 12 pos. 209, Oskar Rabin, VVS USSR $1978 \mathrm{nr}$. 26 pos. 412. Woorbeelden zijn ontleend aan Luchterhandt, OER 1981, p. 466. Zie ook Ginsburgs 1983, p. 243.

276. Riege, StuR 1979 , p. 899.

277. Zie Menschenrechte, p. 110 .

278. Kulik, p. 61 .

279. Daaronder bijvoorbeeld aan de schaker Viktor Korěnoj, VVS USSR 1979, nr. 1, pos 30 en de schrijwer Vladimir Vojnovic, VVS USSR 1981, nr. 25, pos. 818.

280. Bojars, p. 102; Kulik, p. 55; zie ook het bericht in ROW 1979, p. 227. Een recent voorbeeld is te vinden in VVS USSR 1988, nr. 30, pos. 500. In dit korte decreet werd de Armeense politieke activist Arikjan ontslagen van strafrechtelijke vervolging, werd hem de nationaliteit ontnomen en werd bovendien uitgewezen. 
2.2.3.2.1 Invloed op de nationaliteit van de gezinsleden van betrokkene

Art. 18 lid 2 bepaalt uitdrukkelijk, dat ontneming van de nationaliteit geen invloed heeft op het Sovjet-staatsburgerschap van de echtgeno(o)t(e) van betrokkene. Deze garantie biedt echter geen voldoende waarborgen. Zo kan de nationaliteit aan een huwelijkspartner van een dissident gewoon wegens eigen "wangedrag" worden ontnomen ${ }^{281}$.

281. Cf. Scheetz, Ukrainian Quarterly 1982, p. 277; Kowal-Wolk, p. 132. Deze "oplossing" werd bijv. gekozen in het geval van Natalija Solzenicina en van Galina Visnevskaja, de vrouw van Mstislav Rostropovix. 


\section{HOOFDSTUK 3. ALBANIË}

\subsection{Geschmedenis}

\subsubsection{Inleiding}

Albanië was van 1468 tot 1912 een onderdeel van het Turkse rijk ${ }^{1}$. Het Albanese grondgebied was bevolkt door verschillende etnische groepen, met name Albanezen en verder Serviërs, Grieken, Montenegrijnen en Turken. Op 28 november 1912 werd een zelfstandig vorstendom geproclameerd ${ }^{2}$, dat op 20 december van hetzelfde jaar op de Londense conferentie van ambassadeurs ${ }^{3}$ internationale erkenning vond ${ }^{4}$. De grenzen wan de nieuwe staat werden echter pas bij het protocol van Florence van 17 december 1913 definitief vastgesteld ${ }^{5}$. Constitutionele regels werden vastgelegd in de "Statut organique de l'Albanie", dat op 29 juni 1913 door een internationale commissie werd vervaardigd 6 . Tijdens de eerste wereldoorlog werd Albanië door verschillende legers geoccupeerd 7 . Deze bezetting duurde tot 1919. Daarna kwam op 20 januari 1920 een voorlopige Albanese grondwet tot stand, die op 7 maart 1925 toen Albanië een republiek werd, definitief werd vastgesteld ${ }^{8}$. Op 1 september 1928 werd de staatsvorm van Albanië wederom gewijzigd; ditmaal werd het een constitutionele monarchie onder de dictator-koning Zogu ${ }^{9}$. deze werd op 7-8 april 1939 door de Italiaanse bezettingsmacht afgezet, waarna Albanië feitelijk een Italiaanse provincie werd ${ }^{10}$. Op 12 april 1939 werd een personele unie met Italië, onder de koning Vittorio Emmanuele III, geproclameerd ${ }^{11}$. Deze duurde tot de capitulatie van Italië in september 1943. Vervolgens was Albanië tot oktober 1944 door Duitsland bezet ${ }^{12}$.

Reeds in 1940 arganiseerde de oppositie een verzetsbeweging onder de leiding van zogenaamde "Antifascistische raad van het front van de nationale bevrijding", waarin de communisten die onder sterke invloed van de Joegoslavische communistische partij stonden, de leidende rol hadden gekregen ${ }^{13}$. Na een enkele maanden durende Duitse bezetting en de daarop aansluitende burgeroorlog, kwam op 29 november 1944 de communistische partij met de hulp van Joegoslavische en Griekse partizanen aan de macht ${ }^{14}$. De nieuwe machthebbers vormden in januari

1. Kempner, JöR 1926, p 484.

2. Skendi, p. 1; Simonard, p. 129-130.

3. Dat was een conferentie van ambassadeurs van Duitsland, Frankrijk, Groot-Brittannië, Italie, Oostenrijk-Hongarije en Rusland. Polyvios, p. 76.

4. Skendi, p. 2; Kempner, JöR 1926, p. 485; SGS deel 5, p. 7; Peaslee, p. 3.

5. Simonard, p. 212; Mousset, p. 13; Willems, Bevolkingsboekhouding 1955, p. 221.

6. Deze commissie bestond uit diplomaten uit Duitsland, Frankrijk, Groot-Brittannie, Italie, Oostenrijk-Hongarije en Rusland. Simonard, p. 207; Kempner, JöR 1926, p. 485.

7. Door Oostenrijk-Hongarije, Servię, Montenegro, Griekenland, Italië en Frankrijk. Skendi, p. 3; Kempner, JöR 1926 , p. 485.

8. Kempner, JoR 1926 , p. 486 met eem Duitse wertaling op p. 487-494. Italiaanse vertaling in Giannini, p. 304-336. Zie ook Peaslee, p. 4 en Bergmann/Ferid, p. 5.

9. Zogu was reeds sedert 1925 president van de republiek Skendi, p. 9; Peaslee, p. 4.

10. Skendi, p. 14; Bergmann/Ferid, p. 2.

11. Skendi, p. 15; Giannini, p. 187.

12. Skendi, p. 19-20.

13. Skendi, p. 17; Peaslee, p. 4.

14. Skendi, p. 21; Peaslee, p. 4. 
1945 een wolksfrontregering, die in november 1945 door de geallieerden werd erkend ${ }^{15}$. Op 1 januari 1946 werd vervolgens de republiek uitgercepen ${ }^{16}$. De nieuwe Albanese staat was tot 1948 onder sterke invloed van Joegoslavië. Na de breuk tussen Tito en Stalin in 1948 oriënteerde men zich uitsluitend op de Sovjetunie. Deze vriendschap duurde tot 1962, waarna Albanië in de Volksrepubliek China de "sterke broer" vond. Sedert 1973, toen ook deze relatie "stukliep" heeft Albanië zich niet alleen van de westerse wereld, maar ook van alle andere communistische staten afgezonderd ${ }^{17}$. Zeer recentelijk blijken de deuren van Albanie zich althans op economisch gebied iets te openen.

De communisten hadden reeds in het najaar van $1944^{18}$ alle voor de tweede were]doorlog gesloten internationale verdragen opgezegd. Bij wet van 17 mei $1945^{19}$ werden vervolgens alle tussen 1939 en 1944 door de Italianen en Duitsers tot stand gebrachte rechtsregels ingetrokken. De oude vooroorlogse wetgeving bleef van kracht, echter voorzover deze niet in strijd was met de "nieuwe democratische geest" of met regels die de communisten invoerden. Dit laatste werd echter blijkens het decreet van 25 januari $1947^{20}$ zo geïnterpreteerd, dat het oude recht nagenoeg in zijn geheel als ongeldig werd beschouwd. Slechts enkele normen mochten bij wijze van voorbeeld worden gebruikt voorzover ze niet in strijd met de openbare orde waren en er nog geen nieuwe regels voorhanden waren. Na de grondwet van 7 maart $1946^{21}$ begon men met de invoering van nieuwe wetgeving, die tot 1948 sterk door het Joegoslavische en daarna door het recht van de USSR werd beïnvloed. Op 4 juli $1950^{22}$ werd de grondwet gewijzigd. In de jaren zestig ging men onder de Chinese invloed over tot radicale wijzigingen in de wetgeving 23 . Op 28 december $1976^{24}$ werd vervolgens de thans geldende grondwet afgekondigd.

\subsubsection{Het nationaliteitsrecht tot 1946}

\subsubsection{Algemeen}

De Turkse nationaliteitswet van 16 januari 1869 met de wijzigingswet van 5 juli 1894 bleef in Albanië gelden tot de invoering van het burgerlijk wetboek van 1928 waarin in artt. 4-2125 de eerste nationaliteitsrechtelijke regeling van Albanië werd neergelegd ${ }^{26}$. Reeds voor de invoering van het burgerlijk wetboek werden enkele internationale verdragen gesloten, die tevens betrekking hadden op de Albanese

15. Bergmann/Ferid, p. 2-3.

16. Peaslee, p. 4.

17. Stoppel, JOR 1985/2, p. 410; Schwanke, Osteuropa 1963; Bergmann/Ferid, p. 3. Zie over de betrekkingen tussen Albaniēe en Chima in de periode 1969-1979 Topp, Berïchte des BOIS, p. 137 en over de Albanese buitenlandse politiek na de breuk met China, p. 54-93.

18. Decreet nr. 3, G.Z. $1944_{\text {i }}$ nr. 1 .

19. G.Z. 1945, nr. 22 .

20. G.Z. 1947, nr. 9 .

21. G.Z. 1946, nr. 117. Engellse vertaling: Peaslee, p. 6-19.

22. Peaslee, p. 4. Deze grondwet werd nog in 1953, 1954 en 1958 gedeeltelijk gewijzigd.

23. Bergmann/Ferid, p. 4; Stoppel, ROW 1983, p. 221 en in JOR 1985, p. 410.

24. G.Z. 1976, nr. 5; Duitse vertaling bij Roggemann, p. 19-45.

25. In werking getreden op 1 april 1929; Duitse vertaling in SGS deel 5, p. 13-17. Zie daarover De Lapradelle/Niboyet, p. 511-512.

26. De Lapradelle/Niboyet, p. 511. 
nationaliteit. Zo werden in art. 3 van de zogenaamde "Minderheitenschutzerklärung" van 2 oktober $1921^{27}$ enkele algemene beginselen van het Albanese nationaliteitsrecht neergelegd ${ }^{28}$. $\mathrm{Na}$ de totstandkoming van Albanie en het ondergang van het Turkse rijk werd het noodzakelijk om de nationaliteitsrechtelijke positie van etnische Albanezen, die in Joegoslavië, Griekenland en Turkije woonden, te regelen. Met Turkije en Griekenland sloot Albanië verdragen van respectievelijk 15 december $1923^{29}$ en 13 oktober $1926^{30}$. Daarin werd aan etnische Albanezen een optierecht op de Albanese nationaliteit toegekend. Het sluiten van een dergelijk verdrag werd van de Joegoslavische zijde steeds afgewezen, terwijl daar destijds ongeveer teen miljoen etnische Albanezen woonden ${ }^{31}$. Voorts sloot Albanië op 5 april $1932^{32}$ een verdrag betreffende naturalisatie met de Verenigde Staten.

\subsubsection{De regeling van het $B W$ wan 1928}

\subsection{Algemeen}

Het Albanese burgerlijk wetboek werd sterk geïnspireerd door de Franse Code Civil en de Italiaanse Codice Civile, hetgeen uiteraard ook voor de regelling van de nationaliteit gold. Verschillende regelingen werden ook uit de Italiaanse "Legge sulla cittadinanza" van 13 juni $1912^{33}$ overgenomen.

\subsection{Verkrijging van de nationaliteit}

De nationaliteit van Albanië kon volgens de regeling van 1928 worden verkregen van rechtswege, door naturalisatie en door optie. Verwerving van de nationaliteit door optie was mogelijk in twee zeer specifieke gevallen (art. 6 lid 1 sub 2 en art. 15). Gezien het specifieke karakter van beide optierechten wordt aan deze wijze van verkrijging geen aparte paragraaf gewijd. Voor de bespreking van beide optiemogelijkheden zij verwezen naar p. 103 en 104.

\section{a. Verknijging van rechtswege}

De verkrijging van Albanese nationaliteit was van rechtswege gekoppeld aan de volgende rechtsfeiten:

- geboorte uit Albanese ouder(s) (art. 4 lid 1 sub 1 en 2, art. 5);

27. LNTS LX, 174.

28. SGS deel 5, p. 10; Willems, Bevolkingsboekhouding 1955, p. 221. In art. 3 werd o.a. bepaald, dat iedereen, die op het Albanese grondgebied werd geboren en sedert zijn geboorte niet als onderdaan van een andere staat kon worden beschouwd, als Albanees moest worden gezien.

29. State Papers 129, 43; Duitse vertaling in SGS deel 5, p. 12-13 (echter met onjuiste datum, cf. Bergmann/Ferid, p. 5).

30. LNTS VXXXII, 65; Duitse wertaling in SGS deel 5, p. 10-12.

31. Volkopola, OER 1967, p. 244.

32. LNTS CLXII, 31.

33. G.U. 1912, nr. 153. 
- adoptie door Albanezen (art. 5);

- geboorte op het grondgebied of uit in Albanie wonende ouders (art. 4 lid 1 sub 3 en art 6);

- huwelijk met een Albanees (art. 14 lid 2).

\section{i. Geboorte uit Albanese ouder(s)}

Een wettig kind was Albanees indien zijn vader op het tijdstip van de geboorte van het kind de Albanese nationaliteit bezat (art. 4 lid 1 sub 1). Was de vader onbekend of staatloos, dan ontleende het kind zijn nationaliteit aan zijn Albanese moeder. Hetzelfde gold indien het kind bij zijn geboorte niet de nationaliteit van zijn buitenlandse vader verkreeg (art. 4 lid 1 sub 2). Daarbij was het niet van belang of het kind in het binnen- dan wel in het buitenland werd geboren.

Een kind dat tijdens zijn minderjarigheid door een Albanese vrouw of man werd erkend, verkreeg daardoor de Albanese nationaliteit (art. 5 lid 1). Interessant is, dat ook gerechtelijke vaststelling van moeder- of vaderschap de verkrijging van de nationaliteit ex art. 5 bewerkstelligde. Indien de afstamming met betrekking tot beide ouders werd vastgesteld, was het kind slechts Albanees indien de vader de Albanese nationaliteit bezat of in het geval dat het kind anders staatloos zou zijn.

De nationaliteit werd eveneens verkregen door wettiging en adoptie (art. 5 lid 3). Indien het kind op het moment van totstandkoming van de familierechtelijke betrekking reeds meerderjarig was, kon het de verkrijging van de Albanese nationaliteit voorkomen, door binnen één jaar na dat tijdstip te verklaren dat hij deze niet wenste te verkrijgen (art. 5 lid 2).

\section{ii. Geboorte op het Albanese grondgebied}

Een kind dat in Albanië werd geboren en wiens ouders onbekend of staatloos waren, of aan zijn buitenlandse ouder(s) geen nationaliteit kon ontlenen, verkreeg de Albanese nationaliteit iure soli (art. 4 lid 1 sub 3). Een kind dat op Albanees grondgebied werd gevonden en wiens ouders onbekend waren, werd vermoed in Albanië te zijn geboren, hetgeen verkrijging van de nationaliteit ex art. 4 lid 1 sub 3 bewerkstelligde. Het ging hierbij om een praesumptio iuris, waartegen steeds bewijs werd toegelaten, ongeacht de leeftijd van het kind.

Voorts werd de Albanese nationaliteit ipso iure verworven door een kind dat in Albanië werd geboren of dat in het buitenland werd geboren, terwijl zijn ouders op dat tijdstip reeds tien jaren in Albanië woonden, in de volgende gevallen (art. 6 lid 1):

- door het treden in Albanese militaire of staatsdienst (sub 1);

op zijn 21ste verjaardag, mits hij uiterlijk op dat tijdstip reeds sedert tien jaren in Albanië woonde. Betrokkene kon de verkrijging van de nationaliteit evenwel voorkomen, door gedurende zijn 21ste levensjaar te verklaren, dat hij de Albanese nationaliteit niet wilde verkrijgen (sub 3); 
Hoewel de verkrijging van de nationaliteit ex art. 6 lid 1 onder 3 strikt formeel gezien afhankelijk werd gesteld van een wil(sverklaring), kan hier niet worden gesproken van een verkrijging door optie. De Albanese nationaliteit werd namelijk verkregen, indien betrokkene niets deed. De cénjarige termijn waarbinnen ze de nationaliteitsverkrijging konden voorkomen was kort en bovendien objectief gesteld. Het is derhalve aannemelijk dat betrokkenen zeer dikwijls van deze regeling niet op de hoogte waren. Gesteld kan worden dat het hier om verkrijging van rechtswege gaat, met een minieme correctiemogelijkheid voor betrokkene, en niet om vrijwillige verkrijging van de nationaliteit zoals een "echte" optie kan worden getypeerd.

Degenen die voor hun 21ste verjaardag niet aan de tienjarige verblijfseis van art. 6 lid 1 sub 3 voldeden, konden, indien zij in Albanië woonden, tussen hun 20ste en 21ste verjaardag voor het Albanese staatsburgerschap opteren (sub 2).

\section{iii. Huwelijk met een Albanese man}

Ook in het Albanese nationaliteitsrecht gold het beginsel van één nationaliteit in é́n gezin (système unitaire), hetgeen betekende dat een gehuwde vrouw in de regel niet een andere nationaliteit kon bezitten dan haar man. Volgens art. 14 lid 2 verkreeg een buitenlandse vrouw, die met een Albanees een huwelijk sloot, van rechtswege de Albanese nationaliteit, ongeacht of ze door of in verband met haar huwelijk haar oude staatsburgerschap verloor. Ze had ook geen mogelijkheid om de nationaliteitsverkrijging door een wilsverklaring te voorkomen.

\section{iv. Overige gronden voor verkrijging van de nationaliteit ipso iure}

In de regeling van het BW van 1926 konden op verschillende plaatsen nog enkele specifieke gevallen van verkrijging van de Albanese nationaliteit van rechtswege worden gevonden. Zo werden in het tweede lid van art. 6 de zojuist beschreven drie mogelijkheden voor verkrijging van de nationaliteit (art. 6 lid 1, sub 1-3) uitgebreid tot degenen, wier vader ${ }^{34}$, moeder(!) of grootvader van vaderszijde Albanezen door geboorte waren geweest. Voorts werd het Albanese staatsburgerschap onder bepaalde voorwaarden eveneens ipso iure verworven door een vrouw, die door huwelijk met een vreemdeling deze nationaliteit verloor (zie daarover $\mathrm{p}$. 104).

\section{b. Naturalisatie}

Verkrijging van de Albanese nationaliteit door naturalisatie was geregeld in artt. 7-9 van het BW. De bevoegdheid om de nationaliteit te verlenen lag bij de Ministerraad (art. 7). Om voor naturalisatie in aanmerking te kunnen komen, moest de verzoeker aan één van de volgende vereisten voldoen:

3 jaren in Albanese staatsdienst zijn geweest (sub 1); of

34. In deze bepaling ging het om kinderen van personen, die de Albanese nationaliteit reeds woor de geboorte van het kind verloren. Anders verkregen deze kinderen het Albanese staatsburgerschap reeds op grond van art. 4. 
- sedert tenminste wijf jaren zijn woonplaats in Albanië hebben gehad (sub 2); of

- sedert tenminste drie jaren in Albanië hebben gewoond en de staat belangrijke diensten te hebben bewezen, of met een Albanese gehuwd zijn (sub 3);

- ten aanzien van personen die het optierecht van art. 6 lid 1 sub 2 hadden en de verklaring niet binnen de daarvoor gestelde termijn hadden afgelegd, gold een verblijfseis van één jaar (sub 4);

- eveneens gold een énjarig verblijfseis ten aanzien van etnische Albanezen, die in Albanië wilden blijwen wonen (sub 5).

Verder werd gevorderd dat betrokkene een eed van trouw aflegde (art. 8). Een verzoeker die aan de wettelijke vereisten voldeed had geen recht op verlening van de nationaliteit. De Ministerraad had een discretionaire bevoegdheid. Daarnaast bezat de koning de bevoegdheid om ongeacht de wettelijke vereisten bij decreet naturalisaties te verlenen (art. 9).

\section{i Hernaturalisatie}

Ten aanzien van personen die de Albanese nationaliteit ooit hadden bezeten, gold een bijzondere procedure. Bovendien werden er afwijkende naturalisatievereisten gesteld. Ook in dit geval werd de nationaliteit verleend door de Ministerraad, echter slechts indien de Raad van State positief daaromtrent had geadviseerd (art. 13). Gehernaturaliseerd konden worden personen, die:

- $\quad$ in Albanese militaire of staatsdienst traden (sub 1);

- verklaarden dat zij hun vreemde nationaliteit "opgaven", of konden bewijzen dat zij de vreemde staats-of krijgsdienst (waardoor zij de Albanese nationaliteit verloren) hadden opgegeven en binnen één jaar daarna naar Albanië terugkeerden (sub 2);

- de Albanese nationaliteit in verband met verkrijging van een andere nationaliteit hadden verloren en sedert twee jaren in Albanië woonachtig waren.

Art. 15 gaf een bijzondere regeling ten gunste van vrouwen, die de Albanese nationaliteit door huwelijk met een buitenlander verloren. Deze vrouwen konden na de ontbinding van het huwelijk voor de Albanese nationaliteit opteren, indien zij naar Albanië terugkeerden, of reeds voor de ontbinding van het huwelijk aldaar woonachtig waren (art. 15 lid 2). In het geval dat uit het huwelijk geen kinderen geboren werden, verkregen deze vrouwen door een tweejarig verblijf in Albanië van rechtswege weer de Albanese nationaliteit (art. 15 lid 3). Benadrukt dient te worden dat het in dit geval niet om vrijwillige verkrijging van de nationaliteit ging. Bij de vestiging in een land is de wil uitsluitend gericht op het veranderen van de woonplaats, hetgeen nog lang niet betekent, dat betrokken ook de nationaliteit van 
dat land wil verkrijgen. De louter toevallige omstandigheid dat de nationaliteit van dat land enkel door verblijf aldaar wordt verkregen, maakt de verkrijging van de nationaliteit in dat geval niet vrijwillig. Het is zelfs zeer aannemelijk, dat de betrokkene van een dergelijke mogelijkheid van verwerving van het staatsburgerschap niet eens op de hoogte is.

\section{ii. Invloed op de nationaliteit van de gezinsleden van de verzoeker}

Een gehuwde vrouw kon conform het beginsel van éen nationaliteit in én gezin slechts gezamenlijk met haar man worden genaturaliseerd (art. 14). Dit gebeurde automatisch, indien zij daadwerkelijk samenwoonden (art. 16 lid 2). Woonden zij gescheiden en waren er ook geen minderjarige kinderen, dan kon de vrouw door het afleggen van een daartoe strekkende verklaring haar medenaturalisatie verhinderen (art. 16 lid 3).

Minderjarige kinderen van naturalisandi werden steeds met hun ouder(s) medegenaturaliseerd, tenzij zij in het buitenland woonden. Zou een in het buitenland woonachtig kind zijn vreemde nationaliteit desalniettemin door de naturalisatie van zijn ouder in Albanië hebben verloren, dan werd het toch medegenaturaliseerd (art. 17 lid 1). Medegenaturaliseerde kinderen die door geboorte een vreemde nationaliteit bezaten, konden evenwel binnen eén jaar na het bereiken van de meerderjarigheid voor hun oorspronkelijke nationaliteit "kiezen" (art. 17 lid 2). Een echte keuzemogelijkheid had betrokkene echter uitsluitend in het geval dat hij nog steeds de nationaliteit van het land van zijn origine bezat, of dat het desbetreffende recht in een dergelijk geval een optierecht aan het kind toekende. In alle andere gevallen ging het slechts om het verlies van de Albanese nationaliteit door afstand.

\subsection{Verlies van de nationaliteit}

De Albanese nationaliteit kon worden verloren van rechtswege, door het afleggen van een verklaring van afstand en door ontslag. Het verlies van het staatsburgerschap door ontneming kende de regeling van het BW van 1928 niet.

\section{a. Verlies van rechtswege}

De Albanese nationaliteit werd volgens het BW van 1928 van rechtswege verloren door het treden in vreemde krijgs- of staatsdienst (art. 12) en door huwellijk met een buitenlander (art. 15 lid 1).

\section{i. Huwelijk met een buitenlander}

Een Albanese vrouw verloor van rechtswege haar nationaliteit indien zij met een buitenlander in het huwelijk trad en zij daardoor de nationaliteit van haar man verkreeg. Interessant is, dat zij haar nationaliteit kon behouden, indien zij bij het aangaan van huwelijkse voorwaarden haar wil daartoe verklaarde (art. 15 lid 1). 


\section{ii. Het treden in vreemde staats- of krijgsdienst}

Krachtens art. 12 ging de Albanese nationaliteit verloren door het zonder de toestemming van de regering treden in vreemde staats- of krijgsdienst. Het verlies van de nationaliteit trad pas in, indien betrokkene birnen een door de Albanese regering vastgestelde termijn deze dienst niet verliet. Naast het verlies van de nationaliteit werd in art. 12 aan deze personen verboden om zonder toestemming van de regering het Albanese grondgebied te betreden.

\section{b. Afstand}

Het BW van 1928 kende in twee gevallen verlies van de nationaliteit door het afleggen van een verklaring van afstand. Het eerste was geregeld in het reeds besproken art. 17 lid 2 ten gunste van personen, die tijdens hun minderjarigheid tezamen met hun ouder(s) in Albanië werden medegenaturaliseerd. Voorts werd de mogelijkheid van afstand toegekend aan Albanezen die in het buitenland werden geboren. Deze moesten bovendien in een land wonen, waarvan ze de nationaliteit krachtens geboorte bezaten. Een verklaring van afstand kon slechts door een meerderjarige worden afgelegd (art. 10 lid 1). Deze reeds zeer beperkte mogelijkheid van afstand werd nog eens verder geclausuleerd door het tweede lid van art. 10, dat bepaalde, dat het eerste lid slechts gold, voorzover in de internationale verdragen geen daarvan afwijkende regelingen werden neergelegd.

\section{c. Ontslag}

Het verlies van de nationaliteit door ontslag werd in de regeling van het BW niet als zodanig genoemd. De wet sprak van "toestemming" van de regering voor de verkrijging van een andere nationaliteit (art. 11 lid 1) respectievelijk voor het opgeven van de Albanese nationaliteit (art. 11 lid 2). Indien betrokkene zonder de toestemming van de regering een vreemde nationaliteit verkreeg, ging zijn Albanese nationaliteit namelijk niet van rechtswege verloren (art. 11 lid 1). De wet sprak in dat geval van ongeldigheid van de nieuwverworven nationaliteit. Echter, gelet op het beginsel van nationale autonomie in het nationaliteitsrecht, had Albanie slechts het recht om aan deze verkrijging van de nationaliteit geen verlies van de eigen nationaliteit te verbinden. Aangezien betrokkene in zo'n geval nog steeds de Albanese nationaliteit bezat, had Albanië uiteraard ook het recht om hem als uitsluitend eigen onderdaan te behandelen (exclusiviteitsbeginsel) ${ }^{35}$.

Daar het in beide gevallen om het verlies van de nationaliteit op verzoek van betrokkene met "toestemming" van de administratie ging, kan hier gesproken worden van de rechtsfigur van ontslag ${ }^{36}$. Het enige wettelijke vereiste hierbij was, dat betrokkene moest bewijzen, dat hij zijn woonplaats in het buitenland had.

35. Zie daarover ook p. 30-31.

36. Het verlies van de nationaliteit ex art. $11 \mathrm{BW}$ van 1928 wordt door Beitzke, SGS deel 5, p. 25, eveneens als "ontslag" gekwalificeerd. 


\section{i. Invloed op de nationaliteit van de gezinsleden van de verzoeker}

De echtgenote van degene, die uit de Albanese nationaliteit werd ontslagen, verloor automatisch haar nationaliteit indien ze met haar man samenwoonde en ze de nieuwe nationaliteit van haar echtgenoot verwierf (art. 16 lid 1). Minderizrige kunderen van de verzoeker werden eveneens in het ontslag van hun ouder inbegrepen, indien ze bij die ouder woonden en hij het ouderlijk gezag over hen vitoefende (art. 17 lid 3).

\subsubsection{De wet van 1946}

\subsubsection{Algemeen}

Het nieuwe communistische bewind kondigde reeds op 16 december $1946^{37}$ een nieuwe nationaliteitswet af. De sterke invloed die in die periode Joegoslavië op zijn kleine buurland had, was ook op het gebied van het nationaliteitsrecht duidelijk merkbaar. De nieuwe Albanese nationaliteitswet werd sterk naar Joegoslavisch voorbeeld geschreven; sommige artikelen werden zelfs nagenoeg letterlijk overgenomen.

Bij het bepalen van de kring van Albanese onderdanen op het tijdstip van het inwerkingtreden van deze wet, knoopte de overgangsregeling in de eerste plaats aan bij de regeling van het BW van 1928; Albanezen waren volgens art. 24 degenen, die deze nationaliteit op grond van de tot dan toe geldende regels verwierven. Deze kring werd voorts uitgebreid met etnische Albanezen, die bij de verkiezingen van 2 december 1945 hun stem uitbrachten (art. 26). Interessant is voorts, dat het Ministerie van binnenlandse zaken het recht werd voorbehouden om alle naturalisaties tussen 7 april $1939^{38}$ en 29 november 1944 in "heroverweging" te nemen (art. 25). Voorwaarden voor herroeping van naturalisaties werden niet in de wet genoemd.

Art. 22 lid 1 vestigde het vermoeden wan het bezit van Albanese nationaliteit ten aanzien van alle etnische Albanezen die in Albanië geboren of opgevoed waren. Het vermoeden gold totdat het tegendeel werd bewezen, of totdat betrokkene om verkrijging van een andere nationaliteit verzocht.

Ook de Albanese wet van 1946 kende de reeds uit het nationaliteitsrecht van de Sovjetunie bekende bepaling dat een Albanese staatsburger niet tegelijkertijd de nationaliteit wan een andere staat "kon" bezitten (art. 2). Voor een uiteenzetting over het relatieve karakter daarvan, zij verwezen naar p. 31-32.

\subsubsection{Verkrijging van de nationaliteit}

De Albanese nationaliteitswet van 1946 kende verkrijging van de nationaliteit van rechtswege, door optie en door naturalisatie. Aangezien de optie slechts in een zeer specifiek geval mogelijk was (art. 21) zal aan de verkrijging van de nationaliteit door optie geen aparte paragraaf worden gewijd. Voor de bespreking van de enige optiemogelijkheid zij verwezen naar p. 112.

37. G.Z. 1946, nr. 377; Duitse vertaling in SGS deel 5, p. 17-22.

38. Op die dag werd Albanië door Iltaliẻ bezet. 


\subsection{Verkrijging wan rechtswege}

Volgens de wet van 1946 werd verkrijging van de Albanese nationaliteit van rechtswege gekoppeld aan geboorte uit Albanese ouder(s) (art. 4) en aan geboorte op het Albanese grondgebied (art. 5). Door het sluiten van een huwelijk met een Albanese staatsburger kon de nationaliteit niet meer worden verworven. Ook adoptie door Albanese ouders kon geen verkrijging van het staatsburgerschap van rechtswege meer bewerkstelligen. Adoptiefkinderen van Albanezen kregen slechts de mogelijkheid van verlichte naturalisatie (zie p. 109).

\section{a. Geboorte uit Albanese ouder(s)}

Een kind was Albanees, indien beide ouders op het tijdstip van de geboorte van het kind de Albanese nationaliteit bezaten (art. 4 lid 1 sub 1). In het geval dat slechts één van de oudlers het Albanese staatsburgerschap bezat, stelde de wet nog additionele vereisten. Albanees was:

- een wettig kind, mits het huwelijk tussen zijn ouders voor het bevoegde Albanese orgaan werd gesloten (sub 2); of

indien de Albanese ouder met het kind in Albanië woonde, of zich beiden voor het 18de levensjaar van het kind aldaar blijvend vestigden, of indien het kind zich in Albanië kwam vestigen, of om zijn opleiding daar te genieten (sub 3); of

- indien het kind in het buitenland werd geboren en binnen vijf jaren na de geboorte als Albanese staatsburger bij de vertegenwoordiging van Albanië in dat land werd geregistreerd. De registratie was niet vereist, indien het kind anders staatloos zou zijn ${ }^{39}$.

De bovenstaande regels golden eveneens ten aanzien van buitenechtelijke kinderen, die door erkenning of gerechtelijke vaststelling van het vader- of moederschap kind waren geworden van een Albanese ouder (art. 4 lid 2) ${ }^{40}$.

\section{b. Geboorte op het Albanese grondgebied}

Een kind dat op het Albanese grondgebied werd geboren of gevonden en wiens ouders onbekend, van onbekende nationaliteit, of staatloos waren, werd vermoed de Albanese nationaliteit te bezitten. Het tegenbewijs was slechts tot de $14 \mathrm{de}$ verjaardag van het kind mogelijk (art. 5).

39. De wet bepaalde dat de registratie niet nodig was indien het geboorteland van het kind hem als "Albanees onderdaan beschouwde" Dit betekent uiteraard niet, dat de Albanese nationaliteit krachtens het recht van een ander land werd verkregen, maar slechts dat de Albanese wetgever ervan uitging, dat in een dergelijk geval het kind niet de nationaliteit van zijn geboorteland verkreeg. Om staalloosheid wan het kind te voorkomen werd deze uitzondering op de registratieplicht gemaakt. Art. 4 was overigens zeer sterk geïnspireerd door art. 4 van de Joegoslavische nationaliteitswet van 28 augustus 1945, Ur.l. (Uradni list) 64/1945.

40. Cr. SGS deel 5, p. 9. 


\subsubsection{Naturalisatie}

Verkrijging wan de nationaliteit door naturalisatie was geregeld in artt. 7-10 van de wet van 1946. De bevoegdheid om de nationaliteit te verlenen lag bij het Ministerie van binnenlandse zaken. De naturalisatievereisten waren de volgende:

- verzoek van betrokkene (art. 7 lid 1 sub 1);

- leeftijd van 18 jaar (sub 2);

- arbeidsgeschiktheid (sub 2);

- ononderbroken verblijf in Albanië gedurende vijf aan het verzoek voorafgaande jaren (sub 3);

- betrokkene moest kunnen aantonen dat hij door of in verband met de naturalisatie zijn oude nationaliteit zou verliezen. Het was evenwel ook voldoende om te bewijzen dat de nationale staat van de verzoeker geen bezwaar tegen de naturalisatie had (sub 4$)^{41}$;

- goed gedrag (sub 5).

Ten aanzien van enkele categorieën naturalisandi dispenseerde de wet van bepaalde vereisten:

- vreemdelingen die met een Albanese vrouw of man waren gehuwd werden vrijgesteld van de vereisten onder 2,3 en 4 (art. 8 lid 1);

- vreemdelingen die aan het communistische verzet hadden deelgenomen ${ }^{42}$ konden eveneens worden genaturaliseerd zonder te voldoen aan de vereisten sub 2,3 en 4 (art. 27 lid 1);

- ten aanzien van etnische Albanezen golden niet de eisen gesteld onder 3 en 4 (art. 7 lid 3);

- kinderen onder 14 jaar, die door een Albane(e)s(e) werden geadopteerd konden door tussenkomst van hun adoptiefouder(s) worden genaturaliseerd zonder te voldoen aan de hierboven genoemde naturalisatievereisten (art. 8 lid 2) ${ }^{43}$.

41. De eis van art. 7 lid 1 sub 4 gold uiteraard niet ten aanziem wan staatlozen. Het bewijs van geen bezwaar tegen de naturalisatie van de zijde van de nationale staat van betrokkene was niet vereist, indien het recht van dat land verkrijging van een andere nationaliteit in het geheel niet toeliet, of daarvoor redelijkerwijs niet te vervullen woorwaarden stelde (art. 7 lid 2).

42. Hetzelfde gold ten aanzien van kinderen van verzetsstrijders, indien de ouders gevallen, of later overleden waren (art. 27 lid 2).

43. Strikt genomen werd er geen vrijstelling wan het vereiste van goed gedrag verleend. Het is echter niet aan te nemen dat die eis bij kinderen onder 14 jaar ooilt problemen leverde. 
- het afleggen van een ced van trouw (art. 10).

Naast de "gewone" naturalisatie kende art. 9 de mogelijkheid van verlening van de nationaliteit vanwege een dringend staatsbelang ${ }^{44}$

\section{a. Invloed op de natiowaliteit van de gezinsleden van de werzoeker}

Een minderjarig kind van een naturalisandus was slechts automatisch de naturalisatie van zijn ouders deelachtig, indien de nationaliteil aan beide ouders werd verleend (art. 11 lid 1). Werd slechts eén van de ouders genaturaliseerd, dan was de medenaturalisatie van het kind aan enkele additionele vereisten gebonden (art. 11 lid 2):

- het kind moest tezamen met de betreffende ouder in Albanië wonen;

- de ouder moest uitdrukkelijk om de medenaturalisatie verzoeken en

- een kind ouder dan 14 jaar moest zelf met zijn medenaturalisatie instemmen.

\subsubsection{Verlies van de nationaliteit}

De Albanese nationaliteitswet van 1946 kende het verlies van de nationaliteit door afstand, door ontslag en door ontneming. Van rechtswege kon het Albanese staatsburgerschap niet meer worden verloren.

\subsubsection{I Afstand}

Art. 20 kende ten aanzien van twee categorieën personen de mogelijkheid van het verlies van de Albanese nationaliteit door het afleggen van een verklaring van afstand.

- Albanezen die hun nationaliteit door afstamming hadden verworven, konden tot hun 25 ste levensjaar daarvan afstand doen, indien zij in het buitenland werden geboren en konden bewijzen, dat zij de nationaliteit bezaten van hetzij het land waarin ze werden geboren, hetzij van het land waarin ze woonden (art. 20 lid 1);

personen die etnisch geen Albanezen waren ${ }^{45}$ konden van de Albanese nationaliteit na hun 18 de verjaardag afstand doen, indien ze in het buitenland woonden en het bezit van de nationaliteit van een andere staat konden

44. Volgens Vokopola, OER 1967, p. 247, zou deze mogelijkheid de eerste plaats zijn opgenomen ten gurste wan Joegoslavische, Italiaanse en Griekse communisten, die aan de zijde van het communistische verzet in de oorlog hadden gevochten. Aangezien ten aanzien van deze personem reeds art. 27 (dat merkwaardigerwijs niet bij de naturalisatie, maar onder algemene bepalingen werd geplaatst) expliciet bepaalde dat ze nagenoeg zonder vereisten konden worden genaturaliseerd, lijkt mij deze vitleg niet erg waarschijnlijk.

45. Gezien de samenstelling van de bevolking van Albaniê ging het met name om Grieken, Montenegrijnen, Serviërs en Turken. 
bewijzen. Verder moesten ze alle verplichtingen (met name de militaire dienstplicht) tegenover de Albanese staat hebben vervuld (art. 20 lid 2 jo. art. 17 lid 11 sub b en $c)$.

De verklaring van afstand moest worden afgelegd ten overstaan van diplomatieke vertegenwoordigers van Albanië in het buitenland, of tegenover een bevoegde ambtenaar van het Ministerie van binnenlandse zaken (art. 20 lid 3).

\section{a. Invloed op de nationaliteit van de gezinsleden van betrokkene}

Munderjarige kinderen van personen, die van de Albanese nationaliteit afstand deden, waren in het verlies van de nationaliteit door hun ouder(s) inbegrepen, indien:

- beide ouders afstand van de nationaliteit deden, of

- slechts één van de ouders de nationaliteit verloor, terwijl de andere reeds vreemdeling was (ar. 19 lid 1);

- een kind dat ouder dan 14 jaar zelf in het verlies van zijn nationaliteit had toegestemd.

\subsection{Ontslag}

Het ontslag uit de Albanese nationaliteit- ook deze wet sprak van "toestemming tot het opgeven" van de nationaliteit- was geregeld in art. 17 van de wet van 1946. In tegenstelling tot zijn voorganger kende deze wet een vrij uitvoerige regeling van deze wijze van het verlies van de nationaliteit. De vereisten voor het ontslag waren (art. 17 lid 1):

- het indienen van een verzoek (sub a);

- leeftijd van 18 jaar (sub b);

- alle verplichtingen tegenover de staat (met name de militaire dienstplicht) moesten zijn vervuld (sub c) ${ }^{46}$;

- betrokkene moest kunnen bewijzen, dat hij een andere nationaliteit zou verkrijgen (sub d).

De bevoegdheid om het ontslag te verlenen lag volgens het tweede lid van art. 17 bij het Ministerie van binnenlandse zaken, waarbij uitdrukkelijk werd bepaald dat het Ministerie naar eigen inzicht mocht handelen. Hierdoor heeft de wetgever een zeer ruime mogelijkheid voor willekeurige weigeringen geschapen. Het ontslag

46. Verzoekers die voor de militaire dienstplicht geschikt werden bevonden, konden voór het vervullen daarvan slechts vanwege buitengewone omstandigheden worden ontslagen. Bowendien was de toestemming van de minister van defensie vereist (art. 17 lid 5). 
mocht slechts worden verleend onder de voorwaarde dat binnen een in de beschikking gestelde termijn betrokkene inderdaad een andere nationaliteit zou verkrijgen. Indien deze voorwaarde niet werd vervuld, kwam de ontslagbeschikking te vervallen (art. 17 lid 2).

Het ontslag verloor eveneens zijn werking, indien betrokkene eén jaar na de verlening daarvan nog steeds in Albanië woonachtig was en nog geen andere nationaliteit verwierf (art. 17 lid 3). Interessant is nog te vermelden, dat het ontslag slechts in vredestijd mogelijk was (art. 17 lid 4).

\section{a. Invloed op de nationaliteit van de gezinsleden van de verzoeker}

Ten aanzien van de invloed van het verlies van de nationaliteit door ontslag van een ouder op zijn minderjarige kinderen gold dezelfde regeling als bij het verlies van de nationaliteit door afstand (zie p. 111).

Het tweede lid van art. 19 bepaalde voorts dat in het geval dat een minderjarig kind geen vreemde nationaliteit verkreeg, zijn ontslag slechts werking had, nadat het kind zich tezamen met zijn ouders in een ander land vestigde.

Personen die tijdens hun minderjarigheid de Albanese nationaliteit ex art. 19 hadden verioren, hadden tussen hun 18 de en 25 ste jaar een optierecht op het Albanese staatsburgerschap. Hiervoor werd vereist, dat zij zich opnieuw in Albanië hadden gevestigd (art. 21).

\subsection{Ontneming}

Invoering van de mogelijkheid van verlies van de Albanese nationaliteit door ontneming is naast de gelijkstelling van mannen en vrouwen de belangrijkste vernieuwing in het naoorlogse Albanese nationaliteitsrecht. De wet van 1946 bevatte in artt. 13-16 een uitgebreide regeling van de ontneming van de nationaliteit. Een van de belangrijkste redenen voor deze uitvoerige regeling is het feit, dat Albanië geen aparte regelingen kende ten aanzien van personen die met de bezettingsmachten hadden gecollaboreerd ${ }^{47}$. De Albanese nationaliteit kon worden ontnomen aan:

1. Personen die in het buitenland woonden, indien ze tussen hun 18de en 33ste jaar geen plichten tegenover de staat vervulden en binnen vijf jaren na 16 december $1946^{48}$ niet aan de bevoegde Albanese instantie hun woonplaats hadden opgegeven (art. 13 lid 1).

2. Albanezen die afkomstig waren uit een land dat met Albanië in oorlog was geweest en voor of tijdens de oorlog activiteiten ontplooiden, die strijdig waren met de belangen van de VR Albanië (art. 14 lid 1).

3. Genaturaliseerde Albanezen die bij de naturalisatie gebruik hadden gemaakt van valse gegevens, of gewichtige feiten hadden verzwegen, of die binnen vijf

47. SGS deel 5, p. 8.

48. De vijfjarige termijn van art. 13 begon te lopen op de dag van de inwerkingtreding van de wet van 1946. Zie art. 28 van de wet. 
jaar na de naturalisatie wegens een tegen de staat gericht delict werden veroordeeld (art. 14 lid 2).

4. Personen die zich in het buitenland bevonden kon de nationaliteit wegens staatsvijandige activiteiten tijdens of na de oorlog worden ontnomen (art. 14 lid 4).

Bij de onder 1. genoemde categorie ging het niet om een ontnemingsmogelijkheid om politieke redenen, maar om ontneming van de nationaliteit vanwege langdurig verblijf in het buitenland. In de wet werd deze mogelijkheid overigens niet gerangschikt bij de ontneming van de nationaliteit, maar kreeg een zelfstandige plaats als een aparte verliesgrond. Aangezien de nationaliteit door het vervullen van de voorwaarden niet automatisch verloren ging, maar door een constitutieve beschikking van het Ministerie van binnenlandse zaken (art. 13 lid 3), is het juister om ook in dit geval te spreken van ontneming van de nationaliteit. Binnen eén jaar na de publicatie van de beschikking in het staatsblad was het mogelijk om daartegen beroep in te stellen (art. 13 lid 3). Dit was overigens de enige beslissing in nationaliteitsaangelegenheden waartegen een rechtsgang openstond. De bevoegdheid om de nationaliteit te ontnemen lag bij het Ministerie van binnenlandse zaken (art. 15 lid 1). Ten aanzien van personen onder 4 . genoemd, moest het ontnemingsbesluit evenwel door het Presidium van de Volksraad (parlement) of door de rechter worden genomen.

\section{a. Invloed op de nationaliteit van gezinsleden van betrokkene}

Ontneming van de nationaliteit ex art. 13 (afwezigheid) strekte zich tevens uit tot alle kinderen van betrokkene die in het buitenland werden geboren en blijvend buiten Albanië woonden, tenzij de kinderen wel aan de in art. 13 lid 1 genoemde voorwaarden hadden voldaan (art. 13 lid 2).

Van de ontnemingsgronden van art. 14 kon slechts het in het eerste lid van art. 14 genoemde, gevolgen woor het gezin van betrokkene hebben. Zowel de vrouw als de kinderen van betrokkene verloren eveneens hun nationaliteit, tenzij ze konden bewijzen dat ze geen contact met hun man (vader) meer hadden en dat zij zich well loyaal hadden gedragen. Aangezien de onderhavige verliesgrond slechts Albanezen van vreemde afstamming betrof, konden de vrouw en de kinderen hun nationaliteit steeds behouden, indien ze de Albanese afstamming wan de vrouw konden bewijzen (art. 16).

\subsection{HET POSTIEVE NATIONALITETTSRECHT}

\subsubsection{Algemeen}

De breuk met Joegoslavië in 1948 veroorzaakte pas zes jaren later een radicale wijziging in het Albanese nationaliteitsrecht. De relatief goed uitgewerkte 
nationaliteitswet van 1946 werd op 7 juni $1954^{49}$ vervangen door een 11 artikelen kort decreet, dat de toen geldende nationaliteitswet van de Sovjetunie van 1938, respectievelijk het Roemeense decreet van 1952 als voorbeeld nam. Bij wet van 20 juli $1954^{50}$ werd de nieuwe regeling van de Albanese nationaliteit bekrachtigd. Het decreet van 1954 werd als zodanig nooit gewijzigd. Wel verscheen bij decreet van 20 maart $1961^{51}$ een officiële interpretatie van de artt. 2 en 7 van de wet.

Niet alleen vanwege zijn omwang, maar ook wegens de in art. 1 vervatte overgangsregeling is het decreet van 20 julli 1954 waarschijnlijk én van de meest merkwaardige nationaliteitsrechtelijke regelingen in heel Europa. Bij de bepaling van de kring van Albanese onderdanen knoopt art. 1 niet aan bij de situatie op 20 juli 1954 toen het decreet in werking trad, maar gaat men terug tot de dag van de bevrijding, 29 november 1946 . Hieruit wordt door sommigen afgeleid dat het decreet van 1954 terugwerkende kracht heeft ${ }^{52}$. Volgens art. 1 zijn Albanezen:

- personen die op 29 november 1944 de Albanese nationaliteit bezaten en deze daarna niet hebben verloren (sub a);

- kinderen van een Albanese vader en moeder (sub b);

- personen, die de Albanese nationaliteit volgens de wettelijke regels hebben verworven (sub c).

Bij gebreke aan voldoende informatie is het moeilijk met zekerheid vast te stellen of men inderdaad beoogde aan het decreet terugwerkende kracht toe te kennen. Het bepaalde onder $a$ en $b$ wijst inderdaad in deze richting. Aan de andere kant kunnen beide overgangsregels ook worden gezien als een product van slordige wetgevingstechniek. Uit Art. 1 sub a (tweede gedeelte) en onder c zou evenwel kunnen worden afgeleid dat men juist geen terugwerkende kracht had beoogd. Ook aan de hand van artt. 10 en 11 die de intrekking van de wet van 1946, respectievelijk de inwerkingtreding van het decreet regelen, kan niet worden geconcludeerd dat de wet van 1946 ex tunc zou zijn ingetrokken.

Interessant is voorts dat volgens art. 9 alle personen, die op het grondgebied van Albanië wonen en geen Albanezen zijn, terwijl zij ook niet het bezit van een andere nationaliteit kunnen bewijzen, als staatlozen worden gezien. Deze "praesumptio apatridiae" is kennelijk overgenomen uit de Sovjet-nationaliteitswet van 1938 , art. $8^{53}$.

49. Decreet nr, 1874, G.Z. 1954, nr. 10. Duitse vertaling in Bergmann/Ferid, p. 6-7; Nederlandse in NWG, p. 1-2. Zie hierover Vokopola, OER 1967, p. 242-260 en in de Albanese taal Krisafi, Drejtësia popullore $1974 / 2$, p. 54-63.

50. G.Z. 1954 , nr. 12.

51. G.Z. 1961, nr. 2. Zie voor een korte bespreking daarvan Wiener Quellenhefte, p. 1, die overgenomen werd van Meksi, Drejtësia popullore 1963/2, p. 9-19.

52. Vokopola, OER 1967, p. 249.

53. Zie daarover hoofdstuk USSR, p. 77. 


\subsection{Verkrijging van de nationaliteit}

De Albanese nationaliteit kan worden verkregen van rechtswege en door naturalisatie. Verkrijging van de nationaliteit door optie kent het Albanese nationaliteitsrecht niet meer.

\subsubsection{Verkrijging van rechtswege}

De huidige regeling van Albanese nationaliteit kent slechts verkrijging van de nationaliteit van rechtswege bij geboorte uit Albanese ouders (art.1 sub b en art. 2). Een aparte regeling ten gunste van vondelingen, en kinderen van onbekende of staatloze ouders, die in Albanië worden geboren, kent het decreet van 1954 niet.

\subsection{Geboorte uit Albanese ouder(s)}

De Albanese nationaliteit wordt ipso iure verkregen door kinderen, die uit een Albanese moeder en vader worden geboren (art. 1 sub b). Interessant is dat deze regel in art. 1 wordt geplaatst, dat overigens een overgangsrechtelijk artikel is. Een kind met slechts éen Albanese ouder is Albanees in de volgende twee gevallen:

- indien tenminste én van de ouders ten tijde van de geboorte van het kind in Albanië woont (art. 2 lid 1), of

- indien beide ouders op het tijdstip van geboorte van het kind in het buitenland wonen en de ouders gezamenlijk besluiten dat het kind de Albanese nationaliteit zal hebben (art. 2 lid 2).

In het geval van art. 2, eerste lid, is het irrelevant of de Albanese, dan wel de buitenlandse ouder zijn woonplaats in Albanië heeft. Van belang is op deze plaats ook de officiële interpretatie van deze bepaling door het op p. 114 genoemde interpretatiedecreet. Volgens deze uitleg worden Albanezen, die in het buitenland studeren of werken, geacht hun woonplaats in Albanië te hebben ${ }^{54}$.

In het tweede lid van art. 2 spreekt de wet over de mogelijkheid om de nationaliteit van het kind in gezamenlijk overleg tussen de ouders te bepalen. De ouders kunnen echter slechts beslissen of het kind de Albanese nationaliteit zal hebben. De nationaliteit van een andere staat kan door deze keuze van de ouders slechts worden verkregen, indien het recht van de desbetreffende stat eveneens een dergelijke keuzemogelijkheid kent.

\subsubsection{Naturalisatie}

Naturalisatie is de enige wijze van vrijwillige verkrijging van de Albanese nationaliteit. Deze is "geregeld" in art. 3:

54. Cf. Wiener Quellenthefte 1963, p. 1; Bergmann/Ferid, p. 6, 7. 
"Ausländer kann-unabhängig von ihrer Nationalität und Rasse, auf Antrag durch Dekret des Präsidiums der Volksversammlung der Volksrepublik Albanien die albanische Staatsangehörigkeit verliehen worden" 55 .

Dit is de enige bepaling met betrekking tot de verlening van de Albanese nationaliteit. We zien dat deze brede norm aan de overheid een onbeperkte discretionaire bevoegdheid geeft ${ }^{56}$. Het ontbreken van beroepsmogelijkheden teger een afwijzende beslissing accentueert nog eens de onbegrensde mogelijkheid om een naturalisatie willekeurig te weigeren.

\subsection{Invloed op de nationaliteit wan de gezinsleden van de verzoeker}

Indien de nationaliteit aan hun beide ouders wordt verleend, worden hun kinderen, die jonger zijn dan 14 jaar, automatisch meegenaturaliseerd (art. 6 lid 1). Bij kinderen tussen 14 en 18 jaar wordt tevens hun instemming met de medenaturalisatie vereist (art. 6 lid 2). Indien slechts aan één van de ouders de nationaliteit wordt verleend, wordt eventuele medenaturalisatie van minderjarige kinderen aan de will van de ouders overgelaten (art. 6 lid 3). Aangenomen kan worden, dat gevallen waarin één ouder genaturaliseerd wordt, terwijl de andere reeds de Albanese nationaliteit bezit, overleden, of onbekend is, gelijk moeten worden gesteld met het geval waarin beide ouders worden genaturaliseerd.

\subsubsection{Verlies van de nationaliteit}

De Albanese nationaliteit kan worden verloren door ontslag en door ontneming. Verlies van rechtswege of door het afleggen van een verklaring van afstand kent het Albanese nationaliteitsrecht niet.

\subsubsection{Ontslag}

Ook de regeling van het ontslag uit de Albanese nationaliteit is uiterst summier. Art. 5 van het decreet bepaalt slechts, dat voor het "opgeven" van de Albanese nationaliteit de toestemming van het Presidium van de Volksvergadering vereist is. Vereisten woor het ontslag worden in het geheel niet genoemd, hetgeen ook hier op onbeperkte discretionaire bevoegdheid van de overheid wijst ${ }^{57}$. Tegen afwijzing wan een verzoek staan geen rechtsgangen open.

\subsection{Invloed op de nationaliteit van de gezinsleden wan de verzoeker}

Ten aanzien van de invloed van het ontslag van de ouder(s) op de nationaliteit van hun minderjarige kinderen geldt ook hier de regeling van art. 6 . Indien beide ouders worden ontslagen, verliezen hun kinderen onder 14 jaar automatisch hun nationaliteit. Bij kinderen tussen 14 en 18 jaar wordt tevens hun toestemming vereist. Gezien de strekking van deze bepaling mag worden aangenomen dat

55. Vertaling ontleend aan Bergmann/Ferid, p. 7.

56. Cf. Vokopola, OER 1967, p. 249.

57. Cf. Vokopola, OER 1967, p. 249. 
hetzelfde geldt in het geval dat slechts eén wan de ouders wordt ontslagen, terwijl de andere een andere nationaliteit bezit, onbekend, of overleden is.

Art. 7 geeft een regeling voor het geval dat én van de ouders wordt ontslagen en beide ouders de Albanese nationaliteit bezitten. Indien de ouders van het kind in het buitenland wonen, mogen ze gezamenlijk omtrent het verlies van de nationaliteit door hun kinderen onder 14 jaar beslissen. Zijn de kinderen tussen 14 en 18 jaar oud, dan moeten ze ook zelf voor hun ontslag de toestemming verlenen. Ook hier moet het begrip "woonplaats in het buitenland" worden geïnterpreteerd in het licht van het reeds genoemde "Interpretatiedecreet" wan 20 maart 1961. Albanezen kunnen slechts hum woonplaats in het buitenland hebben, indien ze daar anders dan voor studie of beroep verblijven. Wonen de ouders in Albanië, dan heeft ontslag van één van hen geen invloed op de nationaliteit van het kind.

\subsubsection{Ontneming}

Ten aanzien van ontneming van de Albanese nationaliteit bepaalt de wet niets anders dan dat daarvoor het Presidium van de volksvergadering bevoegd is (art 8). Ten overvloede zij er op gewezen dat deze uiterst brede norm onbeperkte mogelijkheden geeft om de nationaliteit willekeurig te ontnemen, zelfs in gevallen waarin betrokkene daardoor staatloos wordt.

\subsection{Invloed op de nationaliteit van gezinsleden wan betrakkene}

Ontneming van de nationaliteit heeft in beginsel geen invloed op de nationaliteit van de huwelijkspartner en van de minderjarige kinderen van betrokkene ${ }^{58}$. Dit betekent evenwel geen beletsel om aan deze personen "zelfstandig" de nationaliteit te ontnemen.

58. Wiener Quellenhefte 1963, p. 1. 


\section{1 GeschinedenIS}

\subsection{Inleiding}

Bulgarije was tussen 1396 en 1878 een provincie van het Turkse rijk ${ }^{1}$. Op grond wan verdragen van San Stefano ${ }^{2}$ en van Berlijn ${ }^{3}$ kwam het in 1878 tot verschillende veranderingen van het Bulgaarse grondgebied, dat toen een autonoom vorstendom binnen het Turkse rijk werd ${ }^{4}$. Op 28 april $1879^{5}$ werd de eerste grondwet wan het worstendom afgekondigd, die vervolgens door de prins Alexander op 13 juli 1881 werd ingetrokkem. Reeds in september 1883 werd de grondwet weer van kracht ${ }^{7}$. Op 5 oktober 1908 verklaarde Bulgarije zich tot een onafhankelijk koninkrijk ${ }^{8}$. Na de tweede Balkaanoorlog ${ }^{9}$ en vervolgens op grond van het in Neuilly gesloten vredesverdrag van 27 november $1919^{10} \mathrm{kwam}$ het opnieuw tot enkele grondgebiedswijzigingen tussen Bulgarije en zijn buurlanden Griekenland, Joegoslaviè en Roemenië. Een volgende grondgebiedswijziging vond plaats op grond van het verdrag van Craiova van 7 september $1940^{11}$ toen Roemenie een deel van het gebied Dobroedsja aan Bulgarije afstond. Het regime in Sofia kondigde begin 1941 een racistische wetgeving af ${ }^{12}$ en op 1 maart $1941^{13}$ trad Bulgarije tot het "Driemachtenpact" (Duitsland, Italië, Japan), waarna Bulgaarse troepen in april 1941 enkele Griekse en Joegoslavische gebieden occupeerden. Op 9 september 1944 werd Bulgarije bezet door het Sovjet-leger ${ }^{14}$. Kort daarna kwam het overwegend communistische "Nationale front" aan de macht, dat tussen 10 en 12 maart 1945 een "nationaal comité" (voorlopige regering) vormde, onder leiding van Dimitrov ${ }^{15}$. Op 8 september 1946 werd bij een referendum tot afschaffing van het koninkrijk besloten, waarna op 15 september van hetzelfde jaar de republiek werd uitgeroepen ${ }^{16}$. Reeds in september 1944 begon men in Bulgarije de oude "burgerlijke" wetgeving te vervangen en op 9 september 1951 werden alle vór 9

1. Karastojanoff, p. 1; Bergmann/Ferid, p. 1.

2. Verdrag van 3 maart 1878, State Papers 69, 732. Zie art. 6. Afgedrukt bij Ghénov, p. 254 (Franse) en p. 255 (Bulgaarse) tekst. Zie ook Albin, p. 190.

3. Verdrag van 13 juli 1878 , State Papers 69 , 749. Zie art.1; afgedrukt bij Ghénov, p. 286-287, Albin, p. 207 , Lut $i_{3}$,, $17-18$.

4. Peaslee, p. 93; Bergmann/Ferid, p. 1-2; De Lapradelle/Niboyet, p. 581.

5. State Papers 70, 1303; Bergmann/Ferid, p. 1.

6. Karastojanoff, p. 2.

7. Ghenov, p. 346 .

8. Albin, p. 232; Peaslee, p. 93; Bergmann/Ferid, p. 1; De Lapradelle/Niboyet, p. 581.

9. Tussen 3 februari 1913 en 23 april 1913. Zie over de Balkanoorlogen Ferrario, p. 175-217.

10. State Papers 112, 781; D.V. (DurZaven vestnik) 1920, nt. 239; Bergmann/Ferid, p. 2.

11. D.V. 1940, nr. 206; Duitse vertaling in ZfoR 1940-41, p. 492; Bergmann/Ferid, p. 2. Zie daarover Nicoloff, ZfoR 1940-41, p. 442-459.

12. Wet tot bescherming wan het volk, D.V. 1941, nr. 16. Zie voor Duitse vertaling en een commentaar van Kojucharoff, ZfoR 1940-41, p. 598-614. Zie over de Jodenvervolging in Bulgarije ook Stainov, ZfoR 1940-41, p. 553-558.

13. Zie bericht in ZaöRV 1940-41, p. 817; Bergmann/Ferid, p. 2.

14. Spasow/Naceva, p. 5 ; Peaslee, p. 94 ; Bergmann/Ferid, p. 2.

15. Bergmann/Ferid, p. 2.

16. Spasow/Načeva, p. 5; Bergmann/Ferid, p. 2. 
september 1944 tot stand gekomen regels nietig verklaard ${ }^{17}$. Bulgarije is reeds sedert de oprichting van het Warschaupact en van de COMECON lid van beide organisaties.

Op 4 december 1947 werd door het "nouveau régime" de eerste grondwet afgekondigd ${ }^{18}$. De grondwet werd vervolgens in 1961 , 1965 en op 16 mei 1971 gewijzigd ${ }^{19}$.

\subsubsection{Het nationaliteitsrecht voor 1944}

\subsubsection{Algemeen}

De eerste regels met betrekking tot de Bulgaarse nationaliteit werden opgenomen in artt. 54-56 van de grondwet van 16 april $1879^{20}$. Volgens deze grondwettelijke bepalingen zouden personen, die in Bulgarije werden geboren en geen andere nationaliteit bezaten, alsmede kinderen van Bulgaarse ouders die in het buitenland werden geboren de nationaliteit van Bulgarije bezitten (art. 54). Ook werden de mogelijkheid van verlening (art. 55) en van het doen van afstand (art. 56) van de nationaliteit in de grondwet vastgelegd. Op grond van de in de grondwet geformuleerde beginselen werd het nationaliteitsrecht verder uitgewerkt in de wet van 17 december $1880^{21}$. Deze nationaliteitswet werd vervolgens op 26 februari 1883 vervangen door een verordening van de prins ${ }^{22}$. $\mathrm{Na}$ het herstel van de grondwet ontstond onenigheid over de vraag of wederom de nationaliteitswet van 1880 , of de verordening van 1883 het geldende nationaliteitsrecht was. Het ging hierbij met name om de vraag wie bevoegd was naturalisatie te verlenen. Volgens art. 13 van de wet van 1880 zou dat het parlement zijn en volgens art. 20 van de verordening de prins. Hoewel het Hof van cassatie in overeenstemming met de opvatting van de Minister van justitie de verordening van 1883 op 24 september 1886 als in strijd met de grondwet verklaarde, werden in de praktijk alle naturalisatieverzoeken gewoon aangehouden ${ }^{23}$. Vervolgens werd de verordening bij wet van 2 februari 1895 gewijzigd, waardoor de wetgever liet blijken dat toch de gewijzigde verordening als geldend recht diende te worden beschouwd ${ }^{24}$.

Op 31 december $1903^{25} \mathrm{kwam}$ een nieuwe nationaliteitswet tot stand, die overigens zeer sterk door het Franse nationaliteitsrecht werd geïnspireerd ${ }^{26}$. Deze

17. Izwestija PNS (Prezidiuma Narodnog Sobrania) 1951, nr. 93. Geilke 1975, p. 7.

18. Spasov/Naceva, p. 6-7; Bergmann/Ferid, p. 2; Zie voor een Engelse vertaling Peaslee, p. 96-110.

19. D.V. 1971, nr. 39. Duitse vertaling in JöR 1973, p. 233-248, met commentaar van Schultz op p. 203-233. Zie ook Spasow/Naceva, p. 7-8. Geilke 1975, p. 9.

20. Bergmann/Ferid, p. 6; De Lapradelle/Niboyet, p. 581. Zie voor cen Duitse vertaling van deze artikelen Polizei Hamburg, p. 19; Karastojanoff, p. 2 en voor een Franse: Stokoff, p. 14.

21. Karastojanoff, p. 2; Bergmann/Ferid, p. 6. Zie woor een commentaar op deze wet Stokoff, Modes ef elfets de l'acquisition de la nationalite Bulgare, diss. Toulouse 1905.

22. Karastojanoff, p. 2. Zie voor een Duitse vertaling Polizei Hamburg p. 19, Franse State Papers 74, 752. Zie voor een commentaar op deze verordening Stokoff, o.c. (vorige noot). Zie ook Hecker, WGO 1971 , p. 324.

23. Karastojanolf, p. 2-3; Bergmann/Ferid, p. 6

24. Karastojanof, p. 3 Hecker, WGO 1971, p. 324.

25. D.V. 1904, nr. 3. Zie voor een commentaar Stokoff, o.c. (noot 21); Stamimiroff, p. 401-407, Karastojanoff, p. 10-44; Lichter, StAZ 1939, p. 253-254.

26. Karastojanoff, p. 3 . 
regeling werd vervolgens gewijzigd bij wetten van: 10 januari $1908^{27}, 8$ december $1911^{28}$, 17 juli 1924 , en 31 mei $1929^{29}$. De nationaliteit van de inwoners van het door Roemenië in 1940 afgestane gebied Dobroedsja werd geregeld in een aparte wet van 18 november $1940^{30}$.

Bulgarije sloot na de eerste wereldoorlog ook enkele internationale verdragen, die (mede) betrekking hadden op de nationaliteit. Dit waren:

- het reeds genoemde vredesverdrag van 27 november 1919 van Neuilly (artt. $39-56,158)^{31}$;

- een "migratieverdrag" met Griekenland van Neuilly van 27 november $1919^{22}$ (artt. 1, 4 en 5);

- een "naturalisatieverdrag" met de Verenigde Staten van 23 november $1923^{33}$;

- een verdrag met Turkije van 18 oktober $1925^{34}$;

- het reeds vermelde verdrag van 7 september 1940 van Craiova met Roemeniê. ${ }^{35}$.

Vervolgens werd het Bulgaarse nationaliteitsrecht bij de wet van 16 december $1940^{36}$ grondig herzien. Hieronder zal deze regeling ook uitwoeriger worden besproken.

\subsubsection{De wet van 1940}

\subsection{Algemeen}

De wet van 1940 bevatte een zeer uitvoerige, zeventig artikelen lange regeling met betrekking tot de nationaliteit en de in nationaliteitsaangelegenheden te volgen procedure. Interessant is dat de overgangsregeling ten aanzien van het bepalen van de kring van Bulgaarse onderdanen bij de inwerkingtreding van deze wet niet

27. D.V. 1908, ar. 9, zie Stanimirof, p. 408,

28. D.V. 1911, ne. 274.

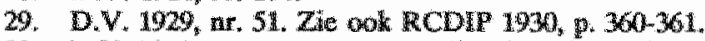

30. D.V. 1940, nR. 263. Duikse vertaling (van de wersie van 1940) in SGS deel 5, p. 51-52, ZfoR 1940-

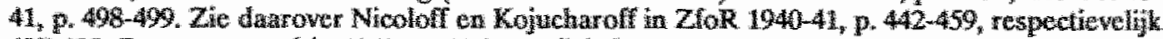
497-498. Dezot werd in 1942 en 1951 gewijzigd.

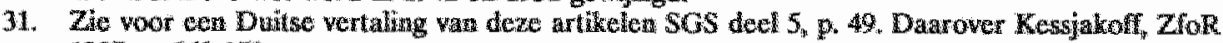
$1927,0,362-372$

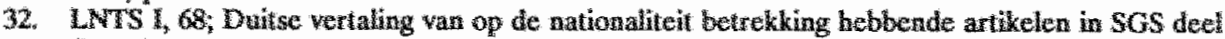
$5, \mathrm{p}, 50$.

33. LVTS XXV, 238. Dit verdrag werd wegens de oorlog buhten werking gesteld tussen 18 juli 1942 en 8 mart 1948. C. Hecker, WGO 1971, p. 323.

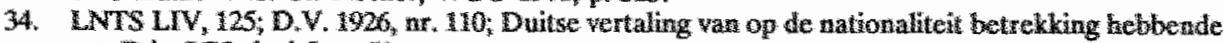
art. B in SGS deel 5 , 50 .

35. Op de nationahteit had betreking annex $C$ van dit verdrag. Duitse vertaling in SCS deel $5_{3} p$. 50-51. Zie daraver Korkiscix, Zaók V 1940-41, p 707-745.

36. D.V. 1940, wr. 288; Duitse vertaling in SGS dee $5,34-43$. 
aanknoopte bij de kring personen, die op grond van de wet van 1903 de Bulgaarse nationaliteit hadden verworven. Art. 61 lid 1 verklaarde als Bulgaren allen, die op het ogenblik van het ontstaan van de Bulgaarse staat aldaar woonachtig waren, en degenen, die in Bulgarije werden geboren voorzover ze nooit een beroep op het bezit van een andere nationaliteit hadden gedaan. Voorts werden er bijzondere overgangsregels ten behoeve van bepaalde groepen personen opgenomen (artt. 62 67).

Art. 2 bevatte de reeds uit de Sovjet-nationaliteitswetten bekende bepaling dat een Bulgaarse staatsburger niet tegelijkertijd de nationaliteit van een andere staat "kon bezitten" (exclusiviteitsbeginsel). Voor een bespreking van de relatieve werking van dergelijke bepalingen zij verwezen naar p. 31-32.

\subsection{Verkrijging van de nationaliteit}

De Bulgaarse nationaliteit kon volgens de wet van 1940 worden verworven van rechtswege en door naturalisatie. Verkrijging van de nationaliteit door het afleggen van een optieverklaring kende deze wet niet.

\section{a. Verkrijging van rechtswege}

De Bulgaarse nationaliteitswet van 1940 kende verkrijging van de nationaliteit ipso iure bij geboorte uit Bulgaarse ouder(s) (art. 7) en in bepaalde gevallen bij de geboorte in Bulgarije (art. 8). Aan een huwelijk met een Bulgaar of adoptie werd geen automatische verkrijging van de nationaliteit gekoppeld. Ten gunste van buitenlandse vrouwen die met Bulgaarse staatsburgers in het huwelijk traden, kende de wet de mogelijkheid van een verlichte naturalisatie.

\section{i. Geboorte uit Bulgaarse ouder(s)}

Een wettig kind verkreeg de Bulgaarse nationaliteit indien zijn vader op het tijdstip van de geboorte van het kind het Bulgaarse staatsburgerschap bezat. Indien uitsluitend zijn moeder Bulgaarse was, verwierf het kind deze nationaliteit in het geval dat de vader staatloos of van onbekende nationaliteit was (art. 7 lid 1).

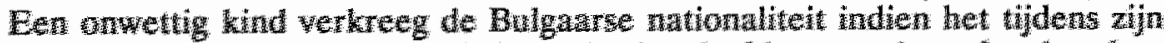

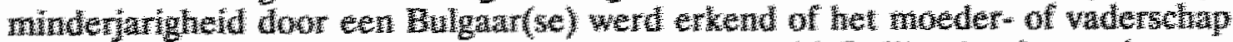

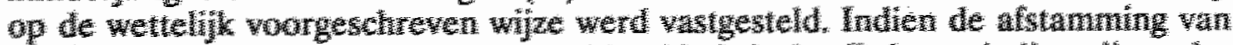

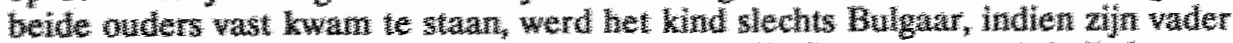

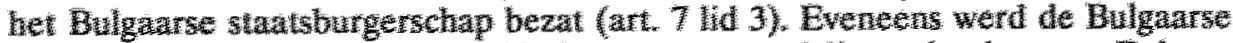

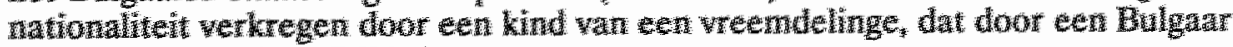
werd gewettigd (art. 7 ild 2).

\section{萑 Geboonte op het Hugarse grondgebied}

Ime soll werd de Dutgaarse nationaliteit in wee gevallent werworven:

door op her Bulgatse grondgebied geboren knderen wan onbekende of staatloze outers (art 8 10 1); 
- door in Bulgarije geboren kinderen van vreemdelingen, die in Bulgarije bun vaste woonplaats hadden, indien deze kinderen binnen éen jaar na het bereiken van de meerderjarigheid geen beroep op het bezit van een andere nationaliteit deden (art. 8 lid 2).

\section{b. Naturalisatie}

Verkrijging van de Bulgaarse nationaliteit door naturalisatie was geregeld in artt. 9 e.v. van de wet van 1940. De wet bepaalde in art. 9 lid 1 dat de nationaliteit kon worden verleend. Hieruit blijkt, dat het mogelijk was een naturalisatie te weigeren, ondanks het feit dat de verzoeker aan alle vereisten voldeed. Tegen een afwijzende beslissing omtrent een naturalisatieverzoek was beroep bij de Minister van justitie mogelijk. Deze nam zijn beslissing op grond van het advies van de speciaal ingestelde "Raad voor nationaliteitsangelegenheden" (art. 48).

Om voor naturalisatie in aanmerking te kunnen komen, moest betrokkene allereerst in het bezit zijn van de toestemming tot verblijf van onbepaalde duur in Bulgarije ${ }^{37}$. Deze toestemming werd verleend door de Minister van justitie en was afhankelijk van onder meer de volgende omstandigheden (art. 27):

- de financiële situatie van de verzoeker (sub 6);

- beroep en opleiding (sub 7);

- kennis van de Bulgaarse taal (sub 9);

- politieke opvattingen van betrokkene (sub 10);

- de nationaliteit van de verzoeker en zijn motieven voor het verkrijgen van de Bulgaarse nationaliteit (sub 11);

- de verzoeker mocht niet in Bulgarije strafrechtelijk zijn veroordeeld (art. 27 lid 2).

Een verleende toestemming strekte zich tevens uit over de vrouw en minderjarige kinderen van betrokkene (art. 32).

Voorts gold als algemeen naturalisatievereiste dat betrokkene gedurende 10 jaren voorafgaande aan zijn naturalisatieverzoek in Bulgarije moest hebben gewoond (art. 9 lid 1). Deze verblijfseis werd in bepaalde gevallen tot vijf, respectievelijk én jaar verkort. Een verblijfseis van vijf jaar gold ten aanzien van (art. 9 lid 2):

kinderen van gewezen Bulgaarse vrouwen die dit staatsburgerschap door huwelijk hadden verloren (sub a, zie ook art. 19);

37. Blijkens de regeling met betrekking tot verkrijging van een dergelijke vergunning (artt. 27-32) ging het niet om een "echte" verblijfs- of vestigingsvergunning, maar een verklaring van geen bezwaar tegen verblijf woor onbepaalde duur. Een vergunning had blijkens art. 31 ook slecht werking in het kader van een naturalisatieprocedure. 
- echtgenoten van Bulgaarse vrouwen, die deze nationaliteit door afstamming verwierven (sub b);

- personen, die de staat grote diensten hadden bewezen, zoals wetenschappelijk werk, een belangrijke uitvinding, of het oprichten van voor de nationale economie belangrijke ondernemingen (sub c);

Ten gunste van de volgende categorieën werd de verblijfseis tot slechts én jaar verkort (lid 3):

- personen van Bulgaarse afstamming (sub a);

- degenen die grote diensten aan de Bulgaarse staatsveiligheid of aan het leger hadden bewezen (sub b);

- personen die in oorlogstijd vrijwillig in Bulgaarse militaire dienst traden (sub c).

Voorts werd ten aanzien van personen die niet op de wettelijk voorgeschreven wijze (artt. 27-32) een vergunning tot vast verblijf hadden verworven, de verblijfseis op twintig jaar gesteld (art. 10 lid 1).

\section{i. Huwelijksnaturalisatie}

De Bulgaarse nationaliteitswet van 1940 was eén van de weinige nationaliteitswetten van die tijd, die geen automatische verkrijging van de nationaliteit door huwelijk kende. Een buitenlandse vrouw die met een Bulgaar in het huwelijk trad, kon binnen drie maanden na de huwelijkssluiting een naturalisatieverzoek indienen zonder te voldoen aan de naturalisatievereisten van artt. 9 en 10 . Ze moest echter wel kunnen bewijzen dat ze niet strafrechtelijk werd veroordeeld en dat zij haar oorspronkelijke nationaliteit door of in verband met het huwelijk verloor (art. 31 jo. art. 37). Hierbij werd niet vereist dat de verzoekster in Bulgarije woonachtig was (art. 37 lid 2). Voldeed betrokkene niet aan de in artt. 31 en 37 gestelde vereisten, of diende ze haar aanvraag te laat in, dan stond voor haar slechts de "gewone" naturallisatie open.

\section{ii. Hernaturalisatie}

Ten aanzien van personen die ooit de Bulgaarse nationaliteit bezaten, werd een bijzondere procedure ingesteld. De vereisten voor hernaturalisatie waren de volgende (art. 23):

- betrokkene mocht de Bulgaarse nationaliteit niet door ontneming of wegens het treden in vreemde krijgsdienst hebben verloren;

- vestiging in Bulgarije;

- betrokkene moest zijn verplichtingen tegenover het leger hebben nagekomen. 
Voorts golden bepaalde beperkingen ten aanzien van de hernaturalisatie van de volgende groepen:

- personen van vreemde etnische afstamming, die van de Bulgaarse nationaliteit afstand hadden gedaan, konden slechts worden gehernaturaliseerd indien ze met een Bulgaarse vrouw gehuwd waren (art. 14);

- gewezen Bulgaarse vrouwen, die hun nationaliteit door huwelijk verloren, konden slechts worden gehernaturaliseerd, indien het huwelijk niet meer bestond (art. 25).

iii. Invloed op de nationaliteit wan de gezinsleden van de verzoeker

Vrouwen van naturalisandi konden op hun verzoek tegelijkertijd met hun man worden genaturaliseerd (art. 11). Een automatische medenaturalisatie van de gehuwde vrouw kende de wet van 1940 uitsluitend in het geval van naturalisatie van een vreemdeling, die gehuwd was met een gewezen Bulgaarse, die haar Bulgaarse nationaliteit door afstamming had verworven (art. 25 lid 2).

Minderjarige kinderen van naturalisandi werden automatisch met hun ouders meegenaturaliseerd, indien de Bulgaarse nationaliteit aan beide ouders, aan de vader alleen, of aan de weduwe geworden moeder werd verleend (art. 12).

\subsection{Verlies van de nationaliteit}

De Bulgaarse nationaliteit kon volgens de wet van 1940 worden verloren van rechtswege, door afstand en door ontneming.

\section{a. Verlies van rechtswege}

De Bulgaarse nationaliteit ging van rechtswege verloren in de volgende gevallen:

- door verkrijging van een vreemde nationaliteit, ongeacht of deze al dan niet vrijwillig werd verworven (art. 14 sub 2) ${ }^{38}$;

- bij veroordeling wegens bepaalde delicten (sub 3);

- wegens het ontvangen van materiële ondersteuning van een vreemde staat zonder wetenschap van de Bulgaarse regering (sub 3);

- wegens het zonder toestemming treden in vreemde krijgs- of staatsdienst (sub $4,5)$;

wegens het geen gehoor geven aan een oproep voor mobilisatie (sub 6);

38. Betrokkene moest binnen 3 maanden ma de verkrijging van een vreemde nationaliteit het Bulgaarse Ministerie van jwstitie daarvan in kennis stellen (art. 20 lid 3). Anders kon hij rekenen met een administratieve boete, voorgeschreven in art. 58 van de nationaliteitswet van 1940 (!). 
- personen van niet-Bulgaarse afstamming verloren de Bulgaarse nationaliteit door vestiging in het buitenland (art. 15 lid 1). Deze verliesgrond had krachtens art. 66 onbeperkte terugwerkende kracht ${ }^{39}$.

Huwelijkssluiting met een buitenlander vormde voor Bulgaarse vrouwen geen grond voor automatisch verlies van de nationaliteit.

Wel hadden deze vrouwen de mogelijkheid om van de Bulgaarse nationaliteit afstand te doen.

Volgens art. 43 moest de naam van degenen die van rechtswege de Bulgaarse nationaliteit verloren, in het register van Bulgaarse staatsburgers worden doorgehaald. De doorhaling geschiedde ambtshalve, op grond van een "Ukaz" van de Ministerraad, op voordracht van de Minister van justitie, met het advies van de Raad voor nationaliteitsangelegenheden. Uit art. 43 blijkt dat deze doorhaling geen constitutieve werking had.

\section{i. Invloed op de nationaliteit van gezinsleden wan betrokkene}

Het verlies van het staatsburgerschap had slechts werking ten opzichte van de vrouw en meerderjarige kinderen van betrokkene indien zij tezamen met haar man, respectievelijk hun vader in een ander land gingen wonen (art. 16 lid 1). In geval dat de ouder(s) het Bulgaarse staatsburgerschap door verkrijging van een vreemde nationaliteit verloren, deelden minderjarige kinderen in het verlies van de nationaliteit van hun ouder(s) slechts, indien zij ook in de verkrijging van het nieuwe staatsburgerschap door de ouder(s) deelachtig waren (art. 16 lid 2).

Opmerkelijk is voorts, dat de nationaliteit voor een wettig minderjarig kind verloren ging doordat zijn moeder met een buitenlander in het huwelijk trad (art. 18).

\section{b. Afstand}

De Bulgaarse nationaliteitswet van 1940 kende het verlies van de nationaliteit door het afleggen van een verklaring van afstand, dat aan de volgende vereisten werd verbonden:

- de verklaring moest in de vorm van een notariële akte worden afgelegd (art. 39 lid 1);

- tegen betrokkene mocht geen strafrechtelijke procedure aanhangig zijn (art. 39 lid 2 sub 3 );

- de verzoeker moest zijn verplichtingen tegenover de overheid hebben nagekomen (art. sub 4);

- betrokkene moest zijn militaire dienstplicht hebben vervuld (art. 39 sub 5);

39. Deze bepaling werd woornamelijk tegen Joodse emigranten gericht. Stainov, p. 552 . 
De verklaring moest bij de Minister van justitie worden ingediend (art. 39 lid 1). Vervolgens moest betrokkene op grond van een "Ukaz" van de Ministerraad op voordracht van de Minister van justitie uit het register van Bulgaarse staatsburgers worden geschrapt (art. 40), , $^{\text {40 }}$ Zowel de "Ukaz" als de doorhaling in het register werkten echter niet constitutief.

Een Bulgaarse vrouw die met een buitenlander trouwde, verloor haar nationaliteit indien zij binnen drie maanden na de huwelijkssluiting verklaarde dat ze de nationaliteit van haar man wilde verwerwen. Ook ten aanzien van deze verklaring werd de notariële vorm vereist (art. 17).

\section{Invloed op de nationaliteit van gezinsleden van betrokkene}

Ten aanzien van de invloed van afstand van het staatsburgerschap op de nationaliteit van de vrouw en minderjarige kinderen van de verzoeker golden dezelfde regels als bij verlies van rechtswege. Zie p. 125 .

\section{c. Ontneming}

De wet van 1940 kende twee gevallen van ontneming van nationaliteit. Het eerste was geregeld in art. 3 dat merkwaardigerwijs tussen de algemene bepalingen werd geplaatst. De nationaliteit kon worden ontnomen wegens het beroep doen op het bezit van een andere nationaliteit. De wet sprak niet van ontneming, maar bepaalde dat een dergelijk beroep:

"kann Veranlassung zum Streichen aus dem Verzeichnis der bulgarischen Staatsangehörigen nach Massgabe des Art. 43 geben". ${ }^{41}$

Doorhaling ex art. 43, werd zoals reeds op p. 125 werd aangegeven, voorgeschreven bij verlies van de nationaliteit van rechtswege (art. 14). In dat geval werd de naam van betrokkene ambtshalve doorgehaald, zodra door het bevoegde orgaan werd vastgesteld dat feiten of omstandigheden zich hadden voorgedaan, die verlies van het staatsburgerschap van rechtswege bewerkstelligden. Het verschil tussen de gevallen van art. 14 en het onderhavige is, dat een beroep op een vreemde nationaliteit als zodanig niet automatisch de doorhaling bewerkstelligde. Pas indien "Ukaz tot doorhaling" tot stand kwam, ging de nationaliteit ex art. 3 verloren, hetgeen als het verlies door ontneming moet worden gezien.

Naast art. 3 kende de wet ook een algemene ontnemingsregeling van artt. 2122 en 44-46. De nationaliteit werd ontnomen door een "Ukaz" van de Ministerraad op voordracht van de Minister van justitie, nadat het advies van de Raad voor nationaliteitsaangelegenheden werd ingewonnen (art. 44). De vereisten voor ontneming waren de volgende:

- woonplaats in het buitenland;

40. Betrokkene moest binmen drie maanden na de publicatie van de "Ukaz" żjn vermogen in Bulgarije te gelde maken en het land verlaten (art. 20 lid 2).

41. Vertaling ontleend aan SGS deel 5 , p. 34. 
- handelingen die de staat schaadden of de staatsveiligheid in gevaar brachten (art. 21 lid 1).

Aan personen van niet-Bulgaarse etnische afstamming ${ }^{42}$ die de nationaliteit door naturalisatie of iure soli (art. 8) verwierven, kon de nationaliteit ook indien ze in Bulgarije woonden, worden ontnomen, indien ze handelingen hadden begaan, die een Bulgaarse staatsburger onwaardig waren, of wegens het gewaar voor de openbare orde of voor de staatsveiligheid (art. 21 lid 2).

Ontneming van de nationaliteit had tot gevolg dat betrokkene die in Bulgarije woonde, of zich aldaar bevond, het land binnen drie maanden na de publicatie van de "Ukaz" in het staatsblad diende te verlaten.

\section{i. Invloed op de nationaliteit van gezinsleden van betrokkene}

Het verlies van het Bulgaarse staatsburgerschap door ontneming had geen invloed op de nationaliteit van de vrouw en van minderjarige kinderen van betrokkene (art. 22 lid 2).

\subsubsection{Het nationaliteitsrecht tussen 1944 en 1948}

De nieuwe machthebbers in Sofia hadden in de periode tot de totstandkoming van een geheel nieuwe nationaliteitswet op 19 maart 1948 verschillende regelingen afgekondigd, die de strekking hadden om bepaalde bijzondere onderwerpen te regelen.

\subsubsection{De verordening van 27 november 1944}

De verordening van 27 november $1944^{43}$ voegde aan art. 15 van de nationaliteitswet van 1940 een "opmerking" 44 toe. Deze had betrekking op Joodse emigranten, die op grond van art. 15 de Bulgaarse nationaliteit van rechtswege verloren, doordat zij het land hadden verlaten. Deze personen hadden de mogelijkheid om het Bullgaarse staatsburgerschap door het indienen van een daartoe strekkend verzoek te herkrijgen. Daarvoor werd echter vereist dat zij binnen 6 maanden na de inwerkingtreding van de verordening (tot 27 mei 1945) naar het land terugkeerden en het verzoek hadden ingediend. De gestelde termijn werd vervolgens bij de verordening van 25 juni $1945^{45}$ verlengd tot zes maanden na het sluiten van het vredesverdrag met de geallieerden van 10 februari $1947^{46}$.

42. Ook deze bepaling was woornamelijk tegen Joden gericht. Stainow, ZfoR 1940-41, p. 552 .

43. D.V. 1944, mr. 263; Duitse vertaling in SGS deel 5 p. 44.

44. Dit is een voorbeeld wan het overnemen van wetgevingstechniek van de Sovjetunic. Zie over de functie van deze "opmerkingen" Hoofdstuk Rusland/USSR, p. 57.

45. D.V. 1945, nr. 170; Duitse wertaling in SGS deel 5, p. 44.

46. Peaslee, p. 94. 


\subsubsection{Andere regelingen}

Van de andere op de nationaliteit betrekking hebbende regelingen dienen te worden vermeld:

- verordening van 26 februari $1945^{47}$ betreffende het behoud van de Bulgaarse nationaliteit bij het treden in vreemde militaire dienst. Deze verordening had betrekking op personen, die aan de republikeinse zijde in de Spaanse burgeroorlog, of in de troepen van de geallieerden vochten ${ }^{43}$;

- verordening van 24 september $1945^{49}$ betreffende behoud van de nationaliteit door politieke emigranten;

- wet van 19 februari $1948^{\text {s0 }}$ betreffende verlichte naturalisatie van Joegoslavische onderdanen.

\subsubsection{De wet wan 1948}

\subsubsection{Algemeen}

De eerste nationaliteitswet van de Volksrepubliek Bulgarije werd op 26 maart 1948 afgekondigd. Bij de bepaling van de kring van Bulgaarse onderdanen bij de inwerkingtreding van deze wet, knoopte de overgangsregel van art. 28 aan bij de kring personen, die deze nationaliteit op grond van daarvoor geldende wetgeving hadden verworven. Ook deze wet bevatte de bepaling, dat een Bulgaarse staatsburger niet tegelijkertijd de nationaliteit van een andere staat "mocht" bezitten (art. 24 lid 1). Voorts valt op dat deze wet in navolging van de grondwet van 1947 in plaats van de oude term "poddanstvo"(onderdaanschap) het begrip "graždanstvo" (frans: citoyenneté) gebruikte.

\subsubsection{Verkrijging van de nationaliteit}

De Bulgaarse nationaliteit kon volgens de regeling van 1948 worden verkregen van rechtswege en door naturalisatie. Verkrijging van de nationaliteit door optie kende deze wet evenals zijn voorganger van 1940 niet.

\subsection{Verkrijging van rechtswege}

In de nationaliteitswet van 1948 werd verkrijging van de Bulgaarse nationaliteit van rechtswege gekoppeld aan geboorte uit Bulgaarse ouder(s) (art. 1) en geboorte op het Bulgaarse grondgebied (art. 2). Adoptie en huwelijk bewerkstelligden geen verkrijging van de nationaliteit. Ten aanzien van geadopteerde kinderen en

47. D.V. 1945 , nr. 56

48. Bergmann/Ferid, p. 6.

49. D.V. 1945, nr. 230.

50. D.V. 1948, nr. 40; Duitse vertaling in SGS deel 5a, p. 13. Ingetrokken door art. 11 van de wet van 1 augustus 1952, IPNS 1952, nr. 104. 
personen die met een Bulgaar(se) waren gehuwd, bestond de mogelijkheid van verlichte naturalisatie.

\section{a. Geboorte wit Bulgaarse ouder(s)}

Een kind verkreeg het Bulgaarse staatsburgerschap indien zijn beide ouders op het tijdstip van de geboorte van het kind de Bulgaarse nationaliteit bezaten (art. 1 lid 1). In het geval dat slechts één van de ouders Bulgaar was, verwierf het kind deze nationaliteit indien:

- het kind in Bulgarije werd geboren, of

- het kind in het buitenland werd geboren en het anders staatloos zou zijn (art. 1 lid 2).

In het buitenland geboren kinderen die niet op grond van art. 1 lid 2 de Bulgaarse nationaliteit verwierven, werden Bulgaren, indien hun beide ouders tijdens de minderjarigheid van het kind hun wil daartoe verklaarden, of indien de minderjarige zich in Bulgarije vestigde. Bij personen boven 14 jaar was tevens hun eigen toestemming vereist (art. 5 lid 1). Toestemming van beide ouders was niet nodig indien de andere ouder reeds overleden was, of geen ouderlijke macht over het kind uitoefende.

$\mathrm{Er}$ werd geen onderscheid tussen wettige en onwettige kinderen gemaakt. Onwettige kinderen verkregen het Bulgaarse staatsburgerschap volgens de zojuist beschreven regels. Uiteraard moest eerst de afstamming van het kind zowel ten aanzien van de moeder, respectievelijk van de vader vast komen te staan. Dit kon gebeuren door erkenning of door gerechtelijke vaststelling van het moederrespectievelijk vaderschap.

\section{b. Geboorte op het Bulgaarse grondgebied}

Iure soli verwierf de Bulgaarse nationaliteit een kind dat in Bulgarije werd geboren of gevonden, en wiens ouders onbekend, staatloos, of van onbekende nationaliteit waren (art. 2). Werd later afstamming uit vreemde ouders vastgesteld, dan verloor het kind de Bulgaarse nationaliteit, ongeacht zijn leeftijd ${ }^{51}$.

\subsection{Naturalisatie}

Verkrijging van de Bulgaarse nationaliteit door naturalisatie was geregeld in artt. 3-5 en de procedure daarvoor in artt. 13-18 van de wet van 1948. De bevoegdheid om over een naturalisatie te beslissen lag bij de Minister van binnenlandse zaken (art. 15). Slechts ten aanzien van hernaturalisatie van personen, aan wie de nationaliteit werd ontnomen, was de Raad van State bevoegd (art. 18). Opvallend is dat deze wet slechts een zeer summiere regeling van de verlening van de nationaliteit kende, terwijl zijn voorganger van 1940 aamzienlijk uitvoeriger was. De enige algemene naturallisatievereisten waren de volgende:

51. Hubernagel, StAZ 1955, p. 135. 
- woonplaats in Bulgarije (art. 3 lid 1 aanhef);

- vijfjarig ononderbroken verblijf (art. 3 lid 1 aanhef).

De tijd die een verzoeker in Bulgaarse dienst in het buitenland had doorgebracht werd met verblijf in Bulgarije gelijkgesteld (art. 3 lid 2). De verblijfseis werd ten aanzien van de volgende categorieën verzoekers tot slechts één jaar verkort:

- etnische Bulgaren (art. 3 lid 1 sub a );

- degenen, die door Bulgaren werden geadopteerd (sub a);

- in Bulgarije geboren kinderen van buitenlanders (sub b);

- degenen die in het Bulgaarse leger hadden gediend (sub c);

- personen die de staat belangrijke diensten hadden bewezen (sub d);

- asielgerechtigden (sub e).

De Raad van State kon krachtens de laatste volzin van art. 3 lid 2 in bijzondere gevallen van de genoemde naturalisatievereisten afzien ${ }^{52}$.

Art. 4 had betrekking op de huwelijksnaturalisatie. Van een buitenlandse echtgeno(o)t(e) van een Bulgaar(se) werd geëist dat hij/zij verklaarde de vroegere nationaliteit "op te willen geven". Aan enig verblijfsvereiste hoefde de verzoek(st)er niet te voldoen ${ }^{53}$. Hetzelfde gold ook ten aanzien van personen die ooit de Bulgaarse nationaliteit bezaten (art. 11). Aangenomen mag worden, dat deze "antibipatridieëis" hoewel dit niet expliciet in de wet werd bepaald, a fortiori ook ten aanzien van alle naturalisandi werd gehanteerd.

Uit het feit dat de nationaliteit kan worden verleend, blijkt dat het aan de Raad van State vrij stond bij de behandeling van naturalisatieverzoeken geheel naar eigen inzicht te handelen. Beroep tegen een afwijzende beschikking was niet mogelijk.

\section{a. Invloed op de nationaliteit van de gezinsleden van de verzoeker}

Medenaturalisatie van minderjarige (tot 18 jaar) ${ }^{54}$ kinderen van naturalisandi was geregeld in art. 5 . Kinderen onder 14 jaar werden automatisch meegenaturaliseerd indien de Bulgaarse nationaliteit aan beide ouders werd verleend, de andere ouder reeds deze nationaliteit reeds bezat, of overleden was. Bij kinderen boven 14 jaar werd steeds hun eigen toestemming vereist (lid 2).

52. Bij de wet van 15 mei 1950, D.V, 1950, nr. 244 werd deze bepaling enigszins redactioneel gewijzigd.

53. Cf. Hubernagel, StAZ 1951, p. 135.

54. De meerderjarigheidsgrens werd naar 18 jaar verlaagd bij de wet van 4 augustus 1949 , D.V. 1949 , nr. 182, art. 2. Zie daarover Hubernagel, StAZ 1951, p. 136. 


\subsubsection{Verlies van de nationaliteit}

De Bulgaarse nationaliteit kon volgens de wet van 1948 worden verloren door ontslag en door ontneming. Verlies van rechtswege of door het afleggen van een verkllaring van afstand kende deze wet niet.

\subsection{Ontslag}

Ontslag uit de Bulgaarse nationaliteit was geregeld in artt. 6,7 en 14 van de wet van 1948. De wettekst sprak echter niet van ontslag, maar van "toestemming voor verkrijging van een andere nationaliteit". Het is interessant te vermelden dat degene die een vreemde nationaliteit bezat(!), of slechts een beroep op het bezit daarvan deed, met een forse geldboete ${ }^{55}$ of zelfs gevangenisstraf ${ }^{56}$ moest rekenen (art. 26). Vereisten voor ontslag werden in de wet in het geheel niet genoemd, hetgeen ook hier op een onbeperkte discretionaire bevoegdheid van de administratie wijst. Het was ook niet mogelijk om tegen een afwijzende beschikking rechtsmiddelen in te stellen. Het ontslag werd verleend door de Minister van justitie en wel onder de opschortende voorwaarde dat betrokkene inderdaad een vreemde nationaliteit verwierf (art. 6 lid 1 ).

Voorts kon bij het verlenen van ontslag worden bepaald, dat betrokkene binnen een bepaalde termijn het land moest verlaten en zijn vermogen in Bulgarije te gelde moest maken (art. 7 lid 2).

\section{a. Invloed op de nationaliteit van de gezinsleden van de verzoeker}

Minderjarige kinderen van betrokkene werden automatisch in het ontslag inbegrepen (art. 6 lid 1). De wet zweeg over het geval dat slechts aan één der ouders het ontslag werd verleend, terwijl de andere ouder Bulgaar bleef.

\subsection{Ontneming}

Aanzienlijk meer aandacht dan aan andere onderwerpen werd door de wetgever geschonken aan het verlies van de Bulgaarse nationaliteit door ontneming. De bevoegdheid om de nationaliteit te ontnemen lag bij de Raad van State (art. 18). Uit de "kan" formulering in de aanhef van art. 8 blijkt dat ook hier voldoende ruimte was om willekeurig te handelen. De nationaliteit kon indien betrokkene in het buitenland verbleef, in de volgende gevallen worden ontnomen:

- wegens het illegaal verlaten van het land (sub a);

wegens het zich "zonder rechtsgrond" in het buitenland bevinden en geen gehoor aan een mobilisatieoproep geven (sub b);

55. Er werd in art. 21 cen boete van 100.000 Lew woorgeschreven, hetgeen bijwoorbeeld het tienvoudige van de verschuldigde naturalisatiegellen bedroeg.

56. Gevangenisstraffen wegens het bezit of verkrijging van een vreemde nationaliteit werden afgeschaft bij het wetboek van strafrecht van 15 maart 1968, D.V. 1968, nr. 23. 
- wegens het zonder toestemming van de regering in vreemde staats- of krijgsdienst treden (sub c);

- wegens handelingen in het buitenland die gevaar vormden voor de belangen van Bulgarije of voor de staatsveiligheid (sub d).

Terwijl de eerste drie ontnemingsgronden met voldoende nauwkeurigheid werden geformuleerd, was de laatstgenoemde bijzonder vaag en werd de invulling daarvan geheel aan de administratie overgelaten. De nationaliteit kon ook worden ontnomen indien betrokkene daardoor staatloos werd.

Krachtens art. 10 werd het vermogen van betrokkene staatseigendom en kon bij een ontnemingsbesluit worden bepaald, dat ook het vermogen van de echtgeno(o)t(e) van getroffene- aan wie de nationaliteit niet werd ontnomen(I)- kon worden geconfisceerd.

\section{a. Invloed op de nationaliteit van gezinsleden wan betrokkene}

Art. 9 bepaalde dat ontneming geen invloed op het staatsburgerschap van de familieleden van betrokkene had.

\subsubsection{Bijzondere regelingen tot 1968}

Gedurende de geldigheid van de wet van 1948 werden nog enkele wetten en verordeningen afgekondigd, die de strekking hadden hetzij de nationaliteitswet van 1948 op enkele plaatsen te wijzigen, hetzij bepaalde nationaliteitsrechtelijke onderwerpen te regelen.

- Bij de wet van 15 mei $1950^{57}$ werd art. 3 lid 2 van de nationaliteitswet van 1948 gewijzigd. De wijzigingswet verleende de Ministerraad uitdrukkelijk de bevoegdheid om in bijzondere gevallen de wettelijke naturalisatievereisten te verlichten, of daarvan in het geheel af te zien. Voorts kon hij vrijstelling van het betalen van naturalisatiegelden verlenen;

- verordening van 22 mei $1950^{58}$ had betrekking op verlichte naturalisatie van etnische Bulgaren die tot 21 december uit Thracië (Griekenland) en Macedonië (Joegoslavië) waren geëmigreerd;

- wet van 11 november $1950^{59}$ betrof vereenvoudigde verkrijging van de nationaliteit door etnisch Bulgaarse immigranten. Bij deze wet werden de voorwaarden voor verwerving van de nationaliteit door deze groep personen nog verder verlicht. Betrokkene moest in Bulgarije zijn woonplaats vestigen,

57. D.V. 1950, nr. 118; Duitse vertaling in SGS deel 5, p. 45.

58. D.V. 1950, nir. 124 .

59. IPNS 1950, $\mathrm{nr}_{\text {. }} 4$. Bij de wet van 1 augustus 1952, IPNS 1952, nr. 65, werden de regels van deze wet "ingebouwd" in de nationaliteitswet van 1948. Hubernagel, StAZ 1955, p. 69. 
verklaren dat hij zijn andere nationaliteit "opgaf" en dat hij de Bulgaarse wilde verwerven ${ }^{60}$;

- wet van 11 november $1950^{61}$ had betrekking op wijziging van art. 6 van de nationaliteitswet van 1948. Aan art. 6 werd een nieuw lid toegevoegd, waarin werd bepaald, dat personen van niet-Bulgaarse afstamming deze nationaliteit door het enkele feit van emigratie verloren ${ }^{62}$;

- wet van 10 februari $1951^{63}$ strekte tot wijziging van de wet van 18 november $1940^{64}$ betreffende de nationaliteit van de inwoners van Dobroedsja;

- bij de wet van 1 augustus $1952^{65}$ werd een wijziging in de competentie in nationaliteitszaken doorgevoerd. Overal waar de nationaliteitswet van 1948 van de Minister van binnenlandse zaken sprak, werd deze door zijn collega van justitie vervangen. Voorts werden bij deze wet enkele bijzondere wetten betreffende verlichte naturalisatie van bepaalde groepen immigranten ingetrokken ${ }^{60}$;

- de wet van 24 oktober $1963^{67}$ maakte de competentiewijzigingen in de nationaliteitswet van 1948 weer ongedaan;

- tenslotte werden bij het wetboek van strafrecht van 15 maart $1968^{68}$ vrijheidsstraffen wegens verkrijging van een vreemde nationaliteit afgeschaft.

Met Turkije werd op 22 maart $1968^{69}$ een migratieverdrag gesloten. Deze regeling had betrekking op personen van Turkse etnische afstamming, wier naaste familieleden voor 1952 naar Turkije waren geëmigreerd. Bij dit verdrag werd aan betrokkenen met het oog op gezinshereniging de mogelijkheid gegeven om Bulgarije te verlaten en zich in Turkije te vestigen. Op grond van dit verdrag verlieten in de jaren 1969-1978 meer dan 120.000 personen het land ${ }^{70}$.

60. Hubernagel, StAZ 1955, p. 69.

61. D.V. 1950 , nr. 272.

62. Het ging hierbij met name om etnische Duitsers, Armeniërs, Joden, Turken en Zigeuners. Hubernagel, StAZ 1955, p. 69 .

63. IPNS 1951, nr. 16.

64. D.V. 1940, n.. 263.

65. IPNS 1952, nr. 65; Duitse vertaling in SGS deel 5a, p. 14.

66. De wet van 19 februari 1948, D.V. 1948, nr. 40 en de wet van 1il november 1950, IPNS 1950, nr. 4.

67. D.V. 1963, 1963; Duitse vertaling en commentaar van Lipowschek in WGO 1963, p. 256-257.

68. D.V. 1968 , nr. 23.

69. D.V. 1969, nr. 82; in werking getreden op 19 augustus 1969.

70. Menschenrechte; p. 109. 


\subsubsection{Algemeen}

Het positieve nationaliteitsrecht van Bulgarije is geregeld in de wet van 7 oktober $1968^{7}$. Verdere voorschriften tot uitwoering van deze wet worden vervat in de Ministerièle verordening van 16 september $1969^{72}$. Deze wet werd gewijzigd bij wetten van 27 april 1979 en van 7 augustus $1986^{73}$. Terwijl de eerste wijziging slechts marginale veranderingen betrof, werd bij de tweede de regelling van verkrijging van de nationaliteit iure sanguinis uitgebreid, en werd de aparte mogelijkheid van ontslag ten behoeve wan etnisch niet-Bulgaarse emigranten geschrapt. Voorts werden ook enkele redactionele aanpassingen wan de tekst doorgevoerd.

De wet van 1968 begint met bepalingen van een min of meer declaratoir karakter, zoals ontkenning van de invloed van het huwelijk of adoptie op de

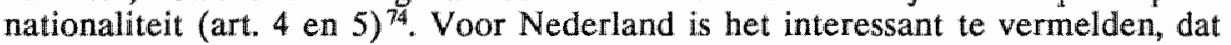
gerechtelijke vaststelling van het bezit van de Bulgaarse nationaliteit in art. 2 uitdrukkelijk wordt verboden, een bepaling, die overigens reeds de wet van 1948 kende (art. 24 lid 2). Het bezit van de Bulgaarse nationaliteit wordt vastgesteld aan de hand van de registers van Bulgaarse staatsburgers die bij het Ministerie van justitie worden bijgehouden ( $\$ 26$ van de verordening) ${ }^{75}$. Deze wet bevat echter niet de "gebruikelijke" bepaling dat Bulgarije een tweede nationaliteit van een eigen onderdaan niet erkent. Dit betekent evenwel niet dat dit uitgangspunt aan betekenis heeft ingeboet ${ }^{76}$.

De houding van Bulgarije tegenover meervoudige nationaliteit is slechts inzoverre milder geworden, dat het bezit van een vreemde nationaliteit niet meer strafbaar is ${ }^{77}$.

\subsubsection{Verkriging van de nationaliteit}

De Bulgaarse nationaliteit kan worden verkregen van rechtswege en door naturalisatie. Verkrijging van de nationaliteit door optie kent het Bulgaarse nationaliteitsrecht niet.

71. D.V. 1968, nr. 79; in werking getreden 14 oktober 1968; Duitse vertaling in Bergmann/Ferild, p. 8-12; WGO 1968, p. 298-304; SLAZ 1969, p. 21-24; Engelse in ILM 1969, p. 1165 e.v. Nederlandsa in de NWG, p. 1-8; zie over deze wet Damjanow, Pravna misul 1984/6, p. 48-58; Masev, Pravna misul 1972/2, p. 46-49; Vulkanow, Bulgarskoto graždanstvo, Sofia 1978; Vulkanow, Prama misul $1084 / 1$ p. $52-59$.

72. D.V. 1969, nr. 72; Duitse vertaling in Bergmann/Ferid, p. 13-17; WGO 1970, p. 55 e.v. Gewijzigd bij de verordening van 14 augustus 1979 , D.V. 1979, nr. 64 .

73. D.V 1979 , nr. 76 en D.V. 1986, nr. 1964. Zie over deze wijziging Sipkov, ILM 1987, p. 422-424.

74. Zie ook Vulkanow, Pravna misul 1984/1, p. 53.

75. Bovendien kan het bezit van de Bugaarse nationaliteit met een paspoort worden bewezen. Vulkanov, p. 5 .

76. Cf. Damjanov, Pravna misul 1984/6, p. 55.

77. Cf. Waehler, StAZ 1969, p. 21 . 


\subsubsection{Verkrijging van rechtswege}

Verkrijging van de Bulgaarse nationaliteit wordt van rechtswege gekoppeld aan:

- geboorte uit Bulgaarse ouder(s) (art. 6);

- geboorte op Bulgaars grondgebied (art. 7).

Adoptie door Bulgaren kan geen verkrijging van de nationaliteit ipso iure bewerkstelligen. Wel heeft een door een Bulgaar geadopteerde vteemdeling de mogelijkheid van vereenvoudigde naturalisatie (art. 11) ${ }^{78}$.

\subsection{Geboorte uit Bulgaarse ouder(s)}

Verkrijging van de Bulgaarse nationaliteit iure sanguinis is geregeld in art. 6 van de wet van 1968. De wetgever verviel in een geheel onnodige casuïstiek, die deze eenvoudige regeling niet erg overzichtelijk maakt. De Bulgaarse nationaliteit wordt verworven door een kind van tenminste één Bulgaarse ouder, ongeacht waar het kind wordt geboren. Tot 1986 werd uitzondering gemaakt ten aanzien van in het buitenland geboren kinderen met slechts één Bulgaarse ouder, die in het land werden geboren waarvan de andere ouder de nationaliteit bezat. Deze kinderen werden niet Bulgaren indien ze aan hun buitenlandse ouder de nationaliteit ontleenden.

Conform het beginsel van gelijke behandeling van wettige en onwettige kinderen (art. 38 lid 4 grondwet) wordt er geen principieel onderscheid tussen categorieën kinderen gemaakt ${ }^{7}$. Onderscheid bestaat echter wel ten aanzien van het vaderschap, dat bij onwettige kinderen niet door een praesumptie, maar door erkenning ${ }^{80}$ of gerechtelijke vaststelling ${ }^{81}$ komt vast te staan. Indien voor verkrijging van de nationaliteit door een buitenechtelijk kind iure sanguinis afstamming van een Bulgaarse vader beslissend is, wordt de nationaliteit met de werking ex tunc vanaf de geboorte van het kind verkregen ( 82 lid 2 verordening). Het instituut van wettiging kent het Bulgaarse recht niet meer ${ }^{82}$.

\subsection{Geboorte op het Bulgaarse grondgebied}

Verkrijging van de Bulgaarse nationaliteit iure soli draagt een subsidiair karakter. Ook hier lijkt door de casuïstische wetgevingstechniek de regeling ingewikkelder,

78. Vulkanov, p. $54,87$.

79. Vulkanov, p. 55-56; Waehler, StAZ 1969, p. 21.

80. Art. 35 van de wet betreffende personen en familie van 18 mei 1985; D. V. 1985, nr. 41.

81. Zie art. 41 van de wet betreffende personen en familie van 18 mei 1985 . Zie ook de "authentieke interpretatie" van het plenum van het opperste gerechtshof betreffende vereenzelviging van de jurisprudentie biji gerechtelijke vaststelling van afstamming nr. 5/1978 van 21 ficbruari 1979 , Soc. pr. 1980 , ar. 4 p. 90.

82. Wettiging werd afgeschaft bij wet op personen- en familierecht van 23 juli 1949, D.V. 1949, nr. 182, in werking getreden op 10 september 1949. Hubmann, StAZ 1951, p. 136-138; Bergmann/Ferid, $p_{n} 25$. 
dan deze in werkelijkheid is ${ }^{83}$. Een kind dat op het Bulgaarse grondgebied wordt geboren of gevonden, verkrijgt de Bulgaarse nationaliteit krachtens art. 7 slechts in het geval dat het anders staatloos zou zijn. Met geboorte op het Bulgaarse grondgebied wordt geboorte op een onder Bulgaarse vlag varend schip of op een in Bulgarije geregistreerd vliegtuig (zie art. 7 sub c) gelijkgesteld ${ }^{84}$.

\subsubsection{Naturalisatie}

Verkrijging van de Bulgaarse nationaliteit door naturalisatie wordt geregeld in de artt. 8-15 en 21-24 van de wet van 1968. Ook deze wet bepaalt dat de nationaliteit kan worden verleend, hetgeen betekent, dat de administratie een onbeperkte discretionaire bevoegdheid heeft. Door Vulkanov ${ }^{25}$ wordt uitdrukkelijk gesteld dat betrokkene geen subjectief recht op naturalisatie heeft. Bovendien worden slechts twee naturalisatievereisten in de wet genoemd. Uit de totstandkomingsgeschiedenis ${ }^{86}$ van de wet blijkt dat aan de administratie de mogelijkheid wordt voorbehouden extra naturalisatieeisen te stellen, bijvoorbeeld met betrekking tot de staatsveiligheid, en dat in ieder geval een positieve instelling tegenover het politieke systeem wordt verlangd. De bevoegdheid om naturalisaties te verlenen ligt bij de Raad van State ${ }^{87}$ die op voordracht van de Minister van justitie bij een decreet zijn beslissing neemt (art. 27). Afwijzing van een beroep geschiedt evenwel door de Minister zelf. Beroep daartegen is niet mogelijk ( $\$ 17$ verordening). Betrokkene kan echter binnen twee maanden na de afwijzing van het verzoek kosteloos een nieuwe aanvraag indienen. Deze mogelijkheid kan althans theoretisch als een soort rechtsmiddel worden gezien.

Een naturalisatieverzoek moet worden ingediend bij het Ministerie van justitie (art. 26). Art. 25 lid 1 regelt uitdrukkelijk de vertegenwoordigingsproblematiek ten aanzien van minderjarigen ${ }^{88}$ die zelfstandig kunnen worden genaturaliseerd ${ }^{89}$ Kinderen tot 14 jaar dienen bij het indienen van een verzoek door hun ouders of voogd te worden vertegenwoordigd. 14 tot 16 -jarigen moeten het verzoek zelf indienen, dat echter door de ouders ${ }^{90}$ of pleegouders medeondergetekend dient te worden. Eventuele meningsverschillen tussen deze groep minderjarigen en hun ouder(s) of voogden worden door de Minister van justitie beslecht. Bepalingen betreffende kinderen onder 14 jaar, en die tussen 14 en 18 jaar gelden mutatis mutandis ook ten aanzien van personen, die (gedeeltelijk) onder curatele zijn gesteld ( $\$ 5$ verordening).

De vereisten om voor naturalisatie in aanmerking te komen zijn de volgende:

83. Op de casuistische aanpak van de wetgever wordt ook krittek uitgeoefend door Vulkanov, Pravaa misul 1984, p. 56.

84. Vulkanow, p. 65-67.

85. Vulkanov, p. 78 en in Pravna misul 1984/1, p. 57.

86. Ste nografische notulen van de vijffe Narodno sobranie (parlement), 7de vergadering, 1969, p. 160. Geciteerd door Vulkanov, p. 81.

87. Tot 1971 was dat het Presidium van het parlement dat bij de introductie wan het Raad vam State werd afgeschaft.

88. In Bulgarije wordt onderscheid gemaakt tussen "malotetieto", de leeftjd tot 14 jaar; "nepulnoletieto", kinderen tussen 14 en 18 jaar en "pulnoletieto", boven 18 jaar. Zie WGO 1968, p. 298; Bergmann/Ferid, p. 10.

89. Vulkanow, p. 80 .

90. Tenzij aan de ouder(s) de ouderlijke macht werd ontnomen. 
- ononderbroken vijfjarig verblijf in Bulgarije, onmiddellijk voorafgaande aan het verzoek (art. 8 lid 1);

- verlies van tegenwoordige nationaliteit (art. 8 lid 1) ${ }^{91}$;

- verklaring van goed gedrag bij personen boven 14 jaar (art. 8 sub a verordening).

Er bestaan ruime mogelijkheden om te kunnen worden genaturaliseerd zonder te voldoen aan de vereisten van art. 8 . Aan de volgende categorieën personen kan dispensatie van de vereisten van art. 8 worden verleend:

- degenen die aan de staat bijzondere diensten hebben bewezen (art. 9);

- etnische Bulgaren; van hen wordt echter wel geëist dat ze hun tegenwoordige nationaliteit "opgeven" 92 (art. 10);

- kinderen van (gewezen) Bulgaarse staatsburgers, of van én (gewezen) Bulgaar, indien de andere ouder staatloos of van onbekende nationaliteit is (art. 11);

- adoptief-kinderen van Bulgaren (art. 11);

- degenen die met een Bulgaar(se) zijn gehuwd (art. 12);

- erkende vluchtelingen (art. 13);

- kinderen met één Bulgaarse ouder, die nog geen 18 jaar oud zijn (art. 15).

\subsection{Hernaturalisatie}

Ook de huidige nationaliteitswet van Bulgarije kent een bijzondere regeling van naturalisatie van degenen die te eniger tijd de Bulgaarse nationaliteit bezaten. De procedure is hierbij dezelfde als bij de gewone naturalisatie. Vereisten voor hernaturalisatie zin de volgende:

- betrokkene moet zich opnieuw in Bulgarije vestigen;

- blijk geven van zijn positieve instelling tegenover het politieke systeem (art. 21);

91. Betrokkene moet afstand van zijn oude nationaliteit doen, respectievelijk een bewijs overleggen dat hij uit die nationaliteit werd, of na de naturalisatie zal worden ontslagen.

92. Hierbij wordt een verklaring, inhoudende dat de naturalisandus zijn oude nationaliteit "opgeeft" woldoende geacht. De vraag of de tegenwoordige nationaliteit van betrokkene inderdaad verloren gaat, is afhankelijk wan de vraag of het nationale recht van de naturalisandus afstand van de nationaliteit in dat geval toelaat. In Bulgarije is men zich kennelijk ervan bewust, dat betrokkene dikwijls zijn andere nationaliteit ondanks die verklaring behoudt en dus door naturalisatie (in het "beste" geval) bipatride wordt. Cf. Damjanov, Pravna misul 1984/4, p. 55; Vulkanov, p. 85. 
- een verklaring van goed gedrag overleggen (art. 12 sub f verordening).

Indien betrokkene de nationaliteit door ontneming verloor, is hernaturalisatie slechts mogelijk, indien het blijkt dat hem de nationaliteit ongegrond werd ontnomen, of dat de gronden voor ontneming intussen hun betekenis hebben verloren (art. 22 lid 1).

\subsection{Invloed op de nationaliteit van de gezinsleden van de verzoeker}

Medenaturalisatie van minderjarige kinderen wordt geregeld in artt. 14 en 24 (hernaturalisatie) van de wet van 1968. Kinderen onder 14 jaar worden automatisch ${ }^{93}$ medegenaturaliseerd, indien:

- aan hun beide ouders de nationaliteit wordt verleend, of

- één van de ouders wordt genaturaliseerd en de andere Bulgaar is of reeds is overleden (artt. 14, 24).

Kunderen tussen 14 en 18 jaar worden onder dezelfde voorwaarden de naturalisatie van hun ouder(s) deelachtig, indien deze kinderen zelf om de medenaturalisatie verzoeken (artt. 14, 24). Art. 14 zwijgt over het geval đat slechts én van de ouders om naturalisatie vraagt, hetgeen echter well door art. 24 lid 2 ten aanzien van hernaturalisatie van één ouder wordt geregeld. Aangezien beide regelingen dezelfde uitgangspunten ten aanzien van mede(her)naturalisatie van minderjarigen hanteren, kan deze lacune door art. 24 lid 2 worden opgevuld. Indien de naturalisandus tevens om medenaturalisatie van zijn minderjarige kinderen verzoekt, moet de andere ouder daarin toestemmen, tenzij aan deze ouder de ouderlijke macht werd ontnomen, of deze reeds is overleden.

\subsubsection{Verlies van de nationaliteit}

De Bulgaarse nationaliteit kan volgens de wet van 1968 worden verloren door ontslag, ontneming en door het herroepen van een naturalisatiebesluit. Het verlies van het staatsburgerschap van rechtswege en door het afleggen van een verklaring van afstand kent het huidige Bulgaarse nationaliteitsrecht niet.

\subsubsection{Ontslag}

Het ontslag uit de Bulgaarse nationaliteit wordt geregeld in de artt. 16-18 van de wet van 1968. Deze wijze van verlies van de nationaliteit is voornamelijk voorzien voor het geval dat betrokkene een vreemde nationaliteit heeft verworven, of verwerven wil. Zo bepaalt het eerste lid van art. 16 dat een Bulgaar niet een vreemde nationaliteit mag verkrijgen of behouden, zonder dat hij uit de Bulgaarse eerst wordt ontslagen ${ }^{94}$. In tegenstelling tot zijn voorganger uit 1948 kent deze wet

93. Vulkanov, p. 93 en in Pravna misul 1984/1 p. 57, spreekt hier van het enige geval van een subjectief recht op naturalisatie.

94. Vulkanov, Pravna misul $1984 / 1$, p. 57. 
echter geen straffen voor verkrijging, respectievelijk bezit van een vreemde nationaliteit.

De vereisten om uit de Bulgaarse nationaliteit te worden ontslagen zijn in art. 17 geformuleerd. Een ontslag kan niet worden verleend zolang:

- betrokkene niet bepaalde op hem rustende verplichtingen heeft geregeld of zekerheid daarvoor heeft gesteld; het gaat om verplichtingen tegenover de staat, staatsbedrijven, maatschappelijke organisaties, verplichtingen uit onrechtmatige daad, of alimentatieverplichtingen (lid 1);

- een man die ouder dan 17 jaar is, zijn militaire dienstplicht niet heeft vervuld ( 811 lid 1 sub $f$ verordening);

- tegen betrokkene een strafrechtelijke procedure aanhangig is (lid 2);

- de verzoeker werd veroordeeld en de straf nog niet is voltrokken (lid 3).

Daarnaast bevat art. 17 lid 4 nog een zeer algemeen geformuleerd ontslagverbod voor het geval dat zich de belangen van staatsveiligheid of andere belangrijke gronden tegen de inwilliging van een ontslagverzoek verzetten. Het ligt voor de hand dat deze vage formule een onbeperkte mogelijkheid voor de meest willekeurige ontslagweigeringen biedt ${ }^{95}$. Tegen een weigering van een verzoek zijn geen rechtsmiddelen toegelaten (art. 17 verordening). De regels betreffende de bij een ontslag te volgen procedure zijn dezelfde als bij naturalisaties. De beslissing wordt genomen bij een decreet van de Raad van State, op voordracht van de Minister van justitie (art. 27). Aan een verzoeker die (nog) in Bulgarije woont, wordt het ontslag steeds verleend onder de ontbindende voorwaarde dat hij binnen één jaar na de verlening een vreemde nationaliteit verwerft, of althans het land verlaat (art. 16 lid 2 jo. art. 29 van de nationaliteitswet jo. $\$ 20$ lid 3 verordening) ${ }^{96}$.

Nauw met het ontslag uit de nationaliteit is verbonden de mogelijkheid om het land te verlaten, waarvoor een bijzondere toestemming wordt vereist. Deze kan willekeurig worden geweigerd en is in het geval dat betrokkene niet tot een etnische minderheid behoort, bijna onmogelijk te verkrijgen. Aan het verlenen van de toestemming is het betalen van een bedrag ter hoogte van ongeveer het gemiddelde maandloon verbonden. Daarnaast moet men de kosten van de genoten schoolopleiding betalen ${ }^{97}$.

Tot de reeds genoemde wetswijziging in 1986 voorzag de wet in een aparte ontslagmogelijkheid ten aanzien van personen van niet-Bulgaarse etnische afstamming die het land wilden verlaten ${ }^{28}$. Deze verloren de nationaliteit door het enkele feit, dat zij uit Bulgarije emigreerden (art. 16 lid 2). Op het eerste gezicht lijkt het vreemd, dat het nationaliteitsrecht van een socialistisch land toe zou laten, dat betrokkene eigenwillig omtrent het bezit van zijn nationaliteit beslist. Aangetekend dient te worden, dat deze bepaling slechts toepassing vond, indien betrokkene met

95. Vulkanov, p. 99-100 wijst er uitdrukkelijk op dat de verzoeker geen recht op ontslag heeft.

96. Vulkanov, p. 106-107.

97. Zie daarover Menschenrechte, p. 109, 126; Kuss, EuGRZ 1987, p. 310-311.

98. Vulkanov, p. 113. 
voorafgaande toestemming van de Raad van State emigreerde 99 . Het ging derhalve slechts pro forma om verlies van rechtswege, in wezen kwam het echter op verlies van de nationaliteit door ontslag neer.

De wet noemde geen vereisten voor het verkrijgen van een vergunning tot emigratie. Volgens Vulkanov ${ }^{100}$ mocht worden aangenomen dat de voorwaarden voor het verkrijgen van het ontslag uit de nationaliteit analoog werden toegepast. Het verlies trad ook in, indien betrokkene daardoor staatloos werd. Door Vulkanov ${ }^{101}$ werd in dit verband terecht opgemerkt, dat het wenselijk ware, dat in de procedure tot verkrijging van een emigratievergunning het bewijs van bezit, respectievelijk waarschijnlijke verkrijging van een andere nationaliteit zou worden geëist.

\subsection{Invloed op de nationaliteit van de gezinsleden van de verzoeker}

Minderjarige kinderen worden nooit automatisch met hun ouder(s) medeontslagen ${ }^{102}$. Kinderen onder 14 jaar worden medeontslagen indien beide ouders om het ontslag verzoeken en het verzoek mede namens de kinderen wordt ingediend. Bij kinderen tussen 14 en 18 jaar wordt tevens hun eigen toestemming vereist (art. 18 lid 1). Wordt slechts eén van de ouders ontslagen, dan is voor het medeontslag van minderjarige kinderen tevens de toestemming van de andere ouder vereist, tenzij aan hem de ouderlijke macht werd ontnomen (lid 2). Op grond van de strekking van deze bepaling mag worden aangenomen, dat de toestemming van de andere ouder niet nodig is, indien deze reeds overleden is, of indien hij/zij de Bulgaarse nationaliteit niet bezit.

\subsubsection{Ontneming en herroeping van naturalisatie}

Ontneming van de Bulgaarse nationaliteit wordt geregeld in art. 20 van de wet van 1968. Deze wijze van verlies van het staatsburgerschap wordt in de praktijk betrekkelijk zelden toegepast ${ }^{103}$. Ook in dit geval gelden dezelfde competentieregels als bij de naturalisatie en ontslag (art. 27).

De nationaliteit kan slechts worden ontnomen aan personen die zich in het buitenland bevinden ${ }^{104}$ en op de volgende gronden:

illegale grensoverschrijding ( lid 1 sub a) ${ }^{105}$;

99. Vulkanov, Pravna misul $1984 / 1$, p. 57.

100. Vulkanov, p. 112-113.

101. Vulkanov, Pravna misul 1984/1, p. 57.

102. Vulkanov, p. 110-111.

103. Vulkanov, Pravna misul 1984/1, p. 58.

104. Vulkanov p. 117 onder verwijzing van de stenografische notulen van de vijfde Narodno sobranie (parlement), 7de vergadering, 1968, p. 161

105. Het is daarbij niet relevant of betrokkene het oogmerk had naar Bullgarije terug te keren of niet. Vulkanow, p. 119. Zie over deze ontnemingsgrond ook Geilke en Lipowschek, WGO 1966, p. 158168. Zie ook artt. 101 en 279-281 van het Bulgaarse wetboek van strafrecht van 15 maart 1968. "Republikflucht" kan met gevangenisstraf tot 5 jaar worden bestraft. 
- overschrijding van het toegestane verblijf in het buitenland met meer dan zes maanden zonder gewichtige redenen (sub b) ${ }^{106 ;}$

- het ontwijken van militaire dienstplicht of van een mobilisatieoproep door verblijf in het buitenland (sub c);

- het zonder toestemming treden in vreemde militaire of staatsdienst (sub d);

- handelingen die de staatsveiligheid of andere belangen van de staat kunnen schaden (sub e) ${ }^{107}$;

- $\quad$ een Bulgaars staatsburger onwaardig gedrag (sub f);

- verkrijging van een vreemde nationaliteit in strijd met de wet (sub g) ${ }^{108}$.

De zogenaamde "Republikflucht" is weliswaar een grond voor ontneming van de nationaliteit, doch in de praktijk worden de illegale emigranten in het bezit van het Bulgaarse staatsburgerschap gelaten. Op grond van een in 1983 ingevoerde wijziging van de paspoortwet is het mogelijk om het verblijf in het buitenland te "legaliseren". Daarvoor is vereist dat betrokkene vóor 1 januari 1982 het land heeft verlaten, of vanwege huwelijk met een vreemdeling(e) reeds sedert vijf jaren in het buitenland woont. Bovendien moest men door zijn gedrag loyaliteit tegenover Bulgarije hebben bewezen ${ }^{109}$.

Uit de formulering van art. 20 blijkt dat de Raad van State ook hier een onbeperkte discretionaire bevoegdheid heeft. Interessant is, dat Vulkanov ${ }^{110} \mathrm{dit}$ uitsluitend als een voordeel voor betrokkene ziet; ook al voldoet hij aan de vereisten voor ontneming, hij kan eventueel zijn staatsburgerschap toch nog behouden. Bij mij roept een dergelijk voordeel echter de nodige twijfels op. Naar mijn mening heeft de justitiabele namelijk meer behoefte aan rechtszekerheid en aan een overheid die niet alles mag doen wat zij zelf wil.

Een consequentie van ontneming van de nationaliteit op gronden onder a $t / \mathrm{m}$ e genoemd is, dat het vermogen van betrokkene moet worden geconfisceerd. Dit automatisme wordt bekritiseerd door Vulkanow ${ }^{111}$ die stelt, dat door een dergelijke maatregel in de eerste plaats de familieleden worden getroffen. In de andere twee gevallen van ontneming kan van confiscatie worden afgezien. De nationaliteit kan ook worden ontnomen indien betrokkene daardoor staatloos wordt ${ }^{112}$. Ondanks

106. Als voorbeeld van een gewichtige reden noemt Vulkanov, p. 120, ziekte wan betrokkene of wan züju familieleden.

107. Het is voldoende dat de handeling vam betrokkene "gevaar" voor de bellangen wan de stat oplevert. Vulkanov, p. 123.

108. Hier moet in de eerste plaats worden gedacht aan naturalisatie in een ander land zonder voorafgaand ontslag uit de Bulgaarse nationaliteit. Vulkanov, p. 124. Het moet in elk gevall om een vrijwillige verkrijging van de nationaliteit gaan, niet bijvoorbeeld verkrijging door huwelijk. Vulkanov, p. 124-125.

109. Zie het wijzigingsdecreet gepubliceerd in D.V. 1983, nr. 50; daarover Menschenrechte, p. 112. Kuss, EuGRZ 1987, p. 311.

110. Vulkanow, p. 118.

111. Vulkanow, Pravna misul $1984 / 1$, p. 58.

112. Vulkanow, p. 118 en in Pravna misul $1984 / 1$, p. 58. 
deze uitvoerige opsomming van ontnemingsgronden geven met name de gronden onder $b$, e en $f$ door hun ruime formulering voldoende ruimte om de nationaliteit willekeurig te ontnemen ${ }^{113}$. Tegen ontneming van de nationaliteit staan geen rechtsmiddelen open.

\subsection{Herroeping van een naturalisatiebesluit}

De wet van 1968 biedt ook enkele mogelijkheden om een naturalisatie te herroepen. Zulks is mogelijk binnen 5 jaar na de verlening van de nationaliteit. Een naturalisatiebesluit kan worden herroepen, indien betrokkene bij zijn naturalisatie gebruik heeft gemaakt van valse gegevens of onjuiste feiten (art. 19 lid 1$)^{114}$.

\subsection{Invloed op de nationaliteit van gezinsleden van betrokkene}

Ontneming van de nationaliteit heeft geen invloed op de nationaliteit van de echtgeno(o)t(e) van betrokkene (art. 20 lid 2).

Herroeping van een naturalisatie werkt tevens ten aanzien van ex art. 14 meegenaturaliseerde kinderen van betrokkene, indien zij ook op grond van valse gegevens of onjuiste feiten werden genaturaliseerd (lid 2). Volgens Vulkanov ${ }^{115}$ kan de Raad van State uit overwegingen van humanitaire aard afzien van herroeping van de naturalisatie ten aanzien van kinderen die daardoor staatloos zouden worden.

113. Volgens. Vulkanow, p. 118 mogen de wettelijke ontnemingsgronden niet analoog worden toegepast. Gezien de vaagheid van deze ontnemingsgronden is een dergelijke "garantie" helaas illusoir.

114. Vulkanov, Pravna misul 1984/1, p. 54.

115. Vulkanov, p. 14-15. 


\section{HOOFDSTUK 5. DUITSLAND/DDR}

\subsection{GESCHIEDENIS}

\subsubsection{Inleiding}

Het Duitse keizerrijk ontstond in 1871 door vereniging van de Noordduitse bond met de Zuidduitse staten op grond van verdragen van Versailles van november 1870. De koning van Pruisen werd de Duitse keizer" ${ }^{1}$. De eerste constitutie van het Duitse Rijk werd geproclameerd in Versailles in $1871^{2}$. Duitsland was een federaal keizerrijk, bestaande uit 25 bondsstaten ${ }^{3}$. $\mathrm{Na}$ de eerste wereldoorlog verloor Duitsland bij de regeling van het vredesverdrag van Versailles ${ }^{4}$ de volgende gebieden: Elsass-Lothringen (Alsace-Lorraine) aan Frankrijk, Eupen, Malmedy en Moresnet aan België, Noordschleswig aan Denemarken, Memelgebied, Posen (Poznan), Westpreussen en Obersilezien aan Polen, het Hultschiner Ländchen aan Tsjechoslowakije en Memelgebied aan Litouwen. Saarland kreeg een aparte status, terwijl Danzig (Gdansk) vrije stad werd ${ }^{5}$. Op 18 juni 1919 veranderde de staatsvorm in een republiek. De eerste grondwet van de nieuwe republiek, de zogenaamde Weimarer Verfassung werd op 11 augustus 1919 afgekondigd ${ }^{6}$. In 1932 won de Nazionalsozialistische Deutsche Arbeiterpartei (NSDAP) de parlementsverkiezingen en op 30 januari 1933 kwam Hitler aan de macht?. Op 13 maart 1938 werd Oostenrijk bij het Duitse rijk ingelijfd ${ }^{8}$. In hetzelfde jaar volgde op grond van het verdrag van München van 29 september 1938 annexatie van het Tsjechoslowaakse Sudetengebied, dat hoofdzakelijk door etnische Duitsers werd bevolkt ${ }^{9}$. In maart 1939 werden vervolgens ook de Tsjechoslowaakse gebieden Bohemen en Moravië (Böhmen en Mähren) ingelijfd ${ }^{10}$. Op 23 augustus 1939 sloot Duitsland een niet-aanvalsverdrag met de USSR dat een geheim protocol betreffende verdeling van interessesferen in Europa bevatte. Op 9 september 1939 marcheerde het Duitse leger vervolgens in Polen, hetgeen als het begin van de tweede wereldoorlog wordt beschouwd. Het Poolse grondgebied werd bij het grens- en vriendschapsverdrag van 28 september $1939^{11}$ tussen Duitsland en de USSR verdeeld. Een gedeelte van Polen en de vrije stad Danzig werd bij Duitsland ingelijfd (Eingegliederte

1. Zie over de verdragen van november 1870 Huber deell 3, p. 732-737 en over het ontstaan wan het keizerrijk, p. 760 .

2. In werking getreden op 16 april $1871 . L D G$, p. 17 .

3. Preussen, Bayern, Sachsen, Würtenberg, Baden, Hessen, Mecklenburg-Schwerin, Braunschweig en andere kleüinere bondssitaten (art. 1 grondwet).

4. In werking getreden op 10 januari 1920 . Zie ook de daarop betrekking hebbende wet van 16 juli 1919; RGBI. (Reichsgesetzblatt), p. 678; Huber deel 7, p. 17-18; Schleser, p. 65.

5. Schleser, p. 65-66; Huber deell 6, p. 471-472.

6. RGBl 1919, p. 1383; Huber deel 5, p. 1204 .

7. Huber deel 7, p. 1261-1266.

8. Wet van 13 maart 1938, RGB1. 1, p. 237. Zie ook Zieger 1980, p. 104.

9. Schmid, p. 20; Further Documents, p. 3-4; Táborsky, p. 5-21. Zie voorts Gesetz über die Wiedervereinigung der sudetendeutschen Gebiete mit dem deutschen Reich van 21 november 1938 (RGBI. I, p. 1641). De tekst is afgedrukt bij Schmid, p. 78.

10. Táborsky, p. 39; SGS deel 18, 1e druk, p. 26; Schmid, p. $21-22$.

11. RGBL. 1940, 1, p. 3; SGS deel 9, p. 15; Arnold, ZfoR 1940-41, p. 149. Zie ook het aanwullende protocol van 4 oktober 1940, RGBI. II, nr. 5; afgedrukt in ZfoR 1939, p. 303-304. 
Ostgebiete), een ander als "Generalgouvernement" onder Duits bestuur gebracht ${ }^{12}$. In de loop der oorlogsjaren werden aan Duitsland nog de volgende gebieden toegevoegd: Eupen, Malmedy en Moresnet, Elsass-Lothringen, Luxemburg, een deel van Joegoslavië en Oekraïne.

Duitsland capituleerde op 8 mei 1945 en werd op grond van het protocol van Londen van 12 september 1944 uiteindelijk in vier bezettingszones (Amerikaanse, Britse, Franse en de USSR-) verdeeld ${ }^{13}$. Het geoccupeerde gebied omvatte Duitsland binnen de grenzen van 31 december 1937. Alle latere grondgebiedsveranderingen werden door de geallieerden als nietig beschouwd Berlijn werd daarbij apart, eveneens in vier zones verdeeld ${ }^{14}$. Op 1 augustus 1948 werden alle Westerse zones tot één gebied verenigd ${ }^{15}$. Op 8 mei 1949 werd door het voorlopige parlement op het grondgebied van de westerse bezettingszone de eerste grondwet van de Bondsrepubliek Duitsland (BRD) aangenomen ${ }^{16}$. Op 23 oktober 1954 werd in Parijs het Duitse staatsverdrag gesloten en op 5 mei 1955 toen dit verdrag in werking trad, werd de bezetting van de inmiddels ontstane BRD ook formeel beëindigd ${ }^{17}$.

In de Sovjet-bezettingszone werden reeds in de jaren 1945-1948 hervormingen van de rechterlijke organisatie gerealiseerd en werden de linkse politieke partijen verenigd in de Sozialistische Einheitspartei Deutschlands (SED) die echter door de communisten werd beheerst ${ }^{18}$. Op 30 mei 1949 werd vervolgens de constitutie van de nieuw ontstane DDR afgekondigd, die op 7 oktober van hetzelfde jaar in werking trad ${ }^{19}$. De grondwet van de DDR werd vervolgens in 1968 en 1974 grondig herzien ${ }^{20}$

De DDR behield niet de federale structur en werd een eenheidsstaat. Op 6 juli 1950 sloot de DDR een grensverdrag met Polen ${ }^{21}$. Op 25 januari 1955 werd het vredeswerdrag tussen de USSR en de DDR ondertekend, waarna op 22 september 1955 de bezetting werd opgeheven ${ }^{22}$. Op 27 januari 1956 trad de DDR toe tot het Warschaupact en is reeds sedert 1950 lid van de COMECON.

Zowel de BRD als andere Westerse landen weigerden zeer lang het bestaan van de DDR te erkennen. In de Bondsrepubliek sprak men met betrekking tot de DDR als over de SBZ (sowjetische Besatzungszone). De verhouding tussen beide

12. Zie de decreten van Hitler van 8 oktober 1939; RGBil. I, p. 2042, ook afigedrukt in ZfoR 193940, p. 215 (met betrekking tot de inlijving) en van 12 oktober 1939, RGBI I, p. 2077 , afgedrukt in ZfoR 1939.40, p. 217 (betreffende het Generalgouwernement). Zie daarover Arnold, ZfoR $1940-41$, p. 148-149.

13. UNTS 227,299 ; Zie daarover Benda t.a., p. 30-31; Peaslee, p. 358.

14. Benda e.a., p. 30-31.

15. Peaslee, p. 358.

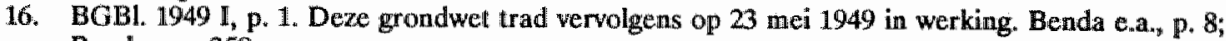
Peaslee, p. 358.

17. RGBI. 1955 , p. 215 ; Benda, p. 8; Peaslee, p. 358.

18. Schmid 1982, p. 44-45; Peaslee, p. 332.

19. GBI. (Gesetzblatt) DDR 1949, p. 5; Schmid 1982, p. 46; Peaslee, p. 332.

20. Zie over de grondwetten van de DDR. Schmid, Die Verfassungssysteme der Bundesrepublik Deutschland und der DDR, eine vergleichende Darstellung Berlin (West) 1982; Roggemann, Die DDR-Verfassungen, Berlin (West) 1980, 3de druk.

21. Bardach e.a., p. 631; Schultz, JöR 1954, p. 368 .

22. Peaslee, p. 332 . 
Duitslanden werd vervolgens geregeld in het zogenaamde "Grundlagenvertrag" van 21 december $1972^{23}$.

\subsubsection{Het nationaliteitsrecht voor 1945}

\subsubsection{Het RuStAG 1913}

\subsection{Algemeen}

Het nationaliteitsrecht van het Duitse rijk was geregeld in het Reichs- und Staatsangehörigkeitsgesetz (RuStAG) van 22 juli $1913^{24}$. Deze wet verving de oude Pruisische regeling van de nationaliteit van de Noordduitse bond van $1870^{25}$. Het RuStAG werd in de loop der jaren meermalen werd gewijzigd ${ }^{26}$ en vormt nog steeds de basis van de huidige nationaliteitsregeling van de Duitse Bondsrepubliek. In de DDR gold het RuStAG tot 23 februari $1967^{27}$.

Het Keizerrijk Duitsland was in de tijd van de invoering van het RuStAG een federale staat. Gezien zijn federale structuur kende Duitsland zowel de federale "Reichsangehörigkeit" als de nationaliteiten van de afzonderlijke bondsstaten "Staatsangehörigkeit". De federale nationaliteit werd in de regel verkregen via verwerving van de nationaliteit van een der bondsstaten; iedere staatsburger van een bondsstaat bezat krachtens $\$ 1$ lid 1 namelijk tevens de "Reichsangehörigkeit". Daarnaast was het echter mogelijk uitsluitend de federale nationaliteit te bezitten. Regels daaromtrent bevatten de $\$$ 33-35 RuStAG.

Onder het nationaalsocialistische bewind heeft men de regeling van verkrijging en verlies van de nationaliteit van het RuStAG door enkele wijzigingswetten en verordeningen gewijzigd. Er werden ondermeer de volgende voor het nationaliteitsrecht van belang zijnde regelingen afgekondigd:

- verordening van 5 februari $1934^{28}$ waardoor de nationaliteit van de bondsstaten werd afgeschaft ${ }^{29}$;

23. BGBL(Bundesgesetzblatt) $1973 \mathrm{II}$, p. 423 .

24. RGBL 1913, p 583; in werking getreden op 1 januari 1914. Zie Schleser, p. 58. Franse vertaling afgedrukt in RDIP 1913, p. 971-978. Zie daarover Cahm, Reichs- und Staatsangehörigkeitsgesetz, 4e druk, Berlin 1914 en in RDIP 1913, p. 321-337; De Lapradelle/Niboyet, p. 514-522.

25. BGBL. van de Noordduitse bond 1870 nr. 20, p. 355. Zie daarover Cahn, Das Reichsgesetz über die Erwerbung und den Verhust der Reichs- und Staatsangehörigkeit vom 1. Juni 1870, Berlin/Leipzig 1889.

26. Het RuStAG werd gewijzigd bij wetten van: 5 nowember 1923, RGBI I, p. 1077; 5 februari 1934, RGBI. I, p. 85; 25 meil 1935, RGBl. I, p. 593; en 20 januari 1942, RGBI. I, p. 40. In de BRD werd de nationaliteitswet vervolgens nog gewijzigd bij wetten van 14 juli 1953 , BGBI. I, p. 551, 19 augustus 1957, BGBl. I, p. 1251; 30 augustus 1960, BGBl. I, p. 721; 19 december 1963, BGBl. I, p. $982 ; 8$ augustus 1969, BGBI. I, p. 1581; 23 jwni 1970, BGBI. I, p. 805; 20 december 1974, BGBl. I, p. 3714; 10 maart 1975, BGBI. I, p. 685; 2 juli 1976, BGBl. I, p. 1749; 29 juni 1977, BGBI. I, p. $1101 ; 18$ juli 1979. BGBI. I, p. 1061 .

27. Op die dag trad de thans geldende nationaliteitswet wan de DDR in werking.

28. RGBI. I, p. 85; afgedrukt in SGS deel 35, p. 26-27.

29. Zie 1: "Die Staatsangehörigkeit in den deutschen Ländern faltt fort. Es gibt nur noch eine Deutsche Staatsangehörigkeit (Reichsangehörigkeit)". 
- wet van 15 mei $1935^{30}$ waardoor de "Einbürgerungsansprüche" werden afgeschaft; bovendien werd bij deze wet ten aanzien van naturalisaties steeds de toestemming van de Rijksminister van binnenlandse zaken voorgeschreven;

- het Reichsbürgerschaftsgesetz van 15 september $1935^{31}$; bij deze wet werd onderscheid gemaakt tussen arische en regimegetrouwe "Reichsbürger" die de politieke rechten hadden en "Staatsangehörigen" die deze niet hadden ${ }^{32}$.

- verordening van 25 november $1941^{33}$ betreffende ontneming van de nationaliteit aan Joodse emigranten.

\subsection{Verkrijging van de nationaliteit}

De Duitse nationaliteit werd volgens de wet van 1913 verkregen van rechtswege en door naturalisatie. Verkrijging van het staatsburgerschap door het afleggen van een verklaring van optie kende deze regeling niet. Wel werd aan een aantal categorieën naturalisandi een soort recht op naturalisatie, een zogenaamde "Einbürgerungsanspruch" verleend (zie p. 148).

\section{a. Verkrijging van rechtswege}

Van rechtswege werd verkrijging van het Duitse staatsburgerschap gekoppeld aan de volgende rechtsfeiten:

- geboorte uit Duitse ouder(s) $(\S 4,5)$;

- $\quad$ het gevonden worden op Duits grondgebied $(\$ 4)$;

- $\quad$ huwelijk met een Duitser ( $\$ 6)$;

Adoptie door Duitse ouders kon geen verkrijging van de nationaliteit ipso iure bewerkstelligen.

\section{i. Geboorte uit Duitse ouder(s)}

Krachtens par 4 lid 1 RuStAG verkreeg een wettig kind de Duitse nationaliteit, indien zijn vader op het ogenblik van de geboorte van het kind Duitser was. Een onwettig kind ontleende zijn nationaliteit aan zijn Duitse moeder, zonder dat het eerst door de moeder moest worden erkend.

Voorts verwierf een buitenechtelijk kind van een vreemdelinge de Duitse nationaliteit in het geval dat het door een Duitser werd gewettigd ( $\$ 5$ ). Dit gold

30. RGBl. 1935 I, p. 593; afgedrukt in SGS deel 35, p. 27.

31. RGBl. 1935 I, p. 1146. Daarover Riege, p. 39-42; Makarow/von Mangoldt, p. 15; Stuckart/Globke, p. 50-58.

32. Zie \$ 2 lid 1: "Reichsbürger ist nur der Staatsangehörige deutschen oder artverwandten Blutes, der durch sein Verhalten beweist dass er gewillt und geeignet ist, in Treue dem Deutschen Volk und Reich zu dienen". Zie ook Riege, p. 39; Stuckart/Globke, p. 55.

33. RGBI. I, p. 722. Schleser, p. 70-71. 
echter niet ten aanzien van reeds gehuwde dochters. Bij hen was het staatsburgerschap van hun man maatgevend. De legitimatie moest echter volgens de voorschriften van het Duitse recht hebben plaatsgevonden. Het staatsburgerschap werd zelfs verkregen indien het kind op het tijdstip van wettiging reeds meerderjarig was. Door een enkele erkenning of gerechtelijke vaststelling van vaderschap werd de verkrijging van de Duitse nationaliteit niet bewerkstelligd ${ }^{34}$.

\section{ii. Vondelingen}

Een kind dat op het Duitse grondgebied werd gevonden, werd geacht Duitse staatsburger te zijn, totdat het tegendeel werd bewezen ( $\$ 4$ lid 2 ). Het ging hierbij om een praesumptio iuris, waartegen bewijs steeds mogelijk was, ongeacht de leeftijd van het kind. Een kind van staatloze ouders dat in Duitsland werd geboren, verwierf op grond van zijn geboorte op het Duitse grondgebied de Duitse nationaliteit niet en werd derhalve apatride.

\section{iii. Huwelijk met een Duitser}

Een buitenlandse vrouw, die met een Duitser in het huwelijk trad, verkreeg krachtens § 6 RuStAG van rechtswege de Duitse nationaliteit. Het staatsburgerschap werd verworven ongeacht of betrokkene door of in verband met het huwelijk haar oude staatsburgerschap verloor. Ze had geen mogelijkheid de nationaliteitsverkrijging door een verklaring te voorkomen.

\section{b. Naturalisatie}

Het RuStAG kende naast de gewone, ook een soort verlichte naturalisatie, waarbij aan bepaalde categorieën verzoekers zogenaamde "Einbürgerungsansprüche" werden toegekend. In die gevallen had betrokkene een recht op naturalisatie.

De bevoegdheid om naturalisatie te verlenen lag bij de regeringen van de bondsstaten. Interessant is, dat van de zijde van de andere bondsstaten bezwaren tegen een naturalisatie konden worden geuit ( $\$ 9$ lid 1$)$. Deze bepaling werd opgenomen vanwege het feit dat iemand die in én bondsstaat werd genaturaliseerd, zich na de naturalisatie ook in de andere bondsstaten kon vestigen ${ }^{35}$. De naturalisatievereisten waren geregeld in $\$ 8$ RuStAG. Om voor de verlening van de nationaliteit in aanmerking te komen, moest de verzoeker aan de volgende vereisten voldoen:

- handelingsbekwaamheid ${ }^{36}$ (onbekwamen konden echter door tussenkomst van hun wettelijke vertegenwoordiger worden genaturaliseerd) (lid 1 sub 1);

- goed gedrag (lid 1 sub 2);

34. RDIP 1913, p. 956.

35. RDIP 1913, p. 957.

36. Het was voldoende dat betrokkene hetzij naar zijn nationaal rechi, hetzij naar Duits recht handelingsbekwaam was. 
- betrokkene moest in staat zijn om inkomsten te verwerven;

- het bezit wan een eigen woning of een eigen onderkomen;

- hij moest in staat zijn om zichzelf en zijn familie te onderhouden (sub 4);

- woonplaats in Duitsland; er werd echter geen verblijf van een bepaalde duur geëist.

Reeds uit het feit dat de naturalisatie volgens de wettekst kon worden verleend, blijkt dat de wet aan de administratie voldoende ruimte gaf naar eigen inzicht te handelen. Deze vrijheid ging zelfs zover, dat de regering het recht had een naturalisatie te weigeren in het geval dat betrokkene aan alle in de wet genoemde naturalisatievereisten voldeed ${ }^{37}$.

\section{i. De "Einbürgerungsansprüche"}

Aan bepaalde groepen personen werden zogenaamde "Einbürgerungsansprüche" toegekend. Dit waren:

- vrouwen, die de Duitse nationaliteit door huwelijk met een buitenlander hadden verloren, nadat het huwelijk werd ontbonden en ze naar Duitsland terugkeerden $(\$ 10)$.

- degenen die hun nationaliteit tijdens de minderjarigheid door ontslag van hun ouders hadden verloren $(\$ 11)$;

- personen die minstens een jaar in Duitse militaire dienst hadden gediend ( $\$$ 12);

- oud-Duitsers (voor hen golden iets stringentere voorwaarden dan voor de in $\$ 11$ bedoelde groep) ( $\$ 13)$.

Deze regeling werd in 1935 door de nazi's geschrapt ${ }^{38}$ en na de val van het Derde rijk opnieuw in het Duitse nationaliteitsrecht ingevoerd.

\section{ii. Invloed op de nationaliteit van de gezinsleden van de verzoeker}

Een naturalisatie strekte zich mede uit over de vrouw en minderjarige kinderen van de verzoeker, tenzij er een uitdrukkelijk voorbehoud werd gemaakt $(\S 12)^{39}$. Noch de vrouw noch de kinderen hadden een mogelijkheid om verkrijging van de nationaliteit te voorkomen. Voorts was het voor de vrouw na de ontbinding van het

37. Illustratief zijn in dit verband de woorden van Cahn, p. 59: "Es bleibt den Einzelstaaten anheimgegeben, Ausländern die Einbürgerung zu verweigern, auch wenn Sie den Voraussetzungen des $\$ 8$ genügen, oder die Einbürgerung von noch weilteren, in $\$ 8$ nicht aufgeführten Bedingungen abhängig zu machen".

38. Zie $\$ 2$ van wet van 2 mei 1935, RGBl. 1935 I, p. 593; afgedrukt in SGS deel 35, p. 27.

39. RDIP 1913, p. 957. 
huwelijk of voor de kinderen na het bereiken van de meerderjarigheid, ook niet mogelijk om de Duitse nationaliteit op eenvoudige wrijze te verliezen. Reeds gehuwde dochters van naturalisandi waren echter steeds van medenaturalisatie uitgesloten.

\subsection{Verlies van de nationaliteit}

De Duitse nationaliteit kon worden verloren van rechtswege, door ontslag en door ontneming. Het verlies van het staatsburgerschap door het afleggen van een verklaring van afstand kende het RuStAG niet.

\section{a. Verlies van rechtswege}

Ingevolge de regeling van het RuStAG van 1913 ging de Duitse nationaliteit van rechtswege verloren in de volgende gevallen:

- door wettiging door een vreemdeling ( $\$ 17)$;

- $\quad$ door huwelijk met een vreemdeling $(\$ 17)$;

- vrijwillige verkrijging van een andere nationaliteit (\$25);

- in bepaalde gevallen wegens het niet-vervullen van de militaire dienstplicht ( $\delta$ 26).

Erkenning of adoptie konden geen verlies van de Duitse nationaliteit bewerkstelligen, zelfs niet, indien betrokkene de nationaliteit van de erkenner, respectievelijk de adoptief-ouder(s) verwierf.

\section{i. Legitimatie door een vreemdeling}

Een buitenechtelijk kind van een Duitse vrouw dat door een vreemdeling werd gewettigd, verloor daardoor de Duitse nationaliteit ( $\$ 17$ sub 5). De legitimatie moest naar Duitse recht geschieden, of in Duitsland erkend zijn ${ }^{40}$. Betrokkene verloor zijn staatsburgerschap zelfs indien hij reeds meerderjarig was. Reeds gehuwde vrouwen verloren hun nationaliteit door wettiging evenwel niet.

\section{ii. Huwelijk met een vreemdeling}

Conform het beginsel van de eenheid van de nationaliteit in een gezin (système unitaire) verloor een Duitse vrouw, die met een buitenlander een huwelijk sloot haar nationaliteit ( $\& 17$ sub 6). Het staatsburgerschap ging verloren zelfs in het geval dat ze niet automatisch de nationaliteit van haar man verkreeg en ze derhalve staatloos werd. $\mathrm{Na}$ de ontbinding van het huwelijk had betrokkene tot 1935 een "Einbürgerungsanspruch".

40. RDIP 1913, p. 962. 


\section{iii. Vrijwillige verkrijging van een andere nationaliteit}

De Duitse nationaliteit ging ook van rechtswege verloren door vrijwillige verkrijging van een andere nationaliteit. Daartoe werd tevens vereist dat betrokkene zijn woonof verblijfplaats in het buitenland had ( $\$ 25$ lid 1). De nationaliteit ging niet verloren, indien betrokkene een voorafgaande toestemming van de Duitse bondsstaat van zijn herkomst verkreeg (lid 2). Deze uitzondering werd opgenomen om Duitse ondernemers in het buitenland de mogelijkheild te geven om eigendomsrechten te kunnen verwerven in landen waarin daarwoor het bezit van de nationaliteit van dat land werd geëist ${ }^{41}$.

\section{iv. Het miet venullen van militaire dienstplicht}

Duitsers die in het buitenland woonden, verloren in bepaalde gevallen op hun 31ste verjaardag automatisch hun nationaliteit wegens het niet vervullen van de militaire dienstplicht in Duitsland ( $\$ 26$ ). Dit verliesgrond kwam waarschijnlijk geheel te vervallen bijeen verordening van 20 . januari $1942^{42}$

\section{b. Ontslag}

De mogelijkheid van ontslag uit de Duitse nationaliteit werd geregeld in $\& 18-24$ RuStAG. De bevoegdheid lag bij de regeringen van de bondsstaten. Er werden geen positief geformuleerde vereisten genoemd. $\$ 22$ bevatte in het eerste lid "ontslagverboden" ten aanzien van bepaalde categorieën personen, die verband hielden met verschillende vormen van militaire dienstplicht. Het tweede lid bepaalde voorts dat in vredestijd het ontslag op andere gronden dan in lid 1 genoemde, niet kon worden geweigerd. Deze bepaling gaf derhalve een zeker recht op het verkrijgen van het ontslag.

Ontslag werd steeds verleend onder de ontbindende voorwaarde dat betrokkene binnen eén jaar zijn woon- of verblijfplaats naar het buitenland verplaatste ( $\$ 24)$.

Een ontslagverzoek ten aanzien van een gehuwde vrouw kon slechts door haar echtgenoot worden ingediend. Was hij Duitser, dat kon de vrouw slechts worden ontslagen, indien het ontslag tevens aan haar man werd verleend $(\$ 18)$.

\section{i. Invloed op de nationaliteit van de gezinsleden van de verzoeker}

Ontslag uit het Duitse staatsburgerschap strekte zich in de regel automatisch uit over de vrouw en de minderjarige kinderen van de verzoeker. Dit gold evenwel niet ten aanzien van reeds gehuwde dochters ${ }^{43}$. Bij kinderen die onder ouderlijke macht of voogdij stonden, was ontslag slechts door tussenkomst van hun wettelijke vertegenwoordiger mogelijk. Daarbij was in de regel tevens de toestemming van het "Vormundschaftsgericht" noodzakelijk (\$19).

41. Cf. Kalm, RDIP 1913, p. 335; RCDIP 1913, p. 963; Flournoy, AJIL 1914, p. 480.

42. C. De Groot diss., p. 397 , noot 137 .

43. In dat geval prevaleerde de nationaliteit van hun man. 
Medeontslagen gezinsleden hadden geen mogelijkheid het verlies van de staatsburgerschap te voorkomen. Na de ontbinding van het huwelijk had de vrouw tot 1935 een "Einbürgerungsanspruch" op het Duitse staatsburgerschap. Hetzelfde gold ten aanzien van meerderjarig geworden kinderen die in het ontslag van hun ouder(s) werden inbegrepen.

\section{c. Ontneming}

Ontmeming van het Duitse staatsburgerschap was geregeld in $\$ \$ 27-29$ van het RuStAG van 1913. De bevoegdheid lag bij de regeringen van de bondsstaten ( $\$$ 27). De nationaliteit kon in de volgende gevallen worden ontnomen:

- indien betrokkene in oorlogstijd of bij oorlogsgevaar weigerde om naar Duitsland terug te keren $(\$ 27)$;

- wegens het zonder toestemming treden in vreemde staatsdienst $(\$ 28)$.

In 1918 werd mogelijk gemaakt om de nationaliteit wegens het ontduiken van belastingen te ontnemen ${ }^{44}$. Deze mogelijkheid werd per 1 januari 1924 weer geschrapt.

\section{i. Ontneming onder het nationaalsocialistische bewind}

Onder het nationaalsocialistische bewind werden de mogelijkheden van ontneming van de nationaliteit aanzienlijk uitgebreid. Bij Wet van 14 juli $1933^{45}$ werd het mogelijk gemaakt om "ongewenste" naturalisaties tussen 9 november 1918 en 30 januari 1933 te herroepen. Op grond van dezelfde regeling werd voorts de mogelijkheid geschapen om de nationaliteit te ontnemen aan personen die in het buitenland woonden :

"...sofern sie durch ein Verhalten, dass gegen die Pflicht zur Treue gegen

Reich und Volk verstösst, die deutschen Belange geschädigt haben".

Op grond van deze vage formule verloren 39.006 mensen hun nationaliteit ${ }^{46}$. Bij verordening van 25 november $1941^{47}$ werd vervolgens aan alle Joden die zich in het buitenland ${ }^{48}$ bevonden de Duitse nationaliteit ontnomen.

44. Zie $\$ 23-25$ van de Wet wam 26 julli 1918, RGBl. 1918, p. 951. De Groot diss., p. 73 .

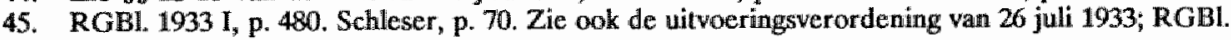
I, p. 538 .

46. De Groot, diss, p. 397 , noot 140 .

47. RGBI. I, p. 722 Schleser, p. 70-71.

48. Onder binnenland werd verstaam Duitsland met de ingelijfle gebieden en het protectoraat Böhmen-Mähren zonder echter de generalgouvernementen en de bezente gebieden. Sehleser, p. 70, noot 2 . 


\section{ii. Invloed op de nationaliteit van de gezinsleden van betrokkene}

Ontneming van de nationaliteit strekte zich automatisch mede over de vrouw en minderjarige kinderen van betrokkene, indien ze samenwoonden met hun man, respectievelijk vader $(\$ 29)$. Ook hier waren gehuwde dochters van het verlies van het staatsburgerschap uitgesloten.

\subsubsection{Het nationaliteitsrecht in door Duitsland bezette en ingelijfde gebieden}

De Duitsers hadden voor de bezette en ingelijfde gebieden verschillende nationaliteitsrechtelijke regelingen getroffen. Hieronder volgt een korte bespreking van regelingen, die golden op de door Duitsland geoccupeerde en geannexeerde gebieden van Joegoslavië, Polen, Tsjechoslowakije en de USSR ${ }^{49}$.

\subsection{Joegoslavië}

Met betrekking tot de inwoners van de bij Duitslland ingelijfde Joegoslavische gebieden Untersteiermark, Krain en Kärnten werd op 14 oktober $1941^{50}$ een verordening afgekondigd. Volgens deze regeling die terugwerkende kracht tot 14 april 1941 had, verwierven alle etnisch Duitse bewoners (deutsche Volkszugehörigen) de Duitse nationaliteit $(\$ 1)$. De tweede groep, de personen "deutschen oder artverwandten Blutes" verwierven de zogenaamde "deutsche Staatsangehörigkeit auf Widerruf" $(\$ 2)$. Aan deze personen kon de Duitse nationaliteit namelijk binnen een termijn van 10 jaren worden ontnomen. Alle andere bewoners werden slechts "deutsche Schutzangehörigen".

\subsection{Polen}

Het door Duitsland geoccupeerde gedeelte van Polen werd gedeeltelijk bij het rijk ingelijfd (Eingegliederte Ostgebiete) en gedeeltelijk als Generalgouvernement onder Duits bestuur gebracht ${ }^{51}$. De bewoners van deze gebieden werden in speciale "Volklisten" geregistreerd en in vier verschillende categorieën verdeeld. Deze verdeling vormde de basis voor verkrijging van de Duitse nationaliteit krachtens een aantal bijzondere regelingen ${ }^{52}$. Aan bepaalde categorieën werd van rechtswege de Duitse nationaliteit toegekend (eerste categorie), terwijl anderen slechts opties (tweede categorie) of de mogelijkheid van verlichte naturalisatie kregen (derde en vierde categorie). Degenen die op grond van deze regelingen niet de Duitse nationaliteit verwierven, werden door Duitsland slechts als Duitse "Schutzangehörigen" beschouwd ${ }^{53}$.

49. Zie voor een overzicht van de regelingen op de ingelijfde en bezette gebieden ook Schleser, p. 75-109.

50. RGBI. I, p. 648; afgedrukt in SGS deel 17, p. 127-129. Zie ook RdErl.d.RMdI van 20 februari 1942, RMBliV, p. 529 en van 19 juni 1942, RMBliV, p. 1326. Zie hierover Schleser, p. 103-104; SGS deel 17, p. $32-35$.

51. Ramus, p. 148; Arnold, ZfOR 1940-41, p. 149.

52. Hierover Arnold, ZFOR 1940-41, p. 148-153; Lichter, StAZ 1941, p. 79-81; Ramus, p. 148-155.

53. Arnold, ZFOR 1940-41, p. 150. 


\subsubsection{Tsjechoslowakije}

Reeds op grond van het verdrag van München werd het Sudetengebied in 1938 bij Duitsland ingelijfd. In het voorjaar 1939 werden vervolgens de gebieden Bohemen en Moravië (Böhmen en Mähren) tot Duits protectoraat uitgeroepen.

\section{a. Het Sudetengebied}

Bij verordening van 12 februari $1939^{54}$ werd in het door Duitsland geannexeerde Sudetengebied het toen geldende Duitse nationaliteitsrecht met terugwerkende kracht tot 10 oktober 1938 ingevoerd $(\$ 1)$.

\section{b. Bohemen en Moravië}

Bij decreet van Hitler van 16 maart $1939^{55}$ verklaarde Duitsland de gebieden Bohemen, Moravië en Silezië tot zijn protectoraat "Böhmen und Mähren" ${ }^{\text {"56. }}$. Op grond van art. 2 van het decreet verkreeg de etnisch Duitse bevolking ervan de Duitse nationaliteit, terwijl de etnische Tsjechen de zogenaamde "Protektoratsangehörigkeit" verwierven ${ }^{57}$. De regeling van de verkrijging van de Duitse nationaliteit door etnische Duitsers die voorheen de nationaliteit van de ČSR bezaten, werd werder aangevuld door de verordening van de Duitse minister van binnenlandse zaken van 20 april $1939^{58}$. $\$ 3$ van deze verordening bepaalde, dat personen die de (juridische) Duitse nationaliteit bezaten en op het grondgebied van het protectoraat woonden, dezelfde rechten bezaten, als de "Protektoratsangehörigen". De vraag of deze personen dan tevens de "Protektoratsangehörigkeit" bezaten, werd in $\$ 1$ lid 1 van een latere verordening van 6 juni $1941^{59}$ evenwel expliciet ontkennend beantwoord.

Een verordening van 3 oktober $1939^{60}$ bevatte voorts een regeling van ontneming van de "Protektoratsangehörigkeit" aan personen, die zich in het buitenland bevonden en handelingen hadden verricht die de belangen van het Duitse rijk konden schaden, of die op vordering van de overheid niet naar het protectoraat terugkeerden. Algemene regels betreffende verkrijging en verlies van de "Protektoratsangehörigkeit" werden geformuleerd in een verordening van 11 januari $1940^{61}$. Deze regeling was gebaseerd op de oude Oostenrijkse regeling die

54. RGB1. 19391 , p. 205.

55. RGBL. 1939 I, p. 485 . Táborsky, p. 39; SGS deel 18 1e druk, p. 26.

56. Táborsky, p. 39-41; Zie uitvoerige over het protectoraat Erdely, Germany's First Eiuropean Protectorate, London 1941.

57. Art. 75/1939 Slg. Daarover Schmid, p. 34-35; SGS deel 18 1e druk, p. 27; Globke, ZfoR 1940, p. 447.

58. Duitse RGBI. I, p. 815; VBIRProt. 1939, p. 60; tekst afgedrukt bij Schmid, p. 80-81. Daarower Schmid, p. 35; SGS deel 18 1e druk, p. 26; Globke, ZfoR 1940, p. 447.

59. Duitse RGBI. 1941, I, p. 308; VBIRProt. 1939, p. 307; afgedrukt bij Schmid, p. 88-98. Daarover Schmid, p. 35; SGS deel 18 le druk, p. 27.

60. Duitse RGBI. 1939, I, p. 1997; VBIRProt. 1939, p. 179. Deze verordening was ínhoudelijk gelijk aan de Duitse wet van 14 juli 1933, RGBI. I, p. 480 . Zie SGS deel 18 le druk, p. 27; Schmid, p. 35.

61. RMBliV 1940, p. 1120; daarover nitvoeriger Globke, ZfoR 1940, p. 448-450. Zie ook de circulaire van de Duitse minister wan binnenlandse zaken van 7 juni 1940, RMBliv 1940, p. 1117. 
reeds Tsjechoslowakije had overgenomen ${ }^{62}$. Voorts verkregen op grond van een circulaire van de Duitse minister van binnenlandse zaken de etnisch Tsjechische bewoners van Slowakije en Karpathorusland, die niet de nationaliteit van Slowakije of Hongarije bezaten, eveneens de "Protektoratsangehörigkeit" ${ }^{63}$.

\subsection{USSR (Oekraïne)}

Na de millitaire bezetting van de Oekraïne werd het "Reichskommissariat Ukraine" opgericht. De bevolking daarvan werd evenals in Polen in speciale "Volkslisten" geregistreerd. De indeling in deze lijsten vormde vervolgens de basis voor toekenning van de Duitse nationaliteit op grond van de verordening van 19 mei $1943^{\mathrm{k}}$.

\subsubsection{Het nationaliteitsrecht tussen 1945 en 1949}

Na de ondergang van het "duizendjarige Duitse rijk" in 1945 werd het Duitse grondgebied in vier bezettingszones verdeeld. Aangezien er in iedler geval tussen 1945 en 1949 geen Duitse staat bestond, ontstaat de vraag of in de periode tussen 1945 en het ontstaan van beide Duitse staten van een Duitse nationaliteit kan worden gesproken. Op deze vraag wordt in de literatuur in de regel een bevestigend antwoord gegeven ${ }^{65}$. Er wordt ervan uitgegaan dat de regeling van het RuStAG van 1913 verder gold, zonder de wijzigingen echter, die het nationaalsocialistische bewind daarin had aangebracht.

\subsubsection{Het nationaliteitsrecht van de DDR tussen 1949 en 1967}

\subsubsection{Algemeen}

De DDR ontstond formeel op 7 oktober 1949, terwijl de souvereiniteitsrechten pas in 1955 werden overgedragen. De vraag of er in de DDR reeds sedert 1949 een eigen nationaliteit, los van die van de BRD, heeft reeds vele pennen in beweging gebracht ${ }^{6}$. Ten aanzien van de kring van onderdanen van deze nieuwe staat werd namelijk geen uitdrukkelijke overgangsregeling getroffen ${ }^{67}$. De enige op de nationaliteit betrekking hebbende wetsbepaling is te vinden in art. 4 lid 1 van de eerste grondwet van de DDR:

"Es gibt nur eine Deutsche Staatsangehörigkeit".

In de DDR wordt in het staatsrechtelijk handboek van Egler e.a. deze bepaling als volgt toegelicht:

62. Zie daarover Schmid, p. 35-36.

63. RMBliV, p. 1117. Schmid, p. 36; Globke, ZfoR 1940, p. 448.

64. RGBI I, 321. Zile daarower Schleser, p. 102-103.

65. Zieger, p. 7; Blumenwitz, JOR 1967/1, p. 175; Kelsen, AJIL 1945, p. 523.

66. De Groot diss., p. 378, noot 157, schat het aantal van boeken en artikelen die zich (mede) met de onderhavige problematick bezig houden op meer dan 100. Zie voor literatuurverwijzingen en overzichten van verschillende meningen (tot 1985) Hecker, ROW 1987, p. 294-300.

67. Cf. Riege, StuR 1967, p. 710. 
"Aus der Entstehungsgeschichte der Verfassung geht hervor, dass sie das Grundgesetz für eine gesamtdeutsche demokratische Republik werden sollte...Der genannte Artikel der Verfassung hatte einen einheitlichen antiimperialistischen gesamtdeutschen Staat in Auge, in dem es keine Landesstaatsangehörigkeiten gebe. ${ }^{\text {"68 }}$

Hieruit blijkt duidelijk dat in de DDR tijdens de eerste jaren van zijn bestaan aan een "Wiedervereinigung" in één DDR werd gedacht ${ }^{69}$. Zo sprak men de jaren vijftig in meerdere regelingen consequent van "die deutsche Staatsangehörigkeit" 70 . Pas sedert ongeveer 1960 wordt steeds het begrip "Bürger der DDR" gebezigd en werden de BRD en West Berlijn uitdrukkelijk als "buitenland" beschouwd ${ }^{71}$. Riege ${ }^{72}$, spreekt thans met betrekking tot de in de jaren vijftig gebezigde termen over de "damals gebrauchlichen Terminologie", zonder daaraan een diepere betekenis toe te (willen) kennen.

Thans wordt in de DDR betoogd, dat in de bovengeciteerde grondwetsbepaling de grondwetgever slechts tot uitdrukking had willen brengen, dat aparte staatsburgerschappen van bondsstaten in de DDR niet meer bestonden en dat een "gesamtdeutsche Staatsangehörigkeit" de grondwetgever in 1949 niet voor ogen kon hebben gestaan. In de zojuist geciteerde passage uit Egler e.a., vinden we de volgende redenering:

"Aus dem Umstand, dass die für einheitliches antifaschistisch-demokratisches Gesamtdeutschland konzipiirte Verfassung nur für die DDR in Kraft gesetzt werden könnte, ergibt sich die enchiedende Konsequenz für ihren Wirkungsbereich. Es war durch das Staatsgebiet umrissen." 73 .

In verband met deze opmerkelijke "ex tunc correctie" van de bedoelingen die de grondwetgever in 1949 had, wordt voorts door Riege, c.s. de opvatting verdedigd, dat een apart DDR-staatsburgerschap reeds sedert 7 oktober 1949 bestaat $^{74}$.

68. Egler e.a., p. 156. Zo ook Riege, StuR 1964, p. 60-61.

69. Zo ook Bernhardt, Mütteilungsblatt des Königsteiner Kreises 1968, p. 26; Blumenwitz, JOR $1967 / 1$, p. 176; Schröder, ROW 1967, p. 234-235; Staatsbürgerschaft, p. 10-11.

70. Zie de verordening van 29 oktober 1953, GBI, 1953 , p. 1090 betreffende de uitgifte van "Personalausweisen". Deze verordening werd pas op 23 september 1963 gewijzigd en werd het woord "Staatsangehörigkeit" met de term "Staatsbürgerschaft" vervangen. Op 30 augustus 1954 werd in de DDR ook een "Anordnung über die Oleichberechtigumg der Frau in Siantsangehörigkeitsrecht" (cursivering van mij, MT) GBI. 1954, p. 431; afgedrukt in SLAZ 1954, p. 248249. Deze verordening gold tot 1967. Van "Deutsche Staatsangehörigen" spraken ook de paspoortwet van 15 september 1954, GBl. 1954, p. 786; (uittreksel afgedrukt in SLAZ 1954, p. 249); 18 van het Konsullargesetz van 22 mei 1957, GBi. I, p. 313; \&2 van de kieswet van 1958 GBI. I, p. 677. CF. Schröder ROW 1967, p. 235.

71. Blumenwitz, JOR $1967 / 1$, p. 177-78 met enkele voorbeelden ${ }^{2}$ Zo ook Wachler, JZ 1968, p. 777.

72. Riege, p. 299.

73. Zo ook Riege, p. 123-124, maar ook Mende, p. 146, in de BRD, denkt in deze richting.

74. Riege, StuR 1967 , p. 710 . Interessant is echter dat in de DDR door Oeser, Völkerrechtliche Grundfragen und Regelung der Staatsbürgerschaft der DDR und der westdeutschen Bundesrepublik, diss. Potsdam/Babelsberg 1962, werd toegegeven, dat pas na de toetreding van de BRD tot het NATO-pact in 1955, sprake kon zijn van een aparte nationaliteit van de DDR, aangezien pas toen de hoop op "Wiedervereinigung" werd opgegeven. Zie Posch, StuR 1964, p. 1968-1971. 


\subsubsection{1 "Twee" Duitse nationaliteiten}

Het bestaan van een aparte nationaliteit van de DDR wordt in de Duitse bondsrepubliek zowel door de (grond)wetgever als door de jurisprudentie en de doctrine nog steeds ontkend. Men gaat ervan uit dat er slechts én Duitse nationaliteit bestaat die nog steeds in het RuStAG geregeld is. Illustratief is in dit verband de verklaring van de woordvoerder van de BRD-regering Von Hase ter gelegenheid van de afkondiging van de nationaliteitswet van de DDR in 1967:

"Das 'Gesetz über die Staatsbürgerschaft der DDR' steht in Widerspruch zul der Tatsache, dass das Reichs-und Staatsangehörigkeitsgesetz von 1913 weiter gültig ist, dass für alle Deutschen die Frage der Staatsangehörigkeit regelt."

In de naam van de regering van de Bondsrepubliek werd zelfs het volgende "argument" gebruikt:

"Da es nicht zwei Völker, sondern nur ein deutsches Volk gebe, könne lediglich nur eine deutsche Staatsangehörigkeit existieren." ${ }^{75}$

In dit verband dient ook te worden gewezen op art. 116 lid 1 van de grondwet van de BRD, waarin het begrip "Deutschen in Sinne des Grundgesetzes" werd ingevoerd. Dat zijn naast de inwoners van de BRD Duitsers ook etnische Duitsers met hun afstammelingen, die uit het grondgebied van het Duitse Rijk volgens de grenzen van 31 december 1937 zijn gevlucht. Men beschouwt deze grondwetsbepaling als een manifestatie van het "Wiedervereinigungsgebot" ${ }^{76}$. De (gezamenlijke) Duitse nationaliteit lijkt zo tot een van de laatste symbolen van de Duitse eenheid te zijn verheven.

In de DDR wordt het bestaan van een gezamenlijke Duitse nationaliteit ontkend, en beschouwt men de toekenning van het BRD-staatsburgerschap aan de DDR-onderdanen als een ongeoorloofde inmenging in de interne aangelegenheden van de $D D R$, die in strijd met het volkenrecht is 7 .

Aangezien de nationaliteit van de BRD derhalve in beginsel door verkrijging van het DDR-staatsburgerschap wordt verworven, ontstond de vraag of ook door verlening van het DDR-staatsburgerschap door een staatsorgaan van de DDR eveneens de nationaliteit van de BRD word verworven. Het Bundesverfassungsgericht van de BRD heeft deze vraag op 21 oktober $1987^{\text {t8 }}$ als volgt beantwoord:

"Aus dem Gebot der Wahrung der Einheit der deutschen Staatsangehörigkeit (Art. 116 Abs. 1, 16 Abs. 1 GG) das eine normative Konkreti-

75. Bulletin des Presse-und Informationsamtes der Bundesregierung 1967, p. 147.

76. Zie de hieronder geciteerde passage uit de uitspraak van het BVerfG van 21 oktober 1987.

77. Zie bijwoorbeeld Riege, Neue Justiz 1978, p. 98-101. In Nederland wordt door De Groot diss., p. 20-21 de vraag of toekenning van de nationaliteit van de BRD aan alle staatsburgers van de DDR in strijd met het volkenrecht is, (althans voor de huidige tijd) ontkennend beantwoord.

78. JZ 1988, p. 144-150; StAZ 1988, p. 78-82. Zie daarover Silagi, StAZ 1988, p. 64-71; Wyduckel, Deutsches Verwaltungsblatt 1988 , p. $284-287$; De Groot diss., p. 20. 
sierung des in Grundgesetz enthaltenen Wiedervereünigungsgebots ist, folgt, dass dem Erwerb der Staatsbürgerschaft der Deutschen Demokratischen Republik für die Rechtsordnung der Bundesrepublik Deutschland in den Grenzen des ordre public die Rechtswirkung des Erwerbs der deutschen Staatsangehörigkeit beizumessen ist".

Terwijl verkrijging van de nationaliteit van de $D D R$ in de regel verwerving van het staatsburgerschap van de BRD met zich meebrengt, hoeft verlies van de DDRnationaliteit niet het verlies van het staatsburgerschap van de Bondsrepubliek te betekenen. Zo behouden allen, aan wie het DDR-staatsburgerschap werd ontnomen, de nationaliteit de BRD ${ }^{79}$.

\subsubsection{Verkrijging en verlies van de nationaliteit van de DDR tot 1967}

De nieuwe machthebbers hebben de nationaliteitsrechtelijke regeling van het RuStAG 1913-zoals deze wet gold vóor de wijzigingen die de nationaalsocialisten daarin brachten- in stand gelaten. Alle bepalingen die in strijd waren met de socialistische openbare orde werden echter als nietig werden beschouwd. Zulks volgde uit art. 144 lid 1 van de grondwet van 7 oktober 1949:

"Alle Bestimmungen dieser Verfassung sind unmittelbar geltendes Recht. Entgegenstehende Bestimmungen sind aufgehoben... Weitergeltende Gesetze sind in Sinne dieser Verfassung aus zu legen."

Dit leidde tot een iets aangepaste interpretatie van bepaalde paragrafen van het RuStAG van 1913. Daarnaast heeft men enkele op nationaliteit betrekking hebbende regelingen afgekondigd. Dit waren:

- verordening van de minister van binnenlandse zaken over de gelijke behandeling van vrouwen in het nationaliteitsrecht van 30 augustus 1954 (AO van 1954) ${ }^{80}$;

- verordening betreffende de procedure in nationaliteitsaangelegenheden van 28 november $1957^{81}$;

- decreet van de Raad van State van 21 augustus $1964^{82}$ betreffende remigratie van in het buitenland woonachtige DDR-staatsburgers, met de verordening van 28 februari $1965^{83}$;

- verordening strekkende tot wijziging van de verordening betreffende de procedure in nationaliteitsaangelegenheden van 28 januari $1965^{\mathrm{s4}}$.

79. Klein, NJW 1983, p. 2291-2292.

80. Zentralblatt 1954, p. 431; afgedrukt in StAZ 1954, p. 248-249. In werking getreden op 1 september 1954. Zieger, p. 9.

81. GBl. $1957 \mathrm{I}$, p. 616.

82. GBI. I, p. 128.

83. GBI. II, p. 246. zie de berichten in ROW 1965, p. 123-124 en 1980, p. 244.

84. GBI. 1965 II, p. 143; zie het bericht in ROW 1965, p. 123. 
Opvallend is dat men bij het totstandbrengen van nieuwe nationaliteitsrechtelijke regelingen bijzondere terughoudend was en dat bepalingen van het RuStAG tot de inwerkingtreding wan de nationaliteitswet van 1967 niet formeel werden gewijzigd ${ }^{85}$.

Hieronder zal worden nagegaan welke correcties op grond van de nieuwe openbare orde en de genoemde bijzonder nationaliteitsrechtelijke regelingen aan het RuStAG werden aangebracht.

\subsection{Verkrijging van de nationaliteit}

Ook in de DDR werd de nationaliteit wan rechtswege en door naturalisatie verkregen.

\section{a. Verkrijging van rechtswege}

Van rechtswege bleef verkrijging van de nationaliteit gekoppeld aan geboorte uit DDR-onderdanen en geboorte op het grondgebied van de DDR. De regeling van verkrijging iure soli van het RuStAG werd ook in de DDR onverkort toegepast en zal derhalve hieronder niet nogmaals worden besproken (zie daarover p. 147). Door huwelijk met een DDR-staatsburger werd in ieder geval na 1954 de nationaliteit niet meer verkregen.

\section{i. Geboorte uit DDR-ouders}

$\$ 4$ RuStAG die betrekking had op verkrijging van het staatsburgerschap iure sanguinis dient zo uitgelegd te worden, dat een kind wiens moeder of vader op het tijdstip van de geboorte van het kind de nationaliteit van de DDR bezat, daardoor DDR-staatsburger werd. Onduidelijk is echter of deze interpretatie reeds sedert 7 oktober 1949 dient te worden toegepast, of pas vanaf 1 september 1954, toen de verordening met betrekking tot gelijke behandeling van vrouwen in het nationaliteitsrecht in werking trad ${ }^{86}$. In $\$ 3$ van de $A O$ van 1954 werd uitdrukkelijk bepaald, dat een kind van hetzij een Duitse moeder, hetzij een Duitse vader de Duitse nationaliteit verwierf.

Voorts werd in art. 33 van de grondwet het onderscheid tussen wettige en onwettige kinderen verboden. Ook hier blijven echter enkele vragen open. Volgens Riege ${ }^{87}$, moest $\$ 4$ RuStAG sedert 7 oktober 1949 conform de grondwet van de DDR worden geïnterpreteerd. Dit zou betekenen dat een buitenechtelijk kind van een vreemdelinge de nationaliteit van de DDR verwierf, indien afstamming van een DDR-vader door erkenning of gerechtelijke vaststelling kwam vast te staan. Aan verkrijging van het staatsburgerschap door legitimatie ( $\$ 5$ RuStAG) zou men derhalve niet meer toekomen. Onduidelijk is echter waarom nog in 1964 door Riege ${ }^{88}$,

85. Cf. Zieger, p. 9. Zelfs door Riege, p. 127 wordt trouwens toegegewen, dat deze terughoudendheid werband hield met de destijds in de DDR nog levende "Wiedervereinigungsgedachte".

86. Zie Zieger, p. 11. Volgens Riege, p. 298-299, had de AO van 1954 slechts een declaratoir karakter. Het ius sanguinis a matre et a patre zou reeds op 7 oktober 1949 op grond van het grondwettelijke verbod van wrouwendiscriminatie (art. 7 lid 2 en art. 30 lid 2) zijn ingevoerd. Anders echter Lichter/Hoffmann, p. 64.

87. Riege, p. 299-300.

88. Riege in zijn habilitatieschrift van 1964, p. 261. Geciteerd bij Zieger, p. 12. 
het schrappen van de legitimatie als grond voor verkrijging van de nationaliteit werd voorgesteld. Wettiging als rechtsinstituut werd overigens bij het "Familiengesetzbuch" (FGB) van 20 december 1965 uit het familierecht van de DDR geschrapt.

Door Riege ${ }^{89}$, wordt overigens toegegeven dat de AO van 1954 die onder meer verkrijging van de nationaliteit van kinderen van nationaliteitsrechtelijk gemengde ouders regelde, slechts op wettige kinderen betrekking had.

\section{ii. Huwelijk met een DDR-onderdaan}

Automatische verkrijging van de nationaliteit door huwelijk ten behoeve van buitenlandse vrouwen ( $86 \mathrm{RuStAG}$ ) wordt in ieder geval na 1954 geacht in strijd te zijn met de grondwet van 1949. Door Riege ${ }^{90}$, wordt evenwel betoogd, dat de nationaliteit reeds sedert 1949 niet iure matrimonii werd verkregen. $\$ 1$ van de AO 1954 die dit uitdrukkelijk bepaalt, had volgens hem slechts een declaratoir karakter. Een dergelijke strekking kan ook worden afgeleid uit de preambule van de verordening, waarin op het discriminatieverbod in de grondwet werd verwezen. Voorts bepaalde de preambule dat de AO van 1954 de strekking had eenheid in de toepassing van het nationaliteitsrecht te garanderen. Op grond hiervan zou evenwel kunnen worden geconstateerd dat in enkele gevallen de nationaliteit vanwege interpretatieproblemen met betrekking tot het RuStAG inderdaad door huwelijk werd verworven. In het geval dat alles duidelijk zou zijn zou de $\mathrm{AO}$ van 1954 overbodig zijn.

\section{b. Naturalisatie}

Met betrekking tot naturalisatie is aan te nemen dat van de verzoeker een positieve instelling tegenover het politieke systeem werd geëist. Voorts bestond er in beginsel geen recht op naturalisatie ${ }^{91}$. In $\$ 2$ lid 2 van de AO van 1954 werd aan ex-Duitse wrouwen, die na 7 oktober 1949 hun nationaliteit door huwelijk met een buitenlander verloren en nog steeds staatloos waren, echter wel een soort recht op hernaturalisatie toegekend.

Tot 1957 , toen de reeds genoemde verordening betreffende de procedure in nationaliteitsrechtelijke aangelegenheden tot stand kwam, bestond er geen regeling van de naturalisatieprocedure. Het verlenen van de nationaliteit en het vaststellen van regels daaromtrent behoorden tot de bevoegdheden van de Minister van binnenlandse zaken. Een naturalisatie kwam tot stand door uitreiking van een naturalisatieoorkonde of van een "Personalausweis". Het tweede werd in de regel uitgereikt aan Duitsers (degenen die conform het RuStAG 1913 de Duitse nationaliteit bezaten), die zich in de DDR kwamen vestigen ${ }^{92}$. Duitsers die buiten de DDR bleven wonen, verwierven het staatsburgerschap van de DDR door zich bij een buitenlandse vertegenwoordiging van de DDR te laten registreren ${ }^{93}$.

89. Riege, p. 299; Cf. Zieger, p. 11.

90. Zie Riege 298-299.

91. Zieger, p. 13.

92. Riege, p. 308-309. Zie cok $\$ 3$ van de werordening betreffende de uitgifte van "Personalausweisen"; GBI. 1953, p. 1090.

93. Zie \$ 18 van het Konsulargesetz van 22 mei 1957; GBl. 1957 I, p. 313. Daarover Egler e.a., p. 160. 


\subsection{Verlies wan de nationaliteit}

De nationaliteit van de DDR werd verloren door ontslag en door ontneming. Verlies van de nationaliteit ipso iure werd als strijdig met de grondwet beschouwd. Volgens Riegee, moet de staat vanwege de "verantwoordelijkheid" die de socialistische maatschappij voor haar leden heeft, elk geval wan het verlies van de nationaliteit van beslissende medewerking van de bevoegde staatsorganen afhankelijk maken. Desalniettemin is het niet geheel duidelijk of een DDRonderdane, die met een vreemdeling in huwelijk trad, tot 1954 daardoor nog haar nationaliteit verloor.

\section{a. Verlies van rechtswege}

Ondanks het grondwettelijk vastgestelde verbod van vrouwendiscriminatie is het niet uitgesloten dat tot 1954 een DDR-onderdane die met een vreemdeling in huwelijk trad, daardoor automatisch haar nationaliteit verloor. Deze conclusie kan namelijk worden getrokken uit het feit dat de reeds genoemde $\$ 2$ lid 2 van de AO van 1954, waarin aan ex-Duitse vrouwen, die na 7 oktober 1949 hun nationaliteit door huwelijk met een buitenlander verloren en nog steeds staatloos waren, een soort recht op hernaturalisatie toekende. Deze bepaling kon slechts op vrouwen betrekking hebben, die volgens het recht van de DDR de nationaliteit verloren en daardoor staatloos werden. In de Bondsrepubliek ging de Duitse nationaliteit sedert 23 mei 1949 namelijk niet meer door huwelijk verloren, indien betrokkene daardoor staatloos zou zijn geworden ${ }^{55}$.

Welbeschouwd moet $\$ 2$ lid 2 worden gezien als een overgangsregeling. Indien deze vrouwen na 1 september 1954 met buitenlanders trouwden, had dit geen verlies van de DDR-nationaliteit kunnen bewerkstelligen. Men wilde de ongewenste en met het beginsel van gelijkheid van sexen strijdige gevolgen van toepassing van $\$ 17$ lid 6 RuStAG "rechttrekken" $\%$

\section{b. Ontslag}

De regeling van het RuStAG met betrekking tot ontslag uit de nationaliteit van de DDR werd in de jaren 1949-1967 nagenoeg ongewijzigd toegepast. Slechts de bepaling dat in vredestijd een zeker recht op ontslag bestond werd in strijd geacht te zijn met het beginsel dat de staat zelf over verkrijging en verlies van het staatsburgerschap beslist.

\section{c. Ontneming}

Een belangrijke plaats nam de mogelijkheid van ontneming in, die reeds in $\$ \$ 27$ en $28 \mathrm{RuStAG}^{97}$ was voorzien. Hiernaast moet worden genoemd een decreet van

94. Riege, p. 315-316.

95. Makarow/von Mangoldt, commentaar bij $\$ 17$ RuStAG, Rdn. 14; De Groot diss, p. 74.

96. Zieger 1969, p. 13, met verwijzing naar het habilitatieschrift van Riege, p. 244.

97. Interessant is bierbij op te merken dat $\$ 27$ en 28 RuStAG in de BRD sedert 23 mei 1949 wegens strijd met art. 16 lid 1 grondwet als niet geschreven worden beschouwd. Cf. De Groot diss., p. 73. 
de Raad van State van 21 augustus $194^{\circ 8}$ betreffende remigratie van in het buitenland wonende DDR-staatsburgers. $\$ 1$ lid 3 bepaalde dat aan personen, aan wie de nationaliteit "wegen grober Verletzung der staatsbürgerlichen Pflichten" werd ontnomen het recht om terug te keren werd ontzegd. Het ging daarbij om personen, die de DDR illegaal verlieten- de zogenaamde "Republikflucht". Uit een statistiek uit 1961 bleek dat in de periode tussen september 1949 en 15 augustus $19612,691.270$ mensen uit de DDR waren gevlucht ${ }^{\$ 9}$.

\subsection{Het postrieve nationalTtertsRecht}

\subsubsection{Algemeen}

De DDR kondigde pas op 20 februari $1967^{100}$ zijn eerste nationaliteitswet, het "Gesetz über die Staatsbürgerschaft der Deutschen Demokratischen Republik" (StBG) af. Naast deze wet werd ook een van 3 augustus $1967^{\text {tol }}$ daterende "Durchführungsverordnung"(DVO) uitgevaardigd, die nadere voorschriften m.b.t de uitvoering van het StBG geeft.

De nationaliteitswet van de DDR begint met de volgende preambule:

"Mit der Gründung der Deutschen Demokratischen Republik enstand in Übereinstimmung mit dem Völkerrecht die Staatsbürgerschaft der Deutschen Demokratischen Republik. Sie ist Ausdruck der Souveränität der Deutschen Demokratischen Republik und trägt zur weiteren allseitigen Stärkung des sozialistischen Staates bei.

Die Staatsbürgerschaft der Deutschen Demokratischen Republik ist die Zugehörigkeit ihrer Bürger zum ersten friedlebenden, demokratischen und sozialistischen deutschen Staat, in dem die Arbeiterklasse die politische Macht in Bündnis mit der Klasse der Genossenschaftsbauern, der sozialistischen Intelligenz und den anderen Werktätigen Schichten ausübt."

Het is in de eerste plaats interessant om aandacht te schenken aan de overgangsbepalingen van het StBG 1967. De overgangsregeling van de nieuwe nationaliteitswet knoopt bij het bepalen van wie op het moment van de inwerkingtreding van het StBG de DDR-nationaliteit bezaten in de eerste plaats aan bij het ontstaan van de DDR op 7 oktober 1949 . Zo bepaalt $\$ 1$ sub a dat het staatsburgerschap van DDR degenen bezitten, die op 7 oktober 1949 Duitse onderdanen waren, in de DDR hun woonplaats hadden en het DDR-staatsburgerschap sedertdien niet hadden verloren ${ }^{102}$. Sub $b$ wordt de kring van DDR-onderdanen verder uitgebreid

98. GBL. 1, p. 128.

99. Die Flucht, p. 15.

100. GBI. 1967 I, p. 3. Afgedrukt in JOR 1967, p. 205, SLAZ 1967, p. 93; Nederlandse vertaling in NWG, p. 1-2.

101. GBL. 1967 II, p. 681. Afgedrukt bij Schleser ${ }_{y}$ p. 423-425, en in StAZ 1968, p. 14. Zie ook het bericht in ROW 1968, p. 13-14.

102. Tot deze groep behoorden derhalve ook bijna drie miljoen personen die tussen 1949 en 1967 de DDR verlieten. Waehler, JZ 1968, p. 777 . Zie over de overgangsregeling ook Schröder, ROW 1967, p. 233-234. 
tot personen die op 7 oktober 1949 de Duitse nationaliteit bezaten, in het buitenland woonden en sindsdien geen ander staatsburgerschap hadden verworven. Ten aanzien van deze tweede categorie wordt verder vereist dat ze zich bij een DDR-vertegenwoordiging als DDR-staatsburgers hadden laten registreren (zie ook 2 DVO). Sub c wordt de derde categorie omschreven: dat zijn degenen, die de nationaliteit van de DDR hadden verworven en tot de inwerkingtreding van het StBG deze nog niet hadden verloren. Tot deze groep behoorden ook personen, die vanuit de Bondsrepubliek kwamen en aan wie een "Einbürgerungsurkunde" of een "Personalausweis" werd uitgereikt ${ }^{103}$.

In $\& 3$ wordt voorts met verwijzing naar het volkenrecht bepaald, dat degenen die de DDR-nationaliteit bezitten, zich tegenover de DDR niet op het bezit van een andere nationaliteit mogen beroepen (lid 1). Tenslotte dient nog te worden gewezen op het tweede lid $\operatorname{van} \& 3$, dat woor de verkrijging van een andere nationaliteit de toestemming van de bevoegde instantie in de DDR eist.

\section{2 .2 Verkrijging van de nationaliteit}

De nationaliteit van de DDR kan worden verkregen van rechtswege ( $\$ 5-6)$ en door naturalisatie ( $\$ 7$ e.v.). Verkrijging van de nationaliteit door optie kent het StBG, evenals overigens het RuStAG, niet. Een dergelijk slechts van de persoonlijke wil van betrokkene afhankelijk recht op de nationaliteit zou volgens Riege ${ }^{104}$, niet te rijmen zijn met het "bijzondere" karakter van het socialistische staatsburgerschap.

\subsubsection{Verkrijging van rechtswege}

In het StBG wordt verkrijging van de nationaliteit van rechtswege gekoppeld aan de geboorte als kind van een DDR-onderdaan en de geboorte, respectievelijk het gevonden worden op het grondgebied van de DDR. Adoptie door DDR-onderdanen heeft geen invloed op de nationaliteit van een kind. Evenmin kan de nationaliteit door het sluiten van een huwelijk worden verkregen. De buitenlandse huwelijkspartner van een DDR-staatsburger heeft geen mogelijkheid van verlichte naturalisatie.

\subsection{Geboorte uit DDR-ouder(s)}

Bij de regeling van de verkrijging van de nationaliteit van de DDR door de geboorte, gaat men van het ius sanguinis a patre et a matre beginsel uit. Krachtens $\$ 5$ verwerft een kind het staatsburgerschap van de DDR, indien hetzij zijn vader, hetzij zijn moeder op het moment van de geboorte van het kind de DDR-nationaliteit bezit. Het is hierbij irrelevant of het kind in het binnen- of in het buitenland wordt geboren ${ }^{105}$.

Er wordt ook geen onderscheid tussen wettige en onwettige kinderen gemaakt. Indien een kind staande een huwelijk of binnen 302 dagen na de ontbinding ervan

103. C. Waehler, JZ 1968, p. 778.

104. Riege, p. 308.

105. Riege, p. 297. 
geboren, wordt de echtgenoot van de moeder geacht zijn vader te zijn ( $\$ 54$ Familiengesetzbuch(FGB)). Een buiten het huwelijk geboren kind van een buitenlandse moeder en een DDR-onderdaan verwerft de nationaliteit van de DDR doordat het door de vader wordt erkend, of doordat het vaderschap gerechtelijk wordt vastgesteld ${ }^{106}$. Verkrijging van de nationaliteit werkt ex tunc, vanaf het moment van de geboorte van het kind ${ }^{107}$.

\subsubsection{Geboorte op het grondgebied en vondelingen}

Het ius soli beginsel geldt in de DDR slechts subsidiair ${ }^{108}$. Een in de DDR geboren kind verkrijgt de nationaliteit van de DDR slechts indien het door zijn geboorte geen ander staatsburgerschap verwerft ( $\$ 6$ lid 1 ). Het gaat derhalve hier om kinderen wier ouders onbekend of staatloos zijn, of die geen nationaliteit aan hun buitenlandse ouder(s) kunnen ontlenen, omdat de nationale wetgeving van de ouder(s) het ius soli beginsel huldigt. Hoewel zulks niet expliciet in de wet wordt bepaald, kan aan de hand van het subsidiaire karakter van de verkrijging van de nationaliteit ex $\$ 6$ lid 1 worden geconcludeerd, dat het kind de DDR-nationaliteit verliest, indien het later blijkt dat het door zijn geboorte een andere nationaliteit bezit.

Een kind dat op het grondgebied van de DDR wordt gevonden en wiens ouders onbekend zijn, verkrijgt daardoor de nationaliteit van de DDR op grond van het bepaalde in $\S 6$ lid 2 . Het kind behoudt deze nationaliteit zolang niet bewezen wordt dat het een andere nationaliteit bezit ${ }^{109}$. Dit bewijs kan te allen tijde worden geleverd.

\subsubsection{Naturalisatie}

Verkrijging van de DDR-nationaliteit door naturalisatie wordt geregeld in $\$ 7$ van de wet van 1967 en in \$ 5-7 DVO. De bevoegdheid om de nationaliteit van de DDR te verlenen ligt krachtens $\$ 15$ lid 1 bij de Ministerraad, waarbij het tweede lid delegatie van deze bevoegdheid uitdrukkelijk toestaat. De vereisten om in de DDR te worden genaturaliseerd zijn de volgende:

- betrokkene moest door zijn gedrag aantonen dat hij de verlening van de nationaliteit van de DDR "waard" is ( $\$ 7$ lid 1 ); hierbij is met name zijn instelling tegenover het politieke systeem van belang ${ }^{110}$;

- de verzoeker dient in de regel zijn vaste woon- of verblijfplaats binnen de DDR hebben ( $\$ 7$ lid 2). Naturalisatie van (nog) niet in de DDR wonende personen is echter mogelijk ${ }^{111}$;

106. Zie voor erkenning $\$ \$ 55$ en 57 enten aanzien gerechtelijke vaststelling van vaderschap, $\$ 56$ FGB. Daarover Grandke, e.a., p. 202-215. Zie ook Riege, p. 300.

107. Riege, p. 300 ; Egler e.a., p. 162.

108. Riege, p. 301; Zieger 1969, p. 18.

109. Cf. Riege p. 302.

110. Riege, p. 305; Riege/Kulke, p. 63-64; Egler e.a., p. 163.

111. Cf. Zieger, p. 19. 
- van de naturalisandus kan worden geëist dat hij bewijs van het verlies van zijn tegenwoordige nationaliteit overlegt ( $\$ 7$ DVO). Volgens Riege ${ }^{112}$, wordt deze eis in de praktijk in de regel ook gesteld. Is de verzoeker onderdaan van een land waarmee de DDR een verdrag omtrent de bestrijding van meervoudige nationaliteit heeft gesloten en daarin de verplichting werd neergelegd om deze eis te stellen, dan is men dat verplicht ${ }^{113}$.

Zelfstandige naturalisatie van minderjarigen is mogelijk. In dat geval moet het verzoek door de wettellijke vertegenwoordiger van het kind worden ingediend ( $\$ 5$ lid 4 DVO).

Geconstateerd moet worden dat het eerste naturalisatievereiste ( $\$ 7$ lid 1$)$ bijzonder vaag is, hetgeen aan de beoordelende instantie onbeperkte discretionaire bevoegdheid geeft. Ook in de formulering "kann ...verliehen werden" werd bewust de ruimte voor "Ermessensfreiheit" gelaten. Volgens Riege ${ }^{114}$, zou een recht op naturalisatie niet in overeenstemming zijn met het "karakter" van het socialistische staatsburgerschap, omdat het steeds mogelijk moet zijn om elk geval geheel apart te beoordelen. Deze mogelijkheid heeft men met het bijzonder vage $\$ 7$ lid 1 inderdaad wel. De beslissingen omtrent naturalisaties zijn niet aan rechterlijke controle onderworpen.

Ten aanzien van buitenlanders die met DDR-staatsburgers trouwen, bestaat geen bijzondere verlichte naturalisatiemogelijkheid. Zulks is gezien het feit dat bij de (gewone) naturalisatie niet wordt geëist dat de verzoeker reeds enige jaren in de DDR heeft gewoond, ook niet nodig ${ }^{115}$.

\subsection{Invloed op de nationaliteit van de gezinsleden van de verzoeker}

Tegelijkertijd met de ouders worden ook hun minderjarige kinderen (onder 18 jaar) ${ }^{116}$ genaturaliseerd, indien daarom uitdrukkelijk is verzocht (art. 8 lid 1). Ook is het mogelijk dat het kind medegenaturaliseerd wordt in geval slechts éen van de ouders om naturalisatie verzoekt. Het tweede lid van $\$ 8$ eist voorts ten aanzien van medenaturalisatie van kinderen die de leeftijd van 14 jaar reeds hebben bereikt, steeds hun eigen toestemming.

\subsubsection{Verlies wan de nationaliteit}

De nationaliteitswet van 1967 kent het verlies van de nationaliteit door ontslag, herroeping van een naturalisatiebesluit en door ontneming. Door het afleggen van een verklaring van afstand wordt het staatsburgerschap van de DDR niet verloren. Volgens Riege ${ }^{117}$, volgt uit het "karakter" van het DDR-staatsburgerschap dat het verlies van de nationaliteit van de DDR steeds een aangelegenheid is, die de hele

112. "Für die Entscheidung über einen Antrag auf Verleihung der DDR-Staatsbürgerschaft is es zumeist wesentlich, dass kein Fall mehrfacher Staatsbilngerschaft entsteht." Riege, p. 307.

113. Riege, p. 307-308. Zie over deze verdragem p. 48 .

114. Riege, p. 308.

115. Cr. Riege, p. 313.

116. De meerderjarigheidsgrens werd bij de wet van 17 mei 1950, GBll 1950 , p. 437 op 18 jaar vastgesteld.

117. Riege, p. 315-316. 
maatschappij van de DDR betreft en dat daarom een beslissing omtrent het verlies van dat staatsburgerschap niet uitsluitend aan de wil van betrokkene kan worden overgelaten. Opgemerkt dient te worden dat staatsburgers van de DDR niet zonder toestemming van het bevoegde orgaan met buitenlanders mogen huwen $(\$ 15$ lid 1 van de Einführungsgesetz zum FGB van 20 december $1965^{118}$ ). Indien betrokkene ingevolge de huwelijkssluiting de nationaliteit van zijn/haar huwelijkspartner verwerft, wordt deze toestemming tevens gezien als een toestemming tot het verkrijgen van een andere nationaliteit, die in $\$ 3$ lid 2 StBG wordt voorgeschreven (\$ 4 lid 4 DVO).

\subsubsection{Ontslag}

Het ontslag uit de DDR-nationaliteit wordt geregeld in $\$ 10$ en 11 StBG en in $\S$ 8-11 DVO. De beslissingsbevoegdheid wordt in $\$ 15$ lid 1 evenals ten aanzien van de naturalisatie gelegd bij de Ministerraad, die zijn bevoegdheid mag delegeren(lid 2). De vereisten voor ontslag zijn de volgende:

- betrokkene moet met de toestemming van de bevoegde instantie van de DDR zijn vaste woon- of verblijfplaats in het buitenland hebben of voornemens zijn zich in het buitenland te vestigen ( $\$ 10$ lid 1$)$; in de praktijk wordt slechts aan in het buitenland woonachtige personen ontslag verleend ${ }^{119}$;

- de verzoeker moet reeds een andere nationaliteit bezitten of althans van plan zijn om deze te verwerven (lid 1);

- er mogen geen gewichtige redenen zijn om het ontslag te weigeren(lid 1);

We zien dat de staat eigenlijk tweemaal omtrent het verlies van de nationaliteit door de verzoeker beslist, aangezien de toestemming voor emigratie als voorwaarde voor het ontslag wordt geformuleerd. In het verleden heeft de BRD met de DDR verschillende afspraken gemaakt, die op de mogelijkheid van emigratie van de DDR-staatsburgers naar de BRD betrekking hebben. Deze emigratie wordt in het kader van gezinshereniging beperkt toegestaan en is van de bereidheid van de BRD om kredieten te verlenen afhankelijk ${ }^{120}$. Aan gepensioneerden wordt echter vrij regelmatig toestemming verleend ${ }^{121}$. Op 30 november $19888^{122}$ werd een nieuwe verordening betreffende de uitgifte van paspoorten afgekondigd. Deze bevat enige verbeteringen zoals de regelingen van termijnen waarbinnen de overheid de beslissing moet nemen en rechterlijke controle van deze beslissingen. Een paspoort kan Echter nog steeds met een vaag beroep op de staatsveiligheid, ordre public, of de belangen van defensie worden geweigerd ( $\$ 13$ lid 1$)$. In een dergelijk geval is de rechterlijke controle van de beschikking uitgesloten.

118. GBL. 1965 I, p. 19.

119. Cf. Riege, p. 318-319; Riege/Kulke, p.67-68.

120. Ook komat het voor dat de DDR voor emigratie van dissidenten van de BRD hoge bedragen wraagt. Zie Menschenrechte, p. 126.

121. In de jaren 1971-1985 zijn 200.000 Duitsers legaal uit de DDR geëmigreerd. Menschenrechte, p. 109.

122. Gbl. 1988, p. 271. 
De tweede voorwaarde voor het ontslag uit de nationaliteit van de DDR heeft de strekking apatridie na het ontslag uit de DDR-nationaliteit tegen te gaan.

Het negatief geformuleerde derde vereiste is bijzonder vaag en wordt noch in de StBG noch in de DVO nader gepreciseerd. Riege ${ }^{123}$, noemt in dit verband een lopende strafrechtelijke procedure tegen de betrokkene en "militaire gronden" zoals het nog niet vervuld hebben van de militaire dienstplicht en kennis van "militaire geheimen". Aangezien de toestemming voor emigratie voorwaarde voor het ontslag is, kan ten aanzien van de "zwingende Gründe" ook te rade worden gegaan bij de "Verordnung zur Regelung von Fragen der Familienzusammenführung und der Eheschliessung zwischen Bürgern der DDR und Ausländern" van 15 september $1983^{124}$. Deze verordening noemt in $\$ 8$ de volgende redenen voor weigering van een toestemming voor emigratie:

- belangen van de DDR, met name met betrekking tot de openbare orde en veiligheid;

- het verbod van emigratie gedurende een bepaalde termijn na het vervullen van de militaire dienstplicht ${ }^{125}$;

- een lopende strafrechtelijke procedure of een nog niet voltrokken vrijheidsstraf.

Voorts noemt Riege ${ }^{126}$ ook beletselen voor het verlenen van toestemming die verband houden met de onderhoudsverplichtingen en zorg voor familieleden, andere schulden en het onbeheerd laten van onroerend goed.

\subsection{Invloed op de nationaliteit van de gezinsleden van de verzoeker}

Ontslag uit de nationaliteit van de DDR heeft geen invloed op het staatsburgerschap van de huwelijkspartner van de verzoeker. Met betrekking tot het medeontslag van minderjarige kinderen van betrokkene zijn de regels betreffende medenaturalisatie van overeenkomstige toepassing ${ }^{127}$. Minderjarige kinderen van de verzoeker worden slechts op uitdrukkelijk verzoek meeontslagen. Bij kinderen van 14 jaar en ouder is tevens hun eigen instemming noodzakelijk.

\subsubsection{Ontneming en herroeping van een naturalisatiebesluit}

De nationaliteit van de DDR kan uitsluitend door de Ministerraad worden ontnomen aan personen, die zich in het buitenland bevinden, wegens "grober Verletzung der Staatsbürgerschaftspflichten" (\$13). Deze bijzonder vage ontne-

123. Riege, p.. 321-322.

124. GBI. I 1983, nr. 26, p. 254. Cf. Riege, p. 322; Kuss, EuGRZ 1987, p. 312 . Gewijzigd bij de verordening van 30 november 1988 , GBl. $1988, \mathrm{p} .274$.

125. Bij het ontslag uit de militaire dienst of andere functies, waarbij men geacht wordt staatsgeheimen te kennen, wordt dikwijls een termijn vastgesteld, waarbinnen betrokkene niet mag emigreren.

126. Riege, p. 322.

127. Egler e.a., p. 165 . 
mingsgrond die uit het reeds genoemde decreet van 31 augustus 1964 werd overgenomen, is tevens het enig wettelijk vereiste. De wet en de DVO zwijgen over eventuele voorbeelden van een gedrag dat de ontneming van de nationaliteit krachtens $\& 13$ rechtvaardigt. Riege ${ }^{128}$, geeft als voorbeeld oorlogsmisdaden, misdaden tegen de vrede en menselijkheid, deelname aan activiteiten die tot onderdrukking of tegen het vrijheidsstreven van andere volkeren gericht zijn, fascisme, militarisme, rassen- en volkerenhaat, spionage, etc. Ondanks deze voorbeelden blijft het feit overeind, dat ontneming van de nationaliteit een sanctie is die hoofdzakelijk bij de zogenaamde "Republikflucht", dat wil zeggen het verlaten van het staatsgrondgebied zonder toestemming van de bevoegde autoriteiten, wordt toegepast. De nationaliteit wordt niet in alle gevallen ontnomen en een duidelijke beleidslijn is hierbij niet te achterhalen. Het is aannemelijk dat de vraag of in een concreet geval de nationaliteit inderdaad wordt ontnomen afhangt van de omstandigheden van het geval en van het politieke klimaat tussen beide Duitslanden op dat moment.

"Republikflucht" komt in de DDR erg vaak voor, volgens Westduitse bronnen zouden sedert 7 oktober 1949 meer dan 3,5 miljoen personen de DDR illegaal hebben verlaten ${ }^{129}$. Naast de regeling van ontneming van het staatsburgerschap in het StBG heeft men in het nabije verleden twee bijzondere voorschriften uitgevaardigd, waardoor de nationaliteit collectief werd ontnomen. Bij wet van 16 oktober 1972 (Regelungsgesetz) ${ }^{130}$ werd aan alle personen, die voor 1 januari 1972 het grondgebied van de DDR illegaal hadden verlaten en niet terugkeerden, collectief de nationaliteit ontnomen ( $\$ 1$ lid 1$)$. Hetzelfde gold ook voor alle afstammelingen van genoemde personen, voorzover zij op de dag van inwerkingtreding van deze wet (17 oktober 1972) eveneens hun woonplaats in het buitenland hadden. Vervolgens werd inhoudelijk dezelfde regeling getroffen bij de verordening van 21 juni $1982^{131}$, die op de tot 1 januari 1981 gevluchte personen betrekking had ${ }^{132}$. Interessant is dat deze verordening niet als een algemene regeling wordt beschouwd, maar als een beschikking krachtens $\$ 13$ van de nationaliteitswet ${ }^{133}$.

Het is opmerkelijk vast te stellen, dat DDR-staatsburgers aan wie de nationaliteit wordt ontnomen in de meeste gevallen toch in een veel betere positie komen te verkeren dan emigranten uit andere Oosteuropese landen. Onderdanen van de DDR emigreren namelijk bijna uitsluitend naar de Bondsrepubliek. Aangezien allen de nationaliteit daarvan bezitten, worden ze door ontneming van het DDR-staatsburgerschap in geen geval staatloos. Ontneming van de nationaliteit betekent in de regel dan ook "slechts" ontneming van het recht naar de DDR terug te keren ${ }^{134}$.

128. Riege, p. 329.

129. Staatsbürgerschaft, p. 17

130. GBI. 11972 , nr. 18 , p. 265.

131. GBI. I 1982, nr. 22, p. 418 .

132. Riege, p. 325 .

133. Riege, p. 325.

134. Riege, p. 331. 


\subsection{Herroeping van naturalisatie}

\$ 12 StBG maakt mogelijk een naturalisatie binnen een termijn van vijf jaren na de totstandkoming van het naturalisatiebesluit te herroepen. De bevoegdheid wordt gelegd bij de Ministerraad ( $\$ 16$ lid 1) Dit verlies van de nationaliteit werkt ex nunc ${ }^{135}$ "Een naturalisatie kan in de volgende twee gevallen worden herroepen.

- indien de verzoeker gebruik heeft gemaakt van valse gegevens of essentiele feiten of omstandigheden heeft verzwegen (lid 1 sub a) en

- vanwege grove verontachtzaming van staatsburgerlijke "plichten" (lid 1 sub b).

Reeds eerder, op p. 12-13 werd daarop gewezen dat het bij de sub b genoemde grond om een bijzondere ontnemingsmogelijkheid met betrekking tot genaturaliseerde DDR-onderdanen gaat ${ }^{136}$.

Noch in de wet, noch in de DVO wordt de vaag geformuleerde $\$ 12$ lid 1 sub b) nader gepreciseerd. Riege ${ }^{137}$, noemt als voorbeelden "neonazistische" of "revanschistische" activiteiten en zware wetsovertredingen. Deze mogelijkheid van het verlies van de nationaliteit stuit in de BRD op stevige kritiek ${ }^{138}$. De bevoegdheid om een naturalisatiebesluit te herroepen ligt bij de Ministerraad ( $\$ 16)$ zonder de mogelijkheid om deze bevoegdheid te delegeren. Hierdoor wordt het exceptionele karakter en het politieke belang van deze wijze van ontneming van de nationaliteit nog bijzonder onderstreept ${ }^{139}$. Het recht om in de DDR te mogen verblijven is in beginsel gekoppeld aan het bezit van de DDR-nationaliteit. In de regel betekent herroeping van de naturalisatie derhalve ook uitwijzing uit de DDR krachtens $\& 7$ e.v. vreemdelingenwet ${ }^{140}$.

\subsection{Invloed op de nationaliteit van de gezinsleden van betrokkene}

Ontneming van het staatsburgerschap heeft blijkens $\S 14$ geen invloed op de nationaliteit van gezinsleden van betrokkene. Deze "garantie" belet uiteraard niet dat aan hen de nationaliteit niet zelfstandig kan worden ontnomen.

135. Riege, p. 328 .

136. Zo ook Bernhardt, Mitteilungsblatt des Königsteiner Kreises 1968, p. 28.

137. Riege, p. 328.

138. Door Zieger, p. 21 wordt hierbij een parallel getrokken met de reeds op p. 151 genoemde Duitse wet van 14 juli 1933 die mogelijk maakte politiek ongewenste naturalisaties ongedaan te maken. Het is interessant in dit verband ook het door Riege, p. 328 aangehaalde voorbeeld van de Verenigde Staten te vermelden, waar de mogelijkheid bestaat om binnen vijf jaar een naturalisatie te herroepen met een beroep op "communistische activiteiten".

139. Cf. Riege, p. 327-328; Zieger, p. 22.

140. Wet van 28 juni 1979, GBI. I 1979, nr. 17, p. 149. Zie Riege, p. 331. 


\subsection{GeschitedenIS}

\subsubsection{Inleiding}

Het Hongaarse koninkrijk ontstond reeds in de 10de eeuw ${ }^{1}$. Na de slag bij Mohacs tegen het Turkse leger in 1526 werd het Hongaarse grondgebied van Hongarije echter verdeeld tussen Turkije, Oostenrijk en het nieuw ontstane, aan Turkije tribuutplichtige, vorstendom Transsylvanie ${ }^{2}$. Het grootste deel van Hongarije dat aan de Turken toekwam, bleef gedurende ongeveer 150 jaar onder de heerschappij van Istanboel, waarna de Habsburgers het gehele Hongaarse gebied in hun macht kregen ${ }^{3}$. Op grond van de zogenaamde "Pragmatische Sanktion" van 1724 had Hongarije een verstrekkende autonomie ${ }^{4}$. In de jaren 1848-49 kwam het in Hongarije tot een opstand tegen de Oostenrijkers en op 14 april 1849 werd er een republiek uitgeroepen ${ }^{5}$. Reeds in hetzelfde jaar kregen de Oostenrijkers de macht weer in eigen handen en werd de autonomie die Hongarije voorheen genoot afgeschaft ${ }^{6}$. Vervolgens werd in 1867 een compromis gesloten, waarbij de Oostenrijks-Hongaarse dubbelmonarchie werd opgericht. Hongarije werd een zelfstandig koninkrijk en had met Oostenrijk slechts de koning-keizer, buitenlandse zaken, leger en financiën gemeenschappelijk? Hongarije had ook een eigen rechtsstelsel. $\mathrm{Na}$ de eerste wereldoorlog werd op 16 november 1918 de "tweede" Hongaarse republiek uitgeroepen ${ }^{8}$. Vervolgens kwamen op 21 maart 1919 de communisten aan de macht en riepen ze naar voorbeeld van de RSFSR de "Socialistische Federatieve Sovjetrepubliek Hongarije" uit ${ }^{9}$. Vervolgens werd op 2 april $1919^{10}$ bij een regeringsverordening eerst een provisorische constitutie afgekondigd, die op 23 juni $1919^{11}$ met een naar voorbeeld van de RSFSR samengestelde grondwet werd vervangen. Interessant is dat ook in Hongarije aan buitenlandse arbeiders en boeren het kiestecht werd toegekend ( $\$ 866-72$ ). Het communistische regime werd echter reeds op 12 augustus 1919 gedwongen het stuur uit handen te geven ${ }^{12}$. Hongarije werd opnieuw een koninkrijk, maar zonder koning ${ }^{13}$. De functie van het staatshoofd werd tussen 1 maart 1920 en 15 oktober 1944 uitgeoefend door de regent admiraal Horthy ${ }^{14}$.

1. Teleki, p. $27_{;}$Karácsony, p. 4.

2. Ortlof, p. 1 .

3. Ortloff, p. 1-2.

4. Ortloff, p. 2 .

5. State Papers, 38, 1123; Teleki, p. 126-127; Peaslee, p. 498.

6. Ortloff, p. 4.

7. Teleki, p. 127-128.

8. Peaslee, p. 429 .

9. Teleki, p. 135; Peaslee, p. 429. Zie uitwoerig over de Hongaarse Sovjetrepubliek Schweissguth, p. 199-211.

10. Regeringsverordening nr. XXVT, TK (Tanácsköztársäg) 11919 , nr. 8; zie voor Duítse vertalling Schweissguth, p. 211-214.

11. TK 1919, nr. 19; Duitse vertaling bij Schweissguth, p. 214-225.

12. Teleki, p. 135 .

13. Sharp, p. 45.

14. Peaslee, p. 429 . 
In 1938 kon Hongarije op grond wan de "Wiener Schiedsspruch" wan 2 november 1938 zijn territorium uitbreiden met het gebied Karpatho-Oekraïne dat voorheen aan Tsjechoslowakije toebehoorde ${ }^{15}$. Voorts werd op grond van de tweede "Wiener Schiedsspruch" van 30 augustus $1940^{16}$ Noord-Transsylvanië, dat daarvoor Roemeens was, bij Hongarije ingelijfd. Hongarije trad in november $1940^{n}$ toe tot het "Driemachtenpact" en haar strijdkrachten occupeerden in april 1941 een gedeelte van Joegoslaviê. Nadat het pro-nazi regime in 1944 werd afgezet, werd Hongarije op 19 maart 1944 door de Duitsers bezet, waardoor het oude regime nogmaals aan de macht kon komen ${ }^{18}$. In 1945 werd het grondgebied van Hongarije door de USSR van de Duitse bezetting bevrijd. Daarna werd een nieuwe regering gevormd, die op 17 januari 1946 opnieuw een republiek uitriep. Op 10 februari werd vervolgens het vredesverdrag tussen Hongarije en de geallieerden ondertekend, waarbij de omvang van het Hongaarse grondgebied binnen de op 1 januari 1938 bestaande grenzen werd teruggebracht. Zo werd de Noord-Transsylvanië aan Roemenië teruggegeven, terwijl de Karpatho-Oekraïne op grond van het verdrag van Moskou van 29 juni $1947^{19}$ tussen Tsjechoslowakije en de USSR, aan de laatste toekwam. Op 20 augustus $1949^{20}$ werd vervolgens de eerste grondwet van de Volksrepubliek Hongarije afgekondigd. Deze grondwet werd voorts meermalen ${ }^{21}$ gewijzigd, laatstelijk in $1983^{22}$.

Hongarije is sedert de oprichting van het Warschaupact en van de COMECON lid van beide organisaties. In $1956 \mathrm{kwam}$ het tot een opstand tegen de USSR, die door een bezetting door de legers van de Warschaupactlanden in november van dat jaar werd beëindigd. In de laatste jaren is in Hongarije een sterke democratiseringstendens waarneembaar.

15. Schmied, p. $281-282$.

16. Zie daarover Makarow, ZaöRV 1940-41, p. 351-355.

17. Zie het bericht in Zä̈RV 1940-41, p. 817 .

18. Sharp, p. 46.

19. SGS deel 18, p. 10,31 ; Schmid, p. 298.

20. Engelse vertaling bij Sharp, p. 104-114.

21. De grondwet werd gewijzigd bij de volgende wetten: IV: 1950; I: 1951; I: 1952; IV en VT: 1953; III, VII en VIII: 1954; II: 1955; III: 1956; II: 1957. Beer, p. 45-48. Het is in de Hongaarse wetgeving gebruikellijk om de wetten die binnen een jaar tot stand komen te bundelen, waarbij afzonderlijke wetten met "artikelen" worden aangeduid en met romeinse cijfers genummerd. In. Hongarije verwijst men naar wetten niet met vermelding van de datum van totstandkoming respectievelijk de vindplaats in het staatsblad, maar door het nummer en jaar van totstandkoming. aan te geven. SGS deel 22, p. 40. In het vervolg zullen in de tekst alle Hongaarse wetten eenvoudig met "de wet van..." worden aangeduid, terwijl in de noot de Hongaarse officiële aanduiding zal worden opgenomen.

22. Zie het bericht in JöR 1984 , p. 252. 


\subsubsection{Algemeen}

De eerste Hongaarse ${ }^{23}$ regeling van de nationaliteit in de huidige betekenis va. het woord was de zogenaamde wet-artikel L: 1879 van 20 december $1879^{24}$. Naasi deze wet werden in de periode tot 1945 ook een aantal bijzondere regelingen met betrekking tot de nationaliteit afgekondigd. Dit waren;

- de wet van 13 maart $1886^{25}$ betreffende herkrijging van de nationaliteit door remigranten;

- de gemeentewet van $1886^{26}$, die voorschriften omtrent het "Heimatrecht" 27 bevatte;

- de wet van 14 maart $1903^{28}$ betreffende het verblijfsrecht van vreemdelingen in de landen van de Hongaarse kroon;

- verordening van 28 september $1921^{29}$ betreffende de uitvoering van de nationaliteitsrechtelijke bepalingen van het vredesverdrag van Trianon;

- de wet van 22 juni $1939^{30}$ betreffende de inlijving van de Karpatho-Oekraïne;

- de wet van 6 oktober $1940^{\text {I1 }}$ betreffende inlijving van de Noord-Transsylvanië;

- de wet van 27 december $1941^{32}$ betreffende inlijving van de door Hongarije bezette Joegoslavische gebieden;

23. De regeling van $\$ \$ 2-32$ van het Oostenrijkse Aligemeine bürgerliche Gesetzbuch van 1811 (ABGB), gold in Hongarije (met de tussenpoos in de jaren 1848-1949) tot 1861.

24. Duitse vertaling in Polizei Hamburg, p. 337-346; SGS deel 22, p. 98-107; Franse in Clunet 1916, P. 729. Zie over deze Lapradelle/Niboyet, p. 664-667; Egyed, ZfoR 1930, p. 495-506.

25. Wet-art. IV: 1886; Duitse vertaling in SGS deel 22, p. 107-108; ZfOR 1930, p. 501. Deze wet werd ingetrokken bij \$ 36 van de wet-art. LX: 1948.

26. Wet-art. XXII: 1886; "Zie voor een Duitse vertaling van woor de nationaliteit relevante bepalingen SGS deel 22, p. 108-110.

27. Dit was een instituut van het Oostenrijks-Hongaarse recht. Het ging om een soort werbliffsrecht in een gemeente en deze was in gewal van behoeftigheid verplicht aan betrokkeno bijstand te verlenen. Het Heimatrecht werd geregeld in de Oostenrijkse Heimatgesetz van 3 december 1863; öRGBL. nr. 105, gewijzigd bij de wet van 5 december 1896, öRGBL. 222. In Hongarije werd de regeling van het Heimatrecht opgenomen in de gemeentewet van 1889; wet-art. XXI: 1886. Zic uiltvoerig ower het Heimatrecht Langhoff, Staatsbürgersehaft und Heimatrecht in Österreich, Wien 1920 en Weiss, Das Heimatrecht, Wien 1906.

28. Wet-art. $V_{s}$ 1903; O.T. 1903, „ar. 2.

29. Duitse vertaling in SGS deel 22, p. 113-118.

30. Wet-art. VI: 1939; zie voor een Duitse vertaling van het op de nationaliteit betrekking hebbende art. 5, SGS, deel 22, p. 123-124.

31. Wet-art. XXVI: 1940; zie voor een Duitse vertaling van het op de nationaliteit betrekking hebbende art. 4 SGS deel 22, p. 128.

32. Wet-art. XX: 1941; zie voor een Duitse vertaling van het op de nationaliteit betrekking hebbende art. 4, SGS deel 22 , p. 135 ; SGS deel 17 , p. 129 . 
Hongarije sloot ook een aantal internationale verdragen die (mede) betrekking hadden op de nationaliteit, namelijk:

- het vredesverdrag van Trianon van 4 juni $1920^{33}$;

- het verdrag met Tsjechoslowakije van 18 februari $1939^{34}$ betreffende de nationaliteit van de bewoners van de Karpatho-Oekraïne;

- het verdrag van 20 mei $1941^{35}$ met Slowakije tot regeling van enkele nationaliteitsrechtelijke onderwerpen;

\subsubsection{De wet van 1879}

\subsection{Algemeen}

De reeds genoemde nationaliteitswet wan 1879 werd meermalen gewijzigd en vormde tot 1948 de basis van het Hongaarse nationaliteitsrecht. De belangrijkste wijziging kwam bij de wet van 1 september $1939^{36}$ tot stand, waarbij aan enkele bepalingen van deze wet zelfs terugwerkende kracht tot 1879 werd verleend. De wet van 1939 bracht een vergaande verscherping van verliesbepalingen met zich mee. Hieronder volgt een bespreking van de Hongaarse nationaliteitswet zoals deze gold na de hierbovengenoemde wijzigingswet van 1939 .

\subsection{Verkrijging wan de nationaliteit}

De Hongaarse nationaliteit kon worden verkregen van rechtswege en door naturalisatie. Andere wijzen van verkrijging van het staatsburgerschap kende de wet van 1879 niet.

\section{a. Verkrijging van rechtswege}

Verkrijging van de Hongaarse nationaliteit werd van rechtswege gekoppeld aan de volgende feiten:

- geboorte uit Hongaarse ouder(s) (\$\$ 3,4);

- geboorte in Hongarije (\$19);

- huwelijk met een Hongaarse man ( $\$ 5)$;

33. Goedgekeurd bij de wet-art. XXIII van 27 juli 1921, J.O. 1921, p. 9887. Zie voor een Duìtse vertaling van de nationaliteitsrechtelijke bepalingen wan het vredesverdrag van Trianom: SGS deel 22, p. 111-113.

34. Duitse vertaling in SGS deel $22, \mathrm{p}, 120-123$.

35. B.K. 1941, nr. 116; S.Z.(Sbirka Zákonn) 1941, nr. 25, pos. 90; Duitse vertaling in SGS deel 22, p. $128-134$.

36. Wet-art. XIII: 1939; Duitse vertaling in SGS deel 22, p. 124-128. Zie daarover Lichter, SLAZ 1940, p. 58 . 
Adoptie en erkenning door een Hongaar hadden geen invloed op de nationaliteit van het geadopteerde kind $^{37}$.

\section{i. Geboorte uit Hongaarse ouder(s)}

Een wettig ${ }^{38}$ kind wiens vader op het tijdstip van de geboorte van het kind de Hongaarse nationaliteit bezat, verwierf deze nationaliteit iure sanguinis. Hetzelfde gold ten aanzien van een buitenechtelijk kind wiens moeder Hongaarse was. Het was daarbij niet van belang of het kind binnen of buiten Hongarije werd geboren (\$3).

Een onwettig kind van een vreemdelinge, dat door een Hongaarse staatsburger werd gelegitimeerd, verwierf krachtens $\$ 4$ de Hongaarse nationaliteit. De wettiging kon geschieden door huwelijk met de moeder van het kind ${ }^{39}$, of als gunst bij een "rescriptio principis" (besluit van de koning) ${ }^{40}$. Bij wettiging door huwelijk werd verder vereist dat het kind op het tijdstip van de huwelijksvoltrekking nog minderjarig was ${ }^{41}$. Indien de vader van het kind echter Hongaar door geboorte was, verkreeg het kind deze nationaliteit ook indien het op dat tijdstip reeds meerderjarig was ${ }^{42}$. Alleen door erkenning werd geen verkrijging van de nationaliteit bewerkstelligd. Een rechterlijk vonnis, waarbij vastgesteld werd dat de reeds overleden vader van een door hem erkend kind de bedoeling had met de moeder van het kind te huwen, had dezelfde gevolgen als wettiging. Ook in dat geval werd door het kind de Hongaarse nationaliteit verworven ${ }^{43}$.

\section{ii. Geboorte op het Hongaarse grondgebied}

Ondanks het feit dat in $\$ 2$ bij de opsomming van verkrijgingsgronden geboorte op het Hongaarse grondgebied ontbreekt, kon het Hongaarse staatsburgerschap ook iure soli worden verworven. Het ging dan om een praesumptio iuris ten aanzien van de verkrijging van de nationaliteit, waartegen steeds bewijs werd toegelaten, ongeacht de leeftijd van het kind. Krachtens $\$ 19$ werd een kind dat in Hongarije werd geboren of gevonden, vermoed Hongaars staatsburger te zijn. Bij vondelingen gold tevens het vereiste dat ze in Hongarije moesten zijn opgevoed ${ }^{44}$.

37. SGS deel 22 , p. 49.

38. Het kind behield deze nationaliteit ook in het geval dat het huwelijk later nietig bleek te zijn, indien tenminste én van de ouders te goeder trouw was. SGS deel 22, p. 48 .

39. In het geval dat het kind overspelig was en de ouders dat wisten, werd het kind door een later huwelijk tussen hen niet gewettigd. SGS deel 22, p. 49.

40. Wettiging werd geregeld bij de wet-art. XXXII: 1894 .

41. Szlezak, SGS deel 22 , p. 49, onder verwijzing naar het besluit van de Minister van binnenlandse zaken nr. 52550 uit 1903; opgenomen in: Sammlung won Verwaltungsentscheidungen deel III, $p$. 373.

42. Szlezak, SGS deel 22 , p. 49 , mett verdere literatuurverwijzingen.

43. SGS deel 22 , p. 49.

44. SGS deel 22 , p. 53 . 
De Hongaarse nationaliteitswet van 1879 huldigde het beginsel van één nationaliteit in het gezin (système unitaire). Krachtens \$ 5 verkreeg een buitenlandse vrouw die met een Hongaar in het huwelijk trad, van rechtswege de Hongaarse nationaliteit, $\mathrm{Ze}$ had geen mogelijkheid om de verwerving van het staatsburgerschap te voorkomen. Door ontbinding van het huwelijk ging de Hongaarse nationaliteit voor deze vrouw weer verloren, ongeacht of ze daardoor haar oorspronkelijke nationaliteit herkreeg $(\$ 35)$. Betrokkene behield de nationaliteit indien het huwelijk later werd vernietigd, mits zij ten aanzien van de vernietigingsgrond te goeder trouw was. Anders verloor ze de Hongaarse nationaliteit ex tunc ${ }^{45}$.

\section{b. Naturalisatie}

Verkrijging van de Hongaarse nationaliteit door naturalisatie was geregeld in \$\$ 6-19 van de wet van 1879. Een naturalisatieverzoek moest worden ingediend bij de burgemeester van de woonplaats van betrokkene, die na de toetsing van het verzoek aan de naturalisatievereisten zijn advies omtrent de naturalisatie aan de Minister van binnenlandse zaken ${ }^{46}$ moest doorsturen $(\$ \$ 9,10)$. Deze nam vervolgens de beslissing omtrent het verzoek ( $\$ 11)$. De Minister had geen discretionaire bevoegdheid. Indien betrokkene aan de vereisten voldeed, moest hij de naturalisatie verlenen. Tegen een afwijzende beschikking was administratief beroep mogelijk ${ }^{47}$. Hierbij dient echter te worden aangetekend, dat de belangrijkste beslissing in een naturalisatieprocedure op het gemeentelijk niveau werd genomen ${ }^{48}$. Gemeentebesturen hadden in Hongarije namelijk een verstrekkende autonomie en zij hadden wel discretionaire bevoegdheid bij het opnemen van buitenlanders in hun gemeente (het verlenen van het "Heimatrecht"). Naturalisatie was krachtens $\$ 8$ lid 1 sub 2 namelijk slechts mogelijk, indien betrokkene kon bewijzen, dat hij in een gemeente het "Heimatrecht" bezat, respectievelijk na zijn naturalisatie zou krijgen ${ }^{49}$. De bepaling van $\$ 8$ lid 2 werd bij de wijzigingswet van 1939 geschrapt $^{50}$.

Naturalisatievereisten waren de volgende:

- volledige handelingsbekwaamheid ${ }^{51}(\$ 8$ lid 1 sub 1$)$;

45. SGS deel 22, p. 49.

46. Tot 1918 was ten aanzien wan de verzoekers die in Kroatië, Slavonië of Dalmatie woonden, de "Ban" bevoegd om een naturalisatie te verlenen. De huidige Joegoslavische gebieden Kroatie, Slavonië en Dalmatie hadden in Hongarije een verstrekkende autonomie met een eigen parlement (Sabor) en de "Ban" die de functie van een soort "staatshoofd" vervulde. Helt gebied van Fiume (Rijeka) was echter direct onder het centrale bestuur geplaatst en ten aanzien van de inwoners daarvan was de Minister van binnenlandse zaken bevoegd.

47. SGS deel 22 , p. $50-51$.

48. Cl. SGS deel 22, p. 50.

49. De ratio van dit vereiste was, dat personen die in een gemeente hun Heimatrecht" hadden, het recht hadden op bijstand van de gemeente, in het geval dat zij miet over voldoende middelen van bestaan beschikten.

50. Cf. Lichter, StAZ 1940, p. 58.

51. Handelingsonbekwamen moesten een naturalisatieverzoek door tussenkomst van hun wettelijke vertegenwoordiger indienen. 
- de verzoeker moest bewijzen, dat hij na de naturalisatie in een gemeente zou worden opgenomen ${ }^{52}$ (sub 2);

- vijfjarig ononderbroken verblijf in Hongarije (sub 3);

- $\quad$ goed gedrag (sub 4);

- betrokkene moest in staat zijn zichzelf en zijn gezin te onderhouden (sub 5);

- de verzoeker moest sedert vijf jaren in de lijst van belastingplichtigen zijn opgenomen $^{53}$ (sub 6);

- het afleggen van een eed van trouw (\$13).

Personen die volgens het Hongaarse recht door een Hongaar werden geadopteerd, konden worden genaturaliseerd zonder te voldoen aan de eisen sub 3,5 en 6 . In dat geval was het voldoende dat hun adoptief-ouder zelf aan de laatste twee vereisten voldeed ( $\$ 8$ lid 2 ).

¿. Invloed op de nationaliteit van de gezinsleden van de verzoeker

Een naturalisatie strekte zich automatisch uit over de vrouw en de minderjarige kinderen ${ }^{54}$, over wie betrokkene ouderlijke macht uitoefende $(\$ 7)$. Noch de vrouw, noch de kinderen hadden de mogelijkheid om de nationaliteitsverkrijging te weigeren.

\subsection{Verlies van de nationaliteit}

De Hongaarse nationaliteit ging volgens de wet van 1879 verloren van rechtswege, door ontslag en door ontneming. Verlies door het afleggen van een verklaring van afstand kende deze wet niet.

a. Verlies van rechtswege

De wet van 1879 koppelde het verlies van de nationaliteit ipso iure aan de volgende feiten:

- wettiging door een buitenlander ( $\$ 33)$;

- huwelijk met een buitenlander ( $\$ 34)$;

- naturalisatie in een ander land (\$ 1 1939);

52. Zie de Gemeentewet van 1886 .

53. Het feitellijk betalen van belastingen was niet woldoende. SGS deel 22, p. 49 .

54. In de literatuur ontstond verschil van mening over de wraag of het woor werkrijging van de nationaliteit door de kinderen van de naturalisandus vereist was dat ze ia de naturalisatieoorkonde werden vermeld. Zie Szlezak, SGS deel 22, p. 49 met verdere literatuurverwijzingen. 


\section{i. Wettiging door een buitenlander}

Ex $\$ 33$ werd de Hongaarse nationaliteit verloren door een onwettig kind dat door een buitenlander werd gewettigd. Het kind verloor de nationaliteit ongeacht zijin leeftijd. Het verlies trad echter niet in, indien het kind door de wettiging niet de nationaliteit van zijn vader verwierf en het tevens in Hongarije bleef wonen.

\section{ii. Huwelijk met een buitenlander}

Een Hongaarse vrouw die met een buitenlander in het huwelijk trad, verloor daardoor de Hongaarse nationaliteit $(\$ 34)$. Het verlies van de nationaliteit trad ook in, indien zij door of in verband met het huwelijk niet de nationaliteit van haar man werwierf. Ze had geen mogelijkheid de Hongaarse nationaliteit te behouden. Indien het huwelijk later ontbonden werd, kon zij worden gehernaturaliseerd. Als enige vereiste gold dan dat zij in Hongarije moest wonen, of althans het voornemen moest hebben, zich in Hongarije te vestigen. Deze mogelijkheid van verlichte hernaturalisatie werd ingevoerd bij de wijzigingswet van 29 augustus 1939 ( $\$ 6$, aanhef en sub 1).

\section{iii. Naturalisatie in een ander land}

Een Hongaar verloor zijn nationaliteit indien hij door naturalisatie een andere nationaliteit verwierf. Deze verliesgrond werd pas bij de wijziging van de nationaliteitswet in 1939 ingevoerd ( $\$ 1$ lid 1 van de wijzigingswet). Interessant is echter dat aan deze wijziging terugwerkende kracht tot de inwerkingtreding van de wet van 1879 werd verleend ( $\$ 1$ lid 2 ). In het geval dat betrokkene reeds vóór de inwerkingtreding van de wijzigingswet op 1 september 1939 in het buitenland werd genaturaliseerd, verloor hij de Hongaarse nationaliteit op 1 september 1939. Indien de vrouw en kinderen van betrokkene tezamen met hun man, respectievelijk vader werden meegenaturaliseerd, verloren ook zij hun nationaliteit (lid 3).

\section{iv. Langdurig verblijf in het buitenland}

De regeling van het verlies van de nationaliteit wegens langdurig verblijf in het buitenland werd bij \& 2 van de wijzigingswet van 29 augustus 1939 aanmerkelijk aangescherpt. De nationaliteit ging van rechtswege verloren, indien betrokkene zich tien jaren ononderbroken in het buitenland bevond, zonder dat hij daar in opdracht van de Hongaarse regering verbleef. De termijn van tien jaar ving aan bij het overschrijden van de grens, respectievelijk op het moment dat de officiële regeringsopdracht in het buitenland afgelopen was $(\$ 2$, leden 2,3$)$. Voorts kon de termijn worden gestuit door een verblijf in Hongarije van meer dan drie maanden ${ }^{55}$.

55. Dit was een aanzienlijke verscherping ten opzichte van de voor 1939 geldende regeling die geen minimumeisen voor stuiting van de termijn stelde ( 31 in de versie tot 1939). Volgens Szlezak, SGS deel 22, p. 5455 was het tot dan bijvoorbeeld voldoende dat betrokkene in een slaapwagen van Parijs door Hongarije naar Istanboel reisde, zonder uit de trein te stappen. 
Betrokkene verloor zijn nationaliteit niet, indien hij telkens vór het verlopen van de termijn bij de Minister van binnenlandse zaken of bij een Hongaarse vertegenwoordiging in het buitenland te kennen gaf dat hij zijn nationaliteit wenste te behouden en daarvoor de toestemming van de Minister van binnenlandse zaken kreeg $(\$ 2 \text { lid } 4)^{56}$.

Het verlies van de nationaliteit strekte zich tevens uit over de vrouw en de minderjarige kinderen van betrokkene, voorzover ze met hun man, respectievelijk vader samenwoonden. Ten aanzien van de kinderen werd tevens vereist dat betrokkene over hen het ouderlijk gezag uitoefende (lid 5).

\section{b. Ontslag}

Het verlies van de Hongaarse nationaliteit was geregeld in $\$ \$ 21-30$ van de wet van 1879 . Evenals bij de naturalisatie lag de bevoegdheid ten aanzien van het verlenen van het ontslag bij de Minister van binnenlandse zaken (\$ 21). In oorlogstijd kon een ontslag slechts door de koning, op voordracht van de regering worden verleend $(\$ 25)$. De vereisten voor ontslag waren de volgende:

- volledige handelingsbekwaamheid of de toestemming van de wettelijke vertegenwoordiger ( $\$ 24$ sub 1$)$;

- betrokkene mocht geen belastingschulden hebben (sub 2);

- tegen de verzoeker mocht niet een strafprocedure aanhangig zijn of een nog niet voltrokken rechterlijk vonnis zijn uitgesproken (sub 3);

- verzoekers die enigerlei militaire verplichtingen hadden, konden slechts worden ontslagen met de toestemming van de Minister van defensie ( $\$ 22$ lid 1 );

- verzoekers die niet van hun militaire verplichtingen vrijgesteld waren, konden na hun 17de jaar slechts worden ontslagen met een van hun gemeentebestuur afkomstige verklaring, dat zij niet enkel om het ontslag verzochten, om de militaire dienstplicht te ontlopen ( $\$ 22$ lid 2).

Ten aanzien van de laatste twee vereisten waren tot 1918 uitzonderingen mogelijk ten aanzien degenen, die voornemens waren na het ontslag de Oostenrijkse nationaliteit te verkrijgen ( $\$ 23$ ). Interessant is voorts, dat in vredestijd het ontslag van een verzoeker die aan de eerste drie vereisten voldeed, uitsluitend op de laatste twee gronden kon worden geweigerd $\left(\$ 24\right.$, aanhef) ${ }^{57}$. Tegen een weigering stond administratief beroep open. Het ontslag werd steeds verleend onder enkele ontbindende voorwaarden. Zo verloor de beschikking haar

56. Het is interessant te vermelden, dat in bet geval dat de Minister op een dergelijke verklaring niet binnen zes maanden reageerde, hij geacht werd zijn toestemming tot het behoud van de mationaliteit te hebben verleend. De regeling tot 1939 was veel soepeler. Betrokkene moest slechts elke tien jaar aan zijn burgemeester vormloos verklaren dat hij Hongaar wilde blijwen. Dit kon zelfs per prentbrief gebeuren. SGS deel; 22, p. 54.

57. Szlezak, SGS deel 22 , p. 55, spreekt hier over een recht op het verkrijgen van het ontslag uit de nationaliteit. 
rechtskracht indien betrokkene niet binnen ến jaar na de verkrijging van het ontslag emigreerde. Hetzelfde gold indien betrokkene in die periode zijn belastingen niet betaalde of in een strafrechtelijke procedure verwikkeld raakte.

\section{Invloed op de nationaliteit van de gezinsleden van de verzoeker}

Ontslag uit de Hongaarse nationaliteit strekte zich op grond van $\$ 26$ automatisch wit over de vrouw en minderjarige kinderen van betrokkene. Ten aanzien van de kinderen werd verder vereist dat zij onder het ouderlijk gezag van de ontslagene stonden. Tevens werd gevorderd dat er geen militaire verplichtingen aan hun medeontslag in de weg stonden $(\$ 22)$. De echtgenote van de ontslagene kon na de beëindiging van het huwelijk worden gehernaturaliseerd onder dezelfde voorwaarden als een gewezen Hongaarse vrouw, die haar nationaliteit door huwelijk verloor ( $\$ 6$ sub 1 van de wijzigingswet van 1939). Een meeontslagen kind kon na de dood van zijn vader, of in ieder geval na het bereiken van de meerderjarigheid eveneens van de verlichte hernaturalisatie van \& 6 van de wet van 1939 gebruik maken.

\section{c. Ontneming}

De wet van 1879 kende in zijn oorspronkelijke versie slechts én ontnemingsgrond, namelijk het zonder toestemming treden in vreemde krijgs- of staatsdienst, indien betrokkene deze dienst op vordering van de bevoegde instantie niet binnen de daarvoor vastgestelde termijn verliet $(\$ 30)$. De regeling van de ontneming van de nationaliteit werd bij $\$ \S 4-7$ van de wijzigingswet van 1939 vervolgens aanzienlijk uitgebreid. De strekking daarvan was om enerzijds communisten en anderzijds nazi's de nationaliteit zo dikwijls mogelijk te ontnemen ${ }^{58}$.

De beslissingsbevoegdheid lag bij de regering $(\$ 8)$. De nationaliteit kon in de volgende gevallen worden ontnomen:

- aan personen die zich in het buitenland bevonden en wegens een dellict tegen de staatsveiligheid veroordeeld waren $^{59}$ ( $\$ 8$ lid 1 sub 1 wet van 1939);

- aan personen die zich in het buitenland bevonden en zich in oorlogstijd schuldig hadden gemaakt aan spionage, of andere diensten aan de vijand, of in het vijandelijke leger actief waren, respectievelijk naar het vijandelijke gebied vluchtten. Deze overtredingen moesten bij rechterlijk vonnis worden vastgesteld lid 1 sub 2 wet van 1939) ${ }^{60}$;

- wegens het zonder toestemming van de regering aanvaarden van een ambt in een vreemde staat of in een buitenlandse politieke organisatie, het in het buitenland aannemen van opdrachten van politieke aard, of wegens lidmaatschap van buitenlandse politieke organisaties (lid 1 sub 3,5 );

58. Cf. SGS deell 22, p. 63.

59. Hierbij ging het om een bijzondere wet-art. III van 1921 tot bescherming wan de staat.

60. Zie ook de wet-art. XLIII wan 1921, $\$ 3$ lid 1; wet-art. II van 1930, $\$ 4$ en wet-art. III van 1930, $\$ 97$. 
- wegens het illegaal verlaten van het land (lid 1 sub 4).

Het gevolg van de ontneming van de nationaliteit was ook, dat betrokkene uitsluitend bij een besluit van de voltallige regering kon worden gehernaturaliseerd (lid 4). De nationaliteit kon ook worden ontnomen in het geval dat betrokkene daardoor staatloos werd. Opgemerkt dient te worden dat alle ontnemingsgronden precies werden geformuleerd, zonder vage "Generalklauseln".

\section{i. Invloed op de nationaliteit van gezinsleden van betrokkene}

Het verlies van de nationaliteit strekte zich slechts uit over de vrouw en de minderjarige kinderen van betrokkene, indien zulks bij het ontnemingsbesluit uitdrukkelijk werd bepaalld (lid 2).

\subsubsection{Het nationaliteitsrecht tussen 1945 en 1948}

In de eerste jaren na de tweede wereldoorlog werden in Hongarije verschillende bijzondere nationaliteitsrechtelijke regelingen afgekondigd. De strekking van deze voorschriften was voornamelijk om aan etnisch Duitse Hongaarse staatsburgers de nationaliteit te ontnemen. De belangrijkste daarvan waren:

- de verordening van 18 oktober $1945^{61}$ betreffende herroeping van de naturalisaties en hernaturalisaties ${ }^{62}$ van etnische Duitsers die sedert 31 augustus 1939 tot stand kwamen. De nationaliteit van deze personen ging per 18 oktober 1945 met werking ex nunc verloren $(\$ 1)$;

- de verordeningen van 22 december $1945^{63}$ en van 12 juli $1946^{64}$. De eerste verordening regelde de uitzetting van etnische Duitsers ${ }^{6 S}$ en bij de tweede werd aan alle uitgezette personen, alsmede aan degenen die het land voor de inwerkingtreding van de verordening vrijwillig hadden verlaten, de Hongaarse nationaliteit ontnomen $(\S 1)$.

61. Verordening nr. 9550, M.K. (Magyar Közlöny) 1945, nr. 154; Duitse vertaling in SGS deel 22, p. $139-140$.

62. Door Szlezak, SGS deel 22, p. 70-71 wordt terecht opgemerkt dat het in wezen om hernaturalisaties van etnische Duitsers ging, die in verband met hun dienst in de "Waffen-SS" de Duitse nationaliteit verwierven en de Hongaarse verloren hadden, en na hun uitdiensttreding in Hongarije werden gehernaturaliseerd. Het is namelijk zeer onaannemelijk dat in de jaren 1939 1945 vele Duitsers zich in Hongarije lieten naturaliseren.

63. Verordening ar. 12330, M.K. 1945, nr. 211; Duïtse vertaling in SGS deel 22, p. 140-142. Zie ook: Arato, RabelsZ 1951, p. 297, Ferid, StAZ 1951, p. 115.

64. Verordening nr. 7970, M.K. 1946, nr. 158; Duitse vertaling in SGS deel 22, p. 142-143; StAZ 1954, p. 247.

65. Krachtens $\$ 1$ van de verordening ging het om personen die bij de laatste wolkstelling hetzij verklaarden dat Duits hun moedertaal was, hetzij dat ze zich tot (etmische) Duitsers rekenden. Ook was voor de uitzetting woldoende, om de gemagyariseerde oorspromkelijk Duitse naam op de Duitse wijze te schrijven, of lid te zijn de "Volksbund" dan wel te hebben gediend in de "Waffen-SS". Degenen, die met een niet-Duitser gehuwd waren, mochten krachtens $\$ 2$ in Hongarije blijven. 
Voorts werd bij wet van 31 maart $1947^{66}$ een regeling van kracht, betreffende de ontneming van de nationaliteit aan bepaalde personen, die zich in het buitenland bevonden. Deze regeling werd echter reeds eén jaar later vervangen door een nieuwe ontnemingswet ${ }^{67}$ van 14 mei 1948 . De bepalingen van deze wet zullen op p. 185-186 worden besproken.

Op het internationale vlak sloot Hongarije met Tsjechoslowakije en Roemenië Hongarije migratieverdragen van respectievelijk 27 februari 1946 en 10 februari $1949^{68}$.

\subsubsection{De wet van 1948}

\subsubsection{Algemeen}

De eerste algemene regeling van de nationaliteit die het "nouveau régime" in Boedapest vervaardigde was de nationaliteitswet van $1948^{69}$. Daarnaast kwam op 14 mei 1948 ook een wet betreffende de ontneming van de nationaliteit ${ }^{70}$ tot stand, waardoor de algemene regeling van de nationaliteitswet werd aangevuld ${ }^{71}$.

Interessant is, dat de overgangsregeling van de wet van 1948 bij de bepaling van de kring van onderdanen op het tijdstip van de inwerkingtreding van deze wet bij de nationaliteitsrechtelijke bepalingen van het vredesverdrag van Trianon aanknoopte ( $\$ 25$ lid 1 ). Het Hongaarse staatsburgerschap werd voorts onder bepaalde voorwaarden aan personen toegekend die deze nationaliteit in verband met hun linkspolitieke activiteiten verloren ( $\$ 36)$. De onderhavige wet bepaalde in $\$ 23$, evenals de meeste andere Oosteuropese nationaliteitswetten, dat personen, die naast de Hongaarse tevens een andere nationaliteit bezaten, uitsluitend als Hongaren moesten worden behandeld (exclusiviteitsbeginsel).

\subsubsection{Verkrijging van de nationaliteit}

Volgens de regeling van de wet van 1948 kon de Hongaarse nationaliteit worden verkregen van rechtswege, door naturalisatie en in eén geval door optie (zie p. 181). Andere wijzen van verwerving van de nationaliteit kende deze wet niet.

66. Wet-art. X: 1947, M.K. 1947, ar. 7; Duitse vertaling in SGS deel 22, p. 143-144,

67. Wet-art. XXVI: 1948; M.K. 1948, nr. 19.

68. Zie de ratificatiewetten XV: 1946, in werking getreden op 15 mei 1946 en XIV: 1949, In werking getreden op 19 juni 1949. Zie Benkö, RabelsZ 1951, p. 297-298. Zie over het werdrag met Tsjechoslowakije ook de beschrijving van het recht vam dat Jand op p. 302.

69. Wet-art. LX: 1948; O.T. 1948, nr. 46; Duitse vertaling in SGS deel 22, p. $163-171$; Rabels Z 1951, p. 302. Zie daarover Benkö, RabelsZ 1951, p. 293-298; Arat6, RabelsZ 1951, p. 281-292; Ferid, StAZ 1951, p. 66-68 en 113; Lichter 1955, p. 785-791. Zie voor een zeer kritisch commentaar SGS deel 22, p. 71-89. In het Hongaars: Beér e.a., Magyar Allámpolgársagi Jogg, Bioedapest 1949 (een "halfofficieel" commentaar).

70. Wet-art. XXVI: 1948; M.K. 1948, nr. 19; Duitse vertaling in SGS deel 22, p. 157-159. Zie ook de uitwoeringsverordening van 18 juli 1948 (nr. 103 300/1948) M.K. 1948, nr. 161, Duitse vertaling in SGS deel 22 , p. 159-162. Zie over deze wet SGS deel 22, p. $89-90$.

71. Cf. SGS deel 22, p. 71 . 


\subsubsection{Verkrijging van rechtswege}

Van rechtswege werd verkrijging van de Hongaarse nationaliteit gekoppeld aan de volgende rechtsfeiten:

- geboorte uit Hongaarse ouder(s) (\$2 lid 1 sub a);

- geboorte op het Hongaarse grondgebied ( $\$ 21$ );

- huwelijk met een Hongaarse man (\$3);

Adoptie door een Hongaar had geen invloed op de nationaliteit van het geadopteerde kind.

\section{a Geboorte wit Hongaarse ouder(s)}

Krachtens $\$ 2$ lid 1 sub a verwierf de Hongaarse nationaliteit een wettig kind wiens vader op het tijdstip van de geboorte van het kind Hongaar was. Hetzelfde gold ten aanzien van een buitenechtelijk kind wiens moeder Hongaarse was. Het was daarbij niet van belang of het kind binnen of buiten Hongarije werd geboren.

Een minderjarig onwettig kind van een vreemdelinge, dat door een Hongaarse staatsburger werd erkend ${ }^{72}$, verwierf krachtens $\$ 2$ lid 1 sub b de Hongaarse nationaliteit. Hetzelfde gold indien zijn afstamming van een Hongaarse man gerechtelijk werd vastgesteld ${ }^{73}$. De Hongaarse nationaliteit werd eveneens verkregen door een onwettig kind, wiens moeder een huwelijk sloot, en de echtgenoot van de moeder de Hongaarse nationaliteit bezat. In dit laatste geval, dat in feite met wettiging door huwelijk overeenkomt ${ }^{74}$, ging men van het vermoeden uit, dat de bruidegom van de moeder het kind door het sluiten van het huwelijk met de moeder, erkende. Deze praesumptie kon door een uitdrukkelijke verklaring van de man echter worden ontkracht ${ }^{75}$.

In het geval dat het kind, wiens afstamming ten opzichte wan zijn vader op één van de drie hierboven beschreven wijzen komt vast te staan, op dat tijdstip reeds meerderjarig was, kon hij binnen eén jaar daarna voor de Hongaarse nationaliteit opteren.

\section{b. Geboorte op het Hongaarse grondgebied en vondelingen}

$\$ 21$ van de wet van 1948 vestigde in het eerste lid het vermoeden van het bezit van de Hongaarse nationaliteit ten aanzien van kinderen, die op het Hongaarse grondgebied werden geboren en anders staatloos zouden zijn. Deze bepaling zou echter slechts gelden met betrekking tot kinderen die na de inwerkingtreding van

72. Erkenning was geregeld in $\$ 10$ wan de wet-art. XXIX: 1946 .

73. 17 van de wet-art. XXIX: 1946 .

74. Hoewel de term wettiging in het Hongaarse familierecht werd geschrapt, bestat dit rechtsinstituut in wexen nog steeds. Krachtens $\$ 20$ van de wet-art. XXIX: 1946 verkreeg een kind door een huwelijk tussen zijn ouders dezelfde status als een wettig kind en verkreeg derhalve de Hongaarse nationaliteit, indien zijn vader Hongaur was. Zie SGS deel 22, p. 74 .

75. SGS deel 22, p. $72-73$. 
een in 33 voorgeschreven verordening betreffende registratie van staatsburgers zouden worden geboren. Volgens Szlezak ${ }^{76} \mathrm{kwam}$ een dergelijke verordening nooit tot stand. Om deze reden is het onduidelijk of de Hongaarse nationaliteit op grond van $\$ 21$ lid 1 kon worden verworven.

Volgens het tweede lid van $\& 21$ werden kinderen die in Hongarije werden gevonden eveneens vermoed Hongaren te zijn, zolang het bezit van een andere nationaliteit niet werd bewezen. Deze bepaling was niet aan de in de vorige alinea genoemde verordening gebonden. Interessant is, dat het kind tevens in Hongarije moest worden opgevoed.

\section{c. Huwelijk met een Hongaarse man}

Het is opmerkelijk dat in de Volksrepubliek Hongarije het beginsel van één nationaliteit in het gezin (système unitaire) in 1948 nog steeds onverkort gold. Krachtens $\& 3$ lid 1 verkreeg een buitenlandse vrouw die met een Hongaar in bet huwelijk trad van rechtswege de Hongaarse nationaliteit, zonder de mogelijkheid om de verwerving van het staatsburgerschap te voorkomen. Door ontbinding van het huwelijk ging de Hongaarse nationaliteit voor deze vrouw echter niet meer verloren, ongeacht of ze daardoor hun oorspronkelijke nationaliteit herkreeg (lid 2).

\subsection{Naturalisatie}

Verkrijging van de nationaliteit door naturalisatie was geregeld in $\$ \$ 4-10$ van de wet van 1948 . Evenals onder de wet van 1879 moest een naturalisatieverzoek bij de burgemeester worden ingediend. Personen die (gedeeltelijk) handelingsonbekwaam waren, moesten bij het indienen van het naturalisatieverzoek door hun wettelijke vertegenwoordiger worden vertegenwoordigd $(\S 7)$. De burgemeester onderzocht of betrokkene aan de vereisten voldeed en zond vervolgens de stukken met zijn advies naar de Minister van binnenlandse zaken, die de beslissingsbevoegdheid had $(\$ 9 \text { jo. } \$ 4)^{77}$. Anders dan onder de vigeur van de wet van 1879 had de Minister echter een onbeperkte discretionaire bevoegdheid. Tegen een afwijzende beschikking stonden geen rechtsmiddelen open ${ }^{7}$. De wet noemde slechts twee naturalisatievereisten:

- onafgebroken verblijf in Hongarije gedurende drie jaren onmiddellijk voorafgaande aan het verzoek ( $\$ 4$ sub a);

- de naturalisatie mocht voor de staat niet nadelig zijn (sub b) ${ }^{79}$.

76. Szllezak, SGS deel 22 , p. 84 .

77. Het is interessant te vermelden dat de naturalisatie gratis was ( $\$ 10$ lid 4).

78. Cf. SGS deel 22 , p. 76 .

79. Volgens de officiële toelichting was een strafblad als zodanig geen belemmering voor de naturalisatie. Bij dit vereiste ging het volgens de toelichting voornamelijk om politicke betrouwbaarheid van betrokkene en om zijn buitenlandse contacten. SGS deel 22, p. 76. Het ironische commentaar van Szlezak op dezelfde pagina kan niet onvermeld bijwen: "Briefwechsel mit einem Philatelisten aus Neusecland kamn somit schaden; Einbruchdiebstähle im Rückfall aber nicht." 
Het behoeft geen betoog dat het bijzonder vaag geformuleerde tweede vereiste een onbegrensde mogelijkheid voor willekeurige weigeringen bood. De Minister mocht krachtens \$ 5 afzien van de verblijfseis indien aan de volgende, cumulatief gestelde vereisten was voldaan:

- de verzoeker moest in Hongarije woonachtig zijn, of het voornemen hebben, zich daar te vestigen;

- tenminste één van zijn voorouders moest de Hongaarse nationaliteit hebben bezeten; en

- (andere) bijzondere gronden voor verlichte naturalisatie dienden aanwezig te zijn.

Daarnaast kende de wet in $\$ 6$ de mogelijkheid van naturalisatie in het staatsbelang, zonder dat betrokkene aan het verblijfsvereiste voldeed. In dat geval werd de nationaliteit verleend door de regering op voordracht van de Minister van binnenlandse zaken.

\section{a. Hernaturalisatie}

De wet van 1948 bevatte enkele bijzondere voorschriften te aanzien van personen, die de Hongaarse nationaliteit ooit hadden bezeten. Zo kon de Minister op grond van $\$ 19$ lid 1 afzien van het vereiste van driejarig verblijf ten aanzien van de volgende categorieën ex-Hongaren:

- degenen, die de Hongaarse nationaliteit door ontslag, langdurig verblijf in het buitenland, of door naturalisatie in een ander land hadden verloren, en zich in Hongarije vestigden en een bijzondere grond voor hun hernaturalisatie aanwezig was (sub 1);

- vrouwen die de Hongaarse nationaliteit door huwelijk met een buitenlander hadden verloren, nadat het huwelijk ontbonden werd ${ }^{80}$, of zij sedert een jaar gescheiden van haar man in Hongarije leefde (sub 2).

In het geval dat betrokkene zijn nationaliteit door ontneming had verloren, kon hij eveneens zonder te voldoen aan het vereiste van driejarig verblijf worden genaturaliseerd. De beslissing omtrent zijn hernaturalisatie moest echter door de regering, op voordracht van de Minister van binnenlandse zaken, worden genomen $(\$ 20)$.

80. Indien betrokkene bij een buitenlands echtscheidingswonnis werd gescheiden moest de uitspraak ook in Hongarije worden erkend. Ook scheiding van tafel en bed was echter voldoende, indien het nationale recht van de echtgencot van betrokkene geen echtscheiding toeliet ( $\$ 19$ lid 2). 


\section{b. Invloed op de nationaliteit van de gezinsleden wan de verzoeker}

Een naturalisatie van een man strekte zich tevens uit over diens wrouw, alsmede over hun minderjarige kinderen over wie betrokkene en/of zijn vrouw de ouderlijke macht uitoefende(n) (\$8). Terwil medenaturalisatie wan de kinderen automatisch geschiedde, was de vrouw slecht in de naturalisatie van haar man inbegrepen; indien er expliciet om werd verzocht. De wet kende geen mogelijkheid van vereenvoudigd verlies van de Hongaarse nationaliteit ten behoeve van de meegenaturaliseerde familieleden voor het geval dat het huwelijk ontbonden werd, respectievelijk de kinderen meerderjarig werden.

\subsubsection{Verlies van de nationaliteit}

De Hongaarse nationaliteitswet van 1948 kende het verlies van de nationaliteif van rechtswege, door ontslag en door ontneming. Het verlies door het afleggen van een verklaring van afstand was niet mogelijk.

\subsection{Verlies van rechtswege}

Het is opmerkelijk dat het communistische Hongarije tussen 1948 en 1957 het verlies van de nationaliteit van rechtswege kende. Zo werd het verlies van de nationaliteit ex lege gekoppeld aan de erkenning en wettiging door een buitenlander, alsmede aan gerechtelijke vaststelling van afstamming van een buitenlandse man $(\$ 13)$ en aan een huwelijk met een buitenlander $(\$ 12)$.

\section{a. Erkenning wettiging of gerechtelijke vaststelling van het vaderschap}

Een buitenechtelijk kind van een Hongaarse vrouw verloor krachtens de bepaling van $\S 13$ lid 1 de Hongaarse nationaliteit, indien het tijdens zijn minderjarigheid door een vreemdeling werd erkend, gewettigd of afstamming van een vreemde man gerechtelijk werd vastgesteld. De nationaliteit ging voor het kind slechts verloren, indien het door de zojuist genoemde rechtsfeiten de nationaliteit van zijn vader verwierf. De wet kende geen mogelijkheid van vereenvoudigde herkrijging van de Hongaarse nationalïteit door een meerderjarig geworden kind dat krachtens $\$ 13$ deze nationaliteit had verloren.

\section{b. Huwelijk met een buitenlander}

Een Hongaarse wrouw verloor haar nationaliteit door huwelijk met een buitenlander, indien zij daardoor de nationaliteit van haar man verwierf ( $\$ 13)$. Er bestond geen mogelijkheid om het staatsburgerschap door bijvoorbeeld een uitdrukkelijke wilswerklaring te behouden. Na de ontbinding van het huwelijk had de exHongaarse vrouw de mogelijkheid van verlichte hernaturalisatie (zie p. 183). 
Ontslag uit de Hongaarse nationaliteit was geregeld in de $\$ 14$ en 15 van de wet van 1948. De bevoegdheid om het ontslag te verlenen lag bij de Minister van binnenlandse zaken ( $\$ 14$ lid 1 , aanhef). Ten aanzien van een (gedeeltelijk) handelingsonbekwame moest een ontslagverzoek door zijn wettelijke vertegenwoordiger worden ingediend. De Minister kon een verzoek toewijzen, indien betrokkene:

- geen belastingschulden had ( $\$ 14$ lid 1 sub a);

- tegen betrokkene een nog niet voltrokken strafrechtelijk vonnis werd uitgesproken (sub b);

Een man tussen 18 en 43 jaar kon bovendien slechts met toestemming van de Minister van defensie worden ontslagen (iid 2).

Uit de "kan"-formulering kan worden geconcludeerd dat de Minister een onbeperkte discretionaire bevoegdheid bezat. Terwijl de twee eerstgenoemde ontslagvereisten voldoende scherp werden geformuleerd, bood de vereiste toestemming van de Minister van defensie nog verdere mogelijkheden om het ontslag willekeurig te weigeren. Er bestond geen mogelijkheid om tegen een negatieve beslissing in beroep te gaan.

a. Invloed op de nationaliteit van de gezinsleden van de verzoeker

Gezinsleden van betrokkene konden uitsluitend zelfstandig worden ontslagen.

\subsection{Ontneming}

Ontneming van de Hongaarse nationaliteit was geregeld zowel in de aparte "ontnemingswet" van 1948, als in de algemene nationaliteitswet van hetzelfde jaar. Volgens de algemene regeling kon de nationaliteit worden ontnomen hetzij door de Minister van binnenlandse zaker, hetzij door de regering op voordracht van dezelfde Minister. De Minister kon de nationaliteit zelf ontnemen wegens het zonder toestemming van de regering treden in dienst van een vreemde staat ( $\&$ 17). De regering kon de nationaliteit ontnemen wegens:

- het zonder toestemming van de regering aanvaarden van een ambt in een vreemde staat of in een vreemde politieke organisatie, het aannemen van opdrachten van politieke aard, of wegens het lidmaatschap van buitenlandse politieke organisaties $\left(\$ 17\right.$ lid 1 sub a) ${ }^{81}$;

- illegale grensoverschrijding (sub b).

81. Het begrip "politieke organisatie" dient breed te worden opgevat. Daaronder kan tewens worden begrepen een communistische partij die van de koers van Moskou algeweken was. Dit was - destijds met de Joegoslavische communistische partij het geval. Cf. SGS deel 22, p. 83. 
- het geen gehoor geven aan een oproep van de regering om binnen een bepaalde termijn uit het buitenland terug te keren ( $\& 1$ van de ontnemingswet van 14 meil 1948).

Ontneming van de nationaliteit had automatisch de confiscatie van het vermogen van betrokkene tot gevolg ( $\$ 17$ lid $3 ; \$ 6$ ontnemingswet).

\section{a. Invloed op de nationaliteit van gezinsleden van betrokkene}

Bij het ontnemingsbesluit kon worden bepaald dat de ontneming zich tevens uitstrekte over de vrouw en de minderjarige kinderen van betrokkene ( $\$ 17$ lid 2; $\$ 4$ ontnemingswet).

\subsection{Het PostTIEVE NATIONALTEETSREChT}

\subsubsection{Algemeen}

Het huidige Hongaarse nationaliteitsrecht wordt geregeld in de wet van 9 juni $1957^{82}$. Opvallend is dat deze wet in een relatief korte tijd zijn voorganger van 1948 opvolgde en dat dit direct na de Hongaarse opstand in 1956 geschiedde. De belangrijkste vernieuwingen waren de uitbreiding van de verkrijging van de nationaliteit iure sanguinis, invoering van de gelijke behandeling van mannen en vrouwen en de afschaffing van het verlies van de nationaliteit van rechtswege. Interessant is voorts $\$ 21$ die bepaalt, dat in geval van collisie tussen een internationaal verdrag en deze nationaliteitswet, de bepalingen van het verdrag prevaleren.

\subsubsection{Verkrijging van de nationaliteit}

De Hongaarse nationaliteit kan worden verkregen van rechtswege en door naturalisatie. Andere wijzen van verkrijging van het staatsburgerschap kent de huidige Hongaarse nationaliteitswet niet.

\subsubsection{Verkrijging van rechtswege}

Verkrijging van de Hongaarse nationaliteit wordt van rechtswege gekoppeld aan de volgende rechtsfeiten:

- geboorte uit Hongarse ouder(s) $(\$ \S 1,3)$;

- geboorte of het gevonden worden op het Hongaarse grondgebied ( $\$ 2)$.

Aan adoptie door een Hongaar(se) worden geen nationaliteitsrechtelijke rechtsgevolgen verbonden.

82. Wet-artikel V: 1957, M.K. 1957, nr. 64. In werking getreden op 1 olktober 1957, Duitse vertaling in SGS deel 22, p. 184-190; Bergmann/Ferid, p. 2-6; Nederlandse in NWG, p. 1-5. Zie daarover SGS deel 22, p. 91-97; Szigeti, Clunet 1961, p. 400-403; Sxirmai, OER 1957, p. 112-117. 


\subsection{Geboonte uit Hongaarse ouder(s)}

Krachtens $\$ 1$ lid 1 sub a is een kind dat uit tenminste eén Hongaarse ouder wordt geboren, steeds Hongaar. "Tussen wettige en onwettige kinderen wordt geen onderscheid meer gemaakt. Indien de moeder van een kind een vreemdelinge is, dan verkrijgt het kind de Hongaarse nationaliteit met werking ex tunc, zodra zijn afstamming van een Hongaarse vader komt vast te staan ( $\$ 3$ lid 1). In deze bepaling wordt uitdrukkelijk verwezen naar de $\$ \S 37-39$ van de wet betreffende familie, huwelijk en voogdij van $1952^{83}$. Naast erkenning en gerechtelijke vaststelling kan het vaderschap thans ook via "wettiging" door huwelijk tussen ouders van het kind komen vast te staan ( $\$ 39$ wet van 1952). De nationaliteit wordt ook verworven indien het kind op het tijdstip van de vaststelling van het vaderschap reeds meerderjarig is. In dat geval heeft hij echter gedurende éen jaar na de vaststelling van zijn afstamming de mogelijkheid om afstand van het Hongaarse staatsburgerschap te doen ( $\$$ lid 2).

\subsection{Geboorte op het Hongaarse grondgebied en vondelingen}

$\$ 2$ van de wet van 1957 bevat een praesumptio iuris betreffende het bezit van de Hongaarse nationaliteit ten gunste van een kind dat in Hongarije wordt geboren of gevonden. Ten aanzien van vondelingen wordt teven geëist dat ze in Hongarije worden opgevoed. De onderhavige bepaling geldt uitsluitend ten aanzien vam kinderen die na de inwerkingtreding van deze wet (op 1 oktober 1957) werden geboren of gevonden. Het vermoeden van $\S 2$ kan steeds worden ontkracht, ongeacht de leeftijd van het kind.

\subsubsection{Naturalisatie}

Verkrijging van de Hongaarse nationaliteit door naturalisatie wordt geregeld in ( $\S \S$ 5-11) van de wet van 1957 . Het gaat om een nogal onoverzichtelijke regeling; de naturalisatievereisten zijn over het gehele hoofdstuk verspreid, sommige gelden absoluut, andere evenwel niet. Bovendien kent de wet ten aanzien van een grote kring personen de mogelijkheid van verlichte naturalisatie. De bevoegdheid om een naturalisatie te verlenen ligt bij de Presidentiële raad"4, die blijkens de "kan"formulering een onbeperkte discretionaire bevoegdheid heeft. Ook deze Hongaarse wet kent de mogelijkheid van naturalisatie van handelingsonbekwamen. Zij kunnen echter slechts door tussenkomst van hun wettelijke vertegenwoordiger worden. genaturaliseerd ( $\$ 9$ lid 1$)$.

Om in Hongarije voor naturalisatie in aanmerking te kunnen komen, moet de verzoeker aan de volgende vereisten voldoen:

- ononderbroken driejarig verblijf in Hongarije ( $\$ 5$ ) en

- de naturalisatie mag voor Hongarije niet nadelig zijn (\$5).

83. Wet-art. IV: 1952. Cr. SGS deel 22, p. 94; Kolossváry, p. 24.

84. Cf. Kolossváry, p. 25. 
Geen verblijfseis wordt gesteld ten aanzien van de volgende groepen naturalisandi:

- afstammelingen van Hongaren ${ }^{85}$ ( 8 sub a);

- personen wier naturalisatie staatsbelang is ( $\$ 6$ sub b);

- degenen die de Hongaarse nationaliteit door ontslag, langdurige afwezigheid of verkrijging wan een vreemde nationaliteit verloren ( $\$ 10$ lid 1$)$;

Bij deze drie categorieën is voldoende dat betrokkene op het tijdstip van het indienen van het naturalisatieverzoek in Hongarije woont, respectievelijk zich aldaar wil vestigen. Voorts kent de wet nog een derde categorie: deze personen kunnen ook worden genaturaliseerd indien ze in het buitenland wonen en geen voornemen hebben om zich ooit in Hongarije te vestigen. Deze personen zijn:

- degenen die met een Hongaar(se) gehuwd zijn ( $\$ 7$ sub a);

- ouders van Hongaarse staatsburgers ( $\$ 7$ sub b);

- degenen die een Hongaars kind wensen te adopteren ( $\$ 7$ sub c);

- degenen, die de Hongaarse nationaliteit door erkenning, legitimatie, gerechtelijke vaststelling van het vaderschap of huwelijk hebben verloren $(\$ 10$ lid 3).

Voorts spreekt blijkens $\& 8$ "ten gunste van de verzoeker" indien hij staatloos is, of hij een verzoek tot ontslag uit zijn vorige nationaliteit heeft ingediend. Het verlies van de oorspronkelijke nationaliteit wordt derhalve niet uitdrukkelijk als eis gesteld. Een tweede vereiste dat evenmin absoluut is gesteld, is dat van het afleggen van een eed van trouw ( $\$ 11$ lid 1 ). In de regel verkrijgt een naturalisatie haar werking nadat de eed is afgelegd, maar indien betrokkene reeds voor de eedsaflegging sterft of verhinderd ${ }^{86}$ is om de eed af te leggen, wordt de nationaliteit desalniettemin verworven.

\subsection{Invloed op de nationaliteit van de gezinsleden van de verzoeker}

Naturalisatie van eên ouder strekt zich automatisch uit over zijn minderjarige kinderen die onder zijn ouderlijk gezag staan. De medenaturalisatie kan worden voorkomen, indien de ouder die genaturaliseerd wordt, daar uitdrukkelijk om vraagt. Het kind zelf heeft deze mogelijkheid echter niet.

85. Het moet om afstammelingen van "juridische" Hongaren gaan. Kolosswáry, p. 25 .

86. Aangenomen mag worden dat de reden voor verhindering hierbij een grote rol speelt. Indien. betrokkene weigert om de eed af te leggen zal de naturalisatie hoogstwaarschijnlijk alsnog wrorden herroepen. 


\subsection{Verlies wan de nationaliteit}

De huidige Hongaarse nationaliteitswet kent het verlies van het staatsburgerschap door afstand, ontslag en ontneming. Het verlies van rechtswege dat zijn voorganger van 1949 nog kende, werd in 1957 geschrapt. De mogelijkheid van afstand bestaat slechts in éen, reeds op p. 187 besproken geval.

\subsubsection{Ontslag}

De bevoegdheid om ontslag te verlenen ligt evenals bij de naturalisatie bij de Presidentiële raad, die ook hier over een zeer grote discretionaire bewoegdheid beschikt. Tegen een afwijzende beslissing is geen beroep mogelijk ${ }^{87}$. Minderjarigen moeten door tussenkomst van hun wettelijke vertegenwoordiger zelfstandig het ontslag aanvragen. Dit geldt ook in het geval dat tevens een ouder van betrokkene om het ontslag verzoekt. De vereisten voor ontslag zijn:

- de verzoeker mag geen belastingschulden hebben ( $\$ 12$ lid 1 sub a);

- tegen betrokkene mag geen strafrechtelijke procedure aanhangig zijn of een nog niet tenuitvoergelegd vonnis zijn uitgesproken (sub b);

- de verzoeker moet kunnen aantonen dat hij een vreemde nationaliteit bezit, respectievelijk waarschijnlijk zal verkrijgen (sub c);

- ten aanzien van mannen die tussen 18 en 51 jaar oud zijn is tevens de toestemming van de Minister van defensie vereist ( $\$ 17$ lid 2).

Volgens $\& 13$ spreekt ten gunste van het verzoek indien betrokkene:

- gehuwd is met een buitenland(s)e(r) en het echtpaar in het buitenland woont, respectievelijk wil gaan wonen (lid 1 sub a);

- (adoptief-) kind is van een vreemdeling, dat tevens in het buitenland werd opgevoed (sub b, c);

- de Hongaarse nationaliteit door huwelijk verwierf en het huwelijk niet meer bestaat (sub d).

Met betrekking tot de mogelijkheden om te emigreren kent Hongarije sedert $1970^{85}$ een soort "recht" op verkrijging van het paspoort, dat bij de laatste wijziging van de paspoortwetgeving zelfs tot een grondrecht werd "gepromoveerd ${ }^{89}$. De zwakke kanten van deze regeling zijn dat de uitreiking van een paspoort onder meer met

87. SGS deel $22, \mathrm{p} .97$.

88. Verordening mr. 4/1970, daarna meermalen gewijzigd. Zie Kuss, EuGRZ 1987, p. 308-309.

89. De verordening nr. 25/1987; M.K. 1987, nr. 61; in werking getreden op 1 januari 1988; Duitse vertaling in WGO 1988, p. 32-38, met commentaar van Brunner op p. 13-32. Zie cok Kuss, EuGRZ 1987, p. 308-309. 
het beroep op de "staatsveiligheid" ( $\$ 13$ sub a) kan worden geweigerd en dat rechterlijke controle wan een weigering uitgesloten is. Van de weigeringsgronden wordt in de praktijk echter niet of nauwelijks misbruik gemaakt ${ }^{90}$. Met name ten aanzien van de emigratie in het kader van gezinshereniging kan worden gezegd dat deze in ruime mate wordt toegestaan ${ }^{91}$.

\subsection{Invloed op de nationaliteit van de gezinsleden wan de verzoeker}

Gezinsleden van de verzoeker kunnen uitsluitend zelfstandig worden ontslagen ( $\S$ 14 lid 1$)^{92}$.

\subsubsection{Ontneming}

De regeling van het verlies van de Hongaarse nationaliteit door ontneming is sedert 1957 slechts in de algemene nationaliteitswet geregeld. De nationaliteit kan alleen worden ontnomen indien betrokkene zich in het buitenland bevindt, ongeacht het feit, of hij daardoor staatloos wordt. De beslissingsbevoegdheid ligt ook hier bij de Presidentiële raad, die blijkens de "kan"-formulering en de vage redactie van de eerste ontnemingsgrond een onbeperkte discretionaire bevoegdheid bezit. $\$ 15$ kent twee ontnemingsgronden:

- zware verontachtzaming van staatsburgerlijke plichten (sub a) en

- veroordeling wegens een zwaar delict in Hongarije of in het buitenland (sub b).

Bij de ontneming van de nationaliteit wordt niet meer automatisch het vermogen van betrokkene geconfisceerd. De mogelijkheid daartoe bestaat echter wel en de beslissing wordt ter discretie van de Presidentiële raad gelaten ( 816 lid 2).

\subsection{Invloed op de nationaliteit van gezinsleden van betrokkene}

Ontneming van de nationaliteit strekt zich niet automatisch uit over de echtgeno(o)t(e) en de minderjarige kinderen ( $\$ 16$ lid 1$)$.

90. Brunner, WGO 1988, p. 29.30; Kuss, EuGRZ 1987, p. 308 309; Menschenrechte, p. 108. In tegenstelling tot de meeste andere Oosteuropese staten (met uitzondering van Joegoslavië en Polen) wordt ook atan degenen die niet tot etnische minderheden behoren dikwijls de toestemming tot emigratie gegeven. In de jaren 1971-1985 waren etnische Hongaren met 14.000 legale emigranten voor etnische Duitsers $(6.500)$ de grootste groep. Zie Menschenrechte, p. 108 109.

91. Zie Brunner, WGO 1988, p. 27; Kuss, EuGRZ 1987, p. 309.

92. Kolossváry, p. 27. 


\subsection{GESCHIEDENIS}

\subsubsection{Inleiding}

Joegoslavië, tot 6 januari $1929^{1}$ "Koninkrijk van Serviërs, Kroaten en Slovenen" (SHS) genaamd, ontstond op 1 december $1918^{2}$. Toen werden de koninkrijken Servië, Kroatië en Slavonië ${ }^{3}$, het vorstendom Montenegro en de Staat van Slovenen, Kroaten en Serviërs ${ }^{4}$ verenigd in eén koninkrijk, onder de Servische dynastie Karadjordjević. Ook Bosnië en Herzegowina die in 1908 door OostenrijkHongarije werden geannexeerd, maakten deel uit van de nieuwe staat. Op 28 juni $1921^{5}$ werd de eerste grondwet afgekondigd. Deze nieuwe staat was een centralistisch georganiseerde constitutionele monarchie. De constitutie werd op 6 januari 1929 door de koning Aleksandar I ingetrokken en in 1933 door een nieuwe vervangen.

Op 25 maart 1941 trad Joegoslavië toe tot het "Driemachtenpact" 6 , doch enkele dagen later werd een coup d"état gepleegd en werd de toetreding weer herroepen. Vervolgens werd Joegoslavië na een kortstondige oorlog in april 1941 bezet door de Duitse, Italiaanse, Hongaarse en Bulgaarse legers. Het Joegoslavische grondgebied werd gedeeltelijk bij de bezetters ingelijfd. Duitsland annexeerde een gedeelte van Slovenië: Stajerska Koroška en Gorenjska (Untersteiermarken, Kärnten en Oberkrain). De andere Sloveense gebieden met de stad Ljubljana (Laibach, Lubiana) en de Kroatische kust met de meeste eilanden werden onderdeel van Italië ${ }^{7}$. De rest van Kroatië werd op 10 aprill 1941 tot de "Onafhankelijke staat Kroatië" (NDH) uitgeroepen ${ }^{8}$. Deze "staat" werd geregeerd door een fascistisch regime en werd slechts door enkele landen erkend ${ }^{9}$. Naar Duits voorbeeld kondigde men ook

1. Bij wet van 3 oktober 1929 werd de naam SHS veranderd in Joegoslavie, hetgeen als illustratie van de zeer sterke centralistische tendens in de tijd van de zogenaamde "zes januari-dictatuur" kan dienen. Deze dictatuur duurde van 6 januari 1929 tot de dood van de koning in 1934. Zie ook Bergmann/Ferid, p. 2 a.

2. Bergmann/Ferid, p. 2a, Pirkmajer, p. 13-14; SGS deel 17, p. 13; Tratnik, p. 420.

3. Het koninkrijk Kroatië en Slavoniê was geen souvereine staat, thate en onderdeel van de Oostenrijk-Hongarije net een relaticf grote autonomie.

4. Deze "staat" bestond sllechts ruim een maand uit het voormalig Oostenrijks gedeclte wan het latere Joegoslavië. Pirkmajer, p. 13-14; Zolger, JöR 1922, p. 182.

5. Sl.n. (Sluzbene novine) 142A/1921; Duitse vertaling in JoR 1922, p. 200-217 met conmentaar van Zolger op p. 190-200.

6. Zie het bericht in ZaöRV 1940-41, p. 817.

7. Zie de Koninklijke decreet-wet van 3 mei 1941, G.U.(Gazetta Ufficialc) 1941 I, nr. 105, p. 1725 ; afigedrukt in ZaöRV $1942-43$, p. 145-146 inhoudende de constitutie van de op het door ltalië bezette gedeelte van Slovenië opgerichte "Provincia di Lubiana". Zie met betrekking tat de kustgebieden de Koninklijke decreet-wetten wan 18 mei en van 7 juni 1941, G.U. 1941, nr. 133, p. 2240; afgedrukt in ZaöRV $1942-43$, p. 146-147 en 148-149.

8. Zie voor de proclamatie van de nieuwe staat ZaöR 1942-43, p. 122. De grenzen van de NDH en de verhouding tot Duitsland en Italie werden geregeld in enkele bilaterale verdragen tussen. de NDH en beide landen, afgedrukt in ZaöR W 1942-43, p. 123-124. Zie voor een Duitse vertaling van de constitutionele regels van de NDH ZaöRV 1942-43, p. 128-140.

9. Duitsland, Italie, Japan, Hongarije, Slowakije, Bulgarije, Roemenië, Finland, Denemarken Spanje, en Mantsjoekwo. Zie het bericht in ZaöRV 1942-43, p. 123; SGS deel 17, p. 29. 
rassenwetgeving af. In Montenegro en Servië werden op 12 juli en 29 augustus 1941 ook "onafhankelijke staten" geproclameerd, doch in tegenstelling tot de NDH oefenden de "regeringen" nooit enige staatsmacht uit en werd geen wetgeving tot stand gebracht. Het hoofdzakelijk door een etnisch Albanese meerderheid bevolkte Zuid-Servische gebied Kosovo werd met enkele kleinere aangrenzende streken, door de Italiaanse bezetters aan Albanië, dat een personele unie met Italië vormde, toegevoegd. Bulgarije en Hongarije lijfden de door hen bezette gebieden eveneens bij hun eigen territorium in. Het gebied Banat in Noord-Servie waar een belangrijke Duitse minderheid woonde, kreeg een aparte status en werd onder Duits militair bestuur geplaatst.

Kort na de occupatie werden verzetsgroeperingen van verschillende signaturen georganiseerd, die zowel onderling als tegen de bezetters vochten ${ }^{10}$. De communistische partizanen onder de leiding van Tito bleken de sterkste te zijn. Na de capitulatie van Italie op 8 september 1943 kregen de partizanen belangrijke delen van Joegoslavië onder controle en vormden daar een eigen bestuur met een eigen wetgeving. Reeds in het najaar van 1942 werd door hen een "Nationaal Antifascistisch Bevrijdingscomité" gevormd, dat als een soort regering ging fungeren ${ }^{11}$. Op 7 maart 1945 werd door dit comité en de Joegoslavische regering in ballingschap een voorlopige coalitieregering gevormd ${ }^{12}$. In tegenstelling tot de andere Oosteuropese landen werd Joegoslavië tot begin mei 1945 niet alleen door de USSR, maar overwegend door het partizanenleger bevrijd ${ }^{13}$. $\mathrm{Na}$ de tweede wereldoorlog werd het Joegoslavische grondgebied hersteld binnen de grenzen van vóór de oorlog, met uitzondering van een gebiedsuitbreiding ten koste van Italië. De grens tussen beide landen werd voorlopig vastgesteld bij het vredesverdrag tussen Italië en de geallieerden van 10 februari $1947^{14}$, waarbij de stad Triëst met de omgeving (Territorio Libero di Trieste, Svobodno Tržaško Ozemlje) in twee zones werd verdeeld die onder respectievelijk Joegoslavisch en geallieerd bestuur werden geplaatst. Bij het Memorandum van Londen van 5 oktober $1954^{15}$ werd de oostelijke zone bij Joegoslavië en de westelijke met de stad Triëst zelf, bij Italië ingelijfd. De definitieve vastststelling van de grens tussen beide staten liet echter tot het verdrag van Osimo van 10 november $1975^{16}$ op zich wachten.

In de op 7 maart 1945 gevormde coalitieregering had de communistische partij reeds de meerderheid ${ }^{17}$. Na verkiezingen in de herfst van $1945 \mathrm{kregen}$ de communisten de macht geheel in eigen handen en op 29 november 1945 werd de

10. Schweissguth, JoR 1976, p. 191; Tratnik, p. 420.

11. Schweissguth, JôR 1967, p. 198-200; Schultz, JöR 1958, p. 292.

12. Deze voorlopige regering werd samengesteld op grond van het accoord tussen Tito en de premier van de regering in ballingschap Subašic, van 16 juni 1944. Cf. Schweissguth, JöR 1967, p. 202 203; Schullz, JöR 1958, p. 292.

13. De troepen van de USSR bewrijdden Belgrado en een gedeelte van Oost-Joegoslavie. Reeds in maart 1945 werd het Rode leger uit het land getrokken. Schultz, JöR 1958, p. 292.

14. G.U. 1947, nr, 200; in werking getreden op 16 september 1947. Sinagra, Rivista di diritto internazionale 1977, p. 485 .

15. Ur.I. FLRJ MP (Uradni list Mednarodne Pogodbe) 6/1954. Het memorandum werd ondertekend door Groot-Brittannië, Italië, Joegoslavië en de Verenigde Staten. Zie daarower Bartos, JRMP 1954/3, p. 4-21.

16. Ur.l. SFRJ MP (Mednarodne pogodbe) 1/1977; authentieke Franse tekst en de Servo-Kroatische vertaling.

17. Schweissguth, JöR 1967, p. 203. 
"Federatieve Volksrepubliek Joegoslavie" (FLRJ) uitgeroepen ${ }^{18}$. Tot 1948 stond de Joegoslavische binnen- en buitenlandse politiek onder sterke invloed van de Sovjetunie. De wat eigenzinnige visie op het socialisme in Joegoslavie leidde in 1948 tot een radicale breuk met de Sovjetunie en andere communistische staten "Deze betrekkingen herstelden zich in het midden van de jaren vijftig enigszins, doch Joegoslavie behield zijn eigen koers die zelfs steeds meer van de rest van de communistische wereld ging afwijken. Zo zijn met name op het economisch en. juridisch gebied belangrijke verschillen tussen Joegoslavië en andere communistische landen ontstaan. Ook in de buitenlandse politiek neemt Joegoslavië een min of meer onafhankelijke positie in. Het land is geen lid van de COMECON en van het Warschaupact en is éen van de oprichters van de organisatie van niet-gebonden landen ${ }^{20}$.

Op 31 januari 1946 werd de eerste grondwet van de volksrepubliek afgekon-

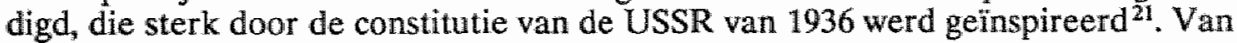
de Sovjetunie nam men ook de federale structuur over. De grondwet werd vervolgens vele malen herzien. Bij de wijziging van $1963^{22}$ veranderde de naam in "Socialistische Federatieve Republiek Joegoslawie" (SFRJ). Bij de wijzigingen van 1974 werden binnen de deelstaat Servie de autonome gebieden Vojvodina en Kosovo opgericht ${ }^{23}$ " De laatste ingrijpende herziening van de federale grondwet werd op 26 november 1988 ingevoerd ${ }^{24}$.

\subsubsection{Het nationaliteitsrecht tor 1941}

\subsubsection{Algemeen}

Zeer opmerkelijk is het feit dat het vervaardigen van een nationaliteitsrechtelijke regeling tot 1928 op zich liet wachten ${ }^{25}$. De enige regelingen die bepaalden wie de nationaliteit van de SHS bezaten, waren die van de vredesverdragen met Oostenrijk (Saint-Germain-en-Laye) ${ }^{26}$, met Hongarije (Trianon) ${ }^{27}$ en met Bulgarije (Neully) ${ }^{28}$. Voorts werden nog in bilaterale verdragen met Italie ${ }^{29}$ en Oostenrijk ${ }^{30}$ nationaliteitsrechtelijke bepalingen opgenomen. Daarnaast bevatte de grondwet van 1921 in art. 4 de bepaling dat de nationaliteit van de SHS "algemeen" was.

18. Ur.l. FLRJ 93/1945. Zie Schweissguth, JöR 1967, p. 193; Schultz, JöR 1958, p. 293.

19. Schultz, JöR 1958, p. 305; Tratnik, p. 420-421.

20. Tratuilk, P. 420-421.

21. Duitse vertaling in JoR 1958, p. 321-324, met het commentaar van Schultz op p. 294-320.

22. Ur.1. SFRJ 14/1963.

23. Ur.l SFRU 9/1974. Zie over deze grondwetswijxiging Schultz, JöR 1974, p. 13-37.

24. Ur.l. SFRJ $70 / 1988$.

25. Op deze situatie werd in de doctrine veel kritick uitgeoefend. Zie Vesel, p. 5 met verdere verwijzingen.

26. Verdrag van 10 september 1919 , Sl.n. $133 / 1920$, artt. $70-82$ en 230.

27 . Verdrag van 4 juni 1920, Sl.n. 140/1921, artt. 61-66 en 213.

28. Verdrag van 7 november $1919 ;$; Sl.n. $211 / 1920$, artt. $39,40 \mathrm{em} 158$.

29. Verdrag van Rapallo van 12 november 1920 , S1.n. $273 / 1920$, art. 7 en het verdrag van Neptumo van 20 julli 1925 , SI.n. $266 / 1928$ dat in zijn geheel betrekking op de nationaliteit had.

30. Verdrag vam Belgrado van 12 september 1920. 
Bovendien bestonden er twee decreten, die bepaalde bijzondere onderwerpen met betrekking tot de nationaliteil regelden ${ }^{31}$.

Gezien de hierboven omschreven situatie was het noodzakelijk dat de oude nationaliteitsrechtelijke regelingen die voor het ontstaan van de SHS in de afzonderlijke gebieden golden ${ }^{32}$, tot de inwerkingtreding van de wet van 1928 van kracht bleven. Conform deze diverse regelingen werden ook naturalisaties verleend ${ }^{33}$.

Uit de tijd voor 1928 is ook een mislukte poging om tot een nationaliteitsrechtelijke regeling te komen een vermelding waard ${ }^{34}$. Reeds in 1919 werd een ontwerp voor een nationaliteitswet aan het (toen nog) tijdelijke parlement aangeboden. Het wetsontwerp strandde echter op het feit dat de optiebepalingen moesten worden afgestemd op de bepalingen van vredesverdragen, die toen nog niet tot stand waren gekomen. Daarom besloot men indertijd om dan maar geen nationaliteitswet in te voeren ${ }^{35}$. Meer succes had een elaboraat dat in 1922 door een staatscommissie werd ontworpen. Dit ontwerp haalde zes jaar later, weliswaar aanmerkelijk gewijzigd, eindelijk de eindstreep ${ }^{36}$.

Op het tweede congres van Joegoslavische juristen in 1926 te Ljubljana, werd een resolutie omtrent de uitgangspunten van de tot stand te brengen nationaliteitswet aangenomen ${ }^{37}$. Deze uitgangspunten waren: ius sanguinis aangevuld met het ius soli, het bestrijden van apatridie en van meervoudige nationaliteit en het beginsel van eenheid van de nationaliteit in één gezin (système unitaire) ten aanzien van de nationaliteit van de gehuwde vrouw en van minderjarige kinderen.

Joegoslavie sloot tot 1941 de volgende internationale verdragen die (mede) betrekking hadden op de nationaliteit:

31. Decreten van 25 november 1920 , Sl.n. 271 en $290 / 1920$ en van 30 augustus 1921 , S1.n. $201 / 1921$.

32. Deze regelingen warem: In het koninkrijk Servië de naturalisatiewet van 8 april 1842 , vermeld in Clunet 1899, p. $949 ; \$ \$ 4$ en 48 van het Burgerlijk Wetboek van 11 maart 1844; Duitse vertaling in Polizei Hamburg, p. 308; SGS deel 17, p. 70; de decreten van 2 mei 1844 en van 14 augustus 1.851; Duitse wertaling in SGS deel 17, p. 70 en het reglement van 20 januari 1860 . Voorts hadden ook de volgende bepalingen van verschillende Servische grondwetten betrekking op de nationaliteit: artt. 22 en 40 van de GW van 29 juni 1869 , artt. 6 en 29 van de GW van 22 december 1888; Duitse vertaling in Polizei Hamburg, p. 307 en art. 29 van de GW van 2 juni 1903; Duitse vertaling SGS deel 17, p. 21. In het vorstendom Montentegro waren de enige nationaliteitsrechtelijke bepalingen te vinden in art. 120 sub 7 en in art. 215 van de grondwet van 6 december 1905; Dutilse vertaling in SGS deel 17, p. 71. In Dalmatiê en Sloveniẽ golden de bepalingen van $\$ \$ 28-32 \mathrm{ABGB}$, het "Auswanderungsgesetz" van 24 maart 1832 en de wet betreffende "Gemeindezugehörigkeit" van 3 december 1863, öRGBI (österreichisches Reichsgesetablatt) 1863, nr. 105, het zogenaamde "Heimatgesetz". In Kroatië, Stavonie, Prekmurje; Medjimurje en Vojodina de Hongaarse nationaliteitswet van 20 december 1879 . Voor Bosnië en Herzegowina tenslotte, waren de nationaliteitsrechtelijke bepalingen te vinden in 8 en 4 van het "Landesstatut für Bosnien und die Herzegowina" van 17 februari 1910, GBI. (Gesetzblatt) für Bosnien und die Herzegowina 1910, nr. 19; Engelse vertaling: State Papers 105, p. 505. Zie over deze oude regelingen Jowanović, p. 7-10.

33. Pirkmajer, p. 18-19.

34. Eigenlijk bestond er ook een ander ontwerp, samengesteld door de toenmalige Minister van binnenlandse zaken Marinkovic, dat echter zowel inhoudelijk , als wetgevingstechisisch zo slecht was, dat het op de snelst mogelijke manier in de archieven van het parlement verdween. Zie Pirkmajer, p. 20.

35. Pirkmajer, p. 19-20.

36. Pirkniajer, p. 20-24.

37. Zie Pirkmajer, p. 25; Vesel, p. 5-6. 
- het "Minderheitenschutzwertrag" van Saint-Germain-en-Laye met Frankrijk, Groot-Brittannië, Italië, Japan en de VS van 10 september $1919^{38}$;

- het verdrag van Rapallo van 12 november 1920 met Italië ${ }^{39}$;

- het verdrag van Rome van 6 april $1922^{40}$ tussen de "erfgenamen" van Oostenrijk-Hongarije: Oostenrijk, Hongarije, Italië, Polen Roemenië, Tsjechoslowakije en de SHS;

- het protocol van Belgrado betreffende vaststelling van de grens met Roemenië (het gebied Banat) van 24 november $1923^{41}$;

- het protocol van Sofia met Bulgarije van 26 november $1923^{42}$;

- het verdrag van Rome van 27 januari $1924^{43}$ met Italië betreffende de vestiging van de vrije stad Rijeka (Fiume);

- het verdrag van Belgrado van 12 september $1924^{44}$ met Oostenrijk;

- het verdrag van Neptuno van 20 juli $1925^{45}$, met Italië;

- het Haags nationaliteitenverdrag van 12 april $1930^{46}$ en het protocol betreffende een geval van staatloosheid, eveneens van 12 april $1930^{47}$,

- het verdrag van Belgrado van 30 januari $1933^{48}$ met Roemenië met aanvullend protocol van Boekarest van 13 maart $1935^{49}$.

38. Sl.n. 133A/1920; in werking getreden op 16 juli 1920 . Duitse vertaling im SGS deel 17, p. 74-78.

39. Sl.n. $273 / 1920$. In werking getreden op 2 december 1921 . Op de nationaliteit had art. VII betrekking, Duitse vertaling daarvan is afgedrukt in SGS deel 17, p. 80-81. Zie ook het verdrag tussen beide staten van 23 oktober 1922, si.n. 44/1924, strekkende tot uitvoering van thet verdrag van 12 november 1921.

40. G.U. 1924, nr. 44; DzU. 1929, nr. 5 pos. 46; oBGBL. 1924, p. 507 . Duitse vertaling in SGS deel 17 , p. 102-103. Door Joegoslavië werd dit verdrag echter nooit geratificeerd.

41. State Papers 123, 1048; Sl.n. 1048/1924. op de nationaliteit had betrekking art. 7 .

42. Sl.n. 162/1924.

43. Sl.n. 65/1924. Duitse vertaling in SGS deel 17, p. 103-104 (uittreksel), artt. 2 en 9.

44. Duitse vertaling in SGS deel 17, p. 104-107.

45. SI.n. 266/1928; G.U. 1928, nr. 234, p. 86; Duitse vertaling in SGS deel 17, p. $107-110$.

46. LNTS CLXXIX, 89; State Papers 137, 230. Zie over dit verdrag ook de viteenzettingen op p. 3737. Dit werdrag werd door Joegaslavië overigens nooit geratificeerd.

47. LNTS CVXXIX, 115; State Papers 137, 242. Door Joegoslavie werd slechts het protocol geratificeerd, namelijk bij verordening wan 27 oktober 1959, Ur. FLRJ 78/1959, annex; UNTS 346,376 . In werking getreden op 15 december 1959 .

48. LNTS CLXVI, 174; M.O. (Monitorul Official (Roemenië)) 1933, nr. 22; Recueil des traités internationaux van bet Joegoslavische ministerie van buitenlandlse zaken 1933 , p. 146-148; Duitse vertaling in SGS deel 17, p. 125-126.

49. LNTS CLXXIX, 58; M.O. 1935, nr. 122. Duitse vertaling in SGS deel 17, p. 126-127. 


\subsubsection{De wet van 1928}

\subsection{Algemeen}

Op 1 november $1928^{50}$ trad de eerste nationaliteitswet wan het koninkrijk SHS eindelijk in werking. De uitgangspunten die op het congres in Ljubljana in 1926 werden geformuleerd, werden door de wetgever overgenomen. Deze nationaliteitswet werd zowel door de Oostenrijkse, als door de Servische regelingen op dit gebied geinspireerd ${ }^{51}$. Voorts kwam op 28 december 1928 een bij deze wet behorend uitvoeringsreglement ${ }^{52}$ van het Ministerie van binnenlandse zaken tot stand.

Van de algemene bepalingen zij gewezen op $\$ 4$, waarin het reeds bekende exclusiviteitsbeginsel werd neergelegd. daarin werd "uitgesloten", dat een Joegoslavische onderdaan tevens een andere nationaliteit bezat ${ }^{53}$. Aan het overgangsrecht waren gewijd \$ 51-53 van de eerste Joegoslavische nationaliteitswet. Deze bepalingen waren nogal slordig geredigeerd en zullen verder buiten beschouwing worden gelaten ${ }^{54}$.

De wet van 1928 bleef nagenoeg ongewijzigd tot de inwerkingtreding van de eerste naoorlogse nationaliteitswet van 1945.

\subsection{Verkrijging van de nationaliteit}

De nationaliteit van de SHS kon worden verkregen van rechtswege, door optie en door naturalisatie.

\section{a. Verkrijging van rechtswege}

Verkrijging van het Joegoslavische staatsburgerschap werd van rechtswege gekoppeld aan de volgende rechtsfeiten:

- geboorte uit Joegoslavische ouder(s) $(\$ \S 7,8)^{55}$;

50. De nationaliteitswet wan 1928, SL.ni. 254/1928, baalde op 21 september 1928 de eindstreep. Duitse vertaling: SGS deel 17, p. 110-124, Engelse: State Papers 129, 935; Franse: Annuaire de l'institut intermational de droit public 1929, p. 538. Zie daarover: Ilic, Zakon o drzavljanstvu Kraljevine SHS, Beograd 1929; Pirkmajer, Slovenski pravnik 1933/5-6 (bijlage) en Zakon o dræzavljanstvu z razlago, Maribor 1929; Vesel, Zakon o drzavljanstvu kraljevine SHS od 21. septembra 1928; Terziev, Praktična uputstva za izvršenje zakona o državljanstvu, Beograd 1936. Peritch, RCDIP 1930, p. 1 e.w.; De Lapradelle/Niboyet, p. 798-805.

51. Zie voor een bespreking van deze wet, waarin naar het Oostenrijkse en het Servische recht wordt gerefereerd Peritch, $\mathbb{R C D I P} 1930$, p. 1-32.

52. Sl.n. 1/1929.

53. Zie daarover p. 32-33. Zie ook Pirkmajer, supplement bij Slowenski Pravnik 1933/7-8, p. 3-6; Jovanovic, p. 18.

54. Zie voor een kritische bespreking van de overgangsbepalingen Vesel, p. 21-26.

55. Hierbij moet worden aangetekend dat de afstamming volgens het personen-en familierecht van de SHS moest worden vastgesteld. Dit was echter geen cenvoudige zaak, omdat noch heit koninkrijk SHS noch het latere koninkrijk Joegoslavië een eigen uniform personen* en familierecht kende. In verschillende gebieden bleven gewoon de verschillende oude regelingen gelden. Dit waren: het Oostenrijkse ABGB, het Servische en Montenegrijnse Burgerlijk Wetboek en het Islamitisch gewoonterecht. Zie ook Gudde, p. 9; Tratnik, WPNR 5708 (1984), p. 510; 
- geboorte of het gevonden worden op het Joegoslavische grondgebied ( 89$)$;

- huwelijk met een Joegoslavische onderdaan ( $\$ 21)$.

Aan adoptie door Joegoslavische ouders werden ipso iure geen nationaliteitsrechtelijke gevolgen gekoppeld $(\$ 46)^{56}$.

\section{i. Geboorte uit Joegoslavische ouders(s)}

Een wettig kind verwierf het staatsburgerschap van Joegoslavië indien zijn vader op het tijdstip van de geboorte van het kind de Joegoslavische nationaliteit bezat, ongeacht waar het kind werd geboren ( $\$ 7$ sub a). Hetzelfde moet worden aangenomen voor het geval dat de Joegoslavische echtgenoot van de moeder 300 dagen voor de geboorte van het kind overleed ${ }^{57}$. Onwettige kinderen volgden de SHS-nationaliteit van de moeder, eveneens ongeacht de plaats van geboorte van het kind ( $\$ 7$ sub b). Een latere erkenning of gerechtelijke vaststelling van afstamming van een buitenlandse vader veranderde hieraan niets ${ }^{58}$.

In $\$ 8$ was de verkrijging van de Joegoslavische nationaliteit door legitimatie geregeld. De voorwaarden voor de verkrijging waren, dat op het ogenblik van de wettiging de vader de nationaliteit van de SHS bezat, en dat het kind jonger dan 21 jaar was. Voorts moet het kind volgens het recht van de SHS worden gelegitimeerd ${ }^{59}$. De verkrijging van de nationaliteit werkte ex tunc, vanaf het tijdstip van de geboorte van het kind.

\section{ii. Geboorte op het Joegoslavische grondgebied en vondelingen}

Een kind van onbekende ouders, of van ouders wier nationaliteit niet bekend was, dat in Joegoslavië werd geboren of gevonden, werd aangemerkt als een staatsburger van de SHS, totdat het tegendeel werd bewezen $(\$ 9)$. Het tegenbewijs kon altijd worden geleverd, ongeacht de leeftijd van het kind. Het geval dat de ouders weliswaar bekend waren, maar het kind staatloos zou zijn omdat het noch de vader, noch de moeder in de nationaliteit kon volgen ${ }^{60}$, was niet in de wet geregeld. Aangezien uit verschillende commentaren ${ }^{61}$ blijkt dat het ius soli slechts een subsidiair beginsel was, zou m.i. moeten worden geconcludeerd, dat het kind in een dergelijk geval aan $\$ 9$ geen nationaliteit kon ontlenen.

Peritch, RCDIP 1930 p. 2-3.

56. Pirkmajer, p. 101; Terziev, p. 53-65; Vesel, p. 21.

57. Peritch, RCDIP 1930, p. 4 .

58. Peritch, RCDIP 1930, p. 4.

59. Zie in dit verband ook noot 55 .

60. Hierbij kan worden gedacht aan gevallen, waarin de nationale wet(ten) van de ouder(s) het ius soli beginsel huldigde( $\mathrm{n}$ ).

61. Zie Pirkmajer, p. 45-46; Blagojević 1947, p. 47; Terziev, p. 5-6; Jovanovic, p. 18. 


\section{iii. Huwelijk met een Joegoslavisch onderdaan}

Een vreemdelinge die met een Joegoslavische man in het huwelijk trad, verkreeg krachtens 810 de Joegoslavische nationaliteit. Een bruid, die deze generositeit van de SHS-wetgever niet op prijs stelde, kon de verwerving van de nationaliteit echter voorkomen door vóor het sluiten van huwelijk te verklaren, dat zij haar oorspronkelijke, door afstamming verkregen nationaliteit ${ }^{62}$ wenste te behouden. Deze mogelijkheid bestond slechts, indien naar haar nationale wetgeving behoud van nationaliteit na het huwelijk met een vreemdeling mogelijk was. Indien een dergelijke verklaring pas na de huwelijkssluiting werd afgelegd, verkreeg ze de Joegoslavische nationaliteit van haar man. In de literatuur werd met het oog op de bepaling van $\$ 4$, die de mogelijkheid dat een Joegoslavische onderdaan tevens een andere nationaliteit bezat "uitsloot", betoogd, dat in een dergelijk geval een gehuwde vrouw haar oorspronkelijke nationaliteit verloor door verkrijging van de nationaliteit van de SHS $^{63}$. Een dergelijke opvatting is uiteraard niet in overeenstemming met het beginsel van nationale autonomie in het nationaliteitsrecht ${ }^{64}$, de Joegoslavische wetgeving kon immers niet bepalen wanneer iemand de nationaliteit van een andere staat verloor.

\section{b. Optie}

Verkrijging van de Joegoslavische nationaliteit door optie was geregeld in $\$ \$ 39$ en 40 van de wet van 1928. Optierechten werden verleend aan gewezen Joegoslavische kinderen die deze nationaliteit tijclens hun minderjarigheid verloren, en aan ex-Joegoslavische vrouwen die het Joegoslavische staatsburgerschap door huwelijk met een vreemdeling verloren.

\section{i. Ex-Joegoslawische kinderen}

Personen, die tijdens hun minderjarigheid de nationaliteit van de SHS hadden verloren doordat hun vader in een ander land werd genaturaliseerd, konden binnen én jaar na het bereiken van de leeftijd van 21 jaar voor de Joegoslavische nationaliteit opteren. Voorwaarde hiervoor was, dat betrokkenen zich binnen de SHS vestigden ( $\$ 39$ lid 1 ). Hetzelfde gold ten aanzien van degenen, die de Joegoslavische nationaliteit als gevolg van legitimatie door een vreemdeling hadden verloren. Krachtens de bepaling van het derde lid was deze optiebepaling echter niet van toepassing op een inmiddels met een vreemdeling gehuwde gewezen SHSonderdane. Het huwelijk werd namelijk geacht de belangrijkste grond voor het bepalen van de nationaliteitsrechtelijke status te zijn ${ }^{65}$.

62. Met de beperking tot een door afstamming verkregen nationaliteit en tot de tijd voor de huwelijkssluiting, trachtte men speculaties met de nationaliteit(en) te voorkomen. Zie hierover Pirknajer, p. 47-48; Terziev, p. 44 .

63. Zie Pirkmajer, p. 47.

64. Zie de uiteenzettingen ower dit beginsel op p. 30-31. Zie in dit verband ook het tussen Oostenrijk, Hongarije, Italië, Roemenië, Tsjechoslowakije en de SHS gesloten verdrag van Rome van 6 april 1922 , in het bijzonder art. 1 : "Les modes d'acquisition ou de la perte de la nationalité sont reglés par la loi de chaque Etat".

65. Pirkmajer, p. 83 en 94. 
Een gewezen SHS-onderdane, die deze nationaliteit door huwelijk met een vreemdeling had verloren, kon na de ontbinding van het huwelijk of scheiding van tafel en bed, opteren voor de Joegoslavische nationaliteit, indien zij zich in de SHS kwam vestigen ( $\$ 40$ lid 1$)^{66}$.

Krachtens de bepaling van het tweede lid van $\$ 40$ werkte deze herverkrijging van de nationaliteit niet tevens ten aanzien van uit het huwelijk geboren minderjarige kinderen van betrokkene. Deze behielden de nationaliteit van de overleden, respectievelijk gescheiden vader. Deze oplossing stond weliswaar op gespannen voet met het système unitaire, maar zoals Pirkmajer ${ }^{67}$ het verwoordde, duurde de beslissende invloed van de vader op het personeel statuut van het kind zelfs na de dood van de vader voort.

\section{c. Naturalisatie}

De wet van 1928 kende zowel een normale, als een bevoorrechte naturalisatieprocedure. De gewone naturalisatie was geregeld in $\$ \$ 11$ e.v. van de wet van 1928. De bewoegdheid om een naturalisatie te verlenen lag bij de Minister van binnenlandse zaken ( $\$ 1.5$ ). In $\$ 11$ lid 1 werden de volgende naturalisatievereisten gesteld:

- betrokkene moest zelf een naturalisatieverzoek indienen (sub 1). De strekking van dit vanzelfsprekend naturalisatievereiste was de vrijwilligheid van de verkrijging van de nationaliteit door naturalisatie te benadrukken ${ }^{68}$;

- leeftijd van 21 jaar of ouder (sub 2) ${ }^{69}$;

- onafgebroken verblijf van 10 jaar op het grondgebied van de SHS (sub 3). Blijkens de overgangsbepaling van $\S 57$ kon deze termijn niet eerder aanvangen dan op 1 december $1918^{70}$;

- betrokkene moest zijn oude nationaliteit reeds hebben verloren ${ }^{71}$, of althans kunnen aantonen dat hij die nationaliteit zal verliezen (sub 4);

66. Interessant is in deze context de gedachte van Purkmajer, p. 96 , dat het bij de mationaliteit van de gehuwde vrouw ging om een soort latente oorspronkelijke nationaliteit, die na de beëindiging wan het huwelijk "herleefde".

67. Pirkmajer, p. 96.

68. Zie Pirkmajer, p. 50.

69. Volgens Peritch, RCDIP 1930, p. 15, mocht betrokkene niet geestelijk gestoord zijn (er werd dus handelingsbekwaamheid vereist). De onder curatele gestelden waren in ieder geval van naturalisatie uitgesloten. In andere grevallen ging het om een quaestio facti, die ad hoc moest worden opgelost.

70. 1 december 1918 was de dag wan de proclamatie van thet koninkrijk SHS.

71. De tekst van de wet gebruikt (ietwat slordig) de term "otpust" (ontslag). Uiteraard was het ook voldoende dat betrokkene, wiens nationale wet de mogelijkheid van afstand kende, op deze wijke. zijn oorspronkelijke nationaliteit had werloren. 
- goed gedrag (sub 5). Deze vrij vage norm verleende een grote discretionaire bevoegdheid aan het beoordelende orgaan ${ }^{22}$;

. betrokkene moest in staat zijn om zichzelf en zijn gezin te onderhouden ${ }^{73}$;

- de gemeente van de verblijfplaats moest bereid zijn om aan de naturalisandus het "Heimatrecht" 74 toe te kennen ${ }^{75}$.

Blijkens de bepaling van het tweede lid van $\S 12$ kon een gehuwde vrouw niet zelfstandig worden genaturaliseerd. Deze regel was opnieuw een manifestatie van het beginsel, dat voor de nationaliteit van de gehuwde vrouw het staatsburgerschap van haar man bepalend was.

Ten aanzien van apatriden, personen wier nationalle wetgeving geen verlies van de nationaliteit door de wil van betrokkene kende, of deze wetgeving het verlies van de nationaliteit automatisch aan de verkrijging van een andere koppelde, werd vereist dat betrokkene verklaarde, dat hij de oorspronkelijke nationaliteit "opgaf" ( $\$ 12$ lid 3). Een dergelijke verklaring had in sommige gevallen een psychologische betekenis voor betrokkene, een andere nationaliteit ging daardoor uiteraard niet verloren.

Verzoekers die de naturalisatievereisten van $\& 12$ vervulden, ontleenden hieraan geen enkel recht op de Joegoslavische nationaliteit. De beslissing omtrent een naturallisatieverzoek werd geheel ter discretie van de beoordelende instantie overgelaten ${ }^{76}$ en tegen afwijzing van een verzoek stonden geen rechtsmiddelen open ${ }^{n}$. Een uitzondering gold echter krachtens $\& 13$ ten gunste van personen, die reeds 30 jaar onafgebroken op het grondgebied van de SHS hadden gewoond en gedurende de laatste tien jaren geen verplichtingen ten aanzien van hum nationale staat hadden vervuld. Deze personen verkregen daardoor een recht op naturalisatie ${ }^{78}$.

Een bijzondere (gunstigere) regeling gold ten aanzien van personen, die etnisch tot Serviërs, Kroaten of Slovenen behoorden. Deze konden worden genaturaliseerd zonder te hebben voldaan aan de vereisten sub 3 en 4 (tienjarig verblijf en het verlies van de oude nationaliteit). Indien deze personen tevens in Joegoslavië

72. Blijkens art. 25 lid 1 van het uitvoeringsreglement moest betrokkene een van het gemeentebestuur van zijn werblijfplaats afkomstige verklaring wan goed gedrag overleggen.

73. Ook hieromtrent moest cen van cen gemeentebestuur afkomstig bewijsstuk worden overlegd (art. 26 lid 1 uitwoeringsireglement). Interessant hierbij is, dat ook een medische verklaring van arbeidsongeschiktheild toereikend was (art. 26 lid 3 uitwoeringsreglement).

74. Zie over dit rechtsinstituut dat Joegoslavie van Oostenrijk-Hilongarije "erfde", ook hoofdstuk Hongarije, p. 171.

75. Deze bepaling is te zien als een manifestatie van de autonomie van de gemeenten. Zie Pirkmajer, p. 53. Bovendien werd aan de gemeenten bij de Gemeentewetten van 31 maart 1933, S1.n. 85XXVI/1933 en van 22 juli 1934 , SI.n. 169-XLIII/1934, de plicht opgelegd om hun inwoners in geval van behoeftightid te onderhouden. Zie $\$ 22$, resp. $\$ 18$. Terziev, p. 13.

76. Zie. Pirkmajer, p. 53; Vesel, p. 9; Peritch, RCDIP 1930, p. 19-20.

77. Pirkmajer, p. 54; Terziev, p. 13; Vesell, p. $10 \mathrm{~m} 11$.

78. Pirkmajer, p. 55 spreekt in dit werband van een soort "verkrijgende verjaring" van het recht op naturalisatie. Voor het geval dat een naturalisatieverzoek van een persoon, bedoeld in 13 desalniettemin werd afgewezen, stond tegen die beschikking een administratieve rechtsgang open. Zie Pirkmajer, p. 55. 
werden geboren, of sedert drie jaren aldaar woonachtig waren, werden zij tevens vrijgesteld van het naturalisatievereiste onder 7 (Heimatrecht). In die gevallen werd door de naturalisatie automatisch het Heimatrecht van de gemeente waarin ze woonden, verkregen ( $\$ 12$ lid 4$)$.

De naturalisandi moesten tevens een eed van trouw afleggen ${ }^{7}$. Indien deze niet binnen zes maanden na de totstandkoming van het naturalisatiebesluit werd afgelegd, kwam de beschikking te vervallen $(\$ 20)$.

\section{i Verlichte naturalisatie}

Bepaalde categorieën personen konden zonder te hebben voldaan aan het vereiste van voorafgaand verlies van de oorspronkelijke nationaliteit en van het tienjarig verblijf worden genaturaliseerd. Het ging hier om de volgende groepen $(\$ 14)$ :

- personen die aan een universiteit in Joegoslavië tot hoogleraar werden benoemd (lid 1 onder 1 );

- personen, bij wier naturalisatie een staatsbelang werd gediend (lid 1 sub 2).

Zoals Pirkmajer ${ }^{80}$ terecht opmerkte, vallen de sub 1 genoemde personen per definitie ook onder de tweede categorie. De reden om de hoogleraren desalniettemin apart te noemen was dat in die gevallen het voorgeschreven onderzoek naar aanwezigheid van het staatsbelang ${ }^{81}$ achterwege kon blijven.

Indien deze personen niet voldeden aan het vereiste van $\$ 12$ lid 1 onder 7 (Heimatrecht), verkregen ze krachtens $\$ 14$ lid 2 bij de naturalisatie automatisch het Heimatrecht van de gemeente waarin ze woonden.

\section{ii. Invloed op de nationaliteit van de gezinsleden van de verzoeker}

Een krachtens $\$ 12,13$ of 14 verkregen naturalisatie werkte tevens ten aanzien van wettige en geadopteerde ${ }^{82}$ kinderen van de naturalisandus die de leeftijd van 21 jaren nog niet hadden bereikt ${ }^{83}$, en ten aanzien van diens echtgenote, tenzij deze door een uitdrukkelijke wilsverklaring voor de huwelijkssluiting haar oorspronkelijke nationaliteit behield ( $\$ 19)^{84}$.

\subsection{Verlies van de nationaliteit}

Volgens de Joegoslavische nationaliteitswet van 1928 ging de nationaliteit verloren van rechtswege, door afstand, ontslag en ontneming.

79. Zie voor de tekst daarvan $\$ 17$.

80. Pirkmajer, p. 58, zie ook Terziev, p. 37.

81. Zie het uitvoeringsreglement, art. 31 lid 2.

82. Zie hierover Peritch, RCDIP 1930, p. 27.

83. Ditzelfde gold tevens ten aanziem van manneljjke kinderen dlie jonger dan 21 jaar waren en die reeds gehuwd waren (geweest). Cr. Peritch, RCDIP 1930; p. 28.

84. Zie in dit verband de uiteenzettingen op p. 198 en Terziev, p. 43-50. 


\section{a. Verlies van rechtswege}

Verlies van de Joegoslavische nationaliteit werd volgens de wet van 1928 van rechtswege gekoppeld aan de volgende rechtsfeiten:

- legitimatie door een vreemdeling $(\$ 30)$;

- huwelijk met een vreemdeling ( $\$ 29)$ en

- langdurig verblijf in het buitenland ( 828 ).

Erkenning of adoptie door een buitenlandse man konden geen verlies van de nationaliteit ipso iure bewerkstelligen.

\section{i. Legitimatie door een vreemdeling}

De nationaliteit van de SHS ging voor een minderjarig (onder 21 jaar) onwettig kind verloren, indien het kind door een vreemdeling werd gelegitimeerd en de nationale wetgeving van de vader hieraan verkrijging van de desbetreffende nationaliteit verbond ( $\$ 30$ lid 1 ). Het moest derhalve gaan om een wettiging, erkend in de nationale staat van de vader, anders had deze geen verkrijging van de nationaliteit tot gevolg kunnen hebben ${ }^{85}$.

Krachtens de bepaling van het tweede lid gold het eerste lid evenwel niet ten aanzien van een met een SHS-staatsburger gehuwde vrouw.

\section{ii. Huwelijk met een vreemdeling}

Een Joegoslavische vrouw verloor in de regel deze nationaliteit indien zij met een vreemdeling in het huwelijk trad. Het staatsburgerschap ging echter niet verloren, indien de nationale wetgeving van de bruidegom geen automatische verkrijging van de nationaliteit door huwelijk kende. Hierdoor werd voorkomen dat een bruid tussen wal en schip raakte, door haar oorspronkelijke nationaliteit te verliezen en niet de nationaliteit van haar bruidegom op het moment van de huwelijkswoltrekking te kunnen verkrijgen. Bovendien kon zij door een uitdrukkelijke wilsverklaring, bijvoorbeeld in de huwelijkse voorwaarden, de nationaliteit van de SHS ook na het huwelijk behouden, ongeacht of zij door huwelijk tevens de nationaliteit van de man verkreeg $(\$ 29)$.

\section{iii. Langdurig verblijf in het buitenland}

Door langdurig verblijf in het buitenland ging de Joegoslavische nationaliteit verloren voor iemand, die zich blijvend buiten de SHS vestigde, indien hij na het bereiken van de leeftijd van 21 jaar gedurende 30 jaren geen verplichtingen ten aanzien van de Joegoslavische staat had vervuld $(\$ 28)^{86}$.

85. Zie ook Pirkmajer, p. 83; Terziev, p. 102.

86. Zie voor een nadere aanduiding van deze verplichtingen $\$ 23$. Pirkmajer, p. 80; Terziev, p. 96. 


\section{b. Afstand}

Personen, die de Joegoslavische nationaliteit door afstamming hadden verkregen, hadden onder bepaalde omstandigheden de mogelijkheid om daarvan afstand te doen. De vereisten waren de volgende:

- geboorte in het buitenland;

- $\quad$ leeftijd tussen 21 en 24 jaar;

- vaste woonplaats in het land van geboorte;

- het bezit van de nationaliteit van het desbetreffende land ( $\$ 31$ lid 1 ).

Ook deze verliesbepaling was niet van toepassing op gehuwde vrouwen ( $\$ 31$ lid 2).

\section{c. Ontslag}

De mogelijkheid van het ontslag uit de Joegoslavische nationaliteit was geregeld in $\$ \$ 22-27$ van de nationaliteitswet van 1928 . De beslissing omtrent verlening van ontslag werd genomen door de Minister van binnenlandse zaken, op voordracht van het hoofd van de provincie waarin betrokkene woonde $(\$ 26)$. Geen ontslag was mogelijk indien de verzoeker:

- dienstplichtig was ( $\$ 23$ lid 1 sub 1 );

- in een strafrechtelijke procedure verwikkeld was ( $\$ 23$ lid 1 sub 2);

- tot een vrijheidsstraf of geldboete veroordeeld was en deze sanctie nog niet ten uitvoer werd gelegd ( $\$ 23$ lid 1 sub 3,4$)$;

- belastingsschulden had ( $\$ 23$ lid 1 sub 5 );

- beroepsmilitair, ambtenaar werkzaam bij bestuursorganen of volksvertegenwoordiger was ( $\$ 23$ lid 2$)$;

- zijn verplichtingen ten opzichte van Joegoslavische natuurlijke en rechtspersonen niet had vervuld $(\$ 24)^{87}$.

Bovendien moest betrokkene 21 jaar of ouder zijn en kunnen bewijzen, dat hij een andere nationaliteit reeds bezat, respectievelijk zou verkrijgen. Ontslag werd telkens

87. Volgens \$26 leden 2 en 3 moest elk ontslagverzoek openbaar worden gemaakt, zodat natuurlijke en rechtspersonen tegenover wie de verzoeker verplichtingen had, gedurende 14 dagen bezwaar tegen ontslag van betrokkene konden indienen. Bleek dat tegen de verzoeker een civiele procedure, procedure tot uitwinning of faillissementsprocedure atanhangig was, dan werd de termijn vam 14 dagen met maximaal één jaar verlengd. 
verleend onder de alternatief gestelde opschortende voorwaarden dat betrokkene inderdaad een andere nationaliteit verkreeg, zich blijvend in het buitenland vestigde, of binnen én jaar na het verlenen van het ontslag het land had verlaten. Nadat een van deze voorwaarden in vervulling was gegaan, werkte het verlies van de nationalliteit vanaf de dagtekening van het ontslagcertificaat $(\$ 27)$.

Een verzoeker, die aan de wettelijke vereisten voldeed, had krachtens $\$ 25$ een recht op ontslag. Tegen een afwijzende beschikking, die door de hoofden van provincies werd genomen, stond beroep bij de Minister van binnenlandse zaken open ( 86 lid 4 ).

\section{i. Invloed op de nationaliteit van de gezinsleden van de verzoeker}

Ontslag uit de Joegoslavische nationaliteit had in beginsel automatisch verlies van het staatsburgerschap door vrouw en door de minderjarige kinderen van de verzoeker tot gevolg. Het verlies van de nationaliteit trad echter slechts in, indien de gezinsleden ook zelf de nieuwe nationaliteit van hun echtgenoot, respectievelijk vader verwierven, of indien ze het land hadden verlaten ( $\$ 37)$. Het staatsburgerschap werd ook niet verloren door een minderjarige dochter van betrokkene die reeds gehuwd was $(\$ 42)$.

\section{d. Ontneming}

Ontneming van de Joegoslavische nationaliteit was geregeld in $\$ \S 32,33$ en 34 van de wet van 1928. De bevoegdheid om het staatsburgerschap te ontnemen lag bij de Minister van binnenlandse zaken. Volgens $\$ 32$ werd de nationaliteit ontnomen aan personen, die in de militaire of staatsdienst van een vreemde staat traden en deze dienst na een herhaalde oproep van de Minister van binnenlandse zaken niet hadden verlaten.

Voorts $\mathrm{kan}^{88}$ een door naturalisatie verkregen nationaliteit van de SHS worden ontnomen in geval van oorlog tussen Joegoslavië en de staat waarvan betrokkene voor de naturalisatie onderdaan is geweest. Ontneming van de nationaliteit in een dergelijk geval werd voorgeschreven als sanctie wegens onttrekken aan de militaire dienst, spionage, of andere handelingen die de SHS konden schaden ( $\$ 33)$. Ten aanzien van personen, die de Joegoslavische nationaliteit ex $\$ 33$ hadden verloren, bepaalde voorts $\$ 36$ dat zij nimmer konden worden gehernaturaliseerd.

\section{Invloed op de nationaliteit van gezinsleden van betrakkene}

Ontneming van de nationaliteit ex $\$ 32$ of $33 \mathrm{kon}^{89}$ zich tevens uitstrekken over de vrouw ${ }^{\circ}$ en de minderjarige kinderen van betrokkene Zulks moest echter in het ontnemingsbesluit uitdrukkelijk worden bepaald $(\$ 34)$.

88. Bij $\$ 33$ ging het om een discretionaire bewoegdheid van de Minister. Zie Pirkmajer, p. 89 Terziev, p. 106.

89. Deze uitbreiding van het verlies dient restrictief te worden geïnterpreteerd. Pirkmajer, p. 91 noemt gewallen van medeplichtigheid of ontduiken van sequestratie. Zie ook Terziev, p. 106-107.

90. Kennelijk ging de Joegoslavische wetgever in 1928 ervan uit dat slechts mannen dergelijke daden konden plegen. 


\subsubsection{Het nationaliteitsrecht tijdens de tweede wereldoorlog}

Over het algemeen wordt aangenomen dat Joegoslavië ondanks de onmogelijkheid van uitoefening van het staatsgezag ook in de jaren 1941-1945 bestond ${ }^{91}$. Hetzelfde geldt ook voor de Joegoslavische nationaliteit. Hieronder zal kort worden ingegaan op de nationaliteitsrechtelijke positie van de bewoners van de bij de bezetters ingelijfde gebieden en van de "Onafhankelijke staat Kroatië".

\subsubsection{De "Onafhankelijke staat Kroatie" (NDH)}

Zoals reeds op p. 191-193 werd gezegd, was de NDH de enige (met de hulp van de bezetters) totstandgekomen entiteit, die een eigen staatsgezag uitoefende. In de NDH werd op 30 april 1941 een nationaliteitswet afgekondigd, die echter geen materiële regeling van de nationaliteit met zich mee bracht. De nationaliteit van de NDH werd verworven en verloren volgens de regels van de oude Joegoslavische nationaliteitswet van $1928^{\circ 2}$. Naar Duits voorbeeld werd er onderscheid gemaakt tussen "Staatsangehörigen" en "Staatsbürger" ${ }^{\text {"93. }}$. Voorts werd bij een decreet-wet van 10 augustus 1942 een regeling van ontneming van de nationaliteit aan emigranten getroffen.

\subsubsection{Duitsland}

Met betrekking tot de inwoners van de gebieden Untersteiermark, Krain en Kärnten werd de verordening van 14 oktober $1941^{\text {94 }}$ afgekondigd. Volgens deze regeling die terugwerkende kracht tot 14 april 1941 had, verwierven alle etnisch Duitse bewoners (deutsche Volkszugehörigen) de Duitse nationaliteit (\$1). De tweede groep, de personen "deutschen oder artverwandten Blutes" verwierven de zogenaamde "deutsche Staatsangehörigkeit auf Widerruf" ( $\$ 2)$. Aan deze personen kon de Duitse nationaliteit namelijk binnen een termijn van 10 jaren worden ontnomen. Alle andere bewoners werden slechts "deutsche Schutzangehörigen".

\subsubsection{Hongarije}

Bij Hongarije werden de gebieden Baćka, Baranja, Prekmurje en Medjimurje ingelijfd, die reeds voor 1918 tot het Hongaarse koninkrijk behoorden. Aan de bewoners van deze gebieden werd bij wet van 27 december $1941^{\text {gs }}$ betreffende de

91. SGS deel 17 , p. 28 , met verdere literatuurverwijzingen.

92. SGS deel 17, p. 29.

93. SGS deel 17, p. 29. In Duitsland bestond sedert 1935 onderscheid tussen "Reichsbürger" en "Staatsangehörigen". Slechts de eersten bezaten de politieke rechten. Zie hierover hoofdstuk Duitsland/DDR, p. 146.

94. RGBL I, p. 648; afgedrukt in SGS deel 17, p. 127-129. Zie ook RdErl.d.RMdI wan 20 februari 1942, RMBliV, p. 529 en van 19 juni 1942, RMBliV, p. 1326. Zie hierover Schlleser, p. 103-104; SGS deel 17, p. 32-35.

95. Duitse vertaling in SGS deel 17, p. 129. De eerste paragraaf van deze wet begon met zulke "mooie" woorden, die, zij het in de Duitse vertaling, niet ongeciteerd kunnen blijven: "Die während der fast dreiundzwanzigjährigen Schicksalprüfung in der Treue zum Vaterland bekräftigten südungarischen Söhne der ungarischen Nation werden ihr mit brïderlichen Liebe wieder angeschlossen und in Schutz genommen. Der kgl. ung. Wehrmacht wird die dankbare 
inlijving, de Hongaarse nationaliteit verleend. Het staatsburgerschap werd echter slechts verkregen door degenen, die op 26 juli $1921^{\%}$ de Hongaarse nationaliteit bezaten en tussen 1 juni 1931 en 11 april 1941 in die gebieden hun vaste woonplaats hadden. De nationaliteit werd eveneens verkregen door de vrouw en kinderen van betrokkene, die onder 24 jaar waren. Het staatsburgerschap werd voorts niet verkregen door degenen die op grond van een optieverklaring de Joegoslavische nationaliteit hadden verworven.

\subsubsection{Bulgarije}

De inwoners van de door Bulgarije bezette en ingelijfde gebieden van de huidige Joegoslavische deelstaat Macedonië, verwierven op grond van een verordening van 9 juni 1942 de Bulgaarse nationaliteit. Voorwaarde voor verkrijging was dat ze van (etrisch) Bulgaarse afstamming waren ${ }^{\text {? }}$.

\subsubsection{Italië}

Voor de gebieden die de Italiaanse bezetters hetzij bij Italie ${ }^{98}$, hetzij bij Albanië ${ }^{99}$ inlijfden, werden geen aparte nationaliteitsrechtelijke regeling getroffen. Op grond van de opvatting dat annexatie van grondgebied automatische verandering van de nationaliteit van de inwoners daarvan bewerkstelligt, kan echter worden aangenomen dat alle inwoners van die gebieden de Italiaanse, respectievelijk Albanese nationaliteit verwierven ${ }^{100}$.

\subsubsection{De wet van 1945}

\subsubsection{Algemeen}

$\mathrm{Na}$ de beëindiging van de bezetting werden alle rechtsvoorschriften van de bezetters en van de NDH nietig verklaard ${ }^{101}$. Hetzelfde gold voor de nationaliteitsrechtelijke regelingen ${ }^{102}$. De vraag wie de Joegoslavische nationaliteit bezaten, moest uitsluitend aan de hand van de nationaliteitswet van 1928 worden beantwoord. Eên van de eerste legislatieve daden van het "nouveau régime" in Belgrado was vervolgens het vervaardigen van een nieuwe nationaliteitswet, die op 28 augustus $1945^{103}$ in werking trad. De strekking van deze wet was voornamelijk zo spoedig mogelijk nationaliteitsrechtelijke sancties te treffen tegen personen, die met de bezettingsmachten hadden samengewerkt, of althans tegen de communisten

Anerkernung der ungarischen Nation für ihre selbstaufopfernde begeisterte Plichterfüllung zumi Ausdruck gebracht". Zie hierover SGS deel 17, p. 35 .

96. Datum wan inwerkingtreding van het vredeswerdrag met Hongarije van Trianon.

97. SGS deel 17, p. 35-36.

98. Zie voor verwijzingen naar de Italiaanse wetgeving betreffende de inlijving noot 7 . Bij decreetwet van 26 december 1941, G.U. 1942, p. 515 , werd vervolgens een groot gedeelte van de Italiaanse wetgeving op de ingelijfde gebieden van toepassing verklaard.

99. Proclamatie van Mussolini van 29 juni 1941.

100. Zie hierover SGS deel 17, p. 36; Jellinek H. p. 116. Anders echter Weis, p. 137.

101. Wet van 23 oktober 1946; Ur. 1. FLRJ $86 / 46$.

102. Djajić èa., p. 91, 224. Bergmann/Ferid, p. 12.

103. Ur.I. FLRJ $64 / 1945$. 
vochten ${ }^{104}$. De wet van 1945 had echter een voorlopig karakter. Na het aannemen van een nieuwe grondwet op 31 januari 1945, trad op 1 juli 1946 een definitieve nationaliteitswet in werking ${ }^{105}$. De tekst van deze nieuwe wet was nagenoeg identiek met die van 1945. Om deze reden zal in het vervolg slechts van de wet van 1945 worden gesproken. Naast de algemene nationaliteitswet kondigde men op 23 oktober $1946^{106}$ een bijzondere ontnemingswet af. Deze regeling betrof ontneming van de nationaliteit aan voormalige officieren en onderofficieren van het Joegoslavische (koninklijke) leger, die zich in het buitenland bevonden en niet naar het land wilden terugkeren, alsmede aan leden van militaire formaties die in dienst van bezettingsmachten waren en naar het buitenland vluchtten en aan andere emigranten.

In verband met de grondgebiedsveranderingen ten opzichte van Italië, werden voorts de volgende regelingen getroffen, die (mede) betrekking hadden op de nationaliteit van de inwoners van deze gebieden:

- vredesverdrag van 15 september 1947 met Italië ${ }^{107}$;

- wet van 2 december 1947 betreffende de nationaliteit van de inwoners van de op grond van het vredesverdrag met Italië bij Joegoslavië ingelijfde gebieden, met de verordening tot uitvoering van deze wet, van 15 december $1947^{108}$;

- memorandum van Londen van 26 oktober $1954^{109}$, betreffende vaststelling van de grens tussen Italië en Joegoslavië;

- wet van 25 oktober 1954 betreffende de nationaliteit van de inwoners van de bij Joegoslavië ingelijfde zone B van de voormalige vrije stad Triëst, met de witvoeringsverordening van 29 december $1954^{110}$;

- verdrag van Osimo 10 november $1975^{111}$ betreffende definitieve verdeling van de voormalige vrije stad Triëst.

104. Blagojevic, RCDIP 1954, p. 30.

105. Ur.l. FLRJ 5-6/1946; Duitse wertaling in SGS deel 17, p. 131; Franse in RCDIP 1949, p. 756. Zie over deze wet Alagic, Godismjak pravnog fakulteta u Sarajevu 1954, p. 1-32; Blagojevic, Drzaviljanstwo, Beograd 1947, Blagojevic, RCDIP 1954, p. 29-37; Cok, Zbornilk radova o stranom i uporednom pravu 1961/1 p. 11-29; Davinić, Anali pravnog fakulteta u Beogradu 1957, p. 349353; Krbek, 1. Zakon o drzavljanstvu sa komentarom, Beograd 1948; SGS deell 17.

106. Ur.L FLRJ 86/1946. Ingetrokken bij wet van 24 mei 1962, Ur.I. FLRJ 22/1962; Duitse vertaling in STAZ 1963, p. 340. Interessant is dat bij de intrekkingswet werd bepaald, dat de nationaliteit slechts aan degenen werd ontnomen, tegen wie een expliciete ontnemingsbeschikking werd uitgevaardigd. Zie ook Bergmann/Ferid, p. 7.

107. Ur.l. FLRJ 74/47. Op de nationaliteit hadden betrekking artt. $19 \mathrm{en} 20$, Duitse vertaling in SGS deel 17, p. 154-155. Op de nationaliteit van bewoners van de vrije stad Triëst was art. 6 van het statuut voor dit gebied (de tweede bijlage wan het verdrag) van toepassing. Duitse vertaling in SGS deel 17, p. 156.

108. Ur.I. FLRJ 104/47; Duitse vertaling, wan de wet in SGS deel 17, p. 156-158 en van de verordening op p. 158-160.

109. Ur.I. FLRJ MP 6/1954.

110. Ur.I. FLRJ $56 / 1954$.

111. Ur.1. SFRU MP 1/1977. Zie daarover Jovanovic, p. 27-31 en Simagra, Rivista di diritto internazionale 1977 , p. $485-505$. 
De nieuwe Joegoslavische nationaliteitswetgeving na de tweede wereldoorlog bracht drie principięle wijzigingen met zich mee. De keuze voor het federatieve staatsbestel van de Federatieve Volksrepubliek Joegoslavië werd op het nationallteitsrechtelijk gebied gemanifesteerd door een "dubbele" nationaliteit: die van de deelstaten en die van de federatie. De tweede belangrijke wijziging was consequente doorvoering van het beginsel van gelijkheid van mannen en vrouwen. Dit kwam tot uiting in de keuze woor het ius sanguinis a patre et a matre en het loslaten van het systeme unitaire ten aanzien van de nationaliteit van de gehuwde vrouw. De derde vernieuwing was gelijkstelling van wettige en onwettige kinderen. Het bestrijden van zowel meervoudige nationaliteit als van apatridie werd ook in de nieuwe Joegoslavische nationaliteitswetgeving als uitgangspunt gehandhaafd.

Evenals de wet van 1928 werd ook de nationaliteitswet van 1945 aangevuld door een uitvoeringsreglement ${ }^{112}$, waarin nadere voorschriften ten aanzien van de toepassing van de wet werden opgenomen.

Interessant is dat art. 25 ten aanzien van personen die etnisch tot één van de Joegoslavische volkeren behoorden, aldaar werden geboren en getogen en tevens binnen de FLRJ hun woonplaats hadden, een vermoeden van het bezit de Joegoslavische nationaliteit bevatte.

Aangezien de wetgever binnen enkele (zomer)maanden ${ }^{113}$ een nieuwe nationaliteitswet "produceerde", zal het feit dat zowel de structuur van de wet(sbepalingen), als de bewoordingen daarvan voorzover mogelijk van de wet van 1928 werden overgenomen, niet veel verbazing wekken. De nieuw geredigeerde bepalingen lieten door dit "legislatieve haastwerk" evenwel het een en ander te wensen over.

\subsection{De verhouding tussen de federale en de deelstaatnationaliteit}

Joegoslavië, dat voor de tweede wereldoorlog een eenheidsstaat was, kreeg een federale structuur naar voorbeeld van de USSR. Evenals in de Sovjetunie werd tegelijkertijd de nationaliteit van de federatie en die van de deelstaten ingevoerd. Om te bepalen wie bij de totstandkoming van de deelstaten de nationaliteit daarvan bezaten, werd bij het nog van Oostenrijk geërfde rechtsinstituut van het "Heimatrecht" aangeknoopt ${ }^{114}$. Na 28 augustus 1945 werd echter de woonplaats voor de deelstaatnationaliteit bepalend ${ }^{115}$.

De verhouding tussen beide Joegoslavische nationaliteiten werd gebaseerd op art. 48 van de grondwet van 1946 en later op art. 12 van de grondwetnovelle 1 16 van 1953, respectievelijk art. 118 van de grondwet van 1963. Volgens deze grondwettelijke bepalingen werd de federale nationaliteit als de primaire beschouwd en die van de deelstaten als de daaruit afgeleide ${ }^{117}$. Aan de verkrijging

112. Ur.I. FLRJ 98/1946, gewijzigd 20/1951; Duitse wertaling (uittreksel) SGS deel 17, p. 145 .

113. De tweede wereldoorlog duurde in Joegoslawie officieel tot 10 mei 1945, terwijl de burgeroorlog nog enkele maanden heeft voortgeduurd.

114. Authentieke interpretatie van het Presidium vam het Parlement m.b.t. art. 37 van de nationaliteitswet van 1945. Zie Bergmann/Ferid, p. 12; Zbirka, p. 57-58.

115. Djajic e.a. p. 288; Bergmann/Ferid p. 12.

116. In Joegoslavië worden grondwetsnovellen met de voor Nederlanders zeer werwarrende term "amandma" (Sloveens), "amandman" (Servo-Kroatisch) aangeduüd.

117. Jovanovic, p. 21-22. 
van het staatsburgerschap van de federatie werd in de regel verwerving van de deelstaatnationaliteit gekoppeld. Verloor betrokkene de nationaliteit van de FLRJ, dan ging automatisch het deelstaat-staatsburgerschap verloren. Naar voorbeeld van de USSR kende men geen nationaliteitswetten van afzonderlijke deelstaten. Pas na de breuk tussen beide landen kwamen in het jaar 1950 nationaliteitswetten van alle Joegoslavische deelstaten tot stand. Het ging om zes nagenoeg identieke, geheel op de federale nationaliteitswet afgestemde regelingen ${ }^{118}$. Aangezien de verhouding tussen de federatie en de deelstaten in de loop van jaren steeds veranderde, zal alleen bij de bespreking van het positieve nationaliteitsrecht iets uitvoeriger worden stilgestaan bij het verschijnsel van de deelstaatnationaliteit.

\subsubsection{Verkrijging van de nationaliteit}

De Joegoslavische nationaliteit werd volgens de wet wan 1945 verworven van rechtswege, door optie en door naturalisatie. De mogelijkheid van verkrijging van het staatsburgerschap door optie werd ingevoerd bij een wijziging van de nationaliteitswet in 1947.

\subsection{Verkrijging van rechtswege}

Van rechtswege werd verkrijging van de Joegoslavische nationaliteit gekoppeld aan de volgende rechtsfeiten:

- geboorte uit Joegoslavische ouder(s) (art. 4) en

- geboorte of het gevonden worden in de FLRJ (art. 6).

Aan adoptie door, respectievelijk huwelijk met een Joegoslavische onderdaan werden van rechtswege geen nationaliteitsrechtelijke gevolgen verbonden.

\section{a Geboorte uit Joegaslavische ouder(s)}

De Joegoslavische nationaliteit werd steeds verworven door een kind wiens beide ouders op het tijdstip van de geboorte van het kind het Joegoslavische staatsburgerschap bezaten, ongeacht waar het werd geboren (art. 4 lid 1 sub 1). Voor het geval dat slechts éen van de ouders van het kind de nationaliteit van de FLRJ bezat, bedacht men een zeer ingewikkelde regelling, die uitsluitend gold ten aanzien van kinderen, geboren na 28 augustus $1945^{119}$. Een kind waarvan één van de ouders de Joegoslavische nationaliteit bezat, verwierf het staatsburgerschap van de FLRJ indien:

118. Voor Bosnie en Herzegowina: de wet van 30 januari 1950, S1.1. van Bosnië en Herzegowina $5 / 1950$; voor Macedonië de wet van 6 juni 1950 , Sluzben vesnik $16 / 1950$; voor Montenegro de wet van 27 januari 1950, SI.I. van Montenegro 3-4/1950; voor Servie de wet van 6 februari 1950, Sluzben glasnik $5 / 1950$ en voor Slovenië de wet van 30 juni 1950, Ur.1. wan Slovenië 20 104/1950),

119. Zie art. 22 lid 2 van het uitvoeringsreglement. 28 augustus 1945 was de dag van inwerkingtreding van de wet van 1945 . 
- zijn ouders ten overstaan van een Joegoslawische autoriteit in het huwelijk traden (art. 4 lid 1 sub 2);

- ển van de ouders van het kind en het kind zelf hun vaste woonplaats in Joegoslavië hadden (art. 4 lid 1 sub 3);

- eén van de ouders zich samen met het kind voor de $18 \mathrm{e}$ verjaardag van het kind in Joegoslavië vestigde (art. 4 lid 1 sub 3);

- het kind alleen voor zijn 18de levensjaar in Joegoslavië woonde, of daar werd opgevoed (art. 4 lid 1 sub 3);

- het kind buiten de FLRJ werd geboren en binnen 5 jaar na de geboorte bij een Joegoslavische vertegenwoordiging in het buitenland werd geregistreerd; de registratie werd echter niet vereist, indien het kind volgens de nationaliteitswetgeving van het desbetreffende land als Joegoslavische staatsburger werd beschouwd (sub 4) ${ }^{120}$.

De verkrijging van de nationaliteilt krachtens art. 4 werkte blijkens art. 22 lid 1 van het uitvoeringsreglement in alle gevallen ex tunc, vanaf het tijdstip van de geboorte van het kind.

\section{b. Geboorte op het Joegoslavische grondgebied en vondelingen}

Iure soli verkreeg de Joegoslavische nationaliteit een kind van onbekende ouders dat in Joegoslavië werd geboren of gevonden (art. 6 lid 1), alsmede een kind van ouders zonder, dan wel van onbekende nationaliteit dat in FLRJ werd geboren (lid 2). Het ging in beide gevallen niet om een "echte" nationaliteitsverkrijging, maar slechts om een reeds uit de wet van 1928 bekend vermoeden daarvan. Nieuw was hierbij het feit, dat deze praesumptio slechts tot de veertiende verjaardag van het kind kon worden weerlegd.

\subsection{Optie}

De mogelijkheid van verkrijging van de Joegoslavische nationaliteit door optie werd ingevoerd bij de wijzigingswet d.d. 27 december 1947. Optierechten werden verleend aan de volgende twee categorieën personen:

- personen die etnisch tot én van de Joegoslavische volkeren behoorden, tussen 1918 en 30 juni 1948 uit Italië naar Joegoslavië emigreerden en 18 jaar of ouder waren (art. 36a);

120. De onderhavige uitzondering op de registratieplicht betekende uiteraard niet dat in een dergelijk gevall de Joegoslavische nationaliteit vollgens het recht van een ander land werd werkregen. Daarmee werd slechts beoogd te woorkomen dat een kind tussen "wall en schip" raakte en staatloos werd. Zie ook NWG, p. 10. 
- personen die voor 10 april 1940 uit voormalige Italiaanse gebieden, die volgens het vredesverdrag van 1947 bij Joegoslavië werden ingelijfd, naar een derde landen emigreerden en 18 jaar of ouder waren (art. 36b).

\section{a. Invloed op de nationaliteit van gezinsleden van betrokkene}

Opties ex artt. 36a-36b van de Joegoslavische nationaliteitswet hadden geen invloed op de nationaliteit van de huwelijkspartner van betrokkene. Interessant is echter dat deze nieuwe regeling vrouwen discrimineerde. Minderjarige kinderen verwierven namelijk alleen de Joegoslavische nationaliteit indien hun vader voor het FLRJ-staatsburgerschap opteerde. Slechts in het geval dat de vader overleden was, was een kind de verkrijging van de nationaliteit door zijn moeder deelachtig (art. 36c).

\subsection{Naturalisatie}

Evenals de wet van 1928 kende ook de nieuwe Joegoslavische nationaliteitswetgeving zowel een normale, als een bijzondere naturalisatieprocedure. Bovendien werden aan een groep naturalisandi zogenaamde "Einbürgerungsansprüche" toegekend. De bevoegdheid om de gewone naturalisatie te verlenen lag bij de Ministers van binnenlandse zaken van de deelstaten. Daarbij werd tevens vereist dat de federale Minister van binnenlandse zaken zijn toestemming tot naturalisatie verleende (art. 10). De vereisten voor de gewone naturalisatie waren opgesomd in art. 8 lid 1 van de wet van 1945 :

- leeftijd van 18 jaar of ouder en arbeidsgeschiktheid (sub 2);

- vijfjarig ononderbroken verblijf in Joegoslavië, waarvan in de regel 2 jaar binnen de deelstaat waarvan hij de nationaliteit wenste te verkrijgen ${ }^{121}$;

- verlies van de oude nationaliteit, althans bewijs, dat de verzoeker deze na de naturalisatie zou verliezen ${ }^{122}$;

- Op grond van het gedrag van de verzoeker moest kunnen worden geconcludeerd dat hij een loyale staatsburger zou zijn (sub 5).

Volgens art. 9 van de wet van 1945 waren de volgende categorieën vreemdelingen van bepaalde naturalisatievereisten vrijgesteld:

- personen, die etnisch tot de Zuidslavische volkeren behoorden ${ }^{123}$, konden worden genaturaliseerd zonder te hebben voldaan aan het vereiste van vijfjarig verblijf en van het verlies van de oude nationaliteit;

121. Zoals reeds werd opgemerkt, werd in de regel tevens de nationaliteit van de deelstaat van de woonplaats van de naturalisandus verkregen.

122. Dit naturalisatievereiste werd letterlijk overgenomen uit de wet van 1928.

123. In tegenstelling tot de wet van 1928 giing het hierbij om de volgende volkeren: Silovenen, Kroaten, Serviërs, Bosniërs en Herzegowiniërs, Montenegrijnen en Macedoniërs. 
- degenen, die met een Joegoslavische staatsburger (ongeacht het geslacht) waren gehuwd, werden bovendien vrijgesteld van het vereiste van minimumleeftijd ${ }^{124}$ en van arbeidsgeschiktheid (art. 9 lid 2).

Voorts kon een kind, jonger dan 14 jaar, dat door een Joegoslavische onderdaan werd geadopteerd, worden genaturaliseerd, zonder te hebben voldaan aan welk naturalisatievereiste dan ook (art. 9 lid 2).

Hiernaast konden bepaalde personen vanwege een staatsbelang worden genaturaliseerd. In een dergelijk geval moest betrokkene slechts voldoen aan de vereiste minimumleeftijd en arbeidsgeschiktheild (art. 11 lid 1). Een naturalisatie ex art. 11 kon uitsluitend door het federale Ministerie van binnenlandse zaken worden verleend (art. 11 lid 2) ${ }^{125}$.

\section{a. Invloed op de nationaliteit van de gezinsleden van de verzoeker}

Een minderjarig kind van een naturalisandus was slechts in de naturalisatie van zijn ouder(s) inbegrepen indien zijn beide ouders werden genaturaliseerd (art. 13 lid 1). Werd de naturalisatie slechts aan één van de ouders verleend, dan moest ten aanzien van medenaturalisatie van minderjarige kinderen tevens aan enkele additionele eisen worden voldaan (art. 13 lid 3):

- het kind moest tezamen met de betreffende ouder in Joegoslavië wonen;

- de ouder moest uitdrukkelijk om medenaturalisatie van het kind vragen;

- kinderen ouder dan 14 jaar moesten zelf in de naturalisatie toestemmen ${ }^{126}$.

\section{b. "Einbürgerungsansprüche"}

In art. 23 van de wet van 1945 werd een aparte mogelijkheid van hernaturalisatie geregeld. De verzoekers hadden een recht op verkrijging van de Joegoslavische nationaliteit. Het staatsburgerschap werd verleend door de federale Minister van binnenlandse zaken. De vereisten om voor deze "Einbürgerungsanspruch" in aanmerking te komen, waren de volgende:

de verzoeker moest vő́r zijn 18e levensjaar de Joegoslavische nationaliteit hebben verloren als gevolg van het verlies van dit staatsburgerschap door zijn

124. Hierbij dient te worden aangetekend dat de meerderjarigheidsgrens in heel Joegoslavië tot 18 jaar werd verlaagd en dat men door huwelijk niet meerderjarig werd.

125. De naturalisatie ex art. 11 was binnen de exclusieve competentie van de federatie, hoewel ook in een dergelijk geval tevens de nationaliteit van een wan de deelstaten werd verkregen. Dit was de deelstaat waar de naturalisandus woonplaats had en bij gebreke daarvan, de deelstaat waarin betrokkene werd geboren. Werd hij in het buitenland geboren (hetgeen doorgaans het geval was), dan verkreeg hij uitsluitend de federale nationaliteit. Dit was overigens de enige uitzondering op de regel, dat elke Joegoslavische staatsburger tevens de nationaliteit van een wan de deelstaten bezat.

126. Kinderen boven 14 jaar hadden slechts een medebeslissingsrecht indien de nationaliteit uitsluitend aan eén van hun ouders werd verleend. Zie ook art. 29 lid 2 van het vitvoeringsreglement. 
ouder(s). Deze moest(en) de Joegoslavische nationaliteit door afstand of ontslag hebben verloren; werd aan de ouder(s) de nationaliteit ontnomen, dan had het kind geen recht op naturalisatie;

- hij moest zich tussen zijn 18de en 25 ste levensjaar in Joegoslavië gaan vestigen en tevens voor zijn 25ste verjaardag het verzoek indienen.

De nationaliteit werd verkregen op het tijdstip van het indienen van het verzoek ${ }^{127}$.

\subsubsection{Verlies van de nationaliteit}

Volgens de wet van 1945 kon de Joegoslavische nationaliteit op de volgende wijzen worden verloren: door het afleggen van een verklaring van afstand, door ontslag en door ontneming. Verlies van het staatsburgerschap van rechtswege kende deze wet niet.

\subsection{Afstand}

De mogelijkheid om van de Joegoslavische nationaliteit afstand te doen was in de wet van 1945 zeer beperkt. Afstand van de nationaliteit was mogelijk indien (art. 22 lid 1$)^{128}$ :

- betrokkene zijn Joegoslavische nationaliteit door afstamming verkreeg;

- hij in het buitenland werd geboren en ook op het tijdstip van het afleggen van de afstandsverklaring in het buitenland woonde;

- betrokkene tussen 18 en 25 jaar oud was; en

- hij hetzij de nationaliteit van het land waarin hij werd geboren, hetzij van het land waarin hij woonde, bezat.

\section{a. Invloed op de nationaliteit van gezinsleden van betrokkene}

In het vierde lid van art. 22 werden de bepalingen van art. 21 betreffende het medeontslag van minderjarige kinderen van overeenkomstige toepassing verklaard op gevallen, waarin de ouder door afstand zijn Joegoslavische nationaliteit verloor Op de huwelijkspartner van betrokkene had afstand van de nationaliteit geen invloed.

\subsection{Ontslag}

Ontslag uit de Joegoslavische nationaliteit was geregeld in de artt. $19 \mathrm{t} / \mathrm{m} 21$ van de wet van 1945. De bevoegdheid om het ontslag te verlenen lag bij het Ministerie van binnenlandse zaken van de deelstaten, die besliste op voorafgaand bindend

128. Zie ook Krbek, p. 30 -31. 
advies van het federale Ministerie van binnenlandse zaken. Vereisten voor het ontslag waren de vollgende:

- leeftijd van 18 jaar of ouder (art. 19 lid 1 sub 2);

- vervulde verplichtingen tegenover de staat (art. 19 lid 1 sub 3);

- bewijs van bezit of van waarschijnlijke verkrijging van een andere nationaliteit (art. 19 lid 1 sub 4 );

- reeds vervulde militaire dienstplicht (vóór het verwullen van de militaire dienstplicht was ontslag slechts in uitzonderingsgevallen en met toestemming van de federale Minister van defensie mogelijk (art. 19 lid 4)).

Volgens het tweede lid van art. 19 kon het ontslag worden verleend onder de ontbindende voorwaarde dat de verzoeker binnen een bepaalde termijn een andere nationaliteit verkreeg. De ontslagbeschikking kwam bovendien in ieder geval automatisch te vervallen, indien betrokkene binnen én jaar noch een vreemde nationaliteit verwierf, noch uit Joegoslavië emigreerde (art 19 lid 3).

a. Invloed op de nationaliteit van de gezinsleden van de verzoeker

Ontslag uit de Joegoslavische nationaliteit had geen gevolgen voor de nationaliteit van de echtgeno(o)t(e) van betrokkene. Minderjarige kinderen werden slechts in het ontslag inbegrepen, indien hun beide ouders de Joegoslavische nationaliteit verloren of indien de andere ouder reeds vreemdeling was. Bovendien moesten kinderen van 14 jaar en ouder zelf met hun medeontslag instemmen. Het staatsburgerschap werd door de kinderen steeds verloren onder de voorwaarde dat ze met hun ouder(s) een andere nationaliteit verwierven of dat ze het land verlieten (art. 21 lid 2). Indien één van hun ouders de Joegoslavische nationaliteit behield, werden minderjarige kinderen nooit het ontslag van hun andere ouder deelachtig.

\subsection{Ontneming}

De regeling van ontneming van het staatsburgerschap werd in de wet van 1945 in vergelijking met zijn voorganger van 1928 aanzienlijk uitgebreid. De ontnemingsmogelijkheden kunnen worden onderverdeeld in ontneming als straf, die geregeld was in art. 16 en ontneming wegens langdurig verblijf in het buitenland, geregeld in art. 15. In alle gevallen kon de nationaliteit echter worden ontnomen ongeacht of betrokkene daardoor staatloos werd.

a. Ontneming als straf

De nationaliteit kon krachtens art. 16 worden ontnomen aan: 
- degenen die etnisch behoorden tot volkeren, die tussen 1941 en 1945 in oorlog met Joegoslavië waren ${ }^{129}$ en die vóór of tijdens de oorlog door hun "niet loyale handelingen de belangen van Joegoslavië hadden geschaad" (lid 1) ${ }^{130}$;

genaturaliseerde Joegoslavische staatsburgers, die deze nationaliteit door fraude verkregen, of die binnen 5 jaar na de naturalisatie bij een rechterlijk vonnis werden veroordeeld wegens een delict "tegen de belangen van de Joegoslavische volkeren of van de staat" (lid 2) ${ }^{131}$.

Voorts bestond de mogelijkheid van ontneming van de nationaliteit aan personen, die in het buitenland de "belangen van de Joegoslavische volkeren of van de FLRJ tijdens de tweede wereldoorlog of daarna hadden geschaad", of hun verplichtingen tegenover de staat miet hadden vervuld (art. 16 lid 3). Dit was een soort "generalklausel" zonder dat deze handelingen nader werden omschreven.

Daarnaast kende het wetboek van strafrecht tot 27 februari 1952 nog ontmeming van de nationaliteit als sanctie bij bepaalde delicten tegen de staat.

Ten aanzien van etnisch Duitse emigranten werd bij een wet d.d. 1 december $1948^{132}$ aan de overgangsbepaling van art. 35 een nieuw lid 2 toegevoegd. Daardoor werd aan alle etnisch Duitse Joegoslavische staatsburgers die zich in het buitenland bevonden en voor of tijdens de tweede wereldoorlog hun loyaliteitsverplichtingen tegenover Joegoslavië hadden geschonden, de nationaliteit ontnomen. Deze bepaling veroorzaakte in de praktijk grote moeilijkheden aangezien het niet voldoende duidelijk was of voor ontneming van de nationaliteit ex art. 35 lid 2 vereist was dat het verlies van de nationaliteit bij een individuele beschikking van de Joegoslavische administratie werd vastgesteld. Aan de onduidelijkheden werd een einde gemaakt bij art. 23 van de nationaliteitswet van 1964, waarin werd bepaald dat allen die voor 1 januari 1965 emigreerden en de nationaliteit van een land verwierven, tot welk(e) staatsvolk(eren) ze etnisch toebehoorden, het Joegoslavische staatsburgerschap met de dag van verwerving van die vreemde nationaliteit verloren.

Bij de wet van 14 oktober $1948^{133}$ werd vervolgens aan de nationaliteitswet een nieuw art. 35a toegevoegd, dat de mogelijkheid opende om elke naturalisatie te "herzien". Deze regeling was kennelijk bedoeld om door de breuk met de andere Oosteuropese landen politiek ongewenste naturalisaties te herroepen. Gronden voor herroeping waren niet in de wet geregeld.

129. Dat waren Duitsers, Oostenrijkers, Italianen, Hongaren en Bulgaren. Deze bepaling werd echter slechts zelden toegepast, aangezien er tem aanzien van de grootste groep, de "Volksduitsers", bij een wijzigingswet in 1948 een aparte regeling werd opgenomen. Jovanovic, p. 23-24.

130. Hieronder dienen ook te worden verstaan personem, die niet direct met de bezettingsmachten, maar met werschillende guerilla-groeperingen die tegen de partizanen vochten, samen hebben gewerkt.

131. De delicten die tot ontmeming van de nationaliteit ex art. 16 lid 2 konden leiden, waren noch in de wet, noch in het uitvoeringsreglement nader gespecificeerd.

132. Ur.1. FLRJ 105/1948. Zie daarover Bergmann/Ferid, p. 12.

133. Ur.1. FLRJ $88 / 48$. 


\section{i. Invloed op de nationaliteit van gezinsleden van betrokkene}

Ten aanzien van de invloed van ontneming van de nationaliteit op het staatsburgerschap van de gezinsleden van betrokkene, bevatte art. 18 lid 1 een opmerkelijke bepaling. Het verlies strekte zich mede uit over de echtgeno(o)t(e) van betrokkene en zijn kinderen, ongeacht hun leeftijd. De familieleden konden dit verlies voorkomen, indien zij zelf(!) konden bewijzen dat zij niets met de "niet-loyale" handelingen van huwelijkspartner, respectievelijk ouder te maken hadden gehad. Dit gold echter uitsluitend indien de nationaliteit op grond van het eerste lid art. 16 werd ontnomen.

Een ontneming van de nationaliteit aan een genaturaliseerde ex art. 16 lid 2 , strekte zich echter altijd automatisch over zijn minderjarige kinderen uit, terwijl de herroeping ex art. 35a naast de minderjarige kinderen ook de huwelijkspartner van betrokkene kon betreffen. Ontneming ex art. 16 lid 3 tenslotte, had in beginsel geen invloed op het staatsburgerschap van gezinsleden van betrokkene. Uiteraard kon aan hen de nationaliteit zelfstandig worden ontnomen.

\section{b. Ontneming wegens langdurig verblijf in het buitenland}

In art. 15 werd voorts voorzien in een mogelijkheid van ontneming van de nationaliteit die niet als straf kan worden gezien. De grond voor ontneming was langdurig verblijf in het buitenland ${ }^{134}$. Degenen die in het buitenland waren gevestigd en gedurende 15 jaar na het bereiken van achttienjarige leeftijd geen verplichtingen tegenover de staat hadden vervuld ${ }^{135}$, en bovendien verzuimd hadden zich bij een buitenlandse vertegenwoordiging van Joegoslavië of bij het federale Ministerie van binnenlandse zaken te laten registreren, verloren de Joegoslavische nationaliteit door een beschikking van het federale Ministerie van binnenlandse zaken (art. 15 lid 1 en 3). De onderhavige verliesbepaling werd gezien de ingewikkelde procedure slechts zeer zelden toegepast ${ }^{136}$.

\section{i. Invloed op de nationaliteit van gezinsleden van betrokkene}

Het verlies ex art. 15 lid 1 of 3 strekte zich tevens uit tot kinderen van betrokkene die in het buitenland waren geboren en gevestigd, indien ook zij de verplichtingen tegenover Joegoslavië niet hadden vervuld.

134. Een owereenkomstige regeling kende reeds $\$ 28$ van de wet van 1928 met het verschil dat volgens die regeling de nationaliteit wan rechtswege ging verloren.

135. Hierbij kan met name worden gedacht aan de militaire dienstplicht. Zie ook Krbek, p. 28 en het uitvoeringsreglement, art. 37, tweede lid.

136. Jovanowic, p. 32 . 


\subsubsection{Algemeen}

De wet van 1945 werd grondig gewijzigd bij de wet van 17 september $1964^{137}$. Deze federale wet werd gevolgd door nationaliteitswetten van alle afzonderlijke deelstaten ${ }^{138}$. Vervolgens werd de wet van 1964 na de grondwetsherziening van 1974 ondanks weinig ingrijpende veranderingen in zijn geheel vervangen door de wet van 24 december $1976^{139}$. Het is namelijk een bijzonderheid van Joegoslavië geworden dat men bij een omvangrijke grondwetsherziening een zeer groot gedeelte van de wetgeving vervangt. Ook indien de wijzigingen in een bepaalde wet marginaal zijn, wordt niet zelden een geheel "nieuwe" wet afgekondigd. Aangezien de huidige Joegoslavische nationaliteitswet, die op 8 januari 1977 in werking trad, voor wat betreft de verkrijgings- en verliesgronden niet of nauwelijks verschilt van die van $1964^{140}$, is het niet zinvol om hier een aparte bespreking van deze codificatie op te nemen. Ook de nummering van wetsartikelen komt in beide wetten bijna exact overeen ${ }^{141}$.

\subsubsection{De verhouding tussen de federale en de deelstaatnationaliteit}

In verschillende landen wordt ten aanzien van de verhouding tussen beide nationaliteiten voor diverse oplossingen gekozen, waarbij steeds een van beide als de primaire en de andere als de daarvan afgeleide wordt beschouwd. In Joegoslavië kan m.i. de nationaliteit van de federatie als de primaire worden gezien ${ }^{142}$. Bij een naturalisatie wordt in de eerste plaats de Joegoslavische nationaliteit ${ }^{143}$ verkregen en op grond daarvan in de regel tevens die van een van de deelstaten. Meestal is dat die, op welk grondgebied betrokkene woont. De beslissing omtrent naturalisatie, ontslag en ontneming van de federale nationaliteit, wordt sedert 1977 zelfstandig door het Ministerie van binnenlandse zaken van de deelstaten genomen ${ }^{144}$. Tussen 1965 en 1977 was de federale Minister bevoegd. Bovendien heeft het verlies van de federale nationaliteit automatisch het verlies van het

137. Ur.1. SFRJ 38/1964; in werking getreden op 1 januari 1965; Duitse vertaling: StAZ 1965, p. 168; WGO 1965, p. 92.

138. In Bosniê en Herzegowina de wet van 28 januari 1965, Sl. 1. $6 / 1965$; in Kroatië de wet van 27 maart 1965, Narodne novine 13/1965; in Macedonie de wet van 6 maart 1965, Slluzben vesnilk $9 / 1.965$; in Montenegro de wet van 10 maart 1965, S1.1. 6/1965; in Servie de wet wan 11 maart 1965, Sluzbeni glasnik $13 / 1965$ en in Slovenië de wet van 31 maart 1965 , Ur.l. 11/1965.

139. Ur.1. 58/1976; Nederlandse wertaling in NWG, p. 1-5; Duitse in Bergmann/Ferid p. 14a-20.

140. De wijzigingen van 1976 betroffen hoofdzakelijk de competentieverdeling in de nationaliteitsaangelegenheden tussen de deelstaten en de federatie. Zie ook Jowanovic, p. 32; \$turm, p. 11.

141. Zie woor een overzicht van de wijzigingen Jovanović, p. 49-57.

142. Anders echter Jovanović, p. 21-22; Sturm, p. 13-14, die voor de periode van na de grondwet van 1974 echter de deelstaatmationaliteit alls het uitgangspunt zien, terwijl Cok, Yugoslaw Law 1977 , p. 26 in het voetspoor van Blagojevic, 1974, p. 25, geen van beide als primair wil typeren.

143. Zeer duidelijk blijkt dit uit art. 10 van de federale nationaliteitswet in de versie van 1976: in thet verzoek tor verlening wan de nationaliteit van de SFRJ dient de verzoeker ook aan te geven welke delstaatnationaliteit hij wenst te verwerven.

144. Sturm, p. 14. 
deelstaat-staatsburgerschap tot gevolg. Het is namelijk niet mogelijk om uitsluitend de nationaliteit van een deelstaat te bezitten.

Zoals gezegd kent Joegoslavië naast de federale wet tevens zes nationaliteitswetten van de verschillende deelstaten ${ }^{145}$. Al deze wetten bevatten overigens een nagenoeg identieke regeling van verkrijging en verlies van de nationaliteit van de verschillende deelstaten, respectievelijk van de federatie. Een uitputtende regeling van deze onderwerpen wordt overigens reeds door de federale wetgever gegeven. Voorts werden in de federale nationaliteitswet in art. 22 verschillende collisieregels opgenomen, om conflictsituaties tussen de deelstaatwetgevingen te kunnen oplossen.

Ook art. 249 van de federale grondwet heeft betrekking op de nationaliteit. Naast enkele bepalingen van zuiver declaratoir karakter, is de bepaling van het derde lid interessant. Volgens dit voorschrift hebben staatsburgers van een deelstaat op het grondgebied van een andere deelstaat precies dezelfde rechten en verplichtingen als personen die wel de nationaliteit van die andere deelstaat bezitten. Met andere woorden: elk onderscheid tussen Joegoslavische onderdanen onderling op grond van hun deelstaatnationaliteit is grondwettelijk verboden. In dit verband rijst de vraag welke belangen in Joegoslavië met het in het leven roepen van het instituut van de deelstaatnationaliteit worden gediend. De nationaliteit als rechtsfiguur bestaat namelijk juist om onderscheid te (kunnen) maken tussen personen die zich op het grondgebied van een entiteit bevinden en "vreemdelingen" zijn en degenen, die daarentegen wel als onderdaan van die entiteit worden beschouwd. Aangezien in Joegoslavië een aantal privaatrechtelijke rechtsgebieden per deelstaat verschillend worden geregeld ${ }^{145}$, zou de nationaliteit als aanknopingspunt in het interregionale collisierecht kunnen dienen. Dit blijkt echter nauwelijks het geval te zijn. De wet betreffende het interregionale collisierecht op het gebied van het personeel statuut, en het familie- en erfrecht van 27 februari $1979^{147}$ knoopt namelijk in de eerste plaats bij het domicilie aan. Het lex patriae wordt slechts subsidiair gehanteerd indien betrokkene buiten Joegoslavië zijn woonplaats heeft ${ }^{148}$.

Wel zou het instituut van de nationaliteit van de deelstaten worden gezien als een manifestatie van het nationale bewustzijn, dat bij de Joegoslavische volkeren bijzonder sterk leeft. Ook in dit verband is het belang van de deelstaatnationaliteit echter gering. Joegoslavië kent namelijk evenals de USSR de etnische nationaliteit, die niet steeds met het staatsburgerschap van de deelstaten overeenkomt, als een juridische categorie. Het nationale bewustzijn manifesteert zich dan ook voornamelijk door de etnische nationaliteit. Zeer veel Joegoslavische onderdanen zijn van hun juridische deelstaatnationaliteit niet eens op de hoogte.

145. De nationaliteitswetten van sommige deelstaten kwamen zelfs wóor de federale nationaliteitswet tot stand. In Bosnie en Herzegowina de wet van 7 april 1977, SI.1. 10/1977; in Kroatie de wet van 1 augustus 1977, Narodne novine 32/1977; in Macedonië de wet van 27 april 1977, Sluzben vesnik 19/1977; in Montenegro de wet van 4 juni 1975, SI.I. 26/1975; in Servië de wet van 15 oktober 1979, Sluzbeni Glasnik 45/1979, gewijzigd bij de wet van 31 maart 1983, Sluzbeni Glasnik 13/1983 en in Slovenie de wet van 29 september 1976 , Ur..1. $23 / 76$.

146. Het personen- en familierecht, het erfrecht, een gedeelte van het vermogensrecht en het arbeidsrecht. Gudde, p. 10, Tratnilk, WPNR 5708 (1984), p. 510.

147. Ur.l. SFRJ $9 / 1979$.

148. Zie Tratnik, p. 429 . 


\section{2 .2 Verkrijging wan de nationaliteit}

De Joegoslavische nationaliteit wordt volgens de wet van 1964 verkregen van rechtswege en door naturalisatie.

\section{2 .1 Verkrijging van rechtswege}

De huidige Joegoslavische nationaliteitswet heeft het ius sanguinis a patre et a matre bij de verkrijging van de nationaliteit van rechtswege als uitgangspunt gehandhaafd. Het ius soli fungeert slechts als een subsidiair beginsel ten aanzien van vondelingen en kinderen van personen wier nationaliteit onbekend is, om staatloosheid van het kind te voorkomen.

\subsection{Geboorte uit Joegoslavische ouder(s)}

Bij de regeling van verkrijging van de nationaliteit üure sanguinis werd de Joegoslavische wetgever geleid door twee uitgangspunten: In de eerste plaats moest de nationaliteit van het kind op gelijke voet kunnen worden afgeleid van zowel de vader, als van de moeder. In de tweede plaats moest bij kinderen, die van nationaliteitsrechtelijk gemengde ouders afstammen, zoveel mogelijk worden voorkomen dat het kind bipatride zou worden. Beide uitgangspunten hebben geleid tot de oplossing in artt. 4 en 5 van de wet van 1964.

Een kind, wiens beide ouders ten tijde van de geboorte van het kind de Joegoslavische nationaliteit bezitten, verwerft het Joegoslavische staatsburgerschap, ongeacht of het binnen, dan wel buiten de grenzen van de SFRJ werd geboren (art. 4 sub 1). Een onwettig kind wordt geacht kind van een Joegoslavische vader te zijn, indien het door een SFRJ-onderdaan wordt erkend, of het vaderschap gerechtelijk wordt vastgesteld ${ }^{149}$.

In het geval dat slechts éen van de ouders het staatsburgerschap van de SFRJ bezit, verkrijgt het kind de Joegoslavische nationaliteit indien:

- het in Joegoslavië wordt geboren (art. 4 sub 2);

- het in het buitenland wordt geboren en de andere ouder staatloos is (art. 4 sub 3$)^{150}$;

- het in het buitenland wordt geboren en het voor zijn 18de levensjaar bij een Joegoslavische vertegenwoordiging in het buitenland, of bij het bevoegde orgaan in Joegoslavië wordt geregistreerd (art. 5 lid 1);

- het in het buitenland wordt geboren en zich voor zijn 18de jaar in Joegoslavië vestigt (art. 5 lid 1);

149. Zie over erkenaing, respectievelijk gerechtelijke vaststelling van vaderschap Bakik, p. 264-270, respectievelijk 270-281 en Gec-Korosec, p. 33-35, 61-64, respectievelijk 35-37, 65-68. Zie ook Sturm, p. 23.

150. Jovanovie, p. 34, Cok, Yugoslav Law 1977, p. 29. 
- het in het buitenland wordt geboren en het anders staatloos zou zijn (art. 5 lid 2).

Een kind dat krachtens de bepalingen wan art. 5 lid 1 of 2 de Joegoslavische nationaliteit heeft verkregen, wordt geacht deze sedert de geboorte te bezitten (art. 5 lid 3).

\subsection{Geboorte op het Joegoslavische grondgebied en vondelingen}

Zoals reeds eerder werd opgemerkt, kan iure soli de Joegoslavische nationaliteit slechts in uitzonderingsgevallen worden verkregen. De strekking van deze regeling is, staatloosheid van een in de SFRJ geboren of gevonden kind te voorkomen 15 . Kinderen van ouders zonder, dan wel van onbekende nationaliteit die in Joegoslavië worden geboren of gevonden, worden vermoed de nationaliteit van de SFRJ te bezitten. Indien tot de $14 \mathrm{e}$ verjaardag van het kind vastgesteld wordt dat beide ouders ${ }^{152}$ van het kind een vreemde nationaliteit bezitten, gaat de Joegoslavische nationaliteit alsnog verloren. Is het kind op het tijdstip van de vaststelling van de nationaliteit van zijn ouders reeds ouder, dan behoudt het de Joegoslavische nationaliteit (art. 6). Sturm ${ }^{153}$ spreekt in dit verband om een verkrijging van de nationaliteit iure soli in combinatie met het "ius educationis".

Het geval dat vóor het $14 \mathrm{e}$ levensjaar van het kind weliswaar de vreemde nationaliteit van zijn ouders wordt vastgesteld, maar dat het kind aan hen geen nationaliteit kan ontlenen ${ }^{154}$, wordt niet expliciet geregeld. Met het oog op de ratio van art. 6 moet naar mijn mening worden aangenomen, dat in een dergelijk geval het kind de Joegoslavische nationaliteit niet verliest, omdat het anders staatloos zou worden.

\subsubsection{Naturalisatie}

Verkrijging van de Joegoslavische nationaliteit door maturalisatie wordt geregeld in de artt. $7 \mathrm{t} / \mathrm{m} 12$ van de wet van 1964. Naast de gewone naturalisatie kent de wet ten behoeve van bepaalde categorieën verzoekers de zogenaamde Einbürgerungsansprüche". In deze gevallen heeft de verzoeker een recht op naturalisatie. De bewoegdheid om over een naturalisatieverzoek te beslissen, wordt thans gelegd bij de Ministeries van binnenlandse zaken van de deelstaten. Tussen 1964 en 1977 was echter het federale Ministerie van binnenlandse zaken bevoegd.

Het is gebruikelijk, dat aan een naturalisandus naast de Joegoslavische nationaliteit ook het staatsburgerschap van de deelstaat waarin hij woont, wordt verleend. Een in het buitenland woonachtige persoon die in Joegoslavië wordt genaturaliseerd, verkrijgt de nationaliteit van een van de deelstaten in de regel pas na vestiging in de SFRJ.

In het eerste lid van art. 7 worden de volgende naturalisatievereisten gesteld:

151. Zie ook Sturm, p. 24; Jowanovic, p. 34; Cok, Yugoslav Law 1977, p. 30.

152. Cf. Cok, Yugoslav Law 1977, p. 31.

153. Sturm, p. 24.

154. Hierbij kan worden gedacht aan gevallen waarin de nationale wet(ten) van de ouders het ius soli beginsel huldig(en)t. 
- een verzoeker die zijn vorige nationaliteit niet van rechtswege door naturalisatie in Joegoslavië verliest, moet "ontslag" 156 uit zijn vorige nationaliteit hebben gekregen, althans kunnen aantonen dat hij na de totstandkoming van de naturalisatie het ontslag zal krijgen (lid 1 sub 2 en lid 2). Indien de nationale wetgeving van de naturalisandus geen mogelijkheid van afstand of ontslag kent, of hiervoor onmogelijk te vervullen voorwaarden stelt, is het voldoende, dat betrokkene verklaart zijn nationaliteit in geval van naturalisatie te willen "opgeven" (lid 3). Door een dergelijke verklaring wordt de andere nationaliteit uiteraard niet verloren, hetgeen de door Joegoslavië ongewenste ${ }^{157}$ meervoudilge nationaliteit van de naturalisandus tot gevolg heeft.

- woonplaats in Joegoslavië gedurende drie jaren onmiddellijk voorafgaande aan het verzoek (lid 1 sub 3 );

- uit het gedrag van betrokkene moet kunnen worden afgeleid dat hij een loyale staatsburger zal zijn (lid 1 sub 4 ).

De wetgever heeft aan drie categorieën verzoekers in art. 8 vrijstelling van bepaalde naturalisatievereisten verleend. In alle gevallen worden betrokkenen gedispenseerd van de eis van het verlies van de oude nationaliteit en van het verblijfsvereiste. Het gaat om de volgende groepen personen:

- Joegoslavische emigranten en hun familieleden worden vrijgesteld van de eis van verlies van de oude nationaliteit en van het verblijfsvereiste (art. 8 lid 1);

- een vreemdeling(e), die met een Joegoslavische onderda(a)n(e) is gehuwd, moet slechts voldoen aan het vereiste van goed gedrag ( $\operatorname{art.} 7$ sub 4);

- een minderjarige die door een Joegoslavische onderdaan wordt geadopteerd, kan worden genaturaliseerd zonder te hebben voldaan aan de vereisten van art. 7. Het naturalisatieverzoek dient te worden ingesteld door de adoptiefouder, terwijl bij een kind van 14 jaar of ouder tevens zijn toestemming wordt vereist.

Onder de categorie "Joegoslavische emigranten" vallen niet slechts personen die ooit in het bezit van de juridische Joegoslavische nationaliteit zijn geweest, doch allen, die etnisch tot éen van de Joegoslavische volkeren behoren ${ }^{158}$. Aangezien in de tijd rond de eeuwwisseling (dus voor het ontstaan van Joegoslavië) een belangrijke emigratiestroom naar de Verenigde Staten plaatsvond, is dat een aanzienlijke

155. Dit geldt ook ten aanzien van naturalisandi, die vóor han $18 d e$ verjaardag in het huwelijk zijn getreden.

156. Het gebruik van de term "odpust" = ontslag bij het onderhavige naturalisatievereiste is inmiddels reeds een traditionele slordigheid van de Joegoslavische wetgever geworden. Bij naturalisandi, wier nationale wetgeving (ook) de mogelijkheid van afstand kent, is zulks uiteraard voldoende.

157. Zie voor een nitvoerig betoog over de nadelen van bipatridie Jovanović, JRMP 1984/1-3, p. 7794.

158. Jovanovic, p. 36,48 . 
verruiming. Ten aanzien van "familieleden" is noch in de wet, noch in de doctrine uitsluitsel te vinden. In ieder geval moeten de huwelijkspartner en de (klein)kinderen van de desbetreffende emigrant bedoeld zijn. Gezien de sterkte van familiebanden in grote delen van Joegoslavië is het zeer wel mogelijk dat de wetgever een ruimere kring personen in gedachten heeft gehad.

Evenals de zojuist genoemde Joegoslavische emigranten, moeten ook personen, bij wier naturalisatie een staatsbelang wordt gediend, slechts voldoen aan het vereiste van de minimumleeftijd (art. 7 sub 1) en van goed gedrag (art. 7 sub 4). Volgens Jovanovic ${ }^{159} \mathrm{kan}$ hier worden gedacht aan vooraanstaande wetenschappers, kunstenaars, politici en "grote vrienden" van Joegoslavië.

Evenals alle andere Joegoslavische nationaliteitswetten $(1928,1945)$ beschouwt ook de positieve nationaliteitswetgeving van de SFRJ de naturalisatie als een gunst, en staat de beslissing daaromtrent geheel ter discretie van het beoordelende orgaan ${ }^{160}$. Volgens art. 180 lid 2 van de federale grondwet bestaat in Joegoslavië in beginsel weliswaar de mogelijkheid om tegen elke beschikking een rechtsmiddel in te stellen, maar door de discretionaire bevoegdheid van de administratie is de mogelijkheid van beroep echter uiterst miniem ${ }^{161}$. Sedert de wijziging van 1976 bepaalt de wet ook uitdrukkelijk dat er geen verplichting bestaat om een afwijzende beschikking te motiveren (art. 7 lid 4). Het beslissende orgaan wordt slechts in de negatieve zin gebonden; geen naturalisatie mag worden verleend, indien aan de wettelijke vereisten niet wordt voldaan.

\subsection{Inwloed op de nationaliteit van de gezinsleden van de verzoeker}

Naturalisatie van beide ouders in Joegoslavië heeft ipso iure werking ten aanzien van hun kinderen die jonger zijn dan 14 jaar (art. 11 lid 1). Indien echter slechts én van de ouders wordt genaturaliseerd, wordt tevens geëist dat het kind in Joegoslavië woont en dat de genaturaliseerde ouder uitdrukkelijk om medenaturalisatie verzoekt ( $a r t .11 \mathrm{lid} 2$ ). Indien echter beide ouders om medenaturalisatie van het kind verzoeken, is de woonplaats niet van belang (art. 11 lid 3). Bij kinderen, die 14 jaar of ouder zijn, wordt voor hun medenaturalisatie steeds hun eigen toestemming vereist (art. 11 lid 4).

\subsubsection{2 "Einbürgerungsansprüche"}

In hoofdstuk III van de wet van 1964, getiteld "Beëindiging van de nationaliteit van de SFRJ" vinden we in art. 20 een aparte mogelijkheid van hernaturalisatie, waarbij de verzoekers een recht op verlening van de Joegoslavische nationaliteit hebben.

159. Jovanowit, p. 36 .

160. Cok p. 31; Jovanovic, p. 35.

161. Beroep zou mogelijk zijn wegens bevoegdheidsgebreken of onjuiste toepassing van de wet. Belangrijlk is in dit werband art. 10 lid 2 van de wet betreffende bestuursgeschillen van 24 december 1976, Ur.l. SFRJ 4/1977: "Es liegt keine unrichtige Anwendung der Vorschriften vor, wenn der zuständige Organ im freien Ermessen auf Grund und innerhalb der Grenzen der Ermächtigung die ihm durch Rechtsworschriften erteilt sind, entschieden hat". Vertalling van Lipowschek in Bergmann/Ferid, p. 10. Door Androjna, p. 46-47, wordt voorts ook gesteld, dat de omstreden beschikking niet op doelmatigheid mag worden getoetst. 
De vereisten om voor "Einbürgerungsansprüche" in aanmerking te komen, zjjin de volgende:

- de verzoeker moet vóór zijn $18 \mathrm{e}$ levensjaar de Joegoslavische nationaliteit hebben verloren als gevolg van het verlies van dit staatsburgerschap door zijn ouder(s). Deze moet(en) de Joegoslavische nationaliteit door afstand of ontslag hebben verloren; werd aan de ouder(s) de nationaliteit ontnomen, dan heeft het kind geen recht op naturalisatie;

- hij moet zich tussen zijn 18de en 25ste levensjaar in Joegoslavië komen vestigen en tevens vóór zijn 25 ste verjaardag het verzoek indienen.

De nationaliteit wordt verkregen op het tijdstip van het indienen van het verzoek ${ }^{162}$.

\subsubsection{Verlies van de nationaliteit}

De huidige Joegoslavische nationaliteitswet kent de volgende wijzen van verlies van de nationaliteit: afstand, ontslag en ontneming.

\subsubsection{Afstand}

Afstand van de Joegoslavische nationaliteit is slechts voor twee categorieën personen mogelijk. In beide gevallen wordt vereist, dat betrokkene tevens een andere nationaliteit bezit en in het buitenland woont. Degenen, die tevens buiten de SFRJ werden geboren en tussen 18 en 25 jaar oud zijn, kunnen altijd afstand van hun Joegoslavische nationaliteit doen (art. 17 lid 1). Na het bereiken van de 25-jarige leeftijd moeten zij echter, evenals personen die in Joegoslavië werden geboren, tevens aan een aantal additionele vereisten voldoen, die ongeveer met die voor ontslag overeenkomen:

- meerderjarigheid (18 jaar); dit geldt uiteraard alleen voor in de SFRJ geborenen (art. 17 lid 2 aanhef);

- tegen betrokkene mag geen strafprocedure aanhangig zijn, of een nog niet ten uitvoer gelegde vrijheidsstraf zijn uitgesproken (art. 17 lid 2 sub 1);

- eventuele alimentatieverplichtingen moeten zijn geregeld (sub 2);

- betrokkene moet zijn publiekrechtelijke verplichtingen hebben nagekomen (sub 3).

Een afstandsverklaring wordt afgelegd ten overstaan van de bevoegde instantie ${ }^{163}$ binnen of buiten Joegoslavië die deze verklaring moet accepteren (art. 17 lid 3).

162. Jovanovic, p. 41; Sturm, p. 36.

163. Dat zijn de diplomatieke of consulaire vertegenwoordigingen van Joegoslavie in het buitenland en de Ministeries van binnenlandse zaken van de deelstaten. 
Deze acceptatie heeft evenwel een zuiver declaratoir karakter ${ }^{164}$. De nationaliteit gaat verloren op het moment waarop de verklaring wordt afgelegd.

\subsubsection{I Invloed op de nationaliteit van gezinsleden van betrokkene}

Het verlies van de Joegoslavische nationaliteit door afstand strekt zich mede uit over de kinderen van betrokkene die jonger zijn dan 14 jaar indien de ouders dit eisen. Dit geldt evenwel slechts indien beide ouders afstand doen of een van hen toch al vreemdeling is (art. 18). In gevallen waarin de andere ouder SFRJonderdaan blijft, behoudt het kind de Joegoslavische nationaliteit. Een kind dat 14 jaar is of ouder, dient zelf met het verlies van de nationaliteit in te stemmen.

\subsubsection{Ontslag}

Het verlies van de nationaliteit door ontslag wordt na de wijzigingen van $1976^{165}$ geregeld in de artt. 14-16 van de Joegoslavische nationaliteitswet. Het ontslag wordt verleend door de Ministeries van binnenlandse zaken van elk der deelstaten. In het eerste lid van art. 14 worden de volgende vereisten voor het ontslag uit de Joegoslavische nationaliteit gesteld:

- leeftijd van 18 jaar of ouder (sub 1);

- geen beletselen met betrekking tot de militaire dienstplicht van betrokkene (sub 2). Nadere regels hieromtrent worden gegeven bij beschikking(en) van de federale Minister van defensie. In de regel wordt geen ontslag verleend, indien betrokkene zijn militaire dienstplicht nog niet heeft vervuld ${ }^{166}$;

- de verzoeker moet aan alle financiële verplichtingen ten aanzien van publiekrechtelijke organen en organisaties hebben voldaan (sub 3);

- de vermogensrechtelijke verplichtingen ten aanzien van eventuele (ex) (huwelijks)partner ${ }^{167}$, kinderen ${ }^{168}$, en/of ouders van betrokkene moeten zijn geregeld (sub 4);

164. Sturm, p. 33. Zie bijvoorbeeld art. 21 lid 4 van de nationaliteitswet van Slovenië, waarin wordt bepaald dat door het bevoegde orgaan "vastgesteld wordt dat de nationaliteit werd verloren".

165. Tussen 1964 en 1976 werd materieel dezelfde regeling neergelegd in de artt. 13-15 m

166. Jovanovic, p. 37-38. Regels daaromtrent werden gegeven in een aparte verordening, gepubliceerd in Ur.I. SFRJ 51/1965.

167. In een aantal Joegoslavische deelstaten bestaat ook alimentatieplicht tussen ex-concubinaatspartners. Hierover Tratnik, WPNR 5708 (1984), p. 510-511.

168. Zie bijvoorbeeld de beslissing van het Servische Opperste gerechtshof van 12 maart 1983, U br. 1627/83, Pravni Zivot 1984 (bijlage), p. 133 (vermeld ook in WGO 1986, p. 176-177) waarin een weigering van ontslag wegens onderhoudsplicht ten aanzien van studerende meerderjarige kinderen toelaatbaar werd geacht. 
- tegen de verzoeker mag geen strafprocedure wegens niet-klachtdelict(en) ${ }^{169}$ aanhangig zijn, en hij moet eventuele vrijheidsstraffen hebben uitgezeten (sub $5)$;

de verzoeker moet kunnen aantonen dat hij reeds een andere nationaliteit bezit, respectievelijk zal verkrijgen (sub 6).

Een ontslagbeschikking vervalt, indien betrokkene binnen 1 jaar na de dagtekening van het besluit geen vreemde nationaliteit verwerft en hij in Joegoslavië blijft wonen (art. 15 lid 1) ${ }^{170}$. Verlaat hij binnen die termijn de SFRJ zonder een vreemde nationaliteit te bezitten, respectievelijk te verwerven dan wordt hij staatloos ${ }^{171}$. Deze staatloosheid kan echter worden voorkomen indien betrokkene binnen 1 jaar na het verlaten van Joegoslavië geen vreemde nationaliteit heeft verkregen en binnen drie maanden daarna hiervan mededeling doet aan het bevoegde orgaan binnen of buiten de SFRJ (art. 15 lid 2).

Net als bij het spiegelbeeld van het ontslag, de naturalisatie, bestaat ook hier voor het bevoegde orgaan geen plicht om het ontslag te verlenen, al heeft betrokkene aan alle wetteiijke vereisten voldaan ${ }^{17}$. Het is echter wel zo, dat de discretionaire bevoegdheid van de administratie hier iets kleiner is. Indien aan alle vereisten wordt voldaan, kan ontslag uitsluitend worden geweigerd op gronden van staatsveiligheid, bijzondere belangen van de staat, of vanwege de (slechte) betrekkingen met het land, waarvan betrokkene de nationaliteit bezit of wenst te verkrijgen. Alleen in deze gevallen bestaat geen plicht om de weigering te motiveren (art. 14 lid 4). Op grond hiervan kan worden geconcludeerd, dat er een zeker recht op ontslag bestaat, hoewel dit gezien de vaagheid van de weigeringsmogelijkheid op gronden van belangen van de staat in bepaalde gevallen illusoir kan blijken te zijn. Beroep tegen een beschikking is theoretisch mogelijk, hoewel de kans op succes evenals bij weigering van een naturalisatie zeer klein is ${ }^{173}$.

Met betrekking tot de mogelijkheden om het land te verlaten kan worden geconstateerd dat in Joegoslavië een zeker "recht" op een paspoort bestaat. De paspoortwet ${ }^{174}$ biedt evenwel voldoende ruimte om naast exact geformuleerde gronden ook op grond van de staatsveiligheid of de belangen van de defensie (art. 43 lid 5) negatief te beschikken en op deze wijze een dergelijk recht illusoir te maken. Bij deze weigeringsgronden bestaat ook geen verplichting de beschikking te motiveren (lid 6), waardoor de mogelijkheid van beroep de facto wordt ontzegd ${ }^{175}$. In de praktijk wordt de paspoortwetgeving evenwel in de regel zeer

169. Een "wervolging" wegens een overtreding is in Joegoslaviez geen strafwervolging maar wordt administratiefrechtelijk wordt afgehandeld. 'Tratnik, p. 424.

170. Zie ook de beslissing van het Federale gerechtshof van 31 juli 1979 ZSO (zbirka sodnih odloxb) 1979 , p. 281.

171. Sturm, p. 31.

172. Jovanovie, p. 37; Sturm, p. 30.

173. Zie p. 222 in het bijzonder noot 161 .

174. Wet van 29 juni 1979, Ur.I. SFRJ 30/1979. Zie daarover Kuss, EuGRZ 1987, p. 309-310.

175. Zie in dit verband twee "politieke" beslissingen van het federale constitutionele gerechtshof met betrekking tot de grondwettigheid van art. 43 paspoortwet: U-il-170/79 van 4 juli $1979 \mathrm{en} \mathrm{nr}$. UI-59/80 van 3 juli 1980. 
liberaal toegepast. Enkel de dissidenten worden vrij regelmatig met de vage weigeringsmogelijkheden gechicaneerd ${ }^{176}$.

\subsection{Invloed op de nationaliteit van de gezinsleden van de verzoeker}

Ten aanzien van minderjarige kinderen van personen, die de Joegoslavische nationaliteit door ontslag verliezen, geldt mutatis mutandis dezeifde regeling als in gevallen waarin de nationaliteit van de ouder(s) door afstand gaat verloren gaat (art. 18).

Voorts kent art. 16 lid 2 een mogelijkheid van zelfstandig ontslag ten behoeve van een in het buitenland woonachtig kind, waarvan één van de ouders de Joegoslavische en de andere een vreemde nationaliteit bezit. In dit geval $\operatorname{kan}^{177}$ bij wijze van uitzondering het ontslag worden verleend, indien het kind aan de vreemde ouder wordt toegewezen en de andere (dus de Joegoslavische) ouder hierin toestemt.

\subsubsection{Ontneming}

In het tweede lid van art. 200 van de federale grondwet staat naast het verbod van uitlevering en uitzetting van de SFRJ-staatsburgers tevens het verbod van ontneming van de nationaliteit. In het derde lid echter, worden twee gevallen genoemd, waarin de ontneming bij wijze van uitzondering mogelijk is. In beide situaties moet betrokkene in het buitenland woonachtig zijn en tevens een andere nationaliteit bezitten. Tot 1964 was het in alle gevallen mogelijk om de nationaliteit te ontnemen, óók indien betrokkene daardoor staatloos werd. In de periode 19641977 kende de wet twee groepen ontnemingsgronden. Bij de eerste groep (art.19oud) kon de nationaliteit slechts worden ontnomen indien betrokkene daardoor niet staatloos werd, terwijl bij de tweede groep (art. 18oud) ontneming steeds mogelijk was. Bij de wijzigingswet van 1977 werd de ontnemingsmogelijkheid vervolgens voor alle gevallen beperkt tot personen, die tevens een andere nationaliteit bezitten.

De Joegoslavische nationaliteit kan worden ontnomen wegens "activiteiten in het buitenland, waardoor internationale of andere belangen van Joegoslavië worden geschaad" (art. 19 lid 1). Deze vage norm wordt in het tweede lid van art. 19 aangevuld door een lijst van voorbeelden van dergelijke activiteiten:

- lidmaatschap van organisaties, wier activiteiten tegen de Joegoslavische grondwettelijke orde zijn gericht (sub 1);

- het verlenen van diensten aan vreemde staten, ondanks een uitdrukkelijk verbod van het bevoegde Joegoslavische orgaan (sub 2);

176. Aan de bekendste Joegoslavische dissident Milovan Djilas bijvoorbeeld, werd 14 jaar geen paspoort witgereikt.

177. Terwijl aan meerderjarigen het ontslag wordt verleend indien aan de wettelijke vereisten wordt voldaan, is ten aanzien van minderjarigen de discretionaire bevoegdheid weer onbegrensd. Zie ook Jowanovic, p. 54. 
- gedrag in het buitenland, waardoor belangrijke Joegoslavische belangen worden geschaad (sub 3);

- $\quad$ een op een andere ondubbelzinnige wijze geopenbaarde weigering van trouw aan Joegoslavië (sub 4).

Daarnaast is ontneming van de Joegoslavische nationaliteit ook mogelijk wegens "het niet willen vervullen van plichten van een Joegoslavische staatsburger" (art. 19 lid 1). Ook in dit geval bevat de wet naast deze "Generalklausel" een aantal voorbeelden van dergelijk gedrag:

- het geen gevolg geven aan beslissingen van rechterlijke of bestuursorganen in Joegoslavië, of weigering om hun jurisdictie te aanvaarden (lid 3 sub 1);

- $\quad$ een expliciete weigering ${ }^{178}$ om (grond)wettelijk voorgeschreven verplichtingen te vervullen (sub 2);

- activiteit in organisaties, wier doelstellingen in strijd zijn met de algemene beginselen van de Handvest van de Verenigde Naties en van de Universele verklaring van de rechten van de mens.

Alle ontnemingsgronden dienen in het licht van het uitzonderingskarakter van deze "sanctie" restrictief te worden geïnterpreteerd. Er bestaat de mogelijkheid om tegen een eventuele ontneming beroep in te stellen, doch gezien het feit dat het beslissende orgaan discretionaire bevoegdheid heeft en niet verplicht is zijn beschikking te motiveren, is de mogelijkheid van rechterlijke controle uiterst beperkt ${ }^{179}$.

Anders dan in vele andere Oosteuropese landen wordt ontneming in Joegoslavië nauwelijks nog beschouwd als een politiek wapen tegen te kritische dissidenten. Dit rechtsinstituut wordt nog hoogst zelden toegepast ${ }^{180}$. Dissidenten worden wel strafrechtelijk vervolgd ${ }^{181}$ en wordt hen dikwijls publicatieverbod opgelegd en/of het paspoort tijdelijk ontnomen. Bovendien moet hier worden aangetekend dat Joegoslavische staatsburgers in beginsel vrij zijn om het land te verlaten en dat een illegale grensoverschrijding niet zoals bijvoorbeeld in Tsjechoslowakije en de DDR als landverraad wordt gezien, maar slechts als een lichte administratieve overtreding, die met een geldboete kan worden afgedaan.

Zoals we zien, kent de huidige Joegoslavische nationaliteitswetgeving sedert 1965 geen ontneming van het staatsburgerschap wegens langdurig verblijf in het buitenland meer. In dit verband zij gewezen op de overgangsregel van art. 23 van de wet van 1964. Volgens deze bepaling verloor op 1 januari $1965^{182}$ iedereen, die zich tot dat tijdstip blijvend in het buitenland vestigde en tevens de nationaliteit van

178. Door een verklaring of een gedraging. Zie Jovanović, p. 40.

179. Zie p. 222 , in bet bijzonder noot 161.
180. Zie voor een recent voorbeeld NRC-Handelsblad vam 17 januari 1989 , waarin melding werd gemaakt van ontmeming van de nationaliteit aan de Bosnische dissident Mihajlo Mihajlov.

181. In de regel op grond wan art. $133 \mathrm{van}$ het federale wetbok van strafrecht: "vijandelijke propaganda'. Zie Tratnik, p. 433.

182. Datum van inwerkingtreding van de wet van 1964 . 
het land tot welk volk(eren) hij etnisch toebehoorde bezat, de Joegoslavische nationaliteit. Deze regeling gold, tenzij bij een internationaal verdrag anders werd bepaald ${ }^{183}$.

Herroeping van een naturalisatie is volgens de huidige Joegoslavische nationaliteitswet niet meer mogelijk.

\subsection{Invloed op de nationaliteit van gezinsleden van betrokkene}

Ontneming van de nationaliteit kan geen invloed op de nationaliteit van de gezinsleden van betrokkene hebben.

183. Jovanovic, p. 44. 


\section{HOOFDSTUK 8. POLEN}

\subsection{GeschiedenNS}

\subsubsection{Inleidung}

Het Koninkrijk Polen omvatte in de 18 de eeuw een veel groter grondgebied dan de huidige Poolse staat. Dit gebied werd in de jaren 1772,1793 en 1795 verschillende malen verdeeld tussen het Koninkrijk Pruisen en het Oostenrijkse en het Russische keizerrijk ${ }^{2}$. Terwijl bij de eerste twee verdelingen het Poolse koninkrijk afstand van bepaalde gebieden moest doen, verdween Polen na de derde verdeling geheel van de kaart van Europa. In 1807 richtte vervolgens Napoleon op het grondgebied dat door Frankrijk werd bezet een nieuwe Poolse staat met een eigen regering onder de naam hertogdom Warschau op ${ }^{2}$. Bij het vredesverdrag van Wenen van 14 oktober 1809 werd het hertogdom uitgebreid met de Oostenrijkse gebieden van het voormalige koninkrijk Polen ${ }^{3}$. Bij de slotakte van het Weense congres van 9 juni 1815 werd Polen (hertogdom Warschau) wederom verdeeld. Deze keer tussen Rusland, Pruisen en de vrije stad Krakau. Rusland kreeg hierbij het grootste deel, echter met de verplichting om aan Polen autonomie toe te kenmen. Polen zou slechts door een personele unie met Rusland zijn verbonden. De Russen richtten op het grondgebied van dit zogenaamde "Kongrespolen" inderdaad een koninkrijk met een eigen grondwet op ${ }^{4}$ De aanvankelijke Poolse autonomie werd door Rusland evenwel steeds verder beperkt. $\mathrm{Na}$ de Poolse opstand en de oorlog met Rusland tussen 1830 en $1831^{5}$ verklaarde men dit gebied bij het organische statuut van 14 februari 1832 tot een Russische provincie ("'gubernia")6". Hierdoor verloor Polen ook de formele autonomie.

Op 5 november 1916 vaardigden Duitsland en Oostenrijk-Hongarije, die destijds het Poolse grondgebied bezetten, een verklaring uit, waarin beide landen zich ten gunste van het ontstaan van een onafhankelijk Polen uitspraken ${ }^{7}$. Ook de regering Kerenskij in Rusland ging na de maartrevolutie in beginsel accoord met de nieuw te vormen onafhankelijke Poolse staat ${ }^{m} 8$. De Poolse problematiek werd bij de onderhandelingen omtrent het vredesverdrag van Brest-Litowsk weer aan de orde gesteld. Art. III van het op 3 maart 1918 ondergetekende verdrag bepaalde uiteindelijk, dat de RSFSR van het voormalige gouvernement Polen afstand moest doen. Het terugtrekken van bezettingsmachten in november 1918 en de onafhanke-

1. De zogenaamde eerste verdeling van Polen vond plaats op grond van het verdrag van 5 augustus 1772, daarover Rostworowski in Gieysztor e.a., p. 266-262; de tweede verdeling van Polen geschiedde op grond wan het verdrag van St. Petersburg van 23 januari 1793, daarover Rostworowski in Gieysztior e.a., p. 300-303 en de derde verdeling wan Polen vond plaats op grond van het verdrag van 24 oktober 1795 , Zie Rostworowsiki in Gieysator e. p. 311-312. Zie over de verdelingen van Polen ook Peaslee, p. 706-707; Makarov, ZaóR V 1929, p. 330 e.V.

2. Zie daarower Bardach e.a., p. 352; Kilenewicz in Gieysztor e.a.s, p. 322-329.

3. Bardach e.al, p. 353; SGS deell 9, p. 11; Makarov, ZaöRV 1929, p. 330.

4. Bardach e.a.t. 360-367.

5. Zie daarover Kienewicz in Gieysator e.a., p. 360-367.

6. State Papers 19, 961; Bardach e.a., p. 386; Makarow, ZaöRV 1929, p. 339; SGS deel 9, p. 12.

7. Daarover Wereszycki in Gieysztor e.a., p. 505-507; Potulicki, p. 6; Peaslee, p. 707; Schattzel, JöR $1923-24$, p. 289.

8. Makarov, ZaöRV 1929, p. 348; SGS deel 9, p. 12. 
lijkheidsverklaring van 11 november 1918 wordt dan ook algemeen beschouwd als het ontstaan van een nieuwe Poolse staat ${ }^{9}$. Het nieuwe Polen had echter noch vastgestelde grenzen, noch een bepaalde kring van onderdanen. De grenzen in het westen en zuiden werden bepaald bij de vredesverdragen na de eerste wereldoor$\log ^{10}$, de grens met de RSFSR, de Oekraine en Witrusland bij het vredesverdrag van Riga van 18 maart $1921^{11}$.

Op 17 maart $1921^{12} \mathrm{kwam}$ een grondwet tot stand, die vervolgens op 23 april $1935^{13}$ werd gewijzigd. Op 9 September 1939 werd Polen aangevallen door Duitsland vanuit het westen en tien dagen later door de USSR vanuit het oosten. Het grondgebied van het wederom verdwenen Polen werd bij het Grens- en wriendschapsverdrag van 28 september $1939^{14}$ tussen beide bezettingsmachten werdeeld. Het door de Sovjetunie bezette gebied werd vervolgens bij de wetten wan 1 en 2 november $1939^{15}$ deels bij de Oekraïne en deels bij Witrusland ingelijfd, terwijl het gebied Wilna aan het toen nog zelfstandige Litouwen werd overgelaten. Een deel van het door Duitsland bezette grondgebied werd onder de naam "Eingegliederte Ostgebiete" bestanddeel van het Duitse rijk en het andere gedeelte werd als "Generalgouvernement" onder Duits bestuur gebracht ${ }^{16}$. Na de Duitse aanval op de USSR op 22 juni 1941 werden alle voormalige Poolse gebieden door de Duitsers bezet.

De Poolse regering vluchtte eerst naar Parijs en vervolgens naar Londen en werd steeds door de geallieerden erkend ${ }^{17}$. Tegen het einde van de tweede wereldoorlog werd de problematiek van de Poolse grenzen opnieuw actueel. Deze werden op de conferenties van Jalta (1944) en Potsdam (17 juli-2 augustus 1945) vastgesteld ${ }^{18}$.

Op 21 juli 1944 werd het communistisch getinte Comité van Nationale Bevrijding opgericht ${ }^{19}$. Op 28 juni 1945 werd vervolgens onder het toeziende oog

9. Makarov, ZaöRV 1929, p. 351; SGS deel 9, p. 12; Peaslee, p. 707; Kienewicz in Gieysztor e.a., p. 518-519; Schätzel, JïR 1923-24, p. 290.

10. Het vredesverdrag van Versailles van 28 juni 1919 met Duitsland, Duitse RGBl. 1919, p. 687; Dz.U.(Dziennik Ustaw Rzeczypospolitej Polski) 1920, wr. 25, pos. 200; zie ook het verdrag vam Gendve tussen Polen en Duitsland van 15 mei 1922, Duitse RGBI. II, p. 237; Dz.U. 1922, pos. 371 en het Pools-Duitse verdrag van Wenen van 30 augustus 1924, Duitse RGBl. 1925 II, p. 33; Dzu.U. 1925, pos. 148. Het vredeswerdrag van Saint-Germain-en-Laye van 10 september 1919 met Oostenrijk, Dz.U. 1919, mr. 17 pos. 114. Zie over de vredeswerdragen Bardach e.a., p. 472-474.

11. LNTS V, 52; State Papers 114, 917; en 137. Daarover Potulicki, p. 7-14 en 19-81; Peretiatkowicd, p. 143; Schătzel, JöR 1923-24, p. 291.

12. Dz.U. 1921, nr. 44, pos. 267; Duitse vertaling in JöR 1923-24, p. 300-310 met commentaar van Schätzel op p. 292-300. Zie ook Sharp, p. 23;

13. Dr. U. 1935, nr. 30, pos. 227. Duitse vertaling bij Car, p. 11-40.

14. Duitse RGBI. 1940, I, p. 3; SGS deel 9, p. 15; zie cok thet aanvullende protocol van 4 oktober 1940 , RGBI. II, nr. 5; afgedrukt in ZfoR 1939, p. 303-304. Zie ook Arnold, ZfoR 1940-41, p. 149 .

15. Irvestija van 4 november 1949 , nr. 256. SGS deel 9, p. 16. Zie ook de Witrussische wet van 14 november 1939; Izvestija van 5 december 1939, ar. 281 en de Oekraïnse wet van 15 november 1939 , Irvestija van 16 nowember 1939 , nr. 284.

16. Zie de decreten van Hitler wan 8 oktober 1939; RGBI. I, p. 2042, ook afgedrukt in ZfoR 193940, p. 215 (met betrekking tot de inlijwing) en van 12 oktober 1939 , RGBI I, p. 2077, afgedrukt in ZfoR 1939-40, p. 217 (betreffende het Generalgouwernement). Zie daarover Arnold, ZfoR 1940-41, p. 148-149.

17. Schultr, JöR 1954, p. 23.

18. SGS deel 9, p. 23-24.

19. Bardach, e.a. p. 625 . 
van de Verenigde Staten, Groot-Brittannië en de USSR door dit comité en van de Poolse regering in ballingschap een regering van "Nationale eenheid" gevormd, die de macht overmam ${ }^{20}$. De Poolse oostgrens werd vervolgens bij het Sovjet-Poolse staatsverdrag van 16 augustus $1945^{21}$ vastgesteld, terwijl de westgrens aan de regelingen bij de vredesverdragen werd overgelaten ${ }^{22}$. Een definitieve vaststelling daarvan liet echter tot het verdrag van 6 juli 1950 tussen Polen en de DDR op zich wachten, toen de grens op de Oder-Neisse-linie werd vastgesteld ${ }^{23}$. De Duitse Bondsrepubliek erkende de Poolse grenzen pas bij het verdrag van 7 december $1970^{24}$.

De Volksrepubliek Polen kende aan het begin geen algemene grondwet. Constitutionele regels werden vervat in drie afzonderlijke regelingen. De eerste daarvan was het "Verfassungsgesetz" van 4 februari $1947^{25}$, waarin de regels voor verkiezing van de president van de republiek werden opgenomen. Op 19 februari $1947^{26} \mathrm{kwam}$ voorts de zogenaamde "Mala konstytucja" (kleine constitutie) tot stand. Het ging om een zeer kort "Verfassungsgesetz" dat de samenstelling en bevoegdheden van de belangrijkste organen van de republiek regelde. Tenslotte kondigde het parlement drie dagen later een declaratie omtrent burgerlijke rechten en vrijheden $\mathrm{af}^{27}$. Op 22 juli $1952^{23} \mathrm{kwam}$ vervolgens een "complete" Poolse grondwet tot stand, die sterke overeenkomsten met die van de USSR vertoonde. Deze constitutie werd vervolgens dikwijls gewijzigd ${ }^{29}$. De laatste belangrijke wijziging dateert uit $1976^{30}$.

Polen is sedert de oprichting van beide organisaties lid van het Warschaupact

20. Schultz, JöR 1954, p. 372; Bardach e.a., p. 629.

21. Dz. U. 1947, nr. 35, pos. 167; zie ook thet werdrag van 15 februari 1951; Dz.U. 1952, nr. 11, pos. 63. Daarover Bardach e.a., p. 630.

22. SGS deel 9, p. 25.

23. DzU. 1951, nr. 14, pos. 100; Duitse vertaling in SGS deel 9, p. 120-121. Zie Bardach e, an p, 631; Scluultz, JöR 1954 , p. 368.

24. Bardach e.a., p. 631 .

25. Dx. U. 1947, ar. 9, pos. 43 .

26. Dz.U. 1947, nr. 18, pos. 71; Engetse vertaling in Sharp, p. 99-103; 1ater gewijzigd bij de wet wan 8 november 1949 , Dz.U. 1949, nr. 57, pos. 447 . Sharp, p. 27-28; SGS deel 9, p. 25.

27. Beide documenten afgedrukt in Mala Konstytucja op p. 7-8, respectierelijk 9-23; Zie darower Schulte, JöR 1954, p. 379 .

28. DzU. 1952, nr. 33; Duitse vertaling in JöR 1954, p. 388-397 met commentaar van Schulliz op p. 379.387.

29. Bierut, p. 47. Deze grondwet werd gewijzigd op 25 september 1954 ; 13 december 1957, 22 december 1960,15 mei 1961 en 19 december 1963; Peaslec, p. 709 . Zie voor een Engelse vertaling van de grondwet zoals het gold na de wijziging van 1963 Peaslee, p. 709-724.

30. De wijziging van 10 februari 1976, Dzu. $1976, \mathrm{mr} .7$, pos. 36; zie voor een Duitse vertaling wan de grondwet na deze wijziging Roggemann, p. 333-358; JöR 1978, p. 30-320. Zic daraver Dzialocha/Patrzallek, OER 1978, p. 236-248; Burda, OER 1978, p. 249-252; Zakrzewski, Jö 1978, p. $297-309$. 
en van de COMECON. Recentelijk heeft zich in Polen een zeer sterke democratiseringstendens doorgezet.

\subsubsection{Het nationaliteiltsrecht voor 1939}

\subsubsection{Algemeen}

De eerste regelingen van de nationaliteit van de na de eerste wereldoorlog ontstane Poolse republiek bevatten de vredeswerdragen ${ }^{31}$ en de nationaliteitswet van 20 januari $1920^{12}$. Deze nationaliteitswet werd aangevuld met de uitwoeringsverordening van 7 juni $1920^{33}$ (UV van 1920/21) en enkele latere wetten en verordeningen.

Voorts sloot Polen de volgende internationale verdragen die (mede) betrekking hadden op de nationaliteit:

- $\quad$ het "Minderheitenschutzvertrag" van Versailles van 28 juni $1920^{34}$;

- het migratieverdrag van 3 september $1919^{35}$ met Frankrijk;

- het verdrag van Genève tussen Polen en Duitsland van 15 mei 192236;

- Lhet verdrag van Rome van 6 april $1922^{37}$ tussen de "erfgenamen" van "wijlen" de Donaumonarchie: Oostenrijk, Hongarije, Italie, Joegoslavië, Polen, Roemenië en Tsjechoslowakije;

- het Pools-Duitse verdrag van Wenen van 30 augustus $1924^{38}$;

31. Het vredesverdrag van Versailles van 28 juni 1919 met Duitsland, Duitse RGB1 1919, p. 687; Dz U. $1920 \mathrm{nr}$. 25, pos. 200. Zie ook de bij dit verdrag behorende Poolse uitwoeringsverordening van 113 juli 1920, Dz. U. 1920, pos. 358, gewijzagd bij de verordening van 19 septenber 1920, Dzu. 1920 , pos. 615 . Het vredesverdrag van Saint-Germain-en-Laye wan 10 september 1919 met Oastenvijk, DzU. 1919, nr. 17, pos. 114 , met de uitvoeringsveror dening van 6 februari $1925, \mathrm{Dz} U$. 1925 , pos. 118 . Het vredesverdrag van Riga van 18 maart 1921 met de RSFSR en de Oekraine DzU. 1921, pos. 375. Het vredesverdrag van Trianon van 4 juni 1920 met Hongarije werd door Polen niet geratificeerd. Zie ook Lapradelle, p. 5-23.

32. Dz.U. 1920, nr. 7, pos. 44. Duitse vertaling in SGS deel 9, p. 52-54. Zie ook Peretiatkowice, p. 64-68; De Lapradelle/Niboyet, p. 728-733.

33. DzU. 1920, nr. 52, pos. 302; Duitse vertaling in SGS deel 9, p. 54-58. Deze verordening kwam evenals de nationaliteitswet tot stand in 1920 , toen de grenzen van de Poolse republiek nog niet vaststonden. De verordening gold echter niet op het voormalig Pruisisch gebied. Ten aanzien daarvan kwam op 20 januari 1921, Dz.U. 1921, pos. 95; Duitse vertaling in SGS deel 9, p. 59-61 een aparte uitvoeringswerordening tot stand. Deze verklaarde op een paar verschillen ten aanzien van bevoegdheden van overheidsorganen na ${ }_{n}$ de UV van 1920 van toepassing. On deze reden zal in het vervolg worden gesproken wan de UV wan 1920/21.

34. Di.U. 1920, pos. 728 .

35. LNTS I, 4, 338 .

36. Duitse RGBI. II, p. 237; Dz.U. 1922, pos. 371. Zie ook de bijbehorende uitvoeringsverordening van 6 mei 1953, Dz.U. 1923 , pos. 361 .

37. Dz.U. 1929 , nr. 46 , pos. 501 ; LNTS XXXI, 343.

38. Duitse RGBL. 1925 II, p. 33; DzU. 1925, pos. 148. 
- het verdrag van Warschau van 6 maart $1925^{39}$ betreffende juridische en financiële vraagstukken met Tsjechoslowakije.

Hieronder zal bij de bespreking van de wet van 1920 telkens ook aan de bij de latere wetten en verordeningen aangebrachte wijzigingen aandacht worden besteed.

\subsubsection{De wet wan 1920}

\subsubsection{Algemeen}

De nationaliteitswet van 1920 kende een vrij beknopte regeling van verkrijging en verlies van de nationaliteit. Aangezien het om een eerste algemene nationaliteitsrechtelijke regeling van een nieuw ontstane staat ging, moest de wetgever in de overgangsbepalingen de nationaliteit van de bewoners van Polen op het ogenblik van inwerkingtreding van de wet regelen. Krachtens de overgangsregeling van art. $2^{40}$ bezaten de Poolse nationaliteit:

- degenen die op het Poolse grondgebied woonden, voorzover ze geen andere nationaliteit bezaten (lid 1 ); sub a $t / m$ d bevatte de wet nadere regels ter bepaling van het begrip "woonplaats in Polen";

- degenen die in Polen werden geboren, indien ze geen andere nationaliteit bezaten (lid 2);

- degenen aan wie de Poolse nationaliteit door de internationale verdragen werd toegekend (lid 3).

Voorts dient te worden gewezen op art. 1 dat bepaalde, dat een Pools onderdaan niet tegelijkertijd staatsburger van een andere staat "kon" zijn (exclusiviteitsbeginsel). Zie over de betekenis van een dergelijke bepaling p. 31-32.

\subsection{Verkrijging van de nationaliteit}

De nationaliteit van de Poolse republiek kon volgens de wet van 1920 worden verkregen van rechtswege, door optie en door naturalisatie. Aangezien de verwerving van de nationaliteit door optie slechts in één zeer specifiek geval mogelijk was, wordt daaraan geen aparte paragraaf gewijd. Voor een bespreking van de enige optiemogelijkheid zij verwezen naar p. 238.

39. LNTS XLVI, 201; in werking getreden op 29 april 1929. Op de nationaliteit hadden betrekking de artt. 1 en 2.

40. Bij de verordening van 19 oktober $1938, \mathbb{D z} . \mathrm{U}$. 1938, nr. 81, pos. 548 werd een nieuw artikel 2 ingevoegd dat de regeling van art. 2 uitbreidde tot de bewoners van het gedeelte van Silezie dat door Tsjechoslowakije aan Polen werd afgestaan. Ramus, p. 36-37. Zie voor een Duitse vertaling van de verordening SGS deel 9, p. 70 . 


\section{a. Verkrijging van rechtswege}

De Poolse nationaliteit werd van rechtswege gekoppeld aan de volgende rechtsfeiten:

- geboorte uit Pool(se) ouder(s) (artt. 5, 6);

- adoptie door Poolse ouders (art. 6);

- geboorte op het Poolse grondgebied (art. 5);

- huwelijk met een Pool (art. 7);

- het treden in militaire of civiele staatsdienst (art. 4 sub 5 wet van 1920, art. 5 UV wan $1920 / 21$.

\section{i. Geboorte uit Poolse ouder(s)}

De Poolse wetgever ging bij de regeling wan de verkrijging van de nationaliteit door geboorte van het ius sanguinis-beginsel uit. Een wettig kind was Pool indien zijn vader ten tijde van de geboorte van het kind de Poolse nationaliteit bezat.

Een onwettig, door de vader niet erkend kind kon zijn Poolse nationaliteilt slechts aan zijn moeder ontlenen (art. 5). Een onwettig kind van een vreemdelinge verwierf de Poolse nationaliteit indien het door een Pool werd erkend of gewettigd. De voorwaarde hierbij was dat het kind niet ouder dan 18 jaar was (art. 6) ${ }^{41}$.

\section{ii. Adoptie doar een Pool}

Polen was een van de weinige landen waar adoptie door Poolse ouders een grond voor verkrijging van het staatsburgerschap van rechtswege opleverde. Een vreemdeling, die vó́r zijn 18de verjaardag door een Pool werd geadopteerd, verkreeg daardoor de Poolse nationaliteit (art. 6) ${ }^{42}$.

iii. Geboorte op het Poolse grondgebied en vondelingen

Ten aanzien van kinderen van onbekende ouders die op het Poolse grondgebied geboren of gevonden werden, bevatte art. 5 een praesumptio iuris van het bezit van de Poolse nationaliteit ${ }^{43}$. Het tegenbewijs was steeds mogelijk $k$, ongeacht de leeftijd van het kind.

41. Ramus, p. 38-39.

42. Ramus, p. 38-39.

43. Ramus, p. 38 . 


\section{iv. Huwelijk met een Pool}

Conform het reeds vaker genoemde beginsel van eenheid van de nationaliteit in een gezin (système unitaire) verkreeg een buitenlandse vrouw, die met een Pool in het huwelijk trad, automatisch de Poolse nationaliteit, ongeacht of ze raar vroegere nationaliteit door of in verband met dit huwelijk verloor of niet (ar. 7) ${ }^{44}$. Betrokkene had geen mogelijkheid de verkrijging van de nationaliteit door het afleggen van een daartoe strekkende verklaring te voorkomen.

\section{v. Militaire of civiele staatsdienst}

Een vreemdeling die een vaste aanstelling in de civiele staatsdienst ${ }^{45} \mathrm{kreeg}$ of in de Poolse militaire dienst werd opgenomen, verkreeg daardoor de Poolse nationaliteit, tenzij er een uitdrukkelijk voorbehoud werd gemaakt (art. 4 sub 5 wet van 1920, art. 5 van de UV van 1920/21). Bij het opnemen van deze verkrijgingsgrond was de wetgever hoogstwaarschijnlijk door $\$ 29$ van het Oostenrijkse ABGB geïnspireerd. Deze verkrijgingsgrond was in Polen echter van zeer beperkte betekenis, omdat ten aanzien van de meeste staats- en legerfuncties het bezit van de Poolse nationaliteit als benoemingsvereiste gold ${ }^{46}$. Bij de wet van 23 mei $1924^{47}$ werd vervolgens de mogelijkheid van nationaliteitsverkrijging door het treden in militaire dienst geschrapt. Deze wet behield echter de mogelijkheid van naturalisatie van buitenlandse militairen in het Poolse leger, zonder dat ze aan alle naturalisatievereisten hoefden te voldoen ${ }^{48}$.

\section{b. Naturalisatie}

Verkrijging van de Poolse nationaliteit door naturalisatie was geregeld in art. 8 van de wet van 1920. In artt. 4-14 van de UV van 1920/21 waren voorts de naturalisatievereisten verder uitgewerkt en een aantal procedurele regels geformuleerd. De bevoegdheid om de Poolse nationaliteit te verlenen lag bij de Minister van binnenlandse zaken (art. 12 wet van 1920). Deze had onbeperkte discretionaire bevoegdheid en was niet verplicht zijn beslissing te motiveren ${ }^{49}$. Art. 17 van de UV van $1920 / 21^{50}$ voorzag echter in de mogelijkheid tegen een negatieve beslissing beroep in te stellen. Nadere regels daaromtrent werden opgenomen in een wet van 1 augustus $1923^{51}$.

Vereisten om voor naturalisatie in aanmerking te komen waren de volgende:

44. Ramus, p. 40.

45. Wat onder civiele staatsdienst moest worden werstaan werd noch in de nationaliteitswet noch in de uitwoeringswerordeningen geregeld. Art. 5 lid 4 van de UV van 1920/21 zei slechts dat bijzondere wetten dat bepaalden.

46. Zie SGS deel 9, p. 30-31.

47. Dz.U. 1924 , pos. 60 .

48. Aan betrokkene kon dispensatie wan de naturalisatievereisten wan art. \& sub 2, 3 of 4 worden verleend. SGS deel 9, p. 31.

49. Ranuos, p. 48 .

50. Art. 17 werd gewijzigd bij verordening van 18 februari 1924, DzU. 1924, pos. 240.

51. DzU. 1923, nr. 91, pos. 712 . 
- goed gedrag (art. 8 lid 1 sub 1 wet van 1920). Dit vereiste werd nader gepreciseerd in art. 9 van de wet van 1920 en in art. 4 lid 1 van de UV van $1920 / 21$. Een verzoeker wiens burgerrechten bij een rechterlijk vonnis werden beperkt mocht in geen geval worden genaturaliseerd in de tijd waarin die beperking gold. Een naturalisatieverbod gold ook indien betrokkene een daad had verricht, die "gerechtvaardigde openbare ergernis of onrust" veroorzaakte. Evenmin was naturalisatie mogelijk indien tegen betrokkene een strafrechtelijke procedure aanhangig was;

- ononderbroken tienjarig verblijf in het land, onmiddellijk voorafgaande aan het werzoek (art. 8 lid 1 sub 2, 3 van de wet van 1920 jo. art. 4 lid 2 UV van $1920 / 21$;

- de verzoeker moest in staat zijn zichzelf en zijn gezin te onderhouden. Voldoende was echter dat hij aannemelijk kon maken dat hij niet ten laste van de openbare kas zou komen (art. 8 lid $\mathbb{1}$ sub 3 van de wet van 1920 jo. art. 4 lid 3 UV van 1920/21);

- kennis van de Poolse taal (art. 8 lid 1 sub 4 wet van 1920). Blijkens art. 4 van de UV van $1920 / 21$ moest betrokkene Pools kunnen spreken ${ }^{52}$;

- tenslotte moest de verzoeker kunnen aantonen dat hij zijn oude nationaliteit door of in verband met de naturalisatie zou verliezen (art. 12 UV van $1920 / 21)$.

Zelfstandige naturalisatie van minderjarigen en andere handelingsonbekwamen was mogelijk. In dat geval moest een naturalisatieverzoek door de wettelijke vertegenwoordiger van betrokkene worden ingediend (art. 8 lid 2 UV van $1920 / 21)^{53}$.

Art. 9 van de wet voorzag in de mogelijkheid om met name ten aanzien van personen die in voormalige Russische gebieden woonachtig waren, van enkele vereisten af te zien ${ }^{54}$. Deze mogelijkheid stond echter niet open in geval van beperking van burgerrechten of een faillissementsprocedure tegen betrokkene.

\section{i. Invloed op de nationaliteit wan de gezinsleden wan de verzoeker}

Tegelijkertijd met de verzoeker werden ook zijn vrouw en minderjarige kinderen (onder 18 jaar) genaturaliseerd, tenzij ten aanzien van hen bij de beschikking een voorbehoud werd gemaakt (art. 13 wet van 1920). De vrouw en de kinderen zelf hadden geen mogelijkheid hun medenaturalisatie te voorkomen. Na de ontbinding van het huwelijk, respectievelijk na het bereiken van meerderjarigheid, hadden ze geen mogelijkheid de Poolse nationaliteit op eenvoudige wijze te verliezen.

5. C. SGS deel 9, p. 28.

53. Ramus, p. 47.

54. Ramus p. 49. 


\section{ii. "Erkenning"}

Verkrijging van de Poolse nationaliteit door erkenning (uznanie) was geregeld in art. 3 van de nationaliteitswet van 1920 . Het ging hierbij om een soort verlichte naturalisatie. Anders dan bij de gewone naturalisatie ging het hier om een recht op verlening van de nationaliteit. De Minister van binnenlandse zaken, die bevoegd was om de nationaliteit te verlenen, had geen discretionaire bevoegdheid. Deze weg stond open voor personen van Poolse etnische afstamming die vanuit het buitenland naar Polen terugkeerden. Het ging voornamelijk om remigranten, die niet reeds op grond van de vredeswerdragen of van de overgangsregeling van de nationaliteitswet van 1920 de Poolse nationaliteit bezaten ${ }^{55}$. De voorwaarden voor verkrijging waren:

\section{- bewijis van Poolse afstamming ${ }^{56}$ en}

- een verklaring van "afstand" van de oude nationaliteit ongeacht of daardoor dat staatsburgerschap werkellijk ging verloren.

Bij verordening van 19 oktober $1938^{57}$ werd aan art. 3 van de wet van 1920 een tweede lid toegevoegd, dat betrekking had op de inwoners van Silezië, dat an Polen door Tsjechoslowakije werd afgestaan. Deze verwierven het Poolse staatsburgerschap indien ze van Poolse afstamming waren en sedert 1 november 1918 in dat gebied woonachtig waren geweest ${ }^{58}$.

\subsection{Verlies van de nationaliteit}

De Poolse nationaliteit werd volgens de regeling van de nationaliteitswet van 1920 verloren van rechtswege en door nietigverklaring van een naturalisatiebesluit. Verlies van het staatsburgerschap door het afleggen van een verklaring van afstand, door ontslag of door ontneming kende de wet van 1920 niet. Reeds bij een verordening van 11 augustus $1920^{59}$ werden echter mogelijkheden voor ontneming. van de nationaliteit geschapen. Voorts was ontneming van het staatsburgerschap geregeld in een aparte wet van 31 maart $1938^{60}$. Aangezien beide regelingen als aanvullingen van de wet van 1920 kunnen worden beschouwd, zullen ze in het kader van de bespreking van deze wet (op p. 239-240) worden beschreven.

\section{a. Verlies van rechtswege}

Het verlies van de Poolse nationaliteit werd gekoppeld aan de volgende rechtsfeiten: vrijwillige verkrijging van een andere nationaliteit, huwelijk met een vreemdeling en het zonder toestemming treden in buitenlandse krijgs- of staatsdienst.

55. Ramus, p. 40 .

56. Regels met betrekking tot het bewijs van Poolse afstamming werden opgenomen in een instructic van de Minister van binnenlandse zaken van 8 augustus 1920. Zie Ramus, p. 44-45.

57. Dz.U. 1838, nr. 81, pos. 548. Zie datarover Ramus, 1980, p. 72-73.

58. SGS deel 9, p. 28 .

59. DzU. $1920 \mathrm{nr} .81$, pos. 540 ; Duitse vertaling in SGS deel 9, p. 59.

60. DzU. 1939, nr. 22, pos. 181; Duitse vertaling in SGS deel 9, p. 67-68. 


\section{¿ Vrijwillige verkrijging van een andere nationaliteit}

Krachtens art. 11 sub 1 van de nationaliteitswet van 1920 ging de Poolse nationaliteit verloren door verkrijging van een andere ${ }^{61}$. In art. 6 sub 1 UV van 1920/21 werd verder bepaald, dat het staatsburgerschap slechts door vrijwillige verkrijging van een andere nationaliteit werd verloren. Wat precies onder vrijwillig moet worden verstaan, vertelde de verordening niet. Aangenomen mag worden dat in ieder geval naturalisatie en optie als vrijwillig werden aangemerkt. Indien betrokkene zijn militaire dienst in Polen nog niet had vervuld, verloor hij echter de nationaliteit slechts indien hij daarvan werd wrijgesteld ${ }^{62}$.

\section{ii. Huwelijk met een vreemdeling}

Interessant is dat noch de wet, noch de UV uitdrukkelijk bepaalde dat Poolse vrouwen hun nationaliteit verloren indien ze met een vreemdeling in huwelijk traden. Deze regel kan echter a contrario worden afgeleid uit art. 10 van de wet van 1920, dat aan gewezen Poolse vrouwen die deze nationaliteit door huwelijk met een buitenlander verloren, ná de ontbinding van dit huwelijk een optie op het Poolse staatsburgerschap verleende. Bovendien werd destijds de onderhavige verliesgrond als volkomen vanzelfsprekend spiegelbeeld van automatische verkrijging van de nationaliteit door huwelijk- die wel in art. 7 van de wet van 1920 werd geregeld- beschouwd. Volgens Ramus en Geilke ging het staatsburgerschap echter niet verloren, in het geval dat betrokkene niet automatisch de nationaliteit van haar man verwierf ${ }^{63}$.

\section{iii. Vreemde openbare of militaire dienst}

De Poolse nationaliteit werd ook verloren door het zonder toestemming treden in vreemde staats- of krijgsdienst. (art. 11 sub 2 van de wet van 1920 jo. art. 6 sub 2 UV van 1920/21). Krachtens art. 115 van de dienstplichtwet van 9 april $1938^{64}$ ging de Poolse nationaliteit eveneens ipso iure verloren door het zonder toestem= ming treden in een vreemde militaire organisatie.

\section{b. Ontneming}

Zoals reeds werd benadrukt, kende de Poolse nationaliteitswet na 1920 , afgezien van beperkte mogelijkheden om een naturalisatiebesluit nietig te verklaren, geen verlies van de nationaliteit door ontneming. Deze "lacune" werd bij de reeds

61. Ramus, p. 55 -59.

62. De wet bepaalde letterlijk dat door deze personen een vreemde nationaliteit niet kon worden verkregen, hetgeen uiteraard onhoudbaar is. Aangenomen moet worden dat verkrijging van cen vreemd staatsburgerschap door Polen niet werd erkend en derhalve ook geen verlies van de nationaliteit kon bewerkstelligen. Cf. Ramus, p. 55 .

63. Ramus, p. 40; Geilke, SGS deeel 9, p. 31.

64. Dz.U. 1938 , nir. 25, pos. 220 ; Ramus, p. 60. 
genoemde verordening van 11 augustus $1920^{65}$ en later bij wet van 31 maart $1938^{\text {s6 }}$ opgevuld.

\section{¿ De verordening van 1920}

De verordening van 11 augustus 1920 had betrekking op ontneming van de mationaliteit aan personen, die in strijd met de voorschriften betreffende de militaire dienstplicht handelden. De bevoegdheid om het staatsburgerschap te ontnemen lag bij de Minister van binnenlandse zaken (art. 6). Gronden voor ontneming waren de volgende:

- desertie in combinatie met vlucht naar het buitenland of naar een door de vijand bezet gebied (art. 1 sub 1);

- verlaten van het land en verblijf in het buitenland met het oogmerk de militaire dienstplicht te ontwijken (art. 1 sub 2);

- het geen gehoor geven aan een oproep voor de militaire dienst door degenen die in het buitenland woonden (art. 1 sub 3).

Deze verordening werd in 1929 aangevuld met verordening van 5 april $1929^{67}$, die echter slechts enkele wijzigingen in de competenties van staatsorganen bevatte. De regeling van ontneming van de nationaliteit van de verordening van 1920 werd wervolgens in art. 114 sub a-c van de dienstplichtwet van 9 april $1938^{68}$ overgenomen. Er werd tevens een nieuwe ontnemingsgrond aan toegevoegd, namelijk het verrichten van werving voor buitenlandse krijgsmacht of militaire organisaties (art. 114 sub d).

Invloed op de nationaliteit van gezinsleden van betrokkene

Ten aanzien van de gevolgen van ontneming van het staatsburgerschap voor de nationaliteit van de gezinsleden van betrokkene werd de regeling van de nationaliteitswet van 1920 met betrekking tot de medenaturalisatie van overeenkomstige toepassing verklaard. Dit betekende dat de vrouw en kinderen van betrokkene onder 18 jaar ${ }^{69}$ hun nationaliteit verloren, tenzij te hunner aanzien een uitdrukkelijk voorbehoud werd gemaakt (art. 13 van de wet van 1920).

\section{ii. De wet van 31 maart 1938}

Bij wet van 31 maart 1938 werden de mogelijkheden voor de ontneming van de Poolse nationaliteit nog verder uitgebreid. Het ging om een maatregel, die met name in ballingschap wonende communisten als doelgroep had ${ }^{70}$. Tijdens de korte

65. Dz.U. 1920, nr. 81, pos. 540; Duitse vertaling in SGS deel 9, p. 59.

66. DzU. 1938, nr. 22, pos. 191; Duitse vertaling in SGS deel 9, p. 67-68.

67. DzU. 1929, pos. 298.

68. Zie daarover Ramus 1980 , p. $264-265$.

69. Ramus, p. 61 .

70. SGS deel 9 , p. 36 . 
geldigheidsduur van deze wet (maart 1938-september 1939) werd aan meer dan 2000 personen de nationaliteit ontnomen ${ }^{71}$. Het staatsburgerschap werd ontnomen door de Minister van binnenlandse zaken (art. 2 lid 1) op voorstel van zijn collega van buitenlandse zaken. Vereiste voor ontneming was, dat betrokkene zich in het buitenland bewond (art. 1, aanhef). Gronden voor ontneming waren de volgende:

- handelingen die de stat schaadden (art. 1 sub a);

- ononderbroken vijfjarig verblijf in het buitenland na het ontstaan van de Poolse republiek in 1918, indien betrokkene zijn verbinding met Polen had verloren (art. 1 sub b);

- het niet terugkeren naar het land op bevel van de bevoegde Poolse instantie (art. 1 sub c).

De Minister was in deze gevallen niet verplicht het staatsburgerschap te ontnemen. Een ontnemingsbesluit behoefde ook niet gemotiveerd te zijn (art. 2 lid 2). De wet voorzag echter wel in de mogelijkheid om bij het opperste administratieve gerechtshof beroep tegen ontneming in te stellen (art. 2 lid 3).

Het gevolg wan ontneming op grond van deze wet was, dat het aan betrokkene behoudens voorafgaande toestemming van de Minister van binnenlandse zaken verboden was het land te bezoeken (art. 5 lid 1$)^{72}$.

\section{Invloed op de nationaliteit wan gezinsleden van betrokkene}

Het verlies van de mationaliteit krachtens de ontnemingswet van 1938 betrof tevens de vrouw en kinderen van betrokkene die nog geen 18 jaar waren, en zich tevens in het buitenland bevonden (art. 3 lid 1). In het geval dat de feitelijke gezinsband was verbroken en dat te hunner aanzien geen gronden voor ontneming bestonden, kon in het ontnemingsbesluit met betrekking tot de gezinsleden een voorbehoud worden gemaakt (art. 3 lid 2). Op grond van art. 4 kon an een gehuwde vrouw ook zelfstandig de nationaliteit worden ontnomen, indien bleek dat de echtelijke gemeenschap feitelijk werd verbroken.

\subsubsection{Het nationaliteitsrecht tijdens de tweede wereldoorlog}

Zoals reeds op p. 230 werd gezegd, werd het gebied van de Poolse republiek in het najaar van 1939 tussen Duitsland en de USSR verdeeld. Hieronder zall aandacht worden besteed aan nationaliteitsrechtelijke regelingen die gedurende de tweede wereldoorlog op de door de USSR en Duitsland bezette gebieden tot stand kwamen.

71. De ontnemingsbesluiten werden in de Monitor Polski gepubliceerd.

72. Overtreding van dit verbod werd gestraft met een gevangenisstraf van 5 jaren en met geldboete. 
Het door het Sovjet-leger bezette gedeelte van Polen werd bij Witrusland, de Oekraïne en het toen nog zelfstandig Litouwen ingelijfd. Aan de bewoners van de geannexeerde gebieden werd bij een besluit van het Opperste Sovjet van de USSR van 29 november 1939 de Sovjet-nationalitelt verleend ${ }^{73}$. Dit gold echter niet voor personen van Duitse etnische afstamming, te wier aanzien bij een verdrag tussen Duitsland en de USSR een aparte regeling werd getroffen. Op grond van dit verdrag hadden deze personen de mogelijkheid om naar de door Duitsers bezette gebieden te verhuizen en aldaar het Duitse staatsburgerschap te verwerven ${ }^{74}$.

\subsubsection{Duitsland"}

het door Duitsland bezet gedeelte van Polen werd gedeeltelijk bij het rijk ingelijfd (Eingegliederte Ostgebiete) en gedeeltelijk als Generalgouvernement onder Duits bestuur gebracht ${ }^{75}$. De bewoners van de beide gebieden werden in speciale "Volklisten" geregistreerd en in vier verschillende categorieën verdeeld. Deze verdeling vormde de basis voor verkrijging van de Duitse nationaliteit krachtens een aantal bijzondere regelingen ${ }^{76}$. Aan bepaalde personen werd van rechtswege de Duitse nationaliteit toegekend (de zogenaamde eerste categorie), terwijl anderen slechts opties (tweede categorie) of de mogelijkheid van verlichte naturalisatie kregen (derde en vierde categorie). Degenen die op grond van deze regelingen niet de Duitse nationaliteit verwierven, werden door Duitsland slechts als Duitse "Schutzangehörigen" beschouwd 7 .

\subsubsection{Het nationaliteitsrecht tussen 1945 en 1951}

De nationaliteitswet van 1920 bleef tezamen met de daarin aangebrachte wijzigingen en de aanvullende regelingen ook na de tweede wereldoorlog van kracht. Daarnaast werden door de nieuwe regering een aantal regelingen afgekondigd, die op behoud, respectievelijk ontneming van de Poolse nationaliteit betrekking hadden. De eerste van deze nationaliteitsrechtelijke regelingen was de wet van 6 mei 1945 betreffende de uitsluiting van "vijandelijke elementen" uit de Poolse samenleving ${ }^{78}$, die op etnische Duitsers betrekking had. Deze regeling werd werder uitgewerkt in verordeningen van 19 en $26 \mathrm{mei} 1945^{*}$. Interessant is dat deze voorschriften opnieuw de tijdens de bezetting samengestelde "Volkslisten" als uitgangspunt nam. Personen, die door de Duitsers in de derde of vierde categorie werden ingedeeld, konden het Poolse staatsburgerschap in de regel behouden, tenzij ze vrijwillig op de lijsten werden geplaatst of op een andere wijze van hun

73. Ramus, p. 195.

74. Zie daarower Globke, ZfoR 1943, p. 1 e.w.

75. Ramus, p. 148; Arnold, ZfoR 1940-41, p. 149.

76. Hierover Arnold, ZfoR 1940-41, p. 148-153; Lichter, StAZ 1941, p. 79-81; Ramus, p. 148-155.

77. Arnold, ZToR 1940-41, p. 150.

78. DzU. 1945, nr. 17, pos. 96 ; Duitse vertaling in SGS deel 9, p. 83-86. Deze wet werd vervolgens op 28 augustus 1945, 30 oktober 1945 en 22 juni 1946 gewijzigd, en bij $\$ 8$ wan decreet van 17 oktober 1946, DzU. nr. 59 , pos. 324, ingetrokken.

79. DzUU. 1945 , ar. 21 , pos. 129 en DzU. 1945 , nr. 130 . 
"ontrouw" tegenover Polen was gebleken. Voorwaarde voor behoud van de Poolse nationaliteit was voorts dat ze een eed van trouw moesten afleggen (artt. 1,2 ). Personen die in de tweede categorie werden ingedeeld, verloren de Poolse nationaliteit, doch ze mochten bij de rechter een "rehabiliteringsverzoek" indienen. Daarbij moesten ze bewijzen dat ze tegen hun wil op de lijsten werden geplaatst en dat ze zich loyaal tegenover Polen hadden gedragen (art. 9). Aan personen van de eerste categorie werd de nationaliteit zonder meer ontnomen.

Pollen sloot voorts met de USSR op 6 juli 1945 in Moskou een verdrag betreffende verandering van de nationaliteit en repatriëring ${ }^{80}$. Dit verdrag had betrekking op in de USSR woonachtige etnische Polen en Joden en in Polen wonende personen die aan een van de Sovjet-volkeren toebehoorden.

Het Poolse grondgebied werd na de tweede wereldoorlog ten koste van Duitsland met enkelle gebieden uitgebreid. Het ging om de voormalige "Freie Stadt Danzig" (Gdansk) en de zogenaamde "Herwonnen gebieden" (Ziemie Odzyskanie) ${ }^{81}$. In een instructie van de Minister van Herwonnen gebieden van 6 april $1946^{62}$ werden regels betreffende bewijs ${ }^{83}$ en vaststelling van etnische Poolse nationaliteit van de bewoners van deze gebieden gegeven. Deze vaststelling was van belang voor de toekenning van de (juridische) Poolse nationaliteit op grond van de wet van 28 april $1946^{84}$. Op grond van deze wet verkreeg iedereen die vóór 1 januari 1945 in de Herwonnen gebieden woonachtig was en wiens Poolse etnische nationaliteit door een speciaal daartoe ingestelde verificatiecommissie vastgesteld werd, het Poolse staatsburgerschap. Betrokken moest tevens een eed van trouw afleggen (art. 1).

In een decreet betreffende de uitsluiting van etnische Duitsers uit de Poolse samenleving van 13 september $1946^{85}$ werd ontneming van het Poolse staatsburgerschap aan personen, die na hun 18 de levensjaar door hun gedrag hun "nationale

80. Zie afkondiging wan dit verdrag in: Soviet-Polish Relations. A Collection of Official Documents 1944-1945, p. 32, geciteerd bij Ramus, p. 181; Kokot/Rysiak, p. 42-43. Zie ook Izvestija van 7 juli 1945. Zie ook het aanvullend protocol van 15 nowember 1945, Izvestija van 15 nowember 1945 .

81. Daarmee werden bedoeld de gebieden ten noorden en ten westen van de Poolse grenzen van 1 september 1939, die na de tweede wereldoorlog onder Pools bestuur kwamen te staan. Zie art. 1 van de op invoering van wet van 28 april 1946 betrekking hebbende circulaire $n r$. 46 wan het Ministerie van de Herwonnen gebieden van 11 mei 1946, publicatieblad van het Mimisterie van de Herwonnen gebieden 1946, ur. 4, pos. 30; Duitse vertaling in SGS deel 9, p. 102-104.

82. Instructie L 6703/II/1349/46; Publicatieblad van het Ministerie van de Herwonnen gebieden 1946, nir. 4 , pos. 26 .

83. Ten aanzien van bewijs van etnische nationaliteit noemde art. 4 onder meer: Poolse afstamming lidmaatschap in Poolse organisaties, Het Pools als moedertaal, vasthouden aan Poolse gebruiken in het gezin, gedrag tijdens de bezetting.

84. DzU. 1946, nr. 15, pos. 106. Duitse vertaling in SGS deel 9, p. 101-102. Zie daarover Ramus, p. 183-190. Zie uitwoerig over de nationaliteit wan de bewoners van Herwonnen gebieden: Dropinski, Administracja i samorzad na Ziemiach odyskanich Seria A, 1, 1946/2-3, p. 3-52. Danzig behoorde nïet tol de Herwonnen gebieden en had een aparte status. Desalmiettemin werd in de praktijk de wet van 28 aprill 1946 ook in Danzig toegepast, totdat dezelfde problematiek bij decreet wan 22 oktober 1947, Dz.U. 1947, nr. 65, pos. 378 werd geregeld. De regeling van dit decreet was analoog aan die van de wet van 28 april 1946. Ramus, p. 190-191.

85. Dr. U. 1946, nr. 55, pos. 310; Duitse vertaling in SGS deel 9, p. 106-108. Dilt decreet trad krachtens art. 16 voor een beperkte tijd in werking, namelijk tot 31 december 1948. De werking daarvan werd echter nog tweemaal met telkens ten jaar verlengd, namelijk bij de wetten van 18 novernber 1948 , Dzu. nr. 57, pos. 453 en van 30 december 1949, Dz.U. 1949, ni. 65, pos. 533. Zie Kokot/Rysiak, p. 43-44. 
Duitse aard" hadden bewezen, geregeld (art. 1 lid 1). Voorbeelden van dergelijk gedrag werden in het decreet niet gegeven, wel in een latere verordening van 10 aprill $1947^{86}$. Ontmeming kon onder in art. 2 omschreven omstandigheden ook de echtgeno(o)t(e) en minderjarige kinderen van betrokkene betreffen. Art. 4 van het decreet voorzag voorts in de mogelijkheid van uitzetting van degenen, aan wie het staatsburgerschap werd ontnomen, terwijl art. 5 bepaalde dat in ieder geval hun vermogen werd geconfisceerd en hun rechtsbevoegdheid werd beperkt ${ }^{87}$. Bij wet van 20 juli $1947^{88}$ werden de nationaliteitsrechtelijke sancties tegen etnische Duitsers stopgezet.

\subsubsection{De wet van 1951}

\subsubsection{Algemeen}

De eerste algemene regeling van verkrijging en verlies van de nationaliteit van de Volksrepubliek Polen liet tot 8 januari $1951^{89}$ op zich wachten. De wetgever voerde bij deze nationaliteitswet enkele principiële wijzigingen in, zoals gelijkstelling van mannen en vrouwen en van wettige en onwettige kinderen, alsmede het loskoppelen van nationaliteit en huwelijk $k^{90}$.

In het eerste artikel van de nieuwe nationaliteitswet kwam het reeds bekende exclusiviteitsbeginsel tot uitdrukking ${ }^{91}$. De overgangsregeling van artt. 2-4 en 15 17 knoopte bij de bepaling van de kring van onderdanen aan bij personen, die op grond van de voorheen geldende wetgeving de Poolse nationaliteit bezaten. Voorts bestond de mogelijkheid om het Poolse staatsburgerschap toe te kennen aan personen, die ten minste sedert 9 mei 1945 in Polen woonden en als Polen werden behandeld. Interessant is voorts art. 4 dat de Poolse nationaliteit ontnam aan degenen, die op 31 september 1939 het Poolse staatsburgerschap bezaten en in 1951 hun vaste woonplaats in het buitenland hadden, mits zij:

- op grond van internationale regelingen een andere nationaliteit verwierven (sub 1); of

- de Russische, Witrussische, Oekraïnse, Litouwse, Letse, Estlandse of Duitse etnische nationaliteit bezaten (sub 2,3$)^{92}$.

86. Dz.U. 1947, nr. 34, pos 163; Duitse vertalling in SGS deel 9, p. 1094113. De verordening noemde in \$ 2 sub c met name het gebruik van de Duitse taal, activiteit in enigerlei Duitse organisaties en de houding ten opzichte van het Polendon. Uit het tweede lid van 1 van het decreet bleek dat het feit dat betrokkenen zich tijdens de bezetting op Duitse afstamming beriepen niet voldoende werd geacht om de nationalliteit te ontnemen. Zie ook Kokot/Rysiak, p. 44.

87. Betrokkene kon niet erven of schenkingen aannemen.

88. DzU. 1950, nr. 29, pos. 270; Duitse vertaling in SGS deel 9, p. 114-117. Zie ook de vile voeringsverordening van 26 juli $1950 ;$ Dz.U. 1950, nr. 32, pos. 284; Duitse vertaling in SCS deel 9, p. 115-116.

89. Dz.U. 1951, nar. 2, pos. 25; Duitse vertaling in SGS deel 9, p. 116-119; In werking getreden op 19 januari 1951. Zie daarover Biskupieski, p. 323-327; Makarov, RabelsZ 1952, p. 407-409; Ramus, p. 226 .

90. Ramus, p. 226 .

91. Daarover Ramus, p. 228, Makarov, RabelsZ 1952, p. 407.

92. Zie daarover Wierzbowski, Nowe prawo $1957 / 7-8$, p. 144. 
In art. 15 lid 1 werden vervolgens alle ontnemingen van de Poolse nationaliteit op grond van de ontnemingswet van 1938 herroepen, voorzover betrokkene op het tijdstip van inwerkingtreding van de nationaliteitswet van 1951 in Polen woonde.

\subsubsection{Verkrijging wan de nationaliteit}

Volgens de nationaliteitswet van 1951 kon het Poolse staatsburgerschap worden verworven van rechtswege, door naturalisatie en slechts in één geval door optie. Gezien het specifieke karakter van deze enige optiemogelijkheid zal daaraan geen aparte paragraaf worden gewijd. Zie over deze optie p. 245.

\subsection{Verkrijging van rechtswege}

De Poolse nationaliteit werd van rechtswege gekoppeld aan de volgende rechtsfeiten:

- geboorte uit Poolse ouder(s) (art. 6) en

- geboorte of het gevonden worden op het Poolse grondgebied (art. 7).

Adoptie door Poolse ouder(s) en huwelijk met een Poolse man waren in tegenstelling tot de regeling van de wet van 1920 geen gronden voor verkrijging van het staatsburgerschap ipso iure meer.

\section{a. Geboorte uit Poolse ouder(s)}

De Poolse nationaliteitswet van 1951 ging bij de regeling van verkrijging van het staatsburgerschap van het beginsel ius sanguinis a patre et a matre uit. Een kind kon zijn nationaliteit op gelijke voet zowel aan zijn moeder als aan zijn vader ontlenen. Voorts werd er tussen wettige en onwettige kinderen geen onderscheid meer gemaakt. Een kind werd sedert zijn geboorte beschouwd als kind van een Poolse vader, indien het vaderschap hetzij door erkenning, hetzij door gerechtelijke vaststelling kwam vast te $\operatorname{staan}^{93}$. De nieuwe regeling van verkrijging van de nationaliteit door geboorte gold blijkens de overgangsregel van art. 16 ook voor kinderen, die voor inwerkingtreding van de wet van 1951 werden geboren(!). Een kind verwierf iure sanguinis de Poolse nationaliteit indien:

- zijn beide ouders op het tijdstip van de geboorte van het kind het Poolse staatsburgerschap bezaten (art. 6 sub 1);

- Cén van zijn ouders de Poolse nationaliteit bezat, terwijl de andere onbekend was, staatloos was, of zijn staatsburgerschap niet kon worden vastgesteld (art. 6 sub 2);

- Eén van zijn ouders op het tijdstip van geboorte van het kind Pool was, terwijl de andere een vreemde nationaliteit bezat en de ouders niet binnen eén

93. Ramus, p. 255-256. 
maand na de geboorte van het kind verklaarden dat ze geen verkrijging van het Poolse staatsburgerschap door het kind wilden (artt. 8, 9).

In het laatstgenoemde geval bestond de mogelijkheid om verwerving van de Poolse nationaliteit te voorkomen slechts, indien het kind het staatsburgerschap van zijn niet-Poolse ouder verwierf (art. 8 lid 1 in fine). Werd er geen verklaring afgelegd, dan werd het kind Pool ${ }^{94}$. Voor het geval dat tussen de ouders geen overeenstemming kon worden bereikt, bestond er de mogelijkheid het geschil aan een rechter voor te leggen (art. 8 lid 2).

Hoewel verkrijging van het staatsburgerschap ex art. 8 strikt formeel afhankelijk werd gesteld van de wil van de ouders van het kind, kan hier niet worden gesproken van verkrijging van de nationaliteit door optie ${ }^{95}$. Het Poolse staatsburgerschap werd verworven indien de ouders van betrokkene niets deden. De termijn van éen maand was bovendien uiterst kort. het is derhalve zeer aannemelijk dat de ouders van het kind in de meeste gevallen van deze mogelijkheid niet eens op de hoogte waren. Gesteld kan worden dat het hier om verkrijging van de nationaliteit van rechtswege gaat, met een minieme correctiemogelijkheid voor betrokkenen en niet om vrijwillige verwerving van het staatsburgerschap zoals een "echte" optie kan worden getypeerd. De nationaliteitswerkrijging ex art. 8 werkte overigens ex tunc, vanaf het ogenblik van de geboorte van het kind ${ }^{\%}$.

Indien de ouders van het kind door hun verklaring verkrijging van het staatsburgerschap door het kind voorkwamen, kreeg het kind op zijn 13 de verjaardag een (echt) optierecht op de Poolse nationaliteit (art. 8 lid 3). Op het tijdstip van het uitbrengen van deze optie moest hij echter in Polen woonachtig zijn.

\section{b. Geboorte op het Poolse grondgebied en vondelingen}

Een in Polen geboren of gevonden kind van onbekende ouders of van ouders wier nationaliteit onbekend was, werd geacht het Poolse staatsburgerschap te bezitten. Het ging hierbij om een praesumptio iuris die gold zolang niet bleek dat het kind door geboorte een ander staatsburgerschap bezat. Zulks was steeds mogelijk, ongeacht de leeftijd van het kind ${ }^{97}$.

\subsection{Naturalisatie}

Verkrijging van de Poolse nationaliteit door naturalisatie was geregeld in art. 10 van de wet van 1951. De bevoegdheid om het staatsburgerschap te verlenen lag bij de Raad van State (art. 13). De maturalisatievereisten waren in tegenstelling tot de wet van 1920 in het geheel niet wettelijk geregeld. Art. 10 lid 2 bepaalde slechts dat van de verzoeker kon worden geëist dat hij bewijs van verlies van zijn oude

94. Of thet tevens de nationaliteit van zijn amdere ouder verwierf, hing uiteraard van de nationale wetgeving wan de andere ouder af.

95. Geilke, SGS deel 9, p. 35, sprak in dit verband van optie met een negatief karakter.

96. SGS deel 9, p. 35.

97. Ramus, p. 258-259. 
nationaliteit overlegde ${ }^{9 \%}$. Het ontbreken van wettelijke naturalisatieeisen bood aan de administratie derhalve onbeperkte discretionaire bevoegdheid.

Art. 15 lid 2 voorzag voorts in de moeilijkheid van verlichte naturalisatie van personen, aan wie de Poolse nationaliteit voór 1 september op grond van de op p. 239-240 besproken wet van 31 maart 1938 werd ontnomen. Deze mogelijkheid hadden degenen, die op het tijdstip van inwerkingtreding van de wet van 1951 in het buitenland woonden. Waren ze in Polen woonachtig, dan werden ze krachtens het eerste lid van art. 15 reeds van rechtswege Polen (zie p. 244). De reden voor deze ruimhartigheid lag in het feit dat ontneming van de nationaliteit op grond van de wet van 1938 voornamelijk communisten betrof.

\section{a. Invloed op de nationaliteit van de gezinsleden van de verzoeker}

De wet van 1951 had geen regeling met betrekking tot medenaturalisatie van gezinsleden van de verzoeker. Deze lacune kan naar mijn mening worden opgevuld aan de hand van de regeling van ontslag die wel regels ten aanzien van minderjarige kinderen van de verzoeker bevatte. Indien het staatsburgerschap aan beide ouders werd verleend, werden hun kinderen die onder hun ouderlijk gezag stonden en jonger waren dan 13 jaar, automatisch meegenaturaliseerd (art. 8 lid 4). In het geval dat slechts én van de ouders werd genaturaliseerd, waren kinderen onder 13 jaar in de naturalisatie inbegrepen indien:

- de naturalisandus alleen het ouderlijk gezag uitoefende;

- de ander ouder reeds de Poolse nationaliteit bezat, of

- de andere ouder voor medenaturalisatie van het kind zijn toestemming verleende (sub 2).

Was het kind reeds 13 jaar of ouder, dan moest hij tevens zelf met zijn medenaturalisatie instemmen.

\section{b. "Repatriëring"}

Onder de naam repatriëring vinden we een aparte mogelijkheid van verlichte naturalisatie ten behoeve van etnische Polen, die onder de vigeur van de wet van 1920 "erkenning" werd genoemd ${ }^{99}$. De wet van 1951 beperkte zich in tot de bepaling, dat repatrianten die met toestemming van de bevoegde instantie remigreerden, "van rechtswege" het Poolse staatsburgerschap verwierven (art. 10 lid 3). Anders dan zijn voorganger stelde de wet van 1951 niet meer de eis dat betrokkene zijn oude nationaliteit verloor.

98. Ramus, p. 266.

99. SGS deel 9 , p. 36 . 


\subsubsection{Verlies van de nationaliteit}

De Poolse nationaliteitswet van 1951 kende het verlies van het staatsburgerschap door ontslag en door ontneming. Verlies door afstand of door nietigverklaring van een naturalisatiebesluit was niet meer mogelijk.

\subsection{Ontslag}

Ontslag uit de Poolse nationaliteit was geregeld in art. 11 van de wet van 1951. Merkwaardig is dat de regeling van ontslag niet als zodanig in de wet werd genoemd, maar werd "verpakt" in een regeling van verlies van de nationaliteit door verkrijging van een andere ${ }^{100}$. Volgens art. 11 lid 1 "mocht" een Pool slechts met voorafgaande toestemming van de Raad van State een ander staatsburgerschap verkrijgen. In geval van een positieve beslissing van de Raad van State, verloor betrokkene zijn nationaliteit op het ogenblik dat hij het staatsburgerschap van een ander land verwierf (art. 11 lid 5). Verkreeg betrokkene geen toestemming en verwierf hij desalniettemin een vreemde nationaliteit, dan ging zijn Poolse staatsburgerschap evenwel niet verloren. We zien derhalve dat de beslissing van de Raad van State ex art. 11 als ontslag uit de Poolse nationaliteit onder de opschortende voorwaarde van verkrijging van een ander staatsburgerschap dient te worden gekwalificeerd.

Evenmin als ten aanzien van de naturalisatie werden hier vereisten in de wet genoemd, hetgeen opnieuw op onbeperkte discretionaire bevoegdheid van de administratie wijst.

\section{a. Invloed op de nationaliteit van de gezinsleden van de verzoeker}

Met betrekking tot medeontslag van minderjarige kinderen werd in art. 11 leden 2-4 onderscheid gemaakt tussen gevallen waarin ontslag aan beide ouders werd verleend en gevallen waarin slechts één van de ouders van het kind werd ontslagen. In het eerste geval werden kinderen onder 13 jaar steeds automatisch meeontslagen. Hetzelfde gold indien éen van de ouders ontslagen werd, terwijl de andere vreemdeling was. Indien slechts één van de ouders werd ontslagen, terwijl de andere Pool bleef, werden kinderen slechts met toestemming van die ouder in het ontslag inbegrepen. De toestemming kon door een rechterlijke beslissing worden vervangen (art. 11 lid 3). Kinderen boven 13 jaar moesten in alle gevallen met hun medeontslag instemmen.

\subsection{Ontneming}

Ontneming van de Poolse nationaliteit was geregeld in art. 12 van de wet van 1951. De Raad van State was bevoegd om het staatsburgerschap in de volgende gevallen te ontnemen aan personen, die zich in het buitenland bevonden:

100. Zo spreekt Geilke in SGS deel 9 , p. 36 niet over verlies door ontslag, maar over verlies "door verkrijging van een vreemde nationaliteit. 
- indien betrokkene de loyaliteitsplicht tegenower de Poolse staat schond (art. 12 sub 1);

- wegens handelingen die essentiēle belangen van de Poolse staat konden schaden (art. 12 sub 2);

- indien betrokkene na 9 mei 1945 het Poolse grondgebied illegaal verliet (art. 12 sub 3);

- wegens weigering om op vordering van de bevoegde instantie naar Polen terug te keren (art. 12 sub 4);

- wegens het ontwijken wan de militaire dienstplicht (art. 12 sub 5);

- wegens een herhaalde strafrechtelijke veroordeling in het buitenland (art. 12 sub 6).

Terwijl de ontnemingsgronden onder 3-6 met voldoende nauwkeurigheid werden omschreven, boden de sub 1 en 2 omschreven gronden door hun vage formulering voldoende mogelijkheden om de nationaliteit willekeurig te ontnemen. Ook uit het feit dat de Raad van State bij aanwezigheid van een ontnemingsgrond de nationaliteit kon ontnemen, blijkt dat dit instrument door de administratie willekeurig kon worden gehanteerd. Volgens Ramus werd het instituut van de ontneming tijdens de geldigheidsduur van de wet van 1951 echter nauwelijks toegepast ${ }^{101}$.

\section{a. Invloed op de nationaliteit van de gezinsleden van betrokkene}

Ontneming van de nationaliteit had in beginsel geen invloed op de nationaliteit van de gezinsleden van betrokkene. Uiteraard kon aan hen de nationaliteit "zelfstandig" worden ontnomen.

\subsection{Het posmeve NATIONALUTERTSREChT}

\subsubsection{Algemeen}

Het huidige Poolse nationaliteitsrecht wordt geregeld in de wet van 15 februari $1962^{102}$. De nieuwe nationaliteitswet bracht voornamelijk wijzigingen in de regeling van verkrijging van het staatsburgerschap door geboorte, door naturalisatie en met betrekking tot verandering van de nationaliteit in verband met huwelijk met zich mee ${ }^{103}$. Het zogenaamde exclusiviteitsbeginsel wordt ook in de huidige wet geëxpliciteerd (art. 2). Het verschil ten opzichte van de vorige wet is echter, dat er

101. Ramus, 1980, p. $280-281$.

102. DzU. 1962, nr. 10, pos. 49. In werking getredem op 21 augustus 1962. Nederlandse vertaling in NWG, p. 1-5; Duitse vertaling in Bergmann/Ferid, p. 10-13.

103. Ramus, p. 280-282; Bergmann/Ferid, p. 8. Zie woor een overzicht van de wijzigingen Geilke, WGO 1962 , p. 62,67 en 83 . 
mu uitdrukkelijk wordt bepaald, dat het slechts om niet-erkenning van het bezit van een eventuele andere nationaliteit door een Pool gaat ${ }^{104}$.

\subsection{Verkrijging van de nationaliteit}

Evenals de vorige nationaliteitswetgeving van Polen kent ook de wet van 1962 verkrijging van het staatsburgerschap van rechtswege en door naturalisatie. Door het afleggen van een verklaring van optie wordt de Poolse nationaliteit niet verworven.

\subsubsection{Verkrijging van rechtswege}

Verkrijging van de Poolse nationaliteit wordt van rechtswege gekoppeld aan de volgende feiten:

- geboorte uit Poolse ouder(s) (artt. 4,6) en

- geboorte of het gevonden worden op Poolse grondgebied (artt. 5, 7).

Door adoptie wordt het Poolse staatsburgerschap niet verworven.

\subsection{Geboonte uit Poolse ouder(s)}

Bij de verkrijging van de Poolse nationaliteit iure sanguinis wordt ook in de huidige regeling het beginsel ius sanguinis a matre et a patre gehandhaafd ${ }^{105}$. Een kind is Pool, indien:

- zijn beide ouders op het tijdstip van de geboorte van het kind de Poolse nationaliteit bezitten (art. 4 lid 1) of

- Eên ouder op het tijdstip van de geboorte van het kind het Poolse staatsburgerschap bezit, terwijl de andere onbekend of staatloos is, of zijn nationaliteit niet kan worden vastgesteld (art. 4 lid 2).

We zien derhalve dat de regeling van de wet van 1951 op dit punt gehandhaafd is gebleven. Ten aanzien van kinderen die uit nationaliteitsrechtelijk gemengde ouders worden geboren, bepaalt art. 6 dat het kind de Poolse nationaliteit verkrijgt, tenzij zijn ouders binnen drie maanden (voorheen én maand) na de geboorte van het kind verklaren dat ze niet willen dat het kind Pool wordt. Deze keuze is slechts mogelijk indien het kind door geboorte tevens het staatsburgerschap van zijn andere ouder verwerft ${ }^{106}$. Voor het geval dat tussen de ouders geen overeenstemming over de nationaliteit van het kind kan worden bereikt, is er rechterlijke

104. Zie daarover Pusylewitsch, p. 58; Gelberg, PiP 1962, p. 335; Seniuta, p. 81 .

105. Ramus; p. 287.

106. Ramus, p. 288; Seniuta, p. 89; Rajski, Palestra 1962/6, p. 54. Een kind van Pools-Nederlandse ouders bijwoorbeeld, verkrijgt ex art. 3 lid 1 RwNed de Nederlandse nationaliteit en derhalve kumnen zijn ouders verkrijging van de Poolse nationaliteit voorkomen, door de in ant. 6 van de Poolse nationaliteitswet bedoelde verklaring af te leggen. 
tussenkomst voorgeschreven (art. 6 lid 2). De vraag is op welk moment de nationaliteit door het kind wordt verkregen. Volgens Kokot, Rysiak en Seniuta ${ }^{107}$, wordt het staatsburgerschap bij de geboorte verkregen en wordt het verloren indien de ouders van hun keuzemogelijkheid gebruik maken, terwijl Gelberg ${ }^{108}$ opteert voor verkrijging van de Poolse nationaliteit op het moment waarop de termijn ex art. 6 verloopt.

Art. 7 bevat een regeling woor het geval dat na de geboorte van het kind de identiteit en/of nationaliteit van één of beide ouders anders wordt vastgesteld dan voorheen werd aangenomen. Hierbij kan worden gedacht aan het geval dat een kind dat uit een buitenlandse vrouw en een aanvankelijk onbekende vader wordt geboren en dat later wordt vastgesteld dat de vader van het kind Pool is. Volgens art. 7 lid 1 heeft deze vaststelling slechts gevolgen voor het staatsburgerschap van het kind indien zij binnen één jaar na zijn geboorte plaatsvindt. Slechts in het geval dat het vaderschap in rechte met succes wordt ontkend, kan dit gevolgen voor de nationaliteit van het kind gedurende zijn minderjarigheid (18 jaar) hebben ${ }^{1109}$. De nationaliteit van kinderen boven 16 jaar kan echter uitsluitend met hun eigen toestemming worden veranderd (art. 7 lid 2).

\subsection{Geboorte op het grondgebied en vondelingen}

Een kind dat in Polen wordt geboren of gevonden en wiens ouders onbekend, staatloos, of van onbekende nationaliteit zijn, verkrijgt krachtens art. 5 het Poolse staatsburgerschap ${ }^{110}$. Deze bepaling berust op een praesumptio iuris sanguinis ten gunste van dergelijke kinderen ${ }^{111}$. Op grond van art. 7 lid 1 is het slechts eén jaar na de geboorte van het kind mogelijk het tegenbewijs te leveren ${ }^{112}$. Komt later vast te staan dlat én of beide ouders van het kind een vreemde nationaliteit bezitten, blijft het kind Pool, ongeacht of hij door geboorte tevens een ander staatsburgerschap verkreeg.

\subsubsection{Naturalisatie}

De Poolse nationaliteitswet van 1962 kent zowel gewone, als verlichte naturalisatie. Verkrijging van de Poolse nationaliteit door gewone naturalisatie is geregeld in art. 8 van de wet van 1962. De bevoegdheid om het staatsburgerschap te verlenen ligt bij de Raad van State (art. 13). Ook de huidige wet is bijzonder zuinig met het noemen van naturalisatievereisten. In het eerste lid van art. 8 wordt een verblijf van minstens vijf jaren voorafgaande aan het indienen van een naturalisatieverzoek vereist. Deze eis wordt vervolgens in het tweede lid gemitigeerd door de mogelijkheid om bij aanwezigheid van bijzonder gronden daarvan af te wijken. Uit de praktijk blijkt dat de Raad van State niet zelden van de verblijfseis afwijkt

107. Kokot/Rysiak, p. 51; Seniuta, p. 107.

108. Gelberg, PiP 1962, p. 335.

109. Rarnus, p. 293.

110. Kokot/Rysiak, p. 51; Gelberg, PiP 1962, p. 335-336.

111. Kokot/Rysiak, p. 51; Swiatkiewicx, Panstwo i zycie $1962 / 6$, p. 2.

112. Kokot/Rysiak, p. 51; Seniuta, p. 90 . 
en dat zelfs personen die niet in Polen wonen, worden genaturaliseerd ${ }^{113}$. Het tweede vereiste is, dat van betrokkene kan worden geëist dat hij een bewijs van het verlies van zijn oude nationaliteit moet overleggen. (art. 8 lid 3). Reeds uit de bewoordingen van deze bepaling blijkt dat de Raad van State van dit vereiste naar believen mag afzien.

\subsubsection{Invloed op de nationaliteit van de gezinsleden van de verzoeker}

Met betrekking tot medenaturalisatie van minderjarige kinderen wordt onderscheid gemaakt tussen gevallen waarin de nationaliteit aan beide ouders wordt verleend en gevallen waarin slechts één van de ouders wordt genaturaliseerd. Indien het staatsburgerschap aan beide ouders wordt verleend, worden hun kinderen die onder hun ouderlijk gezag staan en jonger zijn dan 16 jaar, automatisch in de naturalisatie inbegrepen (art. 8 lid 4). In het geval dat slechts én van de ouders wordt genaturaliseerd, worden kinderen onder 16 jaar meegenaturaliseerd, indien er zich één van de volgende gevallen voordoet:

- de naturalisandus oefent alleen het ouderlijk gezag uit (art. 8 lid 5 sub 1);

- de ander ouder bezit reeds de Poolse nationaliteit (sub 2) of

- de andere ouder verleende voor medenaturalisatie van het kind zijn toestemming (sub 3).

Ten aanzien van kinderen die onder voogdij staan is de toestemming van de voogd vereist, die naar de (vorm)voorschriften van het nationale recht van het kind en voogd moet geschieden (art. 8 lid 6) ${ }^{114}$.

Kinderen die 16 jaar of ouder zijn moeten steeds zelf met hun medenaturalisatie instemmen (art. 8 lid 6).

\subsection{Verlichte naturalisatie}

De wet van 1962 geeft aan bepaalde categorieën verzoekers de mogelijkheid om op eenvoudige wijze te worden genaturaliseerd. Het gaat om:

- kinderen van én Poolse en één buitenlandse ouder die niet reeds van rechtswege het Poolse staatsburgerschap verwierven (art. 6 lid 3);

- buitenlandse vrouwen die met Polen in het huwelijk treden (art. 10);

- ex-Poolse vrouwen die deze nationaliteit door, of in verband met een huwelijk met een buitenlander hebben verloren (art. 11) en

- in Polen woonachtige apatriden.

113. Dit geldt met name ten aanzien hernaturalisatie van degenen die ooit de Poolse nationaliteit bezaten en die w66r 1939 emigreerden. Kokot/Rysiak, p. 55; Ramus, p. 397.

114. Ramus, p. 300 . 
De bevoegdheid om aan bovengenoemde personen de nationaliteit te verlenen ligt bij besturen van "wojewodschappen" waarin betrokkene woont (art. 17 lid 1) en indien de werzoeker in het buitenland woont, bij de consulaten (art. 17 lid 2). Eigenaardig is overigens dat tegen een beslissing van een bestuur van een wojewodschap ingevolge de wet op administratieve procedure van $1960^{115}$ beroep mogelijk is en tegen een besluit van een consulaat niet. De reden hiervoor ligt in het feit dat deze wet alleen ten aanzien van administratieve organen in het binnenland geldt ${ }^{116}$. Hieronder zullen de regeling van verlichte naturalisatie ten aanzien wan elke categorie verzoekers kort worden besproken.

\section{a. Kinderen van één Poolse en één buitenlandse ouder}

Aan kinderen die uit één Poolse en eén buitenlandse ouder worden geboren en die niet reeds krachtens hun geboorte de poolse nationaliteit bezitten, geeft art. 6 lid 3 de mogelijkheid om op eenvoudige wijze alsnog het Poolse staatsburgerschap te verwerven. Betrokkene moet bij het indienen van het naturalisatieverzoek niet jonger dan 16 jaar en niet ouder dan 18 en een half jaar zijn. Andere naturalisatievereisten worden aan de verzoeker niet gesteld. Deze regeling lijkt veel op verkrijging van de nationaliteit door optie, maar het staatsburgerschap wordt pas verworven door de beslissing van het bevoegde orgaan, die een constitutief karakter heeft ${ }^{117}$.

\section{b. Huwelijksnaturalisatie}

Een buitenlandse vrouw die met een Pool in het huwelijk treedt, heeft binnen een termijn van drie maanden na de huwelijkssluiting de mogelijkheid van verlichte naturalisatie. Anders dan bij de zojuist beschreven regeling van art. 6 lid 3 heeft hier de beslissende instantie de mogelijkheid verlening van de nationaliteit afhankelijk te stellen van het overleggen van een bewijs van verlies van de oude nationaliteit van de verzoekster. Tevens bestaat de mogelijkheid de naturalisatie op grond van redenen van staatsveiligheid of openbare orde te weigeren ${ }^{118}$. Door deze regeling werd de Poolse nationaliteitswet in overeenstemming gebracht met het verdrag van New York van 20 februari $1957^{119}$ betreffende de nationaliteit van de gehuwde vrouw. Gezien het feit dat deze mogelijkheid uitsluitend ten behoeve van vrouwen bestaat, kan hier worden geconstateerd dat art. 10 van de Poolse nationaliteitswet van 1962 afbreuk doet aan het beginsel van gelijkheid van geslachten door mannen te discrimineren ${ }^{120}$.

115. DzU. 1960, ar. 30, pos. 168.

116. Ramus, p. 312

117. Ramus, p. 307.

118. Ramus, p. 312; Kokot/Rysiak, p. 54; Seniuta, p. 103.

119. DzU. 1959 , nr. 56, pos. 334. Zie over dit verdrag p. 39.

120. Door Jessurun d"Oliveira, AAe 1985, p. 212 en door De Groot/Tratnik, p. 90-91, wordt overigens gesteld dat het verdrag van New York in zijn wezen ook vrouwen discrimineert. 


\section{c. Gewezen Poolse vrowwen}

Vrouwen die de Poolse nationaliteit door of in verband met een huwelijk met een vreemdeling hebben verloren en wier huwelijk vervolgens werd ontbonden of nietig verklaard, kunnen zich krachtens art. 11 lid 1 op eenvoudige wijze laten naturaliseren. Ook hier bestaat de mogelijkheid om verlening van de nationaliteit van het overleggen van een bewijs van tegenwoordige nationaliteit afhankelijk te maken (art. 11 lid 2). Deze mogelijkheid wordt niet tot een bepaald tijdstip na de beëindiging van het huwelijk begrensd ${ }^{121}$.

\section{d. Apariden}

Personen van onbekende nationaliteit en staatlozen kunnen na een vijfjarig verblijf in Polen op eenvoudige wijze worden genaturaliseerd ${ }^{122}$. Het wordt hierbij wordt niet vereist dat betrokkene reeds sedert zijn geboorte staatloos is. Apatridie op het tijdstip van het indienen van het verzoek is voldoende ${ }^{123}$.

\section{e. "Repatriëring"}

Verkrijging van de Poolse nationaliteit door "repatriëring" wordt geregeld in art. 12 van de wet van 1962 . Voorwaarden voor repatriëring zijn, dat betrokkene van Poolse afstamming of etnische nationaliteit is (pochodzenie of narodowos c) en dat hij een verblijfsvergunning voor onbepaalde tijd in Polen krijgt (art. 12 lid 1,2) ${ }^{124}$. ma de verkrijging van deze vergunning wordt de nationaliteit op het ogenblik van vestiging in Polen verworven. Van de verzoeker wordt geen verlies van de oude nationaliteit geëist ${ }^{125}$. Poolse etnische nationaliteit of afstamming moet blijken uit een onderzoek dat wordt verricht door Poolse vertegenwoordigingen in het buitenland, nadat betrokken een verzoek voor repatriëring heeft ingediend. Blijkens de toelichting ${ }^{126}$ moet betrokkene bewijzen dat hij met Polen verbonden is, waaronder moet worden verstaan: gebruik van de Poolse taal in het gezin, het vasthouden aan Poolse gebruiken, opvoeding van kinderen in "Poolse geest", etc.

\section{i. Invloed op de nationaliteit van de gezinsleden van de verzoeker}

Tezamen met de verzoeker verkrijgen de nationaliteit ook zijn kinderen die jonger zijn dan 16 jaar en onder zijn ouderlijk gezag staan. Indien sllechts eén van de ouders van het kind immigreert, wordt tevens de toestemming van de andere ouder vereist (art.12 lid 3). Kinderen van 16 jaar en ouder moeten zelf met de verkrijging van het staatsburgerschap instemmen (art. 12 lid 5). Voorts bepaalt het zesde lid van art. 12 dat degenen die de Poolse nationaliteit door repatriëring hebben

121. Seniuta, pu 102.

122. Ramus, p. 303 en Seniuta, p 97-98 spreken in dit geval over verkrijging van de nationaliteit door "erkenning".

123. Kokot/Rysiak, p. 55.

124. Ramus, p. 296; Seniuta, p. 90-91; Swiatkievicz, Panstwo i zycie 1962/6, p. 2.

125. Ramus, p. 298.

126. Zie de verwijzingen bij Ramus, p. 297; Kokot/Rysiak, p. 52. 
verkregen en later weer verliezen, deze niet meer op dezelfde wijze kunnen verwerwen ${ }^{127}$.

\subsection{Verlies van de nationaliteit}

De regeling van verlies van de Poolse nationaliteit is in de wet van 1962 in vergelijking met de vorige nagenoeg ongewijzigd gebleven. De belangrijkste wijziging houdt de aanpassing in van het Poolse nationaliteitsrecht aan het verdrag van New York van 1957 betreffende de nationaliteit van de gehuwde vrouw (art. 14 van de wet van 1962). Het Poolse staatsburgerschap kan worden verloren door ontslag en door ontneming. Het verlies van de nationaliteit van rechtswege of door het afleggen van een verklaring van afstand kent het Poolse nationaliteitsrecht niet meer.

\subsubsection{Ontslag}

Evenals onder de vigeur van de wet van 1951 wordt ook thans het ontslag uit de Poolse nationaliteit geconstrueerd als "verlies van het staatsburgerschap door verkrijging van een andere nationaliteit met toestemming van de bevoegde Poolse instantie" (art. 13 lid 1). De wetgever gaat er namelijk nog steeds van uit dat een Pool slechts met toestemming van overheidswege een ander staatsburgerschap kan verkrijgen ${ }^{128}$. Op deze plaats moet nogmaals worden benadrukt dat verkrijging van de nationaliteit van een staat uitsluitend van de regels van die staat afhankelijk is. Het verlies van de Poolse nationaliteit ex art. 13 dient derhalve te worden gekwalificeerd als ontslag uit het Poolse staatsburgerschap onder de opschortende voorwaarde van verkrijging van een andere nationaliteit ${ }^{129}$. Ontslag is uiteraard slechts voorwaardelijk indien de toestemming wordt verleend vórdat betrokkene een ander staatsburgerschap heeft verworven.

De bevoegdheid voor het verlenen van ontslag legde de wet van 1962 aanvankelijk bij de Raad van State (art. 16 lid 1) die op voordracht van de Minister van binnenlandse zaken zijn beslissing zou nemen ${ }^{130}$. In het derde lid van art. 16 werd voorzien in de mogelijkheid dat de Raad van State de Minister van binnenlandse zaken zou kunnen machtigen om aan in het buitenland wonende verzoekers zelf ontslag te verlenen. De Raad van State kon volgens de oorspronkelijke regeling tevens bepalen, dat deze Minister deze bevoegdheid ten aanzien van in het buitenland wonende verzoekers via zijn collega van buitenlandse zaken aan hoofden van consulaten mocht overdragen. Deze delegatiemogelijkheid bestond echter slechts indien betrokkene reeds een vreemde nationaliteit bezat ${ }^{131}$. Bij besluit van 10 januari $19644^{132}$ maakte de Raad van State inderdaad gebruik van zijn delegatiebevoegdheid. Op grond van dit besluit werden de hoofden van consulaten

127. Ramus, p. 296; Seniuta, p. 90.

128. Ramus, p. 314.

129. Betrokkene moet in zijn werzoek aangeven welke nationaliteit hijj wenst te verkrijgen. Indien de "toestemming" wordt verleend, verliest deze echter niet haar werking indien de verzoeker een ander dan het aangegeven staatsburgerschap verwerf. Ramus, p. 316.

130. Ramus, p. 317.

131. Kokot/Rysiak, p. 58.

132. Beslluit nr. 4/64. Zie Kokot/Rysilak, p. 57-58. 
in een aantal Westerse landen bewoegd om zelf ontslag te verlenen ${ }^{133}$. Bij de consulaire wet van 13 februari $1984^{134}$ werd de bevoegdheid met betrekking tot het verlenen van ontslag aan alle in het buitenland wonende personen vervolgens door de wetgever zelf bij de consuls gelegd.

De wet bepaait niet aan welke voorwaarden het ontslag uit de Poolse nationaliteit wordt verbonden. Aangenomen mag worden dat de verzoeker in ieder geval zijn militaire dienstplicht moet hebben vervuld. In de praktijk wordt het ontslag wordt in de regel slechts verleend nadat men met de toesternming van Poolse autoriteiten vijf jaren in het buitenland heeft gewoond ${ }^{135}$.

Geconstateerd moet worden, dat de administratie ook bij ontslag over onbeperkte discretionaire bevoegdheid beschikt. Blijkens art. 1 lid 1 en art. 3 lid 2 sub 4 van de wet betreffende de administratieve procedure bestaat er geen mogelijkheid om tegen een negatieve beslissing beroep in te stellen.

Polen kent evenals Hongarije en Joegoslavië in zijn paspoortwetgeving een zeker recht om het land te verlaten, echter met ruime mogelijkheden om het uitreisvisum willekeurig te weigeren. In de praktijk worden de weigeringsgronden evenwel restrictief geinterpreteerd en kent Polen na Joegoslavië en Hongarije de grootste uitreisvrijheid in Oost-Europa ${ }^{136}$.

\subsubsection{Invloed op de nationaliteit van de gezinsleden van de verzoeker}

Tegelijkertijd met hun beide ouders worden ook kinderen die onder hun ouderlijk gezag staan automatisch meeontslagen (art. 13 lid 2). Voor het geval dat slechts ến van de ouders om ontslag verzoekt, worden kinderen automatisch meeontslagen indien:

- $\quad$ uitsluitend de verzoeker het ouderlijk gezag uitoefent;

- de andere ouder niet de Poolse nationaliteit bezit; of

- de andere ouder voor het ontslag van het kind zijn toestemming verleende (art. 13 lid 3). Deze toestemming kan blijkens art. 13 lid 4 door een rechterlijke beslissing worden vervangen.

Ook hier geldt het algemene uitgangspunt dat kinderen van 16 jaar en ouder zelf met hun ontslag moeten instemmen (art. 13 lid 5).

133. Zie daarover Rannus, p. 316.

134. Da.U. 1984, nr. 9 , pos. 34 .

135. Tot juli 1983 werd mell betrekking tot etrische Duitsers een andere praktijk toegepast. Na de toestemming om het land te verlaten werd ben een paspoort voor staatlozen uilgereikl en ging de nationaliteit verloren op het moment dat zij de Poolse grens owerschreden. Zie Menschenrechte, p. 111; Hecker Behandlung, p. 105 106, 113; Bundestag, Drs. 7/5755 van 13 september 1976 en Drs. $10 / 869$ van 6 januari 1984. Zie over etnisch Duitse emigranten wit Polen ook de afspraak tussen de BRD en Polen van 9 oktober 1975; Bulletin des Presse- und Informationsamtes der Bundesregierung nr. 121 van 10 oktober 1975, p. 1199 en Seeler, NJW 1978, p. 924-927.

136. De paspoortwet werd laatstelijk gewijzigd in 1983, Dz. U. 1983, m. 66, pos. 298. Daarover Kuss, EuGRZ 1987, p. 306-307, 312. In de jaren 1971-1985 hebben 353.000 etaische Duitsers en 49.000 etnische Polen het land legaal verlaten. Zie ook Oschlies, Berichie des BOIS 18/1982. 


\subsection{Ontslag in verband met huwelijk}

Conform art. 3 van het verdrag van New York betreffende de nationaliteit van de gehuwde vrouw bestaat in art. 14 wan de Poolse nationaliteitswet de mogelijkheid om op eenvoudige wijze uit het Poolse staatsburgerschap te worden ontslagen. Deze weg staat open voor:

- Poolse vrouwen die door of in verband met een huwelijk met een vreemdeling ${ }^{137}$ een vreemde nationaliteit hebben verworven art. 14 aanhef en lid 1) en

- vrouwen die door of in verband met een huwelijk met een Pools onderdaan de Poolse nationaliteit verkregen en wier huwelijk werd ontbonden of nietig werd verklaard en die tevens een ander staatsburgerschap bezitten (art. 14 lid 2).

Het ontslag wordt verleend door besturen van wojewodschappen indien de verzoekster in Polen woont en, ten aanzien wan in het buitenland woonachtigen, door consulaten.

Het ontslag ex art. 14 is slechts mogelijk ten aanzien van de verzoekster persoonlijk. Haar kinderen kunnen uitsluitend zelfstandig, in de "gewone" procedure worden ontslagen ${ }^{138}$. Tegen een beslissing van een bestuur van een wojewodschap is beroep mogelijk, tegen een besluit van een consulaat echter niet ${ }^{139}$.

\subsubsection{Ontneming}

De regeling van ontneming van het staatsburgerschap is in de huidige nationaliteitswet in vergelijking met zijn voorganger nagenoeg ongewijzigd gebleven ${ }^{140}$. De bevoegdheid om de nationalliteit te ontnemen ligt uitsluitend bij de Raad van State, die op voorstel van de minister van buitenlandse zaken zijn beslissing neemt (art. 16 lid 3). Het staatsburgerschap kan slechts worden ontnomen indien betrokkene in het buitenland verblijft. De gronden voor ontneming zijn de volgende (art. 15):

- schending van de loyaliteitsplicht (sub 1);

- handelingen die belangen van het Poolse volk ernstige schade kunnen toebrengen (sub 2);

137. Eigenaardig hierbij is dat het om een vreemdeling "naar Pools recht" moet gaan. Dit betekent dat iemand die naast een vreemde ook de Poolse nationaliteit bezit niet als "vreemdeling" wordt aangemerkt. De consequentie hiervan is, dat de weg wan art. 14 niet openstaat voor cen Poolse vrouw die bijwoorbeeld met een Pools/Nederlandse man huwt. Zie ook Ramus, p. 320; Kokot/Rysiak, p. 57 .

138. Ramus, p. 320 .

139. Ramus, p. $312,320$.

140. Ramus, p. 322 . 
- het illegaal werlaten van het land (sub 3) ${ }^{141}$;

- het niet-terugkeren naar Polen op vordering van het bevoegde orgaan (sub 4);

- het ontwijken van de militaire dienstplicht (sub 5);

- herhaalde strafrechtelijke veroordeling in het buitenland voor een delict dat ook in Pollen strafbaar is (sub 6).

Terwijl de ontnemingsgronden onder 3-6 met voldoende nauwkeurigheid zijn omschreven, bieden de onder 1 en 2 genoemde door hun vage formulering voldoende mogelijkheden om het staatsburgerschap willekeurig te ontnemen ${ }^{142}$. Ook uit het feit dat de Raad van State bij aanwezigheid van de zojuist omschreven feiten en omstandigheden de nationaliteit kan ontnemen, blijkt dat dit instrument door de administratie willekeurig kan worden gehanteerd.

\subsection{Invloed op de nationaliteit van gezinsleden van betrokkene}

Ontneming van de nationaliteit heeft geen gevolgen voor de huwelijkspartner en minderjarige kinderen van betrokkene ${ }^{143}$. Uiteraard kan aan hen de nationaliteit "zelfstandig" worden ontnomen.

141. In Polen is evenals in werschillende andere Oosteuropese landen een tendens naar "legalisering" van het verblijf van illegale emigranten waarneembaar en de nationalliteit wordt uitsluitend op deze grond niet meer ontnomen. Zie Menschenrechte, p. 112. Ook degenen die naar Polen terugkeren worden in de regel niet wegens "Republikflucht" vervolgd, wel ewentueel wegens. spionage of bekendmaking van statsgeheimen, in verband met hun uitatingen tegenover builtenlandse autoriteiten. Zie Geistlinger, ROW 1987 , p. 224-225.

142. Ook Ramus, p. 323 geeft toe dat de formuleringen erg vaag zijn en dat bij de toepassing ervan "problemen kuninen ontstaan".

143. Kokot/Rysiak, p. 59. 


\section{HOOFDSTUK 9. ROEMENIË}

\subsection{GraschiEDENIS}

\section{1 .1 Inleiding}

Roemenie ontstond in de jaren 1859-61 door de vereniging van de vorstendommen Moldavië en Walachije, die onder Turkse heerschappij stonden ${ }^{1}$. Op 1 juli $1866^{2}$ kwam vervolgens de eerste Roemeense grondwet tot stand, alhoewel de nieuwe staat zich pas op 9 meil 1877 onafhankelijk verklaarde ${ }^{3}$. Roemenië werd éen jaar later bij de verdragen van San Stefano ${ }^{4}$ en van Berlijn ${ }^{5}$ internationaal erkend ${ }^{6}$. In $1881^{7}$ werd Roemenië een koninkrijk onder koning Karol I. In de eerste wereldoorlog vocht Roemenië vanaf 1916 aan de zijde van de Entente. Op grond van de vredesverdragen $^{8}$ werd het Roemeense grondgebied vervolgens met de door etnische Roemenen bevolkte voormalige Oostenrijks- Hongaarse gebieden Transsylvanië en Boekowina uitgebreid ${ }^{9}$. Bessarabiê, dat tot de Roemeense bezetting in 1918 onder Russische heerschappij stond, werd op grond van het verdrag van Parijs van 28 oktober 1920 eveneens een onderdeel van het Roemeense koninkrijk ${ }^{10}$. Op 28 maart $1923^{11}$ werd de oude grondwet van 1866 door een nieuwe vervangen, die later, op 27 februari $1938^{12}$, werd genovelleerd. Het jaar 1940 bracht Roemenië nieuwe grondgebiedswijzigingen. Zo moest het land Bessarabië en Noord-Boekowina aan de Sovjetunie afstaan ${ }^{13}$, terwijl op grond van

1. Beide vorstendommen werden verenigd op grond van het protocol wan Wemen van 3 juni 1855 , State Papers 45, 54 en van de slotakte van het congres van Parijs van 19 augustus 1858, State Papers 48, 81; Zie Albin, p. 22. De proclamatie van de vereniging vond plaats op 15 december 1961, State Papers 52, 510. Zie Colson, p. 254; Mano, 157; SGS deel 5, p. 58; Wolloch, p. 9; Peaslee, p. 765; Suga, OER 1973, p. 2; Cismarescu, p. 4 (de laatste twee auteurs vermelden als het jaar van vereniging 1859 , toen tussen beide vorstendommen een personele unie ontstond. $\mathrm{Cf}$. Mano, p. 144).

2. M.O. (Monitorul Official) van 1 juli 1866; State Papers 57, 263. Peaslee, p. 765.

3. Suga, OER 1973, p. 2; Wolloch, p. 10 .

4. Verdrag van 3 maart 1878 , State Papers 69,732 ; art. 5 ; Albin, p. 190.

5. Verdrag van 13 juli 1878 ; State Papers 69,749 ; art. 43 ; Albin, p. 224.

6. Suga, OER 1973, p. 2; Wolloch, p. 10; Peaslle, p. 765.

7. Bij een wet van 26 maart 1881 , State Papers $72,1102$.

8. Het verdrag van Versailles van 28 juni 1919 met Duitsland; M.O. 1920, nr. 134; het verdrag van Saint Germain-en-Laye van 10 september 1919 met Oostenrijk; M.O. 1920, 140; het verdrag van Newilly van 27 nowember 1919 met Bulgarije; M.O. 1920, nr. 135 en bet verdrag wan Trianon van 4 juni 1920 met Hongarije; M.O. 1920 , nr. 136.

9. Dutzak, p. 3; Suga, OER 1973, p. 2; Makarow, ZaüRV 1940-41, p. 351-355; Wolloch, p. 10.

10. Het verdrag tussen Frankrijk, Groot-Brittannie, Italië, Japan en Roemenië, State Papers 113, 647; M.O. 1922, mr. 100. Dit werdrag trad echter mooit in werking, omdat het door Japan niet werd geratificeerd. Bessarabië werd na de Roemeense occupatie in maart 1918 reeds op 1 januari 1920 bij Roemenie ingelijfd. Noch het verdrag, noch de anmexatie werden door de USSR erkend. Zie daarover Makarov, ZaöRV 1940-41, p. 336-351; Dutzak, p. 4; Suga, OER 1973, p. 2; SGS deel 5 , p. 66 .

11. M.O. 1923, nr. 282 .

12. M.O. 1939 , nr. 42.

13. Deze gebieden werden op 28 juni 1940 door de USSR bezet. Suga, diss. p. 22; Zie Makarov, ZaöR 1940-41, p. 355-359; SGS deel 5, p. 67; Wolloch, p. 11. 
de "Wiener Scheidsspruch" van 30 augustus ${ }^{14}$ en van het verdrag van Craiova van 7 september ${ }^{15}$ gedeelten van Transsylvanië en van de Dobroedsja bij Hongarije, respectievelijk Bulgarije werden ingelijfd ${ }^{16}$. In november 1940 sloot Roemenië zich aan bij het "Driemachtenpact" en op 22 juni 1941 trad het land in de oorlog tegen de Sovjetunie, hetgeen tot 23 augustus 1944 duurde ${ }^{17}$. Een dag later werd door de koning Michael een coup d'état gepleegd en nog op dezelfde dag verklaarde Roemenië de oorlog aan Duitsland ${ }^{18}$. Met de geallieerden sloot Roemenië vervolgens op 12 september 1944 een wapenstilstandsverdrag ${ }^{19}$. Verder werd bij een koninklijk decreet de grondwet van 1938 buiten werking gesteld en vervangen door de oude van $1923^{30}$. Ofschoon Roemenië in 1944 van partij "wisselde" werd het door de geallieerden als een Duitse bondgenoot behandeld. Op grond van het vredesverdrag van Parijs van 10 februari $1947^{21}$ werden de grondgebiedsveranderingen van 1940 gedeeltelijk ongedaan gemaakt: het aan Hongarije afgestane gedeelte van Transsylvanië werd wederom Roemeens ${ }^{22}$, terwijl Bessarabië en NoordBoekowina onder de heerschappij van de USSR bleven.

In de jaren 1944-45 werden verschillende coalitieregeringen gewormd, waarin de communistische partij pas sinds 6 maart 1945 de meerderheid had ${ }^{23}$. Nadat de communisten alleen de macht in handen kregen, werd op 30 december $1947 \mathrm{de}$ koning gedwongen te abdiceren ${ }^{24}$. Op dezelfde dag nog werd de Volksrepubliek Roemenië geproclameerd. Het communistische regime kondigde op 17 april 1948 een nieuwe grondwet af ${ }^{25}$. Deze werd vervolgens meermalen gewijzigd ${ }^{26}$. Bij de wijziging van 21 augustus 1965 veranderde de naam Volksrepubliek (Republica Populara) in Socialistische republiek (Republica Socialista) ${ }^{27}$.

Roemenië is sedert de oprichting van het Warschaupact en de COMECON lid van de beide organisaties. Binnen het Warschaupact neemt het echter een iets zelfstandigere positie in.

14. Zie SGS deel 5, p. 93-94; Zä̈RV 1940-41, p. 746.

15. M.O. 1940, nr, 212, Duitse vertaling in 2 foR $1940-41$, p. 490 .

16. Suga, OER 1973, p. 2; Korkisch, ZaóRV 1940-41, p. 707-745; Praslec, p. 765; Wolloch, p. 11, 12.

17. Suga, OER 1973, p. 2 .

118. Suga, OER 1973, p. 2; Wolloch, p. 12.

19. Suga diss. p. 13.

20. MO. 1944, nr. 202; Suga, OER 1973, p. 2; Cismarescu, p. 212

21. Guratificeerd door het Roemeense parlement op 23 augustus 1947; Suga diss., p. 25 en OER 1973, p. 2 .

22. Wolloch, p. 12.

23. Wolloch, p. 212-213.

24. Sichultz, p. 142, 148 .

25. M.O. 1948, nt 87 bis. Deze grondwet werd duidelijk door de townalige constituties vasn de Sowjetunie en Joegoslavie geinspireerd. Zie Schultz, JöR 1966, p. 419 e.v.

26. Op 27 september 1952, B.O. (Butetinul Official, de opvolger van M.O. sedert matri 1949) 1952, ar. 1; 20 augustus 1965, B.O. 1965, nr. $1 ; 16$ februari 1968, B.0. 1968, nir. 10; 8 april 1974, B.0. 1974 , nr. $56 ; 27$ december 1974, B.O. 1974, nir. 167; 28 maarl 1975, B. O. 1975, nir. 30; 14 december 1979, B.O. 1979, nir. 103 .

27. Wolloch, p. 14. 


\subsubsection{Het nationaliteitsrecht tot 1944}

\subsubsection{Algemeent}

De eerste regelingen van de Roemeense nationaliteit zijn te vinden in de naturalisatieverordeningen van de vorstendommen Walachije en Moldavië van 1832, die ook na de vereniging van beide vorstendommen nog enige tijd werden toegepast ${ }^{28}$. Vervolgens bracht het burgerlijk wetboek van 1865 (Codul Civil) in artt. $8-20^{29}$ een nieuwe regeling, die sterk door de Franse Code civil werd geinspireerd ${ }^{30}$. Voorts bevatten ook de grondwet van $1866^{31}$ (artt. 7-9 en 30) en de grondwetsnovelle van $1879^{32}$ (art. 7) enkele op de nationaliteit betrekking hebbende bepalingen. $\mathrm{Na}$ de eerste wereldoorlog werd de naturalisatie van buittenlandse Joden geregeld bij de wet van 27 augustus 1918, die vervolgens in de jaren 1918 en 1919 bij een serie van "decreet-wetten" ${ }^{33}$ werd gewijzigd. Voorts werden ten aanzien van de nationaliteit van de bewoners van een gedeelte van de Dobroedsja enkele bijzondere regelingen vervaardigd ${ }^{34}$. De eerste Roemeense algemene nationaliteitswet kwam op 23 februari $1924^{35}$ tot stand. Deze wet werd vergezeld door de verordening van 15 april $1924^{36}$ betreffende de vaststelling van de nationaliteit. Nadere regels betreffende verkrijging en verlies van de nationaliteit werden voorts opgenomen in de verordening van 16 mei $1924^{37}$. Tijdens zijn geldigheidsduur werd de wet van 1924 meermalen gewijzigd. Dit geschiedde bij de volgende regelingen:

- decreet-wet van 29 mei $1928^{38}$ betreffende wijziging van art. 67 ;

- decreet-wet van 17 oktober $1932^{39}$ strekkende tot een nieuwe wijziging van art. 67 ;

- bij decreet-wet van 19 mei $1934^{40}$ werd art. 10bis ingevoegd;

28. SGS deel 5, p. 58 .

29. Zie voor een Duitse vertaling daarvan Polizei Hamburg p. 168-169.

30. Djuvara, p. 20; Wolloch, p. 53-56.

31. M.O. 1966, nr. 142. Deze grondwet werd overigens sterk door de Belgische constitutie van 1931 geünspireerd. Cismarescu, p. 9.

32. M.O. 1879, mr. 232 Duitse vertaling van de grondwet in de versie van 1879 in Polizeil Hamburg p. 170-171. Dearawer Wolloch, p. 57-59.

33. Dit waren de "decreet-wetten" van: 29 december 1918, M.O. 1918, nr. 223; van 2 mei 1919, M.O. 1919 , ar. 33 en van 12 augustus 1919, M.O. 1919, nr. 93.

34. Dat waren de wet van 23 juli 1921, M.O. 1921, nr. 89 met de daarbij behorende verordening vam 8 september 1921, M.O. 1921, nr. 136; deze verordening werd vervolgens gewijzigd bij decreet van 27 december 1921, M.O. 1921, nr. 219.

35. M.O. 1924, nr, 41; in werking getreden op 24 februari 1924. Duitse wertaling in Bl.f.Vergl.Rwiss 1923 , p. 135; Franse in RDIP 1924, p. 468 en Clunet 1925 , p. 838 . Zie daarover Wolloch, p. 79 ; De Lapradelle/Niboyet, p. 737-742.

36. M.O. 1924, nr. 85, Dutzak, p. 1.

37. M.O. 1924, ar, 104 .

38. M.O. 1928, ar. 119 .

39. M.O. 1932, ar. 244.

40. M.O. 1934, nr. 115. 
- decreet-wet van 19 april $1938^{41}$ betreffende ontneming van de nationaliteit;

- wet van 14 juni $1938^{42}$, eveneens betreffende ontneming van de Roemeense nationaliteit en

- decreet-wet van 15 september $1938^{43}$.

Onder de invloed van Duitsland werd op 21 januari $1938^{44}$ een decreet-wet uitgevaardigd, die een "algemene heroverweging" van de Roemeense nationaliteit van Joden invoerde. De strekking van deze regeling werd op frappante wijze verwoord door Gündisch:

"Wenngleich dieses Gesetz eine allgemeine Uberprüfung vorsieht, so hat es doch eine unverkennbar scharfe Spitze gegen das Judentum und mit Recht.

Aus dem bolschewistischen Russland und aus dem im Jahre 1919 und auch noch 1920 kommunistischen Ungarn waren ungezählte Juden über die bessarabische und ungarische Grenze nach Rumänien eingewändert, hatten sich hier niedergelassen und gewannen gestützt von ihren Rassengenossen immer mehr an Einfluss. Handel und Industrie sind heute in Rumänien bis zu $50 \%$ und darüber in jüdischen Händen, ebenso die Presse. ${ }^{15}$

Deze regeling werd aangevuld met decreet-wet van 11 februari $1938^{46}$ en gewijzigd bij decreet-wet van 5 maart $1938^{47}$. In 1946 werden vervolgens alle besluiten die op grond van de decreet-wet van 1938 werden genomen, nietig verklaard ${ }^{48}$.

Volkenrechtelijke verplichtingen van Roemenië op het gebied van het nationaliteitsrecht werden neergelegd in de reeds genoemde vredesverdragen na de eerste wereldoorlog. Daarnaast ondertekende Roemenië het "Minderheitenschutzvertrag" van 9 december $1919^{49}$, dat mede betrekking had op de nationaliteit van de bewoners van de na de eerste wereldoorlog bij Roemenië ingelijfde gebieden. Op 13 oktober $1923^{50} \mathrm{kwam}$ ook een verordening strekkende tot uitvoering van deze verdragen tot stand. In de tijd vór de tweede wereldoorlog sloot Roemenië nog de volgende verdragen, die (mede) betrekking op de nationaliteit hadden:

het reeds op p. 258 genoemde verdrag van 28 oktober 1920 mede betreffende de inlijving van Bessarabië;

41. M.O. 1938 , nr. 92 .

42. M.O. 1938 , nr. 34 .

43. M.O. 1938, $\operatorname{nr}^{2} 219$.

44. MO. 1938, mr. 18, Duitse vertaling in ZfoR 1938, p. $51-58$.

45. Gündisch, ZfoR 1938 , p. 50 . Zie daarover ook Wolloch, p. $109-112$.

46. M.O. 1938 , nr. 35 .

47. M.O. 1938 , nr. 54 .

48. M.O. 1947, nr. 121. Zie Wolloch, p. 121.

49. LNTS V, 336; M.O. 1920, nr. 140 .

50. M,O. 1924, nr. 41. 
- verdrag van Rome van 6 april $1922^{51}$, dat door Roemenië echter nooit werd geratificeerd;

- grensprotocol met Joegoslavië van 24 november $1923^{52,}$

- verdrag van 30 januari $1933^{53}$ met Joegoslavië met aanvullend protocol van 13 maart 1935;

- migratieverdrag met Turkije van 4 september $1936^{54}$;

- verdrag van Craiova van 7 september $1940^{55}$ met Bulgarije, betreffende het gebied Dobroedsja;

- migratieverdrag met Duitsland van 22 oktober $1940^{56}$ met het aanvullende verdrag van $27-30$ meil $1941^{57}$.

Op de nationaliteit had tenslotte ook betrekking art. 3 van de "Wiener Schiedsspruch" van 30 augustus $1940^{58}$ betreffende de inlijving van Transsylvanië bij Hongarije.

\subsubsection{De wet van 1939}

\subsection{Algemeen}

Op 20 januari $1939^{59} \mathrm{kwam}$ een nieuwe algemene regeling van de Roemeense nationaliteit tot stand. Deze wet werd reeds in de loop van het eerste jaar tweemaal gewijzigd ${ }^{60}$. Hieronder volgt een bespreking van de wet van 1939 , zoals deze na beide wijzigingen gold.

51. LNTS XX, 12. Dit was een nationaliteitsrechtelijk verdrag tussen Roemenie, Oostenrijk, Hongarije, Italiè, Pollen en Joegoslaviè. Zie SGS deel 27, p. 353 en deel 30, p. 77.

52. Engelse vertaling in State Papers 123,1048 . Op de nationaliteit had betrekking art. 7.

53. M.O. 1933, nr, 22; LNTS CLXVI, 174; Duitse vertaling in SGS deel 17, p. 125. Het verdrag had in zijn geheel betrekking op het nationaliteitsrecht. Het protocol van 13 maart 1935 had betrekking op art. 3 wan het verdrag. Zie woor het protocol MCO. 1935, nr. 122, LNTS CLXXIX, 58 ; Duitse vertaling in $\$$ GS deel 17 , p. 126.

54. M.O. 1936, mar. 264, CXI.V, 429 met notawisseling betreffende art. II, LNTS CXLV, 438.

55. M.O. 1940, 212; State Papers 144, p. 247. Op de nationaliteit had betrekking annex $C_{n}$ Duitse vertaling datrwan in SCS deel 5, p. 64-65.

56. M.O. 1940, nr. 254; op de nationaliteit had betrekking art. 1 .

57. M.O. 1942 , ar. 76.

58. SGS deel 5, p. 93-94; State Papers 144, 338.

59. M.O. 1939, nr. 17; in werking getreden op 1 februari 1939; Duitse vertaling in SGS deel 5, p. 7182; Engelse in State Papers 149, 856. Zie over deze wet Djuwara, La legislation Roumaine en matière de nationalite, diss. Paris 1940; Keschmann, ZfoR 1938-39, p. 710-727 en ZfoR 1939, p. 96-101; Lichter, StAZ 1940, p. 65-68; Wolloch, Die geschichtliche Entwicklung des Staatsangehörigkeitsrechts in Rumänien, Frankfurt am Main/Bern/New York/Paris 1988.

60. Wet van 27 juli 1939, M.O. 1939, nr. 171; Duitse wertaling met een inleiding van Keschmang in ZfoR $1939-40$, p. $96-101$ en de wet van 20 oktober 1939, M.O. 1939, ar. 243; Duitse vertaling met een inleiding van Keschmann in ZfoR 1939-40, p. 299-303. 
Ook de Roemeense wet van 1939 kende de "traditionele" bepaling dat een Roemeense staatsburger niet tegelijkertijd de nationaliteit van een andere staat mocht bezitten (art. 2).

\subsection{Verkrijging van de nationaliteit}

De Roemeense nationaliteit kon volgens de wet van 1939 van rechtswege, door optie en door naturalisatie worden verkregen. Verkrijging van de nationaliteit door optie werd slechts voorzien ten aanzien van ex-Roemeense vrouwen die hun nationaliteit door huwelijk verloren. Gezien het zeer specifieke karakter van deze optie zal deze bij het verlies van de nationaliteit door huwelijk (p. 267) worden besproken.

\section{a. Verkrijging van rechtswege}

Verkrijging van de Roemeense nationaliteit werd van rechtswege gekoppeld aan de volgende feiten:

- geboorte uit Roemeense ouder(s) (art. 4 lid 1);

- geboorte op het Roemeense grondgebied (art. 4 lid 2);

- huwelijk met een Roemeen (artt. 7-8).

Adoptie door een Roemeen(se) kon geen verkrijging van de nationaliteit ipso iure bewerkstelligen en had ook overigens geen invloed op de nationaliteit van het geadopteerde kind (art. 5).

\section{i Geboorte uit Roemeense ouder(s)}

Iure sanguinis verwierf de Roemeense nationaliteit een wettig kind, waarvan de vader op het tijdstip van geboorte van het kind de Roemeense nationaliteit bezat. Het was daarbij niet van belang waar het kind werd geboren (art. 4 lid 1 sub1). Hetzelfde gold ten aanzien van een onwettig kind, waarvan de moeder de Roemeense nationaliteit bezat (sub 3).

De Roemeense nationaliteit werd voorts verkregen door een onwettig kind van een vreemdelinge, dat voor zijn 21 ste levensjaar door een Roemeense man werd erkend. In bepaalde gevallen ${ }^{61}$ werd het staatsburgerschap ook door gerechtelijke vaststelling van afstamming van een Roemeense vader verkregen (art. 4 lid 1 sub 2). Ook wettiging vóor de 21-jarige leeftijd van het kind bewerkstelligde verkrijging van de nationaliteit van rechtswege (art. 4 lid 1 sub 4). De verkrijging van het staatsburgerschap door het kind werkte ex tunc ${ }^{62}$. De nationali-

61. Roemenië kende twee "soorten" van gerechtelijke vaststelling van vaderschap. Slechts bij de zogenaamde "volledige" vaststelling ontstonden tussen de vader en kind familierechtelijke betrekkingen en werd door het kind de nationaliteit verworven. Zie Djuvara, p. 50; Wolloch, p. 119.

62. Djuvara, p. 52. 
teit werd ook verkregen, indien betrokkene op het tijdstip van vaststelling van het vaderschap, erkenning of legitimatie reeds gehuwd was (art. 6 lid 3).

Het is bijzonder interessant dat in de wet van 1939 de regeling van verkrijging van de nationaliteit door onwettige kinderen niet zelfstandig werd opgenomen, maar bij de verkrijging van de nationaliteit door afstamming werd gerubriceerd ${ }^{63}$.

\section{ii. Geboorte op het Roemeense grondgebied}

Iure soli verwierf de Roemeense nationaliteit een kind van onbekende ouders dat in Roemenië werd geboren (art. 4 lid 1 sub 5). Voorts vestigde art. 4 lid 2 een vermoeden van geboorte in Roemenië ten aanzien van kinderen, die op het Roemeense grondgebied werden gevonden. Deze praesumptio kon te allen tijde worden ontkracht, ongeacht de leeftijd van betrokkene ${ }^{64}$.

\section{iii. Huwelijk met een Roemeense man}

Ook in het Roemeense nationaliteitsrecht gold de hoofdregel, dat een buitenlandse vrouw, die met een Roemeense staatsburger in het huwelijk trad, daardoor automatisch de nationaliteit van haar man verwierf (art. 7 lid 1). In het tweede lid werd voorzien in de mogelijkheid orn verkrijging van de Roemeense nationaliteit te voorkomen, indien betrokkene door het huwwelijk haar oude nationaliteit niet automatisch verloor. Zij moest vór, of uiterlijk tijdens de huwelijksceremonie schriftelijk verklaren dat ze haar oude nationaliteit wenste te behouden ${ }^{65}$.

In het geval dat het huwelijk putatief bleek te zijn, dat het wegens schuld van de vrouw werd gescheiden, of dat haar man overleed, terwijl geen kinderen meer in leven waren, verloor de vrouw van rechtswege de Roemeense nationaliteit (art. 36 sub 3). Werd het huwelijk ongeldig verklaard en waren er geen levende kinderen, dan werd de vrouw zelfs geacht nooit de Roemeense nationaliteit te hebben bezeten (art. 8 lid 1). Waren in dit tweede geval wel kinderen aanwezig, dan bestond voor de vrouw de mogelijkheid om van de Roemeense nationaliteit afstand te doen (lid 2).

\section{b. Naturalisatie}

De Roemeense nationaliteitswet van 1939 kende een zeer uitgebreide regeling van naturalisatievereisten. Er werd ook een bijzondere, uit hoge rechters bestaande commissie ingesteld, die tot taak had om te onderzoeken of de verzoeker aan de naturalisatievereisten voldeed (artt. 32-33) ${ }^{66}$. Op grond van een positief advies van de commissie werd door de Minister van justitie een wetsontwerp ingediend, waarna de naturalisatie bij een formele wet volgde (art. 9) ${ }^{67}$. Om voor een naturalisatie in aanmerking te komen moest betrokken aan de volgende voorwaarden voldoen:

63. Cf. Kesclunaann, ZfoR 1938-39, p. 711-712.

64. Djuvara, p. 54 .

65. Djuvara, p. 52.

66. Keschmann, ZfoR 1938-39, p. 712.

67. Keschmann, ZfoR 1938-39, p. 712. 
- leeftijd van 21 jaar (art. 10 sub 1 );

- geestelijke en lichamelijke gezondheid (sub 2);

- verlies van de oorspronkelijke nationaliteit ${ }^{68}$ (sub 3 en 8 );

- onafgebroken tienjarig verblijf voorafgaande aan het verzoek (sub 4);

- goed gedrag (geen veroordeling wegens een niet-klachtdelict in Roemenië of in het buitenland, geen faillietverklaring en ook mocht de verzoeker geen handelingen hebben verricht die in strijd met de Roemeense belangen konden zijn (sub 5);

- de verzoeker mocht niet ongeneeslijk ziek zijn (sub 6) ${ }^{69}$;

- betrokkene moest voldoende middelen bezitten om zichzelf en zijn gezin te onderhouden, althans in staat zijn om deze te verwerven (sub 7);

- $\quad$ kennis van de Roemeense taal (sub 9) ${ }^{70}$.

Op grond van art. 11 kon aan de volgende categorieën verzoekers dispensatie van de vereisten sub 4 (tienjarig verblijf) en sub 7 (voldoende middelen van bestaan) worden verleend:

- degenen die in het Roemeense leger werden benoemd en zich door hun dapper gedrag hadden onderscheiden, of sedert hun benoeming reeds vijf jaren hadden gediend (sub 1);

- degenen die voor het Roemeense volk "nuttig" waren (sub 2) ${ }^{71}$;

- personen die met een Roemeense ${ }^{72}$ vrouw waren gehuwd (sub 3);

- afgestudeerden van universiteiten of hoge scholen in Roemenië of in het buitenland, indien hun opleiding in Roemenië was erkend (sub 4);

68. Sub 3 werd van betrokkene wereist dat hij een verklaring aflegde waarin hij zijn nationaliteit "opgaf". Deze verklaring had slechts werking indien zajn nationale recht in dat geval de mogetijkheid van afstand van de nationaliteit kende. Onder 8 werd echter vereist dat de naturalisandus aantoonde dat hij zijn vreemde nationaliteit door of tengevolge van de naturalisatie daadwerkelijk verloor. Cf. Keschmann, ZfoR 1938-39, p. 712.

69. Er werd een medische verklaring vereist. Djuwara, p. 63.

70. Betrokkene moest Roemeens kumen lezen en schrijwen. De taalkennis werd hetzij aan de hand van schoolrapporten, hetzij door een examen vastgesteld. Djuvara, p. 64.

71. Hierbij moet worden gedacht aan wetenschappers, uitvinders en belangrijke zakenlieden. Djuvara, p. 65 .

72. Volgens Djuvara, P. 66 moest het om een etnisch Roemeense vrouw gaan. 
- degenen die in Roemenië werden geboren en aldaar tot hun 21ste jaar haddem gewoond, voorzover ze v66r hun 22ste levensjaar het naturalisatieverzoek indienden (sub 5);

- personen die na hun 21ste jaar door een Roemeen werden erkend, gewettigd, of het vaderschap gerechtelijk werd vastgesteld (sub 6);

- kinderen van genaturaliseerde Roemenen, die niet in de naturalisatie van hun ouder(s) deelachtig waren (sub 7);

- vrouwen van genaturaliseerde Roemenen, die niet met hun mannen werden meegenaturaliseerd (sub 8$)^{73}$.

In alle gevallen werd vereist dat de naturalisandus een eed van trouw had afgelegd, waarna de naturalisatie pas rechtskracht kreeg (art. 12).

Interessant is dat een genaturaliseerde Roemeen niet dezelfde politieke rechten had als degene, die deze nationaliteit van rechtswege verwierf ${ }^{74}$. Zo konden genaturaliseerde Roemenen in bepalde functies ${ }^{75}$ in het geheel niet worden benoemd en in andere pas vijf jaar na de naturalisatie (art. 13) ${ }^{76}$.

\section{i. "Erkenning"}

Roemenië kende evenals Polen een aparte vorm van verlichte naturalisatie, "erkenning" genoemd ${ }^{7}$. De nationaliteit werd verleend bij een koninklijk decreet op voordracht van het Ministerie van justitie. Daarbij moest ook advies van de commissie voor vaststelling van naturalisatie- en erkenningsvoorwaarden worden ingewonnen (art. 29). De mogelijkheid van verkrijging van de nationaliteit door erkenning bestond voor vreemdelingen van Roemeense afstamming ${ }^{78}$ die zich in Roemenië kwamen vestigen. Hierbij werd met name gedacht aan etnische Roemenen, die in alle omringende landen woonden en aan remigranten uit Amerika ${ }^{7}$ "Als van Roemeense afstamming zijnde werd beschouwd iedereen, waarvan vader of moeder(!) van Roemeense afstamming was ${ }^{80}$ (art. 28). Voorts golden bij erkenning ook de naturalisatievereisten van art. 10 sub 1 (21 jaar), sub 2 (gezondheid), sub 3 (het "opgeven" van de andere nationaliteit) en sub 5 (goed gedrag).

Verschillen ten opzichte van de gewone naturalisatie waren, dat de erkenning ex tunc werkte, dat erkende Roemenen wel alle politieke rechten bezaten (art.

73. Djuvara p. 69-70.

74. Cf. Keschmann, ZfoR $1938-39$, p. 712 .

75. Zoals Ministers en hoofden wan provinciën. Djuvara, p. 70.

76. Cf. Radu, Revue Roumaine 1972/1, p. 25; Wolloch, p. 120-121.

77. Zie Daarover Djuvara, p. 77.

78. Volgens Djuvara, p. 80 ging het om etnische Roemenen en moest Roemeense afstamming met name worden bewezen aan de hand van uittreksels uit bevolkingsregisters en aktes van burgerlijke stand.

79. Keschmamn, ZfoR 1938-39, p. 712.

80. Volgens de oorspronkelijke tekst werd ook hier vereist dat ten aanzien wan wettige kinderen de vader wan Roemeense afstamming was. De uitbreiding tot de vader of moeder geschiedde bij het wijzigingsdecreet van 27 juli 1939 . Zie SGS deel 5, p. 75. 
30), dat erkenning bij een decreet geschiedde en een groep personen tegelijkertijd betrof ${ }^{81}$.

\section{ii. Invloed op de nationaliteit van de gezinsleden van de verzoeker}

De buitenlandse echtgenote van een naturalisandus werd automatisch met haar man meegenaturaliseerd. Ze had evenwel de mogelijkheid, om binnen een termijn van één maand nadat haar man de eed van trouw had afgelegd, te verklaren dat ze de Roemeense nationaliteit niet wilde verkrijgen. In dat geval werd ze geacht de Roemeense nationaliteit nooit te hebben bezeten (art. 14). Aangezien de termijn voor deze verklaring buitengewoon kort was, is het aannemelijk dat betrokkene slechts in uitzonderingsgevallen van deze mogelijkheid op de hoogte was. Om deze reden kan hier niet over vrijwillige verkrijging van de nationaliteit worden gesproken. Bovendien verkreeg ze de Roemeense nationaliteit indien ze niets deed.

Kinderen onder 21 jaar werden automatisch met hun ouder(s) meegenaturaliseerd. Wettige en door de vader erkende kinderen werden in de naturalisatie van hun vader inbegrepen, terwijl andere buitenechtelijke kinderen de naturalisatie van hun moeder deelachtig waren (art. 16).

Personen die krachtens art. 16 met hun ouder(s) werden meegenaturaliseerd, hadden de mogelijkheid om tussen hun 20 ste en 21 ste verjaardag van de Roemeense nationaliteit afstand te doen. Deze mogelijkheid bestond echter slechts indien ze door de medenaturalisatie hun oorspronkelijke nationaliteit niet verloren, of indien hun vroegere nationale recht aan hen in een dergelijk geval een optierecht toekende (art. 36 sub 6).

De vrouw en minderjarige kinderen van betrokkene verkregen door "erkenning" van hun man, respectievelijk vader automatisch de Roemeense nationaliteit. Ten aanzien van hen golden echter wel de beperkingen van politieke rechten van naturalisandi (art. 13), terwijl ook in hun geval de verkrijging van de nationaliteit ex tunc, van het tijdstip van hun geboorte werkte (art. 31).

\subsection{Verlies van de nationaliteit}

De Roemeense nationaliteit kon volgens de wet van 1939 van rechtswege, door het afleggen van een verklaring van afstand of door ontneming worden verloren. De wet van 1939 kende geen verlies van het staatsburgerschap door ontslag. Aangezien het verlies van de nationaliteit door afstand slechts in twee zeer specifieke gevallen mogelijk was, zal daaraan geen aparte paragraaf worden gewijd. Voor een bespreking van beide afstandsmogelijkheden zij verwezen naar de vorige subparagraaf en p. 264.

\section{a. Verlies van rechtswege}

De Roemeense nationaliteit ging in de volgende gevallen van rechtswege verloren:

- door vrijwillige verkrijging van een vreemde nationaliteit (art. 36 sub 1);

81. Djuvara, p. 81; Wolloch, p. 121. 
- door vaststelling wan afstamming van een buitenlander (art. 36 sub 4, 5);

- door huwelijk met een buitenlander (art. 36 sub 2).

Alle genoemde verliesgronden zullen hieronder in het kort worden besproken.

\section{Vrijwillige verkrijging van een wreemde nationaliteit}

Een Roemeen verloor van rechtswege zijn nationaliteil indien hij door optie of naturalisatie ${ }^{82}$ een andere nationaliteit werwierf (art. 36 sub 1).

Het verlies van het staatsburgerschap strekte zich mede uit tot zijn vrouw en de niet gehuwde kinderen onder 21 jaar, tenzij zij de verkrijging van de nationaliteit door hun man, respectievelijk vader niet deelachtig waren (art. 38 lid 1 en 2). Een vrouw die op grond van deze bepaling haar nationaliteit verloor, kon deze herkrijgen, indien zij binnen éen maand na de naturalisatie of optie van haar man verklaarde, dat ze de vreemde nationaliteit niet wilde verkrijgen (art. 38 lid 2). De mogelijkheid van herkrijging van de Roemeense nationaliteit door een dergelijke verklaring hadden ook de kinderen van betrokkene binnen eén jaar na hun 20 ste verjaardag ${ }^{83}$. De vreemde nationaliteit ging door een dergelijke verklaring uiteraard slechts verloren, indien het recht van het desbetreffende land een dergelijke mogelijkheid van afstand van de nationaliteit kende.

\section{ii. Vaststelling van afstamming van een vreemdeling}

Een onwettig kind dat vóor zijn 21ste levensjaar door een vreemdeling werd gelegitimeerd, verloor van rechtswege zijn nationaliteit, indien het door de wettiging de nationaliteit van zijn vader verwierf (art. 36 sub 4). Vrouwen verloren in dit geval de Roemeense nationaliteit niet, indien ze op het tijdstip van de wettiging waren gehuwd met een Roemeen of met een vreemdeling terwijl ze zich bij het aangaan van het huwelijk het bezit van de Roemeense nationaliteit (ex art. 36 sub 2) hadden voorbehouden.

De Roemeense nationaliteit werd krachtens art. 36 sub 5 eveneens verloren door degenen, die vóór hun 21ste jaar door een buitenlandse man werden erkend of afstamming van een vreemdeling gerechtelijk werd vastgesteld ${ }^{84}$.

\section{iii. Huwelijk met een buitenlander}

Een Roemeense vrouw verloor ex art. 36 sub 2 haar nationaliteit door een huwelijk met een buitenlander, tenzij ze daardoor niet de nationaliteit van haar man verkreeg. Ze had echter de mogelijkheid om het Roemeense staatsburgerschap te

82. Djuvara, p. 87.

83. Djuvara, p. 95.

84. Opmerkelijk is echter, dat niet elke erkemning of gerechtelijke vaststelling verlies van de nationaliteit door het kind bewerkstelligde. Het moest gaan om een erkenning of gerechtelijke vaststelling, waardoor tussen de erkenner en het kind familierechtelijke betrekkingen ontstonden en niet bijwoorbeeld slechts alimentatieplicht van de eerste, zoals het onder omstandigheden naar Duits recht mogelijk was. Zie Djuvara, p. 93. Hij komt tot de conclusie dat erkenning door een Fransman wel en door cen Duitser geen verlies van de Roemeense nationaliteit meebracht. 
behouden, door bij het aangaan van de huwelijkse voonwaarden haar daartoe strekkende wil te verklaren. Deze mogelijkheid bestond ook indien zij door of ten gevolge van het huwelijk de nationaliteit van haar man verwierf.

Eventuele buitenechtelijke kinderen van betrokkene behielden echter de Roemeense nationaliteit (art. 39). Werden ze door de buitenlandse man van hun moeder gewettigd, dan verloren ze hun nationaliteit ksachtens de onder b. besproken bepaling van art. 36 sub 4 .

$\mathrm{Na}$ de ontbinding van het huwelijk herkreeg de ex-Roemeense vrouw indien ze haar door huwelijk werworven nationaliteit verloor, van rechtswege de Roemeense nationaliteit (art. 54 lid 1). In het geval dat ze de nationaliteit van haar ex-man behield, kon ze, nadat ze zich opnieuw in Roemenië vestigde, voor de Roemeense nationaliteit opteren. Deze optie werd niet aan een termijn gebonden (lid 2).

\section{b. Ontneming en herroeping van naturalisatie}

Het verlies van de Roemeense nationaliteit door ontneming was geregeld in artt. 40-51. In vergelijking de vorige wet kunnen verschillende uitbreidingen van ontnemingsmogelijkheden worden gesignaleerd ${ }^{85}$. De nationaliteit werd ontnomen bij een besluit van de Ministerraad en werkte van de dag van de publicatie daarvan in de Monitorul Official (staatsblad) (art. 44). Tegen de beslissing van de Ministerraad werd geen beroep toegelaten.

De wet kende "absolute" en "relatieve" ontnemingsgronden. Terwijl bij de constatering van aanwezigheid van de eerste de nationaliteit moest worden ontnomen, werd bij de tweede de beslissing ter discretie van de Ministerraad overgelaten. De nationaliteit moest worden ontnomen in de volgende gevallen:

- wegens het zonder toestemming van de regering treden in vreemde krijgs- of staatsdienst, of in dienst van een vreemde militaire organisatie (art. 40 sub 1, 2);

- wegens het aanvaarden van bescherming door een vreemde staat (art. 40 sub 3);

- wegens tienjarig verblijf in het buitenland, terwijl betrokkene geen paspoort had, of nadat de geldigheidsduur daarvan was verlopen ${ }^{\text {\$6 }}$ (artt. 48-49).

Art. 41 noemde voorts enkele gronden die tot de ontneming van de Roemeense nationaliteit konden leiden. Reeds deze formulering geeft aan dat beslissingen daaromtrent willekeurig konden worden genomen. Deze "relatieve" ontnemingsgronden waren:

het verlaten van militaire dienst in combinatie met vlucht naar het buitenland of naar door de vijand bezet gebied (sub 1);

85. Wolloch, p. 122.

86. De mationaliteit werd slechts ontmomen indien betrokkene tien jaar zonder een geldig Roemeens paspoort in het buitenland verbleef. Deze termijn werd door het indienen van een aanvraag woor een paspoort of voor verlenging daarvan gestuit (art. 49 lid 2). 
- het op heimelijke en frauduleuze wijze verlaten van het land om de militaire dienstplicht of een andere verplichting met betrekking tot de landsverdediging te ontduiken (sub 2) ${ }^{87}$;

- het ontwijken van de militaire dienstplicht of van een mobilisatieoproep door verblijf in het buitenland (sub 3,4 );

- handelingen die tegen Roemenië waren gericht, het schenden van de loyaliteitsplicht, of een Roemeense staatsburger onwaardig gedrag (sub 5) ${ }^{88}$.

\section{i. Invloed op de nationaliteit van gezinsleden van betrokkene}

Met betrekking tot de invloed van de ontneming van de nationaliteit op het staatsburgerschap van de vrouw en kinderen van betrokkene dient onderscheid te worden gemaakt tussen ontneming wegens langdurig verblijf in het buitenland en de andere ontnemingsgronden. In het eerste geval strekte het verlies van de nationaliteit zich automatisch mede uit over de vrouw en de niet gehuwde kinderen onder 21 jaar. Het verlies trad evenwel niet in ten aanzien van de gezinsleden, die zich op het tijdstip van de ontneming in Roemenië bevonden (art. 51). In de overige gevallen van ontneming verloren de gezinsleden de nationaliteit niet automatisch, maar slechts op grond van een daartoe strekkend besluit van de Ministerraad (artt. 45, 46). De voorwaarden daarvoor werden in de wet niet genoemd.

\section{ii. De wet van 9 december 1940}

Bij de wet van 9 december $1940^{89}$ werden de mogelijkheden om de Roemeense nationaliteit te ontnemen aanzienlijk uitgebreid. Het staatsburgerschap kon krachtens de ruime formulering van art. 1 worden ontnomen aan personen, die in het buitenland woonden en handelingen hadden begaan die schending van de loyaliteitsplicht betekenden, of de belangen en het "prestige" van de staat schade berokkenden. De nationaliteit werd ook hier ontnomen door de Ministerraad, op voordracht van de Minister van justitie (art. 2). Daarbij kon tevens worden bepaald, dat het vermogen van betrokkene werd geconfisceerd. De Ministerraad kon beslissen, dat de nationaliteit tevens werd ontnomen aan de vrouw en kinderen van betrokkene onder 21 jaar (art. 3).

\section{iii. Herroeping van naturalisatie}

De wet van 1939 kende verschillende mogelijkheden om een verlening van de nationaliteit ongedaan te maken. Herroeping was steeds mogelijk, ongeacht hoeveel

87. Dit is de bepaling van sub 2 na de wijziging bij de wet van 27 juli 1939. Djuvara, p. 103. Deze bepaling was gericht tegen deserteurs en politieke emigranten die met valse paspoorten het land ontvluchtten. Djuvara ${ }_{n}$ p. 103.

88. Deze mistige formulering werd door Djuvara, p. 104-107 sterk bekritiseerd.

89. M.O. 1940, nr. 290: Duitse vertaling in SGS deel 5, p. 82. 
tijd die sedert de verlening van de nationaliteit was verstreken. De gronden woor herroeping waren de volgende:

- fraude in de naturalisatie- of erkenningsprocedure (art. 42 lid 1);

- veroordeling tot een vrijheidsstraf van én jaar of meer binnen vijf jaar na de naturalisatie (art. 42 lid 2) deze ontnemingsgrond gold niet ten aanzien van Roemenen, die deze nationaliteit door "erkenning" verwierven ${ }^{90}$.

Terwijl de bovenstaande gronden betrekking hadden op anomalieën bij de naturalisatieprocedure, respectievelijk wangedrag tijdens de "proeftijd" na de naturalisatie, ging het in de volgende gevallen in wezen om uitbreiding van ontnemingsmogelijkheden ten aanzien van een bepaalde groep Roemenen. Het ging hierbij om genaturaliseerde Roemenen, die afkomstig waren uit een land waarmee Roemenië in oorlog was. De nationaliteit kon worden ontnomen wegens:

- handelingen tegen de openbare orde of de staatsveiligheid (art. 43 sub 1);

- spionage of het ondersteunen van handelingen, die tegen de belangen van de staat of van het "volk" waren gericht (sub 2).

\subsubsection{Het nationaliteitsrecht tussen 1940 en 1948}

In de periode tijdens de tweede wereldoorlog en in de eerste jaren daarna werden in Roemenië tal van nationaliteitsrechtelijke regelingen afgekondigd die bepaalde bijzondere onderwerpen regelden. Aangezien Roemenië bijna de hele tweede wereldoorlog Duitse bondgenoot was, is het niet verbazingwekkend dat men daar geen nationaliteitsrechtelijke "reparatiewetgeving" ten aanzien van Roemenen van Duitse etnische afstamming kende. Tot de nieuwe Roemeense nationaliteitswet van 1948 kwamen de volgende nationaliteitsrechtelijke regelingen tot stand:

- decreet-wet van 23 juli $1942^{91}$ betreffende het bewijs van de nationaliteit;

- decreet-wet van 3 september $1942^{92}$ met de verordeningen van 23 mei en van 27 juli $1942^{93}$ met betrekking tot de nationaliteit van de bewoners van Bessarabië en Noord-Boekowina;

- decreet-wet van 19 maart $1943^{\text {年 }}$ strekkende tot wijziging van artt. 8, 36 sub 3 en 59 van de nationaliteitswet van 1939;

90. Djuvara, p. 108.

91. M.O. 1942 , nr. 169.

92. M.O. 1941, nr. 209; Duitse vertaling in SGS deel 5 p. 94.

93. M.O. 1942, nrs. 119 en 173.

94. M.O. 1943, nr. 67. 
- decreet-wet van 9 juli $1943^{\%}$ betreffende herkrijging van de Roemeense nationaliteit door personen, aan wie deze op grond van het decreet-wet van 3 september 1942 was ontnomen;

- wet van 2 april $1945 \%$ met de bijbehorende uitvoeringsverordening 11 augustus $1945^{97}$; betreffende de nationaliteit van de bewoners van Noord-Transsylvanië dat weer bij Roemenië werd ingelijfd;

- wret van 29 mei $1947^{98}$ betreffende de nationaliteit van bepaalde categorieën personen, waaronder de Roemeense Joden (art. 1 lid 2); bij deze wet werd tevens een wijziging in de competentieregels van de nationaliteitswet van 1939 doorgevoerd ${ }^{9 \%}$, deze wet werd ingetrokken bij decreet van 8 juni $1950^{100 ;}$

- wet van 17 januari $1948^{101}$ strekkende tot wijziging van het decreet-wet betreffende de ontneming van de nationaliteit van 8 december $1940^{102}$.

\subsubsection{Het decreet van 1948}

\subsubsection{Algemeen}

De eerste algemene nationaliteitsrechtelijke regeling van het "nouveau régime" in Roemenië was het decreet van 7 juli $1948^{103}$. De belangrijke karakteristiek van deze nieuwe regeling is de doorvoering van het beginsel van gelijkheid van sexen, hetgeen resulteerde in wijziging van de regeling van verkrijging van de nationallteit iure sanguinis en van de verkrijging en verlies van de nationaliteit door huwelijk. Verder valt op dat het decreet van 1948 aanzienlijk korter was dan de wet van 1939.

Van de allgemene bepalingen van de nieuwe regeling is art. 2 interessant dat bepaalde dat een Roemeen niet tegelijkertijd de nationaliteit van een ander land "kon" bezitten en dat voor verkrijging van een vreemde nationaliteit de toestemming van de Minister van justitie vereist was. De overgangsregeling knoopte bij de bepaling van de kring van onderdanen op het tijdstip van de inwerkingtreding van het decreet aan bij personen, die op grond van de vorige regelingen de Roemeense nationaliteit bezaten (art. 34).

95. M.O. 1943 , nr. 158 .

96. M.O. 1945, nr. 78; Duitse vertaling in SGS deel 5 p. 96-97; zie over deze wet ook SGS deel 5 p. 66.

97. M.O. 1945, nr. 82; Duitse vertaling in SGS deel 5 p. 97-100.

98. M.O. 1947, nr.121; Duitse vertaling in SGS deel 5, p. 83-85 en 85-87. Zie daarover Wolloch, p. 199 e. $v$

99. Zo werd een gewone naturalisatie niet meer bij een formele wet, maar bij| een besluit van de Minisiterraad verleend. De Ministerraad kreeg ook beslissingsbevoegdheid bij] de ontreming van de nationaliteit.

100. B.O. 1950, nr. 50 .

101. M.O. 1948, nr. 16; Duttse vertaling in SGS deel 5, p. 82-83.

102. M.O. 1940, nr. 290. Gewijzigd werden artt. 1 en 20 ."

103. M. . 1948, nr. 154; Duitse vertaling in SGS deell 5, p. $87-92$ 
$1952^{104}$

Deze regeling werd reeds in 1952 vervangen door het decreet van 24 januari

\subsubsection{Verkrijging van de nationaliteit}

De Roemeense nationaliteit kon volgens het decreet van 1948 van rechtswege en door naturalisatie worden verkregen. Verkrijging van de nationaliteit door optie of door de bijzondere vorm van verlichte naturalisatie, "erkenning", kende dit decreet niet ${ }^{105}$.

\subsection{Verknjging van rechtswege}

Verkrijging van de Roemeense nationaliteit werd van rechtswege gekoppeld aan de volgende feiten:

- geboorte uit Roemeense ouder(s) (artt. 4-7);

- geboorte op het Roemeense grondgebied (art. 9);

Adoptie door een Roemeen(se) had net als volgens de wet van 1939 geen invloed op de nationaliteit van het geadopteerde kind (art. 8).

\section{a. Geboorte uit Roemeense ouder(s)}

De Roemeense nationaliteit werd verworven door een kind, waarvan beide ouders op het tijdstip van de geboorte van het kind de Roemeense nationaliteit bezaten. Het was daarbij niet van belang, waar het kind werd geboren en of het om een wettig, dan wel onwettig kind ging ${ }^{106}$. In het geval dat slechts éen van de ouders het Roemeense staatsburgerschap bezat, werd het kind Roemeen, met dien verstande dat het binnen één jaar na het bereiken van de meerderjarigheid het recht had om ten overstaan van de Minister van justitie van de Roemeense nationaliteit afstand te doen. Afstand van de nationaliteit werd echter gekoppeld aan de voorwaarde, dat de betrokkene door geboorte tevens een andere nationaliteit bezat (art. 7) ${ }^{107}$.

\section{b. Geboorte op het Roemeense grondgebied}

De regeling van de verkrijging van de nationaliteit iure soli werd nagenoeg letterlijk overgenomen uit de wet van 1939. De Roemeense nationaliteit werd verworven door een kind van onbekende ouders, dat in Roemenië werd geboren (art. 9 lid 1). Voorts vestigde het tweede lid een praesumptio iuris van geboorte in Roemenië ten aanzien van kinderen, die op het Roemeense grondgebied werden

104. M.O. 1952, nr. 5; Suga, OER 1973, p. 7.

105. Cf. SGS deel 5, p. 62 .

106. SGS deel 5 , p. 61.

107. SGS deel 5 , p. 61. 
gevonden. Het tegenbewijs kon te allen tijde worden geleverd, ongeacht de leeftijd van betrokkene.

\subsection{Naturalisatie}

Verkrijging van de Roemeense nationaliteit door naturalisatie was geregeld in artt. 10 e.v. van het decreet van 1948. Art. 10 schiep enige verwarring door te bepalen dat naturalisatie met of zonder "proeftijd" mogelijk was. Het ging echter niet om een proeftijd $n a$ de verlening van de nationaliteit, doch daarmee werd het vereiste verblijf woorafgaande aan het naturalisatieverzoek bedoeld ${ }^{108}$. De nationaliteit werd verleend bij een decreet van het Presidium van het parlement op grond van een besluit van de Ministerraad op voordracht van de Minister van justitie (art. 26). Tegen afwijzing van een verzoek was geen beroep mogelijk. De vereisten om voor naturalisatie in aanmerking te komen waren de volgende:

- ononderbroken vijfjarig verblijf in Roemenië (art. 11 lid 1);

- verlies van de oude nationaliteit (art. 11 lid 1);

- goed gedrag, waarbij vooral niet mocht blijken van een "antidemocratische of de belangen van de Volksrepubliek vijandelijk instelling" van betrokkene (art. 11 lid 1).

De verblijfseis werd krachtens het derde lid van art. 11 tot slechts én jaar verkort ten aanzien van de volgende personen:

- degenen die in Roemenië werden geboren (sub 1);

- degenen die in het Roemeense leger hadden gediend (sub 2);

- $\quad$ degenen die de staat belangrijke diensten hadden bewezen (sub 3);

- asielgerechtigden (sub 4).

De Minister van justitie bezat in dit geval zelfs de bevoegdheid om de éenjarige verblijfseis nog verder te bekorten, of daarvan geheel af te zien (art. 11 lid 4). Geen verblijfseis werd gesteld ten aanzien van huwelijkspartners van Roemeen(se)en, gewezen Roemenen en personen aan wie het "ereburgerschap" werd verleend. Ze konden worden genaturaliseerd indien ze aan de eis van het verlies van de oorspronkelijke nationaliteit voldeden (art. 13).

De naturalisandi dienden tevens een eed van trouw af te leggen, waardoor de naturalisatie haar werking kreeg (art. 15). Anders dan voorheen het geval was, verkreeg een genaturaliseerde Roemeen dezelfde politieke rechten als degenen, die deze nationaliteit van rechtswege bezaten.

108. Cr. SGS deel 5, p. 62. 


\section{a. Invloed op de nationaliteit van de gezinsleden van de verzoeker}

Het is bijzonder interessant dat een buitenlandse huwelijkspartner automatisch in de naturalisatie van de verzoeker werd inbegrepen (art. 14). Indien een gehuwde vrouw genaturaliseerd werd, betekende dit derhalve automatische medenaturalisatie van haar man. De meegenaturaliseerde echtgeno(o)t(e) had echter de mogelijkheid om binnen éen maand na de naturalisatie van zijn/haar partner om ten overstaan van de Minister van justitie te verklaren dat hij/zij de Roemeense nationaliteit niet wilde verkrijgen. Dit gold voorzover betrokkene niet door of tengevolge van het huwelijk reeds haar oorspronkelijke nationaliteit verloor ${ }^{109}$.

Ook minderjarige kinderen van de naturalisandi werden automatisch meegenaturaliseerd (art. 7). In het geval dat slechts én van de ouders werd genaturaliseerd, terwijl de andere vreemdeling bleef, hadden de meegenaturaliseerde kinderen binnen én jaar na het bereiken van meerderjarigheid eveneens de mogelijkheid om van de Roemeense nationaliteit afstand te doen.

\subsubsection{Verlies van de nationaliteit}

De Roemeense nationaliteit kon volgens het decreet van 1948 worden verloren door afstand, ontslag en door ontneming. Aangezien het verlies van het staatsburgerschap door afstand slechts in twee zeer specifieke gevallen mogelijk is, is het niet zinvol om aan de bespreking daarvan een aparte paragraaf te wijden. Beide afstandsmogelijkheden werden reeds op p. 273 en in de vorige subparagraaf genoemd. Anders dan de wet van 1939 kende het decreet van 1948 geen verlies van de nationaliteit ipso iure en door herroeping van een naturalisatiebesluit.

\subsection{Ontslag}

Het ontslag uit de Roemeense nationaliteit werd niet zelfstandig geregeld, maar in het kader van de procedure tot verkrijging van de toestemming van de Minuster van justitie voor verwerving van een andere nationaliteit. De wettelijke constructie kwam neer op het "verlies van rechtswege, wegens verkrijging van een andere nationaliteit", met toestemming van de Minister (art. 16 jo. art. 2). Uit de regeling blijkt evenwel duidelijk dat niet de verkrijging van een andere nationaliteit, maar de "toestemming" van overheidswege hier essentieel was. Om deze reden dient hier gesproken te worden van het verlies van de nationaliteit door ontslag.

Het ontslag werd verleend onder de opschortende voorwaarde van verkrijging van een vreemde nationaliteit. Bovendien moest betrokkene op straffe van verval van de beschikking binnen drie maanden na de verkrijging van een vreemde nationaliteit de Roemeense Minister van justitie daarvan in kennis stellen (art. 29). De Roemeense nationaliteit ging op de dag van die mededeling verloren (art. 16).

Het decreet noemde geen vereisten voor verkrijging van het ontslag, hetgeen betekent dat de Minister van justitie volledige discretionaire bevoegdheid bezat. Aangenomen mag worden dat van betrokkene in ieder geval werd geëist dat hij alle verplichtingen tegenover de staat (met name de militaire dienstplicht) vervuld

109. Cf. SGS deel 5, p. 62. 
had. Ook is het waarschijnlijk dat hangende een strafrechtelijke procedure geen ontslag mogelijk was.

\section{a. Invloed op de nationaliteit van de gezinsleden van de verzoeker}

Het decreet van 1948 bevatte geen regels met betrekking tot medeontslag van de gezinsleden van betrokkene. Aangezien art. 2 bepaalde, dat ook minderjarigen hun nationaliteit niet zonder toestemming van het bevoegde Roemeense orgaan konden verliezen, moet m.i. worden aangenomen, dat de gezinsleden van de verzoeker uitsluitend zelfstandig konden worden ontslagen.

\subsection{Ontneming}

Het verlies van de Roemeense nationaliteit door ontneming was geregeld in de artt. 17, 18 en 30 van het decreet van 1948. De nationaliteit werd ontnomen bij een decreet van het Presidium van het parlement, op grond van een besluit van de Ministerraad, op advies van de Minister van justitie (art. 30). Beroep tegen de beslissing werd niet toegelaten.

De nationaliteit kon krachtens art. 17 worden ontnomen aan de volgende personen:

- degenen die zonder toestemming in dienst van een vreemde staat traden (sub $1)$;

- degenen die in het buitenland woonden, indien ze niet binnen twee maanden na een bevel tot terugkeer naar Roemenië terugkeerden (sub 2);

- degenen die in het buitenland woonden en handelingen hadden begaan die schending van de loyaliteitsplicht betekenden, of de belangen en de goede naam van de staat schade berokkenden ${ }^{110}$ (sub 3);

- degenen die het land illegaal hadden verlaten, of het toegestane verblijf in het buitenland hadden overschreden (sub 4);

- degenen die in de naturalisatieprocedure hadden gefraudeerd (sub 5).

Het vermogen van personen aan wie de nationaliteit werd ontnomen werd geconfisceerd ${ }^{111}$. Interessant is, dat de confiscatie gedeeltelijk terugwerkende kracht had. In art. 18 werd namelijk een op de actio Pauliana lijkende constructie neergelegd. Geconfisceerd werden ook de vermogensbestanddelen die betrokkene in de tijd tussen 23 augustus $1944^{112}$ en de ontneming aan zijn bloed- en aanverwanten tot en met vierde graad, zakenpartners en verschillende adviseurs ver-

110. De formulering van deze ontnemingsgrond leek veel op die van de op p. 270 besproken wet wan 9 december 1940 betreffende de ontneming van de Roemeense nationaliteit die toen in de eerste plaats juist tegen communisten werd gericht.

111. Cr. SGS deel 5, p. 63 .

112. Op die dag koos Roemenië de zijde van de geallieerden. 
vreemdde. Vervreemdingen aan anderen bleven onaangetast, voorzover de verkrijgers hun "goede trouw" konden bewijzen ${ }^{113}$. Een verdere consequentie van de ontmeming van de nationaliteit was, dat betrokkene niet kon worden gehernaturaliseerd.

\section{a. Invloed op de nationaliteit van gezinsleden van betrokkene}

Ontneming van de nationaliteit had in beginsel geen invloed op het staatsburgerschap van de huwelijkspartner en minderjarige kinderen van betrokkene. De vage ontnemingsgronden boden echter voldoende ruimte om aan de gezinsleden van betrokkene de nationaliteit "zelfstandig" te ontnemen.

\subsubsection{Het decreet van 1952}

\subsubsection{Algemeen}

Het Roemeense nationaliteitsrecht werd reeds bij het decreet van 22 januari $1952^{114}$ opnieuw herzien. Deze regeling van de nationaliteit "blonk uit" door haar beknoptheid. Terwijl het decreet van 1948 nog 35 artikelen bevatte, had het decreet van 1952 er nog maar 10. Het ging om een vergaande copie van de nationaliteitswet van de USSR van 1938. Naast het decreet kondigde men op 10 april $1952^{115}$ een uitvoeringsverordening (UV) af, die enkele nadere regels met betrekking tot verkrijging en verlies van de nationaliteit bevatte.

Interessant is de overgangsregeling van het decreet, waarin de kring van onderdanen bij inwerkingtreding van het decreet werd vastgesteld. Naast personen die vóór dat tijdstip de Roemeense nationaliteit hadden verworven en die nog steeds bezaten, waren dat ook in Roemenie woonachtige staatlozen en naar het land teruggekeerde ex-Roemenen.

\subsubsection{Verkrijging van de nationaliteit}

De Roemeense nationaliteit kon volgens het decreet van 1952 worden verkregen van rechtswege en door naturalisatie.

\subsection{Verkrijging van rechtswege}

Verkrijging van de Roemeense nationaliteit werd van rechtswege uitsluitend gekoppeld aan geboorte uit Roemeense ouder(s) (art. 2). Verkrijging van de nationaliteit iure soli werd in het geheel afgeschaft.

113. Deze goede trouw had kennelijk betrekking op de wetenschap dat betrokkene aan de vereisten woor ontmeming van de nationaliteit woldeed.

114. B.O. 1952 nr. 5; Duitse wertaling in SGS deel 5a, p. 24. Art. 1 werd voorts gewijzigd bij het decreet van 9 augustus 1954, B.O. 1954, nr. 38 .

115. B.O. 1952 nr. 19; Duitse vertaling in SGS deel $5 \mathrm{a}$, p. 25. 


\section{a. Geboorte uit Roemeense ouder(s)}

De Roemeense nationaliteit werd steeds verworven door een kind, waarvan beide ouders op het tijdstip van geboorte van het kind de Roemeense nationaliteit bezaten (art. 2 lid 1). Het was daarbij niet van belang, waar het kind werd geboren en of het om een wettig, dan wel onwettig kind ging. In het geval dat slechts eén van de ouders de Roemeense nationaliteit bezat, werd het kind Roemeen indien:

- tenminste én van de ouders zich op het tijdstip van geboorte van het kind in Roemenië bevond (art. 2 lid 2 sub a) ${ }^{116}$; of

- beide ouders op het tijdstip van de geboorte van het kind in het buitenland waren en gemeenschappelijk verklaarden, dat ze wensten dat het kind het Roemeense staatsburgerschap zou verwerven (art. 2 lid 2 sub b).

\subsection{Naturalisatie}

Verkrijging van de Roemeense nationaliteit door naturalisatie was "geregeld" in artt. 3 van het decreet en artt. 6-10 van de verordening. Art. 3 bevatte de reeds uit de Sovjet-wet van 1938 en uit het Albanese decreet van 1954 bekende bepaling, dat de nationaliteit zonder onderscheid naar ras, etnische nationaliteit religie ${ }^{117}$ of cultuur werd verleend door het Presidium van het parlement. Dit nam zijn beslissing op voorstell van de Minister van binnenlandse zaken (art. $6 \mathrm{UV}$ ). Uit de verordening blijken voorts de volgende naturalisatievereisten:

- een verklaring in de vorm van een authentieke akte dat betrokkene zijn oude nationaliteit "opgaf", of een bewijsstuk dat hij apatride was (art. $8 \mathrm{UV}$ );

- een eed van trouw, die merkwaardigerwijs reeds bij het indienen van het naturalisatieverzoek diende te worden afgelegd (art. 9 UV).

Zelfstandige naturalisatie van minderjarigen was mogelijk. Een verzoek ten behoeve van kinderen onder 14 jaar moest door één of beide ouders worden ingediend. Boven deze leeftijd moest het kind zelf zijn naturalisatieverzoek indienen (art. 7 UV). We zien dat reeds aan de hand van de "regeling" van de vereisten voor naturalisatie kan worden geconcludeerd dat de administratie nagenoeg onbeperkte discretionaire bevoegdheid had ${ }^{118}$. In het decreet werd overigens ook bepaald dat de nationaliteit "kon" worden verleend. Beroep tegen afwijzing van een werzoek was niet mogelijk.

Bij het decreet van 24 juni $1955^{119}$ werden voorts mogelijkheden voor gemakkelijke herkrijging van de nationaliteit door repatrianten geschapen.

116. Dat kon ook de niet-Roemeense ouder zijn. Cf. SGS deel 5a, p. 21 .

117. Interessant is overigens, dat in de USSR-en in de Albanese versie van deze bepaling religie niet werd genoemd.

118. Cf. SGS deel 5a, p. 22.

119. B.O. 1955, nr. 18; zie daarover Suga, OER, p. 12-14. De in artt. 1 en 4 van dit decreet gestelde termijnen werden vervolgens verlengd bij de decreten van 29 mei 1956, B.O. 1956, nr. 17; 14 december 1962, B.O. 1962, nr. 25 en van 31 augustus 1965, B.O. 1965, nr. 2. 


\section{a. Invloed op de nationaliteit van de gezinsleden van de verzoeker}

Automatische naturalisatie van de buitenlandse huwelijkspartner van de verzoeker werd in 1952 afgeschaft. De echtgeno(o)t(e) van betrokkene kon volgens het decreet van 1952 slechts via de gewone procedure worden genaturaliseerd.

Medenaturalisatie van kinderen geschiedde automatisch, indien beide ouders van het kind werden genaturaliseerd. Naar mijn mening kan hetzelfde worden aangenomen voor het geval dat de andere ouder reeds de Roemeense nationaliteit bezat. Kinderen boven 14 jaar moesten echter zelf met hun medenaturalisatie instemmen (art. 5 lid 1). Indien slechts éến van de ouders werd genaturaliseerd, terwijl de andere een vreemde nationaliteit bezat, kon het kind slechts zelfstandig worden genaturaliseerd (art. 5 lid 2).

\subsubsection{Verlies van de nationaliteit}

De Roemeense nationaliteit kon volgens het decreet van 1952 worden verloren door ontslag en ontneming.

\subsection{Ontslag}

Het ontslag uit de Roemeense nationaliteit, het decreet sprak van "toestemming voor afstand", werd verleend door het Presidium van het parlement, op voorstel van de Minister van binnenlandse zaken (art. 6 van het decreet jo. art. 6 lid 2 UV).

Het decreet en de UV noemden evenals de regeling van 1948 geen vereisten voor verkrijging van het ontslag, hetgeen betekent dat de Minister van justitie volledige discretionaire bevoegdheid bezat. Aangenomen mag worden dat van betrokkene in ieder geval werd geëist dat hij alle verplichtingen tegenover de staat (met name de militaire dienstplicht) had vervuld. Ook is het waarschijnlijk dat hangende een strafrechtelijke procedure geen ontslag mogelijk was.

Zelfstandig ontslag van minderjarigen was mogelijk, waarbij ten aanzien van kinderen tot 14 jaar het verzoek door eén of beide ouders moest worden ingediend en boven deze leeftijd door het kind zelf (art. 7 UV).

\section{a. Invloed op de nationaliteit van de gezinsleden van de verzoeker}

Met betrekking tot medeontslag van minderjarige kinderen gold dezelfde regeling als ten aanzien van medenaturalisatie. Indien het ontslag aan beide ouders werd verleend, werden hun kinderen onder 14 jaar automatisch meeontslagen (art. 5 lid 1). Hetzelfde kan m.i. worden aangenomen voor het geval dat één van de ouders werd ontslagen, terwijl de andere reeds een vreemde nationaliteit bezat. Kinderen van 14 jaar en ouder dienden zelf met hun ontslag in te stemmen (art. 5 lid 2). In alle andere gevallen bleef het kind Roemeen en kon slechts zelfstandig worden ontslagen. 


\subsection{Ontneming}

Het verlies van de Roemeense nationaliteit door ontneming was "geregeld" in art. 7 van het decreet van 1948, waarin de bevoegdheid aan het Presidium van het parlement werd toegekend. Een andere bepaling met betrekking tot ontneming van de nationaliteit was noch in het decreet, noch in de UV te vinden.

\section{a. Invloed op de nationaliteit van gezinsleden van betrokkene}

Ontneming van de nationaliteit had in beginsel geen invloed op het staatsburgerschap van de huwelijkspartner en minderjarige kinderen van betrokkene. Het ontbreken van een regeling van ontnemingsgronden en de discretionaire bevoegdheid van de administratie boden echter voldoende ruimte om aan de gezinsleden van betrokkene de nationaliteit "zelfstandig" te ontnemen.

\subsection{HET POSTTEVE NATIONALITETTSRP:CHT}

\subsubsection{Algemeen}

Het positieve nationaliteitsrecht van Roemenië wordt geregeld in de wet van 17 december $1971^{120}$. Daardoor heeft Roemenië opnieuw een uitgebreidere regeling van verkrijging en verlies van de nationaliteit gekregen. Deze wet begint met een zeer lange preambule, waarin in hoogdravende bewoordingen de belangrijkste rechten en plichten van Roemeense staatsburgers worden omschreven. De overdreven verheerlijking van de staat en van het Roemeense volk is overigens voor de formuleringen van vele andere bepalingen van deze wet kenmerkend. De overgangsregeling knoopt bij het bepalen van de kring van onderdanen bij de inwerkingtreding van deze wet aan bij de personen die krachtens de vorige regelingen de Roemeense nationaliteit bezaten (art. 26). Nieuw zijn onder meer de in artt. 17 en 18 neergelegde voorschriften met betrekking tot het bewijs in nationaliteitsaangelegenheden. Zo wordt het bezit van de Roemeense nationaliteit in de regel bewezen door een aantekening in het identiteitsbewijs en in het buitenland door het uitreisvisum.

\subsubsection{Verkrijging van de nationaliteit}

De Roemeense nationaliteit kan slecht worden verkregen van rechtswege en door naturalisatie.

\subsubsection{Verkrijging van rechtswege}

De Roemeense nationaliteit wordt van rechtswege gekoppeld aan de volgende rechtsfeiten:

- geboorte uit Roemeense ouder(s) (artt. 5, 6 lid 1);

120. B.O. $1971 \mathrm{I}$, nr, 157; Duitse vertaling in Bergmann/Ferid, p. 2-7; Nederlandse in $N W G_{n}$ p. 1-6c. 
- geboorte op het Roemeense grondgebied (art. 6 lid 2);

- adoptie door een Roemeen(se) (art. 8).

\subsubsection{Geboorte uit Roemeense ouder(s)}

De verkrijging van de Roemeense nationaliteit iure sanguinis is geregeld in artt. 5 en 6 lid 1 van de wet van 1971. De casuilstische aanpak en het opnemen van de hoogdravende, materieelrechtelijk nietszeggende "motivering" in art. $5^{121}$ maken de op zichzelf zeer eenvoudige regeling erg onoverzichtelijk. De regels van artt. 5 en 6 lid 1 laten zich als volgt samenvatten: Een kind verkrijgt de Roemeense nationaliteit, indien tenminste één van zijn ouders op het tijdstip van de geboorte van het kind Roemeen is. Waar het kind wordt geboren is niet van belang 122 . Tussen wettige en onwettige kinderen wordt geen onderscheid gemaakt. Bij buitenechtelijke kinderen moet het vaderschap eerst door erkenning of gerechtelijke vaststelling komen vast te $\operatorname{staan}^{123}$. Nadat zulks is geschied wordt het kind geacht sedert zijn geboorte de Roemeense nationaliteit te bezitten.

\subsection{Geboorte op het Roemeense grondgebied}

De Roemeense nationaliteit wordt ook verworven door een kind dat op het Roemeense grondgebied wordt gevonden, indien zijn beide ouders onbekend zijn (art. 6 lid 2). De verkrijging van de nationaliteit wordt hier gebaseerd op een praesumptie van geboorte uit Roemeense ouder ${ }^{124}$. Indien vór de $18 \mathrm{de}$ verjaardag van het kind de identiteit van tenminste éen ouder wordt vastgesteld en blijkt dat het kind aan die ouder een vreemde nationaliteit ontleent, gaat de Roemeense nationaliteit voor het kind ex nunc verloren (art. 25) ${ }^{125}$. De wet bepaalt niet expliciet wat rechtens is, indien in het zojuist beschreven geval blijkt dat de andere ouder van het kind Roemeen is. Op grond van het uitgangspunt dat een kind van een Roemeense ouder steeds de Roemeense nationaliteit bezit (artt. 5, 6 lid 1) mag m.i. worden aangenomen, dat zo'n kind het Roemeense staatsburgerschap niet verliest.

121. De "prachtformulering" van art. 5 luidt in de Duitse vertaling: "Als Ausdruck der Verbindung zwischen Eltern und Kindern, der ununterbrochenen Kontinuität der Generationen auf dem Boden der Ahnen, die fur die Erfüllung der Ideale sozialler und mationaler Freiheit gekärmplt haben, sind die von Ellern rumänischer Staatsbürgerschaft auf dem Territorium der Sozialistischen Republik Rumänien Geborenen rumänische Bürger." Vertaling ontleend aau Bergmann/Ferid, p. 4 .

122. Cf. Deleanu, p. 75 ; Suga, OER 1973, p. 11; Radu, Revue Roumaine 1972/1, P. 27.

123. Zie woor erkenning artt. $57-58$ en voor gerechtelijke vaststelling van vaderschap artt. 59-60 wan het familiewetboek van 92 december 1953, B.O. 1954, ar. 1/4. Zie ook Deleanu, p. 93-95.

124. Radu, Revue Roumaine $1972 / 1$, p. 28.

125. Blijkt de ouder staatloos te zijn, dan werliest het kind de nationaliteit niet. Radu, Revue Roumaine $1972 / 1$, p. 28. 


\subsection{Adoptie door een Roemeen(se)}

Verkrijging van de Roemeense nationaliteit door een kind dat door een Roemeen(se) wordt geadopteerd, is én van de vernieuwingen, die bij de wet van 1971 zijn ingevoerd. Een kind verwerft de Roemeense nationaliteit indien op het tijdstip van adoptie tenminste één van zijn adoptief-ouders de Roemeense nationaliteit bezit en het kind nog geen 18 jaar oud is(art. 8). De nationaliteit wordt verkregen op het moment dat de adoptie door de President van de republiek ${ }^{126}$ wordt goedgekeurd ${ }^{127}$. Wordt de adoptie nog vóór de 18 -jarige leeftijd van het kind vernietigd, dan verliest het kind dat in het buitenland woont of naar buitenland emigreert de Roemeense nationaliteit met werking ex tunc. Bij ontbinding van de adoptie gaat de nationaliteit onder dezelfde voorwaarden ex nunc verloren (art. 9). Blijft het kind in Roemenië wonen, dan behoudt het zijn nationaliteit ${ }^{128}$.

\subsubsection{Naturalisatie}

Verkrijging van de Roemeense nationaliteit door naturalisatie is geregeld in artt. 10-16 van de wet van 1971. De nationaliteit kan krachtens de bepaling van art. 10 worden verleend bij een decreet van de President van de republiek. Reeds uit de "kan-formulering" kan worden afgeleid dat de President van de republiek een onbeperkte discretionaire bevoegdheid bezit. Tegen de afwijzing van een verzoek zijn geen rechtsmiddelen toegelaten. De wet bevat in art. 10 de volgende naturalisatievereisten ${ }^{129}$ :

- vijfjarig verblijf in Roemenië (sub a);

- op grond van het gedrag van de verzoeker moet kunnen worden afgeleid dat hij een trouwe burger zal zijn en zijn plichten naar behoren zal vervullen en dat hij het Roemeense staatsburgerschap waardig blijkt te zijn (sub b);

- leeftijd van 18 jaar (sub c);

de verzoeker moet "maatschappelijk nuttige" arbeid verrichten of in geval van arbeidsongeschiktheid over voldoende middelen van bestaan beschikken (sub d);

126. Sedert de grondwetswijziging wan 1974 zij de bevoegdheden die de nationaliteitswet van 1971 aan de Raad vam State toekende, op de President van de republiek overgegaan. Zie Deleanu, p. 103.

127. Dith wordt niet expliciet in de wet geregeld, doch in de literatuur wordt aangenomen dat de nationaliteit niet voor de goedkeuring kan worden verkregen. Deze goedkeuring is namelijk vereist bij ellke adoptie van een vreemdeling door Roemeense staatsburgers. Deleanu, p. 109 110; Radu, Revue Roumaine 1972/1, p. 29, met verwijzing naar Draganu, Drept constitutional, p. 197-198. Zie ook Wolloch, p. 277.

128. Cf. Deleanu, p. 111-112; Suga, OER 1973, p. 15; Radu, Revue Roumaine 1972/1, p. 29.

129. Zie cok Deleanu, p. 115-116; Suga, OER 1973, p. 15. 
- betrokkene moet in de vorm van een authentieke akte verklaren, dat hij van zijn oude nationaliteit afstand doet (zelfs als hij geen bezit(!)) en iedere band met een andere staat opgeeft (sub e);

- het afleggen van een eed van trouw (artt. 13,14); een naturalisatie werkt pas vanaf het moment dat de eed wordt afgelegd.

Ten aanzien van de vereiste verblijfsduur kent art. 10 sub a enkele uitzonderingen. Zo wordt een verblijf van drie jaar geëist ten aanzien van personen die met een Roemeen(se) gehuwd zijn, terwijl degenen die in Roemenië werden geboren, kunnen worden genaturaliseerd indien ze op het moment van het indienen van het naturalisatieverzoek in Roemenië wonen. In art. 11 wordt voorts de mogelijkheid voor hernaturalisatie van gewezen Roemenen geopend, zelfs indien ze ook na de naturalisatie in het buitenland blijven wonen ${ }^{130}$. Alle drie groepen moeten echter wel aan de overige naturalisatievereisten voldoen, met dien verstande dat in het buitenland woonachtigen de eed pas dienen af te leggen indien ze zich in Roemenië vestigen (art. 14 lid 3 ).

\subsection{Invloed op de nationaliteit van de gezinsleden van de verzoeker}

Kinderen van de naturalisandi die jonger zijn dan 14 jaar, worden automatisch meegenaturaliseerd, indien tenminste aan éen van de ouders de nationaliteit wordt verleend en ze tezamen met die ouder in Roemenië woonachtig zijn (art. 16 lid 1). De wet voorziet niet in de mogelijkheid dat een meerderjarig geworden medegenaturaliseerd kind van de Roemeense nationaliteit afstand doet.

\subsubsection{2 "Repatriëring"}

Verkrijging van de nationaliteit door de bijzondere vorm wan verlichte naturalisatie, "repatriëring", is geregeld in art. 7 van de wet van 1971. De voorwaarden voor de verwerving van de nationaliteit zijn, dat betrokkene ooit in het bezit van de Roemeense nationaliteit is geweest, naar Roemenië is teruggekeerd en dat hij de in art. 13 voorgeschreven eed van trouw aflegt ${ }^{\mathrm{t3}}$. De nationaliteit wordt ook hier verleend door de President van de republiek. Ook hier bestaat geen verplichting een verzoek in te willigen, hoewel betrokkene aan alle vereisten voldoet.

$\mathrm{De}$ onderhavige vorm van verlichte naturalisatie heeft een betrekkelijk lange voorgeschiedenis. Tijdens de tweede wereldoorlog vochten vele Roemenen in de Duitse, Sovjet- en Franse legers, waardoor ze onder de vigeur van de wet van 1939 en van het decreet van 1948 de nationaliteit hadden verloren ${ }^{132}$. Bij het reeds genoemde decreet van 24 juni 1955 werden vervolgens de mogelijkheden voor gemakkelijke herkrijging van de nationaliteit door repatrianten geschapen. De regeling van art. 7 van de huidige nationaliteitswet kan derhalve worden gezien als een verlengstuk van die regeling. Ook kan worden gesteld dat verkrijging van de nationaliteit door repatriëring in een zekere zin de terugkeer van de verkrijging van

130. Cr. Suga, OER 1973, p. 16; Radu, Revue Roumaine 1972/1, p. 30.

131. Cf. Deleanu, p. 95-96; Suga, OER 1973, p. 14.

132. Suga, OER 1973, p. 11-12. 
de nationaliteit ten behoeve van etnische Roemenen door erkenning, die de wet van 1939 kende, betekent. Het verschil is echter dat die wet een ruimere werking had, aangezien nu uitdrukkelijk wordt vereist dat betrokkene in het bezit van de juridische Roemeense nationaliteit is geweest. Bovendien werkte verkrijging door erkenning ex tunc, terwijl repatriëring slechts ex nunc werking heeft (lid 4) ${ }^{133}$.

\section{a. Invloed op de nationaliteit van de gezinsleden van de verzoeker}

De huwelijkspartner van een persoon die op grond van art. 7 de Roemeense nationaliteit verwerft, heeft de mogelijkheid om in de verkrijging van de nationaliteit deelachtig te zijn, indien hij verklaart dat hij van zijn tegenwoordige nationaliteit afstand doet en dat hij het Roemeense staatsburgerschap wenst te verwerven (lid 3). Tevens moet hij een eed van trouw afleggen.

Kinderen van de gerepatrieerden die jonger zijn dan 18 jaar, worden in de verkrijging van de nationaliteit door hun ouder(s) deelachtig, indien tenminste aan éen van hun ouders de nationaliteit wordt verleend (lid 2). Het kind verwerft het Roemeense staatsburgerschap evenwel niet, indien het met de andere ouder in het buitenland blijft wonen. Evenmin als bij de gewone naturalisatie kan een meerderjarig geworden kind afstand doen van de Roemeense nationaliteit.

\subsubsection{Verlies van de nationaliteit}

De Roemeense nationaliteit kan worden verloren door ontslag en door ontneming. Opmerkelijk is, dat in de Roemeense literatuur ${ }^{134}$ de eerste een uitzonderingswijze en de tweede als de normale wijze van het verlies van de nationaliteit wordt gekarakteriseerd. Andere wijzen van het verlies van de nationaliteit kent het Roemeense nationaliteitsrecht niet.

\subsubsection{Ontslag}

Het verlies van de Roemeense nationaliteit door ontslag is geregeld in artt. 22-23 van de wet van 1971. De wettekst spreekt niet van ontslag, maar van "toestemming tot het doen van afstand" 135 , die kan worden verleend door de President van de republiek (art. 22 lid 1). Opmerkelijk is, dat in de wet uitdrukkelijk wordt bepaald, dat ontslag slechts in uitzonderingsgevallen mogelijk is. De voorwaarden voor het ontslag worden geformuleerd in art. 22:

- leeftijd van 18 jaar of ouder (aanhef);

- betrokkene moet bij een authentieke akte verklaren dat hij na het verlies van de nationaliteit geen handelingen zal verrichten die de staat kunnen schaden (lid 1 sub a);

133. De nationaliteit wordt verkregen op het moment van de eedsaflcgging. Radu, Revue Roumaine $1972 / 1$, p. 30

134. Deleanu, p. 123; Suga, OER 1973, p. 16; Radu, Revue Roumaine 1972/1, p. 31.

135. Suga, OER 1973, p. 17 spreekt bij het ontslag over "Verzicht durch Genemigung". 
- het ontslag is niet mogelijk hangende een strafprocedure tegen betrokkene of indien tegen hem een straf ten uitwoer moet worden gelegd (sub b);

- de verzoeker moet aan al zijn verplichtingen tegenover de staat, de rechts- en natuurlijke personen hebben voldaan, respectievelijk zekerheid daarvoor hebben gesteld (sub c);

De Roemeense paspoortwetgeving ${ }^{136}$ kent geen recht op het verlaten van het land. Een uitreisvisum kan op vage gronden worden geweigerd. Het grootste aantal emigranten behoort tot de Duitse minderheid, hoewel het ook voor etnische Roemenen mogelijk is om toestemming te krijgen ${ }^{137}$. In de laatste jaren lijkt Roemenië zijn eigen onderdanen als een "exportartikel" te beschouwen. "Zo werd op 6 november $1982^{138}$ een regeling met betrekking tot terugbetaling van "schulden" aan de staat, sociale organisaties en natuurlijke personen uitgevaardigd. Deze regeling, die met name tegen emigratiewillige intellectuelen is gericht schrijft voor, dat men de kosten van de genoten gymnasium- en universitaire, of hogeschoolopleiding in harde valuta(!) terug moet betalen (art. 2). De bedragen zijn ongeveer $\$ 3.700$ voor gymnasium en tussen $\$ 3.000$ en 4.000 voor elk studiejaar aan de universiteit of hoge school ${ }^{139}$. Slechts de gepensioneerden worden van deze verplichting vrijgesteld. Bovendien moeten alle onroerende goederen die de emigranten bezitten zonder vergoeding aan de staat worden overgelaten (art. 5). Ook de cultuurgoederen moeten worden achtergelaten, waarvoor men wel een door de staat vast te stellen vergoeding ontvangt (art. 6). Deze regeling van terugbetaling van opleidingskosten wordt niet (meer) toegepast net betrekking tot etnische Duitsers en emigranten naar de Verenigde Staten. Voor de eersten betaalt de BRD thans het met Boekarest in verband met kredietovereenkomsten afgesproken vrijkoopsom van ongeveer DM 8.000. De VS hebben de vrijstelling van terugbetaling van opleidingskosten kunnen bereiken door Roemenië economische sancties in het vooruitzicht te stellen ${ }^{140}$.

\subsection{Invloed op de nationaliteit van de gezinsleden van de verzoeker}

Het verlies van de nationaliteit door ontslag heeft volgens art. 23 lid 1 geen invloed op de nationaliteit van de huwelijkspartner en de minderjarige kinderen van betrokkene. in het tweede lid van art. 23 wordt echter een uitzondering gemaakt ten opzichte van minderjarige kinderen voor het geval dat het ontslag aan beide ouders wordt verleend. Zij verliezen automatisch de Roemeeense nationaliteit, indien ze gezamenlijk met hun ouders in het buitenland (gaan) wonen. Hetzelfde geldt voor het geval dat slechts eén van de ouders wordt ontslagen, terwijl de

136. Paspoortdecreet van 24 maart 1970, B.O. 1970, nr. 32, laatstelijk gewijzigd op 25 december 1985 , B.O. I, 1985, mr. 75. Zie daarover Kuss, EuGRZ 1987, p. 310 .

137. In de jaren 1971-1985 emigreerden 152.500 etnische Duitsers en 27.500 etnische Roemenen legaal uil Roemenië. Menschenrechte, $p .109$.

138. B.O. 1982, nr. 95; Duitse vertaling bij Wolloch, p. 358-361. Zie daarover Wolloch, p. 299-301.

139. Deze bedragen werden door de Roemeense autoriteiten bekendgemaakt. Zie Wolloch, 300.

140. Roemenie mott 11,000 etnische Duitsers per jaar laten emigreren. Volgens een bericht in het NRC-Handelsblad van 25 februari 1989 werd de "prijs" eind 1988 tot DM 9.900 verthoogd. Zie Kuss, EuGRZ 1987, p. 310; Menschenrechte, p. 127. 
andere ouder onbekend of reeds overleden is (lid 3). De nationaliteit gaat voor het kind dat in het buitenland woont verloren op het moment dat zijn beide ouders worden ontslagen.

\subsubsection{Ontslag in verband met adoptie door vreemdelingen}

De Roemeense nationaliteitswet van 1971 kent in art. 24 een aparte mogelijkheid van ontslag ten behoeve van een minderjarig Roemeens kind, dat door vreemdelingen wordt geadopteerd. De voorwaarde voor het verlies van de nationaliteit is, dat het kind door adoptie de nationaliteit van zijn adoptiefouders verwerft (art. 24 lid 1). De ouders moeten om het ontslag tegelijkertijd met de adoptie verzoeken, of uiterlijk totdat het kind meerderjarig wordt. Ook in dit geval wordt het ontslag verleend door de President van de republiek en heeft deze discretionaire bevoegdheid ${ }^{141}$.

Indien de adoptie tijdens de minderjarigheid van het kind ongedaan wordt gemaakt, herkrijgt het kind automatisch de Roemeense nationaliteit indien het in Roemenië woont, of indien het zich nog tijdens de minderjarigheid aldaar komt vestigen (art. 24, leden 2, 3).

\subsubsection{Ontneming}

Het verlies van de Roemeense nationaliteit door ontneming wordt geregeld in artt. 19-21 van de wet van 1971. De bevoegdheid om de nationaliteit te ontnemen ligt bij de President van de republiek (art. 19 lid 2), die beslist op voordracht van het Ministerie van binnenlandse zaken (art. 28 lid 1) ${ }^{142}$ "Tegen de ontneming van het staatsburgerschap zijn geen rechtsmiddelen toegelaten. De regeling van ontneming begint in het eerste lid van art. 19 met de volgende "Generalklausel":

"Jener, der sich vom Land lostrennt, seine Verpflichtung der Treue zum Vaterland verletzt, die Interessen des Volkes verrät, gegen die Einheit, die Souveränität und die Unabhängigkeit des Staates handelt, jegliche andere Art feindlicher Handlungen oder solche Handlungen verübt, die dem guten Ruf Rumäniens Abbruch tun, wird unwürdig den hohen Titel eines rumänischen. Staatsbürgers zu tragen" ${ }^{143}$.

Voorts worden in art. 19 lid 2 een aantal van dergelijke handelingen genoemd:

- handelingen die tegen de staat zijn gericht, of die de goede naam van Roemenië schaden (sub a);

het zonder toestemming treden in vreemde staats- of militaire dienst bij verblijf in het buitenland (sub b);

141. Deleanu, p. 133-134; Wolloch, p. 307.

142. Suga, OER 1973, p. 17.

143. Vertaling ontleend aan Bergmann/Ferid, p. 9. 
- het illegaal verlaten van het land $(\text { sub } c)^{144}$;

- verkrijging van de Roemeense nationaliteit in strijd met de wet (sub d);

- verkrijging van een vreemde nationaliteit zonder voorafgaand ontslag uit de Roemeense (sub e).

De nationaliteit kan ook worden ontnomen in het geval dat betrokkene daardoor staatloos wordt.

9.2.3.2.1 Invloed op de nationaliteit van gezinsleden van betrokkene

Ontneming van het staatsburgerschap heeft blijkens art. 21 geen invloed op de nationaliteit van de huwelijkspartner en minderjarige kinderen van betrokkene. Deze garantie is gezien de vage formulering van met name de ontnemingsgrond van art. 19 lid 2 sub a uiteraard nogal betrekkelijk.

144. Ook in Roemenië is de tendens naar "legalisering" van het verblijf van illegale emigranten waarneembaar. Menschenrechte, p. 112. In dit verband zij ook gewezen op het reeds besproken decreet van 1982 met betrekking tot de terugbetaling wan opleidingskosten door "legale" emigranten. In art. 7 van dit decreet vinden we een bepaling, die tegen de "illeggalen" is gericht. Daarin maakt de staat het voor zichzelf mogelijk, om zich voor de opleidingskosten op het vermogen van betrokkene te verhalen. 


\subsection{GESCHMRDENIS}

\subsubsection{Inleiding}

De Tsjechoslowaakse republiek (CSR) ontstond op 28 oktober $1918^{1}$ op een gedeelte van het grondgebied van het voormalige Oostenrijks-Hongaarse Keizerrijk. Tot de nieuwe staat gingen de Oostenrijkse gebieden Bohemen, Moravië en Silezië en de Hongaarse gebieden Slowakije en Karpathorusland, behoren ${ }^{2}$. Op grond van de na de eerste wereldoorlog gesloten vredesverdragen ${ }^{3}$ werd het grondgebied van de nieuwe republiek uitgebreid met de voormalige Oostenrijkse gebieden Weitra en Feldsberg en met het zogenaamde Hultschiner Ländchen (Hluxin), dat voorheen aan Duitsland toebehoorde 4 . De eerste Tsjechoslowaakse grondwet kwam vervolgens tot stand op 29 februari $1920^{5}$.

De bevolking van de jonge Tsjechoslowaakse republiek was etnisch zeer verschillend. Volgens een volkstelling in 1930 woonden er $51,15 \%$ Tsjechen, $22,32 \%$ Duitsers, $15,76 \%$ Slowaken, 4,78\% Hongaren, 3,79\% Russen, $1,3 \%$ Joden en $0,9 \%$ andere volkeren ${ }^{6}$. In deze etnische verscheidenheid van de bevolking lag ook de voornaamste oorzaak voor het uiteenvallen van de CSR eind 1938/begin 1939. Toen moest Tsjechoslowakije eerst op grond van het verdrag van München van 29 september 1938 aan het Duitse Rijk het Sudetengebied afstaan?. Vervolgens hadden ook Polen en Hongarije inlijving van enkele gebieden kunnen bereiken ${ }^{8}$.

Als een laatste "reddingspoging" gaf de regering in Praag toe aan het autonomiestreven in Slowakije en in Karpathorusland en veranderde de ČSR in een federale staat. Het parlement nam op 18 november 1938 een voorlopige grondwet van de nieuwe federatie aan. Deze bestond uit de deelstaten Bohemen/Moravië,

1. Wet betreffende de oprichting van de $\operatorname{CSR}$, wan 28 oktober 19:18, art. 11/918 Sb. (Sbirka zákonu). Het is in Tsjechoslowakije gebruikelijk wetten met "artikel" en het nummer van de verschijning in het staatsblad te citeren. Zie over de gebeurtenissen van eind oktober 1918 witvoerig Strauss, p. 267-287. Zie voorts Peaslee, p. 222; Mercier, p. 80; Sobota, p. 179-180; SGS deell 18, p. 11; Bergmann/Ferid, p. 2; Korkisch, WGO 1969, p.165; Schumid, p. 10.

2. Papánek, p. 71-78; SGS deel 18, p. 11; Korkisch, WGO 1969, p. 158; Schmid 1979, p. 10; SGS decl 18 , p. 11; Weyr, JoR 1922 , p. $351-375$.

3. Het verdrag van Saint-Germain-en-Laye van 10 september 1919; State Papers 113, 464; art. $507 / 1921 \mathrm{Sb}$, in werking getreden op 16 juli 1920 , met Oostenrijk en het verdrag van Versailles vam 28 juni 1919; State Papers 113, 470; wet-art. 217/1921, sb. in werking getreden op 10 januari 1920 , met Duitsland.

4. SGS deel 18, p. 11; Schmid 1979, p. 11. Zie over de problematiek van het Hultschiner Ländchen: Bollacher, Das Hultschiner Ländchen im versailler Friedensvertrag, Stuttgart, 1930.

5. Art. 121/1920 Sb.; in werking getredem op 6 maart 1920. Zie Sobota, p. 203-208; Päpanek, p. 79.

6. Zie over de nationaliteitenproblematiek in de CSR Winkler, Die Tschehoslowakei im Spiegel der Stalistik, Karlsbad/Leiprig 1937; Mercier, p. 147-195.

7. Schmid 1979, p. 20; Further Documents, p. 3-4; Táborsky, p. 5-21. Zie voorts Gesetz über die Wiedervereinigung der sudetendeutschen Gebiete mit dem deutschen Reich van 21 november 1938, RGBL. I, p. 1641. Duitse vertaling bij Schmid 1979, p. 78.

8. Polen na de onderhandelingen in Warschau op 19 en 21 oktober 1938 en Hongarije op grond van de zogenaamde "tweede Wiener Schiedsspruch" van 2 november 1938, vitgesproken door de Duitse en Italiaanse regering. Daarover Táborsky, p. 21-23; Schmid 1979, p. 20. 
Slowakije en de Karpatho-Oekraïne (een nieuwe benaming voor Karpathorusland) 9 Tot een definitieve grondwet is men niet meer gekomen. Op 14 maart 1939 hadden zich Slowakije en de Karpatho-Oekraïne zelfstandig verklaard ${ }^{10}$, terwijl Bohemen en Moravië door de Duitsers werden binnen gevallen en tot een Duits protectoraat werden uitgeroepen ${ }^{11}$. De Karpatho-Oekraïne werd reeds enkele dagen na de onafhankelijkheidsverklaring door Hongarije geannexeerd ${ }^{12}$. Slowakije bleef echter tot 1945 op papier een onafhankelijke staat. Feitelijk stond het onder Duitse invloed ${ }^{13}$.

In 1945 werd het grondgebied van de vroegere CSR door de Sovjetunie van de Duitse en Hongaarse bezetting bevrijd. De Russen stelden op 9/10 mei 1945 de regering van de $\mathrm{CSR}^{\mathrm{i}}$ in ballingschap in staat opnieuw de regeringsmacht over het grondgebied van de ĆSR vó́r het verdrag van München uit te oefenen ${ }^{14}$. De Karpatho-Oekraïne moest echter (ditmaal onder de naam TranskarpathenOekraïne) op grond van het Verdrag van Moskou van 29 juni $1945^{15}$ aan de USSR worden afgestaan. De nieuwe regering stelde zich op het standpunt dat de Tsjechoslowaakse republiek tot 1945 als subject van het volkenrecht binnen de in 1919 vastgestelde grenzen had bestaan. Slechts de uitoefening van staatsgezag was in de "tijd van onvrijheid" (tussen 30 september 1938 en 4 mei 1945) ${ }^{16}$ onmogelijk ${ }^{17}$. Conform deze doctrine hadden alle rechtsvoorschriften die vó́r 30 september 1938 tot stand kwamen, hun geldigheid behouden, terwijl alle in "de tijd van onvrijheid" tot stand gekomen rechtsregels als nietig werden beschouwd. Het verdrag van München, alsmede alle grondgebiedsveranderingen van 1938/39 en rechtsvoorschriften die tussen 1939 en 1945 tot stand kwamen, werden bij wet van 2 oktober $1946^{18}$ formeel nietig verklaard.

De "burgerlijke" regering bleef aan het stuur tot februari 1948, toen de communistische partij bij gelegenheid van een regeringscrisis de macht geheel in eigen handen kon krijgen ${ }^{19}$. Pas toen raakte Tsjechoslowakije geheel onder de invloed van de Sovjetunie. Het land is sedert de oprichting van het Warschaupact

9. Schmid 1979, p. 21.

10. Slowensky zákonnik 1939 , nr. 1; Durica, p. 70; Zie uitvoerig over de gebeurtenissen in Slowakije Rabl, ZaöRV 1939-40, p. 284-321.

11. Trborsky p. 39; SGS deel 18, 1e druk, p. 26; Schmid 1979, p. $21-22$.

12. Taborsky, p. 30; p. 21-22. De Karpatho-Oekraine had een hoofdzakelijk etmisch Russische bevolking en genoot in de CSR een zekere autonomie. Zie daarower Ballreich, p. 50-82.

13. Zie het "Schutzvertrag" tussen Duitsland en Slowakije van 18/23 maart 1939; RGBI. 1939 II, p. 607 ; cok afgedrukt in ZaöRV 1939-40, p. 510-511. De "zelfstandigheid" wan het regime in Slowakije kan door de volgende woorden van Schwartz, p. 10, worden geillustreerd: "Dic staatliche Unabhängigkeît und das autoritäre System dieses Staates sind neben dem deutschen Schutz die sichersten und stärksten Garanten für die Zukunft. Sie stellen zugleich einen wirksamen Beitrag zu Sicherung des Friedens in Europa durch Adolf Hitler dar". Zie ook uitwoerig: Durica, La Slovacchia e le sue relazioni politiche con la Germania 1939/1945; Padowa, 1964.

14. Beuer, p. 97; SGS deel 18, 1e druk, p. 31; Schmid 1979, p. 38.

15. Art. 186/1946 Sb. Zie Beuer, p. 179-182; Schmid, p. 38; zie ook SGS deel 18, te druk, p. 31. Russische tekst afigedrukt bij Vilkov, p. 61-62. Zie bok het aanvullende protocol wan hetzelfde datum.

16. Zie de regeringsverordening art. 23/1945 Sb.; SGS deel 18, 1e druk, p. 31.

17. Schmid 1979, p. 38; SGS deel 18 , 1e druk, p. 31 met verdere literatuurverwijzingen.

18. Art. 195/1946 Sb. Zie Schmid 1979, p. 38.

19. Sharp, p. 39; Peaslee, p. 222. 
en de COMECON lid van beide organisaties. In $1968 \mathrm{kwam}$ het onder de staatsen partijchef A. Dubcek tot verschillende hervormingen die tot doel hadden het politieke en economische systeem te democratiseren. Aan deze ontwikkelingen werd in augustus 1968 door een militaire interventie van de strijdkrachten van het Warschaupact een einde gemaakt.

De eerste grondwet van de volksrepubliek werd op 9 mei $1948^{20}$ afgekondigd en werd vervolgens op 11 juli $1960^{21}$ grondig herzien. Bij deze grondwetswijziging veranderde de naam van het land in Tsjechoslowaakse Socialistische Republiek (CSSR) ${ }^{22}$. De Grondwet van 1960 werd in de loop der jaren meermalen gewijzigd ${ }^{23}$. De belangrijkste daarvan was die door het "Verfassungsgesetz" van 27 oktober $1968^{24}$, waarbij de staatsvorm veranderde in een federatie met als deelstaten de Tsjechische Socialistische Republiek (ĆSR) en de Slowaakse Socialistische republiek (SSR). Dit decentraliseringsstreven werd echter reeds bij de grondwetswijziging van 20 december $1970^{25}$ weer ingeperkt.

\subsubsection{Het mationaliteitsrecht tot 1939}

\subsubsection{Algemeen}

In de vredesverdragen ${ }^{26}$ na de eerste wereldoorlog werd aandacht besteed aan nationaliteitsvragen. De hoofdregel was, dat alle personen, die op het grondgebied van de CSR hun "Heimatrecht" 27 (in de voormalige Oostenrijks-Hongaarse gebieden), respectievelijk de woonplaats (in de gebieden die voorheen aan Duitsland toebehoorden) hadden, eo ipso hun vroegere nationaliteit verloren en die van de ČSR verwierven.

\section{Art. $150 / 1948 \mathrm{Sb}$.}

21. Art. $100 / 1960 \mathrm{sb}$.

22. SGS deel 18, p. 9 .

23. De grondwet wan 1960 werd gewijzigd bij de volgende "Verfassungsgesetze": van 12 december 1967 , art. 110/1967 Sb; van 9 maart 1968 , art. $28 / 1968 \mathrm{Sb}$; van 25 juni 1968 , art. $81 / 1968 \mathrm{Sb}$; van 27 oktober 1968, art. 143/1968 Sb.; van 27 oktober 1968, art. 144/1968 Sb.; van 5 juni 1969, art. 155/1969 Sb.; van 6 julli 1971, art. 43/1971. Sb. en van 21 juni 1978, art. 62/1978 Sb. Zie Roggemann, $\mathrm{p}_{*} 461$.

24. Art. 143/1968 Sb., in werking getreden op 1 januari 1969. Zie Plank, Práway Obzor 8/1969, p. 681-711. Bijj de onderhavige wijzigingswet werden de volgende bepalingen van de grondwet van 1960 geschrapt: 1 lid $2,39-85,90,107-109$ en 111. Roggemann, p. 461. Zie voor Duitse vertaling. van de grondwet wan de CSSR van 1960 zoals zij geldt na de wijzigingen van 1968 Roggemann: p. $463-538$.

25. Art. 125/1970 Sb. Zie hierover SGS deel 18, p. 36-37; Matousek/Grospit Právnik 1973, p. 222234.

26. Zie voor de vredesverdragen met Oostenrijk en Duitsland noot 3 en met betrekking tot Hongarije, het verdragg van Trianon van 4 juni 1920; State Papers 113, $468_{\text {; }}$ art. 102/1922 Sb.; in werking getreden op 26 juli 1921 . Op de nationaliteit hadden betrekking artt. $64,65,70-82,91$, 92,230 ein 249 sub b van het verdrag van Saint-Germain-en-Laye; artt. 84-86, 278 en 434 van het verdrag van Versailles en artt. 61-66 van het verdrag van Trianon.

27. Het Heimatrecht was een instituut van het Oostenrijks recht. Het ging daarbij om een soort verblijfsrecht in gemeenten. In de Tsjechoslowaakse literatuur wordt het Heimatrecht met de term "domovskê pravo" aangeduid. Zie bijvoorbeeld Matušek, Správni pravo 3/1981, p. 155; Másilko, Socialisticka zákonnost 3/1980, p. 147. Zie over het Heimatrecht ook hoofdstuk Hongarije, p. 171. Aangezien het Duitse recht geen Heimatrecht kende, werd woor de gewone woonplaats (ordentliche Wohnsitz) als criterium gekozen. SGS deel 18, 1e druk, p. 12-13. 
Op grond van een wet van 28 oktober $1920^{28}$ bleven de oude nationaliteitsrechtelijke regelingen van Oostenrijk-Hongarije in de nieuwe staat voorlopig van kracht. Dat waren in het Oostenrijkse gedeelte van de Dubbelmonarchie: $\$ \$ 28$ 30 en 32 van het "Allgemeine bürgerliche Gesetzbuch Osterreichs" (ABGB) ${ }^{29}$, het zogenaamde "Heimatgesetz" van $1863^{30}$ en enkele bijzondere regelingen die (mede) betrekking hadden op de nationaliteit. In het Hongaars gedeelte waren van kracht: de nationaliteitswet van $1879^{31}$ en de regeling van het "Heimatrecht" in de Gemeentewet van $1886^{32}$. In de voormalige Duitse gebieden werd het Oostenrijkse nationaliteitsrecht ingevoerd ${ }^{33}$.

De eerste Tsjechoslowaakse grondwet van 29 februari $1920^{34}$ bevatte in $\$ 4$ enkele bepalingen die betrekking hadden op de nationaliteit. In het eerste lid werd bepaald dat er een algemene ĆSR-nationaliteit bestond en in het tweede lid van $\$ 4$ werd de bevoegdheid om verkrijging en verlies van de nationaliteit te regelen aan de wetgever geattribueerd. In het derde lid werd tenslotte het beginsel neergelegd, dat het bezit van een vreemde nationaliteit door ĆSR-onderdanen niet werd erkend (exclusiviteitsbeginsel) ${ }^{35}$.

Als uitwerking van art. 4 van de grondwet kondigde men vervolgens op 9 april 1920 een "Verfassungsgesetz" 36 af. In deze wet werd de inhoud van de nationaliteitsrechtelijke bepalingen van de vredesverdragen van na de eerste wereldoorlog opgenomen ${ }^{37}$ en enkele wijzigingen in de Oostenrijks-Hongaarse nationaliteitsrechtelijke regelingen aangebracht. Bovendien werd de regering in \$ 19 gemachtigd om ten aanzien van onderwerpen die niet door vredesverdragen werden geregeld, nieuwe verdragen met de betrokken staten te sluiten.

In een volgend "Verfassungsgesetz" d.d. 1 juli $1926^{38}$, die als lex Dérer bekend is geworden, werd aan een bepaalde groep voormalige Hongaarse staatsburgers (die niet reeds op grond van de vredesverdragen de ČSR-nationaliteit hadden

28. Art. 11/1920 Sb.

29. ABGB van 1 juni 1811, JGS (Justizgesetzsammlung) nr. 946 in werking getreden op 1 januari 1812. Zie Cerny/Črvenka, p. 7; SGS deel 18, 1e druk, p. 14.

30. Wet van 3 december 1863 , oRGBl. nr. 105, gewijzigd bij de wet van 5 december 1896, öRGBl. nr. 222. Zie Cerny/Cervenka, p. 7; Korkisch, WGO 1969, p. 158; SGS deel 18, 1e druk, p. 14; Schmid 1979, p. 17. Het Heimatgesetz zal in het werwolg als HG worden afigekort.

31. Wet-art. L: 1879. Cerny/Cervenka, p. 7. Zie over de citeerwijze van Hongaarse wetten hoofstuk Hongarije, p. 170. Deze wet zal in het vervolg als W1879 worden afgekort.

32. Wet-Art. XXII: 1886. Zie Cerny/Cervenka, p. 7; Korkisch, WGO 1969, p. 158; SGS deel 18, 1 e druk, p.1.4.

33. SGS deel 18 , p. 14.

34. Art. 121/1920, Sb. Zie daarover Weyr, JöR 1922 , p. $351-375$.

35. $\$ 4$ lid 3 bepaalde letterlijk dat een onderdaan vam een vreemde staat miet tegelijkertijd onderdaan wan de CSR kon zijn. Zie over deze, in de nationaliteitswetten van de Oosteuropese landen dikwijls woorkomende bepaling p. 31-32.

36. Art. 236/1920 Sb.; Duitse vertaling in SGS deel 18, 1e druk, p. 55-60. Sobota, p. 247-251. Een "Verfassungsgesetz" is een wet in formele zin die volgens de voor een grondwet geldende voorschriften tot stand komt en in de hiërarchie naast de grondwet staal. Vanwege het ontbreken wan een adequate term in de Nederlandse taal zal hier steeds de Duitse aanduiding worden gebezigd. Zie ook de uitvoeringsverordening van 30 oktober 1920, art. 601/1920 $\mathrm{Sb}$; daarover Sobota, p. 282-285.

37. Zie SGS deel 18, 1e druk, p. 14; Korkisch, WGO 1969, p. 158-159.

38. Art. 152/1926 $\mathrm{Sb}$.; in werking getreden op 22 augustus 1926. 
verworven) in verband met hun woonplaats in de CSR de mogelijkheid van vereenvoudigde naturalisatie toegekend ${ }^{3 *}$.

De ĆSR sloot vervolgens de volgende internationale verdragen die (mede) betrekking hadden op de nationaliteit:

- het "Minderheitenschutzvertrag" van Saint-Germain-en-Laye van 10 december $1919^{40}$ met de geallieerden;

- het migratieverdrag van 20 maart 1920 met Frankrijk ${ }^{41}$;

- het verdrag van Brünn (Brno) 7 juni $1920^{42}$ met Oostenrijk betreffende het staatsburgerschap en de bescherming van minderheden;

- het verdrag van Praag van 29 juni $1920^{43}$ met Duitsland met betrekking tot de nationaliteit;

- het verdrag van Warschau van 23 april $1925^{44}$ met Polen, betreffende juridische en financiële vraagstukken;

- het verdrag van Praag van 16 juni $1928^{45}$ met de Verenigde Staten betreffende naturalisatie;

- het verdrag van 20 november $1938^{46}$ met Duitsland, met betrekking tot de nationaliteit na het verdrag van München.

De verdragen met Oostenrijk en met Duitsland (van 1920) werden beschouwd als uitwoering van de in $\$ 19$ van het "Verfassungsgesetz" van 1920 gegeven machtiging aan de regering om in internationale verdragen nadere regels met betrekking tot

39. Het ging om een groep personen die op voormalige Hongaarse gebieden woonachtig waren en dic vanwege uiteenlopende interpretaties van de Hongaarse gemeentewet in de CSR, respectievelijk Hongarije, staatloos werden. Cf. SGS deel 18, 1e druk, p. 17.

40. Art. $507 / 1919 \mathrm{Sb}$; State Papers 113, 464; in werking getreden op 16 juli 1920. Op de nationaliteit hadden betrekking de artt. 1-6. Zie voor een Duitse vertaling daarvan SGS deel 18, 1e druk, $p$. 53-54.

41. LNTS III, $2,140$.

42. Wet-art. 107/1921 Sb.; State Papers 113, 918; LNTS III, 3, 190; in werking getreden op 10 maart 1921. Op de nationaliteit hadden betrekking de artt. 1-16. Daarover Sobota, p. 307-312. Zie voor een Duitse vertaling van de belangrijkste bepalingen SGS deel 18, 1e druk, p. 60-63.

43. Art. 308/1922 Sb; Duitse RGBl. 1920, p. 2227; LNTS XX, 86. In werking getreden op 12 september 1922. Zie ook de regeringsverordening wan 18 december 1924 , art. $20 / 1925 \mathrm{Sb}$.

44. Art. 56/1926 Sb.; LNTS XLVI, 201; in werking getreden op 29 april 1929. Op de nationaliteit hadden betrekking de artt. 1 en 2 . Daarover Sobota, p. 427-431.

45. Art. 169/1929 Sb.; LNTS XCVI, 301; Duitse vertaling in SGS deel 18, 1e druk, p. 63-65. Zie ook de wet betreffende de uitvoering van dit verdrag van 29 april 1930, art. 60/1930 Sb.

46. Duitse RGBI. 1938 II, p. 896; $300 / 1938$ Sb. In werking getreden op 26 november 1938. Duitse vertaling bij Sehmid 1979 , p. 74-77. Zie ook de daarop betrekking hebbende regeringsverordening van 25 november $1938,301 / 1938 \mathrm{Sb}$. 
de nationaliteit te treffen. Derhalve werden beide verdragen geacht deel uit te maken van deze wet en directe werking te hebben ${ }^{47}$.

10.1.2.2 De regelingen van het $A B G B$ en van de Hongaarse nationaliteitswet van 1879

\subsection{Algemeen}

De oude Oostenrijkse en Hongaarse bepalingen bleven in de Ć SR tot 1948 van kracht. Op 31 maart 1938 werd weliswaar aan het parlement een ontwerp voor een nieuwe nationaliteitswet aangeboden, doch vanwege het uiteenvallen van de CSR haalde dit wetsvoorstel nooit de eindstreep ${ }^{48}$. Hieronder volgt een korte bespreking van bepalingen betreffende verkrijging en verlies van de nationaliteit. Daarbij wordt de Oostenrijkse regeling steeds als uitgangspunt genomen. In de gevallen dat de Hongaarse regeling precies dezelfde was zal worden volstaan met vermelding van de desbetreffende bepalingen van de Hongaarse wetten.

\subsection{Verkrijging van de nationaliteit}

De Tsjechoslowaakse nationaliteit kon worden verkregen van rechtswege en door naturalisatie.

\section{a. Verkrijging van rechtswege}

Van rechtswege werd verkrijging van de nationaliteit gekoppeld aan de volgende rechtsfeiten:

- geboorte uit Tsjechoslowaakse ouder(s) (\$\$28, 161 en 162 ABGB en $\$ 6$ HG; $\S 3,4$ W1879),

- geboorte of het gevonden worden in de ČSR ( $\$ 2$ van de wet van $1920 ; \$ 18$ en 19 lid $3 \mathrm{HG}$; $\$ 19$ W1879);

- huwelijk met een Tsjechoslowaak ( $\$ 16$ van de wet van 1920).

- benoeming als ambtenaar ( $\$ 1$ lid 4 van de wet van 1920).

Door adoptie door een Tsjechoslowaakse man kon de nationaliteit van de ČSR niet worden verkregen ( $\$ 6$ lid $4 \mathrm{HG} ; \& 8$ W1879).

47. Aldus een beslissing van het Opperste administratieve gerechtshof in Praag van 30 november 1923, Z. 201/23. Geciteerd bij Schmied, SGS deel 18, le druk, p. 16 voetnoot 4.

48. Schmid 1979 , p. 20 ; SGS deel 18 , 1e druk, p. 17-18. 


\section{i. Geboorte uit Tsjechoslowaakse ouder(s)}

Volgens $\$ 28 \mathrm{ABGB}(\$ 3 \mathrm{~W} 1879)$ werd een wettig kind van een Tsjechoslowaakse vader ČSR-onderdaan, indien zijn vader op het tijdstip van de geboorte van het kind deze nationaliteit bezat. Een onwettig kind volgde de Tsjechoslowaakse nationaliteit van zijn moeder ( $\$ 6$ lid $2 \mathrm{HG}, \S 3 \mathrm{~W} 1879$ ). Het was niet van belang of het kind in Tsjechoslowakije of in het buitenland werd geboren.

De nationaliteit van de ĆSR kon voorts ook worden verkregen door een kind wan een vreemdelinge, dat tijdens zijn minderjarigheid (tot 21 jaar) door een Tsjechoslowaak werd gelegitimeerd. Deze nationaliteitsverkrijging werkte ex nunc ${ }^{49}$. Een kind kon worden gewettigd door huwelijk $\$ 6$ lid 3 HG jo. 161 ABGB; 4 W1879) of bij beslissing van de regering ( $\$ 162 \mathrm{ABGB})^{50}$. Erkenning door een Tsjechoslowaak kon geen verkrijging van de nationaliteit door het kind bewerkstelligen.

\section{ii Geboorte op het Tsjechoslowaakse grondgebied en vondelingen}

Een kind dat op het grondgebied van de CSR werd geboren of gevonden, werd vermoed de nationaliteit van de ĆSR te bezitten. Het tegenbewijs was steeds toegelaten, ongeacht de leeftijd van het kind. ( $\$ 2$ W 1920; $\$ 18$ en 19 lid 3 HG; $\$ 19$ W1879). In Slowakije en Karpathorusland werd ten aanzien van vondelingen tevens de eis gesteld, dat ze in Slowakije, respectievelijk in Karpathorusland moesten worden opgevoed $(\$ 19 \mathrm{~W} 1879)$.

\section{iii. Huwelijk met een buitenlander}

Een buitenlandse vrouw verkreeg door een huwelijk met een Tsjechoslowaak van rechtswege de nationaliteit van de ČSR ( $\$ 16$ W1920). Een overeenkomstige bepaling kenden overigens ook het oude Oostenrijkse en Hongaarse recht in het "Hofkanzleidekret" van 23 februari $1833^{51}$ en $\$ 7$ HG; $\& 5$ W 1879 . De nationaliteitsverkrijging strekte zich niet over eventuele kinderen van betrokkene ${ }^{52}$. Het staatsburgerschap werd verkregen, ongeacht of betrokkene door of in verband met het huwelijk haar oude staatsburgerschap verloor. Ze had ook geen mogelijkheid de verwerving van de nationaliteit te voorkomen.

\section{iv. Verkrijging door een ambtelijke aanstelling}

Volgens $\$ 10$ van het HG in de versie van 1896 verwierven dat alle ambtenaren, notarissen en geestelijken door hun vaste aanstelling het "Heimatrecht" in de gemeente waarin zij hun standplaats aangewezen kregen. Aangezien krachtens \& 2 HG buitenlanders geen "Heimatrecht" konden bezitten, werd daardoor automa-

49. Beslissing van het Opperste administratieve gerechtshof in Praag, van 29 maart 1932, Z. 2091/32; SGS deel 18, 1e druk, p. 19.

50. De zogenaamde "legitimatio per rescriptum principis", waarbij de "Landesfürst" van $\$ 162 \mathrm{ABGB}$ in CSR door de regering werd vervangen (dit krachtens \& 64 lid 2 van de grondwet van 1920). Zie SGS deel 18, le druk, p. 19.

51. JGS nr. 2595. Zie ook Krainz, p. 150.

52. SGS deel 18 , 1e druk, p. 20. 
tisch de Tsjechoslowaakse nationaliteit verkregen ${ }^{53}$. Het Hongaarse nationaliteitsrecht kende overigens geen verkrijging van de nationaliteit door ambtelijke aanstelling. In $\$ 3$ van het op p. 292 genoemde verdrag van Brürn (Brno) verplichtte de CSR zich echter $\$ 10$ van het $\mathrm{HG}$ te respecteren en derhalve ambtelijke aanstelling op zijn gehele grondgebied als verwervingsgrond van de nationaliteit te erkennen. De wraag is echter of dit slechts als een overgangsbepaling dient te worden gezien die, ten aanzien van personen, die tot de inwerkingtreding van dit verdrag werden benoemd betrekking had, of dat het de bedoeling was om de onderhavige verkrijgingsgrond ook nadien te laten werken ${ }^{54}$.

\section{b. Naturalisatie}

Verkrijging van de nationaliteit van de CSR door naturalisatie was geregeld in $\S$ $30 \mathrm{ABGB}, \S 2 \mathrm{HG}$ en in $\$ 8 \mathrm{~W} 1879$. Beslissingen omtrent naturalisaties werden door de provinciale besturen genomen. Een recht op naturalisatie of een mogelijkheid om tegen een negatieve beslissing rechtsmiddelen aan te wenden was er niet ${ }^{55}$. De naturalisatievereisten waren in de CSR verschillend, naar gellang de verzoeker in door het Oostenrijkse of door het Hongaarse nationaliteitsrecht beheerst gebieden woonde. Volgens de Oostenrijkse regeling van $\$ 30 \mathrm{ABGB}$ moest de verzoeker aan de volgende vereisten voldoen:

- in staat zijn om inkomsten te verwerven;

- zedelijk gedrag;

- tien jaar in de CSR wonen;

- bewijs omtrent opneming in een gemeente kunnen overleggen;

- zijn oude nationaliteit verliezen.

Naturalisandi moesten tevens een eed van trouw afleggen. Het niet afleggen van de eed had echter geen ongeldigheid van de naturalisatie tot gevolg ${ }^{56}$.

De Hongaarse regeling van $\S 8$ W1879 kende daarentegen de volgende naturalisatievereisten:

- volledige handelingsbekwaamheid (lid 1 sub 1);

53. SGS deel 18 , le diruk, p. 18 .

54. Volgens Schmied, SGS deel 18, 1e druk, p. 21 kon door ambtelijke aanstelling in Slowakije en Karpathorusland de nationaliteit namelijk niet worden verkregen. Deze opvatting staat echter op gespannen voet met het feit dat in $\$ 3$ van het verdrag van Brünn geen enkel voorbehoud werd gemaakt ten aanzien van genoemde gebieden. Uit het verdrag blijkt evenmin dat 3 slechis als een overgangsregeling werd bedoeld. Dit verdrag werd namelijk beschouwd als onderdeel van de constitutie en had in de CSR directe merking. Voorts werd in $\$ 13$ lid 2 W1920 uitdrukkelijk bepaald, dat de regeling van de wet van 5 december 1896 (strekkende tot wijziging van het HG) met betrekking tot het verlenem van het "Heimatrecht" eveneens in de voormalige Hongaarse gebieden gold.

55. SGS deell 18, 1e druk p. 20.

56. SGS deel 18, 1e druk, p. 20. 
- de verzoeker moest een bewijs omtrent opneming in een gemeente kunnen overleggen (lid 1 sub 2);

- ononderbroken vijfjarig verblijf (lid 1 sub 3);

- goed gedrag (lid 1 sub 4);

- betrokkene moest in staat zijn zichzelf en zijn gezin te onderhouden (lid 1 sub 5);

- de verzoeker moest sedert vijf jaren in de lijst van belastingsplichtigen zijn opgenomen (sub 6);

- het afleggen van een eed van trouw $(\$ 13)$.

i. Invloed op de nationaliteit van de gezinsleden van de verzoeker

De vrouw van de naturalisandus, alsmede hun kinderen, die jonger waren dan 18 jaar, werden krachtens $\$ 16$ W1920 automatisch in de naturalisatie van hun man, respectievelijk vader inbegrepen. Er bestond geen mogelijkheid om de medenaturalisatie te voorkomen.

\subsection{Verlies van de nationaliteit}

De Tsjechoslowaakse nationaliteit kon van rechtswege, door ontslag en door ontneming worden verloren. De laatste twee wijzen van verlies van het staatsburgerschap kende uitsluitend de in Slowakije en in Karpathorusland geldende Hongaarse regeling.

a. Verlies van rechtswege

Het verlies van de ČSR-nationaliteit werd van rechtswege gekoppeld aan:

- wettiging door een buitenlander ( $\$ 6$ HG; $\$ 33$ W1879)

- huwelijk met een buitenlander ( $\$ 32,92 \mathrm{ABGB} ; \$ 34$ W1879);

- verkrijging van een andere nationaliteit ( $\$ 4$ lid 3 van de grondwet van 1920);

- langdurig verblijf in het buitenland (alleen in Slowakije en Karpathorusland) (\$31 W1879).

\section{i. Wettiging door een vreemdeling}

Een onwettig kind van een Tsjechoslowaakse vrouw verloor zijn nationaliteit indien het tijdens zijn minderjarigheid door een vreemdeling werd gelegitimeerd $(\$ 6 \mathrm{HG}$; 
$33 \mathrm{~W} 1879)^{57}$. De nationaliteit ging slechts verloren op voorwaarde dat het kind daardoor de nationaliteit van zijn vader verwierf. Volgens de Hongaarse regeling ging het staatsburgerschap verloren zelfs indien het kind op het tijdstip van wettiging reeds meerderjarig was.

\section{ii. Huwelijk met een buitenlander}

Een Tsjechoslowaakse vrouw verloor haar nationaliteit door een huwelijk met een buitenlander ( $\$ 32,92 \mathrm{ABGB} ; \$ 11$ lid $1 \mathrm{HG} ; \$ 34$ W1879). De nationaliteit ging verloren ongeacht of zij door het huwelijk het staatsburgerschap van haar man verwierf. Ongeldigverklaring van het huwelijk had een herstel van de nationaliteit met terugwerkende kracht tot gevolg ( $\$ 11$ lid $3 \mathrm{HG}_{;} \& 37 \mathrm{~W} 1879$ ). Na de ontbinding van het huwelijk stond voor betrokkene slechts gewone naturalisatie open.

\section{iii. Verkrijging van een andere nationaliteit}

De nationaliteit van de ČSR ging ipso iure verloren door verkrijging van een vreemde nationaliteit. Het was daarbij niet van belang of het om al dan niet vrijwillige verkrijging van het vreemde staatsburgerschap ging. Deze verliesgrond was geen erfenis van Oostenrijk-Hongarije, maar volgde rechtstreeks uit $\$ 4$ lid 3 van de Grondwet van 1920.

\section{iv. Langdurig verblijf in het buitenland}

De Hongaarse wet van 1879 kende voorts het verlies van de nationaliteit vanwege langdurig verblijf in het buitenland. Deze verliesgrond was derhalve uitsluitend van toepassing op personen, die in een gemeente in Slowakije of Karpathorusland hun "Heimatrecht" bezaten. De nationaliteit ging verloren indien betrokkene tien jaren ononderbroken buiten de ČSR had gewoond, zonder dat hij in opdracht van de regering naar het buitenland ging. De tienjarige termijn ving aan op het tijdstip van overschrijding van de grens, respectievelijk op het moment waarop een eventuele regeringsopdracht was volbracht (lid 2). Betrokkene kon echter het verlies van de nationaliteit voorkomen door een vormeloze mededeling aan het gemeentebestuur van zijn (laatste) woonplaats in de CSR te richten waarin hij verklaarde zijn nationaliteit te willen behouden (lid 3). Deze verliesgrond werd echter in 1920 bij een wet betreffende de nationaliteit van emigranten geschrapt ${ }^{38}$.

\section{b. Ontslag}

Reeds hiervoor werd gezegd dat het ontslag uit de CSR-nationaliteit slechts in Slowakije en in Karpathorusland mogelijk was. Het verlies van het staatsburgerschap door ontslag was geregeld in de $\$ 21-30$ van de wet van 1879 . De bevoegdheid ten aanzien van het verlenen van het ontslag lag bij de Minister van

57. De Oostenrijkse regeling van het $\mathrm{HG}$ stelde tevens de eis dat een in het buitenland tot stand gekomen legitimatie in het land erkend was. Cf. SGS deel 18, 1e druk, p. 21.

58. Art. 71/1922 Sb. Zie Schmid, p. 18. 
binnenlandse zaken ( $\$ 21)$. In oorlogstijd kon ontslag slechts door de voltallige regering worden verleend $(\$ 25)$. Vereisten voor ontslag waren de volgende:

- volledige handelingsbekwaamheid of toestemming van de wettelijke vertegenwoordiger ( $\$ 24$ sub 1 );

- betrokkene mocht geen belastingschulden hebben (sub 2);

- tegen de verzoeker mocht geen strafprocedure aanhangig zijn of een nog niet voltrokken strafrechtelijk vonnis zijn uitgesproken (sub 3);

- verzoekers die enigerlei militaire verplichtingen hadden, konden slechts worden ontslagen met de toestemming van de Minister van defensie ( $\$ 22$ lid 1 );

verzoekers die niet van hun militaire verplichtingen wrijgesteld waren, konden na hun $17 \mathrm{de}$ jaar slechts worden ontslagen indien zij een verklaring van het gemeentebestuur van hun woonplaats overlegden, waarin stond dat zij niet slechts om de militaire dienstplicht te ontwijken om het ontslag verzochten (8 22 lid 2).

Interessant is, dat in vredestijd het ontslag van een verzoeker die aan de eerste

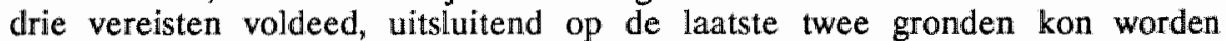
geweigerd $\left(\$ 24\right.$, aanhef). Hierdoor werd een soort recht op ontslag gecreëerd ${ }^{59}$.

Het ontslag werd steeds verleend onder enkele ontbindende voorwaarden. Zo verloor de beschikking haar rechtskracht indien betrokkene niet binnen één jaar na de verkrijging van het ontslag emigreerde. Hetzelfde gold indien betrokkene in die periode zijn belastingen niet betaalde of in een strafrechtelijke procedure verwikkeld raakte.

\section{i. Invloed op de nationaliteit van de gezinsleden van de verzoeker}

Ontslag uit de Tsjechoslowaakse mationaliteit strekte zich op grond van \$ 26 W1879 automatisch uit over de vrouw en minderjarige kinderen van betrokkene. Ten aanzien van kinderen werd verder vereist dat zij onder het ouderlijk gezag van ontslagene stonden. Tevens werd gevorderd dat er geen beletselen in verband met hun militaire verplichtingen $(\$ 22 \mathrm{~W} 1879)$ hun medeontslag in de weg stonden.

\section{c. Ontneming}

Ontneming van de nationaliteit was evenals het ontslag slechts mogelijk ten aanzien van personen, die in een gemeente in Slowakije of in Karpathorusland hun Heimatrecht hadden. De wet van 1879 kende slechts éen ontnemingsgrond, namelijk het zonder toestemming treden in vreemde krijgs- of staatsdienst. Betrokkene verloor zijn staatsburgerschap slechts indien hij deze dienst op

59. Schmied, SGS deel 18, te druk, p. 20 spreekt hier over een "Anspruch auf Entlassung" . Cf, ook SGS deel 22, p. 55 . 
vordering van de bevoegde instantie niet binnen de daarvoor vastgestelde termijn verliet ( $\$ 30$ W1879).

\section{Invloed op de nationaliteit van gezinsleden van betrokkene}

Ontneming van het staatsburgerschap had geen invloed op de nationalitcit van gezinsleden van betrokkene. Uiteraard kon hen de nationaliteit "zelfstandig" worden ontnomen.

\subsubsection{Het nationaliteitsrecht tussen 1939 en 1945}

Zoals reeds op p. 289 werd gezegd, viel de Tsjechoslowaakse republiek in het voorjaar van 1939 uiteen. Op het grondgebied van de ČSR ontstonden de nieuwe zelfstandige staten Slowakije en Karpatho-Oekraïne. De tweede werd echter direct na de onafhankelijkheidsverklaring bij Hongarije ingelijfd. Bohemen, Moravië en Silezië werden een Duits protectoraat. Hierna zal voor elk gebied een summier overzicht van de op de nationaliteit betrekking hebbende regelingen worden gegeven.

\subsubsection{Slowakije}

In het op 14 maart $1939^{60}$ zelfstandig geworden Slowakije kwam op 25 september 1939 een op de nationaliteit betrekking hebbend "Verfassungsgesetz" tot stand ${ }^{61}$. Deze wet bevatte een algemene regeling van verkrijging en verlies van de Slowaakse nationaliteit ${ }^{62}$. Voorts sloot Slowakije met Duitsland twee verdragen ${ }^{63}$, waarin de nationaliteit van personen die etnisch tot de Slowaken, respectievelijk de Duitsers behoorden, werd geregeld.

\subsubsection{Karpatho-Oekraïne}

Karpatho-Oekraïne werd reeds enkele dagen na de zelfstandigheidsverklaring bij Hongarije ingelijfd ${ }^{64}$. Krachtens $\$ 5$ van de wet betreffende de inlijving van de Karpatho-Russische gebieden bij Hongarije van 23 juni $1939^{65}$, herkregen alle inwoners van de Karpatho-Oekraïne, die tot de inwerkingtreding van het Vredesverdrag van Trianon op 26 juli 1921 de Hongaarse nationaliteit bezaten en krachtens dit verdrag ČCSR-onderdanen werden, het Hongaarse staatsburgerschap ${ }^{66}$.

60. Zue wet wan 14 maant 1939, art. 1/1939 SZ. (Sbirka Zákonu); Durica 61-86; Taborsky, p. 42-43.

61. Art. 255/1939 Sb; Duitse vertaling in SGS deel 18, p. 73-78. Deze regeling werd arangevuld mett het "Verfassungsgesetz" van 26 juni 1941 , art. 160/1941 Sb.; Dütse vertaling in SGS deel 18 , $1 \mathrm{e}$ druk, p. $81-82$.

62. Zive daarover Schmid 1979, p. 29-30 en uitwoerig, Nowak, Státne obcianstwo v Slowenskej republike, Bratisllawa 1939.

63. Het verdrag van Bratislawa wan 27 december 1939 , Duitse RGB1. 1940, I, p. 29 en het verdrag van 14 januari 1941. Daarover Sichmid 1979, p. 30-31.

64. Taborsticy, p. 41-42.

65. Wet-Art. VT: 1939. SGS decll 18, 1e druk, p. 29; Schmid 1979, p. 32-33.

66. Daarover Schmid 1979, p. 32-33. 
Bij decreet van Hitler van 16 maart $1939{ }^{67}$ verklaarde Duitsland de gebieden Bohemen, Moravië en Silezië tot zijn protectoraat "Böhmen und Mähren" ${ }^{\text {. Op }}$ grond van art. 2 van het decreet verkreeg de etnisch Duitse bevolking ervan de Duitse nationaliteit, terwijl de etnische Tsjechen de zogenaamde "Protektoratsangehörigkeit" verwierven ${ }^{69}$. Het ging daarbij om een vorm van Duitse "Schutzangehörigkeit", hetgeen betekent dat ze door Duitsland tegenover andere staten als eigen onderdanen werden beschouwd ${ }^{70}$. De niet-Duitse bevolking van het protectoraat werd aan sterke germanisatie blootgesteld ${ }^{71}$.

De regeling van de verkrijging van de Duitse nationaliteit door etnische Duitsers die voorheen de nationaliteit van de ĆSR bezaten, werd verder aangevuld door de verordening van de Duitse Minister van binnenlandse zaken van 20 april $1939^{72} . \& 3$ van deze verordening bepaalde, dat personen die de (juridische) Duitse nationaliteit bezaten en op het grondgebied van het protectoraat woonden, dezelfde rechten bezaten als de "Protektoratsangehörigen". De vraag of deze personen dan tevens de "Protektoratsangehörigkeit" bezaten, werd in $\$ 1$ lid 1 van een latere verordening d.d. 6 juni $1941^{73}$ evenwel expliciet ontkennend beantwoord.

Een verordening van 3 oktober $1939^{74}$ bevatte voorts een regeling van ontneming van de "Protektoratsangehörigkeit" aan personen, die zich in het buitenland bevonden en handelingen hadden verricht die de belangen van het Duitse Rijk konden schaden, of die op vordering van de overheid niet naar het protectoraat terugkeerden. Algemene regels betreffende verkrijging en verlies van de "Protektoratsangehörigkeit" werden geformuleerd in een verordening van 11 januari $1940^{75}$. Deze regeling was gebaseerd op de oude Oostenrijkse regeling die reeds de CSR overnam ${ }^{76}$. Voorts verkregen op grond van een circulaire van de Duitse Minister van binnenlandse zaken de etnisch Tsjechische bewoners van Slowakije en Karpathorusland, die niet de nationaliteit van Slowakije of Hongarije bezaten, eveneens de "Protektoratsangehörigkeit" 7 .

67. RGBI. 1939 I, p. 485 . Táborsky, p. 39; SGS deel 18, 1e druk, p. 26.

68. Táborsky, p. 39-41; Zie uilvoerig over het protectoraat Erdely, Germany"s First European Protectorate, London 1941..

69. Art. 75/1939 Slg. Daarover Schmid 1979, p. 34-35; SGS deel 18, 1e druk, p. 27; Globke, ZfoR 1940, p. 447.

70. Zie over de "Protektoratsangehörigkeit" Globke, ZfoR 1940, p. 447-457. Zie ook SGS deel 18. p. 26; Schmid 1979 , p. 35.

71. Daarover uitvoerig Luža, p. 187-204.

72. Duitse RGBI. I, p. 815; VBIRProt. 1939, p. 60 tekst afgedrukt bij Schmid 1979, p. 80-81. Daarover Schmid 1979, p. 35; SGS deel 18, le druk, p. 26; Globke, ZfoR 1940, p. 447.

73. Duitse RGBI. 1941, I, p. 308; VBIRProt. 1939, p. 307; afgedrukt bij Schmid 1979, p. 88-98. Danrover Schmid 1979, p. 35; SGS deel 18, 1e druk, p. 27.

74. Duitse RGBL. 1939, I, p. 1997; VBIRProt. 1939, p. 179. Deze verordening was inhoudelijk gelijk aan de Duitse wet wan 14 julli 1933, RGBI. I, p. 480 . Zie SGS deel 18, 1e druk, p. 27; Schmid 1979 , p. 35.

75. RMBilV 1940, p. 1120; daarover uitvoeriger Globke, ZfoR 1940, p. 448-450. Zie ook de circulaire van de Duitse Minister van binnenlandse zaken van 7 juni 1940, RMBliV 1940, p. 11 117.

76. Daarover Schmid 1979 , p. $35-36$.

77. RMBliV 1940, p. 1117. Schmid 1979, p. 36; Globke, ZfoR 1940, p. 448. 


\subsubsection{Het Sudetengebied}

Het Sudetengebied werd op grond van het verdrag van München in het najaar van 1938 bij het Duitse Rijk ingelijfd. Bij verordening van 12 februari $1939^{78}$ werd het toen geldende Duitse nationaliteitsrecht ${ }^{79}$ met terugwerkende kracht tot 10 oktober 1938 ingevoerd $(\$ 1)$.

\subsubsection{De regelingen tussen 1945 en 1949}

\subsubsection{De politiek ten opzichte van de Duitse en de Hongaarse minderheid}

Nadat de "burgerlijke" regering in ballingschap in mei 1945 weer de macht overnam, werden enkele op de nationaliteit betrekking hebbende regellingen afgekondigd. Conform de op p. 289 genoemde doctrine van juridische en internationaalrechtelijke continuîteit van de ČSR, ging men ervan uit dat alle personen die tot 1938 de nationaliteit van Tsjechoslowakije bezaten, nog steeds ČRRonderdanen waren ${ }^{80}$. Interessant is echter dat deze opvatting slechts ten aanzien van etnisch Slavische personen consequent werd aangehangen. In het "Verfassungsdekret" van 2 augustus $1945^{81}$ ging men ten aanzien van de etnisch Duitse en Hongaarse bevolking ervan uit, dat deze personen tussen 1938 en 1945 op grond van nietige(?) regelingen van de bezettingsmachten de Duitse, respectievelijk Hongaarse nationaliteit verwierven ${ }^{82}$. Daardoor verloren ze krachtens art. 1 lid 1 de CSR-nationaliteit met de werking ex tunc. Deze inconsequentie werd vervolgens zo uitgelegd, dat de "nietige" nationaliteitsrechtelijke regelingen van de bezetters door het genoemde decreet weer werden erkend ${ }^{83}$. Aan etnische Duitsers en Hongaren die niet de (juridische) Duitse of Hongaarse nationaliteit verwierven, werd de Tsjechoslowaakse door het decreet echter ex nunc ontnomen. Deze weinig elegante "oplossingen" had de ČSR-regering nodig om de etnisch Duitse en Hongaarse bevolking uit te wijzen. Dat kon namelijk alleen als betrokkenen geen Tsjechoslowaakse nationaliteit bezaten ${ }^{84}$.

78. RGBI. 1939 I, p. 205.

79. Dat waren het Reichs-und Staatsangehörigkeitsgesetz van 22 juli 1913, RGBl. 1913, p. 583 ; 3 en $\$ 4$ lid 1 ,lid 2 sub 2 en 4 en lid 3 van de Verordnung über die deutsche Staatsangehörigkeit van 5 februari 1934, RGB1 1934 I, p. 85; Gesetz zur Änderung des Reichs- und Staatsangehörigkeitsgesetzes van 15 mei 1935, RGBI 1935 I, p. 593; 2 leden 1, 3-5 en \& 3 van het Gesetz niber den Widerruf won Eimbürgerungen und die Aberkennung der Deutschen Staatsangehörigkeit van 14 juli 1933, RGBL. 1933 I, p. 480 en sub II en II van $\$ 2$ van de bij de wet van 1933 behorende uitvoeringsverordening van 26 juli 1933, RGBI 1933 I, p. 538 .

80. SGS deel 18, le druk, p. 31.

81. Art. 33/1945 Sb. Zie voor Duitse vertaling SGS deel 18, 1e druk, p. 83-85. Daarover LuZa, p. 270276 ; SGS deel 18, 1 e druk, p. 22-23; Cerny/Cervenka, p. 90-92.

82. Daarover Luża, p. 270-276.

83. Zie de circulaire van de Minister van binnenlandse zaken betreffende de uitvoering van thet decreet, art. A-4600-16/18-45-Ref. A wan 24 augustus 1945; gepubliceerd in het Publicaticblad van deze Minister (Vestnik minustra vnitra CSR) 1945 nr. 3, p. 21. Zie ook Cerny/Cerwenka, p. 91; SGS deel 18, p. $23-24$.

84. Cf, SGS deel 18, 1e druk, p. 31-32; Schmid 1979, p. 299. Volgens Korkisch, WGO 1969, p. 160, betrof de ontneming bijna een derde van de bevolking die de CSR in 1938 had. Volgens Luxa, p. 300 , werden ongeveer 3,4 miljoen personen uitgezet. 
Op 27 februari $1946^{85}$ sloot de ČSR met Hongarije een verdrag betreffende de "uitwisseling van bevolking", de waarin de mogelijkheid werd geschapen om etnisch Hongaarse inwoners van de CSR aan wie men eerst bij het hierboven genoemde decreet de CSR-nationaliteit ontnam, tegen etnisch Tsjechische of Slowaakse inwoners van Hongarije te "ruilen". Op grond van deze "constructie" zou de CSR naar schatting $450.000^{86}$ etnische Hongaren, die hoofdzakelijk in Slowakije woonden, kwijt kunnen raken. Vanwege tegenstand van Hongaarse zijde kon ditt plan echter niet worden gerealiseerd.

Tegenover de expatrieëringspolitiek ten aanzien van de niet-Slavische bevolking stonden maatregelen, die aan etnisch Tsjechische en Slowaakse buitenlanders de terugkeer naar CSR zouden vergemakkelijken. In verschillende "Verfassungsgesetze $^{\text {"87 }}$ schiep men mogelijkheden om deze immigranten op eenvoudige wijze de nationaliteit van de ČSR te verlenen.

De Tsjechoslowaakse minderhedenpolitiek veranderde radicaal onder de versterkte invloed van de USSR nadat in Tsjechoslowakije in 1.948 de communistische partij de macht overnam ${ }^{88}$. Reeds bij een regeringsverordening van 13 april $1948^{89}$ werden de mogelijkheden voor hernaturalisatie van etnische Duitsers en Hongaren, aan wie bij het op p. 301 besproken decreet uit 1945 de CSR nationaliteit werd ontnomen, uitgebreid. Doordat zowel in de CSR als in Hongarije de communisten aan de macht kwamen, werden de betrekkingen tussen de beide landen aanzienlijk verbeterd. Deze ontwikkeling kwam eveneens tot uitdrukking in een versnelde "reïntegratie" van etnische Hongaren, terwijl men ten opzichte van Duitsers wat terughoudender was ${ }^{90}$. Een andere reden voor deze terughoudendheid is het feit dat tot 1948 verreweg de meeste etnische Duitsers het land reeds hadden verlaten, terwijl er nog steeds een groot aantal Hongaren woonde. Op 28/29 september 1948 kwam het Executiefcomité van de Slowaakse communistische partij met een programma betreffende de "wederopneming van etnische Hongaren in het politieke leven". De hoofdmoot van dit programma was "herverlening" van de ĆCRnationaliteit aan personen van Hongaarse afkomst. Het sluitstuk van deze ontwikkeling was de wet van 25 oktober $1948^{91}$ waarin hernaturalisatie van etnische Hongaren praktisch op het afleggen van een eed van trouw neerkwam.

Ten aanzien van etnische Duitsers, die eveneens door het decreet van 1945 inzake de ontneming van de CSR-nationaliteit werden getroffen, heeft men met enige vertraging een soortgelijke politiek toegepast. Eerst werden bij twee

85. 145/1946 Sb.; wet-art. XV: 1946; in werking getreden op 15 mei 1946; Duitse vertaling in SGS deel 18, 1e druk, p. 90-95. Zie ook "Verfassungsgesetz" van 13 september 1946, art. 179/1946 Sb. Duitse wertaling in SGS deel 18, 1e druk, p. 95-96, waardoor de regeling van het verdrag werd aangevuld. Zie ook Korkisch, WGO 1969, p. 161.

86. SGS deel 18, le druk, p. 38. Volgens Hongaarse bronnen zou het om 600.000 etnische Hongaren gaam. Zie Further Documents, p. 5.

87. Zie wet van 12 april $1946,74 / 1946 \mathrm{Sb}$. Deze politiek werd ook doorgezet na de machtsovername door de communisten in februari 1948 . Zie verder wetten 28 april 1948, Sb. 1948, ar. 107 en van 22 februari 1950, Sb. 1950, nr. 25. Daarover SGS deell 18, 1e druk, p. 40.

88. Cf. Luża, p. 302 .

89. Art. $77 / 1948$ Sb.; Duitse vertaling in SGS deel 18, 1e druk, p. 99 . Zie ook beschilkking van de Minister vam binnenlandse zaken van 16 april $194877 / 1948 \mathrm{Sb}$; Duitse vertaling in SGS deel 18 , le druk, p. 101.

90. SGS deel 18, p. 29.

91. Art. 245/1948 Sb; Duitse vertaling in SGS deel 18, 1e druk, p. 103-104. 
verordeningen in $1949 / 50^{92}$ de mogelijkheden van hernaturalisatie uitgebreid. Vervolgens werd aan alle etmische Duitsers die nog in de CSR woonden en nog niet de nationaliteit van Tsjechoslowakije bezaten, bij wet van 24 april $1953^{93}$ eenvoudig het Tsjechoslowaakse staatsburgerschap verleend. Deze "Zwangseinnbürgerung" wordt door Schmied sterk bekritiseerd ${ }^{94}$.

\subsubsection{De wet betreffende verkrijging en verlies van de nationaliteit door huwelijk}

Verkrijging en verlies van de nationaliteit door huwelijk werden in een aparte wet d.d. 29 mei $1947^{95}$ geregeld. Een buitenlandse vrouw, die met een Tsjechoslowaak in het huwelijk trad, kon op grond van $\$ 11$ lid 1 vó́r de huwelijkssluiting respectievelijk tot drie maanden daarna, bij de volksvergadering van de "okres" $\%$ van haar woonplaats om vereenvoudigde naturalisatie verzoeken. In geval van een positieve beslissing werkte de naturalisatie vanaf het moment van de huwelijkssluiting.

Krachtens \& 2 lid 1 verloor een Tsjechoslowaakse haar nationaliteit door een huwelijk met een buitenlander indien zij door het huwelijk de nationaliteit van haar man verkreeg. Met de toestemming van het Ministerie van binnenlandse zaken kon zij op eigen verzoek de ĆSR-nationaliteit echter behouden. Het verzoek moest voor de huwelijkssluiting of binnen drie maanden daarna worden ingediend. Deze wet werd bij de nationaliteitswet van 1949 ingetrokken.

\subsubsection{De IPR-wet van 1948}

De wet op het Internationaal Privaatrecht van $1948^{\circ 7}$ bevatte enkele op de nationaliteit betrekking hebbende bepalingen. In $\$ 50$ behield de ĆSR zich het recht voor, personen die naast de Tsjechoslowaakse ook een andere nationaliteit bezaten, uitsluitend als eigen staatsburgers te behandelen. Bij polypatriden die uitsluitend vreemde nationaliteiten bezaten, was de laatst verworven nationaliteit maatgevend $(\$ 51)$.

92. Verordlening van 20 november 1949, art. 252/1949 Sb. en beschikking van de Minister van binnenlandse zaken van 5 april 1950, art. $50 / 1950 \mathrm{Sb}$. Zie voor Duitse vertaling SGS deel $18,1 \mathrm{e}$ druk, p. 109-110 en 110-111.

93. Art. 34/1953 Sb. Duitse vertaling in SGS deel 18, 1e druk, p. 111.

94. Schmied in SGS deel 18, 1e druk, p. 43-44. Zijn kritiek lijkt mij echter niet geheel terecht, aangezien deze personen anders staatloos zouden zijn. Zie hierover ook Schmid 1979, p. 46-47.

95. Art. $102 / 1947 \mathrm{Sb}$.

96. Eerst lag de beslissingsbevoegdheid bij het Ministerie van binmenlandse zaken, verwolgens werd bij een verordening(art. 116/1949 \$b.) deze bevoegdheid geplaatst bij de volkswergaderingen van de "okres'en". "Okres" kan het beste met het Duitse woord "Bezirk" worden vertaald.

97. De wet van 11 maart 1948, art. 41/1948 Sb. In $1963 \mathrm{kwam}$ cen nieuwe IPR-wet tot stand, art. $97 / 1963 \mathrm{Sb}$. Zie ower de IPR-wet van 1963 en de nationaliteit Másilko ${ }_{m}$ Socialistickå Zákonnost $1974 / 1$, p. $383-391$ en $1980 / 3$, p. 144-156. 


\subsubsection{Algemeen}

In overeenstemming met de Tsjechoslowaakse doctrine vam rechtscontinuiteit "herleefden" in mei 1945 de in Tsjechoslowakije "gerecipieerde" oude Oostenrijkse en Hongaarse algemene regelingen van verkrijging en verlies van de nationaliteit. Deze rechtsvoorschriften, die op zichzelf al onoverzichtelijk genoeg waren, werden nog eens doorkruist door de reeds genoemde decreten, verordeningen en wetten die na de oorlog tot stand kwamen ${ }^{\%}$.

In de nieuwe grondwet van 9 mei $1948^{99}$ had $\& 165$ betrekking op de nationaliteit. Daarin werd bepaald dat in de CSR een algemene nationaliteit bestond; deze regel werd reeds in $\$ 4$ lid 1 van de grondwet van 1920 opgenomen. Interessant is echter dat de bepaling van $\S 4$ lid 3 waarin de ĆSR een dubbele nationaliteit bij haar eigen onderdanen weigerde te erkennen, niet in de nieuwe grondwet werd overgenomen ${ }^{100}$.

Op 13 juli $1949^{101}$ kwam een nieuwe nationaliteitswet tot stand, die een algemene regeling van verkrijging en verlies van de nationaliteit bevatte. De oude Oostenrijkse en Hongaarse regelingen werden bij deze wet, tezamen met enkele andere na 1918 tot stand gekomen wetten die betrekking hadden op de nationaliteit, ingetrokken ${ }^{102}$. De nationaliteitswet van 1949 werd vervolgens in 1958 gewijzigd.

\subsubsection{Verkrijging van de nationaliteit}

Volgens de wet van 1949 kon de Tsjechoslowaakse nationaliteit van rechtswege en door naturalisatie worden verkregen. Verkrijging van de nationaliteit door optie kende deze wet niet.

\subsubsection{Verkrijging van rechtswege}

Verkrijging van de Tsjechoslowaakse nationaliteit werd van rechtswege gekoppeld aan:

- geboorte uit een ČSR-ouder(s) (\$1);

- $\quad$ het gevonden worden op het Tsjechoslowaakse grondgebied ( $\$ 1)$;

98. Schmid 1979 , p. 49.

99. Art. 150/1948 Sb.

100. De reden daarvoor zou wolgens Schmied zijn dat een aantal hoge partijfunctionarissen zowel de nationaliteit van de Sovjetunie, als van de CSR bezat en het bezit van de Sovjet-nationalitteit destijds als een grote eer werd beschouwd. Schmied, SGS deel 18, 1e druk, p. 46. en OER 1959, p. 119-120. Deze opvatting werd echter bestreden door Bruegel, OER 1962, p. 70.

101. Wet van 13 juli 1949, art. 194/1949 Sb. In werking getreden op 1 oktober 1949. Duitse vertaling in SGS deel 18, 1e druk, p. 105-109.

102. Daaronder: wet van 29 mei 1947, art. 102/1947 Sb. omtrent werkrijging en werlies van de CSRnationaliteit door huwelijk. Zie Korkisch, WGO 1969, p. 161-162. Het HG werd overigens reeds bij de wet $\operatorname{van} 30$ juni 1948 , art. 174/1948 $\mathrm{Sb}$. ingetrokken. 
Adoptie door een CSR-staatsburger had geen nationaliteitsrechtelijke gevolgen voor het kind, terwijl legitimatie als een rechtsinstituut sedert 1 oktober 1949 niet meer bestaat ${ }^{103}$.

\section{a. Geboorte uit Tsjechoslowaakse ouder(s)}

Een kind verwierf de nationaliteit van de CSR indien het op het Tsjechoslowaakse grondgebied werd geboren en hetzij zijn moeder, hetzij zijn vader op het tijdstip van de geboorte van het kind de nationaliteit van de CSR bezat ( $\$ 1$ lid 1$)$. Hetzelfde gold ten aanzien van een kind, dat weliswaar in het buitenland werd geboren, doch waarvan beide ouders het Tsjechoslowaakse staatsburgerschap bezaten ( $\$ 1$ lid 2 , eerste volzin).

In het buitenland geboren kinderen waarvan slechts éen van de ouders de ĆSR-nationaliteit bezat, konden deze nationaliteit niet ipso iure verkrijgen. Ten behoeve van hen voorzag $\$ 1$ lid 2 , tweede volzin in een vereenvoudigde naturalisatie, die op p. 306-307 zal worden besproken.

De Tsjechoslowaakse nationaliteitswet van 1949 bevatte geen uitdrukkelijke regeling ten aanzien van de verkrijging van de nationaliteit door onwettige kinderen. Gezien de volledige gelijkstelling tussen wettige en onwettige kinderen mag evenwel worden aangenomen dat ten aanzien van buitenechtelijke kinderen eveneens de regeling van $\$ 1$ leden 1 en 2 van toepassing was ${ }^{104}$. Een kind werd beschouwd als kind van een CSR-onderdaan, indien hij tijdens zijn minderjarigheid door een Tsjechoslowaak werd erkend of het vaderschap gerechtelijk werd vastgesteld.

\section{b. Vondelingen}

Ten aanzien van vondelingen bevatte $\S 1$ lid 3 een praesumptio iuris van het bezit van de ČSR-nationaliteit. Het tegenbewijs was steeds mogelijk, ongeacht de leeftijd van betrokkene. De wet van 1949 kende geen verkrijging van het staatsburgerschap door kinderen van staatloze ouders, die in Tsjechoslowakije werden geboren ${ }^{105}$.

\subsection{Naturalisarie}

Met betrekking tot de naturalisatie werd in de wet van 1949 onderscheid gemaakt tussen een gewone en een verlichte procedure. Ten aanzien van elke naturalisandus die ouder was dan 15 jaar werd geëist, dat hij een bij $\$ 4$ voorgeschreven eed van trouw aflegde. De eedsaflegging was een constitutief vereiste, doch in uitzonderingsgevallen kon daarvan worden afgezien.

De bevoegdheid om een gewone naturalisatie te verlenen lag bij het Ministerie van binnenlandse zaken ( $\$ 3$ lid 1 aanhef). De naturalisatievereisten waren de volgende:

103. Cerny/Červenka, p. 58. SGS deel 18, p. 40.

104. Cerny/Cervenka, p. 52.

105. Cerny/Cervenka, p. 53. 
- betrokkene mocht geen handelingen tegen de staat hebben begaan (sub a); dit vereiste werd in $1958^{106}$ vanwege zijn vanzelfsprekendheid geschrapt ${ }^{107}$;

- een ononderbroken verblijf in Tsjechoslowakije van 5 jaar ( $\$ 3$ lid 1 sub b);

- het verlies van de oude nationaliteit (sub c);

- het afleggen van een eed van trouw, voorzover de naturalisandus reeds ouder dan 15 jaar was ( 84 ).

We zien dat het vereiste sub a reeds voldoende vaag was om een naturalisatie willekeurig te weigeren. In het tweede lid werd niettemin uitdrukkelijk bepaald dat de beslissing omtrent een naturalisatieverzoek geheel ter discretie van het Ministerie stond. Er bestond geen recht op naturalisatie ${ }^{108}$. Voorts mocht het Ministerie in bijzondere gevallen dispensatie van de vereisten sub $b$ en $c$ verlenen ${ }^{109}$,

\section{a. Invloed op de nationaliteit van de gezinsleden van de verzoeker}

Volgens het derde lid van $\$ 5$ konden gehuwden tezamen worden genaturaliseerd, waarbij echter het verzoek van elk der echtgenoten zelfstandig werd beoordeeld. Kinderen die nog geen 15 jaar oud waren, werden tegelijkertijd met hun ouder(s) genaturaliseerd, mits zulks uitdrukkelijk werd verzocht. Indien slechts één van de ouders werd genaturaliseerd moest de andere ouder met de medenaturalisatie van het kind instemmen. De toestemming van de andere ouder kon door de rechter worden vervangen ${ }^{110}$. Was een kind reeds ouder dan 15 jaar, dan kon hij slechts zelfstandig worden genaturaliseerd. De wet bevatte geen regeling betreffende vertegenwoordiging van handelingsonbekwamen. Aangenomen mag worden dat een onbekwame zijn naturalisatieverzoek via zijn wettelijke vertegenwoordiger moest indienen.

\section{b. Verlichte naturalisatie}

De regeling van verlichte naturalisatie leek veel op verkrijging van de nationaliteit door optie. Het verschil was echter, dat de verlening van de nationaliteit door de overheid constitutief was en dat de beslissende instantie discretionaire bevoegdheid bezat. De beslissingsbevoegdheid lag bij de volksvergaderingen van de "okres'en", waarin de verzoeker woonachtig was. De mogelijkheid van verlichte naturalisatie werd geboden aan de volgende categorieën personen:

- in het buitenland geboren kinderen, waarvan én van de ouders ten tijde van de geboorte van het kind de Tsjechoslowaakse nationaliteit bezat. De ouder

106. Bij wet d.d. 17 oktober 1958 , art. $72 / 1958 \mathrm{Sb}$.

107. Cerny/Cervenka, p. 56.

108. Cerny/Cervenka, p. 56.

109. Cerny/Črvenka, p. 56.

110. Cerny/Cervenka, p. 56. 
die het CSR-staatsburgerschap bezat, moest binnen één jaar na de geboorte van het kind een verzoek indienen bij de volksvergadering van de okres, waarbinnen de betrokken ouder zijn woonplaats had ( $\$ 1$ lid 2 tweede volzin) ${ }^{11}$;

- buitenlandse vrouwen, die met een Tsjechoslowaak in het huwelijk traden. Het verzoek kon reeds vóór de huwelijkssluiting, doch moest uiterlijk zes maanden daarna worden ingediend. Ongeacht de datum van de beslissing werkte de verkrijging van de nationaliteit vanaf het moment van de huwelijkssluiting ( $\$$ 2 lid 1). Tezamen met haar werden op haar verzoek haar minderjarige kinderen die nog geen 15 jaar oud waren, medegenaturaliseerd(lid 2).

Aan beide groepen naturalisandi waren afgezien van de reeds genoemde eedsaflegging geen andere eisen gesteld.

\subsubsection{Verlies van de nationaliteit}

De nationaliteit van de ČSR kon van rechtswege, door ontslag en door ontneming worden verloren. Het verlies door het afleggen van een verklaring van afstand kende de wet van 1949 niet.

\subsection{Verlies van rechtswege}

Een Tsjechoslowaakse vrouw die met een vreemdeling in het huwelijk trad, verloor van rechtswege haar nationaliteit indien zij door het huwelijk de nationaliteit van haar bruidegom verwierf $(\$ 5)$. $\mathrm{Zij}$ had echter de mogelijkheid om tot zes maanden na de huwelijkssluiting de bevoegde "okres" te verzoeken om haar Tsjechoslowaakse nationaliteit te mogen behouden. Vereisten voor het verkrijgen van deze toestemming werden in de wet niet genoemd. \& 5 werd bij de wetswijziging van 1958 geschrapt. Sedertdien kent de Tsjechoslowaakse nationaliteitswet geen verlies van het staatsburgerschap van rechtswege meer.

\subsection{Ontslag}

De bevoegdheid om het ontsllag uit de nationaliteit te verlenen, lag bij de volksvergaderingen van de "okres'en" van de woonplaats van betrokkene. De Vereisten voor het ontslag werden niet in de wet $(\$ 6)$ genoemd. Volgens Cerny en Cervenka werd ontslag slechts verleend, indien betrokkene (met toestemming van de bevoegde Tsjechoslowaakse instantie) in het buitenland woonde, of nadat de Minister van buitenlandse zaken aan betrokkene de toestemming voor emigratie verleende. Voorts werd ontslag slechts verleend indien de Minister van binnenlandse zaken en de financiële dienst van de okres van betrokkene daarmee instemden ${ }^{112}$. Bij een Ministeriële verordening van 11 november $1955^{113}$ werd tevens het

111. Indien betrokkkene geen woonplaats in CSR had, was moest zijn verzoek bij de okres van zijn laatste woonplaats in Tsjechoslowakije worden ingediend. Was deze onbekend of onduidelijk, dan was voor Tsjechen de okres van Praag en woor Slowaken die van Bratislawa bevoegd ( $\$ 9$ lid 2).

112. Cerny/Čerwenka, p. 80.

113. Art. $60 / 1955 \mathrm{Sb}$. 
betalen van een bedrag tussen 40 en 500 Kronen vastgesteld. Het ontbreken van ontslagvereisten in de wet gaf aan de administratie een onbegrensde discretionaire bevoegdheid. Een verzoeker had geen recht op ontslag ${ }^{114}$.

\section{a. Invloed op de nationaliteit van de gezinsleden van de verzoeker}

Indien aan een ouder het ontslag uit de Tsjechoslowaakse nationaliteit werd verleend, werden zijn kinderen, die jonger dan 15 jaar waren, meeontslagen, indien daar uitdrukkelijk om werd verzocht ( $\$ 6$ lid 2). Indien slechts één van de ouders om ontslag verzocht, moest de andere ouder daarmee instemmen. Ook in dit geval kon de vereiste toestemming door de rechter worden vervangen ${ }^{115}$. Kinderen van 15 jaar of ouder konden slechts zelfstandig uit de Tsjechoslowaakse nationaliteit worden ontslagen. Evenmin als bij de naturalisatie bevatte de wet een regeling betreffende vertegenwoordiging. Aangenomen mag worden dat ook bij ontslag de tussenkomst van de wettelijke vertegenwoordiger van het kind vereist was ${ }^{116}$.

\subsection{Ontneming}

Ontneming van de Tsjechoslowaakse nationaliteit werd geregeld in $\$ 7$ van de wet van 1949. Deze wijze van verlies van het staatsburgerschap was voornamelijk gericht tegen politieke tegenstanders van het communistische regime. De regeling van ontneming werd in 1958 uitgebreid (zie p. 310). De nationaliteit mocht slechts worden ontnomen, indien betrokkene zich in het buitenland bevond, ongeacht echter, of hij daardoor staatloos werd (lid 1 aanhef). De bevoegdheid lag bij het Ministerie van binnenlandse zaken. Ontnemingsgronden van $\$ 7$ waren de volgende:

- $\quad$ handelingen die tegen de belangen van de staat waren gericht (lid 1 sub a);

- illegale grensoverschrijding (sub b);

- het niet terugkeren uit het buitenland op vordering van het Ministerie van binnenlandse zaken (lid 1 sub c);

- het bezit van een andere nationaliteit (lid 2).

De eerstgenoemde ontnemingsgrond bood aan het Ministerie een onbegrensde mogelijkheid om de nationaliteit willekeurig te ontnemen. Voorts kan ook de mogelijkheid van ontneming van de nationaliteit wegens het enkele feit dat men tevens een ander staatsburgerschap bezat, als bijzonder bedenkelijk worden gezien.

Naast de regeling van de nationaliteitswet kenden de wet strekkende tot bescherming van de Volksdemocratische republiek ${ }^{117}$ en het wetboek van strafrecht

114. Cerny/Cervenka, p. 81.

115. Cerny/Cervenka, p. 80.

116. Zo ook Cerny/Cervenka, p. 80.

117. Art. $231 / 1948$ in werking getreden 24 oktober 1948 en ingetrokken bij het wetboek van strafrecht van 1 augustus 1950, art. 86/1950 Sb. Zie Cerny/Cervenka, p. 94. 
in de periode tussen 24 oktober 1948 en 31 december $1956^{118}$ ontneming van de nationaliteit als bijkomende straf bij een aantal politieke misdrijven ${ }^{119}$.

\section{a. Invloed op de nationaliteit van gezinsleden van betrokkene}

Ontneming van het staatsburgerschap had geen invloed op de nationaliteit van gezinsleden van betrokkene. Uiteraard kon aan hen de nationaliteit "zelfstandig" worden ontnomen.

\subsubsection{De wijziging van de nationaliteitswet in 1958}

De nationaliteitswet van 1949 werd slechts érnmaal gewijzigd, namelijk bij wet van 17 oktober $1958^{120}$. Gewijzigd werden $\& 1$ lid $2, \$ 2$ lid $1, \$ 3$ leden 1,2 en $\$ 7$ lid $2,88^{12 n}$. Deze wetswijziging had hoofdzakelijk betrekking op huwelijken tussen Tsjechoslowaakse vrouwen en vreemdelingen, op de Hongaarse minderheid en op de ontneming van de nationaliteit aan Tsjechoslowaakse emigranten. Andere wijzigingen waren van overwegend redactioneel karakter.

\subsubsection{Gehuwde vrouwen}

Een ČSR-onderdane die met een buitenlander in het huwelijk trad en daardoor zijn nationaliteit verwierf, had krachtens $\$ 5$ van de wet van 1949 tot zes maanden na de huwelijkssluiting de mogelijkheid om met toestemming van de overheid haar nationaliteit te behouden. Deze mogelijkheid was in de praktijk echter van weinig belang; wanneer een Tsjechoslowaakse met een onderdaan van een socialistische staat in het huwelijk trad, verwierf ze zijn nationaliteit namelijk toch niet automatisch. Was de bruidegom nit het westen afkomstig, dan werd het huwelijk in de CSR meestal niet erkend, aangezien een wet uit $1952^{122}$ voor dergelijke huwelijken toestemming van de Minister van binnenlandse zaken voorschreef ${ }^{123}$. De onderhavige wijzigingswet $(\S 8$ lid 1 (nieuw)) sloot automatisch verlies van de ČSRnationaliteit door huwelijk in alle gevallen uit. De bedoeling van deze wijziging was om gelijkheid van man en vrouw te realiseren; ten aanzien van met buitenlandse vrouwen huwende mannen gold de verliesbepaling van de oude $\$ 5$ namelijk niet ${ }^{124}$.

118. De wet van 12 juli 1950 , Art. $86 / 1950 \mathrm{Sb}$. Deze mogelijkheid werd bij de wijzigingswet van 19 december 1956, art. 63/1956 Sb. weer geschrapt. Cerny/Cervenka, p. 94.

119. Hoogverraad ( 88$)$, sabotage $(\$ \$ 84,85$ lid 2 en 3), het verlaten van het land ( $\$ 95)$, spionage $(\$ 86,87)$ etc.

120. Art. $72 / 1958 \mathrm{Sb}$. Zie over deze wijziging uitvoeriger Schmied, OER 1959, p. 119-121. Duitse vertaling van de wijzigingswet in SGS deel 18 , p. 51-52.

121. Bij Cerny/Cervenka wordt op p. 142-149 de tekst van de nationaliteitswet zoals deze na de wijzigingen van 1958 gold afgedrukt, waarbij per $\$$ ook de oude tekst wordt weergegeven.

122. De wet van 29 oktober 1952 , art. $59 / 1952 \mathrm{Sb}$.

123. Schmied, OER 1959 , p. 119.

124. Schmied, OER 1959 , p. 119. 


\subsubsection{De Hongaarse minderheid}

Reeds op p. 301-302 werd ingegaan op de nationaliteitsrechtelijke positie wan personen van Hongaarse afstamming. Ondanks de verruiming van de mogelijkheid van vereenvoudigde naturalisatie van etnische Hongaren, die door het "Verfassungsdekret" van 1945 de ČSR-nationaliteit verloren, bleef nog een aantal etnische Hongaren in de CSR wonen, zonder de nationaliteit daarvan te bezitten. Ten aanzien van deze restgroep heeft men in 1958 voor dezelfde "oplossing" gekozen als in 1953 bij de etnische Duitsers. Bij art. III van de wijzigingswet van 1958 werd aan alle personen van Hongaarse afkomst die bij het "Verfassungsdekret" van 1945 door de ontneming van de nationaliteit werden getroffen, de Tsjechoslowaakse nationaliteit verleend ${ }^{125}$.

\subsubsection{Emigranten}

De in 1958 gewijzigde $\& 7$ lid 2 van de Tsjechoslowaakse nationaliteitswet bood de mogelijkheid om aan personen, die vijf jaar zonder toestemming van de regering in het buitenland hadden gewoond, en zich niet bij een vertegenwoordiging van de ČSR hadden laten registreren, de Tsjechoslowaakse nationaliteit te ontnemen. Het staatsburgerschap kon worden ontnomen ongeacht of betrokkene daardoor staatloos werd. Volgens Katǔ̌čak woonden in het buitenland ruim twee miljoen personen, die in 1945 de nationaliteit van de ĆSR bezaten, terwijl zich slechts 5000 lieten registreren ${ }^{126}$.

\subsection{HeT POSTIIEVE NATIONALTTERTSRECHT}

\subsubsection{Algemeen}

Tsjechoslowakije werd ingevolge de grondwetswijziging van $1968^{127}$ een federale staat, bestaande uit de Tsjechische en de Slowaakse Socialistische republiek. Deze wijziging in het staatsbestel had ook grote consequenties voor het nationaliteitsrecht. In de ĆSSR bestaan sedertdien namelijk zowel de nationaliteit van de deelstaten, als de nationaliteit van de federatie.

De nationaliteit van de CSSR wordt thans geregeld in het federale "Verfassungsgesetz" van 27 oktober $1968^{128}$ en in de nationaliteitswetten van de Tsjechische Socialistische Republiek en van de Slowaakse Socialistische Republiek van respectievelijk 29 april $1969^{129}$ (WĆCR) en 28 december $1968^{130}$ (WSSR). De

125. Schmied, OER 1959, p. 120-121.

126. Katušçak, Právnik 1968, p. 826-827.

127. Art. 143/1968 Sb. in werking getreden op 1 januari 1969. Plank, Pravny Obzor 1969/8, p. 681-711.

128. Art. 165/1968 Sb.; Nederlandse vertaling: NWG, p. 1-3; Duitse in Bergmann/Ferid, p. 6b-6c; WGO 1969, p. 164-166.

129. Art. 39/1969 Sb; Nederlandse vertaling: NWG, p. 3-7; Duitse in Bergmann/Ferid, p. 6i-8a; SGS deel 18, p. 60-65. Daarover Korkisch, WGO 1969, p. 157-176; Schmid, p. 51-55; SGS deel 18, p. 36-46.

130. Art. 206/1968 Sb; Nederlandse vertaling in: $\mathrm{NWG}$, p. 3-7; Duitse in Bergmann/Ferid, p. 6d-6h; SGS deel 18, p. 56-60. Zie daarover Schmid, p. 56-60; Korkisch, WGO 1969 p. 157-176; SGS deel 18 , p. 36-46. 
federale wet is een kaderwet, die de grondslagen voor verkrijging en verlies van de nationaliteit aangeeft, terwijl beide onderwerpen in de deelstaatwetgeving in detail worden geregeld. De nationaliteitswetten van beide deelstaten zijn bijzonder onoverzichtelijk, aangezien er tevens de verkrijging van de Slowaakse nationaliteit door (kinderen van) Tsjechen en omgekeerd uitvoerig in wordt geregeld.

Voorts zij aangetekend dat niet alle bepalingen van de nationaliteitswet van 1949 zoals deze gold na de wijziging van 1958 werden ingetrokken ${ }^{131}$. De wet van $1949 / 58$ moet nog steeds worden toegepast in alle gevallen waarin de nieuwe wetgeving niet in een andere regeling voorziet ( $\$ 9$ federale nationaliteitswet). Dit is met name het geval bij het verlies van de nationaliteit door ontneming.

Bij de grondwetswijziging van $1970^{132}$ werd de op de nationaliteit betrekking hebbende $\& 5$ van de grondwet veranderd. De federale nationaliteitswet zou niet meer slechts de grondslagen van de verkrijging en verlies van de nationaliteit van de deelstaten regelen, maar een uitputtende regeling geven. De primaire regelgevingsbevoegdheid zou daardoor duidelijk bij de federatie komen te liggen ${ }^{133}$. Een nieuwe federale regeling is echter nog steeds niet tot stand gekomen.

\subsubsection{De verhouding tussen de federale en de deelstaatnationaliteit}

De nationaliteit van de federatie wordt verworven, respectievelijk verloren, door verkrijging, respectievelijk verlies van de nationaliteit van één van de deelstaten ( $\$$ 5 lid 1 grondwet). In tegenstelling tot het nationaliteitsrecht van de USSR en Joegoslavië is het niet mogelijk uitsluitend de nationaliteit van de ĆSSR te bezitten ${ }^{134}$. De vraag welke nationaliteit in de ĆSSR prevaleert, laat zich niet gemakkelijk beantwoorden. Het feit dat de wetten van beide deelstaten voor een groot gedeelte een herhaling van de federale regeling zijn, spreekt voor de voorrang van de federatie. Aan de andere kant wordt de federale nationaliteit uitsluitend door verkrijging of verlies van de deelstaatnationaliteit verkregen, respectievelijk verloren. Ook de beslissingsbevoegdheid wordt steeds bij de organen van de deelstaten gelegd.

Ook met betrekking tot Tsjechoslowakije kan de vraag worden gesteld, inhoeverre het bestaan van de nationaliteit van de deelstaten functioneel is. In $\$ 5$ lid 2 van de grondwet is het namelijk verboden om onderscheid te maken tussen de CSSR-staatsburgers op grond van hun deelstaatnationaliteit. Voorts hebben de deelstaten in de CSSR niet zoals in Joegoslavië een eigen familie- en erfrecht. In ieder geval betekent het bestaan van de nationaliteit van de deelstaten een manifestatie van de autonomie van de Slowaken.

131. Korkisch, WGO 1969, p. 163. Ingetrokken werden slechts $\$ \$ 1,2,3$ lid 2 en $\$ \$ 4,9$ en 11.

132. Art. $125 / 1970 \mathrm{Sb}$.

133. Slapnicka, Die neuere Verfassungsentwicklung in der Tschechoslowakischen Sozialistischen Republik, in: Verfassungs- und Verwaltungsreformen in den sozialistischen Staaten, Berlin, 1977 , p. 149-178; SCS deel 18, p. 37.

134. Schmid 1979 , p. 50 . Korkisch, WGO 1969 , p. 162 Zie over de problematick van de verhouding tussen de federale en de deelstaatnationaliteit ook Plank, Právny obzor 1969/8, p. 695-711. 


\subsubsection{Verkrijging van de nationaliteit}

Ter wille van de overzichtelijkheid wordt hieronder steeds gesproken van de verkrijging en verlies van de Tsjechoslowaakse nationaliteit, hoewel in de besproken wettelijke regelingen strikt genomen om de Tsjechische of Slowaakse nationaliteit en daardoor tevens de CSSR-nationaliteit sprake is. De nationaliteit van de CSSR wordt zoals gezegd middels verkrijging van het staatsburgerschap van de ene of de andlere deelstaat verworven. De Tsjechische en Slowaakse nationaliteitswet kennen verkrijging van de nationaliteit van rechtswege en door naturalisatie. Een nationaliteitsverkrijging door optie is slechts voorzien voor Tsjechen die de Slowaakse nationaliteit willen verkrijgen en vice versa.

\subsubsection{Verkrijging van rechtswege}

Verkrijging van de nationaliteit van de ČSSR wordt van rechtswege gekoppeld aan de volgende rechtsfeiten:

- geboorte uit ČSSR-ouder(s) ( $\$ 8$ lid 1 en 3 WČ́SR; $\$ 8$ lid 1 en 3 WSSR);

- het gevonden worden in de ČSSR ( $\$ 8$ lid 5 WČSR; $\$ 8$ lid 5 WSSR);

Door geboorte op het grondgebied van de CSSR of adoptie door Tsjechoslowaken wordt de nationaliteit van de CSSR niet verkregen ${ }^{135}$.

\subsection{Geboorte uit ČSSR-ouder(s)}

De wetgevers in beide deelstaten gaan van het ius sanguinis a matre et a patre uit. Een kind van én hetzij Tsjechische hetzij Slowaakse ouder verkrijgt de nationaliteit van de ĆSSR ongeacht waar het wordt geboren ( $\$ 8$ lid 1 en 3 WČSR; \& 8 lid 1 en 3 WSSR).

Ten aanzien van verwerving van het staatsburgerschap door onwettige kinderen bevatten de Tsjechoslowaakse nationaliteitswetten geen uitdrukkelijke regeling. Gezien de volledige gelijkstelling tussen wettige en onwettige kinderen mag evenwel worden aangenomen, dat ook ten aanzien van hen de regels van $\$ 8$ leden 1 en 3 WČCSR en WSSR van toepassing zijn. Ten aanzien van de vader van het kind moet de afstamming uiteraard door erkenning of gerechtelijke vaststelling van het vaderschap worden vastgesteld ${ }^{136}$. De nationaliteit wordt slechts verworven, indien het kind op het tijdstip van de vaststelling van het vaderschap nog minderjarig is.

135. SGS deell 18, p. 43.

136. Zie $\$ 52$, respectievelijk $\$ 54$ leden 1 en 2 van het familiewetboek van 2 december 1963, art. $94 / 1963$ Sb. Cf. SGS deel 18, p. 40. 


\subsubsection{Vondelingen}

Kinderen die op het grondgebied van de CSSR worden gevonden, worden vermoed de ĆSSR-nationaliteit te bezitten ( $\$ 8$ lid 5 WCSR; $\$ 8$ lid 5 WSSR) Het gaat hierbij om een praesumptio iuris, waarvan tegenbewijs steeds mogelijk is, ongeacht de leeftijd van het kind.

\subsubsection{Naturalisatie}

De huidige nationaliteitswetgeving van Tsjechoslowakije kent zowel een gewone als een verlichte naturalisatieprocedure. De tweede is gereserveerd voor buitenlandse vrouwen, die met Tsjechoslowaken in het huwelijk treden. De bevoegdheid om een gewone naturalisatie te verlenen ligt bij de Ministers van binnenlandse zaken van de deelstaten. Zij bezitten hierbij een grote discretionaire bevoegdheid. Een recht op naturalisatie bestaat niet ${ }^{137}$. Een beroep tegen een afwijzende beschikking is niet mogelijk.

De vereisten om voor naturalisatie in aanmerking te komen zijn de volgende:

- ononderbroken vijfjarig verblijf in de CSR of SSR (\$10 lid 1 WĆSR en WSSR) hierbij gold verblijf vóór 1 januari 1969 binnen de CSSR als verblijf binnen de deelstaat, waarvan de nationaliteit de verzoeker wenste te verkrijgen ( $\$ 10$ lid 2 CSR en SSR) ${ }^{138}$;

- het verlies van de oude nationaliteit ( $\$ 10$ lid 1 WČ́SR en WSSR);

- verzoekers ouder dan 15 jaar dienen een eed afleggen, waarvan in bijzondere gevallen kan worden afgezien ( $\$ 11$ lid 2 WČSR en WSSR);

- de verzoeker moet een positieve instelling tegenover het politieke systeem hebben ${ }^{139}$.

We zien dat het laatstgenoemde vereiste voldoende vaag is om een naturalisatie willekeurig te weigeren. Ook uit het feit dat volgens de wettekst de nationaliteit kam worden verleend, blijkt dat het Ministerie over een nagenoeg onbeperkte discretionaire bevoegdheid beschikt.

\subsection{Invloed op de nationaliteit wan de gezinsleden van de verzoeker}

Kinderen van de verzoeker die jonger dan 15 jaar zijn, worden slechts tezamen met hun ouder genaturaliseerd, indien er uitdrukkelijk om wordt verzocht. Indien slechts éen van de ouders om naturalisatie verzoekt, wordt bovendien de toestemming van de andere ouder vereist ( $\$ 10$ lid 4 ). Deze toestemming kan door een rechterlijke

137. Schmid 1979 , p. 52 ; SGS deel 18 , p. 42 .

138. Merkwaardig genoeg is deze overgangsbepaling bij de naturalisatie te vinden. $\mathrm{Zij}$ was overigens per 1 januari 1974 uitgewerkt, aangezien slechts tot die dag verblijf voor 1 januari 1969 relevant was geweest.

139. Dit vereiste werd wanwege zijn vanzelfsprekendheid niet in de wet genoemd. Cf. Cerny/Cervenka, p. 56. 
beslissing worden vervangen. Kinderen van 15 jaar of ouder kunnen slechts zelfstandig worden genaturaliseerd. De wetten bevatten geen regeling met betrekking tot vertegenwoordiging van handelingsonbekwamen. Aangenomen mag worden dat een (gedeeltelijk) onbekwame slechts door tussenkomst van zijn wettelijke wertegenwoordiger kan worden genaturaliseerd.

\subsection{Verlichte naturalisatie}

Buitenlandse wrouwen, die met een Tsjechoslowaak in het huwelijk treden hebben tot 6 maanden na de huwelijkssluiting de mogelijkheid om zich te laten naturaliseren. Hierbij zij aangetekend, dat ČSSR-onderdanen slechts met toestemming van overheidswege met een vreemdeling mogen huwen ${ }^{140}$.

De beslissingsbevoegdheid met betrekking tot de huwelliksnaturalisatie ligt bij de volkswergadering van de "okres" van hun woonplaats ( $\$ 9$ lid 2 WČSR en WSSR). Een buitenlandse man die met een "Tsjechoslowaakse een huwelijk sluit, heeft een dergelijke mogelijkheid echter niet ${ }^{141}$. Het is merkwaardig dat nationaliteitswetgeving van een socialistische staat op dit punt onderscheid tussen mamnen en vrouwen maakt. Interessant daarbij is, dat voor Tsjechen die met Slowaken huwen, of omgekeerd, wèl de mogelijkheid bestaat om voor de deelstaatnationaliteit van de andere huwelijkspartner te opteren. Deze optie komt aan beide geslachten toe ( $\$ 9$ lid 1 WČ SR en WSSR).

\section{a. Invloed op de nationaliteit van de kinderen van de verzoekster}

Kinderen van de verzoekster, die jonger zijn dan 15 jaar, worden in de naturalisatie van hun moeder slechts inbegrepen, indien er uitdrukkelijk om wordt verzocht ( $\&$ 9 lid 2 WCSR en WSSR). Toestemming van de andere ouder van het kind wordt in dit geval niet vereist ${ }^{142}$.

\subsubsection{Verlies van de nationaliteit}

De nationaliteit van de deelstaten en daardoor die van de CSSR kan worden verloren door ontslag en ontneming. Het huidige Tsjechoslowaakse nationaliteitsrecht kent geen verlies van het staatsburgerschap van rechtswege of door het afleggen van een verklaring van afstand.

\subsubsection{Ontslag}

De nationaliteitswetten van beide deelstaten bevatten slechts bepalingen omtrent de bevoegdheid met betrekking tot de verlening van het ontslag en regels ten aanzien van medeontslag van minderjarige kinderen van de verzoeker. De beslissing wordt genomen door de volksvergadering van de "okres" waarin de verzoeker woont, respectievelijk laatstelijk heeft gewoond ( $\$ 14$ lid 3 WČSR en WSSR).

140. Zie $\$ \mathbb{1}$ van de wet van 29 oktober 1950 , art. $59 / 1950 \mathrm{Sb}$. en de verordening van de Minüster van binnenlandse zaken nr. 182/59, Uredni list van 10 september 1959. Cf. Menschenrechte, p. 119.

141. Plank, Prámy Obzor 1969, p. 709; SGS deel 18, p. 41.

142. Plank, Právny Obzor 1969 , p. 709; SGS deel 18, p. 41 . 
Vereisten voor ontslag worden in het geheel niet wettelijk geregeld. In de praktijk wordt ontslag in de regel slechts verleend, indien betrokkene zijn vaste woomplaats in het buitenland heeft ${ }^{143}$.

Voor vestiging in het buitenland is een bijzondere toestemming vereist ${ }^{144}$. Deze kan willekeurig worden geweigerd en is in het geval dat betrokkene niet tot een etnische minderheid behoort, moeilijk te verkrijgen ${ }^{145}$. Met betrekking tot etnische Duitsers werd door de ĆSSR in het verdrag van Praag met de BRD van 11 december 1973 toegezegd om deze groep potentiële emigranten welwillend te behandelen ${ }^{146}$. Aan het verlenen van de toestemming is het betalen van een bedrag verbonden, dat tot 10.000 Kronen kan oplopen ${ }^{147}$. Daarnaast moet men de kosten van de genoten schoolopleiding betalen ${ }^{148}$.

\subsection{Invloed op de nationaliteit van de gezinsleden van de verzoeker}

Volgens $\$ 14$ lid 2 WČSR en WSSR kunnen gehuwden gemeenschappelijk een ontslagverzoek indienen, maar het verzoek wordt voor elk der partners zelfstandig beoordeeld. Indien er uitdrukkelijk om wordt verzocht, wordt het ontslag tevens verleend aan kinderen van de verzoeker die jonger zijn dan 15 jaar. In geval dat slechts én van de ouders om ontslag uit de ĆSSR-nationaliteit verzoekt, is voor het medeontslag van het kind de toestemming van de andere ouder vereist. Kinderen van 15 jaar of ouder kunnen enkel zelfstandig uit de Tsjechoslowaakse nationaliteit worden ontslagen. Evenals bij de naturalisatie mag ervan uit worden gegaan dat een handelingsonbekwame een ontslagverzoek via zijn wettelijke vertegenwoordiger moet indienen.

\subsubsection{Ontneming}

Het verlies van de Tsjechoslowaakse nationaliteit door ontneming is hoofdzakelijk geregeld in de "oude" wet van 1949/58. Terwijl de Slowaakse nationaliteitswet in $\$ 15$ slechts naar die regeling verwijst, werd in de Tsjechische wet later $\$ 14 \mathrm{a}$ ingevoegd, die de gronden voor ontneming uitdrukkelijk regelt ${ }^{149}$. In $\$ 14 a$ CSR worden alle ontnemingsgronden van de wet van $1949 / 58$ met enkele redactionele veranderingen herhaald en drie nieuwe daaraan toegevoegd. De bevoegdheid om de nationaliteit te ontnemen wordt in beide deelstaten bij de respectievelijke Ministeries van binnenlandse zaken gelegd ( $\$ 14 \mathrm{a}$ WČSR; $\$ 7$ wet van 1949/58).

143. Schmid 1979 , p. 52; SGS deel 18 , p. 44.

144. Zie de wet over reisdocumenten van 18 juni 1965 , art. 63/1965 Sb. Zie daarover Kuss, EuGRZ 1987 , p. $307-308$.

145. Menschenrechte, p. 109.

146. BGBI. 1974 II, p. 989 . In de Jaren 1971-1985 verlieten bijwoorbecld 16.000 etnische Duitsers legaal Tsjechoslowaküje. Daarover Menschenrechte p. 108-109. Zie ook Bundestag Drs. 8/285 van 15 april 1977, wragen 147 en 148; Hecker Behandlung, p. 140.

147. Gemiddeld maandloon in de CSSR was in 19852974 Kronen. Menschenrechte, p. 127.

148. Mededeling van de federale Minister van financiën van 20 december 1976 , art. 162/1976 $\mathrm{Sb}$. Gewijzigd bij mededeling van 18 november 1980; 166/1980 Sb. Zie daarover Menschenrechte, p. $109,126$.

149. \$14a werd ingevoegd bij een decreet met de kracht van wet, uirgevaardigd door het Presidium van de Tsjechische Nationale raad van 6 november 1969, art. $24 / 1969 \mathrm{Sb}$. Duitse vertaling in Bergmanm/Ferid, p. $6 \mathrm{~g}$. 
Ter wille van de overzichtelijkheid zullen de ontnemingsgronden van $\$ 7$ van de wet van 1949/58 kort worden herhaald:

- handelingen die tegen de belangen van de staat zijn gericht (lid 1 sub a);

- illegale grensoverschrijding (sub b);

- het niet terugkeren uit het buitenland op vordering van het Ministerie van binnenlandse zaken (lid 1 sub c);

- het bezit van een andere nationaliteit (lid 2).

- vijfjarig verblijf in het buitenland zonder toestemming van de regering ( $\$ 7$ lid 2 volgens de wijziging in 1958).

Naar aanleiding van een sterke emigratiestroom na de gebeurtenissen van $1968^{150}$ werden aan de Tsjechische nationaliteitswet in $\$ 14 \mathrm{a}$ de volgende ontnemingsgronden toegevoegd:

- vrijwillige verkrijging van een andere nationaliteit (lid 1 sub a WČ́SR) ${ }^{151}$;

- het zonder toestemming treden in vreemde krijgsdienst (sub b WČ́SR);

- lidmaatschap of actieve participatie in organisaties wier activiteiten tegen de grondwet van de ĆSSR zijn gericht (sub c).

Gezien het bovenstaande kan althans theoretisch de situatie ontstaan dat vanwege dezelfde handelingen aan een Tsjech wel de nationaliteit kan worden ontnomen en aan een Slowaak niet. Van praktisch belang lijkt mij dit echter niet. Ofschoon het treden in een vreemde krijgsdienst en lidmaatschap in staatsvijandige organisaties niet als ontnemingsgrond in Slowakije zijn voorgeschreven, zouden ze gemakkelijk onder de ruime grond "staatsvijandige activiteiten" ( $\$ 7$ lid 1 sub a van de wet van $1949 / 58$ ) vallen. Echt verschillende ontnemingsgronden kennen beide deelstaten derhalve niet.

We zien dat volgens de wet het illegaal verlaten van het land of een ongeoorloofde verlenging van een toegestaan bezoek aan het buitenland een voldoende grond voor ontneming vormen. De zogenaamde "Republikflucht" wordt in $\$ 109$ wetboek van strafrecht als een zwaar misdrijf met straffen bedreigd ${ }^{152}$. In

150. SGS deel 18, p. 44-45.

151. Het is niet duidelijk waarom deze bepaling in de wet van de CSR werd opgenomen. Dezelfde paragraaf biedt in het tweede lid immers de mogelijkheid om het CSR-staatsburgerschap te ontnemen aan degenen die tevens een andere nationaliteit bezitten, ongeacht of de verkrijging van die andere nationaliteit vrijwillig was of niet.

152. Dit delict wordt onder misdrijven tegen de staatsveiligheid gerangschikt en wordt bedreigd met een gevangenisstraf van 6 maanden tot 5 jaar. Gaat het om geheimendragers of dienstplichtigen, dan is de straf drie tot tien jaar. Cf. Schmied, WGO 1977, p. 351. Bowendien vallen in de CSSR opengevallen erfenissen wan illegale immigranten in de regel aan de staat toe. Zie dasrover Schunid, WGO 1986, p. 266-271. 
de praktijk bleek echter dat het gezien het grote aantal vluchtelingen onmogelijk was aan al die mensen de nationaliteit te ontnemen. Deze sanctie bleef beperkt tot enkele prominente dissidenten ${ }^{153}$. Op 23 februari 1973 werd vervolgens een amnestie voor alle vluchtelingen afgekondigd, die tot het eind van dat jaar terugkeerden en die nog niet een andere nationaliteit hadden verworven ${ }^{154}$.

In 1977 kwamen bijzondere regels ten aanzien van illegale emigranten tot stand. Het ging om de "Richtlijnen met betrekking tot de regeling van de verhouding tussen de CSSR en de staatsburgers, die zich zonder toestemming van de overheid in het buitenland bevinden" van 1 juni $1977^{155}$. Deze regeling is te zien als een manifestatie van een reeds in andere landen gesignaleerde tendens om het verblijf van illegale emigranten in het buitenland te "legaliseren". Aan deze personen kan onder bepaalde omstandigheden een paspoort voor terugkeer naar de CSSR (art. 2), of toestemming voor verblijf in het buitenland worden verleend (artt. 3-5). In de regel wordt daarvoor geëist dat ze reeds vijf jaar in het buitenland hebben gewoond en betaling van 4.000 DM verlangd. Bovendien dienen ze een loyaliteitsverklaring te ondertekenen. Daarnaast dienen ook de kosten van de genoten opleiding in de CSSR te worden betaald ${ }^{156}$. Voorts bestaat de mogelijkheid dat ze op eigen verzoek uit het staatsburgerschap worden ontslagen (artt. 6-8), waarvoor opnieuw 4.000 DM wordt verlangd ${ }^{157}$.

De artt. 9-11 voorzien tenslotte in ontneming van de nationaliteit als een "ultimum remedium" in geval dat betrokkene zich schuldig heeft gemaakt aan:

"...feindlichen Kundgebungen im ausländischen Rundfunk oder Fernsehen oder auf Versammlungen von Organisationen und Institutionen im Ausland auftreten oder an feindlichen Aktionen teilnehmen oder auf eine Weise öffentlich die sozialistische Ordnung in der CSSR und ihre Bündnissverpflichtungen entwürdigen oder das Ansehen der tschechoslowakischen Räpresentanten und tschechoslowakischen staatlichen und gesellschaftlichen Institutionen herabsetzen".

We zien dat deze bepaling zo ruim geformuleerd is, dat alle kritische uitlatingen in buitenlandse media, op lezingen, e.d. daaronder te brengen zijn.

Het feit dat blijkens deze regeling voor ontneming van de nationaliteit (anders dan volgens de wetten) het niet voldoende is, dat betrokkene zich illegaal in het buitenland bevindt, betekent niet dat de richtlijnen aan bepalingen van de nationaliteitswetten derogeren. Art. 16 lid 2 van de richtlijnen bepaalt uitdrukkelijk dat alle bepalingen van de nationaliteitswetten onverminderd van kracht blijven.

153. Züe voor cen aantal voorbeelden Schmied, WGO 1977 , p. 352-353.

154. Schmied, WGO 1977 , p. 351.

155. Ustredni Vestnik nr. 2 van 1 juni 1977. Zie Schmid 1979, p. 53 ; Hunaček, Osteuropa 1978, p. A 307-A 312; Schmied, WGO 1977, p. 351-357.

156. Volgens een bericht in de Frankfurter Allgemeine Zeitung van 29 nowember 1986 moet men bij de "regeling van de verhouding tot de CSSR" in thet totaal een bedrag van 10.000-15.000 DM betalen. Zie ook Bundestag, Drs. 10/6684 van 5 december 1986, vragen 33-34; Hecker Behandlung, p. 141-142; Menschenrechte, p. 112.

157. Menschenrechte, p. 112. 
10.23.2.1 Invloed op de nationaliteit van gezinsleden van betrokkene

Ontneming van de nationaliteit heeft geen invloed op de huwelijkspartner en minderjarige kinderen van betrokkene ( $\$ 8$ wet van 1949/58). Ondanks deze bepaling bieden de ruim geformuleerde ontnemingsgronden en de nagenoeg onbeperkte discretionaire bevoegdheid van de administratie voldoende mogelijkheden om aan de familieleden van betrokkene de nationaliteit "zelfstandig" te ontnemen. 
III. VERGELIJKENDE SAMENVATTING 


\section{HOOFDSTUK 1. HET "OUDE" NATIONALITEITSRECHT IN DE OOSTEUROPESE LANDEN}

\subsection{VerkRUGing VAN DE NATTONALTEIT -}

\subsubsection{Verkrijging van rechtswege}

De voornaamste grond voor verkrijging van de nationaliteit van rechtswege in de Oosteuropese landen voordat de communistische partijen de regeringsmacht overnamen was afstamming uit onderdanen van het desbetreffende land (ius sanguinis). Het ius soli speelde slechts een subsidiaire rol, met het doel staatloosheid van een kind te voorkomen. Voorts werd het ius soli in sommige landen gecombineerd met het treden in staatsdienst, het genieten van opleiding of langdurige woonplaats in het desbetreffende land en enkele andere bijzondere gronden voor verkrijging van rechtswege.

\subsubsection{Ius sanguinis}

In alle Oosteuropese landen ontleende in de regel en wettig kind zijn nationaliteit aan zijn vader en een onwettig kind aan zijn moeder. Volgens het recht wan Albanië en Bulgarije volgde een wettig kind evenwel het staatsburgerschap van zijn moeder, indien zijn vader van onbekende nationaliteit of staatloos was. In alle andere landen was het kind in een dergelijk geval staatloos. Uitsluitend Albanië kende voorts verkrijging van het staatsburgerschap door een wettig kind van een Albanese moeder voor het geval dat het kind aan zijn vader, die een vreemd staatsburgerschap bezat, geen nationaliteit ontleende "

Legitimatie van een minderjarige vormde in alle Oosteuropese landen een grond voor verkrijging van het staatsburgerschap van de vader. Volgens de Duitse en Hongaarse regelingen werd de nationaliteit zelfs door een meerderjarige verworven, in Hongarije evenwel op voorwaarde dat zijn vader Hongaar door geboorte was.

Alleen via erkenning werd het staatsburgerschap slechts verkregen in Albanië, Bulgarije en Roemenië. Interessant is voorts dat in Roemeniẻ de nationaliteit zelfs werd verkregen, wanneer de erkende persoon reeds gehuwd was en dat de verkrijging van het staatsburgerschap volgens de wet ex tunc werking had. Roemeniê was bovendien het enige land waarin verkrijging van de nationaliteit via erkenning en legitimatie niet apart, maar bij de verkrijging van het staatsburgerschap fure sanguinis werd gerangschikt. Slechts Albanie en Roemenië kenden tenslotte verkrijging van de nationaliteit door gerechtelijke vaststelling van het vaderschap ${ }^{2}$.

Adoptie was uitsluitend een grond voor verkrijging van de nationaliteit van rechtswege volgens het recht van Albanië en Polen.

1. Deze regeling werd van art. 1 lid 2 van de Italiaanse nationaliteitswet van 1912 overgenomen.

2. In Roemenië moest het daarbij om de zogenaamde "volledige" vaststelling van het waderschap gaan. Zie p. 263. 


\subsubsection{Geboorte op het grondgebied en vondelingen}

Geboorte op het grondgebied van een Oosteuropees land kon als zodanig geen verkrijging van de nationaliteit bewerkstelligen. Alle rechtsstelsels stelden voor de verkrijging van het staatsburgerschap iure soli nog additionele eisen. Zo werd volgens de Russische en Albanese regeling de nationaliteit verkregen door geboorte op het grondgebied in combinatie met het treden in militaire dienst ${ }^{3}$. Volgens het Albanese recht was in plaats van geboorte op het grondgebied ook voldoende dat het kind in het buitenland werd geboren, mits zijn ouders op het tijdstip van geboorte van het kind tenminste tien jaren in Albanië hadden gewoond. Het Albanese staatsburgerschap werd voorts ook verkregen door een in Albanië geboren kind ${ }^{4}$, dat tot zijn 21 ste verjaardag reeds tenminste tien jaren in Albanië had gewoond. Voldeed betrokkene niet aan deze verblijfseis, dan kon hij voor het Albanese staatsburgerschap opteren. Een vergelijkbare regeling kende ook de Bulgaarse wet van 1940 volgens welke een in Bulgarije geboren kind het Bulgaarse staatsburgerschap verkreeg indien het aldaar zijn vaste woonplaats had en tot éen jaar na het bereiken van de meerderjarigheid geen beroep op het bezit van een vreemde nationaliteit deed.

Het meest voorkomend additioneel vereiste bij verwerving van het staatsburgerschap iure soli was de eis dat de ouders van het kind onbekend, van onbekende nationalliteit, of staatloos waren. Een dergelijke regeling kenden Albanië, Bulgarije, Hongarije, Joegoslaviē, Polen, Roemenië en Tsjechoslowakije. In al deze gevallen ging het om een praesumptio iuris van het bezit van de nationaliteit, waartegen bewijs steeds toegelaten was, ongeacht de leeftijd van het kind.

Alle Oosteuropese landen behalve Rusiand en Bulgarije kenden voorts een praesumptio iuris van bezit van het staatsburgerschap ten gunste van vondelingen. In Albanië en Roemenië gebruikte men een constructie volgens welke een vondeling vermoed werd op het grondgebied van het desbetreffende land te zijn geboren en op deze grond de nationaliteit van dat land had verworven. De Hongaarse regeling, die tevens in Slowakije en Karpathorusland (Tsjechoslowakije) gold, eiste tevens dat ze in het land werden opgevoed.

\subsubsection{3 lus matrimonii}

Alle Oosteuropese landen met uitzondering van Bulgarije gingen van het système unitaire-beginsel uit. Een vreemdelinge verwierf door een huwelijk automatisch het staatsburgerschap van haar man. De nationaliteit werd ook verworven indien zij door huwelijk niet haar oorspronkelijke nationaliteit verloor en derhalve bipatride werd. Slechts in Joegoslavië en Roemenië had betrokkene de mogelijkheid om verkrijging van het staatsburgerschap door een verklaring vór de huwelijkssluiting te voorkomen. Deze mogelijkheid bestond slechts indien betrokkene haar oude nationaliteit niet automatisch door huwelijk verloor. In Joegoslavië gold verder de beperking dat slechts een staatsburgerschap dat de

3. In Albanię tevens het treden in Albanese staatsdienst.

4. Ook bij deze regeling werd geboorte in Albanie met het geval dat het kind in het buitenland werd geboren gelijkgesteld, mits zijn ouders op dat tijdstip reeds sedert tien jaren in Albanie woonachtig waren. 
buitenlandse bruid door afstamming verwierf, kon worden behouden. Volgens de Bulgaarse wet van 1940 had een met een Bulgaar gehuwde buitenlandse vrouw tot drie maanden na de huwelijkssluiting de mogelijkheid van vereenvoudigde naturalisatie. Het is bijzonder interessant dat een dergelijke mogelijkheid onder bepaalde voorwaarden ${ }^{5}$ ook aan een met een Bulgaarse vrouw gehuwde man werd geboden.

\subsubsection{Andere gronden voor verkrijging van het staatsburgerschap ipso iure}

Andere dan de hierboven genoemde gronden voor verwerving van het staatsburgerschap ipso iure kwamen in het nationaliteitsrecht van de Oosteuropese landen nauwelijks voor. In Albanië kende men een regeling volgens welke een kind, wier vader, moeder(!) of grootvader aan de vaderszijde Albanezen door geboorten waren geweest, door het treden in Albanese militaire of staatsdienst, of door een tienjarig verblijf in het land vór het bereiken van de meerderjarigheid, de Albanese nationaliteit verwierf. Degenen die niet aan deze tienjarige verblijfseis voldeden, konden voor de Albanese nationaliteit opteren.

Polen en Tsjechoslowakije kenden voorts verkrijging van het staatsburgerschap door een vaste aanstelling in staatsdienst en in Polen tussen 1920 en 1924 ook door het treden in militaire dienst. In Tsjechoslowakije werd de nationaliteit eveneens verworven door buitenlandse notarissen en geestelijken. In Polen was verkrijging van het staatsburgerschap door het treden in staatsdienst echter van ondergeschikt belang, aangezien voor de meeste overheidsfuncties het bezit van de Poolse nationaliteit was vereist.

\subsubsection{Optie}

Verkrijging van de nationaliteit door zuiwere opties nam in geen van de Oosteuropese landen, behalve Rusland, een belangrijke plaats in. De regeling van het Russische keizerrijk kende een relatief uitgebreide kring optiegerechtigden. Dit waren degenen die in Rusland waren geboren of opgevoed, voorts vreemdelingen die in Russische militaire dienst traden, alsmede geestelijken van niet-Russischorthodoxe godsdienst die door de overheid naar Rusland werden geroepen. Tenslotte werd een optierecht verleend aan gewezen Russische vrouwen, nadat hun huwelijk met een buitenlander werd ontbonden.

In de andere landen werden optierechten in de regel eveneens verleend aan vrouwen, die hun staatsburgerschap door of in verband met een huwelijk met een vreemdeling hadden verloren, meestal onder de voorwaarde dat betrokkene zich na de ontbinding van het huwelijk weer in het land kwam vestigen (Albanië, Joegoslavië, Pollen en Roemenië). De Albanese regeling van 1928 verleende voorts optierechten aan personen die daar werden geboren (of in het buitenland geboren, terwijl de ouders reeds tien jaar in Albanië woonden) en tot hun 21ste levensjaar minder dan tien jaar in Albanië hadden gewoond. Woonde betrokkene reeds 10 jaar of meer in het land, dan verkreeg hij de Albanese nationaliteit ipso iure. Joegoslavië kende tenslotte optierechten ten behoeve van meerderjarig geworden

5. Deze mogelijkheid bestond slechts indien betrokkene met een Bulgatse gehuwd was en zijm echigenote haar Bulgaarse nationaliteit door afstamming verwierf. 
ex-Joegoslavische kinderen, die deze nationaliteit hetzij door legitimatie door een vreemdeling, hetzij doordat ze tezamen met hun ouder(s) in een ander land werden genaturaliseerd, hadden verloren. Ook ten aanzien van hen werd geëist dat ze zich in het binnenland moesten vestigen.

\subsubsection{Naturalisatie}

De bevoegdheid om een naturalisatie te verlenen, werd in de Oosteuropese landen bij verschillende overheidsinstanties geplaatst. De zwaarste procedure was in Roemenië waar het staatsburgerschap bij een formele wet moest worden verleend. In Albanië waren de Koning of de Ministerraad bevoegd, in Rusland, Hongarije, Joegoslavië en Polen de Ministers van binnenlandse zaken. In Bulgarije was de Minister van justitie bewoegd, terwijl in Tsjechoslowakije provinciale besturen naturalisaties verleenden. Hongarije kende een regeling, die de belangrijkste beslissing bij de gemeentebesturen plaatste. De Minister van binnenlandse zaken, die formeel de beslissing nam, moest conform het advies van de gemeente handelen en had geen discretionaire bevoegdheid.

In de regel was er geen sprake van een recht op naturalisatie. Slechts Duitsland (tot 1935) en Joegoslavië kenden ten behoeve van bepaalde categorieën naturalisandi zogenaamde "Einbürgerungsansprüche". In andere landen had het bevoegde orgaan nagenoeg onbeperkte discretionaire bevoegdheid, die slechts in Polen en Hongarije door de mogelijkheid van administratief beroep enigszins was beperkt.

De nationaliteitswetten van de afzonderlijke landen hanteerden verschillende naturalisatievereisten, die in Bulgarije, Polen en Roemenië het meest uitgebreid waren uitgewerkt. De meest beknopte regeling van naturalisatievereisten kende Rusland. De Bulgaarse nationaliteitswet van 1940 bevatte een uitgebreide regeling van voorwaarden voor verkrijging van een vergunning voor verblijf van onbepaalde duur. Een dergelijke vergunning was een vereiste voor de naturalisatie.

In Rusland, Hongarije, Joegoslavië, Roemenië en Tsjechoslowakije werd in de eerste plaats vereist dat betrokkene meerderjarig, respectievelijk handelingsbekwaam was. In andere landen was zelfstandige naturalisatie van minderjarigen en andere handelingsonbekwamen mogelijk, mits het naturalisatieverzoek door de wettelijke vertegenwoordiger van betrokkene werd ingediend.

De verblijfseis die afzonderlijke landen hanteerden, was verschillend. In Bulgarije, Joegoslavië, Polen, Roemenië en het voormalig Oostenrijks gedeelte van Tsjechoslowakije werd een ononderbroken verblijf van tien jaren geëist. In andere landen gold een verblijfsvereiste van vijf jaar, terwijl de Duitse wet slechts bepaalde dat de verzoeker in Duitsland moest wonen.

In Bulgarije, Duitsland, Hongarije, Joegoslavië, Roemenië en Tsjechoslowakije werden aan naturalisandi uitdrukkelijk economische eisen gesteld; betrokkene moest in staat zijn zichzelf en zijn gezin te onderhouden. In Hongarije, Joegoslavië en Tsjechoslowakije werd dit vereiste gehanteerd in het kader van de eis van verkrijging van het "Heimatrecht" in een gemeente, waarvoor voornamelijk financiële voorwaarden golden. In Rusland moesten naturalisandi bewijsstukken omtrent hun beroepsbezigheid overleggen, waaruit kan worden geconcludeerd dat ook daar de vermogenstoestand van betrokkene van belang was. Het is aan te 
nemen dat dergelijke overwegingen ook in Albanië, Bulgarije en Duitsland- hoewel niet uitdrukkelijk in de wet vereist- een rol speelden.

De nationaliteitswetten van Rusland, Albanië, Hongarije, Joegoslavië en Tsjechoslowakije eisten voorts dat naturalisandi een eed van trouw aflegden.

Het is aannemelijk dat in alle landen tevens het vereiste van "goed gedrag" werd gehanteerd, hoewel dit slechts in Bulgarije, Hongarije, Polen, Roemenie en Tsjechoslowakije uitdrukkelijk in de wet werd vermeld. De meest uitgewerkte criteria met betrekking tot het gedrag van de verzoeker bevatten de Poolse en de Roemeense regeling. Opmerkelijk is voorts dat de Bulgaarse nationaliteitswet van 1940 uitdrukkelijk bepaalde dat ook politieke opvattingen van betrokkene, zijn nationaliteit, alsmede zijn motieven voor het indienen van het naturalisatieverzoek bij de beslissing een rol speelden.

Het verlies van de oude nationaliteit werd in Joegoslavië, Polen, Roemenië en Tsjechoslowakije uitdrukkelijk als een naturalisatievoorwaarde gesteld. In het geval dat de verzoeker de nationaliteit bezat van een land dat geen verlies van het staatsburgerschap door de wil van betrokkene kende, was het voldoende dat hij verklaarde dat hij zijn oude nationaliteit "opgaf".

Kennis van de landstaal gold slechts in Bulgarije, Polen en Roemenië als een vereiste voor naturalisatie. De Roemeense regeling van 1939 is voorts interessant door het feit dat aan naturalisandi ook de eis van geestelijke en lichamelijke gezondheid werd gesteld.

\subsubsection{Verlichte naturalisatie}

Alle landen behalve Hongarije en Tsjechoslowakije kenden tevens verlichte naturalisatie. De beslissing tot verlening van naturalisatie werd door hetzelfde orgaan genomen als bij de "gewone", waarbij ten aanzien van bepaalde groepen naturalisandi in de regel (gedeeltelijke) vrijstelling van de verblijfseis werd verleend. Soms hoefde betrokkene ook niet aan de economische vereisten en/of aan de eis van het verlies van de oude nationaliteit te voldoen. Duitsland (tot 1935) en Joegoslavië kenden ten behoeve van bepaalde groepen personen zogenaamde "Einbürgerungsansprüche". Deze personen hadden namelijk een recht op naturalisatie, zodat aan de beslissende instantie de discretionaire bevoegdheid werd ontnomen.

In alle landen werd de mogelijkheid van verlichte naturalisatie met name geboden aan personen, die aan de staat belangrijke diensten hadden bewezen. Daaronder werden in de regel verstaan economische activiteiten van grotere omvang, of belangrijke prestaties op het gebied wan kunst en/of wetenschap, alsmede dienst in het leger of staatsdienst. In Albanië Bulgarije en Roemenië telden ook diensten op het persoonlijk vlak, zoals huwelijk met een onderdane wan de desbetreffende staat, mee. In Bulgarije dat als enige geen automatische verkrijging van het staatsburgerschap door huwelijk kende, had een vrouw die met een Bulgaar een huwelijk sloot eveneens de mogelijkheid van bevoorrechte naturalisatie.

Etnische nationaliteit vormde een grond voor verlichte naturalisatie in Albanië, Bulgarije, en Joegoslavië, terwijl volgens het Poolse en Roemeense recht dit de grond voor de bijzondere vorm van geprivilegieerde naturalisatie, "erkenning", opleverde. 
Voorts kenden verschillende landen nog enkele specifieke gronden voor verlichte naturalisatie. Zo hadden in Rusland de mogeiijkheid an bevoorrechte naturalisatie meerderjarige kinderen van degenen, die door naturalisatie of optie de Russische nationaliteit verwierven, voorts buitenlandse boeren en arbeiders, alsmede emigranten van slavische afkomst en onderdanen van landen, waarmee Rusland een verdrag strekkende tot verkorting van de verblijfseis sloot. In Albanië kende men voorts verlichte naturalisatie ten behoeve van optiegerechtigden die niet binnen de gestelde termijn hun optie hadden uitgebracht. In Duitsland kende men ook "Einbürgerungsansprüche" ten behoeve van ex-Duitse vrouwen, die hun nationaliteit door huwelijk met een buitenlander hadden verloren, alsmede personen die hun Duitse nationaliteit als gevolg van het verlies van het staatsburgerschap door hun ouder(s) hadden verloren. Ook alle andere oud-Duitsers hadden (aan iets strengere voorwaarden verbonden) recht op naturalisatie. In Roemenie kende men voorts verlichte naturalisatie van personen, wier afstamming van een Roemeense vader na hun meerderjarigheid kwam vast te staan en degenen die in Roemenië werden geboren en tot hun 20ste levensjaar daar woonden. In Albanië verkreeg deze tweede categorie de nationaliteit overigens van rechtswege.

\subsubsection{1 "Erkenning"}

In Polen en Roemenië kende men voorts nog verkrijging van het staatsburgerschap door een bijzondere vorm van verlichte naturalisatie, "erkenning". In beide gevallen ging het om een wijze van verkrijging ten behoeve van personen van Poolse, respectievelijk Roemeense etnische afstamming, die zich in het land kwamen vestigen. Anders dan in Roemenië werd volgens de Poolse regeling vereist dat betrokkene over een vestigingsvergunning beschikte en had een verzoeker die aan alle vereisten voldeed, een recht op verkrijging van het staatsburgerschap. In beide landen moest betrokkene zijn oude nationaliteit door middel van een verklaring "opgeven". Roemenië hanteerde men ook bij "erkenning" de vereisten van goed gedrag, leeftijd van 21 jaar en goede gezondheid. In beide landen had de verkrijging van het staatsburgerschap werking ex tunc, dus vanaf het tijdstip van de geboorte van betrokkene.

\subsubsection{Hernaturalisatie}

De Albanese en Bulgaarse regeling van 1926 respectievelijk 1940 kenden als enige wetten aparte regels ten aanzien van hernaturalisatie. In Albanië ging het om een verzwalarde procedure: de beslissing werd evenals bij de gewone naturalisatie, genomen door de Ministerraad, doch slechts na positief advies van de Raad van State $^{6}$. Deze procedure was slechts voorgeschreven ten aanzien van personen, die de Albanese nationaliteit door het treden in vreemde militaire of staatsdienst, of door ontslag hadden verloren. De eersten werden vrijgesteld van de verblijfseis van vijf jaar, ze moesten verklaren dat ze hun eventuele andere nationaliteit "opgaven", bewijzen dat ze de vreemde dienst hadden verlaten en in Albanië woonden. Ten

6. De Raad van State was toen in Albanie cen adviesorgaan van de regering, opgericht naar voorbeeld van de italiaanse Consiglio di Stato. 
aanzien van personen die de Albanese nationaliteit door ontslag hadden verloren, werd slechts een tweejarig verblijf in het land geëist.

In Bulgarije golden dezelfde procedurele regels als bij de gewone naturalisatie en ging het eigenlijk om een verlichte naturalisatie. Van de verzoeker werd slechts geëist dat hij in Bulgarije woonde. Van deze verlichte hernaturalisatie werden echter degenen uitgesloten, die de Bulgaarse nationaliteit door ontneming of het treden in vreemde krijgs- of staatsdienst hadden verloren en gewezen Bulgaarse vrouwen die deze nationaliteit door of in verband met een huwelijk met een buitenlander hadden verloren, voor de duur van dit huwelijk. Voorts konden personen van niet-Bulgaarse etnische afstamming, die de Bulgaarse nationaliteit door afstand verloren, slechts van deze hernaturalisatie gebruik maken indien zij met een (juridisch) Bulgaarse vrouw waren gehuwd.

\subsubsection{Invloed op de nationaliteit van de gezinsleden van de verzoeker}

In alle Oosteuropese landen met uitzondering van Bulgarije werd een gehuwde vrouw automatisch in de naturalisatie van haar man inbegrepen. Bulgarije kende slechts automatische medenaturalisatie voor het geval dat het om een gewezen Bulgaarse ging, die deze nationaliteit door afstamming had verworven. In alle andere gevallen moest ze zelfstandig worden genaturaliseerd. In Albanië werd ten aanzien van automatische medenaturalisatie vereist dat betrokkene samen met haar man woonde. Voorts kenden de regelingen van Albanië, Joegoslavië en Roemenië beperkte mogelijkheden om door middel van een schriftelijke verklaring de medenaturalisatie te voorkomen ${ }^{7}$. De Poolse wet kende voorts de mogelijkheid dat ten aanzien van de vrouw van de naturalisandus in het naturalisatiebesluit een voorbehoud werd gemaakt.

Minderjarige kinderen (onder 21 jaar, in Polen en Tsjechoslowakije onder 18 jaar) van naturalisandi werden in de regel met hun ouder(s) meegenaturaliseerd. Wettige en door de vader erkende kinderen werden meegenaturaliseerd indien hun beide ouders, of hun vader alleen genaturaliseerd werd(en), terwijl andere onwettige kinderen in de naturalisatie van hun moeder deelachtig werden. Slechts de regelingen van Albanië en Roemenië gaven aan een meegenaturaliseerd kind bij het bereiken van de meerderjarigheid de mogelijkheid om van de zo verworven nationaliteit afstand te doen. In Polen bestond voorts de mogelijkheid dat ten aanzien van minderjarige kinderen van betrokkene bij het naturalisatiebesluit een woorbehoud werd gemaakt. Merkwaardig was de regeling in Rusland: minderjarige kinderen van betrokkene werden nooit in de naturalisatie van hun ouder(s) deelachtig. Terwijl ten behoeve van meerderjarige kinderen van naturalisandi verlichte naturalisatie van het kind mogelijk was, moesten de minderjarigen wachten totdat ze 21 jaar oud werden.

In Polen en Roemenië deelden de echtgenotes en minderjarige kinderen en vrouwen van betrokkenen in de verkrijging van de nationaliteit door "erkenning". In Roemenië kregen ze evenals andere naturalisandi niet alle politieke rechten.

7. In Joegoslavië bestond deze mogelijkheid slechts voor vrouweri, die hun oorspronkelijke nationaliteit reeds bij het aangaan van het huwelijk met de naturalisandus hadden behouden. In Albanie was behoud van de nationaliteit door de vrouw van een naturalisandus slechts mogelijk indien thet echtpaar gescheidem leefde en er geen kinderen uit dit huwelijk waren voortgekomen. 


\subsubsection{Verlies van rechtswege}

In het "oude" nationaliteitsrecht van de Oosteuropese landen komen we de volgende gronden voor het verlies van het staatsburgerschap van rechtswege tegen: wettiging door een vreemdeling, huwelijk met een buitenlander, verkrijging van een andere nationaliteit, vestiging of verblijf in het buitenland, het zonder toestemming treden in vreemde militaire of staatsdienst, het ontwijken of niet vervullen van militaire dienst. Slechts in Roemenië verloor een kind zijn nationaliteit ook in het geval dat hij door een buitenlander werd erkend, of, in bepaalde gevallen, doordat het vaderschap gerechtelijk werd vastgesteld. Aan adoptie door een vreemdeling(e) werd in geen van de Oosteuropese landen van rechtswege het verlies van het staatsburgerschap verbonden.

\subsubsection{Wettiging of erkenning door een vreemdeling}

Het verlies van de nationaliteit door een minderjarige ${ }^{8}$, die door een buitenlandse man werd gewettigd, kenden de regelingen van Duitsland, Hongarije, Joegoslavië, Roemenië en Tsjechoslowakije. Het staatsburgerschap ging door wettiging evenwel niet verloren, indien het kind door de legitimatie of erkenning niet de nationaliteit van zijn vader verwierf. Slechts de regeling van Joegoslavië gaf aan een kind dat op de onderhavige grond zijn nationaliteit verloor, de mogelijkheid om na het bereiken van de meerderjarigheid zijn oude nationaliteit door optie te herkrijgen. In andere landen stond voor betrokkene slechts (her)naturalisatie open; in Duitsland had hij een "Einbürgerungsanspruch".

\subsubsection{Huwelijk met een vreemdeling}

Volgens de regelingen van alle landen behalve Bulgarije verloor een vrouw automatisch haar nationaliteit door huwelijk met een buitenlander. De Bulgaarse wet van 1940 gaf een dergelijke vrouw de mogelijkheid om van het staatsburgerschap afstand te doen. De nationaliteit ging volgens het recht van Albanië, Joegoslavië, Polen en Rusland niet automatisch verloren indien de vrouw daardoor staatloos zou worden. De regelingen van Albanië, Joegoslavië en Roemenië gaven betrokkene de mogelijkheid om het verlies van de nationaliteit te voorkomen door bij het aangaan van huwelijkse voorwaarden te verklaren dat ze haar oude nationaliteit wenste te behouden. Deze mogelijkheid bestond ongeacht of zij door of in verband met haar huwelijk tevens het staatsburgerschap van haar man verwierf. Slechts de Bulgaarse wet van 1940 gaf een regeling voor het geval dat betrokkene minderjarige kinderen had. Deze verloren door huwelijkssluiting automatisch de Bulgaarse nationaliteit. $\mathrm{Na}$ de ontbinding van het huwelijk had betrokkene in Albanië, Joegoslavië, Polen en Rusland de mogelijkheid om voor haar oude nationaliteit te opteren, terwijl in Hongarije en Tsjechoslowakije verlichte naturalisatie voor haar openstond. In Duitsland had ze een "Einbürgerungsanspruch".

8. In Hongarije ook meerderjarige. 


\subsubsection{Vreemde militaire of staatsdienst}

Het treden in vreemde militaire of staatsdienst was in Albanië, Bulgarije en Polen een grond voor verlies van de mationaliteit van rechtswege, terwijl in Duitsland, Hongarije, Joegoslavië en Roemenië een dergelijke handeling tot ontneming van het staatsburgerschap kon leiden.

Volgens de Bulgaarse regeling was zelfs voldoende dat betrokkene zonder toestemming van de overheid materiële ondersteuning uit het buitenland ontving. Volgens de Albanese wet moest men aan betrokkene eerst een termijn stellen waarbinnen hij de vreemde dienst moest verlaten. Pas het geen gehoor geven aan een dergelijk oproep bewerkstelligde verlies van het staatsburgerschap, dat als bijkomend gevolg had dat betrokkene niet naar Albanië terug mocht komen.

\subsubsection{Verkrijging van een andere nationaliteit}

Het verkrijgen van een andere nationaliteit was een grond voor het automatisch verlies van het staatsburgerschap van Bulgarije, Duitsland, Hongarije, Joegoslavië, Polen, Roemenië en Tsjechoslowakije. De regelingen van Hongarije ${ }^{\%}$, Polen en Roemenië eisten dat het om vrijwillige verkrijging van de nationaliteit (optie of naturalisatie) ging. Een Duitser, die een vreemde nationaliteit verwierf, verloor zijn staatsburgerschap slechts indien hij tevens in het buitenland woonde. Het staatsburgerschap ging echter niet verloren, indien betrokkene van de bondsstaat waarvan hij de nationaliteit bezat, de toestemming voor het behoud van het staatsburgerschap kreeg.

\subsection{Invloed op de nationaliteit van de gezinsleden van betrokkene}

Volgens de Bulgaarse en Joegoslavische regeling verloren minderjarige kinderen van betrokkene hun staatsburgerschap, indien ze in de naturalisatie van hun ouder(s) deelachtig waren. Volgens het Roemeense recht verloor ook de vrouw van betrokkene daardoor haar nationaliteit, waarbij ze de mogelijkheid had om het Roemeense staatsburgerschap door optie te herkrijgen. Meerderjarig geworden kinderen die het verlies van de nationaliteit door hun ouders deelachtig waren konden volgens de regeling van Joegoslavië voor hun oude nationaliteit opteren.

\subsubsection{Langdurig verblijf of vestiging in het buitenland}

Volgens de Hongaarse regeling die eveneens in een gedeelte van Tsjechoslowakije gold ${ }^{10}$, ging de nationaliteit verloren door een tienjarig verblijf in het buitenland zonder dat betrokkene ter vervulling van een officiële opdracht in het buitenland was. De termijn kon worden gestuit door een mededeling aan de gemeente van betrokkene ${ }^{11}$ of door een verblijf in het land van drie maanden. De vrouw en minderjarige kinderen van betrokkene deelden in het verlies van de nationaliteit

9. In Hongarije ging het staatsburgerschap slechts door naturalisatie verloren.

10. In Tsjechoslowakje werd deze verliesgrond in 1922 afgeschaft.

11. Iedere onderdaan van Hongarije en Tsjechoslowakije had een "Heimatgemeinde" waarvan hij het "Heimatrecht" bezat. 
indien zij bij hun man, respectievelijk vader woonden. Volgens de Bulgaarse regeling verloren personen van niet-Bulgaarse etnische afstamming hun staatsburgerschap, doordat ze zich in het buitenland vestigden.

\subsubsection{Het niet vervullen van militaire dienstplicht}

De Duitse nationaliteit ging in sommige gevallen verloren voor in het buitenland woonachtige personen, die tot hun 31ste levensjaar niet in Duitsland hun militaire dienst hadden vervuld. De Bulgaarse nationaliteit ging volgens de regelling van 1940 zelfs verloren in het geval dat betrokkene een mobilisatieoproep ontweek. In Polen en Roemenië waren verschillende vormen van niet-nakoming van militaire verplichtingen een grond voor ontneming van de nationaliteit.

\subsection{Afstand}

Een algemene regeling van het verlies van de nationaliteit door het afleggen van een verklaring van afstand kenden slechts de nationaliteitswetten van Albanië en Joegoslavië. Zelfs hier ging het echter om een beperkte kring afstandsgerechtigden. het verlies van het staatsburgerschap door afstand was mogelijk ten aanzien van in het buitenland woonachtige personen die in het buitenland werden geboren, meerderjarig ${ }^{12}$ waren en krachtens geboorte de nationaliteit van het land bezaten waarin ze woonden. Voorts hadden slecht volgens het Albanese recht de mogelijkheid van afstand meerderjarig geworden kinderen van naturalisandi die in de naturalisatie van hun ouder(s) in Albanië deelachtig waren.

\subsubsection{Ontslag}

Verlies van de nationaliteit door ontslag kenden alle Oosteuropese landen, behalve Bulgarije, Polen, Roemenië en het voormalig Oostenrijks gedeelte van Tsjechoslowakije, die echter alle automatisch werlies van de nationaliteit wegens vrijwillige verkrijging van een ander staatsburgerschap kenden. De bevoegdheid om het ontslag te verlenen, lag in de regel bij dezelfde organen als bij de naturalisatie. In Albanië werd de regeling van ontslag niet onder deze naam maar als "toestemming voor verkrijging van een vreemde nationaliteit" in de wet opgenomen. Volgens het recht van Duitsland, Hongarije en Joegoslavië werd ontslag steeds verleend onder de voorwaarde dat betrokkene (meestal binnen één jaar) na de verlening van het ontslag het land verliet of een andere nationaliteit verwierf, voorzover hij deze niet reeds bezat.

De Duitse, Hongaarse en Joegoslavische regeling waren de enige die betrokkene in bepaalde gevallen een recht op ontslag verleenden.

De vereisten voor ontslag waren verschillend. De meest uitgewerkte regeling kende de Hongaarse wet van 1879. De meeste landen eisten dat betrokkene zijn verplichtingen tegenover de staat en tegenover natuurlijke personen voldeed. Bij deze verplichtingen moet worden gedacht aan verschillende vormen van militaire dienstplicht (Duitsland, Hongarije, Joegoslavië en Tsjechoslowakije) en aan

12. Volgens het Joegoslavische recht was afstand slechis tussen het 21 ste en 24 ste levensjaar vani betrokkene mogelijk. 
privéschulden en belastingen (Rusland, Hongarije, Joegoslavië en Tsjechoslowakije). In Hongarije was het ontslag ook niet mogelijk indien tegen de verzoeker een strafrechtelijke procedure aanhangig was of in het geval dat hij tot een vrijheidsstraf was veroordeeld, die nog niet ten uitvoer werd gelegd. In Albanië werd slechts geëist dat betrokkene in het buitenland woonde. De Duitse wet bepaalde voons dat gehwwde vrouwen niet zelfstandig konden worden ontslagen en dat bij mincierjarigen de tussenkomst van hun wettelijke vertegenwoordiger vereist was en in de meeste gevallen toestemming van een "Vormundschaftsgericht".

\subsubsection{Invloed op de nationaliteit van de gezinsleden van de verzoeker}

Een uitdrukkelijke regeling van de invloed van ontslag op het staatsburgerschap van de gezinsleden van betrokkene hadden de nationaliteitswetten van Duitsland, Hongarije (die ook in een gedeelte van Tsjechoslowakije gold) en Joegoslavië. De vrouw en minderjarige kinderen werden automatisch meeontslagen, waarbij de Hongaarse regeling eiste dat ten aanzien van kinderen geen hindernissen in verband met de militaire dienstplicht bestonden. Na de ontbinding van het huwelijk had de vrouw, alsmede meerderjarig geworden kinderen ${ }^{13}$ in Hongarije en Tsjechoslowakije de mogelijkheid van verlichte naturalisatie, terwijl hen in Duitsland (tot 1935) een "Einbürgerungsanspruch" werd toegekend. Gezien het toen nog tamelijk absoluut geldende beginsel van het système unitaire moet waarschijnlijk worden aangenomen dat in Albanië, Roemenië en Polen de vrouw en minderjarige kinderen van betrokken eveneens automatisch in het ontslag van hun man, respectievelijk vader werden inbegrepen. Ten aanzien van Rusland kan medeontslag van kinderen in twijfel worden getrokken aangezien het spiegelbeeld van het ontslag, naturalisatie, zich niet mede over de kinderen uitstrekte.

\subsubsection{Ontneming wan nationaliteit en herroeping van naturalisatie}

Ontneming van de nationaliteit was in het "oude" nationaliteitsrecht van de Oosteuropese landen geen onbekend rechtsinstituut. Geen ontneming van het staatsburgerschap was echter voorzien in Rusland, Albanie en in het voormalig Oostenrijks gedeelte van Tsjechoslowakije. Voorts is opvallend dat in verschillende landen (Bulgarije, Duitsland, Hongarije, Polen en Roemenië) de reeds bestaande erg beperkte mogelijkheden voor ontneming aan het eind van de dertiger jaren aanzienlijk werden uitgebreid. Naast een uitbreiding in de algemene nationaliteitswet kwamen in Polen en Roemenië in 1938, respectievelijk 1940 nog aparte ontnemingswetten tot stand. Voorts werd in Tsjechoslowakije direct na de tweede wereldoorlog door het "burgerlijke" regime Beney tot massale ontneming van het staatsburgerschap aan etnische Duitsers en Hongaren overgegaan. Verlies van de nationaliteit door intrekking, respectievelijk herroeping van een naturalisatie kenden slechts Duitsland tussen 1933 en 1945, Polen en Roemenië. Interessant is dat in Roemenië ook een "erkenning" in bepaalde gevallen kon worden herroepen; in Polen was dit niet mogelijk. Roemenië kende voorts als het enige land een verdeling in absolute en relatieve ontnemingsgronden. De absolute ontnemingsgron-

13. Volgens de Hongaarse regeling ook reeds na de dood van de vader. 
den leidden tot verplichte ontneming van de nationaliteit, terwijl bij de relatieve de beslissing ter discretie van de administratie werd overgelaten.

Bulgarije en Hongarije waren de enige landen die in enkele gevallen verlies van het staatsburgerschap als bijkomende straf bij en strafrechtelijke veroordeling kenden.

De bevoegdheid om het staatsburgerschap te ontnemen werd geplaatst bij de Ministerraad (Bulgarije, Roemenië), de regering (Hongarije, Tsjechosllowakje) of de Minister van binnenlandse zaken (Duitsland, Joegoslavië). De beslissende instantie had in de regel grote, zoniet onbeperkte discretionaire bevoegdheid, een mogelijkheid van beroep bestond slechts in Hongarije en Polen. Volgens de Bulgaarse en Roemeense regeling kon bij het ontnemingsbesluit tevens worden bepaald dat het vermogen van betrokkene werd geconfisceerd. Voorts kon wolgens de Bulgaarse wet van 1940 worden bepaald dat betrokkene het land moest verlaten. Volgens de Poolse ontnemingswet van 1938 werd aan betrokkene verboden om naar het land terug te keren ${ }^{14}$.

Ontneming van het staatsburgerschap was ook mogelijk ten aanzien van in het binnenland woonachtige personen, hoewel de meeste ontnemingsgronden op degenen, die zich in het buitenland bevonden, betrekking hadden. Slechts de Bulgaarse wet bepaalde uitdrukkelijk dat betrokkene in het buitemland moest wonen. Ten aanzien van Bulgaren van niet-Bulgaarse etnische afstamming gold deze voorwaarde echter niet.

Het meest vaak voorkomende grond voor ontneming van de nationaliteit (Duitsland, Hongarije, Joegoslavië Roemenië en het voormalig Hongaars gedeelte van Tsjechoslowakije) was het zonder toestemming van de overheid treden in vreemde militaire of staatsdienst. In de andere landen was dit een grond voor verlies van rechtswege. Volgens de Hongaarse regeling kon de nationaliteit slechts worden ontnomen, indien betrokkene niet binnen een door de bevoegde instantie vastgestelde termijn de vreemde dienst verliet. Hongarije kende sedert 1939 tevens ontneming van het staatsburgerschap wegens het aanvaarden van een ambt in een vreemd land, activiteiten of lidmaatschap in buitenlandse politieke organisaties e.d.

Verschillende overtredingen met betrekking tot de militaire dienstplicht waren voorts een grond voor ontneming van de nationaliteit in Duitsland, Polen en Roemenië.

Ontneming van het staatsburgerschap wegens schending van de loyaliteitsverplichtingen of handelingen die de staatsveiligheid of andere belangen van de staat konden schaden kenden de regelingen van Bulgarije, Duitsland tussen 1941-1945, Hongarije, Joegoslavië 15 , Polen en Roemenië. De Roemeense nationaliteitswet van 1939 en de Bulgaarse van $1940^{16}$ kende ook ontneming wegens een staatsburger "onwaardig gedrag". Voorts kenden verschillende regelingen diverse specifieke ontnemingsgronden, namelijk: een beroep doen op het bezit van een andere nationaliteit (Bulgarije) het ontduiken van belastingen (Duitsland sedert 1918), diensten aan de vijand, spionage etc. (Hongarije ${ }^{17}$, Joegoslavië ${ }^{18}$ en Roemenië),

14. Deze regeling had slechts betrekking op in het buitenland wonende personen.

15. In Joegoslavië was deze ontnemingsgrond beperkt tot de oorlogstijd en tot personen, die vroeger de nationaliteit van het land bezaten waarmee Joegosiavie in oorlog was.

16. Volgens de Bulgaarse wet moest het gaan om personen van niet-Bulgaarse (etnische) afstamming.

17. In Hongarije moest een dergelijke overtreding door de rechter worden vastgesteld. 
langdurig verblijf in het buitenland zonder contact met het eigen land te houden (Polen, Roemenië), het niet terugkeren uit het buitenland op wordering van het bevoegde orgaan (Polen) en het aanvaarden van bescherming van een vreemde staat (Roememië).

Herroeping van de verlening van het staatsburgerschap kenden slechts Polen en Roemenië. In Polen ging het om een echte herroeping, die slechts mogelijk was wegens fraude in de naturalisatieprocedure en wegens schendingen van de wet tijdens de procedure. De herroepingsmogelijkheid was begrensd tot vijf jaar na de naturalisatie. In Roemenië was herroeping steeds mogelijk en niet alleen wegens fraude bij de naturalisatieprocedure, maar ook wegens een strafrechtelijke veroordeling binnen vijf jaar na de naturalisatie. Bovendien kon een naturalisatie of erkenning worden herroepen wegens handelingen tegen de openbare orde, staatsveiligheid en andere belangen van de staat. In al die gevallen ging het derhalve om ontneming van de nationaliteit. In Duitsland voerde men in 1933 een mogelijkheid in om politiek "ongewenste" naturalisaties te herroepen.

\subsubsection{Invloed op de nationaliteit van gezinsleden van betrokkene}

De vrouw en minderjarige kinderen van betrokkene waren zelden automatisch in de ontneming van het staatsburgerschap aan hun man, respectievelijk vader inbegrepen. Een dergelijke regeling kende slechts Roemenië bij ontneming wegens langdurig verblijf in het buitenland, voorzover de gezinsleden eveneens in het buitenland woonden. De kinderen moesten voorts ongehuwd zijn. Volgens de Poolse regelingen waren de gezinsleden echter steeds bij de ontneming inbegrepen, tenzij in het ontnemingsbesluit te hunner aanzien een voorbehoud werd gemaakt. Volgens de andere regelingen kon in het besluit worden bepaald dat tevens de gezinsleden van betrokkene de nationaliteit verloren.

Noch de Poolse noch de Roemeense wet hadden bepalingen betreffende de invloed van de herroeping van een naturalisatie of erkenning op het staatsburgerschap van minderjarige kinderen van betrokkene.

18. Ook ontneming van de nationaliteit op deze grond was beperkt tot de in noot 15 omschrewen gevallen. 


\section{HOOFDSTUK 2. DE EERSTE REGELINGEN VAN DE "NOUVEAUX REGIMES"}

\subsection{VERKRUJGing VAN DE NATIONALTETT}

De nationaliteit werd volgens de eerste "socialistische" nationaliteitsrechtelijke regelingen in de regel verworven van rechtswege of door naturalisatie. Verkrijging van het staatsburgerschap door een zuivere optie kwam slechts zeer sporadisch voor. Verkrijging van de nationaliteit door een bijzondere vorm van verlichte naturalisatie, "erkenning", werd uit de Roemeense nationaliteitswetgeving geschrapt. In Polen kwam ongeveer dezelfde mogelijkheid onder de naam "repatriëring" echter terug.

\subsubsection{Verkrijging van rechtswege}

De gronden voor verwerving van de nationaliteit van rechtswege in de eerste communistische nationaliteitswetten waren het ius sanguinis, en slechts subsidiair het ius soli. Het ius matrimonii en het treden in staatsdienst en andere bijzondere gronden voor verkrijging van rechtswege werden in alle landen die deze kenden geschrapt. Huwelijk werd in een aantal landen slechts een grond voor verlichte naturalisatie.

\subsubsection{I lus sanguinis}

De regelingen van verkrijging van de nationaliteit iure sanguinis werden door de "nouveaux régimes" in alle Oosteuropese landen aanmerkelijk veranderd. De eerste vernieuwing was de invoering van het beginsel ius sanguinis a matre et a patre. Volgens de eerste regelingen in alle Oosteuropese landen met uitzondering van Hongarije, kon een kind zijn nationaliteit op gelijke voet zowel aan zijn moeder als aan zijn vader ontlenen. Het was daarbij niet van belang of het kind in het binnenof buitenland werd geboren. In de Hongaarse wet van 1948 vindt men echter nog steeds de oude formule, volgens welke wettige kinderen de (Hongaarse) nationaliteit van de vader volgden en onwettige die van de moeder. Stond bij een buitenechtelijk kind de afstamming met betrekking tot zijn vader vast, dan verkreeg het kind zijn nationaliteit. De Hongaarse regeling was woorts ook de enige die aan een vorm van "wettiging" 1 nog verkrijging van de nationaliteit verbond. Het instituut van wettiging werd overigens niet uit het familierecht van alle Oosteuropese landen geschrapt. Wettiging is bijvoorbeeld in de meeste Joegoslavische deelstaten nog steeds mogelijk ${ }^{2}$. Adoptie door onderdanen van een bepaald land werd in geen van de eerst "socialistische" nationaliteitswetten een grond voor verkrijging van het staatsburgerschap ipso iure. In Albanië, Bulgarije en Joegoslavië kon een geadopteerd kind echter zonder enige naturalisatievereisten worden genaturaliseerd.

De tweede algemene karakteristiek van alle eerste socialistische nationaliteitswetten in Oost-Europa was, dat er behalve in Hongarije geen onderscheid.

1. Zie over deze "wettiging" hoofdstuk Hongarije, p. 181 .

2. Tratnik, $p .430$. 
tussen wettige en onwettige kinderen meer werd gemaakt. Een onwettig kind kon het staatsburgerschap van zijn vader volgen, indien het werd erkend of het vaderschap gerechtelijk werd vastgesteld. Een aparte regeling van verkrijging van het staatsburgerschap door onwettige kinderen werd enkel in de Hongaarse en Roemeense nationaliteitswet opgenomen.

De regelingen van verkrijging van het staatsburgerschap maakten in de regel een onderscheid tussen gevallen waarin de ouders van het kind dezelfde nationaliteit bezaten en gevallen waarin de ouders een verschillende nationaliteit bezaten. Slechts in het eerste geval verkreeg een kind steeds de nationaliteit van het desbetreffende land. In het tweede geval werden er additionele vereisten gesteld, terwijl in Hongarije steeds de nationaliteit van de vader prevaleerde.

\subsection{Kinderen van ouders met verschillende nationaliteüen}

Door kinderen, die uit nationaliteitsrechtelijk gemengde ouders werden geboren, werd het staatsburgerschap volgens de hierna volgende regels verkregen. Volgens de USSR- (tussen 1930 en 1968), alsmede krachtens de DDR-, Poolse en Roemeense regelingen werd door het kind het staatsburgerschap verkregen op de enkele grond dat éen van de ouders op het tijdstip van geboorte van het kind het desbetreffende staatsburgerschap bezat. De Poolse wet van 1951 gaf hierbij de ouders van het kind een uiterst beperkte mogelijkheid om de nationaliteitsverkrijging door het kind te voorkomen, terwijl Roemenië aan een meerderjarig geworden bupatride kind de mogelijkheid van afstand van het staatsburgerschap toekende.

Andere landen en de USSR (tussen 1918 en 1930) stelden voor het geval dat de nationaliteit van de ouders verschillend was, met het oog op het voorkomen van meervoudige nationaliteit van het kind additionele vereisten. De meest ingewikkelde regeling van deze vereisten kende de Joegoslavische wet van 1945. In Albanië en Bulgarije moest het kind op het grondgebied van dat land zijn geboren. Werd een kind in het buitenland geboren, dan verkreeg het de nationaliteit van Albanië, Bulgarije, Joegoslavië en (althans theoretisch) Polen op grond van een gezamenlijke verklaring van zijn ouders. Volgens het Albanese recht was deze verkllaring niet vereist, indien het kind anders staatloos zou zijn. In de RSFSR (1918-1924) en in Polen werd deze voorwaarde omgekeerd: De nationaliteit werd verkregen, tenzij de ouders uitdrukkelijk verklaarden dat het kind niet de RSFSR-, respectievelijk Poolse nationaliteilt zou hebben. Een ander vereiste, dat in Albanie en Bulgarije ten aanzien van in het buitenland geboren kinderen werd gehanteerd, was vestiging. of opleiding in het desbetreffende land tijdens de minderjarigheid van het kind. Interessant is dat een kind dat ouder was dan 14 jaar zijn veto tegen verkrijging van het staatsburgerschap mocht uitspreken. Interessant is ook, dat de regeling van de USSR (1924-1930) die gedeeltelijk ook in Joegoslavië werd gerecipieërd, niet het land van geboorte van het kind, doch het land van de woonplaats van de ouder(s) als criterium nam. Een kind verwierf de nationaliteit, indien tenminste éen van zijn ouders op het tijdstip van de geboorte van het kind in het binnenland woonde. Woonden beide ouders in het buitenland, dan werd voor de verkrijging van het Sovjet-staatsburgerschap een gezamenlijke werklaring van de ouders vereist. Volgens de Joegoslavische regeling was verklaring van de Joegoslavische ouder voldoende. Indien het kind anders staatloos zou zijn, verkreeg hij het Joegosiavische staatsburgerschap ook zonder deze verklaring. 
De regelingen wan de RSFSR tussen 1918 en 1924 en de Albanese en Joegoslavische nationaliteitswet van 1946 , respectievelijk 1945 , gaven aan een meerderjarig geworden kind voorts de mogelijkheid van de nationaliteit afstand te doen.

Tsjechoslowakije kende ten aanzien van in het buitenland geboren kinderen van slechts één Tsjechoslowaakse ouder slecht de mogelijkheid van vereenvoudigde naturalisatie.

\subsubsection{Ius soli}

De regelingen van werkrijging van de nationaliteit door geboorte op het grondgebied werden in de meeste landen niet in belangrijke mate gewijzigd. In de Sovjetunie, Albanië en Bulgarije werden de op p. 322 genoemde regelimgen van verkrijging van de nationaliteit door geboorte op het grondgebied in combinatie met het treden in militaire dienst of langdurig verblijf in het land geschrapt.

Het meest opmerkelijk was de ontwikkeling in de Sovjetunie. Tussen 1917 en 1924 bestond er in het geheel geen regeling, waarna de verordening van 1924 de merkwaardige praesumptio van het bezit van de Sovjet-nationaliteit ten behoeve van iedereen, die zich in de USSR bevond en niet het bezit van een andere nationaliteit kon bewijzen, introduceerde. In 1938 werd deze regeling "omgedraaid" en werd iedereen die niet het bezit van de USSR- of een andere nationaliteit kon bewijzen als staatloos beschouwd. In alle andere Oosteuropese landen werden de "voorrevolutionaire" regelingen grotendeels gehandhaafd. In Albanië en Joegoslavië werd de mogelijkheid van het leveren van het tegenbewijs tegen de praesumptio van het bezit van de nationaliteit beperkt tot de $14 \mathrm{e}$ verjaardag van het kind, hetgeen zeer zeker als een duidelijke verbetering kan worden gezien. In Bulgarije werd de mogelijkheid van verkrijging door geboorte op het grondgebied in combinatie met vaste woonplaats en geen beroep op het bezit van een andere nationaliteit geschrapt. Nieuw was de regeling van de verkrijging van de Bulgaarse nationaliteit door vondelingen. In de DDR bleef de oude regeling van de RuStAG van 1913 tot 1967 gehandhaafd, waarna pas in de wet van 1967 onder meer een regeling van verkrijging van de nationaliteit door vondelingen werd ingevoerd. In Hongarije werd de eis dat een vondeling tevens in Hongarije moest worden opgevoed gehandhaafd, terwijl geboorte op het grondgebied pas na de inwerkingtreding van de huidige nationaliteitswet in 1957 verkrijging van het staatsburgerschap kan bewerkstelligen. In Polen en Roemenië werden de oude regelingen niet gewijzigd. In Tsjechoslowakije schrapte men de eis van opvoeding in het land ten alanzien van vondelingen, alsmede de mogelijkheid van verkrijging van het staatsburgerschap door geboorte in de CSR.

\subsubsection{Ius matrimonii}

De eerste "narevolutionaire" nationaliteitswetten van alle Oosteuropese landen behalve Hongarije kenden geen automatische verkrijging van de nationaliteit door huwelijk meer. Aan vreemdelingen, die met eigen onderdanen huwden, werd in de USSR (tussen 1930 en 1938), Albanië, Bulgarije, Joegoslavië, Roemenië en Tsjechoslowakije de mogelijkheid van verlichte naturalisatie geboden. Opmerkelijk is, dat vollgens de Tsjechoslowaakse regeling de vereenvoudigde huwelijksnaturali- 
satiemogelijkheid slechts ten aanzien van buitenlandse vrouwen bestond. In andere landen werd hierbij geen onderscheid tussen mannen en vrouwen meer gemaakt.

In de RSFSR (tot 1924) had de buitenlandse vrouw(1), die met een onderdaan van dit land in het huwelijk trad, bij de huwelijkssluiting een optierecht op de Russische nationaliteit. In de USSR (na 1938), de DDR (in ieder geval sedert 1954) en in Polen had het huwelijk in het geheel geen invloed op het staatsburgerschap. Buitenlandse huwelijkspartners konden de nationaliteit wan hun echtgenoten slechts via de gewone naturalisatieprocedure verwerven. Het was echter wel zo, dat de nationaliteitswetten van Polen en van de USSR geen naturalisatievereisten noemden en derhalve niet uitgesloten is dat bij een huwelijk sneller werd genaturaliseerd.

\subsubsection{Optie}

In de eerste "nieuwe" nationaliteitsrechtelijke regelingen kreeg verkrijging van het staatsburgerschap door optie nog een bescheidener plaats toegewezen dan voorheen reeds het gevall was. In het geheel geen zuivere optierechten kenden de regelingen van de USSR (sedert 1924), Albanië, Bulgarije, de DDR, Roemenie en Tsjechoslowakije.

De naturalisatieverordening van de RSFSR van 1921 kende een optierecht ten behoeve van kinderen van naturalisandi die ten tijde van de naturalisatie van hun ouder(s) ouder waren dan 14 jaar en niet met hen werden meegenaturaliseerd. Voorts kende de RSFSR het reeds genoemde optierecht ten behoeve van buitenlandse vrouwen, die met zijn onderdanen in het huwelijk traden. In Polen werd een optiemogelijkheid ingevoerd ten behoeve van een kind van nationaliteitsrechtelijk gemengde ouders, die zich binnen éen maand na de geboorte van het kind tegen verkrijging van het Poolse staatsburgerschap door het kind hadden uitgesproken. Het kind verwierf het optierecht op zijn $13 \mathrm{e}$ verjaardag. Een optierecht op de Hongaarse nationaliteit had een kind, dat tijdens zijn meerderjarigheid door een Hongaar werd erkend, gewettigd, of met betrekking tot wie het waderschap van een Hongaar gerechtelijk werd vastgesteld. In Joegoslavië tenslotte, werd in 1947 bij een wijziging van de nationaliteitswet aan enkele groepen voormalige Italiaanse onderdanen een optierecht toegekend.

\subsection{Naturalisatie}

De regelingen van verkrijging van de nationaliteit door naturalisatie hebben onder de nieuwe machthebbers belangrijke wijzigingen ondergaan. In de eerste plaats is er in verschillende landen (USSR, Bulgarije, Duitsland, Polen en Roemenië) verlegging van de beslissingsbevoegdheid naar de hoogste staatsorganen (Presidium wan het Opperste Sovjet, Presidium van het Parlement, Raad van State) waar te nemen. In RSFSR werd (althans ten aanzien van in het binnenland woonachtige naturalisandi) de bevoegdheid aanvankelijk gelegd bij lagere overheden. Reeds sedert 1924 werd de bevoegdheid echter geplaatst bij de hoogste organen van de deelstaten, respectievelijk federatie (Centrale Executiefcomité's en hun opvolgers, de Presidia van de Opperste Sovjets). In Albanië, Hongarije, Joegoslavië en Tsjechoslowakije lag deze bevoegdheid bij de Ministers van binnenlandse zaken. 
In geen van de Oosteuropese landen was naturalisatie van in het buitenland woonachtige personen uitgesloten, hoewel in de meeste landen in de regel vereist werd dat betrokkene op het grondgebied van dat land woonde. In de RSFSR/USSR ging men zelfs zover dat alle nationaliteitsrechtelijke regelingen competentieregels bevatten ten aanzien van verzoekers die in het buitenland wonen.

Ten aanzien van de wettelijke naturalisatievereisten zijn grote verschillen te signaleren. In de RSFSR/USSR werden naturalisatievereisten niet of nauwelijks in de wet genoemd. De wet van 1938 bepaalde slechts dat er geen onderscheid naar ras of etnische herkomst mocht worden gemaakt. In andere landen ging men niet zover om in het geheel geen vereisten te noemen, maar de wetgevers in de DDR, Bulgarije, Hongarije en Polen waren desalniettemin bij het noemen van naturalisatievereisten bijzonder zuinig.

In geen van de Oosteuropese landen (met uitzondering van Albanië en Joegoslavië) werd volgens de eerste "socialistische" nationaliteitswetten meerderjarigheid, respectievelijk handelingsbekwaamheid als naturalisatievereiste gesteld. Minderjarigen en andere handelingsonbekwamen konden door tussenkomst van hun wettelijke vertegenwoordiger worden genaturaliseerd.

In alle landen werden de eisen van minimaal verblijf voorafgaande aan de naturalisatie in vergelijking met het "oude" recht verkort. In USSR, DDR en Polen werd zelfs in het geheel geen eis met betrekking tot verblijf van een bepaalde duur gesteld. Een vijfjarig verblijf werd geëist in Albanië, Bulgarije, Joegoslavië, Roemenië en Tsjechoslowakije, terwijl de verblijfseis in Hongarije zelfs op drie jaren werd gesteld.

In Albanië, Joegoslavië, Roemenië en Tsjechoslowakije werd van de naturalisandi geëist dat ze hun oude nationaliteit verloren, respectievelijk al het mogelijke moesten doen om deze te verliezen. In Albanië mocht betrokkene zijn oude staatsburgerschap echter behouden, indien hij bewees dat zijn land geen bezwaar tegen de dubbele nationaliteit maakte. De wetten van de DDR en Polen bepaalden slechts dat van betrokkene kon worden geëist dat hij zijn oorspronkelijke nationaliteit verloor. In de RSFSR/USSR, Bulgarije en Hongarije werd het vereiste van verlies van de oude nationaliteit niet in de wet gesteld.

Het is aannemelijk dat in alle landen het vereiste van "goed gedrag" werd gehanteerd, hoewel in de RSFSR/USSR, Bulgarije en Polen zulks niet in de wet werd geëxpliciteerd. In de DDR, Hongarije, Roemenië en Tsjechoslowakije kleurde men dit vereiste nader in door te bepalen, dat betrokkene de verlening van het staatsburgerschap waard moest zijn (DDR), dat de naturalisatie niet voor de staat nadelig mocht zijn (Hongarije), dat betrokkene van geen "antidemocratische of van andere met de belangen van de staat" strijdige instelling blijk had gegeven (Roemenië) of dat de naturalisandus geen daden tegen de staat had verricht (Tsjechoslowakije).

Albanië en Joegoslavië, die overigens de meest uitgewerkte regeling van naturalisatievereisten hadden, eisten voorts dat betrokkene arbeidsgeschikt moest zijn. In de andere landen werden geen economische naturalisatievereisten gesteld. 


\subsubsection{Hernaturalisatie}

Met betrekking tot de hernaturalisatie is er in de eerste "socialistische" nationaliteitswetten geen eenduidige verandering waar te nemen. Terwijl Albaniê en Bullgarije, die voorheen als enige landen een bijzondere regeling van hernaturalisatie kenden, deze in 1946, respectievelijk 1948 hadden afgeschaft, werd een dergelijke regeling in Hongarije toen juist nieuw ingevoerd. Het ging daarbij om een verlichte naturalisatie waarbij aan de verzoeker dispensatie van de verblijfseis kon worden verleend. Deze mogelijkheid werd beperkt tot Hongaren die hun nationaliteit door ontslag, langdurig verblijf of naturalisatie in het buitenland hadden verloren, op voorwaarde dat betrokkene zich in het land vestigde en er een bijzondere grond voor herverlening van de nationaliteit aanwezig was. Verloor betrokkene zijn nationaliteit door ontneming, dan kon hij slechts bij een besluit van de regering worden gehernaturaliseerd, terwijl anders de Minister van binnenlandse zaken bevoegd was. De mogelijkheid van verlichte hernaturalisatie stond eveneens open voor vrouwen, die hun nationaliteit door of in verband met het huwelijk hadden verloren, nadat het huwelijk ontbonden was of betrokkene sedert én jaar gescheiden van haar man in Hongarije woonde. Andere vereisten werden aan deze categorie naturalisandi niet gesteld.

Een zeer beperkte mogelijkheid van verlichte hernaturalisatie werd voorts in Polen (1951) en Roemenië (1948) ingevoerd. In Polen konden in het buitenland woonachtige personen, aan wie op grond van de wet van 1938 het staatsburgerschap werd ontnomen, worden gehernaturaliseerd, zonder dat ze aan de naturalisatievereisten hoefden te voldoen. Woonden ze in Polen, dan verwierven ze deze nationaliteit overigens reeds van rechtswege. In Roemenië konden gewezen Roemenen zonder te voldoen aan de verblijfseis van vijf jaar worden gehernaturaliseerd.

\subsubsection{Verlichte naturalisatie}

Alle eerste "socialistische" nationaliteitswetten behalve die van de DDR en de USSR (sedert 1938) kenden vrij uitgebreïde mogelijkheden voor verlichte naturalisatie ten behoeve van bepaalde categorieën verzoekers. De nationaliteitswetten bevatten in de regel zeer ingewikkelde regelingen, waarbij aan de verzoeker een gehele of gedeeltelijke vrijstelling van de verblijfseis werd verleend. In sommige landen werd ten aanzien van bepaalde groepen naturalisandi eveneens afgezien van de eis van verlies van de oude nationaliteit (Albanië, Joegoslavië en Tsjechoslowakije). Slechts in Tsjechoslowakije ging het bovendien om een vereenvoudigde procedure: Een verlichte naturalisatie werd niet zoals de gewone door het Ministerie van binnenlandse zaken, maar door plaatselijke besturen verleend.

De meest voorkomende grond voor verlichte naturalisatie was het bewijzen van belangrijke diensten aan de staat. Dikwijls werd deze grond ingekleurd door dienst in het leger van de desbetreffende staat (Bulgarije, Roemenië) of deelname aan het communistische verzet tijdens de tweede wereldoorlog (Albanië).

Huwelijk met een onderdaan van Albanië, Joegoslavië, Roemenië en Tsjechoslowakije was een grond voor verlichte naturalisatie. Aangetekend zij echter dat in Tsjechoslowakije deze mogelijkheid slechts ten aanzien van een met een 
Tsjechoslowaak gehuwde vrouw bestond, terwijl in de andere drie landen geen onderscheid tussen beide geslachten werd gemaakt.

In Albanië, Joegoslavië en Bulgarije kwam ook een kind dat door een onderda(a)n(e) van deze landen werd geadopteerd, voor bevoorrechte naturalisatie in aanmerking.

Etnische nationaliteit vormde een grond voor verlichte naturalisatie in Albanie, Bulgarije en Joegoslavië, terwijl in Hongarije afstamming van een juridisch Hongaarse voorouder voldoende was ${ }^{3}$.

Van overige gronden voor geprivilegieerde naturalisatie zij nog vermeld: geboorte in het land (Bulgarije en Roemenie) en geboorte uit één ouder, onderdaan van het desbetreffende land, tenzij het kind reeds van rechtswege die nationaliteit bezat (USSR fussen 1924 en 1930 en Tsjechoslowakije) ${ }^{4}$. In al deze gevallen ging het in wezen om een correctie met betrekking tot de regeling van verkrijging van het staatsburgerschap van rechtswege op grond van het ius soli en het ius sanguinis beginsel.

Geheell uniek was de mogelijkheid van werlichte naturalisatie van buitenlandse boeren en arbeiders op grond van de grondwet van de RSFSR en de verordeningen van 1924 en $1930 / 31$ in de USSR. Deze zogenaamde "Klassenzugehörigkeit" verdween echter in 1938 voorgoed uit de Sowjet-nationaliteitswetgeving. Voorts kwamen volgens de tussen 1924 en 1938 geldende regelingen ook politieke emigranten en asielgerechtigden voor verlichte naturalisatie in aanmerking.

\subsubsection{1 "Einbürgenungsansprïche"}

Joegoslavië kende als het enige Oosteuropese landen een recht op hernaturalisatie ten behoeve van meerderjarig geworden kinderen die hun staatsburgerschap als gevolg van het verlies van de nationaliteit door hun ouder(s) door afstand of ontslag verloren. Voorwaarde voor deze naturalisatiemogelijkheid was, dat betrokkene zich opnieuw in het land vestigde en hij tussen 18 en 25 jaar oud was. Onder het "oude" recht had dezelfde kring personen een optierecht op de Joegoslavische nationaliteit.

\subsubsection{Invloed op de nationaliteit van de gezinsleden wan de verzoeker}

Ten aanzien van de regeling van de invloed van de naturalisatie op de nationaliteit van de gezinsleden van betrokkene zijn belangrijke veranderingen te signaleren. In de eerste plaats werd automatische medenaturalisatie die de vrouw van betrokkene betrof, in alle landen afgeschaft. In Roemenië werd er een opmerkelijke regeling ingevoerd, volgens welke de huwelijkspartner van een naturalisandus, ongeacht of het een man of een vrouw was, automatisch werd meegenaturaliseerd. Betrokkene had echter wel de mogelijkheid om binnen eén maand na de naturalisatie afstand

3. In dit geval omvat bet vereiste van juridische afstamming een bredere kring personen dan dit bij etnische afstamming het geval zou zijn gewest. Hongarije was immers to 1918 een multinationale statat, die weel groter was dan de Hongaarse staat na 1918.

4. In Tsjechoslowakije moest het verzoek binmen Een jaar na de geboorte van het kind worden ingediend, terwijl in de USSR het kind pas na het bereiken wan de meerderjarigheid zelfstandig kon worden genaturaliseerd. 
van de Roemeense nationaliteit te doen. In andere landen verkreeg de huwelijkspartner van een naturalisandus in de regel de mogelijkheid van verlichte naturalisatie, hetgeen zowel ten aanzien wan mannen als wrouwen gold.

Met betrekking tot de invloed van naturalisatie van ouder(s) op het staatsburgerschap van hun minderjarige kinderen (in alle landen tot 18 jaar) werden in de eerste "socialistische" nationaliteitswetten verschillende uitgangspunten gehanteerd. In de regel werd er onderscheid gemaakt tussen de gevallen wararin beide ouders werden genaturaliseerd en gevallen waarin slechts aan één van de ouders het staatsburgerschap werd verleend.

Indien beide ouders van het kind werden genaturaliseerd, werd het kind in de RSFSR/USSR, Albanië, Bulgarije, Hongarije, Joegoslavië, Polen en Roemenië automatisch meegenaturaliseerd. De regelingen van de USSR (sedert 1930) en Polen gaven een kind dat ouder was dan 14, respectievelijk 13 jaar (Polen) de mogelijkheid om een veto tegen zijn medenaturalisatie uit te spreken. Volgens het recht van de DDR en Tsjechoslowakije werden minderjarige kinderen slechts in de naturalisatie van hun beide ouders deelachtig indien er uitdrukkelijk om werd verzocht. In Tsjechoslowakije was de medenaturalisatie van kinderen slechts mogelijk tot het $15 \mathrm{de}$ levensjaar van het kind. Was het kind ouder, dan kon het slechts zelfstandig worden genaturaliseerd.

Indien slechts aan één van de ouders de nationaliteit werd verleend werden enkel in Hongarije en Roemenië de minderjarige kinderen automatisch meegenaturaliseerd, waarbij de Roemeense regeling aan een meerderjarig geworden kind de mogelijkheid van afstand van het Roemeense staatsburgerschap toekende. Het andere uiterste waren dan weer de regeling van de USSR (tussen 1924 en 1978) en Bulgarije, die voor het geval dat het staatsburgerschap slechts aan cén van de ouders werd verleend, geen medenaturalisatie van kinderen kenden. Medenaturalisatie van kinderen was in Bulgarije desalniettemin mogelijk, indien de andere ouder reeds overleden was of de Bulgaarse nationaliteit reeds bezat, doch deze beide gevallen staan in feite gelijk met het geval dat beide ouders werden genaturaliseerd. Een dergelijke regeling kende ook Polen, waar automatische medenaturalisatie van het kind bij verlening van de nationaliteit aan éen ouder mogelijk was indien de andere ouder Pool was, geen ouderlijke macht bezat, of zijn toestemming voor de medenaturalisatie verleende. Ook in dit geval kon zich een kind dat ouder dan 13 jaar was tegen zijn medenaturalisatie uitspreken. In Albanië en Joegoslavië werd een kind tezamen met éên ouder op verzoek van do betrokken ouder meegenaturaliseerd, indien het samen met de genaturaliseerde ouder in het binnenland woonde. Een kind boven 14 jaar had de mogelijkheid om zijn veto tegen de medenaturalisatie uit te spreken. Volgens de regeling van de RSFSR (tussen 1921 en 1924) tenslotte, werd een kind onder 14 jaar niet meegenaturaliseerd, tenzij zijn ouders gezamenlijk verklaarden dat ze dat wensten. Indien het kind niet werd meegenaturaliseerd, kreeg het op zijn 14de verjaardag een optierecht op de RSFSR-nationaliteit. Was het kind ten tijde van de naturalisatie van zijn ouders reeds 14 jaar of ouder, dan kon het enkel zelfstandig worden genaturaliseerd. 
De nationaliteit werd volgens de eerste nationaliteitsrechtelijke regelingen van de socialistische landen in de regel verloren door ontslag en ontneming. Verlies van rechtswege en door afstand kwam slechts zeer sporadisch voor.

\subsubsection{Verlies van rechtswege}

Verlies van het staatsburgerschap van rechtswege kenden in Oost-Europa uitsluitend de eerste nationaliteitswetten van Hongarije en Tsjechoslowakije. Volgens de Hongaarse regeling van 1948 ging dit staatsburgerschap van rechtswege verloren voor een minderjarige, wiens afstamming van een vreemdeling door erkenning, wettiging of gerechtelijke vaststelling kwam vast te staan en het kind daardoor de nationaliteit van zijn vader verwierf. Zowel Hongarije als Tsjechoslowakije kenden voorts verlies van de nationaliteit van rechtswege ten aanzien van vrouwen die met een vreemdeling in het huwelijk traden en daardoor de nationaliteit van hun man verwierven. Het verlies van de nationaliteit van rechtswege werd in Hongarije in 1957 en in Tsjechoslowakije in 1958 geschrapt.

\subsubsection{Afstand}

Een beperkte mogelijkheid van verlies van de nationaliteit door afstand kenden de regelingen van de RSFSR tussen 1918 en 1924, en de nationaliteitswetten van Albanië, Joegoslavië en Roemenië van respectievelijk 1946, 1945 en 1948. In alle gevallen werd deze mogelijkheid geboden aan meerderjarigen die tevens een andere nationaliteit bezaten. Volgens de RSFSR- en Roemeense regeling ging het slechts om kinderen, die uit nationaliteitsrechtelijk gemengde ouders werden geboren, zonder dat daarbij nadere vereisten werden gesteld. In Albanië en Joegoslavië kende men echter een algemene afstandsmogelijkheid ten behoeve van allen, die in het buitenland werden geboren en daar tussen hun 18 de en 25 ste jaar woonachtig waren ${ }^{5}$.

\subsubsection{Ontslag}

Verlies van de nationaliteit door ontslag kenden reeds de eerste mationaliteitswetten van allle Oosteuropese landen, behalve die van de RSFSR. De eerste Sovjet-regeling van ontslag dateert uit 1924. Ten aanzien van de bevoegdheid om ontslag te verlenen, golden in de meeste landen dezelfde regels als bij de naturalisatie (zie p. 337). Slechts in de USSR en Tsjechoslowakije was dat niet het geval. Interessant is dat in de Sovjetunie sedert 1938 de bevoegdheid naar een hoger orgaan (Presidium van het Opperste Sovjet USSR) werd verlegd, terwijl in Tsjechoslowakije in 1949 plaatselijke besturen bevoegd werden. Tussen 1930 en 1938 kende men in de USSR tevens de mogelijkheid van een vereenvoudigde

5. Hieronder vielen bijvoorbeeld ook kinderen van uitsluitend Joegoslavische ouders die in Australië werden geboren en daar woonachtig waren. 
ontslagprocedure ten behoeve van onderdanen, die met een buitenland(s)e(r) in het huwelijk traden.

De mogelijkheid van ontslag werd in Polen en Roemenie nieuw ingevoerd. In Polen werd het ontslag geconstrueerd als verlies van het staatsburgerschap "van rechtswege" door verkrijging van een ander staatsburgerschap en in Roemenie als het verlies van de nationaliteit door "afstand". Verlening van het ontslag was in beide landen voorwaardelijk. De reeds uit het "oude "recht bekende constructie van voorwaardelijke ontslagverlening handhaafden de wetten van Albanië, Bulgarije, de DDR en Joegoslavië. De voorwaarde was het verlaten van het land of het verkrijgen van de nationaliteit. In de andere landen was ontslag steeds definitief, ongeacht of daardoor staatloosheid werd veroorzaakt.

Vereisten voor ontslag werden in de USSR tot 1978 niet in de wet genoemd. Evenmin waren ze geregeld in de nationaliteitswetten van Bulgarije, Polen en Tsjechoslowakije.

Slechts in Albanië en Joegoslavië werd meerderjarigheid als voorwaarde voor de verkrijging van ontslag gesteld. In de andere landen kon een minderjarige derhalve door tussenkomst van zijn wettelijke vertegenwoordiger zelfstandig worden ontslagen. Voorts moest de verzoeker bewijzen dat hij reeds een vreemde nationaliteit bezat, respectiewelijk waarschijnlijk zou verkrijgen.

Doorgaans werd geëist dat betrokkene aan verplichtingen tegenover de staat, met name de militaire dienstplicht en het betalen van belastingen had voldaan (Albanië, DDR, Hongarije Joegoslavië). In Hongarije kon een man tussen 18 en 43 jaar slechts met de toestemming van de Minister van defensie worden ontslagen.

Een lopende strafrechtelijke procedure tegen de verzoeker, of een nog niet ten uitvoer gelegd strafrechtelijk vonnis betekende een beletsel voor ontslag volgens het recht van Hongarije en Roemenië. Slechts in Roemenië werd uitdrukkelijk bepaald dat betrokkene ook geen schulden aan natuurlijke personen mocht hebben. Merkwaardig is dat de Roemeense wet van 1948 verder eiste dat betrokkene bij een authentieke akte verklaarde dat hij na het verlies van het staatsburgerschap geen handelingen zou verrichten die de belangen van de staat zouden kunnen schaden. Er was overigens geen sanctie voor niet-nakoming van die belofte voorzien.

\subsubsection{Invloed op de nationaliteit van de gezinsleden van de verzoeker}

De regelingen van de invloed van ontslag op de gezinsleden van betrokkene hebben in de eerste socialistische nationaliteitswetten belangrijke wijzigingen ondergaan. Automatisch medeontslag van de vrouw van betrokkene werd in alle landen afgeschaft. Minderjarige kinderen werden in de USSR, Albanië, Joegoslavië en Polen onder bepaalde voorwaarden echter wel automatisch meeontslagen. OP verzoek werden ze in het ontslag van hun ouder(s) inbegrepen in Roemenië en Tsjechoslowakije, in de tweede echter slechts tot de leeftijd van 15 jaar. In Bulgarije en Hongarije gaven de nationaliteitswetten geen uitdrukkelijke regeling van medeontslag van minderjarige kinderen.

Er werd in de regel onderscheid gemaakt tussen het geval dat het ontslag aan beide of slechts aan één ouder van het kind werd verleend. Werden beide ouders ontslagen, dan werden in de USSR, Albanië, Joegoslavië en Polen de kinderen van 
betrokkene automatisch meeontslagen, woorzover ze niet ouder dan 14 jaar (in Polen 13 jaar) waren. Waren ze ouder, dan was tevens hun toestemming vereist. Volgens de Joegoslavische regeling hadden meeontslagen kinderen die naar het land terugkeerden tussen hun 18de en 25ste levensjaar een "Einbürgerungsanspruch".

Met het ontslag van beide ouders moeten gevallen worden gelijkgesteld, waarin de andere ouder uitsluitend een andere nationaliteit bezat of reeds overleden was. Alleen de Poolse nationaliteitswet gaf trouwens daarvoor een uitdrukkelijke regeling.

In het geval dat slechts eén van de ouders werd ontslagen, werden de minderjarige kinderen nooit automatisch in het ontslag van hun ouder inbegrepen. Men koos voor de volgende oplossingen: in de USSR, Albanië, Joegoslavië, en Polen werd de beslissing daaromtrent aan de wil van beide ouders overgelaten, waarbij een kind boven 14 jaar ( 13 jaar in Polen) het recht had om een veto tegen zijn ontslag uit te spreken. Behalve in de USSR, waar tussen 1924 en 1930 een gezamenlijke verklaring van beide ouders werd geëist, was het voldoende dat de andere ouder de toestemming voor het ontslag gaf. Deze kon volgens de Poolse wet van 1951 door een rechterlijke beslissing worden vervangen. In Roemenie en Tsjechoslowakije werden de minderjarige kinderen uitsluitend ontslagen indien de betrokken ouder daarom verzocht; met de andere ouder werd geen rekening gehouden. In Tsjechoslowakije tenslotte, konden slechts kinderen tot 15 jaar met hun ouder worden meeontslagen en boven deze leeftijd kon dit slechts zelfstandig gebeuren.

\subsubsection{Ontneming}

De regelingen van de ontneming van de nationaliteit werden in de eerste "socialistische" nationaliteitswetgeving in de regel uitgebreid. Naast de algemene nationaliteitsrechtelijke regelingen kende men in de RSFSR/USSR, de DDR, Hongarije, Joegoslavië en Polen ook een bijzondere ontnemingswetgeving. Terwijl in Polen deze uitsluitend tegen de etnisch Duitse bevolking was gericht, ging het in de RSFSR/USSR, de DDR, Hongarije en Joegoslavië (tevens) om de "eliminering" van de eigen politieke oppositie, die zich dikwijls in het buitenland bevond. In Tsjechoslowakije, waar de communistische partij pas in 1948 aan de macht kwam, werd de nationaliteitsrechtelijke "vergeldingswetgeving" tegen etnische Duitsers en Hongaren reeds door de "burgerlijke" regering van Benes in gang gezet. Bulgarije en Roemenië kenden geen nationaliteitsrechtelijke sancties tegen etnische Duitsers, aangezien ze evenals Hongarije zelf partij bij het Driemachtenpact waren geweest. Albanië en Joegoslavië hadden dergelijke regels in de algemene nationaliteitswet opgenomen.

De Sovjetunie kende tot 1930 geen algemene regeling van ontneming van het staatsburgerschap. Het staatsburgerschap werd ontnomen op grond van de deelstaatwetgeving en enkele federale regelingen met betrekking tot bepaalde groepen emigranten. Sedert 1930 is ontneming van het staatsburgerschap in de algemene nationaliteitswetten van de Sovjetunie opgenomen. Ontneming van het staatsburgerschap als een bijkomende straf bij politieke delicten kende men in de USSR tussen 1924 en 1958, in Joegoslavië tussen 1945 en 1952 en in Tsjechoslowakije tussen 1950 en 1958. 
De bewoegdheid om de nationaliteit te ontnemen lag in de regel bij de hoogste staatsorganen: Centrale Executiefcomite's van de deelstaten 1930-1938 en daarna het Presidium wan het Opperste Sovjet van de USSR, Presidia van Parlementen en hun opvolgers de Raden van State en in Hongarije in sommige gevallen bij de regering. In Albanië (in sommige gevallen), Hongarije, Joegoslaviè en in Tsjechoslowakije was de Minister van binnenlandse zaken bevoegd. De beslissende instantie had in alle landen een nagenoeg onbeperkte discretionaire bevoegdheid.

Het staatsburgerschap kon in alle landen worden ontnomen ongeacht of betrokkene daardoor staatloos werd. De nationaliteitswetten van Bulgarije en Tsjechoslowakije stelden uitdrukkelijk de eis dat betrokkene in bet buitenland moest wonen. In andere landen was ontneming van het staatsburgerschap aan eigen ingezetenen mogelijk, hoewel de ontnemingsgronden in de regel op in het buitenland verblijvende personen waren gericht. Ontneming van de nationaliteit had in ieder geval ${ }^{6}$ in Hongarije, Joegoslavië en Roemenië automatische confiscatie van het vermogen van betrokkene tot gevolg. In Roemenië bedacht men zelfs een soort "actio Pauliana" om zelfs de vermogensbestanddelen die betrokkene in de laatste jaren voor de ontneming vervreemdde, bij de confiscatie te betrekken.

De nationaliteit kon evenals in de "oude" wetgeving in de regel worden ontnomen wegens schendingen van de loyaliteitsplicht en andere handelingen die de staatsveiligheid (of andere belangen van de staat) konden schaden. Deze ontnemingsgrond kenden in diverse bewoordingen alle Oosteuropese landen behalve Hongarije. Interessant is dat in dit land de ontneming van het staatsburgerschap wegens het aanvaarden van een ambt in een vreemd land, activiteiten of lidmaatschap in buitenlandse politieke organisaties letterlijk van de wet van 1939 werd overgenomen.

Geen van de eerste nationaliteitswetten bepaalde overigens uitdrukkelijk dat het staatsburgerschap ook wegens een staatsburger van het desbetreffende land onwaardig gedrag kon worden ontnomen.

Het zonder toestemming treden in buitenlandse militaire of staatsdienst bleef een grond voor ontneming van de nationaliteit in Bulgarije, de DDR, Hongarije en Roemenië.

Het illegaal verlaten van het land, respectievelijk een ongeoorloofde overschrijding van thet toegestane verblijf in het buitenland werd als een grond voor ontneming van de nationaliteit ingevoerd in Bulgarije, de DDR, Hongarije, Roemenie en Tsjechoslowakije. Polen kende deze ontnemingsgrond reeds sedert 1938.

Voorts kende men nog ontneming van het staatsburgerschap wegens: langdurig verblijf in het buitenland met de voorwaarde dat betrokkene zijn staatsburgerlijke plichten niet vervulde (Albanië en Joegoslavië), fraude in de naturalisatieprocedure (Albanië en Joegoslavië), het ontwijken van de militaire dienstplicht en herhaalde strafrechtelijke veroordeling in het buitenland (Polen). De Tsjechoslowaakse nationaliteit kon zelfs wegens thet enkele bezit van een vreemde nationaliteit worden ontnomen.

6. Zulks werd in de genoemde landen met uitzondering van Joegoslavie witdrukkelijk in de mationaliteitswetten bepaald. Het is derhalve niet uitgesloten dat in de andere landen aparte regelingen bestonden, die de confiscatie voorschreven. 
2.2.4.1 Invloed op de nationaliteit van gezinsleden van betrokkene

Ontneming van de nationaliteit kon enkel in Albanië en Joegoslavië bij bepaalde ontnemingsgronden automatisch verlies van de nationaliteit door de vrouw en kinderen van betrokkene bewerkstelligen. Volgens de regelingen van Hongarije en Polen kon bij een ontnemingsbesluit worden bepaald dat de familieleden van betrokkene eveneens de nationaliteit verloren. Volgens de Poolse regeling kon ontneming slechts het verlies van het staatsburgerschap door kinderen onder 13 jaar bewerkstelligen. 


\section{HOOFDSTUK 3. DE ONTWIKKELINGEN TOT OP HEDEN}

\subsection{Verkruging VAN DE NATIONALTTETT}

\subsubsection{Verkaijging van rechtswege}

\subsubsection{Ius sanguinis}

Volgens de regelingen van verkrijging van het staatsburgerschap iure sanguinis verkrijgt in alle Oosteuropese landen een kind wiens beide ouders de nationaliteit van een bepaald land bezitten, het staatsburgerschap van het desbetreffende land. Het is daarbij niet van belang of het kind wettig of onwettig is en of het in het binnen- of buitenland werd geboren.

Met betrekking tot de verkrijging van de nationaliteit door kinderen van nationaliteitsrechtelijk gemengde ouders was in de Sovjetunie eerst een tendens naar uitbreiding van de kring van USSR-onderdanen waar te nemen, die haar hoogtepunt bereikte in de regeling van 1930 , volgens welke een kind steeds de nationaliteit van de USSR verwierf, indien het tenminste én Sovjet-ouder had. Een dergelijk kind had na zijn meerderjarigheid geen mogelijkheid om van de USSR-nationaliteit afstand te doen. In 1968 werd deze ruimhartige toekenning van de USSR-nationaliteit opnieuw enigszins ingeperkt door voor de verkrijging van de nationaliteit additionele eisen te stellen zoals geboorte in de Sovjetunie, feitelijk verblijf van één van de ouders in de Sovjetunie, of een gezamenlijke werklaring van beide ouders. De huidige nationaliteitswet van de USSR hanteert dezelfde regels, slechts het criterium van feitelijk verblijf in de USSR werd met de woonplaats vervangen. Voorts wordt er nu uitdrukkelijk bepaald dat in het gewal dat de niet-Sovjet-ouder staatloos of van onbekende nationaliteit is, het kind Sovjet-burger wordt.

In Albanië, Bulgarije en Roemenië is evenals in de USSR een ontwikkeling naar uitbreiding van het staatsburgerschap iure sanguinis waar te nemen. In Albanië werd de aan Joegoslavië ontleende regeling van de wet van 1946 in 1954 vervangen door ongeveer dezelfde als de USSR sedert 1978 kent: de nationaliteit wordt door het kind verkregen indien éen van de ouders zijn woomplaats ${ }^{1}$ in het land heeft of op grond van een gezamenlijke verklaring van beide ouders. In Bulgarije verwierf tussen 1968 en 1986 een kind van één Bulgaarse ouder niet de Bulgaarse nationaliteit, indien het in het nationale land van zijn buitenlandse ouder werd geboren en het staatsburgerschap van dat land verkreeg. Een dergelijk kind had well de mogelijkheid van werlichte naturalisatie. Sedert 1986 is echter een kind van tenminste één Bulgaarse ouder steeds Bulgaar, ongeacht de plaats waar het wordt geboren. Roemenië schafte in 1952 de afstandsmogelijkheid ten behoeve van polypatride kinderen van Roemeense ouders af en voerde dezelfde regeling als Albanië 1954 in. Thans kent Roemenië dezelfde regeling als Bulgarije.

Bulgarije, de DDR, Hongarije, Roemenië en Tsjechoslowakije zijn thans het meest ruimhartig bij de toekenning van het staatsburgerschap door geboorte. Een kind verkrijgt steeds de nationaliteit van deze landen, indien één van zijn ouders het desbetreffende staatsburgerschap bezit. De huidige Tsjechoslowaakse regeling

1. Het begrip woonplaats in Albanië is erg breed. Zie hoofdstuk Albaniè, p. 115 . 
maakte de grootste sprong: tenwijl volgens de wet van 1949 slechts een verlichte naturalisatiemogelijkheid ten aanzien van een in het buitenland geboren kind van slechts én ĊSRR-ouder bestond, verkrijgt het thans steeds ipso iure de CSSRnationaliteit.

Polen heeft in de huidige wet de regeling van 1951 gehandhaafd, waarin slechts enige verbeteringen werden aangebracht. Zo werden de termijn voor de verklaring van de ouders dat het kind niet Pool zal worden, wan én tot drie maanden verlengd.

In Joegoslavië werd in 1964 de oude regeling van 1945 gewijzigd, waardoor verkrijging van het Joegoslavische staatsburgerschap door in het buitenland geboren kinderen van nationaliteitsrechtelijk gemengde ouders beperkter is geworden. Een dergelijk kind dat door zijn geboorte tevens een andere nationaliteit verwerft, verkrijgt slechts het Joegoslavische staatsburgerschap op grond van een daartoe strekkende verklaring van zijn ouders, of op grond van vestiging in de SFRJ tijdens zijn minderjarigheid.

Met betrekking tot de regeling van verwerving van het staatsburgerschap door kinderen die uit nationaliteitsrechtelijk gemengde ouders worden geboren, kunnen we de besproken rechtsstelsels in twee hoofdgroepen verdelen: tot de eerste groep behoren landen, waarvan de nationaliteit wordt verkregen indien tenminste één van de ouders van het kind het staatsburgerschap van dat land bezit: Bulgarije, de DDR, Hongarije, Polen (met een kleine correctiemogelijkheid ten behoeve van ouders), Roemenië en Tsjechoslowakije. In de tweede groep kunnen de USSR, Albanië en Joegoslavië worden geplaatst, waar voor de verkrijging van de nationaliteit door het kind steeds additionele eisen worden gesteld. De zwaarste gelden in Joegoslavië, de lichtste in de USSR en Albanië.

Adoptie is in de USSR sedert 1978 en in Roemenië sedert 1971 een grond voor verkrijging van de nationaliteit van rechtswege, terwijl in Bulgarije en Joegoslavië voor adoptiefkinderen van onderdanen van beide landen de mogelijkheid van verlichte naturalisatie openstaat.

\subsubsection{Ius soli}

Met betrekking tot de regeling van verkrijging van de nationaliteit iure soli hebben de USSR en Albanië de grootste verandering in het nationaliteitsrecht ondergaan. Het vermoeden van bezit van de Sovjet-nationaliteit ten behoeve van iedereen die zich in het land bevond, dat in 1924 werd ingevoerd, werd in 1938 vervangen met de daaraan tegenovergestelde "praesumptio apatridiae". Vervolgens werd in 1954 bij een decreet énmalig het staatsburgerschap aan personen die aldaar langdurig woonden, alsmede aan hun kinderen verleend, waarna de praesumptio apatridiae evenwel verder bleef gelden. Volgens de huidige regeling verkrijgt een kind van in de Sovjetunie wonende apatride ouders de nationaliteit van de USSR. Voor de eerste keer wordt in een Sovjet-nationaliteitswet een regeling van verkrijging van de nationaliteit door vondelingen opgenomen. Kinderen van onbekende ouders die in de USSR worden gevonden verwerven thet USSR-staatsburgerschap van rechtswege. In Albanië is de ontwikkeling evenwel in de tegenovergestelde richting gegaan. Bij het thans geldende decreet van 1954 werd de goed uitgewerkte regeling van de wet van 1946 vervangen met een "praesumptio apatridiae" naar voorbeeld 
van de USSR-wet van 1938. Iure soli wordt de Albanese nationaliteit sedertdien niet verkregen.

In alle andere Oosteuropese landen is de ontwikkeling veel rustiger geweest. Een kind dat op het grondgebied van het desbetreffende land wordt geboren of gewonden verkrijgt het staatsburgerschap van dat land indien het anders staatloos zou zijn. In Tsjechoslowakije geldt dit echter slechts ten aanzien van vondelingen en niet met betrekking tot in de CSSR geboren kinderen van staatloze of onbekende ouders. In Hongarije wordt ten aanzien van vondelingen ook in de huidige regeling de eis van opvoeding in het land zelf gehandhaafd. In Joegoslavie, Polen en Roemenië wordt ten aanzien van vondelingen van een vermoeden van geboorte uit ouder(s), staatsburgers wan dat land, uitgegaan. Nieuw is in de Joegoslavische regeling dat deze praesumptio slechts kan worden ontkracht indien voor de $14 \mathrm{e}$ verjaardag van het kind de afstamming uit beide vreemde ouders wordt vastgesteld en het kind daardoor een vreemde nationaliteit bezit. De mogelijkheid van het leveren van het tegenbewijs wordt volgens het Poolse recht tot slechts eén jaar na de geboorte van het kind beperkt en in Roemenië tot het bereiken van de meerderjarigheidsgrens. In Bulgarije heeft men de regeling zeer casuistisch uitgewerkt. Tenslotte is in de huidige nationaliteitswet van de DDR, anders dan voorheen, ook verkrijging van het staatsburgerschap door geboorte in het land wettelijk geregeld.

\subsubsection{Optie}

Verkrijging van de nationaliteit door een zuivere optie is in de loop der jaren geheel uit de nationaliteitswetten van de Oosteuropese landen verdwenen.

\subsubsection{Naturalisatie}

De bevoegdheid om een naturalisatie te verlenen is in de regel bij de hoogste staatsorganen gebleven, behalve in Joegoslavië en Tsjechoslowakije, waar de Ministeries van binnenlandse zaken van de deelstaten zijn bevoegd. Met betrekking tot de regeling van de naturalisatievereisten waren de ontwikkelingen verschillend. In de RSFSR/USSR is men bij het uitgangspunt om geen positief geformuleerde naturalisatievereisten te geven ${ }$ gebleven. Slechts de regeling van negatieve vereisten die woor het eerst in 1938 werden opgesomd, werd in 1978 iets uitgebreid. In Albanie verliet met in 1954 de uitgewerkte regeling van naturalisatievereisten naar Joegoslavisch voorbeeld, om evenals de toenmalige Sovjet-wet wan 1938 niet of nauwelijks naturalisatievereisten te noemen. Hetzelfde gold voor Roemeniè tussen 1952 en 1971 . In de huidige Roemeense regeling wordt echter opnieuw een uitgebreidere regeling van naturalisatievereisten opgenomen. Nagenoeg ongewijzigd bleven de regelingen in Joegoslavië en Hongarije, terwijl de regelingen van naturalisatievereisten in Bulgarije, Polen en Tsjechoslowakije iets werden uitgebreid.

De positiefrechtelijke regelingen van naturalisatievereisten kunnen als volgt worden samengevat: slechts de wetten van Joegoslavië en Roemenië stellen meerderjarigheid als voorwaarde voor naturalisatie. In alle andere landen is zelfstandige naturalisatie van minderjarigen mogelijk. 
In Bulgarije, Polen (sedert 1962) en Tsjechoslowakije wordt vereist dat betrokkene vijf jaar onmiddellijk voorafgaande aan het naturalisatieverzoek in het land heeft gewoond. In Joegoslavië werd in 1964 de vijfjarige verblijfseis tot drie jaren verkort, terwijl dezelfde eis reeds sedert 1948 in Hongarije wordt gesteld. In de USSR, Albanië (sedert 1954), de DDR en Roemenië (sedert 1952) wordt geen eis van een bepaalde duur als naturalisatievereiste gesteld.

Het verlies wan de oude nationaliteit wordt in alle landen behalve in de USSR, Albanië en Hongarije uitdrukkelijk in de wet gesteld. Volgens de wetten van de DDR en Polen kan van betrokkene zulks worden geëist.

Het is aan te nemen dat in alle landen het vereiste van "goed gedrag" wordt gehanteerd, hoewel zulks in de USSR, Albanië en Polen niet uitdrukkelijk in de wet wordt bepaald. In sommige landen kleurt men dit vereiste nader in, door te bepalen dat betrokkene de verlening van het staatsburgerschap waard moet zijn (DDR, Roemeniè), dat de naturalisatie niet voor de staat nadelig mag zijn (Hongarije), of dat de naturalisandus geen daden tegen de staat heeft verricht (Tsjechoslowakije). Tenslotte moet in Joegoslavië en Roemenië uit het gedrag van de verzoeker kunnen worden afgeleid dat hij een loyale burger zal zijn.

Slechts in Roemenië wordt geëist dat betrokkene arbeidsgeschikt moet zijn. Bovendien moet volgens de Roemeense regeling de naturalisandus "maatschappelijk nuttige" arbeid verrichten en in geval van arbeidsongeschiktheid over voldoende middellen van bestaan beschikken.

\subsubsection{Verlichte naturalisatie}

De regelingen van verlichte naturalisatie werden in de latere wetgeving van de Oosteuropese landen in de regel nog verder uitgebreid. Slechts in de USSR, Albanië en Roemenië (tussen 1952 en 1955) ging de ontwikkeling in de tegenovergestelde richting. De USSR en Albanië kennen evenals de DDR in het geheel geen regels met betrekking tot verlichte naturalisatie. Hetzelfde gold voor het Roemeense decreet van 1952, totdat in 1955 de "repatriëring" werd ingevoerd.

Volgens de thans geldende regelingen gaat het bij de verlichte naturalisatie steeds om (gedeeltelijke) vrijstelling van de verblijfseis en in sommige gevallen ook van het vereiste van verlies van de oude nationaliteit. De bevoegdheid ligt doorgaans bij hetzelfde orgaan als bij de gewone naturalisatie. In Polen en Č́SSR zijn echter plaatselijke besturen bevoegd.

De regelingen van werlichte naturalisatie werden met enkele nieuwe gronden uitgebreid, terwijl het dienen in militaire dienst in de huidige nationaliteitswetten niet meer wordt opgenomen. Slechts in Bulgarije, Hongarije en Joegoslavië worden "bijzondere diensten" nog als een grond voor geprivilegieerde naturalisatie genoemd. In Polen (sedert 1951) en in Roemenië (sedert 1955) vinden we een bijzondere vorm van verlichte naturalisatie, "repatriëring", die grosso modo met de uit het "burgerlijke" recht bekende "erkenning" overeenkomt (zie p. 253 en 283 284).

Etnische nationaliteit is nog steeds een grond voor verlichte naturalisatie in Bulgarije en Joegoslavië, terwijl in Hongarije voldoende is, dat de verzoeker van een juridische Hongaar afstamt.

Een vreemdeling die met een onderdaan van Bulgarije, Hongarije, Joegoslavië, Polen, Roemenië of Tsjechoslowakije huwt, heeft eveneens de mogelijkheid van 
geprivilegieerde naturalisatie. Opmerkelijk is echter dat in Polen en Tsjechoslowakije deze weg uitsluitend voor vrouwen openstaat.

In Bulgarije en Joegoslavië bestaat een mogelijkheid van verlichte naturalisatie ten behoeve van adoptief-kinderen van Joegoslavische, respectievelijk Bulgaarse onderdanen, terwijl in Hongarije vreemdelingen, die een Hongaars kind wensen te adopteren, zelf de mogelijkheid van de verkrijging van het staatsburgerschap door bewoorrechte naturalisatie hebben. In de Sovjetunie en Roemenie is sedert 1978, respectievelijk 1971 adoptie een grond voor verkrijging van de nationaliteit door het geadopteerde kind van rechtswege.

Voorts kunnen van de geprivilegieerde naturalisatie gebruik maken: vluchtelingen (Bulgarije), in bepaalde gevallen degenen die te eniger tijd de desbetreffende nationaliteit hebben bezeten (Hongarije, Joegoslavië, Polen, Roemenië), apatriden (Polen) en ouders van staatsburgers van het desbetreffende land (Hongarije).

\subsubsection{1 lus matrimonii}

Met betrekking tot verkrijging van de nationaliteit in verband met het huwelijk waren de ontwikkelingen verschillend. In de RSFSR kende men nog een optierecht voor een met een onderdaan van dit land huwende buitenlandse vrouw, waarna in de USSR tot 1938 een mogelijkheid van verlichte naturalisatie ten behoeve van beide geslachten openstond. Sedert 1938 heeft de buitenlandse huwelijkspartner slechts de mogelijkheid van gewone naturalisatie. Geen wijzigingen van betekenis kunnen worden waargenomen in Bulgarije, de DDR, Joegoslavië, Roemenië en Tsjechoslowakije. Terwijl in de DDR het standpunt, dat het huwelijk in het geheel geen invloed op het staatsburgerschap heeft, onverkort werd gehandhaafd, kennen de andere landen verlichte naturalisatie ten behoeve van buitenlandse huwelijkspartners van hun onderdanen, waarbij behalve in Polen en Tsjechoslowakije geen onderscheid tussen vrouwen en mannen wordt gemaakt.

Albanië, Hongarije, Polen en Roemenië hebben in hun huidige regelingen echter nog principiële wijzigingen opgenomen. Albanië en Roemenië schaften in 1954, respectievelijk 1952 verlichte naturalisatie van buitenlandse huwelijkspartners af. In Roemenië werd deze echter in 1971 heringevoerd. In Polen en de CSSR werd de ontwikkeling beinvloed door het verdrag betreffende de nationaliteit van de gehuwde vrouw van New York van 20 februari 1957. Terwijl in Polen volgens de regeling van 1951 huwelijk in het geheel geen invloed op het staatsburgerschap had, werd tien jaar later een mogelijkheid van verlichte naturalisatie ten behoeve van buitenlandse vrouwen, die met Polen huwen, ingevoerd. De ĆSSR kende echter reeds in de wet van 1949 verlichte huwelijksnaturalisatie ten aanzien van buitenlandse vrouwen. In Hongarije werd in 1957 met het beginsel van eenheid van de nationaliteit in een gezin gebroken. Sedertdien kent Hongarije ten behoeve van zowel vrouwen als mannen de mogelijkheid van verlichte huwelijksnaturalisatie.

De thans geldende regelingen van verkrijging van het staatsburgerschap in verband met het huwelijk kunnen in drie groepen worden verdeeld. Volgens het recht van de USSR, Albanië en de DDR heeft huwelijk geen invloed op de nationaliteit. Buitenlandse huwelijkspartners van onderdanen van deze landen hebben slechts de mogelijkheid van gewone naturalisatie. Alle andere landen kennen een geprivilegieerde huwelijksnaturalisatie. In Bulgarije, Hongarije, Joegoslavië en Roemenië wordt met betrekking tot deze mogelijkheid geen 
onderscheid tussen beide geslachten gemaakt. In Polen en Tsjechoslowakije staat de verlichte naturalisatiemogelijkheid echter uitsiuitend ten behoeve wan buitenlandse vrouwen open. Dit is voor twee socialistische landen een zeer opmerkelijke regeling.

\subsubsection{2 "Repatriëring"}

In Roemenië werd de bijzondere vorm van verlichte naturalisatie, "erkenning", bij eerste socialistische nationaliteitswet van 1948 afgeschaft, en vervolgens in 1955 onder de naam "repatriëring" in een gewijzigde vorm weer ingevoerd. Hetzelfde gebeurde in Polen reeds bij de eerste socialistische mationaliteitswet van 1951. Terwijl in Polen de regeling ongeveer dezelfde is gebleven, zijn in Roemenië belangrijke verschillen met betrekking tot het oude recht te signaleren. Zo wordt thans de kring van potentiële verzoekers beperkt tot die personen, die ooit de juridische Roemeense nationaliteit hebben bezeten. Bovendien werkt verkrijging van de nationaliteit ex nunc. In Polen wordt thans anders dan in de wet van 1920 een vestigingsvergunning uitdrukkelijk als voorwaarde voor verkrijging van het staatsburgerschap gesteld. Aan de andere kant wordt niet meer geëist dat betrokkene zijn eventuele andere nationaliteit moet verliezen.

In beide landen delen minderjarige kinderen in de verkrijging van de nationaliteit door hun ouders volgens dezelfde regels als bij de gewone naturalisatie (zie p. 353-354).

\subsubsection{Hernaturalisatie}

De enige Oosteuropese landen die thans nog bijzondere voorwaarden ten aanzien van hernaturalisatie kennen, zijn Bulgarije, Joegoslavië en Roemenië. In Bulgarije, waar dit na een tussenpoos van 20 jaar in 1968 opnieuw werd ingevoerd, gaat het eigenlijk om een verlichte naturalisatie, waarbij de verzoeker vrijgesteld wordt van de vijfjarige verblijfseis en van het vereiste van verlies van zijn tegenwoordige nationaliteit. Betrokkene moet zich in het land hebben gevestigd, blijk hebben gegeven van een positieve instelling tegenover het politieke systeem en een verklaring van goed gedrag overleggen.

In Joegoslavië gaat het om de reeds uit het oude Joegoslavische recht bekende "Einbürgerungsansprüche". Het gaat om meerderjarig geworden Joegoslavische kinderen, die hun nationaliteit als gevolg van ontslag of afstand uit/van de nationaliteit door hun ouder(s) verloren. De enige voorwaarde is, dat betrokkene zich in het land zelf moet vestigen.

In Roemenie levert het feit dat betrokkene ooit de Roemeense nationaliteit heeft bezeten, een grond voor "gewone" verlichte naturalisatie ${ }^{2} o p$, zelfs als hij in het buitenland woont. Komt betrokkene terug naar Roemenië, dan staat de mogelijkheid van "repatriëring" voor hem open.

2. Slechts vrijstelling van de verblijfseis. 


\subsubsection{Invloed op de nationaliteit van de gezinsleden van de verzoeker}

De regelingen van medenaturalisatie van minderjarige kinderen van naturalisandi zijn in de loop der jaren miet in belangrijke mate gewijzigd. Ook op dit gebied zijn de meeste veranderingen in de wetgeving van de RSFSR/USSR waar te nemen. Terwijl de eerste regeling van 1921 de beslissing omtrent de medenaturalisatie nog geheel aan de ouders van het kind overliet, worden sedert 1924 kinderen jonger dan 14 jaar zonder uitzonderingen meegenaturaliseerd, indien het staatsburgerschap aan beide ouders van het kind werd verleend. In het geval dat slechts eén van de ouders wordt genaturaliseerd, hanteerde men ten aanzien van medenaturalisatie in het verleden drie verschillende uitgangspunten: tot 1938 mochten de ouders, indien het kind jonger was dan 14 jaar, geheel zelfstandig daarover beslissen; was het kind tussen 14 en 18 jaar oud, dan was de toestemming van het kind nodig. Tussen 1938 en 1978 was medenaturalisatie in het geval dat slechts eén vam de ouders werd genaturaliseerd geheel uitgesloten. De huidige regeling breidt de mogelijkheden voor medenaturalisatie van kinderen vervolgens weer uit. Ook in thet geval dat slechts éen van de ouders wordt genaturaliseerd, wordt het kind op verzoek van die ouder in de naturalisatie inbegrepen; voorwaarde is dat het kind in de USSR woont of indien het kind in het buitenland woont, dat de andere ouder staatloos is. Kinderen die ouder zijn dan 14 jaar moeten in alle gevallen schriftelijk met de medenaturalisatie instemmen. In alle andere landen (met uitzondering van Roemenië) bleef men ook in de latere wetgeving dezelfde uitgangspunten hanteren en werden slechts marginale wijzigingen in de regelingen aangebracht. In Roemenië heeft men de automatische medenaturalisatie van de echtgeno(o)t(e) van de naturalisandus, alsmede de mogelijkheid van afstand ten behoeve van bipatride meegenaturaliseerde kinderen geschrapt. Kinderen die in Roemenië wonen, worden thans slechts tot de leeftijd van 14 jaar automatisch aan de naturalisatie van hun ouder(s) deelachtig. $\mathrm{Na}$ het bereiken van deze leeftijd moeten ze zelf met hun medenaturalisatie instemmen.

De thans geldende regels betreffende medenaturalisatie van minderjarige kinderen kunnen als volgt worden samengevat: in het geval dat de nationaliteit aan beide ouders wordt verleend, worden de kinderen automatisch meegenaturalliseerd in: de USSR, Albanië, Bulgarije, Hongarije, Joegoslavië, Polen en Roemenië. De wetten van de USSR, Albanië, Joegoslaviê en Polen geven aan een kind dat ouder is dan 14 (in Polen 16) jaar de mogelijkheid zijn veto tegen de medenaturalisatie uit te spreken. De Poolse regeling eist voorts dat de ouders het ouderlijk gezag over het kind uitoefenen. In Bulgarije en Roemenië kunnen slechts kinderen tot 14 jaar worden meegenaturaliseerd; zijn ze ouder, dan staat uitsluitend zelfstandige naturalisatie voor ze open. In Hongarije kan van automatische medenaturalisatie op verzoek van de ouders worden afgezien. In de DDR en Tsjechoslowakije kent men geen automatische medenaturalisatie. Medenaturalisatie op verzoek is mogelijk, maar in Tsjechoslowakije slechts ten aanzien van kinderen tot 15 jaar. In de DDR moet een kind ouder dan 14 jaar zelf met zijn medenaturalisatie instemmen.

Slechts in de nationaliteitswetten van Bulgarije en Polen worden gevallen waarin én ouder wordt genaturaliseerd, terwijl de andere geen ouderlijk gezag 
over het kind heeft ${ }^{3}$, reeds de desbetreffende nationaliteit bezit, of overleden is (alleen Buigarije) expliciet met gevallen van naturalisatie van beide ouders gelijkgesteld. Gezien de ratio van de regelingen van medenaturalisatie van minderjarige kinderen mag worden aangenomen dat hetzelfde ook voor de andere landen geldt.

Indien slechts één van de ouders wordt genaturaliseerd, worden slechts in Hongarije en Roemenië zijn minderjarige kinderen automatisch in de naturalisatie inbegrepen. In Roemenië wordt daarbij de eis gesteld, dat de kinderen bij die ouder moeten wonen. In Albanië, Bulgarije en Polen wordt geëist dat de ouders, alsmede de kinderen zelf, indien ze ouder dan 14 jaar (16 jaar in Polen) zijn, met de medenaturalisatie instemmen.

In de USSR, de DDR, Joegoslavië en Tsjechoslowakije worden minderjarige kinderen slechts op uitdrukkelijk verzoek van hun genaturaliseerde ouder met hem meegenaturaliseerd. In Tsjechoslowakije wordt tevens geëist dat het kind niet ouder dan 15 jaar is en dat de andere ouder zijn toestemming verleent. In de USSR stelt men bovendien de eis dat het kind in de USSR woont of indien het kind in het buitenland woonachtig is, dat de andere ouder staatloos is. Kinderen die ouder zijn dan 14 jaar moeten met de medenaturalisatie instemmen.

\subsection{VERLIES VAN DE NATTONALITET}

\subsubsection{Afstand}

Verlies van de nationaliteit door afstand die in het verleden zeer zelden mogelijk was, werd in alle Oosteuropese landen met uitzondering van Joegoslavië en Hongarije uit de nationaliteitswetten geschrapt. In Joegoslavië werden in 1964 de reeds sedert 1945 bestaande mogelijkheden van verlies van het staatsburgerschap door afstand uitgebreid. Deze weg staat thans open voor alle polypatriden met vaste woonplaats in het buitenland ${ }^{4}$. Indien ze tevens in het buitenland werden geboren en tussen 18 en 25 jaar oud zijn, kunnen ze altijd afstand doen; in andere gevallen kan dit slechts, indien ze aan een aantal vereisten voldoen, die ongeveer dezelfde zijn als bij ontslag.

In Hongarije bestaat slechts de mogelijkheid van afstand ten behoeve van kinderen van niet-Hongaarse vrouwen, wier afstamming van een Hongaarse vader tijdens hun meerderjarigheid wordt vastgesteld en die als gevolg daarvan de Hongaarse nationaliteit hebben verworven. Afstand is mogelijk gedurende eén jaar na de verkrijging van de nationaliteit. Het gaat hier om een uitbreiding van de verkrijging wan de Hongaarse nationaliteit ten opzichte van de regeling van 1948 volgens welke een dergelijk kind slechts een optierecht op het Hongaarse staatsburgerschap kreeg.

3. In Bulgarije moet het ouderlijk gezag aan de desbetreffende ouder zijn ontnomen.

4. Joegoslawische "gastarbeiders" wordem in beginsel geacht hun vaste woonplaats in Joegoslavie te hebben. Tratnik, p. 433. 


\subsubsection{Invloed op de nationaliteit van gezinsleden van betrokkene}

Ten aanzien van minderjarige kinderen van betrokkene gelden in Joegoslavië dezelfde regels als bij ontslag (zie p. 357). In Hongarije bestaat geen uitdrukkelijke regeling. Uit de algemene regels volgt, dat de kinderen van betrokkene de Hongaarse nationaliteit slechts verliezen, indien hun andere ouder vreemdeling is.

\subsection{Ontslag}

De regelingen van ontslag uit het staatsburgerschap van de Oosteuropese landen zijn in de laatste decennia met uitzondering van de Albanese wet uitgebreider geworden. Zo worden in de huidige nationaliteitswetten van de USSR, Bulgarije en Roemenië anders dan voorheen ontslagvereisten genoemd. Geen wijzigingen in de wettelijke regeling van het ontslag zijn echter te constateren in Tsjechoslowakije. In Polen werd een mogelijkheid van verlicht ontslag in verband met het huwelijk en in Roemenië ten behoeve van door vreemdelingen geadopteerde kinderen ingevoerd. Het ontslag wordt in de meeste landen nog steeds verleend onder de voorwaarden van het verlaten van het land en/of verkrijging van een andere nationaliteit.

De mogelijkheid van verlies van de nationaliteit door ontslag is met name bedoeld voor degenen, die willen emigreren en een andere nationaliteit reeds bezitten, of willen verkrijgen. Uitsluitend. Hongarije, Joegoslavië en Polen kennen aan hun onderdanen een vaag recht op het verlaten van het land toe, dat echter door te vaag geformuleerde weigeringsmogelijkheden op wankele voeten staat. Ook de praktijk met betrekking tot emigratie is in deze drie landen veel liberaler dan elders in Oost-Europa, waar in de regel slechts de toestemming wordt gegeven indien betrokkene tot een etnische minderheid behoort. Ook in het kader van gezinshereniging zijn de mogelijkheden voor emigratie iets ruimer. In de USSR, Bulgarije, Roemenië en de CSSR moet de verzoeker de kosten van zijn genoten opleiding vergoeden.

In de USSR (ten aanzien van Joden) en in de DDR wordt ontslag in de regel gekoppeld aan de toestemming voor emigratie. Aan betrokkene wordt geen toestemming voor het verlaten van het land verleend, als hij niet tegelijkertijd om ontslag uit de nationaliteit vraagt. Aan beide beschikkingen is het betalen van een geldsom verbonden, die aanmerkelijk hoger is indien de verzoeker naar het Westen wenst te emigreren.

Voorts wordt in ieder geval met betrekking tot Polen, Roemenen, Tsjechen en Slowaken voor het ontslag uit de desbetreffende nationaliteit het betalen van een overdreven hoog bedrag verlangd.

De bevoegdheid om ontslag te verlenen ligt in de meeste landen bij de hoogste staatsorganen: het Presidium van het Opperste Sovjet, de Raad van State, het Presidium van het Parlement, de President van de republiek (de USSR, Bulgarije, Albanië, Hongarije en Roemenië). In de DDR is de Ministerraad bevoegd, in Joegoslavië de Minister(ie)s van binnenlandse zaken van de deelstaten. Een uitzondering vormt de ČSSR waar de bevoegdheid bij de plaatselijke besturen wordt gelegd. In Polen wordt het verlenen van ontslag volgens de wet van 1962 aan de Raad van State geattribueerd, echter met de mogelijkheid van delegatie aan de 
Minister van binnenlandse zaken. Met betrekking tot het ontslag van degenen die in het buitenland wonen, zijn de consuls in de desbetreffende landen bevoegd.

De regellingen van vereisten voor ontslag werden zoals gezegd in de meeste landen uitgebreid. In Albanië echter, worden sedert 1954 geen wereisten in de wet genoemd. Geen wettelijke voorwaarden voor ontslag kennen voorts de nationaliteitswetten van Polen en Tsjechoslowakije. In de USSR kent men een verdeling in zogenaamde absolute en relatieve ontslagbeletselen.

Slechts de Joegoslavische en Roemeense wet stellen de voorwaarde dat betrokkene meerderjarig moet zijn.

In alle landen wordt van betrokkene geëist dat hij aan de verplichtingen tegenover de staat, waaronder met name de militaire dienstplicht, heeft voldaan. In de USSR is dat overigens een relatief ontslagbeletsel. In Hongarije wordt ten aanzien van mannen tussen 18 en 51 jaar zelfs steeds de toestemming van de Minister van defensie vereist, en in Bulgarije en Joegoslavië is ontslag van mannen bowen 17 jaar slechts na het vervullen yan de militaire dienstplicht mogelijk. Over het algemeen wordt van betrokkene geëist dat hij ook zijn verplichtingen tegenover de maatschappelijke organisaties, bedrijven en natuurijke personen (alimentatie, onrechtmatige daad, etc.) heeft geregeld.

Voorts is dikwijls geen ontslag mogelijk (absoluut beletsel in de USSR) in het geval dat tegen betrokkene een strafrechtelijke procedure aanhangig is of dat een straf ten uitwoer moet worden gelegd. Dit vereiste wordt in de USSR, Bulgarije, Hongarije, Joegoslavië en Roemenië expliciet in de wet gesteld.

De nationaliteitswetten van de USSR (absoluut beletsel), Bulgarije, de DDR en Joegoslaviè geven uitdrukkelijk aan dat ontslag om redenen van staatsveiligheid kan worden geweigerd. Van deze weigeringsgrond blijkt in ieder geval in de USSR misbruik te worden gemaakt, waarbij begrippen "staats- en militair geheim" wel eens tot de meest absurde gevallen werden uitgebreid. Het feit dat in andere landen een dergelijk vereiste niet wettelijk is geregeld, betekent uiteraard niet dat deze voorwaarde niet wordt gehanteerd. De discretionaire bevoegdheid van het beslissende orgaan en het ontbreken van beroepsmogelijkheden bieden hiervoor voldoende ruimte.

De Roemeense wet van 1971 schrijft een verklaring van betrokkene bij een authentieke akte voor, waarin hij verklaart dat hij geen handelingen zal begaan, die de staat zullen kunnen schaden. Sancties voor niet-nakoming worden in de wet niet voorzien. In Joegoslavie bestaat voorts een zeer vage weigeringsmogelijkheid op grond staatsveiligheid, bijzondere belangen van de staat of slechte betrekkingen met de staat waarvan betrokkene de nationaliteit bezit of wenst te verkrijgen ${ }^{5}$. Interessant is echter dat indien betrokkene aan overige vereiste voldoet, ontslag uitsluitend op deze gronden mag worden geweigerd. Hierdoor heeft betrokkene een soort "Entlassungsanspruch", een constructie die uit de "burgerlijke" nationaliteitswetgeving van Duitsland en Hongarije bekend is.

In Polen werd in 1962 onder de invloed van het verdrag van New York betreffende het staatsburgerschap van de gehuwde vrouw een mogelijkheid van vereenvoudigd ontslag in verband met het huwelijk ingevoerd. Deze weg staat open voor vrouwen die door of in verband met een huwelijk met een vreemdeling een andere nationaliteit verwerven en voor gewezen vreemdelingen die door of in

5. Hierbij kan worden gedacht aan Chili, Israël, Paraguay en Zuid-Afrika. 
verband met een huwelijk met een Pool de Poolse nationaliteit hebben verkregen, in beide gevallen nadat het huwelijk wordt ontbonden. De bevoegdheid ligt bij plaatselijke besturen en bij consulaten, indien de verzoekster in het buitenland woont. Roemenië tenslotte, kent sedert 1971 een aparte ontslagmogelijkheid ten behoeve van minderjarige Roemenen, die door vreemdelingen worden geadopteerd.

\subsubsection{Invloed op de nationaliteit van de gezinsleden wan de verzoeker}

Ontslag kan in alle landen slechts invloed hebben op het staatsburgerschap van minderjarige kinderen van betrokkene. Zijn vrouw of man kan uitsluitend zelfstandig worden ontslagen. Automatisch ontslag van minderjarige kinderen kennen voor bepaalde gevallen de nationaliteitswetten van de USSR, Albanië, Joegoslavië en Polen. In Bulgarije en de CSSR kunnen minderjarigen slechts op verzoek van de ouder(s) worden meeontslagen. Bulgarije eist bij kinderen boven 14 jaar tevens hun eigen toestemming, terwijl in Tsjechoslowakije slechts ten aanzien van kinderen tot 15 jaar medeontslag mogelijk is. Volgens het recht van Hongarije en de DDR tenslotte, kunnen minderjarige kinderen wan de verzoeker uitsluitend zelfstandig worden ontslagen.

Voorwaarde voor automatisch ontslag in de USSR, Albanië Joegoslavië en Polen is steeds, dat het ontslag aan beide ouders wordt verleend. Het geval dat slechts én van de ouders wordt ontslagen, terwijl de andere niet de desbetreffende nationaliteit bezit, moet worden gelijkgesteld met het geval van ontslag van beide ouders. Slechts de Poolse wet bepaalt dat met zoveel woorden. In Polen wordt bovendien nog geëist dat de ouder(s) het ouderlijk gezag over het kind uitoefenen. De regelingen van USSR, Albanië, Joegoslavië en Polen geven aan kinderen ouder dan 14 (in Polen 16) jaar steeds het recht hun veto tegen het medeontslag uit te spreken.

Indien het ontslag aan één van de ouders wordt verleend en deze om medeontslag van de minderjarige kinderen verzoekt, wordt in de USSR, Bulgarije, Joegoslavië en Polen tevens de toestemming van de andere ouder geëist. Volgens de Poolse wet kan deze toestemming door een rechterlijke uitspraak worden vervangen. Geen inspraak heeft de andere ouder in Tsjechoslowakije, terwijl men in Albanië een geheel andere regeling heeft bedacht. Indien beide ouders in het buitenland wonen ${ }^{6}$, mogen zij zelf over het medeontslag beslissen. Wonen ze in Albanië, dan wordt een kind onder 14 jaar automatisch meeontslagen en bowen deze leeftijd slechts met eigen toestemming.

\subsubsection{Ontneming van nationaliteit en herroeping van naturalisatie}

Alle nationaliteitswetten van de Oosteuropese landen kennen verlies van het staatsburgerschap door ontneming. Desalniettemin wordt dit rechtsinstituut slechts in uitzonderingsgevallen als een "ultimum remedium" tegen te kritische dissidenten toegepast. Aangezien ontnemingsbesluiten uitsluitend in de USSR in het staatsblad worden gepubliceerd zijn exacte gegevens daaromtrent helaas niet voorhanden. Aparte ontnemingsregelingen kwamen in de laatste decennia met uitzondering van

6. Hierbij moet in het oog worden gehouden dat het begrip "woonplaats in het buitenland" een eigen, zeer beperkte inhoud heeft. Zie p. 11.5 . 
de DDR en Tsjechoslowakije niet tot stand. Ook ontneming van het staatsburgerschap door de rechter als bijkomende straf bij bepaalde politieke delicten behoort sedert 1958 tot de geschiedenis.

Evenals op andere gebieden heeft ook hier de meest "schokkende" de ontwikkeling in Albaniê plaats gehad. In 1954 werd de naar Joegoslavisch voorbeeld uitgewerkte regeling van ontneming vervangen door een uiterst summiere "regeling", die slechts het bevoegde orgaan aangeeft. In Tsjechoslowakije werd de regeling van ontneming in 1958 gedeeltelijk gewijzigd waarna de huidige wet van 1968 gewoon de oude regeling van toepassing verklaarde? ${ }^{7}$. In $1977 \mathrm{kwam}$ voorts ook een aparte regeling ten aanzien van verlies van de nationaliteit door emigranten tot stand. In Bulgarije werd in 1968 een regeling van herroeping van naturalisatie ingevoerd. Een aparte regeling van herroeping van naturalisatie kent thans uitsluitend nog het recht van de DDR. Nagenoeg ongewijzigd bleven voorts de regelingen van ontneming in de USSR en Polen.

De bevoegdheid om het staatsburgerschap te ontnemen is volgens de huidige nationaliteitswetten in de regel bij de hoogste staatsorganen gebleven. Het Presidium van het Opperste Sovjet van de USSR, de dararmee vergelijkbare Raden van State of Presidentiële Raden in de meeste andere landen, de Ministerraad in de DDR en de President van de republiek in Roemenië. In Joegoslavië en Tsjechoslowakije zijn echter de Ministers van binnenlandse zaken van de deelstaten bevoegd.

De nationaliteit kan in alle landen met uitzondering van Joegoslavië worden ontnomen ongeacht of betrokkene daardoor staatloos wordt. Volgens de wetten van Bulgarije, de DDR (behalve bij genaturaliseerden binnen 5 jaar na de naturalisatie), Joegoslavië, Polen en Tsjechoslowakije is ontneming van het staatsburgerschap siechts mogelijk ten aanzien van personen die in het buitenland wonen. Ontneming van de nationaliteit heeft in Joegoslavië en Bulgarije (bij de meeste ontnemingsgronden) confiscatie van het vermogen van betrokkene tot gevolg. Volgens de regeling van Hongarije kan het vermogen van betrokkene worden geconfisceerd. Andere nationaliteitswetten zwijgen over vermogensrechtelijke consequenties van de ontneming. In de regel betekent ontneming van het staatsburgerschap tevens het verbod tot het land te worden toegelaten, respectievelijk uitwijzing, indien betrokkene zich in het land bevindt.

De huidige nationaliteitswetgeving van de Oosteuropese landen kent nog steeds schending van loyaliteitsverplichtingen en handelingen die de staatsveiligheid of andere belangen van de staat kunnen schaden, als de voornaamste ontnemingsgronden. Een dergelijke regeling bestaat in Bulgarije, de DDR, Joegoslavië, Hongarije, Polen, Roemenië en Tsjechoslowakije. De wetten van de USSR en Albanië noemen weliswaar geen gronden voor ontneming, maar in ieder geval ten aanzien van de USSR blijkt uit de praktijk dat deze grond ook daar wordt gehanteerd. Als voorbeeld van dergelijk gedrag kan met name worden gedacht aan kritische uitingen in doorgaans buitenlandse media over de omstandigheden in het desbetreffende land. De wetten van de USSR, Bulgarije en Roemenie spreken ook over een "staatsburger onwaardig" gedrag. In Bulgarije is dat een zelfstandige ontnemingsgrond terwijl in USSR en Roemenië deze termen in een

7. In Tsjechoslowakje vervaardigde mem in 1969 weliswaar een eigen regeling wan ontnemingsgronden, die echter materiecl niet van die wan de wet van 1949/58 afwijkt. 
soort "Generalklausel" ten aanzien van alle gevallen van ontneming worden gebezigd.

Illegale grensoverschrijding, respectievelijk ongeoorloofde verlenging van het toegestane verblijf in het buitenland is expliciet als een grond voor ontneming van de nationaliteit geformuleerd in de nationaliteitswetten van Bulgarije, Polen, Roemenië en Tsjechoslowakije. In de andere landen kan "Republikflucht" onder de vage "Generalklauseln" worden gebracht. Slechts in Joegoslavië is het enkel illegaal verlaten van het land in geen geval voldoende om de nationaliteit te ontnemen. In de DDR en Tsjechoslowakije heeft men voor dit geval aparte regelingen tot stand gebracht. In sommige Oosteuropese landen (USSR, Albanië, DDR, Roemenië, ČSSR) wordt het illegaal verlaten van het land als een zwaat misdrijf beschouwd en in verband met landverraad gebracht.

Hoewel in bijna alle Oosteuropese landen de "Republikflucht" volgens de wet een grond voor ontneming van de nationaliteit oplevert, wordt deze mogelijkheid in de regel bijna niet meer toegepast. In Bulgarije, Hongarije, Polen, Roemenië en de CSSR is een duidelijke tendens naar "legalisering" van het illegale verblijf in het buitenland waarneembaar. Er worden alsnog toestemmingen voor emigratie verleend. In ieder geval Tsjechoslowakije verbindt daaraan betaling van een relatief hoge geldsom. Met betrekking tot Joegoslavië kan gezien de brede uitreismogelijkheden niet van "Republikflucht" worden gesproken. Ten Aanzien van Albanië zijn geen gegevens beschikbaar en in de USSR en de DDR bestaat deze "legaliseringstendens" nog(?) niet.

Het treden in vreemde militaire of staatsdienst zonder de toestemming van de overheid is alleen in Bulgarije uitdrukkelijk als ontnemingsgrond in de wet opgenomen. Zonder twijfel kan dergelijk gedrag tevens worden gebracht onder de ruime formulering "grove veronachtzaming van staatsburgerlijke plichten" die voorts in de DDR en Hongarije ontneming van de nationaliteit teweeg kan brengen.

Strafrechtelijke veroordeling kan in Hongarije en Polen tot ontneming van het staatsburgerschap leiden. Volgens de Poolse regeling moet het om recidive gaan en betrokkene in het buitenland veroordeeld moet zijn, terwijl het in Hongarije om een zwaar in het binnen- of buitenland begaan delict moet gaan.

Verkrijging, respectievelijk bezit van een vreemde nationaliteit zijn in Bulgarije, Roemenië en Tsjechoslowakije voldoende om het staatsburgerschap te ontnemen. Voorts kent men in Polen ontneming van de nationaliteit wegens ontwijken van de militaire dienstplicht.

In Bulgarije, de DDR en Roemenië kan het staatsburgerschap tevens worden ontnomen wegens fraude in de naturalisatieprocedure. In de eerste twee landen gebeurt dit in het kader van herroeping van de naturalisatie die binnen vijf jaar na de totstandkoming daarvan mogelijk is. In Roemenië gaat het om een "gewone" ontnemingsgrond: verkrijging van de Roemeense nationaliteit is in strijd met de wet.

\subsubsection{Invloed op de nationaliteit van gezinsleden van betrokkene}

Ontneming van de nationaliteit heeft in beginsel geen invloed op het staatsburgerschap van de gezinsleden van betrokkene. Een dergelijke garantie wordt met zoveel woorden in de nationaliteitswetten van de meeste Oosteuropese landen opgenomen. Dit verhindert natuurlijk niet dat de nationaliteit aan de gezinsleden 
zelfstandig kan worden ontnomen, hetgeen in ieder geval in de Sovjetunie ten aanzien van een aantal vrouwen van bekende dissidenten is voorgekomen. 


\section{CONCLUSIES}




\section{HOOFDSTUK 1. CONCLUSIES MET BETREKKING TOT VERKRIJGING EN VERLIES VAN DE NATIONALITEIT}

\section{ALGEMENE OPMERKINGEN}

Indien we nagaan hoelang de nieuwe machtshebbers hadden gewacht om "eigen" nationaliteitsrechtelijke regeling tot stand te brengen, kunnen we het volgende constateren: in de RSFSR, Joegoslavië en Albanië kondigde men reeds enkele maanden na de machtsovername nieuwe nationaliteitswetten af. In de RSFSR gebeurde dat gedeeltelijk in de grondwet en gedeeltelijk in drie aparte wetten, eén op het gebied van het personen- en familierecht, alsmede in een aparte naturalisatie- en ontnemingswet ${ }^{1}$. Pas na de oprichting van de USSR kwam een algemene regeling van verkrijging en verlies van de nationaliteit tot stand. In Joegoslavië vaardigden de nieuwe machthebbers reeds binnen enkele maanden na hun machtsovername een nieuwe nationaliteitswet uit. Echt nieuw was deze wet echter niet. Het ging om een gereviseerde versie van de bestaande wet van 1928 waarin enkele principiële wijzigingen werden aangebracht. De oude tekst werd vergaand overgenomen. Ook vele lacunes getuigen van de grote haast, die men met de invoering van die wet kennelijk had. In Albanië had de wetgever het gemakkelijker. De nauwe banden, die dit land destijds met Joegoslavië onderhield, maakten het mogelijk om de Joegoslavische wet grotendeels over te nemen. In Bulgarije, Hongarije, Polen, Roemenië en Tsjechoslowakije kwamen de mationaliteitswetten in respectievelijk 1948, 1948, 1951, 1948 en 1949 tot stand. In de regel geschiedde dit derhalve steeds éen of meer jaren, nadat de communistische partijen de regeringsmacht overnamen. In al deze landen beschouwde men het nationaliteitsrecht kennelijk niet als éen van de gebieden waarin onmiddellijk belangrijke wijzigingen moesten worden aangebracht ${ }^{2}$. De DDR nam hierbij een uitzonderingspositie in. De eerste algemene nationaliteitswet van dit land kwam pas 18 jaar later dan de communistische regering. Tot dan gold gewoon het RuStAG van 1913, voorzover deze wet niet in strijd was met de openbare orde van de DDR. Daarnaast kondigde men sinds 1954 nog enkele bijzondere regelingen af.

In de Sovjetunie werden de nationaliteitsrechtelijke regelingen na de eerste algemene nationaliteitswet van 1924 nog drie keer grondig veranderd $(1930,1938$, 1978). Thans heeft de USSR van alle Oosteuropese landen de meest recente mationaliteitswet. In de andere landen werden de nationaliteitswetten in de regel slechts één keer grondig gewijzigd. Uitzonderingen vormen Roemenië, waar het nationaliteitsrecht reeds tweemaal herzien werd en de DDR, waar men bij de "eerste" wet van 1967 is gebleven. De huidige nationaliteitswetten van overige landen dateren uit 1954 (Albanië), 1957 (Hongarije), 1962 (Polen), 1964 (Joegoslaviè), 1968 (Bulgarije, Tsjechoslowakije) en 1971 (Roemenië). In de meeste wetten werden daarna enkele (marginale) wijzigingen aangebracht. Afgezien van de nationaliteitsrechtelijke "vergeldingswetgeving" na de burgeroorlog in de RSFSR

1. Het decreet betreffende naturalisaties van 5 april 1918 , het familiewetboek van 16 september 1918 en de verordening betreffende ontneming van de nationaliteit aan emigranten van 28 oktober/15 december 1921.

2. Hoewel men in Bulgarije reeds in september 1944 de "burgerlijke" wetgeving begon te verwangen, lwam de nationaliteitswet pas in 1948 aan de beurt. 
en in verschillende andere landen na de tweede wereldoorlog, heeft men enkel in de DDR en Tsjechoslowakije aparte nationaliteitsrechtelijke regelingen getroffen, die betrekking hadden op ontneming van de nationaliteit aan illegale emigranten.

In alle landen met uitzondering van de USSR, Albanië en Roemenië verliep de ontwikkeling op het gebied van de nationaliteitswetgeving nadat de communistische partijen aan de macht kwamen zonder verrassende "omwentelingen". In de USSR bleef de regeling van 1930 duidelijk in de lijn van de eerste algemene wet van 1924. De stalinistische wet van 1938 brak echter met de lijn van zijn voorgangers af. De belangrijkste kenmerken van deze uiterst korte wet waren: in het geheel geen regeling van verkrijging van de nationaliteit door geboorte, het uitsluitend aangeven van het bevoegde orgaan bij naturalisatie, ontslag en ontneming en de praesumptio apatridiae van art. 8. Het Roemeense decreet van 1952 en de Albanese regeling van 1954 waren getrouwe copieën van het voorbeeld dat hen de "grote broer" in 1938 gaf. In beide landen ging het daarbij echter om reeds de tweede door de "nouveaux régimes" tot stand gebrachte regeling. In 1946 (Albanië) en 1948 (Roemenië) kwamen eerst redelijk uitgewerkte nationaliteitswetten tot stand, waarin een minder sterke invloed van de Sovjet-wetgeving te bespeuren was. Terwijl Albanië bij deze eigenaardige regeling uit 1954 is gebleven, keerde men in 1971 in Roemenië en in 1978 in de USSR terug naar uitgebreidere regelingen. De huidige nationaliteitswet van de USSR kan worden beschouwd al een voortzetting van de regelingen van 1924 en 1930. De huidige Roemeense wet vertoont zelfs vergaande overeenkomsten met de eerdere nationaliteitswet van 1939.

Met betrekking tot de andere landen is het moeilijk van een duidelijke voorbeeldwerking van het recht van de USSR te spreken. In de tijd waarin de communistische partijen in deze landen aan de macht kwamen gold in de Sovjetunie de wet van 1938 . Geen van de eerste nationaliteitswetten van de Oosteuropese socialistische landen kan als een copie van deze wet worden beschouwd. Wel kunnen met betrekking tot bepaalde onderwerpen overeenkomsten worden ontdekt met de regeling van de Sovjet-wet van 1938 of met vroegere Sovjetwetgeving, zoals het medebeslissingsrecht van kinderen boven een bepaalde leeftijd. in geval van naturalisatie en ontslag, het niet noemen van naturalisatie- en/of ontslagvereisten, het verlenen van beslissingsbevoegdheid met betrekking tot naturalisatie, ontslag en ontneming aan de hoogste staatsorganen, alsmede de regeling van verkrijging van de nationaliteit door onwettige kinderen.

\subsection{VerkRuIGING VAN DE NATIONALITERT}

De nationaliteit van de Oosteuropese landen wordt evenals in het Westen in de regel van rechtswege of door naturalisatie verworven. Verkrijging van de nationaliteit door een zuivere optie, is in Oost-Europa niet mogelijk ${ }^{3}$.

3. Dergelijke optierechten komen ook niet in alle Westeuropese landen voor. Geen zuivere optierechten kemnen bijvoorbeeld Duitsland, Frankrijk, Oostenrijk, Zwitserland. Cf. De Groot diss., p. 216-227. 


\subsection{Verkrijging wan rechtswege}

Verkrijging van de nationaliteit iure sanguinis is ook nadat de communistische partijen aan de macht kwamen het belangrijkste uitgangspunt gebleven. Ius soli is in alle landen slechts een subsidiaire verwervingsgrond voor het geval dat een kind anders staatloos zou zijn. Huwelijk kan in de Oosteuropese landen geen verkrijging van de nationaliteit ipso iure bewerkstelligen. Wel is een huwelijksrelatie met een onderdaan in diverse landen een grond voor verlichte naturalisatie.

\subsubsection{Ius sanguinis}

\subsubsection{Inleiding}

De regelingen van verkrijging van de nationaliteit iure sanguinis in Oost-Europa hebben in de tweede helft van de jaren veertig onder de invloed van communistische denkbeelden enkele principiële wijzigingen ondergaan, die zeer zeker als werbeteringen ten opzichte van het "oude" recht in die landen en het toenmalige recht van de Westeuropese landen moeten worden betiteld. A fortiori geldt dit voor de RSFSR/USSR, waar deze wijzigingen reeds bijna dertig jaar eerder dan in de andere Oosteuropese landen werden ingevoerd. Zo werd in alle Oosteuropese landen met uitzondering van Hongarije reeds bij de eerste "socialistische" nationaliteitsrechtelijke regellingen het ius sanguinis a patre et a matre ingevoerd; een kind kan zijn nationaliteit op gelijke voet zowel aan zijn vader als aan zijn moeder ontlenen.

Het tweede nieuwe uitgangspunt, dat met uitzondering van Hongarije, ook reeds sedert de eerste generatie van de "socialistische" nationaliteitswetten geldt, is gelijkstelling van wettige en onwettige kinderen. Een buitenechtelijk kind verkrijgt de nationaliteit van zijn vader, indien diens vaderschap hetzij door erkenning, hetzij gerechtelijk wordt vastgesteld. Een uitzondering vormde hierbij echter de USSR, waar tussen 1944 en 1968 een onwettig kind de Sovjet-nationaliteit uitsluitend iure sanguinis a matre kon verwerven.

\subsection{1.2 Ius sanguinis a patre et a matre, versus: meenoudige nationaliteit}

In alle Oosteuropese landen verwerft een kind, waarvan beide ouders de nationaliteit van het desbetreffende land bezitten, steeds het staatsburgerschap van dat land. In een dergelijk geval verkrijgt het kind in de regel derhalve ook geen meervoudige nationaliteit ${ }^{4}$.

Interessanter is echter na te gaan hoe de regelingen van verkrijging van de nationaliteit door uit nationaliteitsrechtelijk gemengde ouders geboren kinderen zich hebben ontwikkeld. Regelingen van dit onderwerp zijn een goede indicator van de doelstelling van een wetgever om het aantal onderdanen van het eigen land zoveel mogelijk uit te breiden. Dit geldt des te sterker, indien een ruime regeling van verkrijging van de nationaliteit niet wordt gecompenseerd door gemakkelijke

4. Afgezien wan gevallen waarin reeds eén van de ouders bipatride is of het kind in een ius soliland wordt geboren. 
mogelijkheden van vrijwillig verlies van het staatsburgerschap ten behoeve van biof polypatriden.

Dit kan worden geillustreerd aan de hand van het Nederlandse recht. Volgens art. 3 lid 1 RwNed is een kind van hetzij een Nederlandse moeder, hetzij een Nederlandse vader steeds Nederlander, ongeacht waar het wordt geboren. Heeft een dergelijk kind tevens een andere nationaliteit, dan kan hij na zijn meerderjarigheid het Nederlanderschap door een simpele verklaring verliezen (art. 15 sub b RwNed).

Kent een land eenzelfde regeling van verkrijging van de nationaliteit iure sanguinis als Nederland, maar hebben meerderjarig geworden bi- of polypatriden geen recht op eenvoudig verlies van de nationaliteit van dat land, dan komt hetgeen dat op het eerste gezicht ruimhartigheid van een nationale wetgever lijkt te zijn, op het opdringen van een nationaliteit neer. Een regeling die bovendien aan de staat de mogelijkheid geeft het verlies van de nationaliteit door betrokkene willekeurig te weigeren, verdraagt zich niet met art. 15 lid 2 van de Universele Verklaring van de rechten van de mens, dat een voorwaardelijk recht op het veranderen van de nationaliteit waarborgt (zie daarover p. 42-43). Dit recht houdt immers in, dat iemand die de nationaliteit van een bepaald land bezit, bij verkrijging van het staatsburgerschap van een ander land het recht moet hebben de eerste nationaliteit te verliezen. Geen ${ }^{5}$ van de Oosteuropese landen (behalve in bepaalde gevallen Joegoslavië) kent aan zijn onderdanen een recht op verlies van de nationaliteit toe. Betrokkene kan op zijn eigen wens slechts door ontslag zijn staatsburgerschap verliezen, waarbij de doctrine in die landen eenstemmig betoogt dat de verzoeker geen recht op ontslag heeft. Het ontslag kan in alle Oosteuropese landen op vage gronden willekeurig worden geweigerd.

Kinderen van ouders die de nationaliteiten van een Oost- en een Westeuropees land bezitten, worden zeer dikwijls bi- of polypatriden. Het staatsburgerschap van Bulgarije, de DDR, Hongarije, Roemenië en Tsjechoslowakije wordt namelijk steeds verkregen indien één van de ouders de nationaliteit van één van deze landen bezit, ongeacht waar het kind wordt geboren. Met een klein voorbehoud kan hetzelfde worden gezegd ten aanzien van kinderen van Sovjet-burgers, Albanezen en Polen ${ }^{6}$. De Joegoslavische nationaliteit wordt in een dergelijk geval echter uitsluitend automatisch verworven indien het kind in Joegoslavië wordt geboren.

Indien we de ontwikkeling van de regelingen van verkrijging van de nationaliteit iure sanguinis in de Oosteuropese landen na de machtsovername door de communistische partijen onder de loep nemen, kan een duidelijke tendens naar uitbreiding van verkrijging van het staatsburgerschap worden gesignaleerd. De enige uitzondering vormt Joegoslavië, waar de ontwikkeling juist in de tegenovergestelde richting is gegaan. Deze uitbreiding wordt echter voor een groot gedeelte weer teniet gedaan, voorzover beide ouders van het kind de nationaliteit van landen

5. Strikt genomen geldt dit niet voor Hongarije, waar men in een zeer beperkt geval de mogelijkheid van afstand kent (zie p. 187).

6. Volgens de Albanese en de Sovjet-regeling wordt de nationaliteit door een kind niet automatisch verworven indien zijn beide ouders in het buitenland wonen. Het begrip "woonplaats in het buitenland" dient echter zeer restrictief te worden geïnterpreteerd. In Polen hebben de ouders van het kind binnen drie maanden na zijn geboorte de mogelijkheid om verkrijging van de Poolse nationaliteit door middel van een verklaring te voorkomen. 
bezitten die met elkaar antibipatridieverdragen hebben gesloten ${ }^{7}$. Aangezien deze verdragen slechts tussen Oosteuropese landen onderling werden gesloten, moet worden geconstateerd dat de uitbreiding wan het iure sanguinis verkregen staatsburgerschap van Oosteuropese landen voornamelijk "Westwaarts" is gegaan. In Nederland geboren wettige kinderen van een Nederlandse en een Bulgaarse, DDR - Hongaarse, Roemeense of Tsjechoslowaakse burger zijn steeds bipatriden. Dikwijls ontstaat bipatridie ook indien de andere ouder van het kind Sovjet-burger, Albanees of Pool is. Hetzelfde geldt in het geval dat de "Westerse" ouder van het kind Belg, Brit, Duitser, Fransman, Griek, Italiaan, Spanjaard, of Zwitser is en het kind in dat land wordt geboren ${ }^{8}$. Met uitzondering van België en Groot-Brittannië wordt het kind ook steeds bipatride, indien het in een willekeurig ander land wordt geboren. Het bovenstaande geldt voorts ook indien het kind onwettig is en de moeder van het kind één van de genoemde "Westerse" nationaliteiten bezit. In het omgekeerde geval, dat de vader Westeuropeaan is, is het aantal bipatriden kleiner, aangezien een aantal Westeuropese landen ten aanzien van onwettige kinderen geen automatische verkrijging van de nationaliteit iure sanguinis a patre kent ${ }^{9}$.

\section{a. Het probleem}

Uit de uiteenzettingen op deze en de vorige pagina volgt, dat kinderen van een Oost- en een Westeuropeaan in de regel bipatriden worden. Aangezien de nationaliteit van de meeste Oosteuropese landen moeilijk te verliezen is, zullen zij dit dikwijls ook hun hele leven blijven. Met elke daaropvolgende generatie wordt het aantal van "Oost-West" bipatriden alleen nog groter.

Het bezit van een meervoudige nationaliteit kan voor de betrokkenen zelf in abstracto zowel voor- als nadelen hebben, hoewel de staten het zowel in het Westen als in het Oosten steeds als onwenselijk beschouwen. Of polypatridie in concreto voordelig is of niet, is afhankelijk van de vraag welke nationaliteiten betrokkene heeft. Gezien de huidige situatie in de Oosteuropese landen is het aannemelijk, dat een kind van een emigrant uit Oost-Europa, Joegoslavië wellicht ${ }^{10}$ uitgezonderd, in de regel niet de wens heeft om zich ooit in zijn tweede vaderland te vestigen, of op enig ander "voordeel" van zijn socialistische staatsburgerschap beroep te doen. Het gaat om personen die sedert hun geboorte in het Westen verblijven en geen voornemen hebben om ooit naar hun Oosteuropese vaderland te emigreren. Wel vinden ze het dikwijls aangenaam om als toeristen of in het kader van familiebezoek naar die landen te reizen. Dergelijke reizen zijn ook in thet belang van de Oosteuropese landen, aangezien ze een belangrijke bron van harde valuta zouden kunnen zijn. Een groot beletsel daarvoor vormt echter het feit dat alle Oosteuropese landen personen, die hun eigen en een of meer andere nationali-

7. Zie daarover p. 45-48.

8. Zie art. 8 BNW voor België, Section $1 \mathrm{en} 2$ BNA voor Groot-Brittannie, \$ 4 RuSLAG voor de BRD, art. 17 CNF voor Frankrijk, art. 5 van de wet wan 1983 voor Italiè, 7 ostBG voor Oostenrijk, art. 7 C.c. esp. voor Spanje, art. 1 BüG woor Zwitserland.

9. Zie voor een overzicht De Groot diss., p. 199-203.

10. Bij de emigratic uit de meeste Joegoslavische deelstaten gat het voornamelijk om economische emigranten en spelen de politieke bezwaren tegen de terugkeer een minder sterke rol als bij de andere landen. Gezien de steeds sterkere politieke en economische crisis in dit land lijkt mij Joegoslavië zijn uitzonderingspositie langzamerhand te verliezen. 
teiten bezitten, uitsluitend als hun eigen onderdanen behandelen. Dit zogenaamde exclusiviteitsbeginsel wordt in alle Oosteuropese landen zeer sterk benadrukt. Zulks impliceert dat personen met Oosteuropese en Westerse nationaliteiten hun Oosteuropese "vaderland" niet met hun Westerse paspoort mogen bezoeken, dat zij toestemming van dat land voor verblijf in het buitenland nodig hebben, dat ze tevens in dat land dienstplichtig zijn en hen de terugreis kan worden geweigerd. Hoewel het mij niet aannemelijk lijkt dat iemand die zijn grootouders in een Oosteuropees land bezoekt, prompt in militaire dienst zal worden opgeroepen, of wegens gebruik van een vreemd paspoort of vanwege ongeautoriseerd verbliff in het Westen strafrechtelijk zal worden vervolgd, bestaat die mogelijkheid in ieder geval theoretisch we ${ }^{11}$. Een dergelijke mogelijkheid, die door de Westerse media helaas niet zelden door resten van koude-oorlog propaganda wordt "opgeblazen", wordt echter door betrokkenen als een belangrijke belemmering voor een eventueel bezoek aan het tweede vaderland beschouwd.

\section{b. Twee mogelijke oplossingen}

De zojuist geschetste problemen kunnen op twee wijzen worden opgelost. De eerste mogelijkheid is de door geboorte verkregen meervoudige nationaliteit op verdragsbasis te beperken. Dit zou kunnen gebeuren door het sluiten van bilaterale werdragen tussen afzonderlijke West- en Oosteuropese landen.

Bij het ontwerpen van dergelijke verdragen zouden de reeds bestaande verdragen in Oost-Europa voor een groot gedeelte als voorbeeld kunnen dienen. De ouders van een pasgeboren bipatride kind zouden dan moeten worden verplicht binnen een bepaalde termijn na de geboorte van het kind gezamenlijk te beslissen welke nationaliteit het kind zal hebben. Het zou dan naar mijn mening wenselijk zijn om aan dergelijke kinderen bij het bereiken van de meerderjarigheid de mogelijkheid te geven, om op vereenwoudigde wijze (optie, verlichte naturalisatie) de nationaliteit van de andere ouder te verwerven. Door de gebruikmaking van deze mogelijkheid zou de oorspronkelijk verkregen nationaliteit automatisch moeten worden verloren.

Uiteraard moet hier de vraag worden gesteld in hoeverre de Oosteuropese staten bereid zouden zijn dergelijke verdragen te sluiten. Naar mijn mening zijn er gronden voor enig optimisme aanwezig. Zo wordt bijvoorbeeld door Riege ${ }^{12}$ betoogd, dat de DDR degelijke regelingen zelfs nastreeft. Voorts kan ook op grond van het feit dat deze landen onderling antibipatridieverdragen hebben gesloten, worden geconcludeerd dat men dergelijke regelingen wenselijk acht. Niet in de laatste plaats schept ook de huidige dooi in de Oost-West betrekkingen een gunstig klimaat voor de totstandkoming van deze regelingen.

Bezwaarlijk voor de Oosteuropese staten zou echter kunnen zijn, dat deze antibipatridieverdragen ook betrekking zouden hebben op personen die in OostEuropa worden geboren en wier ouders waarschijnlijk voor de Westerse nationaliteit zullen kiezen, zodat deze kinderen derhalve niet gedwongen zouden kunnen worden om na de meerderjarigheid in Oost-Europa te blijven. Thans kunnen de

11. Cf. Hecker, WGO 1986, p. 32.

12. Riege, p. 300-301. 
Oosteuropese landen een eventueel bezit wan een Westerse nationaliteit door een dergelijke persoon immers eenvoudig negeren.

De tweede oplossing is, dat in verdragen niet het bezit van dubbele nationaliteit wordt tegengegaan, maar slechts de voor betrokkene nadelige gevolgen daarvan. De verdragsluitende partijen zouden zich dan moeten verplichten bipatriden die in de andere staat wonen, uitsluitend als onderdaan van de staat waarin ze wonen te beschouwen. Een bijwoorbeeld in Nederland wonende Nederlander/Roemeen zou dan met zijn Nederlandse paspoort zijn grootouders in Roemenië kunnen bezoeken, zonder dat men hem daar aan enige verplichtingen van Roemeense staatsburgers zou mogen "herinneren". Deze mogelijkheid komt derhalve neer op regelingen, die de VS reeds met Bulgarije, DDR, Joegoslaviẽ en Polen hebben getroffen ${ }^{13}$. Deze tweede oplossing van het probleem heeft om de volgende redenen mijn sterke voorkeur:

De omstandigheid dat verschillende van dergelijke verdragen reeds tussen de VS en enkele Oosteuropese landen bestaan, getuigt wan het feit dat het althans met betrekking tot een aantal landen om een politiek haalbare oplossing gaat.

Een dergelijke regeling zou voor betrokkenen zelf minder ingrijpend zijn dan het voorkomen van meervoudige nationaliteit. De situatie in Oost-Europa kan immers dusdanig veranderen, dat het bezit van de nationaliteit van althans bepaalde Oosteuropese landen niet meer als bezwaarlijk kan worden beschouwd. Dit kan m.i. reeds nu met betrekking tot het Joegoslavische en wellicht ook ten aanzien van het Hongaarse en Poolse staatsburgerschap ${ }^{14}$ worden gezegd.

Ook voor de Oosteuropese landen zou een dergelijke regeling niet te ingrijpend zijn en daardoor waarschijnlijk politiek meer aanvaardbaar. We moeten namelijk niet vergeten dat de bestaande antibipatridieverdragen slechts tussen socialistische landen onderling werden gesloten, zodat de desbetreffende personen nog steeds binnen hun "eigen kring" van de "socialistische" landen blijven.

Voorts zouden dergelijke regelingen slechts betrekking hebben op personen. die in het Westen wonen en die men in Oost-Europa als staatsburger de facto toch al "kwijt" is.

Gezien het bovenstaande concludeer ik dat de als tweede aangedragen mogelijkheid zeer zeker een reële en voor alle betrokken partijen aanvaardbare oplossing van door het bezit van meervoudige nationaliteit ontstane problemen biedt. Het sluiten van dergelijke verdragen is in het gemeenschappelijk belang van alle Westerse landen waar zich emigranten uit Oost-Europa bevinden. Om deze reden acht ik het wenselijk dat het sluiten van deze verdragen in het kader van de Raad van Europa en van de EG wordt bevorderd. Gezien het feit dat de Conferentie voor Veiligheid en Samenwerking in Europa (CVSE) een kader voor besprekingen tussen "Oost en West" op hoog niveau vormt, zou het sluiten van dergelijke verdragen ook in dit verband ter sprake kunnen worden gebracht.

13. Voorts bestaat er een dergelijk verdrag tussen de DDR en Oostenrijk. Door Hecker, WGO 1986, p. 33, wordt de wenselijkheid van een overeenkomstige regeling tussen de beide Duitse staten onderstreept.

14. De politieke ontwikkelingen in deze beide landen wijzen op een zeer sterke liberaliseringstendens. Een illustratie hiervan is de recente versoepeling van de paspoortwetgeving in Hongarije, waarin het recht op verlaten van het land zelfs tot een grondrecht wordt verheven. 


\subsection{Onwettige kinderen}

Het tweede nieuwe uitgangspunt dat in het nationaliteitsrecht van de socialistische landen zeer vroeg werd ingevoerd, is gelijkstelling van wettige en onwettige kinderen. Men heeft de regel doorbroken, volgens welke wettige (dus ook gewettigde) kinderen hun nationaliteit aan hun vader ontleenden en onwettige in beginsel aan hun moeder.

In de Oosteuropese nationaliteitswetten zijn geen aparte regelingen wan verkrijging van de nationaliteit door erkenning, respectievelijk gerechtelijke vaststelling van vaderschap opgenomen. Ten aanzien van onwettige kinderen gelden gewoon dezelfde regelingen als met betrekking tot wettige. Verkrijging van de nationaliteit wordt gekoppeld aan het bestaan van familierechtelijke betrekkingen tussen ouder en kind, die aan de hand van de regels van het personen- en familierecht dienen te worden vastgesteld. De consequentie hiervan is, dat onwettige kinderen ingevolge erkenning of gerechtelijke vaststelling van vaderschap de nationaliteit van hun Oosteuropese vader verkrijgen.

De redenen voor de nationaliteitsrechtelijke gelijkstelling van wettige en onwettige kinderen moet naar mijn mening worden gezien in twee omstandigheden. De eerste ligt besloten in het ius sanguinis-beginsel zelf. Alle landen in OostEuropa zijn traditioneel typische "ius sanguinis"- landen. Consequente toepassing van dit uitgangspunt eist, dat het bestaan van een feitelijke (in de regel dus ook juridische) afstammingsband tot de verkrijging van de nationaliteit iure sanguinis a patre leidt. De sociale band tussen ouder en kind is hierbij niet van belang. We moeten namelijk niet vergeten dat een onwettige vader met de moeder en het kind in een op een huwelijk lijkende relatie samen kan wonen, maar ook uitsluitend de functie van zogenaamde "Zahlvater" kan hebben, zonder er een andere dan financiële relatie met het kind op na te houden. Zelfs een eventueel verval van de familierechtelijke betrekking tussen ouder en kind door adoptie door buitenlander(s) heeft in geen enkel Oosteuropees land automatische gevolgen voor de nationaliteit van het kind, ook indien het door adoptie het staatsburgerschap van zijn adoptief-ouder(s) verwerft.

De tweede reden voor de vroege nationaliteitsrechtelijke gelijkstelling van wettige en onwettige kinderen in Oost-Europa is naar mijn mening de wens om elke discriminatie op grond van geboorte uit te bannen. Het gelijkheidsbeginsel wordt immers door de communisten zeer sterk gepropageerd.

In het Westen wordt in België, Finland, Frankrijk, Griekenland, Italië, Luxemburg, Portugal, Spanje, Turkije en volgens het voorontwerp voor een nieuwe Zwitserse nationaliteitswet ${ }^{15}$, de nationaliteit door erkenning of gerechtelijke vaststelling van vaderschap verkregen. Geen verkrijging van de nationaliteit iure sanguinis a patre van rechtswege kennen echter Denemarken, Duitsland, GrootBrittannië, IJsland, Ierland, Noorwegen, Oostenrijk en Zweden ${ }^{16}$.

15. België (art. 8 jo. art. 3 BNW), Finland ( $\$ 3$ a), Frankrijk (art. 29 CNF), Griekenland (art. 2), Italie (art. 5 lid 1), Luxemburg (art. 2), Portugal (art. 1), Spanje (17 lid 2 C.c. esp.), Turkije (art. 2) en Zwitserland (art. 1 voorontwerp). Een overzicht van de regelingen van een aantal zojuist genoemde landen wordt gegeven door De Groot diss., p. 201-203.

16. In Zweden wordt de nationaliteit op werzoek echter wel verkregen indien de vader ouderlijk gezag uitoefent en beide ouders on de nationaliteitsverkrijging vragen. Een kind ouder dan 15 jaar heeft bovendien een instemmingsrecht. 
Nederland neemt een zeer eigenaardige positie in. Terwijl een minderjarige vreemdeling die door een Nederlander wordt erkend, van rechtswege Nederlander wordt, wordt de nationaliteit bij een gerechtelijke vaststelling van vaderschap niet werkregen ${ }^{17}$. Dit is het gevolg van de regeling van het BW (art. 1: 394), waardoor een geslaagde vaderschapsactie geen vestiging van familierechtelijke betrekkingen tussen "vader" en kind ten gevolge heeft, maar slechts alimentatieverplichting van de vader tegenover het kind. Volgens art. 1 jo. art. 3 RwNed kan de Nederlandse nationaliteit namelijk uitsluitend aan de "juridische" vader worden ontleend ${ }^{18}$.

Het is niet uitgesloten dat in de toekomst in het perspectief van het uitbannen van discriminatie op grond van geboorte ook landen die thans geen verkrijging van het staatsburgerschap iure sanguinis a patre met betrekking tot onwettige kinderen kennen, een dergelijke regeling invoeren, zoals men bijwoorbeeld in Zwitserland voomemens is. De vraag is echter of er in alle gevallen waarin voor verkrijging van de nationaliteit iure sanguinis a patre door onwettige kinderen naast de afstamming additionele eisen worden gesteld, gesproken kan worden van discriminatie.

Een belangrijke overweging om de afstammingsband sec als onvoldoende voor automatische verkrijging van de nationaliteit iure sanguinis a patre te beschouwen, is de omstandigheid, dat een onwettig kind dikwijls geen, of althans minder sterke sociale banden met zijn vader heeft dan een wettig kind. Dit argument geldt echter niet ten aanzien van kinderen van ouders, die in een op huwelijk lijkende relatie samenwonen. Indien ze in dit geval niet op dezelfde voorwaarde de nationaliteit aan hun vader kunnen ontlenen als wettige kinderen, is er m.i. sprake van discriminatie. Om dit probleem op te lossen, is een regeling denkbaar, volgens welke onwettige kinderen, die wel aan een bepaald minimum aan sociale banden met hun vader voldoen, bijwoorbeeld gemeenschappelijke huishouding gedurende een zekere periode, dezelfde nationaliteitsrechtelijke positie moeten hebben als wettige kinderen. Aan wettige kinderen zouden dan echter ook dezelfde minimumeisen met betrekking tot de sociale band tot hun vader moeten worden gesteld. Zo zou een wettig kind geen nationaliteit mogen ontlenen aan een vader die niet samen met de moeder en het kind woont, etc. Het is echter evident dat het ontwerpen van een regeling van objectieve additionele eisen met betrekking tot de sociale band tussen vader en kind, die in geen geval een discriminerende uitwerking zou hebben en waardoor de rechtszekerheid niet zou worden aangetast, een onbegonnen werk is. Hiernaast bestaan nog twee alternatieven.

Het eerste zou het verlaten van de bloedband als het toedelingscriterium voor de nationaliteitsverkrijging zijn. De verwerving van de nationaliteit door een kind zou voortaan uitsluitend aan een soort "sociaal ouderschap" worden gekoppeld. Hier zouden echter enorme problemen mee gemoeid zijn. Allereerst zouden aan dit "ouderschap" bepaalde minimumeisen moeten worden gesteld, namelijk een bepaald minimum aan sociale contacten tussen "ouder" en kind. Er zouden echter meer personen aan de gestelde eisen kunnen voldoen. Hierbij kan worden gedacht aan de juridische ouders, lesbische en homoparen, pleegouders, of wellicht zelfs aan buren, die langdurig "babysitten", terwijl de wettige ouders het kind vanwege hun

17. Zie kritisch daarover Tratnik, NJB 1989, p. 298.

18. Zie voor de definitic van het begrip "vader" art. 1 sub $d$ RwNed: "...de man tot wie het kind anders dan door adoptie, in de cerste graad in opgaande lijn in familierechtelijke betrekking staat;". 
drukke banen nauwelijks zien. Zo zou het kunnen voorkomen, dat meer "ouders", met verschillende nationaliteiten, aan de minimumeisen voor verkrijging van hun nationaliteit door het kind voldoen. Het moge duidelijk zijn dat een dergelijke "oplossing" een enorme chaos zou veroorzaken.

Het tweede alternatief zou zijn gelegen in het schrappen van verkrijging van de nationaliteit iure sanguinis a patre zowel bij wettige, als bij onwettige kinderen. Een kind zou dan uitsluitend aan zijn moeder de nationaliteit ontlenen. Een dergelijke regeling zou echter in plaats van de kinderen hun vaders discrimineren en is reeds om deze reden onbruikbaar.

We hebben zojuist gezien dat het onmogelijk is om een goed alternatief voor de verkrijging van de nationaliteit iure sanguinis a patre door onwettige kinderen te bedenken. Het enige criterium dat objectief en relatief gemakkelijk vast te stellen is, is de juridische afstamming, althans de bloedband ${ }^{19}$. Indien verkrijging van de nationaliteit van de vader van rechtswege aan deze voorwaarde sec wordt verbonden, kan in geen geval wan discriminatie worden gesproken. Wellicht zou tegen een dergelijke oplossing kunnen worden ingebracht dat dan ook een kind dat zijn vader nooit heeft gezien, aan hem (misschien daarom ten onrechte) de nationaliteit zou ontlenen. Dit kan echter ook worden gezegd met betrekking tot wettige kinderen, wier vader reeds voor de geboorte wan het kind de moeder heeft verlaten. In dit geval wordt de Nederlandse nationaliteit namelijk wel verkregen, indien de vader Nederlander is. Bovendien zie ik niet in waarom het vaderschap als zodanig niet een toereikende grond voor verkrijging van de nationaliteit iure sanguinis zou kunnen zijn. Vanuit dit perspectief zie ik de regelingen in de Oosteuropese landen, die alle voor het enkele criterium van het juridische vaderschap ${ }^{20}$ hebben gekozen, als de optimale regelingen van verkrijging van de nationaliteit door onwettige kinderen.

\section{a. Een voorstel tot wijziging van het Nederlands recht}

Reeds in de vorige paragraaf werd gewezen op de thans onbevredigend geregelde nationaliteitsrechtelijke positie van natuurlijke kinderen van niet-Nederlandse vrouwen, wier afstamming van een Nederlandse vader door de rechter wordt vastgesteld $^{21}$. Naar huidig recht verwerven ze zoals gezegd de Nederlandse nationaliteit niet. Dit lijkt mij niet in overeenstemming te zijn met in art. 1 van de grondwet neergelegde gelijkheidsbeginsel, noch met het ius sanguinis beginsel, dat de belangrijkste grond voor verkrijging van het Nederlanderschap vormt. Het laatstgenoemde uitgangspunt houdt in, dat een kind van een Nederlander de Nederlandse nationaliteit dient te bezitten, omdat, wat pathetisch gezegd, hem "Neêrlands bloed door d'aadren vloeit". Zo wordt het Nederlanderschap verkregen door wettige kinderen van een Nederlander (art. 3), door kinderen die door een Nederlanders worden erkend, gewettigd (art. 4), of zelfs geadopteerd (art. 5). We mogen echter niet vergeten dat het bloed bij de eerste drie de iure weliswaar

19. De bloedband zou als een subsidiair criterium kunnen dienen in gevallen, waarin thet kind geen juridische vader heeft, terwijl zjjn afstamming wel door een rechterlijke beslissing vaststaat, zoals het naar positief Nederlands recht mogelijk is.

20. Gerechtelijke vaststelling van vaderschap is in al deze landen mogelijk en er worden daardoor familierechtelijke betrekkingen gewestigd.

21. Zie over dit onderwerp colk Tratnik, NJB 1989, p. 298. 
"Neêrlands" is, doch de facto ook Belgisch, Duits, Frans, etc. kan zijn. Bij de geadopteerde kinderen bestaat de bloedband zelfs dikwijls in het geheel niet. Is het vaderschap met betrekking tot een Nederlandse man gerechtelijk vastgesteld, dan bestaat heden geen twijfel meer dat de vader van het kind Nederlander is. Voor het nationaliteitsrecht geldt dit echter niet. De wetgever verschuilt zich achter de onaanvaardbare "oplossing" van het BW dat het vaderschap, hoewel het onomstotelijk door een rechter werd vastgesteld, nog steeds ontkent. Hierdoor wordt een onderscheid tussen erkende en niet-erkende kinderen geschapen, dat de toets aan art. 1 grondwet (de rechter mag dat "dankzij" art. $120 \mathrm{GW}$ niet doen, de wetenschap en het parlement echter wel) niet kan doorstaan.

De Groot stelt met het oog op de naderende wijziging van het afstammingsrecht ${ }^{22}$, waardoor een gerechtelijke vaststelling van het vaderschap familierechtelijke betrekkingen tussen het kind en zijn door de rechter "vastgestelde" vader zal doen ontstaan, voor, om tegelijkertijd een daarmee corresponderende wijziging van de nationaliteitswet in te voeren. Voor de periode vo6r de wijziging van het afstammingsrecht, staat hij slechts een optierecht ten behoeve van dergelijke kinderen voor ${ }^{23}$. Aangezien ook een optierecht slechts door een wijziging van de RwNed kan worden ingevoerd, zou ik willen bepleiten direct consequent te zijn en verkrijging van de nationaliteit van rechtswege in te voeren. De nationaliteitsverkrijging wordt in de huidige regeling weliswaar gekoppeld aan het bestaan van familierechtelijke betrekkingen, doch geheell vanzelfsprekend is dat niet. In een typisch ius sanguinis-land zoals Nederland, is het evengoed denkbaar dat verkrijging van de nationaliteit ook aan een feitelijke afstammingsrelatie wordt gekoppeld ${ }^{24}$.

\subsubsection{Naturalisatie en optie}

Een algemene karakteristiek van de regelingen van de naturalisatie in Oost-Europa is, dat in geen enkel land naturalisatie als een aan bepaalde voorwaarden gebonden recht van de verzoeker wordt beschouwd. Hetzelfde geldt overigens ook ten aanzien van alle Westeuropese landen. Enkel in Nederland werd van regeringszijde betoogd dat naturalisatie een recht is, doch enkele te vaag geformuleerde naturalisatievereisten maken ook hier een recht op naturalisatie illusoir. Het belangrijkste verschil tussen de regelingen van naturalisatie in Oost en WestEuropa ligt in het feit, dat in Oost-Europa in de regel geen mogelijkheden bestaan voor een onpartijdige rechterlijke controle van naturalisatiebesluiten. Een dergelijke mogelijkheid bestaat bijvoorbeeld in Nederland wel ${ }^{25}$.

22. TK $1987-88,20626$, nr. $11-2$.

23. De Groot diss., p. 323-324.

24. Zie in dit verband de reeds in 1940 verschenen diss. van Djuvara, waar hij op p. 50 m.b.t. het Roemeense recht stelt: "Il est absurde dans un pays de jus sanguinis qu'un individu qui a réussi a établir judicairement sa fuliation me puisse pas bënéficier de la nationalité de son père."

25. Tegen een afwijzing van een naturalisatieverzoek die door de Minister wan justitie geschiedt, staat krachtens de wet AROB beroep open bij de Afdeling Rechtspraak van de Raad wan State. Zie De Groot/Tratnik, p. 125-127. 
Met betrekking tot de regelingen van naturalisatievereisten valt op dat de verblijfseisen in de regel korter zijn dan in West-Europa ${ }^{26}$ en dat in alle landen behalve Joegoslavië en Roemenië minderjarigen zelfstandig kunnen worden genaturaliseerd. Voorts valt op dat in de USSR, Albanië en de DDR in de wet niet of nauwelijks naturalisatievereisten worden genoemd. Hierdoor wordt de discretionaire bevoegdheid van de staatsorganen alleen maar vergroot. Verder is het opmerkelijk dat er ruime mogelijkheden bestaan om personen die niet in de desbetreffende staat wonen, te naturaliseren.

Regelingen van zuivere optierechten ten behoeve van meerderjarigen komen in Oost-Europa niet voor. Reeds onder het oude recht kenden slechts enkele Oosteuropese landen verkrijging van het staatsburgerschap door optie. Geen zuivere optierechten kennen thans in West-Europa bijvoorbeeld de BRD, Frankrijk, Oostenrijk en Zwitserland.

Het feit dat een zuivere optie in de Oosteuropese landen niet mogelijk is, doet vermoeden dat dit een bijzonderheid van het socialistische nationaliteitsrecht is. Dit zou ook in overeenstemming zijn met het in Oost-Europa verdedigde theoretische standpunt dat de nationaliteit niet zonder beslissende medewerking van de staat mag worden verkregen of verloren. Opmerkelijk is echter dat de nationaliteitswetten van vele Oosteuropese landen de ouders van een kind, alsmede kinderen boven een bepaalde leeftijd zelf, juist wel in een aantal gevallen over verkrijging of verlies van de nationaliteit laten (mee) beslissen. Hierbij denk ik aan het recht van ouders om in bepaalde gevallen de nationaliteit van het kind te bepalen (USSR, Joegoslavië) of althans verkrijging van een nationaliteit te voorkomen (Polen) en aan de in de meeste Oosteuropese landen voorkomende regels met betrekking tot medenaturalisatie en medeontslag van minderjarigen die de ouders van het kind en aan het kind zelf een medebeslissingsrecht verlenen. Ook in de meeste antibipatridieverdragen die deze landen onderling hebben gesloten, wordt aan betrokkene zelf, of aan zijn ouders (bij minderjarigen) in vele gevallen de mogelijkheid gegeven om over verkrijging of verlies van de nationaliteit te beslissen. Het is echter wel zo, dat het in deze verdragen steeds om een keuze tussen twee Oosteuropese nationaliteiten gaat.

Voorts werd er reeds op p. 29 op gewezen dat de grens tussen verkrijging van de nationaliteit door optie enerzijds en door verlichte naturalisatie anderzijds, dikwijls zeer moeilijk is te trekken. In de praktijk gaat het dikwijls slechts om een theoretisch verschil. De meeste Oosteuropese landen kennen namelijk zeer uitgebreide mogelijkheden van verlichte naturalisatie, die grosso modo met de "gecontroleerde opties" in vele Westerse landen overeenkomen. De nationaliteit wordt verworven op grond van een verklaring/verzoek van betrokkene, die door de staat moet worden "geaccepteerd". Voor verkrijging van de nationaliteit worden weinig eisen gesteld en het staatsorgaan dat de beslissing neemt, heeft discretionaire bevoegdheid.

26. In geen van de Oosteuropese landen wordt de verblijfseis op meer dan 5 jaren gesteld. In WestEuropa wordt een verblijf van 12 jaar geëist in Zwitserland; 10 jaar in de BRD, Oostenrijk, Spanje; 7 jaar in Noorwegem; 6 jaar in Portugal en 5 jaar in Belgiè, Frankrijk, Groot-Brittannié, IJsland, Ierland, Italie, en Nederland. 
Het bovenstaande leidt naar mijn mening tot de slotsom dat in de Oosteuropese landen ondanks het ontbreken van "echte" optierechten vele mogelijkhedien voor eenvoudige verkrijging van het staatsburgerschap bestaan, doch de staat behoudt zich in de regel slechts het recht voor, om desgewenst in concrete gevallen "een stokje" voor de verwerving van de nationaliteit te steken. Het belangrijkste verschil met betrekking tot vereenvoudigde verkrijging van de nationaliteit (optie, verlichte naturalisatie) tussen de West- en Oosteuropese landen ligt derhalve in de onbegrensde beslissingsmacht van de staat(sorganen) in Oost-Europa.

\subsection{VERLIES VAN DE NATIONARTTETT}

In de Oosteuropese landen kan de nationaliteit worden verloren door ontslag en ontneming. Verlies door het afleggen van een verklaring van afstand kent slechts Joegoslavië en in één uiterst beperkt geval Hongarije. Geen van de Oosteuropese landen kent echter verlies van het staatsburgerschap van rechtswege.

\subsubsection{Ontslag en afstand}

Geen van de Oosteuropese landen kent een recht op ontslag. Overal wordt de discretionaire bevoegdheid van het beoordelende orgaan voorop gesteld. Ook hier is Joegoslavië tot op zekere hoogte een uitzondering. Daar heeft de verzoeker een zekere "Entlassungsanspruch". Aan iemand die aan alle overige vereisten ${ }^{27}$ voldoet, kan het ontslag slechts op gronden van staatsveiligheid of de belangen van de staat worden geweigerd. Deze weigeringsgrond is echter zo vaag dat het recht op ontslag ook in Joegoslavië op wankele voeten staat.

De conclusies die met betrekking tot de naturalisatie werden getrokken kunnen ook op deze plaats worden herhaald. De staat behoudt zich steeds het recht voor, om met betrekking tot het verlies van de nationaliteit het laatste woord te spreken.

De regelingen van ontslag uit de nationaliteit zijn nauw verbonden met de mogelijkheden om het land te verlaten. Geen van de Oosteuropese landen kent een onvoorwaardelijk recht op emigratie. In Hongarije, Joegoslavië en Polen bestaat een dergelijk recht theoretisch wel, doch de wettelijke regelingen van deze landen bieden toch nog voldoende mogelijkheden om dit "recht" willekeurig te ontzeggen. Deze mogelijkheden worden echter in de praktijk van alle drie de landen relatief zelden toegepast. In de andere landen wordt in de regel slechts emigratie van etnische minderheden en in verband met gezinshereniging beperkt toegestaan. Uit de praktijk van verschillende staten blijkt voorts dat de regelingen van emigratievergunningen en ontslag uit de nationaliteit dikwijls worden gebruikt om de staatskas te vullen. De verlangde bedragen zijn in de regel hoger, indien betrokkene naar het Westen wenst te emigreren. Bovendien zijn ze duidelijk hoger dan de reële kosten van de procedure en staan in wanverhouding met het gemiddelde inkomenspeil in die landen. Daarnaast moet men in ieder geval in de USSR, Bulgarije, Roemenië en de ČSSR de kosten van zijn opleiding "vergoeden". Het meest schrijnende voorbeeld gaf Roemenië met zijn decreet van 1982 waarin

27. Meerderjarigheid, vervulde verplichtingen tegenover de staat en tegenover natuurlijke personen, geen strafrechtelijke procedure en bewijs van het bezit, respectievelijk waarschijnlijke verkrijging van een andere nationaliteit. 
deze vergoeding op 3.000-4.000 Dollars per studiejaar werd vastgesteld en betrokkene bovendien zijn onroerende goederen in Roemenië worden ontnomen. Thans wordt voor emigratie van etnische Duitsers een som van ongeveer DM 10.000 verlangd, die echter door de BRD wordt betaald. Ook in andere Oosteuropese landen bevinden zich etnische Duitsers in de regel in een betere positie dan andere potentiële emigranten. Ze emigreren in de regel naar de BRD waarvan ze de nationaliteit soms reeds bezitten, of deze in elk geval gemakkelijk door naturalisatie kunnen verwerven. Bovendien bevordert de BRD hun emigratiemogelijkheden door daar kredietfaciliteiten voor de Oosteuropese landen tegenover te stellen.

In de USSR (met betrekking tot Joden) en de in DDR wordt de mogelijkheid tot emigratie gekoppeld aan het daaraan voorafgaande ontslag uit de nationaliteit. De strekking daarvan is tweeledig: in de eerste plaats heeft de staat de mogelijkheid om van een eerste toestemming alsnog af te zien. In de tweede plaats wordt op deze wijze tweemaal betaling door betrokkene vereist. Eerst voor het ontslag en dan nog eens voor de toestemming om bet land te verlaten.

Het feit dat het ontslag in alle Oosteuropese landen willekeurig kan worden geweigerd staat tenslotte op gespannen voet met art. 15 lid 2 van de Universele verklaring van de rechten van de mens, dat een voorwaardelijk recht op het veranderen van de nationaliteit waarborgt en uitdrukkelijk bepaalt dat dit recht niet willekeurig mag worden ontzegd (zie daarover p. 42-43). Gezien het nauwe verband tussen de mogelijkheden om het land te verlaten en de mogelijkheden wan verlies van de nationaliteit kan ook worden gesteld, dat de regelingen van alle Oosteuropese landen op gespannen voet staan met art. 12 lid 2, dat het recht geeft om een land, ook het eigen, te verlaten In al deze landen kan dit recht namelijk willekeurig worden geweigerd.

Slechts in Joegoslavië en in één zeer specifiek geval in Hongarije kan de nationaliteit door afstand worden verloren. In alle overige Oosteuropese landen is ontslag de enige mogelijkheid om vrijwillig de nationaliteit te verliezen. Ook onder de vigeur van het oude recht bestonden in de meeste Oosteuropese landen geen mogelijkheden van afstand van de nationaliteit. In de Westerse landen daarentegen, wordt aan meerderjarige polypatriden in de regel wel de mogelijkheid gegeven om van hun nationaliteit afstand te doen ${ }^{28}$.

\subsubsection{Ontmeming}

De mogelijkheid van ontneming van de nationaliteit bestaat in alle Oosteuropese landen. De meest voorkomende ontnemingsgronden zijn "schending van de loyaliteitsplicht" en "handelingen die de staat kunnen schaden". Ontneming van de nationaliteit is in alle Oosteuropese landen behalve Joegoslavië zelfs mogelijk in het geval dat betrokkene daardoor staatloos wordt.

Voorts valt te constateren dat de ontnemingsgronden in alle landen erg vaag zijn geformuleerd, dat de daadwerkelijke beslissing aan de discretie van het bevoegde orgaan wordt overgelaten en dat er geen (reële) rechtsmiddelen tegen ontneming openstaan. Deze omstandigheden leiden tot de slotsom dat het in alle Oosteuropese landen mogelijk is om de nationaliteit willekeurig te ontnemen. Een

28. Cr. De Groot diss., p. 287-290. 
dergelijke mogelijkheid is in strijd met art. 15 lid 2 van de Universele verklaring, dat willekeurige ontneming van de nationaliteit verbiedt (zie p. 41-42). Voorts kan op grond van het feit dat ontneming ook mogelijk is indien betrokkene daardoor staatloos wordt, geconcludeerd worden, dat de regelingen van ontneming van de nationaliteit van alle Oosteuropese landen, behalve Joegoslavië in strijd met het in art. 15 eerste lid van de Universele verklaring gewaarborgde recht op een nationaliteit zijn (zie p. 41).

Ondanks de brede wettelijke mogelijkheden wordt in de praktijk van de mogelijkheid van ontneming zeer weinig gebruik gemaakt. Ontneming van de nationaliteit komt slechts in enkele gevallen met name in de USSR, de DDR en de CSSR voor, ten aanzien van in het buitenland wonende dissidenten. In de laatste decennia hebben slechts de DDR en de ČSSR enkele regelingen van collectieve ontmeming van de nationaliteit aan emigranten tot stand gebracht. In beide landen bleken die regelingen echter niet te werken. Daarom is het niet verbazingwekkend dat men met verschillende "amnestieregelingen" en nadere regels met betrekking tot illegale emigranten (ĆSSR) de effecten van collectieve ontnemingen will beperken.

Het feit dat de nationaliteit zelden wordt ontnomen, kan worden verklaard door het feit dat dit rechtsinstituut verouderd is. Ontneming heeft alleen een doel als de functie van het bezit van een nationaliteit als een onderscheiding, zowel door de staat, als door betrokkene zelf als zeer belangrijk worden gezien. Het is weliswaar zo dat de wetten van de USSR, de DDR en Roemenië die indruk geven, doch het feit dat ontneming van de nationaliteit zelden voorkomt, bewijst het tegendeel. De desbetreffende passages uit de nationaliteitswetten van deze landen ${ }^{29}$ hebben eigenlijk een propagandistische functie, waaraan niet al te veel belang dient te worden gehecht. Zelfs in de DDR waar laatstelijk in 1981 een collectieve ontnemingswet werd uitgevaardigd, stelt Riege ${ }^{30}$ uitdrukkelijk dat ook personen de nationaliteit van de DDR kunnen bezitten, die dit bezit niet waard zijn. De ontnemingsregelingen werden in de meeste landen kort voor de tweede wereldoorlog door de toenmalige regimes van rechtse signatuur aanzienlijk uitgebreid en vervolgens door de nieuwe machthebbers in die landen geërfd. Deze gebruikten die regelingen om Duitse etnische minderheden en politieke tegenstanders van de nieuwe regimes te kunnen uitzetten. Vervolgens zijn die regelingen in de wetten gebleven "voor het geval dat...". Ook de aparte regeling van ontneming van de Tsjechische nationaliteit die kort na de gebeurtenissen in 1968 werd ingevoerd, bevestigt dit. Ontneming van de nationaliteit heeft derhalve nagenoeg uitsluitend de functie van een straf bij politieke delicten. Daardoor begeeft het nationaliteitsrecht zich op een terrein dat reeds door de strafwetgeving wordt geregeld. Het is derhalve niet verbazingwekkend dat om een persoon te straffen doorgaans de gebruikelijke strafrechtelijke middelen worden gebruikt. Alle Oosteuropese landen kennen immers uitgebreide catalogi van politieke delicten, die een "passend" middel tegen dissidenten zijn, voorzover ze in het land verblijven. Ontneming van de nationaliteit en de daaropvolgende uitzetting zou in een dergelijk geval immers voor negatieve publiciteit in de Westerse media zorgen. Woont betrokkene in het buitenland, dan is hij aan de jurisdictie van het desbetreffende land ontsnapt. Men

29. Art. 18 van de USSR,, art. 19 van de Roemeemse, en $\$ 16$ lid 1 van de DDR-nationaliteitswet.

30. Riege, p. 99. 
kan hem dan alleen nog persoonlijk treffen door hem de nationaliteit te ontnemen en hem daardoor impliciet de toelating tot het land te ontzeggen (CSSR). Wordt hem dan na enige tijd (in de regel met een Westers paspoort) een bezoek aan zijn "ex-vaderland" toegestaan, dan moet die Oosteuropese staat echter diplomatieke bescherming door zijn nieuwe nationale staat dulden.

Ook in de Westeuropese landen komen we ontnemingsmogelijkheden tegen, dikwijls op dezelfde gronden als in Oost-Europa. Het belangrijkste verschil tussen de mogelijkheden van ontneming van de nationaliteit in "Oost" en "West" is echter dat in het Westen dikwijls beroepsmogelijkheden bestaan. Voorts zijn de mogelijkheden van ontneming op politieke gronden door de grondrechten in de nationale grondwetten, de ECRM en andere mensenrechtenvoorschriften zeer beperkt $^{31}$.

Slechts in Bulgarije, de DDR en Roemenië is het mogelijk een naturalisatiebesluit te herroepen. Aangezien deze mogelijkheid de laatste twee landen ook buiten de gevallen van fraude in de naturalisatieprocedure bestaat, kan worden geconcludeerd, dat in beide landen onderscheid wordt gemaakt tussen genaturaliseerde en andere staatsburgers. De naturalisandi verkrijgen weliswaar dezelfde rechten als anderen, doch hebben meer, althans verder strekkende verplichtingen, aangezien ten aanzien van hen bredere ontnemingsmogelijkheden bestaan. Dit is echter geen typische karakteristiek van Oosteuropese landen. Ook in West-Europa kan de nationaliteit in verschillende landen aan genaturaliseerden gemakkelijker worden ontnomen ${ }^{32}$.

\subsection{INVLOED VAN VERANDERING VAN NATIONALTTETT VAN OUDERS OP HET STAATSBURGERSCHLP VAN HUN MINDERIARUGE KINDEREN}

\subsubsection{Inleiding}

Veranderingen van de nationaliteit van ouders hebben in de regel invloed op de nationaliteitsrechtelijke status van hun minderjarige kinderen. De nationaliteit van een persoon verandert in Oost-Europa in geval van naturalisatie, in bepaalde gevallen bij vaststelling van zijn afstamming, alsmede door afstand, ontslag en ontneming.

In de Oosteuropese landen worden met betrekking tot de invloed van veranderingen van de nationaliteit van ouder(s) twee belangrijke uitgangspunten gehanteerd. Het eerste is, dat er onderscheid wordt gemaakt tussen gevallen waarin de nationaliteit van beide ouders verandert en gevallen waarin slechts eén van de ouders een nationaliteit verwerft of verliest. Het tweede uitgangspunt is het medebeslissingsrecht van een kind dat een bepaalde leeftijd heeft bereikt en van de ouder van het kind, wiens nationaliteit niet wordt gewijzigd.

Ook hier kan worden geconstateerd dat het recht van de USSR reeds sedert 1921 aan deze uitgangspunten is aangepast. De andere landen volgden in de regel

31. Zo wordt bijwoorbeeld in Italië de onder het fascistische bewind ingevoerde mogelijkheid wan ontmeming wegens handelingen die de belangen van de staat kunnen schaden, die ook in de meeste Oosteuropese landen voorkomt, sedert 1947 in strijd met de grondwet geacht, indien het om ontneming om politieke gronden gaat. Zie De Groot, diss., $p_{n} 124$.

32. Bijvoorbeeld in Zwitserland, Groot-Brittannië en Spanje (zie p. 16-17). 
reeds bij de eerste "communistische" nationaliteitswetten. Interessant is dat een dergelijke ontwikkeling ook in Westeuropese landen met vertraging van enkele tientallen jaren op gang is gekomen. Oostenrijk loopt in dit opzicht vooruit ${ }^{33}$.

Vaststelling (wijziging) van afstamming (erkenning, gerechtelijke vaststelling, "wettiging" door huwelijk in Hongarije) en adoptie kunnen wijziging van de nationaliteit van betrokkene bewerkstelligen. Voornamelijk moet hier worden gedacht aan verkrijging van de nationaliteit van een Oosteuropees land, indien afstamming van en onderdaan van het desbetreffende land wordt vastgesteld. Vaststelling van afstamming van een vreemdeling brengt hoogst zelden verlies van een Oosteuropese nationaliteit met zich mee, gezien het feit dat volgens de meeste nationaliteitswetten voor het behoud van de nationaliteit door betrokkene voldoende is, dat slechts één van de ouders de desbetreffende nationaliteit bezit.

Geen van de Oosteuropese landen kent echter een aparte regeling van verkrijging en verlies van de nationaliteit door eventuele kinderen van degenen, die tengevolge van vaststelling (wijziging) van hun afstamming de nationaliteit van een Oosteuropees land verwerven, respectievelijk verliezen. De nationaliteit van kinderen van betrokkene moet dan volgens de algemene regels worden vastgesteld. Indien een van de ouders van het kind door vaststelling (wijziging) van zijn afstamming een Oosteuropese nationaliteit verwerft, terwijl de andere ouder reeds onderdaan van het desbetreffende land is, bezit het kind in de regel toch al sedert zijn geboorte die nationaliteit. Is de andere ouder vreemdeling, dan deelt het kind in de meeste gevallen in de verkrijging van de nationaliteit van zijn ouder, wiens afstamming wordt vastgesteld (gewijzigd). Wordt tengevolge van vaststelling of wijziging van afstamming de nationaliteit van een Oosteuropees land verloren, dan verliezen in de regel ook de kinderen van betrokkene die nationaliteit, tenzij hun andere ouder in het bezit van de desbetreffende nationaliteit blijft.

\subsubsection{Naturalisatie, optie, ontslag en afstand}

Bij naturalisatie, optie, ontslag en afstand treedt de wijziging van de nationaliteit (mede) op grond van een wilsverklaring van betrokkene in. Een dergelijke verklaring impliceert tot op zekere hoogte wellicht ook de wil om de nationaliteit van minderjarige kinderen van betrokkene te veranderen. In nagenoeg alle nationaliteitswetten van Oosteuropese landen kan een relatief uitgewerkte regeling met betrekking tot medenaturalisatie van minderjarige kinderen worden aangetroffen. Deze regeling wordt dan ofwel van overeenkomstige toepassing op medeontslag verklaard, ofwel men treft met betrekking tot ontslag een aparte regeling aan die op dezelfde beginselen is gebaseerd. Om deze redenen zal hieronder slechts nader worden ingegaan op de regelingen van medenaturalisatie.

\subsubsection{Medenaturalisatie}

Minderjarige kinderen worden (in de landen die automatische medenaturalisatie kennen) in de regel slechts automatisch meegenaturaliseerd, indien de nationaliteit aan beide ouders wordt verleend, of de andere ouder reeds het desbetreffende staatsburgerschap bezit. Bij naturalisatie van één ouder, krijgt de andere een

33. Zie daarover De Groot diss., p. 148-153. 
medebeslissingsrecht. Dit is gezien het feit dat de ouders gezamenlijk een dermate belangrijke beslissing als werkrijging van een nationaliteit door het kind behoren te nemen, m.i. een juist uitgangspunt. Bovendien verliest het kind door zijn medenaturalisatie dikwijls de nationaliteit van die andere ouder. Voorts lijkt mij de Poolse regeling, die voor het geval van onenigheid tussen de ouders rechterlijke tussenkomst voorschrijft, een verstandige keuze. Ook het aan kinderen zelf toegekende vetorecht lijkt mij een zeer goede oplossing. Op deze wijze wordt namelijk voorkomen, dat een dergelijk kind tegen zijn wil een vreemde nationaliteit opgedrongen krijgt. Een medebeslissingsrecht ten behoeve van het kind is des te meer op zijn plaats, indien hij door de medenaturalisatie zijn oude nationaliteit verliest.

Het is opmerkelijk vast te stellen dat in de voorstellen die De Groot ${ }^{34}$ met betrekking tot medenaturalisatie van minderjarige kinderen in Nederland doet, de meeste zojuilst genoemde in Oost-Europa gehanteerde uitgangspunten terug te vinden zijn, terwijl dezelfde auteur op een andere plaats er stellig van overtuigd is, dat in het Oosteuropese nationaliteitsrecht geen inspiratie voor verbetering van het Nederlands recht kan worden gevonden ${ }^{35}$.

\subsubsection{Enige voorstellen tot wijziging van het Nederlands recht}

\subsubsection{Inleiding}

De Nederlandse wetgever lijkt zich op het standpunt te stellen, dat een minderjarig kind van een Nederlander steeds Nederlander moet zijn, ongeacht de wil van het kind zelf en van de andere ouder, die eventueel een vreemde nationaliteit bezit. De achtergrond hiervan moet worden gezocht in het feit dat de Nederlandse wetgever noch de vader noch de moeder van het kind wil discrimineren. Dit uitgangspunt wordt kennelijk doorgetrokken uit de regeling van verkrijging van de nationaliteit iure sanguinis (artt. 3, 4,5) en manifesteert zich voorts in de artt. 4 en 5 met betrekking tot eventuele kinderen van degenen, die door erkenning, wettiging of adoptie Nederlander worden. Bij de regeling van optie (artt. 6, 28) wordt dit uitgangspunt merkwaardigerwijs verlaten. Volgens de regeling van artt. 6 en 28 RwNed verwerven eventuele kinderen van optanten niet de Nederlandse nationaliteit. Het genoemde uitgangspunt keert weer terug bij de naturalisatie (art. 11) en bij de regeling van verlies door minderjarigen (artt. 14, 16). Door deze regelingen worden echter situaties gelijk gesteld die in het geheel niet gelijk zijn. Wettige kinderen (art. 3 lid 1) verkrijgen de nationaliteit reeds bij geboorte en kunnen derhalve geen wil met betrekking tot verkrijging van de nationaliteit vormen. Voorts is de verkrijging van de nationaliteit onafhankelijk van de wil van zowel de Nederlandse als de buitenlandse ouder. Wellicht zou kunnen worden gesteld dat indien iemand die met een Nederlander een huwelijk sluit en daarna een kind ter wereld brengt door deze twee handelingen impliciet in verkrijging van de Nederlandse nationaliteit door het kind heeft ingestemd. Een dergelijke redenering lijkt me echter te ver gaan.

34. De Groot diss, p. 328. Zijn woorstellen worden ook hieronder, op p. 381 weergegeven.

35. De Groot, diss $x$, p. 3-4. Zie ook mijn uiteenzettingen over de intersystemaire rechtsvergelijking op het gebied van het nationaliteitsrecht op p. $21-23$. 
Wordt echter de vader van een 17-jarige vreemdeling in Nederland genaturaliseerd, dan zal het kind zelf, alsmede zijn buitenlandse moeder die niet om het Nederlanderschap verzoekt, ongetwijfeld een uitgesproken mening omtrent de wenselijkheid van verkrijging van het Nederlanderschap hebben.

\subsubsection{Kinderen van naturalisandi en optanten}

In Nederland wordt een minderjarig kind steeds automatisch medegenaturaliseerd, tenzij ten aanzien van hem een uitdrukkelijk woorbehoud werd gemaakt. Kinderen boven 12 jaar, alsmede hun wettelijke vertegenwoordiger, worden gehoord. Aan deze regeling kleven de volgende bezwaren:

- een kind dat door de verzoeker wordt verzwegen, wordt steeds meegenaturaliseerd;

- het kan voorkomen dat de verzoeker bij de naturalisatie (nog) niet weet dat hij een kind heeft ${ }^{36}$;

- de ouder die niet om naturalisatie verzoekt ouder wordt gediscrimineerd, terwijl deze in de regel het ouderlijk gezag over het kind uitoefent. Bovendien verliest het kind door medenaturalisatie dikwijls de nationaliteit van die ouder;

- een kind boven een bepaalde leeftijd behoort m.i. het recht te hebben om medenaturalisatie te weigeren.

Door De Groot, geïnspireerd door Oostenrijks recht, wordt in dit verband voorgesteld art. $11 \mathrm{RwNed}$ dusdanig te wijzigen, dat minderjarige kinderen slechts op verzoek van de naturalisandus zouden kunnen worden genaturaliseerd. Voorts zou volgens hem de toestemming van de wettelijke vertegenwoordiger van het kind en die van de andere ouder, die geen wettelijke vertegenwoordiger is, vereist moeten worden. Deze toestemming voorziet hij echter uitsluitend voor gevallen waarin het kind door zijn medenaturalisatie de nationaliteit van die ouder verliest. De toestemming van de andere ouder en van de wettelijke vertegenwoordiger zou door de rechter moeten kunnen worden vervangen. Kinderen boven 12 jaar zouden volgens $\mathrm{De}$ Groot in beginsel slechts met hun eigen toestemming kunnen worden genaturaliseerd. De toestemming van het kind zou door de rechter slechts moeten kunnen worden vervangen, indien het kind door de medenaturalisatie niet zijn oude nationaliteit verliest.

De door De Groot voorgestelde regeling ondervangt voor een groot gedeelte de bovenstaande bezwaren, doch doet tevens enkele nieuwe ontstaan. Doordat hij bij het zoeken naar een oplossing niet wan een principieel onderscheid tussen naturalisatie van beide en slechts éen ouder uitgaat, is zijn voorstel naar mijn mening onnodig ingewikkeld. Er wordt ook de toestemming van de andere ouder geëist in gevallen waarin deze vanzelfsprekend is. In bepaalde gevallen waarin deze toestemming m.i. echter noodzakelijk zou zijn, wordt daarvan afgezien. Hierbij

36. Denk aan cen gerechtelijke vaststelling van vaderschap in het buitenland, waardoor ex tunc familierechtelijke betrekkingen worden gevestigd. 
kan voornamelijk worden gedacht aan gevallen waarin de andere ouder van het kind zich niet laat naturaliseren. Waarom zou dan het kind juist het nationaliteitsrechtelijke "pad" van de genaturalliseerde ouder moeten volgen? Een groot bezwaar is voorts dat er bij wijze van voorvraag steeds zou moeten worden vastgesteld welke nationaliteit het kind bezit en of deze door de medenaturalisatie verloren gaat. Aan een dergelijke vaststelling kleeft immers het bezwaar dat deze vaststelling moeilijk kan zijn en het lijkt mij niet onwaarschijnlijk dat de rechter al te snel geneigd zou zijn aan te nemen dat de andere nationaliteit niet verloren gaat en dat medenaturalisatie in het belang van het kind is. De door De Groot voorgestelde regeling zou derhalve de naturalisatieprocedure die toch al lang duurt, onnodig kunnen vertragen. Tenslotte zou indien het voorstel van De Groot zou worden gevolgd, de beslissing omtrent verkrijging van het Nederlanderschap in handen van twaalfjarige kinderen worden gelegd. Naar mijn mening zou op deze wijze het gevaar van een niet goed overwogen beslissing bijzonder groot zijn. Het bepalen van een leeftijdsgrens is uiteraard steeds arbitrair, doch het komt mij voor dat het op 12 jaar stellen daarvan toch te optimistisch is. Door De Groot werd deze leeftijdsgrens gekozen met het oog op de hoorplicht van 12-jarige kinderen in art. 11 lid 2 RwNed, de wetgeving op het gebied van het namenrecht en de regels ten aanzien van de toewijzing van kinderen bij echtscheiding. Deze gevallen liggen echter beduidend anders. In de eerste plaats krijgen in de genoemde gevallen minderjarigen slechts het recht om hun mening te laten horen en geen medebeslissingsrecht. In de tweede plaats lijkt het mij evident dat een kind van 12 jaar zich weinig of niets onder het begrip nationaliteit kan voorstellen. Het al dan niet dragen van een naam, respectievelijk het al dan niet wonen bij een bepaalde ouder zijn uiteraard veel minder abstract. M.i. zou het derhalve wenselijker zijn, om naar voorbeeld van de meeste Oosteuropese landen, de grens op de leeftijd van 14 jaar te stellen.

Naar mijn mening zou de regeling van art. 11 RwNed er als volgt uit moeten zien:

Een minderjarig kind jonger dan 14 jaar zou in het geval dat beide ouders worden genaturaliseerd, automatisch moeten worden meegenaturaliseerd, indien beide ouders het ouderlijk gezag over het kind uitoefenen. Oefenen niet beide ouders het ouderlijk gezag uit, dan moet tevens de toestemming van een eventuele voogd die geen ouder is, worden vereist. Hetzelfde moet gelden in gevallen die materieel met naturalisatie van beide ouders gelijk staan, namelijk indien de andere ouder reeds de Nederlandse nationaliteit bezit, overleden of staatloos is. In al deze gevallen lijkt het mij overbodig de toestemming van de andere ouder te eisen, aangezien hij toch Nederlander is of wordt en derhalve hoogstwaarschijnlijk geen redelijk belang bij niet-naturalisatie van het kind heeft. Om dezelfde redenen kan de medenaturalisatie automatisch geschieden, echter met uitdrukkelijke vermelding van kinderen in het naturalisatiebesluit. Deze vermelding moet constitutieve werking hebben.

Wordt slechts ến van de ouders genaturaliseerd, dan zou het Nederlanderschap aan zijn minderjarige kinderen uitsluitend op grond van een daartoe strekkend verzoek van die ouder moeten worden verleend. De andere ouder, die zich niet laat naturaliseren maar die wel het ouderlijk gezag uitoefent, behoort steeds medebeslissingsrecht te hebben. Tot het uitoefenen van het ouderlijk gezag behoort immers ook de beslissing omtrent verkrijging van een nationaliteit door het kind. Oefent de andere ouder geen ouderlijk gezag uit, dan zou tevens de 
wettelijke vertegenwoordiger van het kind het recht van de andere ouder moeten hebben. De toestemming van de andere ouder, respectievelijk wettelijke vertegenwoordiger zou echter door de kinderrechter ${ }^{37}$ moeten kunnen worden vervangen, indien de andere ouder geen redelijk belang bij niet-naturalisatie van het kind kan aantonen. Een redelijk belang zou vermoed ${ }^{38}$ moeten worden aanwezig te zijn, indien het kind door zijn medenaturalisatie de nationaliteit van die andere ouder zou verliezen.

Een 14-jarige moet in beginsel uitsluitend met zijn eigen toestemming kunnen worden meegenaturaliseerd. Deze toestemming mag naar mijn mening door de kinderrechter slechts kunnen worden vervangen indien het kind door de uitoefening van zijn vetorecht staatloos blijft of wordt. Een kind dat zijn veto uitspreekt, zou echter steeds een optierecht op het Nederlanderschap moeten hebben. Deze optiemogelijkheid ondervangt het bezwaar van een niet goed overwogen beslissing van een minderjarige.

De hierboven beschreven regeling met betrekking tot medenaturalisatie zou eveneens van toepassing moeten worden verklaard bij verkrijging van het Nederlanderschap door optie ex artt. 6 en 28 RwNed. Uit de uiteenzettingen over het rechtskarakter van beide wijzen van verkrijging van de nationaliteit op p. 2730 volgt dat er tussen beide geen wezenlijk onderscheid bestaat. Om deze reden acht ik het wenselijk dat minderjarige kinderen van optanten onder dezelfde voorwaarden als die van naturalisandi in de verkrijging van de Nederlandse nationaliteit deelachtig kunnen zijn.

37. Hier wordt aansluiting gezocht bij art. 1: 246 leden 1, 2 Nederlands BW.

38. Een praesumptio iuris. 


\section{HOOFDSTUK 2. HOE "ANDERS" IS HET NATIONALITEITSRECHT IN OOST-EUROPA?}

\subsection{INLEIDING}

Hieronder zullen de twee belangrijkste verschillen tussen de regelingen van de verkrijging en werlies van nationaliteit in Oost en West-Europa nader worden geanalyseerd. Het gaat om de volgende twee verschillen:

- beslissingsmacht in nationaliteitsaangelegenheden en

- medenaturalisatie en medeontslag van minderjarige kinderen.

Aan de hand daarvan zal de vraag worden beantwoord in hoeverre het nationaliteitsrecht als zodanig in Oost-Europa inderdaad anders is en of er bepaalde kenmerken te vinden zijn die als typerend voor het nationaliteitsrecht van door communistische partijen geregeerde landen kunnen worden genoemd.

\subsection{BESLISSINGSMACHT IN NATIONALITEITSAANGRLEGENHEDEN}

Nadat de eerste generatie van "socialistische" nationaliteitswetten het daglicht aanschouwde, schreef Makarov het volgende:

"Die Rechtsvergleichung auf dem Gebiete des Staatsangehörigkeitsrechts lehrt uns, dass im Verlauf der letzten Jahrzehnte sich ein bestimmter Typ von Staatsangehörigkeitsgesetzen herausgebildet hat, der den sog. Volksdemokratien eigen ist, jedoch darüber hinaus dem Geist eines jeden totalitären Regimes entspricht. In diesen Gesetzen werden der Regierung weitgehende Befügnisse zugesprochen und ihr Ermessen bei der Ausübung dieser Befügnisse wird durch möglichst wenige Gesetzesvorschriften eingeschränkt." ${ }^{\text {"1 }}$.

Thans, nadat in de meeste Oosteuropese landen de tweede generatie van "socialistische" nationaliteitswetten reeds meer dan tien jaren geldt, kan de conclusie van Makarov grotendeels worden herhaald. Hierbij zij wel aangetekend, dat de wettelijke voorschriften die de discretionaire bevoegdheid van regeringen beperken, in de regel iets uitgebreider zijn geworden.

De almacht van de staat(sorganen) bij de beslissing over verkrijging en verlies van de nationaliteit is derhalve nog steeds een belangrijke karakteristiek die aan alle Oosteuropese landen gemeenschappelijk is. Luchterhandt ${ }^{2}$ spreekt in dit verband van het "typische" etatistische element van het nationaliteitsrecht van die staten. Geen van de Oosteuropese landen kent verkrijging van de nationaliteit door een zuivere optie, een recht op naturalisatie wordt consequent ontkend; uitsluitend Joegoslavië kent aan een bepaalde categorie verzoekers een "Einbürgerungsan-

1. Makarow, RabelsZ 1952, p. 407. Makarow was woordat hij naar Duitsland emigreerde overigens hoogleraar in de Sowjetunie.

2. Luchterhandt, OER 1984, p. 131. 
spruch" toe. In alle landen bestaan weliswaar uitgebreide mogelijkheden van geprivilegieerde naturalisatie, in de ĆSSR en Polen zelfs door plaatselijke besturen te verlenen, maar de staat behoudt zich steeds het laatste woord voor, dat niet aan toetsing door een onafhankelijke rechter kan worden onderworpen.

Het meest duidelijk toont zich de almacht van de staat bij het verlies van de nationaliteit, dat onder bepaalde voorwaarden conform art. 15 lid 2 de Universele verklaring als een recht dient te worden beschouwt (zie p. 42-43). Uitsluitend in Joegoslavie is echter afstand van de nationaliteit mogelijk en komt in dit verband zelfs het woord "pravica" (recht) in de nationaliteitswet voor. In andere landen wordt het staatsburgerschap in de regel slechts door ontslag verloren. Een uitzonderingspositie nemen tot op zekere hoogte Polen en Hongarije in. Het eerste land kent de unieke mogelijkheid van ontslag door consulaten en door plaatselijke besturen. In Hongarije wordt de discretionaire bevoegdheid van het beslissende orgaan tenminste enigszins beperkt door het feit dat de wet een aantal omstandigheden noemt waarin de kans op een positieve beslissing groter is. Sommige staten (met name Roemeniè en de CSSR) zijn geneigd hun eigen staatsburgers als "exportartikelen" te gebruiken. Ook de dubbele toetsing (aparte toestemming voor emigratie en aparte voor ontslag) in de USSR en de DDR kan moeilijk anders worden verstaan dan het onnodig bemoeilijken van het verlies van de nationaliteit en als een wijze om van betrokkene dubbele betaling te verlangen voor hetgeen waarop hij recht zou moeten hebben. De mogelijkheid van ontneming, die zeer zelden wordt toegepast, is een middel om politieke tegenstanders van het regime uit het land te weren.

Inhoeverre zijn deze omstandigheden typerend voor communistische landen? Reeds door Makarov ${ }^{3}$ werd geconcludeerd dat de genoemde kenmerken in het nationaliteitsrecht van elke totalitaire staat kunnen voorkomen. Zo konden de bovengenoemde omstandigheden voor een groot gedeelte ook worden gesignaleerd in de tijd vlak voor de tweede wereldoorlog, toen in de meeste van de in dit boek besproken landen dictaturen van rechtse signatuur aan de macht waren. De staatsorganen hadden een onbeperkte discretionaire bevoegdheid, beroepsmogelijkheden bestonden niet of nauwelijks, de beslissingsbevoegdheid werd dikwijls geplaatst bij de hoogste staatsorganen en ontneming werd op grotendeels dezelfde gronden als een wapen tegen politieke emigranten gehanteerd. Het enige verschil was, dat deze toen dikwijls juist communisten waren. Ook de omstandigheid dat de ontslag- en emigratieregelingen voor de staat lucratief kunnen zijn, hadden reeds de nazi's met betrekking tot de Joden ontdekt. Het is derhalve aan te nemen dat de situatie in Oost-Europa sedert de tweede helft van de jaren dertig in dit opzicht ongeveer ongewijzigd is gebleven. In de Westeuropese landen is het althans in de huidige tijd anders: de staatsorganen hebben weliswaar dikwijls discretionaire bevoegdheid, doch deze wordt beperkt door de nationale en internationale ontwikkelingen op het gebied van grond- en mensenrechten, die eigenlijk pas na de tweede wereldoorlog op gang zijn gekomen, dus juist in de tijd waarin OostEuropa zich reeds had geîsoleerd. De tweede beperking wordt opgelegd door de steeds sterkere ontwikkeling van het bestuursrecht in de Westerse landen. Het gaat hierbij met name om het besef dat de overheid aan bepaalde spelregels is gebonden, zoals in Nederland aan de algemene beginselen van behoorlijk bestuur,

3. Zie de hierboven, op p. 384 geciteerde woorden van Makarov in RabelsZ 1952, p. 407. 
en om de steeds grotere bescherming die de onafhankelijke rechterlijke macht tegen de overheid aan de burger verleent. In Oost-Europa staat dit de justitiabele beschermende aspect van het bestuursrecht nog steeds in kinderschoenen; woorzover het zelfs niet geheel afwezig is. Het ontbreken van een duidelijke scheiding der machten maakt rechterlijke controle op het bestuur onmogelijk. Ook dit geldt niet geheel ten aanzien van Joegoslavië, waar tenminste het beginsel dat tegen elke beschikking een rechtsmiddel openstaat, in de grondwet is neergelegd en het bestuur tot op zekere hoogte door de rechter kan worden gecontroleerd. Doch ook in dit land valt in politiek gevoelige gevallen van de rechterlijke macht niet al te veel bescherming te verwachten ${ }^{4}$.

Naar mijn mening moeten bovengenoemde verschillen tussen het nationaliteitsrecht in Oost en West worden verklaard door de verschillen in het bestuursrecht. Niet het nationaliteitsrecht is op dit punt anders maar het administratieve recht. Zouden bijvoorbeeld in Hongarije dezelfde middelen voor rechtsbescherming tegen de overheid bestaan als bijvoorbeeld in Zwitserland, dan zouden de verschillen met betrekking tot de besluitvorming in nationaliteitsaangelegenheden tussen beide landen miniem worden.

Door Riege bijwoorbeeld, wordt met verschillende argumenten verdedigd dat de hierboven omschreven "positie" van de staat in nationaliteitszaken inherent is aan de marxistische opvatting van recht en staat. In de USSR wordt echter "eerlijk" toegegeven, dat het hierbij eenvoudig om een manifestatie van het beginsel van de staatssouvereiniteit op het gebied van het nationaliteitsrecht gaat. Hier komt naar mijn mening nog bij dat de staatsorganen in die landen in de comfortabele positie verkeren dat ze niet of nauwelijks oppositie hebben, die hen die positie zou kunnen ontnemen. Dan is het gemakkelijk om regels die de status quo (i.c. de onbeperkte discretionaire bevoegdheid) handhaven, tot wet te maken. Niet zelden is m.i. niet de marxistische ideologie de oorzaak van het recht in die landen, maar een demagogisch middel om "rechtvaardiging" daarvoor te vinden, hoe doorzichtig deze een ideologisch onbevooroordeelde jurist ook voorkomt.

\subsection{Medenaturalisatie, en medeontslag van minderuarige kinderen}

Met betrekking tot de regelingen van medenaturalisatie en medeontslag van minderjarige kinderen kan als bijzonderheid het medebeslissingsrecht van het kind zelf en dikwijls ook van de andere ouder wiens nationaliteit niet verandert, worden genoemd. De vraag is echter in hoeverre dit een bijzonderheid van het Oosteuropese nationaliteitsrecht is. Weliswaar kent in het Westen thans slechts Oostenrijk soortgelijke regelingen, doch ik acht het zeer zeker niet uitgesloten dat ook in andere landen in de toekomst overeenkomstige regelingen zullen worden ingevoerd. Door $\mathrm{De}$ Groot werden reeds dienovereenkomstige voorstellen met betrekking tot Nederland gedaan.

4. Dit geldt met name als bepaalde "taboe's" zoals bijwoorbeeld de bellangen van het leger op het spel staan. Over een recent voorbeeld van een dubieuze procedure waarin de rechter met gemak het grondwettelijk gewaarborgdle recht op proces in eigen taal schond, werd in het NRCHandelsblad gedurende juli 1988 uitwoerig bericht. Zie ook Wall Street Journal van 8 september 1988 en uitvoerig in het Sloveens: Horvat, e.a., V imenu ljudstva (proces pred vojaskim sodišcem v Ljubljani, junij, julij 1988), Ljubljana 1988. 
Op deze plaats wil ik een parallel trekken met de historische ontwikkeling van de regelingen van verkrijging van de nationaliteit wure sanguinis door (althans) wettige kinderen in Europa. Terwijl rond 1950 een kind in de meeste Oosteuropese landen zijn nationaliteit op gelijke voet zowel aan zijn vader als aan zijn moeder kon ontlenen, werd in West-Europa het staatsburgerschap destijds primair iure sanguinis a patre verworven. Pas met een vertraging van verschillende (tientallen) jaren werd ook in de meeste Westerse landen het ius sanguinis a matre et a patre ingevoerd (in Nederland en België in 1985).

Gezien het bovenstaande kan worden geconcludeerd dat de Oosteuropese regelingen van medenaturalisatie en van medeontslag van minderjarigen zich op dit moment weliswaar van de Westerse onderscheiden, maar naar mijn mening gaat het evenals bij de regelingen van verkrijging van de nationaliteit iure sanguinis enkele decennia geleden, slechts om een tijdelijke voorsprong op de Westerse landen, die in de toekomst waarschijnlijk zal verdwijnen. Typerend voor het recht van de door de communistische partijen geregeerde landen is het medebeslissingsrecht van de ouders en van de minderjarige zelf derhalve niet.

\subsection{SLOT}

Tot besluit kan worden geconcludeerd, dat de regelingen van verkrijging en verlies van de nationaliteit in de Oosteuropese landen zich niet wezenlijk van dienovereenkomstige regelingen in Nederland en andere Westerse landen onderscheiden. De gronden voor verkrijging en verlies zijn in Oost-Europa dezelfde als in de Westeuropese landen. Weliswaar is de beslissingsmacht met betrekking tot verkrijging en verlies van de nationaliteit in de Oosteuropese landen veel sterker dan in het Westen overgelaten aan de discretionaire bevoegdheid van de staatsorganen, doch de verk laring daarvoor moet worden gezocht in het feit dat het administratief recht in die landen aan de burger niet of nauwelijks bescherming biedt.

Ook zijn er geen andere elementen die als typerend voor door communistische partijen geregeerde landen zouden kunnen worden omschreven. Het nationaliteitsrecht in Oost-Europa bevat tegenstrijdigheden. Terwijl de regelingen van verkrijging van de nationaliteit van rechtswege en met betrekking tot medenaturalisatie en medeontslag als voonuitstrevend kunnen worden getypeerd, zijn de regelingen met betrekking tot de beslissingsbevoegdheid bij naturalisatie, ontslag en ontneming vanuit het oogpunt van een Westerse jurist verouderd. Het feit dat ontneming van de nationaliteit als een politiek wapen wordt gebruikt is geen typisch kenmerk van communistische staten, maar kan in elke totalitaire staat voorkomen. Het nationaliteitsrecht van dezelfde landen (vlak) vó́r en tijdens de tweede wereldoorlog is het meest sprekende bewijs daarvoor.

Gezien het bovenstaande denk ik niet dat bij doorzetting van "glasnost"" en perestrojka" in de USSR en de sterke democratiseringstendensen in Hongarije en Polen wezenlijke wijzigingen van de nationaliteitswetten te verwachten zijn. Bij mogelijke wijzigingen kan worden gedacht aan precisering van naturalisatie- en ontslagvoorwaarden, eventueel ook aan verplaatsing van de beslissingsbevoegdheid naar minister(ie)s, wellicht met de invoering, respectievelijk verbetering van beroepsmogelijkheden. 

SAMENVATTINGEN 

Het nationaliteitsrecht in de Oosteuropese landen

Het voorliggende werk is een onderzoek naar de historische ontwikkelingen van de regelingen van verkrijging en verlies van de nationaliteit in Oost-Europa. Het boek bevat vier delen. In het eerste deel wordt aandacht besteed aan enkele theoretische vraagstukken zoals de inhoud en de functie van de nationaliteit zowel in de Westals in de Oosteuropese doctrine. Hierbij wordt de stelling ingenomen dat mationaliteit op zichzelf een koppelbegrip is, dat het behoren van een persoon tot een bepaalde staat weergeeft en waaraan verschillende staten verschillende rechtsgevolgen kunnen verbinden. De functie van de nationaliteit wordt gezien als een soort hekwerk, waardoor een staat onderscheid tussen zijn eigen onderdanen en vreemdelingen kan maken. Voorts wordt ingegaan op de zogenaamde "intersystemaire rechtsvergelijking", zowel in het algemeen, als op het gebied van het nationaliteitsrecht. Hierbij wordt gesteld dat vergelijking van het recht van landen met verschillende politieke systemen nuttig kan zijn, onder omstandigheden ook voor een Westerse jurist, die inspiratie voor verbetering van het eigen recht zoekt.

Vervolgens wordt ingegaan op de terminologie die in dit boek wordt gebezigd. De wijzen van verkrijging van de nationaliteit worden onderverdeeld in verkrijging van rechtswege, door optie en door naturalisatie en de wijzen van verlies in verlies van rechtswege, door afstand, ontslag en ontneming. De termen optie en afstand die in verschillende landen uiteenlopende inhoud hebben, worden gereserveerd voor gevallen, waarin betrokkene zelf, uitsluitend door zijn eigen wilsverklaring verkrijging, respectievelijk verlies van een bepaalde nationaliteit kan bewerkstelligen.

In het tweede deel wordt het nationaliteitsrecht van alle zogenaamde "Oosteuropese" landen (Rusland (de RSFSR tot 1924 en de USSR), Albanië, Bulgarije, Duitsland (en sedert 1949 de DDR), Hongarije, Joegoslavië, Polen, Roemenië en Tsjechoslowakije) systematisch beschreven. Allereerst wordt ingegaan op bepalingen van verschillende internationale verdragen, waaruit ook verplichtingen voor de Oosteuropese landen voortvloeien. De beschrijving van het recht van elk land vangt aan met een korte historische inleiding, waarna verschillende nationaliteitsrechtelijke codificaties worden beschreven, te beginnen met de regelingen die golden onmiddellijk vóór de tweede wereldoorlog. Bij Rusland treedt een tijdverschuiving op, aangezien in dit land de communistische partij reeds in 1917 aan de macht kwam. De regelingen van de nationaliteit in de besproken landen worden op drie momenten met elkaar vergeleken. Allereerst gaat het om een vergelijking tussen de nationaliteitswetgevingen voordat de communistische partijen in die landen aan de macht kwamen. De tweede fase van vergelijking betreft de eerste generatie van "socialistische" nationaliteitswetten in Oost-Europa, om zo na te kunnen gaan welke wijzigingen de "nouveaux régimes" hebben ingevoerd en inhoeverre daarbij het recht van de USSR als voorbeeld diende. Tenslotte worden de ontwikkelingen tot op heden, alsmede het huidige nationaliteitsrecht in die landen naast elkaar gezet. 
In alle Oosteuropese landen werden nadat de communistische partijen aan de macht kwamen, enkele ingrijpende wijzigingen in het nationaliteitsrecht doorgevoerd. In sommige landen gebeurde dit reeds enkele maanden na de machtsovername (RSFSR, Albanië, Joegoslavië) terwijl in andere landen daarmee één of meerdere jaren werd gewacht. In de DDR duurde het zelfs 18 jaar voordat een nieuwe "socialistische" nationaliteitswet het daglicht aanschouwde.

De wijzigingen hadden in de eerste plaats betrekking op verkrijging van de nationaliteit iure sanguinis a matre, op de invloed van het huwelijk op de nationaliteit van de gehuwde vrouw en op de afhankelijke verkrijging en verlies van de nationaliteit door minderjarige kinderen. Terwijl de zojuist genoemde wijzigingen zonder meer als zeer vooruitstrevend kunnen worden omschreven, gingen de andere in de tegenovergestelde richting. Zo werden de mogelijkheden van verkrijging van de nationaliteit door zuivere opties en van verlies van het staatsburgerschap door afstand nog beperkter dan voorheen. De staten toonden een duidelijke neiging om zelf het laatste woord over verkrijging en verlies van de nationaliteit uit te spreken. Voorts werd de bevoegdheid om over naturalisatieen ontslag uit de nationaliteit te beslissen bij de hoogste staatsorganen geplaatst en werd hen door de vage wettelijke formuleringen een vrijwel onbeperkte discretionaire bevoegdheid toegekend. Er waren geen reële mogelijkheden voor beroep. De regelingen van ontneming van de nationaliteit werden in landen die deze voor machtsovername door de communistische partijen niet kenden (Rusland, Albanië) ingevoerd, in andere landen werden ze gehandhaafd en soms zelfs uitgebreid. Voor een gedeelte waren de brede ontnemingsmogelijkheden historisch bepaald. Verschillende Oosteuropese landen hadden namelijk onder de Duitse bezetting geleden en daarbij ging het eigenlijk om "wraak" tegen de etnisch Duitse bevolking (Joegoslavië, Polen en Tsjechoslowakije, waar dit nog onder het "burgerlijke" regime van Beneš geschiedde). De andere oorzaak voor handhaving, respectievelijk invoering van brede ontnemingsmogelijkheden was de eliminatie van eigen politieke oppositie door deze "over de grens te zetten". Juist deze regelingen waren echter zeer dikwijls gewoon geërfd van de vorige regimes. In de regel waren dat regimes van rechtse signatuur, die in de tweede helft van de dertiger jaren dezelfde regelingen juist tegen de communisten hanteerden (Bulgarije, DDR, Hongarije, Polen, Roemenië). Voorts zij nog vermeld dat geen enkele Oosteuropese nationaliteitswet in belangrijke mate door de destijds geldende uiterst korte stalinistische nationaliteitswet van de USSR werd beïnvloed. Wel was in Albanië en in Bulgarije de invloed van de Joegoslavische wetgeving op dit gebied te bespeuren.

De ontwikkeling op het gebied van het nationaliteitsrecht in Oost-Europa was in de laatste vier decennia in vergaande mate uniform. Uitzonderingen vormen tot op een zekere hoogte Albanië, Joegoslavië en Roemenië. De specifieke ontwikkelingen in Roemenië en Albanie leidden tot het vervaardigen van nieuwe stalinistische nationaliteitsrechtelijke regelingen in 1952, respectievelijk 1954. Het decreet van 1954 geldt nog steeds in Albanië, terwijl Roemenië in 1971 weer naar een uitgebreidere regeling van de nationaliteit is teruggekeerd, waarvoor echter met het nationaalsocialisme verwante elementen kenmerkend zijn. Voor het nationaliteitsrecht van beide landen is echter nog steeds de meest vergaande vrijheid van de administratie en daar tegenover de grootste onmacht van de justitiabele typerend. 
In Joegoslavië ging de ontwikkeling sedert de breuk met Stalin in 1948 in een andere richting. De nationaliteitswet van 1945 werd nog in 1964 en 1977 herzien en is thans waarschijnlijk alls de meest "aanvaardbare" nationaliteitswet van OostEuropa te beschouwen. Men heeft interessante oplossingen bedacht voor problemen bij de beperking van meervoudige nationaliteit enerzijds el de verkrijging van de nationaliteit iure sanguinis a matre et a patre anderzijds. Joegoslavië kent voorts als enig Oosteuropees land verlies van de nationaliteit door afstand en een soort recht op ontslag. Bovendien is het het enige iand in OostEuropa waar ontneming van de nationaliteit niet mogelijk is, indien zulks apatridie tot gevolg zou hebben. Het feit echter dat ontneming van de nationaliteit nog steeds niet uit de nationaliteitswet is geschrapt en dat de administratie met de "toverspreuk" "staatsveiligheid of "de belangen van de defensie" willekeurig alle zogenaamde rechten van de justitiabele illusoir kan maken, duidt er op dat ook in Joegoslavië het nationaliteitsrecht nog steeds grote gebreken vertoont.

De regelingen van de nationaliteit in de andere Oosteuropese landen kunnen tussen de beide "polen" worden geplaatst. Het recht van met name de DDR en in iets mindere mate ook van de USSR, Bulgarije en van de CSSR neigt naar Albanië en Roemenië, terwijl Hongarije en Polen meer met het Joegoslavische nationaliteitsrecht gemeenschappelijk hebben. De belangrijkste karakteristiek van de nationaliteitswetgeving in deze landen is de discretionaire bevoegdheid van de administratie bij beslissingen omtrent naturalisatie, ontslag en ontneming van de nationaliteit. Daarbij moet echter wel worden aangetekend, dat er een lichte tendens naar meer wettelijke regels die deze vrijheid tenminste enigszins beperken, waarneembaar is. Het instituut van ontneming van de nationaliteit wordt in de praktijk zelden toegepast, in de regel echter tegen politieke tegenstanders van de communistische regimes in die landen.

Naast deze negatieve kenmerken, die overigens in elk totalitair regime te vinden zijn, heeft het nationaliteitsrecht in Oost-Europa ook een aantal positieve karakteristieken. Deze landen waren in Europa de eerste, die de gelijkheid van mannen en vrouwen in het nationaliteitsrecht gestalte hebben gegeven door invoering van het beginsel ius sanguinis a patre et a matre en door aan de gehuwde vrouw een geheel zelfstandige nationaliteitsrechtelijke positie te geven. De Westeuropese landen hadden verschillende decennia nodig om thun achterstand op deze twee punten in te halen. De huidige regelingen in de meeste Oosteuropese landen kennen ook een ander onderwerp dat in West-Europa nog in de kinderschoenen staat, namelijk de nationaliteitsrechtelijke emancipatie van minderjarigen boven een bepaalde leeftijd (meestal 14 jaar).

De regelingen van verkrijging van de nationaliteit van rechtswege tonen behalve in Joegoslavië een duidelijke tendens tot uitbreiding van de nationaliteit van die landen in gevallen, waarin de ouders van een kind verschillende staatsburgerschappen bezitten. Aangezien deze tendens zich ook in andere Europese landen heeft ontwikkeld, leidt dit tot meervoudige nationaliteit van kinderen die uit nationaliteitsrechtelijk gemengde ouders worden geboren. Zijn de ouders van het kind Oosteuropeanen, dan wordt meervoudige nationaliteit van het kind in vele gevallen door de bilaterale verdragen die deze landen onderling hebben gesloten, voorkomen. Gaat het om kinderen van een Oost- en een Westeuropeaan, bijvoorbeeld kinderen van in het Westen wonende emigranten, dan zijn deze in de 
regel bipatriden en zullen dat dikwijls hun hele leven blijven. Gezien het feit dat in alle Oosteuropese landen het zogenaamde exclusiviteitsbeginsel een belangrijke rol speelt, worden deze personen door hun Oosteuropese "vaderlanden" uitsluitend als eigen onderdanen behandeld. Dit betekent, dat ze bij een eventueel bezoek aan deze landen met eventuele onaangenaamheden, zoals militaire dienstplicht, toestemming voor buitenlands verblijf en weigering van de terugreis rekening moeten houden. Dergelijke omstandigheden vormen in ieder geval een obstakel voor reizen van deze personen naar Oost-Europa in het kader van familiebezoek en bezoek als toeristen. Dergelijke reizen zouden bovendien voor de Oosteuropese landen een welkome bron van harde valuta kunnen zijn. Om dergelijke problemen op te lossen worden twee mogelijke oplossingen aangedragen (zie p. 368-369). De eerste is het sluiten van bilaterale verdragen tussen Oost- en Westeuropese landen waardoor dubbele nationaliteit van uit nationaliteitsrechtelijk gemengde ouders geboren kinderen wordt voorkomen. De ouders van het kind zouden binnen een bepaalde termijn na de geboorte van hun kind zijn nationaliteit moeten kiezen. $\mathrm{Na}$ zijn meerderjarigheid zou een dergelijk kind recht op vereenvoudigde verwerving van de andere nationaliteit moeten hebben. De oorspronkelijke nationaliteit zou daardoor automatisch gaan verloren. De tweede oplossing, waaraan de voorkeur wordt gegeven, is het sluiten van bilaterale verdragen, waarin slechts de voor betrokkenen bezwaarlijke gevolgen van hun dubbele nationaliteit worden voorkomen. Zo zouden de verdragsluitende staten zich moeten verplichten, polypatriden die ook hun nationaliteit bezitten, uitsluitend als onderdanen van de staat waarin ze wonen, te behandelen. Dergelijke verdragen sloten de Verenigde staten reeds met Joegoslavië, Bulgarije, de DDR en Polen, alsmede Oostenrijk met de DDR.

Aangezien de vraag of in Oost-Europa enige inspiratie voor voorstellen tot verbetering van het Nederlands recht kan worden gevonden een nevendoel van dit onderzoek was, worden in het vierde deel, eerste hoofdstuk, enkele voorstellen tot wijziging van de Rijkswet op het Nederlanderschap worden gedaan.

a. Een minderjarige vreemdeling, wiens afstamming van een Nederlandse vader gerechtelijk is vastgesteld, dient van rechtswege de Nederlandse nationaliteit te verwerven (zie p. 372-373).

b. Art. 11 dient dusdanig te worden gewijzigd, dat een kind jonger dan 14 jaar slechts automatisch wordt meegenaturaliseerd, indien aan zijn beide ouders de Nederlandse nationaliteit wordt verleend. Hetzelfde moet gelden indien slechts een van de ouders wordt genaturaliseerd, terwijl de andere reeds de Nederlandse nationaliteit bezit, of staatloos is. Laat de andere ouder zich niet naturaliseren en bezit hij/zij een vreemde nationaliteit, dan is voor medenatwralisatie van het kind eveneens zijn toestemming nodig. Deze kan door de kinderrechter worden vervangen, indien deze ouder geen redelijk belang bij niet-naturalisatie van het kind kan aantonen. Indien niet de beide ouders het ouderlijk gezag over het kind uitoefenen, moet tevens de toestemming van een eventuele voogd, die geen ouder van het kind is, worden geëist. Kinderen boven 14 jaar moeten bovendien steeds hun eigen toestemming verlenen. Deze moet door de kinderrechter uitsluitend kunnen worden vervangen, indien het 
kind door uitoefening van zijn wetorecht staatloos zou blijven, of worden. Een kind dat zich tegen zijn medenaturalisatie uitspreekt, dient een ongelimiteerd optierecht op het Nederlanderschap te hebben. Medenaturalisatie dient in een naturalisatiebesluit uitdrukkelijk te worden vermeld en deze vermelding moet constitutieve werking hebben (zie p. 382-383).

c. De onder $b$, voorgestelde wijzigingen dienen in art. 6 van overeenkomstige toepassing te worden verklaard op kinderen van degenen die ex artt. 6 en 28 voor het Nederlanderschap opteren (zie p. 383). 


\section{DEUTSCHE ZUSAMMENFASSUNG}

\section{Das Staatsangehörigkeitsrecht in den asteuropäischen Staaten}

In diesem Buch wird die geschichtliche Entwicklung auf dem Gebiet des Erwerbs und des Verlustes der Staatsangehörigkeit in den osteuropäischen Staaten untersucht. Im ersten Teil werden einige theoretische Fragen behandelt, so etwa der Begriff und die Funktion der Staatsangehörigkeit in der westlichen und in der osteuropäischen Doktrin. Der Verfasser ist der Auffassung, daB die Staatsangehörigkeit ein Anknüpfungspunkt für die Zuteilung von Rechten und Pflichten, darstellt der die Zugehörigkeit einer Person zu einem bestimmten Staat vermittelt. Verschiedene Staaten können jedoch unterschiedliche Rechte und Pflichten mit der Staatsangehörigkeit verbinden. Hierbei wird die Funktion der Staatsangehörigkeit vor allem darin gesehen, daß Staaten diese gebrauchen, die Abgrenzung zwischen den eigenen Untertanen und Ausländern vorzunehmen. Weiter wird die Problematik der sogenannten "intersystemaren Rechtsvergleichung" im allgemeinen und auf dem Gebiet des Staatsangehörigkeitsrechts erörtert. Der Verfasser ist der Meinung, daß ein derartiger Vergleich auch für einen westlichen Jurist von Nutzen sein kann, der Inspiration für die Verbesserung des eigenen Rechtssystems sucht.

Weiterhin wird die im Buch benützte Terminologie verdeutlicht. Einerseits wird der Erwerb der Staatsangehörigkeit in Erwerb von Rechts wegen, durch Option und durch Einbürgerung unterteilt, andererseits wird bei dem Verlust der Staatsangehörigkeit zwischen dem Verlust von Rechts wegen, durch Verzicht, Entlassung und durch Aberkennung unterschieden. Insbesondere die Begriffe Option und Verzicht werden in den verschiedenen Rechtsordnungen für unterschiedliche Variationen der erleichterten Einbürgerung beziehungsweise Entlassung verwendet. In diesem Buch werden beide Begriffe ausschließlich für den Erwerb, beziehungsweise den Verlust der Staatsangehörigkeit auf Grund einer Willenserklärung des Betroffenen benützt.

Im zweiten Teil wird das Staatsangehörigkeitsrecht der sogenannten "osteuropäischen" Staaten Russland (die RSFSR bis 1924 und die UdSSR), Albanien, Bulgarien, Deutschland (seit 1949 die DDR), Ungarn, Jugoslawien, Polen, Rumänien und die Tschechoslowakei systematisch beschrieben. Zunächst aber werden die einschlägigen Bestimmungen internationaler Verträge, soweit zumindest einer der behandelten Staaten hierbei Partei ist, erörtert. Eingegangen wird auch auf die Allgemeine Erklärung der Menschenrechte von 1948 sowie insbesonders auf die bilateralen Abkommen zur Verringerung der doppelten Staatsangehörigkeit, die die osteuropäischen Staaten miteinander abgeschlossen haben. Die Beschreibungen des Rechts der einzelnen Staaten werden mit kurzen, allgemein historischen Exkursen eingeleitet, wonach die Behandlung der verschiedenen staatsangehörigkeitsrechtlichen Kodifikationen folgt. Grundsätzlich wird mit dem Staatsangehörigkeitsrecht der einzelnen Staaten kurz vor dem zweiten Weltkrieg begonnen. Eine Ausnahme gilt nur im Falle von Russland/UdSSR, weil die kommunistische Partei in diesem Land bereits 1917 die Macht ergriffen hat.

Im dritten Teil werden die Staatsangehörigkeitsregelungen an drei Stellen miteinander verglichen. Zunächst werden die staatsangehörigkeitsrechtlichen Regelungen der osteuropäischen Staten vor der Machtergreifung durch die 
kommunistischen Parteien untersucht. Die zweite Phase des Vergleiches betrifft die erste Generation der "sozialistischen" Staatsangehörigkeitsgesetze. Untersucht wird, welche Änderungen die Kommunisten in ihrem Staatsangehörigkeitsrecht vorgenommen haben und, ob dabei das Recht der UdSSR als Vorbild gedient hat. Zuletzt werden die Entwicklungen auf dem Gebiet der Staatsangehörigkeit bis zum heutigen Tage miteinander verglichen.

Im vierten Teil dieser Arbeit werden hieraus Folgerungen bezïglich einiger Erwerbs- und Verlustgründe gezogen, sowie Vorschläge zur Ânderung des niederländischen Staatsangehörigkeitsgesetzes von 1984 unterbreitet.

Alle osteuropäische Staaten haben in ihrem Staatsangehörigkeitsrecht einige tiefgreifende Änderungen durchgeführt. In einigen Staaten geschah dies schon innerhalb der ersten Monate nach der Machtergreifung (RSFSR, Albanien, Jugoslawien), in den anderen Staaten hat man damit allerdings ein oder mehrere Jahre gewartet. In der DDR ließ das erste neue Staatsangehörigkeitsgesetz sogar 18 Jahre auf sich warten.

Die Kommunisten haben vor allem Änderungen auf dem Gebiet des Erwerbs und Verlustes der Staatsangehörigkeit kraft Gesetzes durchgeführt. Diese Änderungen bewirkte die Einführung des ius sanguinis a matre et a patre und die Abschaffung des automatischen Erwerbs/Verlustes der Staatsangehörigkeit durch Heirat. Auch der Erwerb/Verlust der Staatsangehörigkeit durch Minderjährige bei Änderung der Staatsbürgerschaft ihrer Eltern wurde häufig neu geregelt.

Diese Änderungen sind ohne weiteres als sehr positiv zu bewerten. Leider kam es auch zu Änderungen im negativen Sinne. So wurden die Möglichkeiten des Erwerbs/Verlustes der Staatsangehörigkeit durch Option oder Verzicht noch weiter eingeschränkt. Die Kompetenz bezüglich der Einbürgerung, Entlassung und Aberkennung wurde auf die höchsten Staatsorgane übertragen, die durch besonders weit formulierte Gesetzestexte eine unbeschränkte Ermessensfreiheit erhielten. Möglichkeiten für die gerichtliche Überprüfung ihrer Entscheidungen gab es nicht.

Eine besondere Stellung nahmen die Regelungen der Aberkennung der Staatsangehörigkeit (Zwangsausbürgerung) ein. In den Staaten, die vor der Machtergreifung durch die kommunistische Partei keine Aberkennung kannten (Russland, Albanien), wurde diese eingeführt. In den anderen Staaten wurden die Möglichkeiten zur Aberkennung häufig sogar ausgebreitet. Teilweise war diese Erweiterung historisch bedingt. In jenen Staaten, die schwer unter der deutschen Besatzung gelitten haben (Jugoslawien, Polen, die Tschechoslowakei) handelte es sich um eine staatsangehörigkeitsrechtliche "Revanche" gegen die in diesen Staaten lebenden Volksdeutschen. Der Ausbürgerung folgte nämlich die Vertreibung. In der CSR geschah dies allerdings noch unter der "bürgerlichen" Regierung von Beneక. Die andere Ursache der Ausbreitung der Aberkennungsmöglichkeiten war der Wunsch der kommunistischen Regierungen ihre politische Opposition "auszuschalten", indem die Mitglieder dieser Opposition ebenfalls ausgewiesen wurden. Die Regelungen der Aberkennung auf politischen Gründen waren häufig von den vorherigen, meist rechts orientierten Regimen, geerbt worden. Damals wurden dieselbe Regelungen allerdings gegen die Kommunisten benützt (Bulgarien, die DDR, Ungarn, Polen, Rumänien). 
Keine der ersten osteuropäischen Staatsangehörigkeitsgesetze war aber als eine weitgehende Kopie des Gesetzes der UdSSR aus 1938 zu betrachten. Vor allem im albanischen Gesetz aus 1946 und teilweise auch im bulgarischen Staatsangehörigkeitsgesetz aus 1948 war allerdings ein Einflub der jugoslawischen Regelung aus 1945 zu bemerken.

Die Entwicklung des Staatsangehörigkeitrechts in Osteuropa verläuft in den letzten vier Jahrzehnten weitgehend übereinstimmend. Ausnahmen bilden allerdings Albanien, Rumänien und Jugoslawien. Die besondere Lage in den ersten beiden Staaten führte schon in 1954, bzw. 1952 zur Übernahme des äuBerst kurzen stalinistischen Staatsangehörigkeitgesetzes der UdSSR von 1938. Während dieses Gesetz aus 1954 in Albanien noch immer gilt, ist Rumänien 1971 zu einer ausführlicheren Regelung zurückgekehrt, die aber starke den Regelungen der Nazionalsozialisten ähnelnde Elemente enthält. Beide Staaten kennzeichnet immer noch die weitgehende Ermessungsfreiheit des Staates und die entsprechende Unmündigkeit der einzelnen Personen auf dem Gebiet des Staatsangehörigkeitrechts.

In Jugoslawien verlief die Entwicklung seit der Spaltung zwischen diesem Staat und dem Rest Osteuropas im Jahre 1948 jedoch ganz anders. Das Gesetz aus 1945 wurde noch 1964 und 1976 weitgehend geändert und ist heutzutage als die aus westlicher Sicht meist "akzeptabele" Staatsangehörigkeitsregelung Osteuropas zu betrachten. Man hat auch interessante Lösungen für die Verringerung der Doppelstaatigkeit einerseits und den Erwerb der Staatsangehörigkeit iure sanguinis a patre et a matre anderseits gefunden. Jugoslawien kennt als einziger Staat Osteuropas den Verlust der Staatsangehörigkeit durch Verzicht und gibt seinen Staatsbürgern sogar ein beschränktes Recht auf Entlassung. Weiterhin ist Jugoslawien der einzige Staat in Osteuropa der Aberkennung der Staatsangehörigkeit ausschließlich in den Fällen zulässt, wenn der Betroffene dadurch nicht staatenlos wird. Die Tatsache aber, daß in Jugoslawien die Aberkennung noch immer möglich ist und die Verwaltungsbehörden unter Berufung auf die Zauberformeln "Staatssicherheit" und "die Interessen der Landesverteidigung" alle sogenannte Rechten des Einzelnen negieren können, verdeutlichen die Mängel auch im jugoslawischen Staatsangehörigkeitsrecht.

Die Staatsangehörigkeitsregelungen in den anderen fünf sozialistischen Staaten können zwischen die beiden Extreme, Albanien auf der einen Seite und Jugoslawien auf der anderen, eingereiht werden. Vor allem das Recht der DDR, aber auch von der UdSSR, Bulgarien und der ĆSSR steht den Regelungen Albaniens und Rumäniens näher, wohingegen die Staatsangehörigkeitsregelungen Ungarns und Polens mehr Öbereinstimmungen mit der jugoslavischen Gesetzgebung aufweisen. Das allgemeine Merkmal des Staatsangehörigkeitsrechts aller osteuropäische Staaten bleibt allerdings die Ermessensfreiheit im Hinblick auf die Entscheidungen über die Einbürgerung, Entlassung und Aberkennung der Staatsangehörigkeit. Erwähnenswert ist allerdings, da $B$ in den meisten Staaten eine leichte Tendenz nach mehr gesetzlicher Beschränkung dieser Ermessensfreiheit wahrgenommen werdem kann. Von der Möglichkeit der Aberkennung wird in der Praxis nur selten Gebrauch gemacht, dann jedoch meistens gegen die politischen Gegner der jeweiligen kommunistischen Regierung.

Neben diesen negativen Kennzeichen, die, so muß bemerkt werden, in allen totalitären Staaten vorkommen, hat das Staatsangehörigkeitsrecht der osteuropä- 
ischen Staaten auch mehrere positiv zu bewertende Charakteristika. So sind es diese Staaten, die die Gleichberechtigung der Frau auf dem Gebiet der Staatsangehörigkeit durch Einführung des ius sanguinis a matre et a patre und der selbständigen staatsangehörigkeitsrechtlichen Position der verheirateten Frau, in Europa als erste verwirklicht haben. Die westlichen Staaten brauchten mehrere Jahrzehnte, um diese Entwicklung nachzuvollziehen. Die heutigen Regelungen der meisten osteuropäischen Staaten kennen auch eine Besonderheit, die positiv zu bewerten ist, und zwar die staatsangehörigkeitsrechtliche Emanzipation der Minderjährigen ab einem bestimmten Alter (meistens ab 14 Jahre). Sie können über die Erstreckung der Einbürgerung/Entlassung ihrer Eltern auf sie selbst mitbestimmen.

Die Regelungen des Staatsangehörigkeitserwerbs durch Abstammung aller osteuropäischen Staaten mit Ausnahme von Jugosiawien zeigen eine deutliche Tendenz zur Ausbreitung des Untertanenkreises. Die Staatsangehörigkeit wird durch ein Kind schon dann erworben, wenn ein Elternteil des Kindes die betreffende Staatsbürgerschaft besitzt. Die gleiche Regelung gilt inzwischen auch in den meisten westlichen Staaten. Kinder won Eltern mit verschiedenen Staatsangehörigkeiten werden also im Prinzip Doppelstaater. Wenn aber beide Eltern die Staatsangehörigkeiten zweier osteuropäischer Staaten besïtzen, erwirbt das Kind häufig nur eine Staatsbürgerschaft, weil die meisten sozialistischen Staaten bilaterale Vertråge zur Vermeidung der doppelten Staatsangehörigkeit miteinander geschlossen haben. Die Kinder von Ost- und Westeuropäern, zum Beispiel die Kinder von im Westen wohnhaften Emigranten, werden jedoch Doppelstaater und es nicht selten auch ihres ganzes Leben lang bleiben. Unter Berücksichtigung, daB in allen osteuropäischen Staaten das "Exklusivitätsprinzip" gilt, kann die doppelte Staatsangehörigkeit diesen. Personen einige Probleme bereiten. Sie werden in diesen Staaten nämlich grundsätzlich als ausschließlich eigene Staatsangehörige behandelt. Wenn sie im ihrem "zweiten Vaterland" ihre Familienangehörigen besuchen, als Touristen oder aus beruflichen Grünnden dorthin reisen, müssen sie also mit einigen unangenehmen Folgen ihrer sozialistischen Staatsbürgerschaft rechnen. Es handelt sich zum Beispiel um die Wehrpflicht, um die Erlaubnis zum Auslandsaufenthalt und um die Möglichkeit der Ausreiseverweigerung. Die Tatsache mit derartigen Problemen konfrontiert werden zu können, bedeutet sicherlich eine Behinderung dieses Personenkreises bei Reisen nach Osteuropa. Andererseits sind diese Reisen für die osteuropäischen Staaten von Bedeutung, weil sie eine bedeutende Quelle ihrer Deviseneinkommen darstellen können. Der Verfasser gibt zwei Alternativen an, um diese Probleme zu lösen (siehe S. 368-369). Die erste Möglichkeit ist, bilaterale Verträge zwischen ost- und westeuropäischen Staaten zu schließen, wodurch die durch Abstammung erworbene doppeiten Staatsangehörigkeiten verringert werden. Durch diese Verträge sollten die Eltern eines neugeborenen Kindes eine ihrer Staatsangehörigkeiten für das Kind wählen müssen. Das Kind sollte nach seiner Mehrjährigkeit allerdings das Recht auf erleichterten Erwerb der Staatsangehörigkeit des anderen Elternteils besitzen müssen. Die andere Staatsangehörigkeit sollte er durch diese Wahl automatisch verlieren. Die zweite Möglichkeit, die der Verfasser auch bevorzugt, ist, durch bilaterale Verträge nicht die doppelte Staatsangehörigkeit zu verringern, sondern nur die für die Doppelstaater hieraus resultierenden unangenehmen 
Folgen. Die vertragsparteien Staaten sollten sich verpflichten, die Personen, die auch ihre Staatsangehörigkeit besitzen ausschließlich als Staatsbürger des Wohnsitzstaates zu behandeln. Derartige Verträge haben die Vereinigte Staaten schon mit Jugoslawien, Bulgarien, der DDR und Polen geschlossen, sowie Österreich mit der DDR.

Da ein Nebenziel dieser Forschungsarbeit auch die Suche nach Inspiration zur Verbesserung des eigenes Rechtssystems war, wurden im vierten Teil, 1. Kapitel einige Vorschläge bezüglich Änderungen des niederländischen Staatsangehörigkeitsgesetzes von 1984 erörtert und unterbreitet.

a. Ein minderjähriges Kind, dessen Abstammung von einen ruiederländischen Vater gerichtlich festgestellt wird, soll von Rechts wegen die niederländische Staatsangehörigkeit erwerben müssen (siehe S. 372-373)

b. Art. 11 sollte in der Form geändert worden, daß die Einbürgerung sich nur auf die Kinder unter 14 Jahren erstreckt, wenn die Staatsangeörigkeit beiden Elternteilen verliehen wird. Das gleiche sollte in dem Falle gelten, wenn der andere Elternteil staatenlos oder bereits Niederländer ist. Wenn der andere Elternteil sich nicht einbürgern läßt und eine fremde Staatsangehörigkeit besitzt, sollte die Erstreckung auf das Kind mur erfolgen, wenn dieser Elternteil seine Zustimmung dazu erteilt. Die mangelnde Zustimmung des Elternteils sollte durch das Vormundschaftsgericht ("Kinderrechter" in den Niederlanden) ersetzt werden können, wenn der Elternteil, der die Zustimmung verweigert, kein redlichen Interesse an der Nicht-Einbürgerung des Kindes nachweisen kann. Im Falle, daß nicht beide Eltern die elterliche Gewalt über das Kind ausüben, sollte der gesetzliche Vertreter das Recht des anderen Elternteils besitzen. Eine Erstreckung auf ein bereits vierzehnjähriges Kind sollte grundsätzlich nur erfolgen, wenn dieses Kind in die Erstreckung eingewilligt hat. Ein Kind, das seine Zustimmung verweigert, sollte ein unbefristetes Optionsrecht auf die niederländische Staatsangehörigkeit erhalten. Die mangelnde Einwilligung des Kindes sollte durch das Vormundschaftsgericht nur ersetzt werden können, wenn das Kind durch die Verweigerung seiner Einwilligung staatenlos bleibt oder wird. Eine Erstreckung der Einbürgerung sollte in der Einbürgenungsurkunde ausdrücklich erwähnt werden müssen. Diese Erwähnung sollte konstitutive Wirkung haben (siehe S. 382-383).

c. Die unter b. vorgeschlagenen Änderungen sollten im Art. 6 und 28 entsprechend auf die Kinder von Personen, die durch Option die niederländische Staatsangehörigkeit erwerben, Anwendung finden (siehe S. 383). 


\section{The Law of Citizenship in the Countries of Eastern Europe}

This study deals with the historical development of the regulations governing acquisition and loss of citizenship in the East European countries. The book is divided into four parts. In the first part, the author starts by describing some theoretical issues such as the substance of citizenship and its function according to Eastern and Western European doctrines. The author sees citizenship as a concept reflecting the allegiance of a person to a state, to which legal rights and duties are attached by municipal and international law. States use citizenship primarily as a criterion to distinguish between their own citizens and aliens.

Subsequently, the author discusses the problem of the inter-systematic comparative law comparison between laws of countries with different social systems, in particular with regard to citizenship law. It is the author's view, that such comparisons are also useful for some purposes to Western lawyers, seeking inspiration in comparative law for the improvement of their own legal systems. At the end of the first part, the author deals with the terminology used in the book. Acquisition of citizenship is subdivided into acquisition ipso jure, by option and by naturalization, and loss of citizenship into loss of citizenship ipso jure, by discharge, i.e. at the applicant's request, by renunciation and by deprivation. The terms 'option' and 'renunciation' in particular are often used in various legal systems for different forms of privileged naturalization and discharge. In this book, the terms 'option' and 'renunciation' are used exclusively for acquisition and loss of citizenship, respectively, by the express will of the individual in question.

In the second part, a description is given of the regulations governing citizenship in all East European countries (the Soviet Union, Albania, Bulgaria, the German Democratic Republic, Hungary, Yugoslavia, Poland, Romania and Czechoslovakia). Prior to describing the regulations governing citizenship of these nine countries, the author discusses the provisions of international treaties on citizenship, which have been ratified by at least one East European country. In addition, special attention is given to the Universal Declaration of Human Rights and to the 'network' of bilateral agreements entered into by the East European countries for the purpose of reducing dual citizenship. Subsequently the various codifications of the laws of citizenship, beginning with the codification in Soviet Union, followed in alphabetical order by the other countries, are discussed. The description of the law of each state commences with a short general historical introduction, followed by an explanation of regulations that were operative before the communist parties came to power.

In the third part, the regulations governing citizenship are compared over three periods of time. Firstly, the provisions that were in existence prior to the communist regimes are discussed, secondly, the first generation of 'socialist' citizenship acts, and finally the subsequent developments are described. The purpose of these comparisons is to discover what changes the communist governments have enacted, and how citizenship regulations have developed up to the present day.

In the fourth part, the author offers his conclusions as to the different rules governing acquisition and loss of citizenship and provides an answer to one of the 
principal questions, namely whether the laws of citizenship in Eastern Europe contain elements that are typical of socialist countries and completely different from the regulations covering the same field of law in Western Europe. The author also proposes some changes in the Dutch Nationality Act of 1984.

After the communist parties took over, all East European countries introduced new citizenship acts. In some countries, e.g. the RSFSR, Yugoslavia and Albania this took place within months. In the other countries it took from one to several years. The German Democratic Republic is an exception; its first socialist citizenship act saw the light 18 years after the communist government came to power. The changes enacted by the new governments were for the most part related to the acquisition and loss of citizenship ipso jure, e.g. by the introduction of the rule "jus sanguinis a matre et a patre" and the abolition of an automatic change in citizenship for a woman upon marriage. There were also new regulations governing the extension of acquisition and loss of citizenship by the parents to their minor children. Although these particular changes can be labeled as very advanced, there were also changes in the opposite direction. The acquisition of citizenship by option became an even more rare option and the authority for taking decisions on naturalization, discharge from and deprivation of citizenship was largely vested in the highest administrative bodies. The vague language of the citizenship acts allowed unlimited discretionary freedom to the administration in these matters. Further, there were no realistic means of judicial review of these decisions.

The regulations governing the loss of citizenship by deprivation formed a special problem. In countries without this option (Russia, Albania), it was introduced by new governments. In the other countries, the possibility of deprivation, incorporated in former legislation, was maintained, or even extended. To some extent, broadening the scope for deprivation should be seen in the light of the historical background. Yugoslavia, Poland and Czechoslovakia had suffered considerably under German occupation and in these countries the rules governing deprivation in the case of their ethnic German nationals must be viewed as 'revenge' on Germany. The ethnic Germans were first deprived of their citizenship and subsequently expelled. In Czechoslovakia, it should be noted, this had already begun to happen under the 'bourgeois' government of Benes. The second reason for broadening the rules on deprivation was that the communist regimes first wanted to get rid of their own political opposition by expelling them, or by prohibiting their return. Ironically, the regulations governing deprivation of citizenship were often inherited from the old right-wing regimes (Bulgaria, the German Democratic Republic, Hungary, Poland, Romania), that had used the same rules against members of the communist parties.

Generally speaking, it can be said that none of the first socialist citizenship acts was simply a copy of the extremely short Stalinist Soviet Citizenship Act of 1938. The influence of the Yugoslav Act of 1945 is noticeable in Albania, in particular, but in Bulgaria too.

Over the last forty years, the development of citizenship legislation in Eastern Europe has been fairly uniform. The exceptions are Albania, Yugoslavia and Romania. In Albania and Romania, in 1954 and 1952, respectively, new regulations were enacted which were faithful copies of the Soviet Citizenship Act of 1938. Although this same decree is still in effect in Albania; Romania returned to a more 
detailed legislation, with clear National Socialist-seeming elements in 1971. A common feature of the citizenship laws of both countries is the far-reaching discretionary freedom of the administration and the very weak legal position of the individual in matters of citizenship. In Yugoslavia since the clash with Stalin in 1948, citizenship law developed very differently. The Citizenship Act of 1945 was altered considerably in 1964 and 1976 , and can now be regarded as the most acceptable regulation of citizenship in Eastern Europe. It offers interesting solutions with regard to equality of the sexes and reduction of dual citizenship. Yugoslavia is furthermore the only country in Eastern Europe that allows its citizens to renounce their citizenship, and gives them a limited right to lose it by discharge. Deprivation is not possible, if the person in question becomes stateless, as a result. However, if is within the power of Yugoslav administration to turn every right granted to its citizens into an illusion by the simple use of the magic formula "security of the state" or "the national defense interests". This together with the fact that it is possible to deprive its citizens of their citizenship, is evidence of the considerable shortcomings of Yugoslav citizenship law.

The regulations of the other five countries can be classified as ranging between the two extremes described above. Legislation in the German Democratic Republic and Czechoslovakia in particular, but also in the USSR and Bulgaria tend more towards the law in Albania and Romania, whereas the Polish and the Hungarian Citizenship Acts have more in common with the rules of citizenship in Yugoslavia. The discretionary freedom of the administration in respect of decisions on naturalization, discharge and deprivation remains the principal characteristic of citizenship law in all East European countries. It should be stated, however, that in most of these countries there is a slight tendency to introduce specific legal rules limiting this freedom. Use is very seldom made of the existing possibilities of deprivation, and in the event mostly against political opponents of the regimes.

Apart from these negative features, typical of all totalitarian states, the laws of citizenship in Eastern Europe also contain positive elements. East European countries were the first countries in Europe to achieve an equal position for men and women by introducing the principle of jus sanguinis a patre et a matre and by granting the married women an independent position under the law of citizenship. It took the Western countries several decades to achieve the same goals.

Another area where citizenship regulations in Eastern Europe can still be labeled as very advanced compared with the rest of Europe concerns the emancipation of minors above a certain age; in most countries over 14 years of age.

In all East European countries, with the exception of Yugoslavia, the regulations for acquisition of citizenship show a strong tendency to extend the citizenship of these East European countries to the children, in cases where the parents of a child possess a different citizenship. Since the same tendency exists in most Western countries, children of parents with various citizenships often acquire dual citizenship. In Eastern Europe, when both parents possess different East European citizenships, the child, by virtue of the network of bilateral agreements between the East European countries, in most cases, obtains the citizenship of only one of his parents. If one of the parents is a West and the other an East European, for example an immigrant in Western Europe married to a West European, their children generally possess dual citizenship and very often remain dual citizens all 
their lives. Since every East European country regards those of its nationals who possess one of more other citizenships exclusively as its citizens (the principle of exclusivity), when wishing to visit their East European homeland such persons must reckon with several umpleasant surprises, which might entail being drafted for military service, requiring permission for residence in another country or, of being refused permission to leave the country, etc. This is certainly an obstacle, when, for example, they want to visit their grandparents in Eastern Europe, or go there as tourists. Such travel, on the other hand, could be a welcome source of foreign currency for the East European states.

The author offers two solutions to these problems (see p. 368-369). One is the conclusion of bilateral agreements between West and East European countries regulating dual citizenship of children, born to parents, who are citizens of the respective contracting countries. Within a determinate period of time after the birth of the child, the parents should decide which citizenship the child is to possess. Upon reaching full age, the child should then have the right to acquire the citizenship of the other parent in a privileged procedure. Acquisition of this new citizenship should result in the automatic loss of the original citizenship.

The second solution, which in the author's opinion is to be preferred, would not lie in the prohibition of dual citizenship, but in the elimination of the disadvantages of such bipatride status, for the person in question. These agreements should oblige each state to consider those of its nationals who also possess a second citizenship exclusively as citizens of their country of residence. Such bilateral agreements have already been concluded between the United States and Yugoslavia, Bulgaria, the German Democratic Republic and Poland, and between Austria and the German Democratic Republic.

A secondary purpose of this study is to collect ideas useful for improving the Dutch Citizenship Act of 1984. In part IV, chapter 1 a number of proposals are made for such change.

a. It should be possible for a minor alien to acquire Dutch citizenship ipso jure where it is established in court that said minor was fathered by a Dutch citizen (see p. 372-373).

b. Article 11 should be amended in such a way that the naturalization of a parent shall only automatically extend to this parent's children under 14 years of age in cases where both parents are naturalized, or where one parent is going to be naturalized and the other parent is a already Dutch citizen, or where the latter is stateless. When the other parent possesses foreign citizenship and does not apply for naturalization, his consent should be required. If this parent does not consent and fails to prove any reasonable interest in the non-naturalization of the child, such consent would be replaced by a court decision. When the parental authority is exercised by a third person, the consent of this third person should be required, as well. When the minor child has reached the age of 14 years, naturalization of a parent should, in principle, not extend to the child without the consent of the child itself. If the child does not agree with its naturalization together with the parent(s), consent should be replaced by a court decision only in cases where the child would remain or become stateless 
as a result of the naturalization of the parent(s). The child who refuses to be naturalized should have a full right to acquire Dutch citizenship by option. In every decision on naturalization it should be expressly stated whether the naturalization also applies to the minor children of the naturalized person(s). In the absence of such express statement, the children are to be regarded as not having been naturalized (see p. 382-383).

c. The amendments proposed under b. should, mutatis mutandis, be applied to the children of persons who acquire Dutch citizenship by option (articles 6 and 28). See p. 383. 


\section{POVZETEK V SLOVENSČINI}

\section{Pravo državljanstva v državah vzhodne Evrope}

$\checkmark$ pricujoci raziskavi obravnava pisec zgodovinski razvoj ureditev pridobivanja in izgube državljanstva v državah vzhodne Evrope. Knjiga obsega štiri dele.

V prwem delu so najprej obravnavana nekatera teoretična vprašanja državljanstva, kot sta vsebina in funkcija te pravne institucije, tako $v$ zahodno, kot $v$ vzhodnoevropski pravni teoriji. Avtor zavzema stališče da je državljanstvo samo po sebi navezna okoliš̌ina, ki ponazarja pripadnost posameznika neki državi. Različne države uporabljajo državljanstvo za navezovanje različnih pravnih posledic (pravic in dolžnosti). Funkcija državljanstva je predvsem v tem, da služi državam kot kriterij za razlikovanje med lastnimi subjekti in tujci.

Zatem avtor obravnava problematiko primerjave prava držav različnimi družbeno-politiěnimi ureditvami tako na splošno, kot na področju državljanstva. Pisec zavzema stališce, da je takšna primerjava lahko koristna tudi za zahodnoevropskega pravnika, ki se loti primerjalnega prava $\mathrm{z}$ namenom da najde navdih za izboljšanje prava lastne države.

$\mathrm{Na}$ koncu prvega dela razlaga pisec $v$ tej knjigi uporabljeno terminologijo. Načini pridobivanja državljanstva so razdeljeni na pridobivanje po samem zakonu, $z$ opcijo in $z$ naturalizacijo (podelitvijo). Načini izgube pa so razdeljeni na izgubo ipso iure, $z$ odrekom, odpustom in odvzemom. Predvsem pojma opcija in odrek se v razliěnih pravnih redih uporabljata za različne oblike privilegirane naturalizacije, oziroma odpusta, ko o pridobitvi odloča pristojni državni organ. V tej knijgi sta pojma opcija in odrek uporabljana izkljueno v primerih, ko posameznik pridobi ali izgubi državljanstvo na podlagi lastne izjave volje, državni organ pa nima pravice, da bi v primeru ko posameznik izpolnjuje vse pogoje za opcijo oziroma odrek, to izjavo zavrnil.

V drugem delu je obravnavano pravo državljanstva vseh tako imenovanih vzhodnoevropskih držav: Sovjetske zveze, Albanije, Bolgarije, Nernške demokratǐ̌ne republike, Madžarske, Jugoslavije, Poljske, Romunije in Cehoslovaške. Uvodoma se avtor posveð̌a določbam razliěnih mednarodnih pogodb ki se dotikajo problematike državljanstva in pri katerih je podpisnik vsaj ena od obravnavanih držav. Posebna pozornost je posvečena tudi čenu 15 Splošne deklaracije o clovekovih pravicah in mreži bilateralnih pogodb s ciljem preprezevanja dvojnega državljanstva, ki so jih med seboj sklenile vzhodnoevropske države. Sledi oris zakonodaje na področju državljanstva, najprej v Sovjetski zvezi potem pa po abecednem vrstnem redu v vseh drugih državah. Opis prava posameznih držav se prične s splošnim zgodovinskim uvodom, cemur sledi obravnava posameznih kodifikacij s področja prava državljanstva, ki se pričenja z zakoni o državljanstvu, ki so $v$ posameznih državah veljali neposredno pred prihodom komunističnih partij na oblast.

$\checkmark$ tretjem delu sledi primerjava ureditev državljanstva v treh fazah. Prva obsega "buržoazno" zakonodajo državljanstva v vzhodni Evropi, druga prve "socialistične" zakone o državljanstvu in tretja nadaljnji razvoj vse do današnjih dni. Namen teh primerjav je ugotoviti, katere spremembe so bile vpeljane po prihodu komunistov na oblast in kaǩsen je bil nadaljni razvoj v teh državah na področju državljanstva.

$\checkmark$ cetrtem delu sledijo sklepi glede posameznih načinov pridobivanja in izgube državljanstva poleg tega pa avtor podaja odgovor na eno izmed bistvenih vprašanj, 
namreč, ali vsebuje pravo državljanstva evropskih socialističnih držav specifične elemente, ki se povsem razlikujejo od pravnih ureditev tega področja v zahodini Evropi. Pisec predlaga tudi nekatere spremembe nizozemskega zakona o državljanstvu iz leta 1984.

V vseh socialističnih državah vzhodne Evrope je prißlo po prihodu komunisticnih strank na oblast do nekaterih načelnih sprememb v pravni ureditvi državljanstva. V nekaterih državah (RSFSR, Albanija, Jugoslavija) so bili že v casu nekaj mesecev sprejeti novi zakoni o državljanstvu. V drugih državah pa je eno ali celo ve` let కe veljala stara zakonodaja. Izjema je Nemška demokratična republika, ki je uvedla svoj prvi zakon o državljanstvu sele 18 let po nastanku te države leta 1949. Pri nobenem od teh prvih zakonow o državljanstwu pa ni šlo za posnemanje takrat veljavnega skrajno kratkega stalinistiénega sovjetskega zakona o državljanstvu iz leta 1938. Predvsem v Albaniji, delno pa tudi v Bolgariji, je bilo opaziti vpliv jugoslovanskega zakona o državljanstvu.

Spremembe ki so jih vpeljali prvi socialistični zakoni o državljanstvu so bile predvsem na področju pridobivanja in izgube državljanstva po samem zakonu, namrec uveljavitew nacela ius sanguinis a matre et a patre in pa odprava avtomatične spremembe državljanstva pri sklenitvi zakona. Zanimive novosti so prinesle tudi ureditve vpliva spremembe državljanstva staršev na državljanstvo njihovih mladoletnih otrok. Vse te spremembe lahko $v$ primerjavi $\mathrm{z}$ zahodno Evropo nedvomno označimo kot zelo napredne.

Zal je prišlo tudi do sprememb $\mathrm{v}$ negativnem smislu. Tako so bile zelo omejene možnosti pridobivanja državljanstva $z$ opcijo in izgube $z$ odrekom, pristojnost za odločanje o naturalizaciji, odpustu in odvzemu pa se je praviloma prenesla na najvisje državne organe, ki so imeli po zaslugi izredno skopih in nepreciznih zakonskih določb praktično neomejeno diskrecijsko pravico.

Poglavje zase je bilo področje odvzema državljanstva. Države ki te institucije prej sploh niso poznale (RSFSR, Albanija), so jo uvedle, v drugih državah pa so obdržali, ali celo razširili možnosti odvzema iz starih zakonov. Te razširitve so bile deloma zgodovinsko pogojene. Veと držav vzhodne Evrope ki so zelo trpele pod nemško okupacijo (Jugoslavija, Poljska, ĆSSR) je imelo na svojem ozemlju močne nemske manjšne, ki so postale cilj "mašcevalnih" ukrepov v obliki odvzema državljanstva in $s$ tem zvezanega izgona iz države. Treba pa je pripomniti, da se je to $v$ CSSR zgodilo se pod "buržoaznim" Beneševim režimom. Drugi razlog za razširitev možnosti odvzema državlljanstva je videti predvsem v tem, da so se komunisti na ta način lahko "znebili" lastne politične opozicije. Prav možnosti odvzema državljanstva iz političnih razlogov so bile dostikrat "podedovane" od prejšnjih režimov, ki so billi praviloma (skrajno) desničarski in so tako rekoč iste zakonske dolocbe uporabljali ravno proti komunistom (Bolgarije, Nemśka demokraticna republika, Poljska in Romunija).

$\mathrm{V}$ zadnjih కtirih desetletjih je sel razvoj na področju prava državljanstva $v$ vzhodnoevropskih državah večinoma v enaki smeri. Izjeme pa predstavljajo do neke mere Albanija, Jugoslavija in Romunija. Posebne okolišcine so $v$ Albaniji in Romuniji leta 1954, oziroma 1952 pripeljale do uvedbe izredno kratkih stalinističnih ureditev državljanstva. Ta izrazita kopija sovjetskega zakona o državljanstvu iz leta 1938 velja v Albaniji se danes, medtem ko pa se je Romunija leta 1971 vrnila $k$ obširnejšemu zakonu o držaljanstvu, za katerega pa so značilni izrazito nacionalno- 
socialističcno obarvani elementi. Značlnost obeh držav pa je ostala neomejena moč administracije na eni in nemož posameznikov na drugi strani.

V Jugoslaviji pa je sel razvoj v povsem drugačni smeri. Zakon o državljanstvu je bil bistveno spremenjen se leta 1964 in 1976 in ga danes lahko smatramo za najboli "sprejemljiv" zakon o državljanstvu $v$ vzhodni Evropi. Jugoslovanski zakonodajalec je uvedel zanimive rešitve za preprečevanje dvojnega državljanstva na eni in za uveljavitev nacela ius sanguinis a matre et a patre na drugi strani. Poleg tega je SFRJ edina evropska socialistična država ki priznava svojim državljanom neko omejeno pravico do izgube (spremembe) državljanstva (odrek, odpust) in ki dovoljuje odvzem samo $v$ primeru ko dotična oseba poseduje tudi neko drugo državljanstvo in torej ne more postati apatrid. Toda dejstvo da je odvzem državljanstva se mogoč in da lahko pristojni organ s "čarobnima" formulama "interesi narodne obrambe" in "državna varnost" poljubno vsako pravico posameznika do spremembe državljanstva napravi iluzorno, kaže na to, da tudi sedanji zakon o državljanstvu SFRJ క̌e vedno vsebuje dokajšnje pomankljivosti, ki so s stališča pravne države in obrambe človekovih pravic nezaželene.

Ureditve državljanstva $v$ ostallih petih vzhodnoevropskih državah pa lahko postavimo med obe "skrajnosti". Medtem ko se se predvsem pravo Nem̌̌ke demokratične republike, v nekaj manjß̌i meri pa tudi Čhoslovaške, Sovjetske zveze in Bolgarije približuje Albanski in Romunski ureditvi, pa imata zakona o državljanstvu Madžarske in Poljske ver skupnih zmačilnosti z jugoslovanskim. Najpomembnejša karakteristika ki je skupna prav vsem socialističnim državam v Evropi, pa je diskrecijska pravica državnih organov pri odločanju o pridobivanju in izgubi državljanstva in odsotnost, oziroma nemožnost realne kontrole teh odločitev s strani neodvisnih sodnikov. Mora pa se poudariti da je v skoraj vseh državah opazna tendenca $\mathbf{k}$ natančnejsim zakonskim določbam, ki to diskrecijsko pravico omejujejo. Institut odvzema državljanstva, se sicer v praksi vseh vzhodnoevropskih držav le redko uporablja, praviloma pa proti političnim nasprotnikom vladajoči režimov w țeh državah.

Poleg nastetih negativnih karakteristik, ki niso znacilne le za komunistične, ampak za vse totalitarne režime, pa ima pravo državljanstva v vzhodni Evropi tudi določene izrazito pozitivne značilnosti. Te države so bille prve v Evropi, ki so na področju državljanstva realizirale enakopravnost žensk. Zahodnoevropske države so potrebovale vec desetletij da so lahko ta zaostanek nadoknadile.

Sedanje ureditve državljanstva $v$ vzhodnoevropskih državah pa poznajo se eno resitev $k i$ je $v$ primerjavi $\mathrm{z}$ zahodom zelo napredna, namreč emancipacijo mladoletnikov nad določeno starostno mejo (praviloma 14 let). Njim je načeloma dana pravica da sami odlocajo o tem ali bodo deležni naturalizacije oziroma odpusta iz državljanstva, za katero prosi eden ali oba starša.

Ureditve pridobivanja državljanstva vzhodnoevropskih držav po poreklu kažejo z izjemo Jugoslavije možno tendenco $k$ razširitvi kroga lastnih državljanov; državljanstvo se namrex praviloma pridobi že če eden od staršev poseduje državljanstvo dotične države. če imata oba starša državljanstvi vzhodnoevropških držav, pridobi otrok po zaslugi mreže bilateralnih pogodb ki jih je večina teh držav med seboj sklenila, kljub vsemu praviloma le eno državljanstvo. Ko pa gre za otroke državljanov zahodno- in vzhodnoevropskih držav (npr. na zahodu rojeni otroci emigrantov), pa postanejo ti glede na to da tudi v večini zahodnoevropskih 
držav veljajo enaka pravila glede pridobivanja državljanstva iure sanguinis, zelo pogosto bipatridi. Glede na to da se $v$ wseh državah vzhodne Evrope močno poudarja tako imenovano načelo izključnosti (nepriznavanje eventualnega tujega državljanstva lastnih državljanov) se te osebe obravnavajo izključno kot državljani vzhodnoevropskih držav. To pomeni da lahko ob obisku teh "drugih" nacionalnih držav računajo $z$ neprijetnostmi kot so vojaška obveznost, dovoljenje za bivanje $v$ tujini, prepoved izhoda iz države, itd. Te okolišine vsekakor predstavljajo doloceno oviro pri obiskih družinskih clanov in turisticnih potovanjih. Takšna potovanja pa so tudi $v$ interesu vzhodnoevropskih držav, saj pomenijo dobrodošel vir deviznega zaslužka.

Za rešitev teh težav predlaga pisec dve možni rešitvi (glej str. 368-369). Prva je omejitev po poreklu pridobljenega dvojnega državljanstva, po vzorcu bilateralnih pogodb, ki so jih med seboj že sklenile vzhodnoevropske države. Starši novorojenega otroka bi morali $v$ določenem roku izbrati državljanstvo otroka, ki pa bi pri polnoletnosti moral imeti pravico do enostavne pridobitve državljanstva drugega od staršev in bi $\mathbf{v}$ taken primeru avtomatično izgubil svoje prejșnje državljanstvo. Drugo rešitev vidi avtor $\mathrm{v}$ billateralnih pogodbah ki dvojnega državljanstva ne preprečujejo, ampak odpravljajo le za posameznika neprijetne posledice bipatridnega statusa. Tako bi se državi pogodbenici morali obvezati da polipatride ki imajo tudi njuno državljanstvo obravnavata izključno kot državljane države $\mathrm{v}$ kateri dotična oseba živi. Takšne pogodbe so združene države Amerike že sklenile z Jugoslavijo, Bolgarijo, Poljsko in Nemško demokratično republiko. Slednja pa je sklenila takšno pogodbo tudi z Avstrijo.

Glede na to da je bil eden izmed postranskih ciljev pričujoče raziskave tudi iskanje navdiha za spremembe nizozemskega zakona o državljanstvu, daje pisec $v$ prvem poglavju Cetrtega dela predloge spremembe tega zakona.

a. Po samem zakonu mora pridobiti državljanstvo mladoletni tujec, glede katerega se sodno ugotovi da njegov oče poseduje nizozemsko državljanstvo (glej str. 372-373).

b. 11. člen se mora tako spremeniti, da bo otrok mlajsi od 14 let avtomatično deležen naturalizacije svojih staršev le $\mathrm{v}$ primeru, ko se državljanstvo podeli obema staršema. Isto mora veljati v primeru ko je naturaliziran le eden od staršev, medtem ko je drugi Nizozemec, ali pa nima državljanstva. Ce drugi od staršev ne prosi za naturalizacijo in ima tuje državljanstvo, pa mora biti za naturalizacijo otroka potrebno tudi njegovo soglasje. To soglasje se lahko nadomesti $z$ odlozbo sodnika za mladoletnike ce se soglasje zavrne, roditelj ki ga zavrne pa ne more pokazati upravičenega interesa pri nenaturalizaciji otroka. Ce eden od staršev ne izvrsuje roditeljske pravice, pa je potrebno tudi soglasje otrokovega zakonitega zastopnika. Otroci starejsi od 14 let morajo biti v vsakem primeru deležni naturalizacije enega ali obeh staršev le na podlagi lastnega soglasja. Otrokovo soglasje se lahko nadomesti $z$ odločbo sodnika za mladoletnike izključno $\mathrm{v}$ primeru ko bi otrok ki ne da soglasja ostal ali pa postal apatrid. $V$ primeru da otrok ne da soglasja mora imeti neomejeno pravico pridobiti nizozemsko državljanstvo $\mathrm{z}$ opcijo. V vsaki odločbi o 
naturalizaciji je treba izrečno navesti ali so naturalizacije deležni tudi otroci prosilca. Ta navedba mora imeti konstitutiven učinek (glej str. 382-383).

c. Pod b. navedene spremembe se morajo smiselno uporabljati tudi za primere ko eden ali oba starła pridobi državljanstvo $z$ opcijo na podlagi 6 . ali 28 . člena (glej str. 383). 
LITERATUUR

ALAGIC

ALBIN

ANDRASSY

ANDROJNA

ANSBACH/MOHR

ARLT

ARNOLD

B.AJÁKT

BAIÁKI

BAKIĆ

BALLREICH

BARABASEVV e.a.

BARDACH e.a.

BARTELS
Alagic, D. Problem apatridije

Godišnjak pravnog fakulteta u Sarajevu 1954, p. 1-32

Albin, P. Les grands traités politiques

Paris 1912

Andrassy, J. Medjunarodno pravo

\&e druk, Zagreb 1984

Androjna, V. Zakon o upravnih sporih s sodno prakso Ljubljana 1977

Ansbach, T. en Molir, M. Die allgemeine Erklärung der Menschenrechte von 1948-Auftrag und Wirkung

Neue Justiz 1988, p. 480-484

Arlt, R. Rechtswergleichung im Bereich der Landwirtschaft, in: Die Rolle der Rechtswergleichung in der Rechtswissenschaft, Rechtsausbildung und Rechtspraxis der DDR sowie in der ideologischen Auseinandersetzung, Tagung des Nationalkomitees für Rechtswissenschaft der DDR am 7. Mai 1981

Potsdam-Babelsberg 1982, p. $42-50$

Arnold, E. Staatsangehörigkeiltsfragen im Generalgouvernement

ZfoR $1940 / 41$, p. 148-153

Bajáki, V. Magyar állampolgárság-kettös âllampolgărság Budapest 1973

Bajaki, V. Obscee i osobennoe v pravovom regulirovanii graždanstva v evropejskïch socialistizeskich stranach SGiP $1976 / 11$, p. $80-86$

Bakić, V. Porodično pravo SFRJ

Beograd 1982

Ballreich, H. Karpathenrussland. Ein Kapittel tschechischer Nationalitâtenrechts und tschechischer Nationalitättenpolitik. Heidelberg 1938

Barabašev, G.B. e.a. Sovetskoe gosudarstvennow pravo 2e druk, Moskva 1975

Bardach, J. e.a. Historia panstwa i prawa Polskiego Warszawa 1977

Bartels, H.-J. Methode und Gegenstand intersystemarer Rechtsvergleichung

Tübingen 1982 
EARTOS:

BENKÖ

Van den BERG

BERNHARDT

BEUER

BIERUT

BILINISKY

BILINSKYY

BISKUPSKI

BLAGOJEVIĆ 1947

BLAGOJEVIĆ

BLAGOJEVIĆ Méthode

BLATOVA

BLUMENWTTZ

BOGDAN

BOGUSLAVSKIJ/RUBANOV
Bartos, M. Memorandum o Trstu od 5. oktobra 1954. Prawni asvrt

JRMP 1954/3, p. 421

Benkö, L. Ungarn; Staatsangehörigkeitsrecht

Rabels: Z 1951, p. 293-298

Van den Berg, G.P. Sovjet staatsburgerschap: een eretitel? NRC Handelsblad 19 december 1978

Bernhardt, H. Das Staatsburgerschaftsgesetz der DDR. Mitteilungsblatt des Kömigsteiner Kreises 1968

p. 25-29

Beuer, G. New Czechoslowakia and the Historical Background London 1947

Bierut, B. O konstytucji Polskiej Rzeczypospolitej Ludowej Warszawa 1952

Bilinsky, A. Rechtstellung der Unionsrepubliken in de UdSSR JOR $1976 / 2$, p. $51-59$

Bilinsky, A. Zum neuen Staatsbürgerschaftsgesetz der UdSSR JOR $1978 / 2$, p. $263-265$

Biskupski, K. voorwoord in: Konstytucja i podstawowe akty ustawodawcze Polskiej Rzeczypospolitej Ludowej

Zbior tekstów

Warszawa 1952

Blagojevič, B.T. Državljanstvo (s naroxitim obzirom na pravo SFRJ)

2e druk, Beograd 1947

Blagojević, B.T. La nationalité d'origine en Yougoslavie RCDIP 1954, p. 29-37.

Blagojevic, B.T. La méthode comparative juridique, in: Inchieste di diritto comparato, deel 2: Buts et méthodes du droit compare, p. 15-40

Padova/New York 1973

Blatova, N.T.(red.) Meždunarodnoe pravo

Moskva 1987

Blumenwitz, D. Das neue Staatsbürgerschaftsgesetz der DDR JOR $1967 / 1$, p. 174-204.

Bogdan, M. Different Economic Systems and Comparative Law

CLY 1978 p. 89-155

Bogruslavskij, M.M. en Rubanov, A.A.

Pravovoe položenie sovetskich grazdan za granicej

Moskva 1961 
BOJARS

BOLDUR

BOLLACHER

BRINKMAN

BRUEGEL

BRUNNER

BRUNNER

BURDA

BYSTRICKY

CADERE

CAHN

CAPATINA

CAR

CASSIN

CIGOJ
Bojars, Ju.R. Grażdanstvo v mezdunarodnom i vautreninem prave

Rüga 1981

Boldur, A. La Bessarabie et les rélations Russo-Roumaines Paris 1927

Bollacher, E. Das Hultschiner Ländchen in

Versailler Friedenswertrag

Stuttgart 1930

Brinkman, CJ. Het Nederlandse Nationaliteitsrecht in de praiktijk

Alphen aan den Rijn/'s-Gravenhage 1985

Bruegel, J.W. Das neue tschechoslowakische Staatsbürgerschaftsgesetz von 1958

OER 1962, p. 70-71.

Brunner, G. Das Menschenrecht auf Freizingigkeit im Sowjetrecht: Völkerrecht, Gesetzesrecht, und Verwaltungermessen, in: Law and the Gorbachev Era, D.D. Barry(red.), p. 205-216

Law in Eeastern Europe, nr. 39

Brunner, G. Das neue ungarische Passrecht WGO 1988, p. 13-38

Burda, A. Bemerkungen zum Verfassungsreform in Polen von 1976

OER 1978 p. 249-252

Bystricky, R. Za marxistickoø srounávaci pravovedu

Právnik 1962, p. 625-637

Cadere, V. Quelques réflections sur les études de science juridique comparative

RIDC 1971, p. 849-855

Cahn, W. Das Reichsgesetz über die Erwerbung und den Verlust der Reichs- und Staatsangehörigkeit vom 1. Juni 1870 Berlin/Leipzig 1889

Capatina, O. Feststellung der Staatsangehörigkeit von Mebrstaatern im rumänischen $\mathbb{R}$ echt

WGO 1973 , p. 309-319.

Dic Verfassung de Republik Polen vom 23 April 1935 (inleiding van $\mathrm{S}$. Car)

Warschiau 1935

Cassin, R. La déclaration universelle et la mise en oeuwre des droilts de l'homme

Recueil des Cours 1951, II, p. 235-367

Cigoj, S. Obligacije. Sistem splošnega obligacijskega prava v teoriji, sodstvu in primerjalnem pravu

Ljubljana 1976 
CISMARESCU

COLSON

CONSTTTUTIE

CONSTITUTIONS

CZAPLINSKI

CERNIČENKO

CERNICENKO

CERNY/CERVENKA

CIKVADZE/ZIVS

COK

COK

DAMJANOV

DAVID

DAVINIĆ

DELEANU

DENNIS
Cüsmat escu, M. Einführung in das rumänische Recht Darmstadt 1981

Colson, F. Nationalité et régéneration des paysans MoldoValaques

Paris 1862

Constitutie (grondwet) van de Unie van socialistische sowjetrepublieken

Moskou 1980

Blomstein, A.P. en Gisbert, H.F. (red.) Constitutions of the World, Vol. XVI

New York, losbladige editie

Czapiinski, W. Ustawa o obywatelstwie PiP 1951/2 p. 564572.

Cerničnko, S.V. Pravo naciji na samoopredelenie i voprosy graždanstva

SGiP $1964 / 1$, p. $110-114$

Cernicenko, S.V.Meždunarodnopravovye voprosygraždanstwa Moskva 1968

Cerny, J. en Červenka, V. Státní obłànstvi ĆSSR Praha 1963

Cikvadze, V.M. en Zivs, S.L. Spravilltel"noe pravovedenie v praktike meždunarodnogo maučnogo sotrudničestwa SGiP $1966 / 2$, p. $12-20$

Cok, V. Problemi razlicitog državljanstva u porodici Zbornik radova o stranom i uporednom pravu $1961 / 1$, p. 1129

Cok, V. The Citizenship

Yugoslaw Law 1977, p. 25-43

Damjanov, C. Otstranjavanje na dvojnoto graždanstwo spored mezdunarodnoto i bulgarskoto vnutre:̌no pravo Pravna misul $1984 / 6$, p. $48-58$

David, R. Les grands systèmes de droit contemporain 18e druk, Paris 1982

Davinic, A. Otpust iz državljanstwa

Anali pravnog fakulteta u Beogradu 1957 , p. 349-353

Deleanu, I. Cetatenia Romana

Cluj-Napoca 1976

Deminis, A. Soviet Russia and Federated Russia

Political Science Quarterly 1923, p. 520-551 
DEVELOPMENT

DJAJIĆ e.a.

DJUVARA

DRAGANU

DROBNIG

DROPINSKI

DUFOUR

DURDENEVSKIJ

DURDENEVSKIJ

DURICA

DUTCZAK

DZIALOCHA/PATRZALEK

EGLER e.a.

EGYED

ENCIKLOPEDIJA
Development of the negotiations between Czechoslowakia and Hungary concerning the movement of populations

Memoire tchécoslovaque présentế a la conference de la paix Paris 1946

Djajič e.a. Priručnik za rad maticara Beograd 1960

Djuvara, N.M. La legislation Roumaine en matiere de nationalité

Diss. Paris 1940

Draganu, T. Natura juridica a cetateniei

Studia Universitatis Babes Bolyai Series iurispru dentia 1968 , p. 13-26.

Drobnig, U. Rechtswergleichung zwischen Rechtsordnungen verschiedener Wirtschaftssysteme

RabelsZ 1984, p. 233-244

Dropinski, I. Obywatelstwo polskie na ziemiach odzyskanich Administracja i samorzad na Ziemiach odryskanich Seria A, $1,1946 / 2-3$, p. $3-52$

Dufour, R. La nationalité dans l"URSS

RGDIP 1930, p. $511-520$

Durdenevskij, V.N Die Sowetstaatsangehörigkeit und ihre Neuregelung im Jahre 1930

ZfoR 1931, p. 332-352

Durdenevakij, V.N. Das Staatsangehörigkeitsgesetz der UdSSR von 1931

ZfoR 1931, p. 518-520

Durica, M.S. La Slovacchia e le sue relazioni politiche con la Germania 1938/1945

Padova, 1964

Dutcak, B. Die Feststellung der rumänischen Statatsangehörigkeit

Cermauti 1924

Dzialocha, K. en Patrzalek, A. Zur polnischen Verfassungsreform von 1976

OER 1978 p. $236-248$

Egler, G. e.a. Staatsrecht der DDR-Lehrbuch

Berlin (Oost) 1977

Egyed, S. Ungarisches Staatsangehörïgkeïtsgesetz ZfoR 1930, p. $495-506$

Bolsaja Sowetskaja Enciklopedija Sojuza Socialisticeskich Sovetskich Respublik

(onder hooldredactie van Vvedenskij, B.A.; Duitse vertaling onder redactie van Fikenscher)

Leipzig 1959 
EÖRSY

ERDELY

ESAJAN

FELDBRUGGE 1979

FELDBRUGGE Encyclopaedia

FELDBRUGGE

FELDBRUGGE 1988

FERID

FERRARIO

FLOURNOY

DIE FLUCHT

FREUND

FURTHER DOCUMENTS

GAJDUKOV

GEČ-KOROSEC
Eôrsy, G. Reflexions sur la méthode de la comparaison des droits dans le domaine du droit civill RIDC 1967 , p. $397-418$

Erdely, E.V. Germany's First European Protectorate London 1941

Esajain, A.A. Nekotorye voprosy sovetskogo grazdanstva Erevan 1966

Feldbrugge, FJ.M.(red.) The Constitution of the USSR and the Union Republics: Analysis, Texts, reports Alphen aan den Rijn/Germantown 1979

Feldbrugge, FJ.M.(red.) Encyclopaedia of Soviet Law 2e druk, The Hague 1985

Feldbrugge F.J.M. The Soviet law on Emigration Soviet Jewish Affairs 1987/9, p. 21-23

Feldbrugge, F.J.M. Sovjet-Unie (Inleiding in het Sovjet recht), in: D. Kokkini-Latridou, Een inleiding tot het rechtsvergelijkend onderzoek

Deventer 1988, p. 494-511

Ferid, M. Zum ungarischen Staatsangehörigkeitsrecht nach dem Gesetz vom 24.12.1948 (G.A. LX: 1948) StAZ 1951, p p $6-68$

Ferrario, C.A. Storia dei Bulgari Milano 1940

Flournoy, R.W. Observations on the New German Law of Nationality

AJIL 1914, p. 447-486.

Die Flucht aus der Sowjetzone und die Spermassnamen des kommunistischen Regimes wom 13. August 1961 in Berlin Bonn/Berlin (West) 1961

Freund, D. Das neue Staatsangehörigkeitsgesetz der USSR ZfoR 1930 , p. 706-708

Further documents respecting Czechoslovakia including the agreement concluded at Munich on September 29, 1938 Presented by the secretary of state for Foreign Affairs to Parliament by command of His Majesty

London 1938 (79234-31.58)

Gajdukov, D. Graždlanstvo SSSR

Moskwa 1940

Geč-Korošec, M. Družnsko pravo SFRJ, deel 2 Ljubljana 1984 


\section{GEILKE}

GEILKE 1975

GEILKE 1983

GEILKE/LIPOWSCHEK

GEISTLINGER

GELBERG

GELBERG

GHENOV

GIANNINI

GIEYSZTOR e.a.

GINSBURGS

GINSBURGS

GINSBURGS

GINSBURGS 1979

GINSBURGS 1983
Geilke, G. Das polnische Staatsangehörigkeitsrecht von 1962 WGO $196267-72,83$

Geilke, G. Einführung in das bulgarische Recht

Darmstadt 1975

Geilke, G. Einführung in das sowjetische Recht 2e druk, Darmstadt 1983

Geilke, G. en Lipowschek, A. Republikflucht, illegaler Grenzubertritt in Ost- und Südosteuropa

WGO 1966, p. 158-168

Geistlinger, M. Die Ahndung der "Republikflucht" entsprechend dem Recht der sozialistischen Staaten Osteuropas als Flüchtllingsanerkennung

ROW 1987, p. 223-232

Gelberg, L. Nowa ustawa o obywatelstwie polskim PiP 1962, p. 334-342

Gelberg, L. Nowa ustawa o obywatelstwie radaieckim PiP $1980 / 6$, p. $50-56$

Ghénov, G.P. Actes et traites internationaux concernant la Bulgarie

Sofia 1940

GLANNINI, A. L'Albania. Dall' indipendenza all* unione con I'Italia (1913-1939)

Milano 1940

Gieysztor, A. e.a. Zgodovina Poljske (Sloveense vertaling) Ljubljana 1982

Ginsburgs, G. Soviet Citizenship legislation and Statelessness as a Consequence of the Conflict of Nationality Laws ICLQ 1966, p. 1-54

Ginsburgs, G. Soviet Citizenship Law, Law in Eastern Europe no. 15

Leyden 1968

Ginsburgs, G. Soviet Law and the Acquisition of Citizenship at Birth

University of Toronto Law Review 1971, p. 71-80

Ginsburgs, G. The new Soviet Citizenship law and Human Rights (manuscript)

Camden 1979

Ginsburgs, G. The Citizenship, Law of the USSR Law in Eastern Europe no. 25

The Hague/Boston/Lancaster 1983 
GINSBURGS 1988

GLOBKE

GORLE

GRAHN

DE GROOT

DE GROOT preadwies

DE GROOT/TRATNIK

DE GROOT diss.

DE GROOT losbl, ad.

GRANDKE e.a.

GRÖNBERG

GRZYBOWSKY

GUDDE
Ginsburgs, G. The new Rules on Entry into and Exit rom the USSR on Private Business, in: Law and the Gorbachev Era, D.D. Barry (ed.), p. 217-252; Law in Eastern Europe, ar. 39 Dordrechl/Boston/London 1988

Globke, H. Die Protektoratsangehörigkeit ZfoR 1940, p. $447-457$

Gorle, F.H.E. Die Kodifizierung der Gesetzgebung in der Sowjetunion

JOR 1981/1, p. 9-35

Grahn, W.Zur Notwendigkeit rechtsvergleichender Forschung im Sozialismus, in: Die Rolle der Rechtsvergleichung in der Rechtswissenschaft, Rechtsausbildung und Rechtspraxis der DDR sowie in der ideologischen Auseinandersetzung, Tagung des Nationalkomitees für Rechtswissenschaft der DDR am 7. Mai 1981

Potsdam-Babelsberg 1982, p. 30-32

De Groot, G.R. Nationaliteitsrecht en emancipatie van de vrouw in de Bondsrepubliek

NJB 1975 , p. $782-787$

De Groot, G.R. Gelijkheid van man en vrouw in het nationaliteitsrecht, Preadwies voor de Nederlandse vereniging voor rechtswergelijking $\mathrm{nr} .25$

Deventer 1977

De Groot, G.R. en Tratnik, M. Nationaliteitsrecht Zwolle 1986

De Groot, G.R. Staatsangehörigkeitsrecht im Wandel, diss. Maastricht 1988, 's-Gravenhage 1988, Köln/Berlin/Born/München 1989

De Groot, G.R. Nationaliteitsrecht, in Personen en Familierecht, Deventer, losbladige editie

Grandke, A. e.a. Familienrecht- Lehrbuch 3e druk, Berlin (Oost) 1981

Grünberg, C. Das Grundgesetz der russischen Sowjetrepublik Leipzig 1919

Graybowsky, S.M. Les buts des recherches et les méthodes des travaux sur le droit comparé, in: Inchiestle di diritto comparato, deel 2: Buts et metthodes du droit compare, p. 317-335

Padova/New York 1973

Gudde, A.J.Th.M. Het Joegoslavische Huwelijksgoederen- en erfrecht

Deventer 1984 
GÜNDISCH

HECKER

HECKER

HECKER

HECKER

HECKER

HECKER

HECKER Behandlung

HORVAT e.a.

HUBER

HUBERNAGEL

HUBERNAGEL

HUBMANN

HUMPHREY
Gündisch, K. Das Dekretgesetz vom 21. Januar 1938 betr. die Uberprüfung der rumänischen Staatsbürgenschaft ZfoR 1938, p. 50-58

Hecker, H. Ubersicht über Gesetzgebung (1879-1969) und völkerrechtliche Verträge (1897-1968) Bulgariens zum Staatsangehörigkeitsrecht

WGO 1971, p. 321-327

Hecker, H. Die Staatsangehörigkeitsregelungen in Europa, Werkhefte des Instituts für Internationale Angelegenheiten deer Universität Hamburg, deel 25

Hamburg 1974

Hecker, H. Einfluss der Adoption auf die Staatsangehörigkeit StAZ 1985, p. 153-163

Hecker, H. Erleichterungen für Doppelstaater in Konsularverträgen der USA mil kommunistischen Staaten WGO 1986, p. 31-33

Hecker, H. Die Doppelstaaterverträge des Ostblocks WGO 1986, p. 273-283

Hecker, H. Deutsch-deutsche Doppelstaatigkeit? ROW 1987, p. 294-300

Hecker, H. Die Behandlung von Staatsangehörïgkeitsfragen in 1.-10. Deutschen Bundestag (1949-1987)

(manuscript) 1988

Horvat, $\mathbf{M}_{*}$ e.a. $\mathrm{V}$ imenu ljudstva (proces predl vojaškim sodišcem v Ljubljani, junji, julij 1988)

Ljubljana 1988

Huber, E.R. Deutsche Verfassungsgeschichte seit 1789 , delen 3 en 7

Stuttgart/Berlin/Köln/Mainz 1978 en 1984

Hubernagel, G. Das neue bulgarische Staatsangehörigkeitsgesetz vom 19. März 1948

StAZ 1951, p. 135-136.

Hubernagel, G. Änderungen im Staatsangehörigkeitsrecht Bulgariens

StAZ 1955 , p. 69

Hubmann, H. Bulgarisches. Personen- und Familienrecht SLAZ 1951, p. 136-138

Humphrey, J. Impact and Juridical Character of the Universal Declaration, in: Human Rights: Thirty Years After the Universall Declaration (Ramcharan, B.G., red.)

The Hague/Boston/London 1979 
HUNACEK

IGLICAR

IIIIC

JAKOVENKO

JELLINEK, G.

JELLINEK, H.

JESSURUN d'OLIVEIRA

JESSURUN d'OLIVEIRA

JESSURUN d'OLIVEIRA

JOVANOVIĆ

JOVANOVIC

\section{KAHN}

KANGER

KARACSONY

KARASTOJANOFF
Hunatek, Z. Prag: Richllinien zur Regelung der Beziehurigen gegenüber Emigranten

Osteuropa 1978, p. A 307-A 312

Igliixar, A. Unod v sociologijo

Ljubljana 1986

Ilic, Zakon o drzavljanstvu Kraljevine SHS

Beograd 1929

Jakowenko, D.T. Radjans'ke gromadjanstwo

Kiev 1960

Jellinek, G. Allgemeine Staatslehre

3e druk, Berlin 1914

Jellinek, H. Der automatische Erwerb und Verlust der Staatsangehörigkeit durch vôlkerrechtliche Vorgänge, zugleich ein Beitrag zur Lehre von der Staatensukzession

Berlin/Detmold/Kôln 1951

Jessurun d'Oliveira, H.U. Discriminatie en nationaliteitsrecht, noot bij HR 12 oktober 1984,

AAe 1985 , p. $209-215$

Jessurun d'Oliveira, H.U. Moet het verdrag van 20 februari 1957 betreffende de nationaliteit van de gehuwde vrouw nu wel of niet worden opgezegd?

NJB 1985, p. $50-54$

Jessurun d'Oliveira, H.U. Nationaliteit, in: International Recht en Vrouwen, onder redactie van $H$. van Maarseveen e.a.; deel 1.

Zwolle 1987, p. 279-291

Jovanović, L. Državljanstvo socijalisticke federativne republike Jugoslavije

Beograd 1977

Jovanović, L. Savremeni medjunarodnopravni problemii dvojnog drzavljanstva

JRMP 1984/1-3, p* 77-94.

Kahn, W. La loï allemande de la nationalite

RDIP 1913, p. 321-337.

Kanger, H. Human Rights in the U.N. Declaration diss. Uppsala 1984

Karácsony, J. Les droits historiques de la nation hongroise a l'intégrite territoriale de son pays

2e druk, Budapest 1920

Karastojanoff, D.I. Erwerb und Verlust der bulgarischen Staatsangehörigkeit

diss. Halle 1909 


\section{KATUSCAK}

KAZANSKY

KELSEN

KEMPNER

KESCHMANN

KESCHMANN

KESCHMANN

KESSJAKOFF

KIRICENKO

KLEIN

KNAPP

KO SWAN SIK

KOESSLER
Katušak, L. Poznämka $\mathbf{k}$ asnove zákona o cestovnych dokladoch a $k$ návehu novej právnej upravy státneho obcianstva. vo federativnej CSSR

Právnik 1968, p. 825-827

Kazansky, P. Aperçu sur la condition des êtrangers en Russie Clunet 1898, p. $225-233$

Kelsen, H. The legal Status of Germany according to the Declaration of Berlin

AIIL 1945, p. 518-526

Kempner, $R$. Albaniens Statsverfassung

JöR 1926, p. $484-494$

Keschmann, F. Gesetz vom 16.1.1939 iber den Erwerb und. Verhust der rumänischen Staatsbürgerschaft

ZfoR 1938-39, p. 710-727

Keschmann, F. Giesetz vom 27.7. 1939 zu Abänderung und Ergånzang einiger Bestimmungen des Gesetzes über den Erwerb und Verlust der rum. Staatsbürgerschaft wom 19.1.1939 ZfoR 1939, p. 96-101

Keschmann, F. Gesetz wom 20. Oktober 1939 über Abänderung und Ergänzung der Bestimmungen des Art. 62 des Gesetzes über den Erwerb und Verlust der rumänischen Staatsbürgerschaft

ZfoR 1939, p. 299-302

Kessjakoff, BiD. Die bulgarische Stzatsangehörigkeit nach dem Friedemsvertrag von Neuilly

ZfoR 1927, p. 353-372

Kirizenko, M. Graždanstvo sojuza SSSR

Socialisticeskaja zakonnost $1972 / 11$, p. $9-13$

Klein, E. DDR-Staatsbürgerschaftserwerb und deutsche Staatsangehörigkeit

NJW 1983, p. 2289-2292.

Knapp, V. Verträge im tschechoslowakischen Recht. Ein Beitrag zur Rechtswergleichung zwischen Landern mit verschiedenen Giesellschaftsordnungen

RabelsZ 1962, p. $495-518$

Ko Swan Sik Nationaliteit in het Volkenrecht

Preadvies woor de Nederlandse Vereniging voor Internationaal Recht

Deventer 1981.

Koessler, M. "Subject", "Citizen"', "National" and "Permanent Allegiance"

Yale Law Journal 1946-47, p. 58-76 
KOJUCHAROFF

KOJUCHAROFF

KOKKINI-IATRIDOU preadvies

KOKKINI-LATRIDOU

KOKOT/RYSIAK

KOLOSVÁRY

KORKISCH

KORKISCH

KOROVINE

KOSTOV

KOWAL-WOLK

KOZLOVA/SEVCOV

KOZEVNTKOV

KRAINZ
Kojucharoff, A. Gesetz vom 21.1. 1941 zum Schutze der Nation ZfoR 1940-41 p. 184-188

Kojucharoff, A. Gesetz vom 18. November 1940 zur Regelung der Staatsangehörigkeit in der Dobrudscha ZfoR 1940-41 p. 497-499

Kokkini-Iatridou, D. Enkele methodologische aspecten van rechtsvergelijking, Preadvies voor de Nederlandse vereniging voor rechtsvergelijking 1985 , nr. 36

Deventer 1985

Kolkini-Iatridou, D. e.a. Een inleiding tot het rechtsvergelijkend onderzoelk

Deventer 1988

Kokot, J. en Rysiak, G. Die Polnische StaatsbürgerschaftGrundsätze, Erwerb und Verlust. In: Staatsangehörigkeit, soziale Grundrechte, wissenschaftlische Zusammenarbeit nach dem Recht der Bundesrepublik Deutschland und der Volksrepublik Polen

Berlin/Heidelberg/New York 1976, p. 35-60

Kolosváry, 1. Die Rechtstellung des Ausländers in Ungarn Baden- Baden 1974

Korkisch, Fr. Die rumãnischen Gebietsabtretungen an Ungarn und Bulgarien und die Regelung damit zusammenhängender Volkstumsfragen

ZaöRV 1940-41, p. 707-745

Korkisch, F. Das Staatsangehörigkeitsrecht der Tschechosllowakei

WGO 1969 p. $157-176$

Korovine, E. La népublique des soviets et le droit international RGDIP 1925, p. 292-312

Kostov, D. Grażdanstwoto na novorodenoto dete spored meždunarodnoto pravo

Pravna misul 1982/6, p. 64.75

Kowal-Wolk, T. Die sowjetische Staatsbürgerschaft, insbesondere ihr Erwerb und Verlust

Framkfurt am Main/Bern 1982

Kazlova, E.I. en Sevcov, V.S. Sovetskoe gosudarstvennoe pravo Moskva 1978

Kozevnikov, F.I. Meždunarodnoe pravo Moskva 1987

Krainz, J. System des österreichischen allgemeinen Privatrechts, erster Band 2e druk, Wien 1894 


\section{KRAVČUK}

KRBEK

KRISAFI

KUCINSKU

KULIK

KUSS

KUSEJ e.a.

LANGHOFF

DE LAPRADELLE

DE LAPRADELLE/NIBOYET

\section{LAUTERPACHT}

LEMKIN

LEPESKTN

LESAGE

LEVIN

LICHTER
Kravěcuk S.S. (red.) Staatsrecht der UdSSR vertalling van Sovetskoe gosudarstvennoe pravo Berlin (Oost) 1982

Krbek, I. Zakon o drtavljanstvu sa komentarom Beograd 1948.

Krisafi, K. Shtetësia

Drejtesia popullore $1974 / 2$ p. 51-63.

KuCinskij, V.A. Persönlichkeit, Freiheit und Recht, vertaling van: Licmost svoboda i prawo

Berlin (Oost) 1980

Kulik, R.I. Zakon o graždanstwe SSSR Moskva 1980

Kuss, K.-J. Das Recht auf Ausreise und Auswanderung in der Gesetzgebung sozialistischer Staaten

EuGRZ 1987, p. 305-312

Kušej, G. e.a. Uvod v pravoznanstwo

2e druk, Ljubljana 1986

Langhoff, L. Staatsbürgerschaft und Heimatrecht in Österreich Wien 1920

De Lapradelle, A. La loï Polonaise sur $\mathbb{I}$ nationalité et les traités de Versailles.

Paris 1924

De Lapradelle, A. en Niboyet, J.-P. Répertoire de droit international, deel IX

Paris 1931

Openheim, L. International Law, a Treatise, deel I onder red. van Lauterpacht, $H$.

8e druk, London/New York/Toronto 1955

Lemkin, $\mathbb{R}$. Axis Rule in Occupied Europe

Washington 1944

Lepeskin, A.I. Kurs sovetskogo gosudarstvemnogo prava, deel 1

Moskva 1960

Lesage, M. La Constitution de l'URSS, textes et commentaires Paris 1978

Levin, D.M. (red.) Pravovoe polozenie inostrancev v RSFSR. Spravoćnik dlja inostrancev optantov i bežencev Moskwa 1923

Lichter, M. Das bulgarische Staatsangehörigkeitsrecht SLAZ 1939, p. 253-254 
LICHTER

LICHTER

LICHTER

LIPOWSCHEK

LIPOWSCHEK

LIVRE

LOEBER

LOMONOSOVA

LUBY

LUCHTERHANDT

LUTFI

LUZA

MAKAROV

MAKAROV

MAKAROV
Lichter, M. Änderung des ungarischen Staatsangehörigkeitsrechts

StAZ 1940, p. 58

Lichter, M. Die rumänische Staatsangehörigkeit

StAZ 1940, p. $65-68$

Lichter, M. Die Staatsangehörigkeit in den eingegliederten Ostgebieten

StAZ 1941, p. 79-81

Lipowschek, A. Änderung des Staatsbürgerschaftsgesetzes vor Bulgarien

WGO 1953 , p. $256-257$

Lipowschek, A.Jugoslawien: Änderungen im Staatsangehörigkeitsrecht

WGO 1965, p. 87-98

Livre du Centennaire de la Société de législation comparée, deel II.

Paris 1971

Loeber, D.A. Rechtsvergleichung zwischen Ländern mit verschiedener Wirtschaftsordnung.

RabelsZ 1961, p. 201-229.

Lomonosova, M.V. Gosudarstvennoe pravo Moskva 1967

Luby, S. Predmet porovnăvacej právnej vedy

Právni Obzor 1970, p. 3-21

Luchterhandt, $O$. Das neue sowjetische Staatsbürgerschaftsgesetz

OER 1981, p. 458-467.

Lutfi, K.O. Die wölkerrechtliche Stellung Bulgariens und Ostrumeliens

diss. Erlangen 1903

Luxa, R. The Transfer of the Sudeten Germans

New York 1964

Makarow, A. N. Die Staatsangehörigkeit in SowjetRussland Ostrecht 1926, p. 3-34

Makarow, A. N. Die Russisch-Polnische Rechtisbeziehungen seit 1815 unter spezieller Berücksiclttigung der Staatsangehörigkeitsfragen

ZaöRV 1929, p. 330-367

Makarov, A. N. Gesetz über die Staatsangehörigkeit der Union der sozialistischen Sowjetrepubliken

ZaöRV 1938, p. $801-805$ 
MAKAROV

MAKAROV

MAKAROV

MAKAROV

MAKAROV

MAKARON

MAKAROV

MAKAROV

MAKAROV/VON MANGOLDT

MALA KONSTYTUCJA

MALAJA ENCIKLOPEDUA

MANO

MARESCEAUX
Makaroy, A. N. Gesetze über Fragen der Staatsangethörigkeit 1935-1938

ZaöRV $1939-40$, p. $531-560$

Makarow, A.N. Verordmung des Prấsidiums des Obersten Rates der UdSSR vom 7 September 1940 über den Enwerb der Staatsangehörigkeît der UdSSR durch die Staatsangehörige der Litawischen, Lettischen und Estnischen Sozialistischen Sowjetrepublieken

ZfoR $1940-41$, p. $184-188$

Makarov, A.N. Der sowjetrussisch- finnische Konflikt ZaöRV 1940-41, p. 294-330

Makarov, A.N. Die Eingliederung Bessarabiens und der Nordbukowina in die Sowjetunion

ZaöRV 1940-41, p. 336-359

Makarov, A.N. Verordnung des Präsidiums des Obersten Rates der UdSSR vom 8. März 1941 über die Wiederzuerkennung der Staatsangehörigkeit der UdSSR an die Bewohmer Bessarabiens und ïber den Erwerb der Sowjetstaatsangehörigkeit durch die Bewohner der Nord-Bukowina

ZfoR $1940-41$, p. $524-529$

Makarov, A.N. Die Eingliederung der Baltischen Staaten in die Sowjetunion

ZaöRV 1940-41, p. 682-707

Makarov, A.N. Das polnische Staatsangehörigkeitsgesetz vom 8 januar 1951

RabelsZ 1952, p. 407-4019

Makarov, A.N. Allgemeine Lehren des Staatsangehörigkeitsrechts

2e druk, Bonn 1962

Makarow, A.N. en von Mangoldt, H. Deutsches Staatsangehörigkeitsrecht

3e druk, Frankfurt am Main, losbladige editie

Mala Konstytucja

Warszawa 1948

Malaja enciklopedija, Vvedenskij, B.A. (red.)

3e druk, Moskva

Mano, J.G. L'union des principautes Roumaines diss. Paris 1900

Maresceaux, M.H. Nationalite et statut personnel dans les instruments des Nations. Unies, in: Verwilghen, Nationalite Bruxelles 1984, p. 13-72 
MARX/ENGELS

MÁSILKO

MASEV

MATOUSEK/GROSPIČ

MATUSEK

MAURACH

MAURACH 1955

MEDER

MEESEN

MEISSNER

MENDE

MENSCHENRECHTE

MENŽINSKIJ/KOZZEVNIKOV

MERCIER

MERTENS

MOUSSET
Marx, K. en Engels, Fr. Ausgewählte Werke in sechs Bänden Frankfurt am Main 1970

M.ảsilko, v. Státni obłánstvi v ¿s mežinarodnim pravu soukromem

Socialistická zakonnost 1974, p. 388-392

Masev, D. Meždunarodnopravni aspekti na grazdlanstvoto i zakonodatelnata mu uredba w NR Bulgarija Prayna misull $1972 / 2$ p. 39-49

Matoušek, St. en Grospic, J. Uplatneni Leninskych principu v ceskoslovienské federaci

Právnilk 1973, p. 222-234

Matušek, V. Osvedcovanie ceskoslovenskeho státneho obxianstva Správni prawo 1981, p. 153-156

Maurach, R. Das Staatsangehörigkeitsrecht der Sowjetumion Königsberg 1942

Maurach, R. Handbuch der Sowjetwerfassung

München 1955

Medler, W. Werdegang der baltischen Staaten

ZFoR $1940-41$, p. 124-147

Meesen, K.M. Verfassungsrechtliche Grenzen einer Neuregelungder Staatsamgehörigkeit imgeteilten Deutschland JZ 1972, p. 673-679

Meissner, B. Die Neue Verfassung der UdSSR

JöR 1978, p. 321-451

Mende, U. Die gesamtdeutsche Staatsangehörigkeit in: Staatsangehörigkeit und Völkerrecht in Deutschland, 1977, p. $127-171$

Menschenrechte in den Staaten des Warschauer Paktes. Bericht der unabhängiger Wissenschasftlerkommission Bundestag, Drucksache 535/87 vom 12. November 1987

Menžinskij], V.I. en Kožemikov, F.I. Meždunarodnoe pravo Moskva 1964

Mercier, M. La formation de l'état tchécoslovaque Chartres 1923

Mertens, L. Die: Auswanderung sowjetischer Juden Osteuropa 1987, p. A 519 - A 522

LAlbanie devant I'Europe (1912-1929)

Paris 1930 
NEUMANN

NICOLOFF

NOWAK

NWG

ORTLOFF

OSAKWE

OSCHLIES

PANKRATOV

PÄPANEK

PEASLEE

PERETLATKOWICZ

PERITCH
Neumann, G. $\mathrm{Zu}$ einigen Problemen der Vergleichung aussenwirtschafticher Materien in den intersystemaren Wirtschaftsbeziehungen ${ }_{j}$ in: Die Rolle der Rechtsvergleichung in der Rechtswissenschaft, Rechtsausbildung und Rechtspraxis der DDR sowie in der ideologischen Auseinandersetzung, Tagung des Nationalkomitees fïr Rechtswissenschaft der DDR am 7. Mai 1981 van 7 meii 1981

Potsdam-Babelsberg 1982, p. 56-60

Nicolof, M. Die Dobrudschafrage vor und nach der Regelung von Craiova

ZfoR 1940-41, P. 442-459

Nowak, J. Stătne obxianstvo * Slovenskej republike

Bratislawa 1939

Nationaliteitswetgeving thans bewerkt door F.Th. Zilverentant, med medewerking van $\mathrm{C} . J$. Brinkman, J. Dekker en R.M. Pruimers

"s-Gravenhage, losbl.ed.

Ortloff, H. Das Magyarentum in Ungarn

Berlin/Leiprig 1904

Osakwe, C. Recent Soviet citizenship Legislation

AJCL 1980, p. 625-643

Oschlies, W. Exodus Poloniae? Polnische Ausreise- und Emigrationsfragen 1980-1982

Berichte des BOIS 18/1982

Pankrattov, I.F. Obsuždenie doklada o zadacach instituta prava AN SSSR w svete rešenij XX s"ezda KPSS

SG:P $1959 / 7$, p. $143-146$

Pápanek, J. La Tchechoslovaquie, histoire politique de sa création

Prague 1923

Peaslee, AJ. Constitutions of Nations

Volume III: Europe

3e druk, The Hague 1974

Peretiatkowick, A. Konstytucja Rzeczypospolitej polskiej i wazniejsze ustawy polityczne $\mathrm{i}$ administracyne uzupelnione statutem ligi narodow

Poznan 1928

Peritch, M.J. La nouvelle loi yougoslave sur la nationalité du 21 septembre 1928

RCDIP 1930, p. 1-32 
PETERI

PIRKMAJER

PTRKMAJER

PLANK

PLENDER

PLOTKIN

POLIZEI HAMBURG

POLJANSKIJ

POLYVIOS

POPESCU

POPOVITS

POSCH

POTULICKI
Pêteri, Z. Einige Problcme der sozialistischen Rechtswergleichung in: Die Rolle der Rechtsvergleichung in der Rechitswissenischaft, Rechtsausbildung und Rechtspraxis der DDR sowie in der ideologischen. Auseinandersetzung Tagung des Nationalkomütees für Rechtswissenschaft der DDR am 7 . Mail 1981

Potsdam-Babelsberg 1982, p* 19-24

Pirkmajer, $O$. Zakon o držaljamstvu z raxlago Maribor 1929.

Pirkmajer, O. Enotna načela o pridobivanju državljanstva v slovansikih drzavah

Coreferaat bij 1 . kongres wan juristen in slavische staten van 1933 in Bratislawa

Slowenski pravnik $1933 / 7-8$ (bijlage)

Plank, K. Problem dwojiteho statneho obcianstva $y$ ceskoslowenskej federacii

Pránny Obzor 1969, p. 681-711

Plender, R. International Migration Law

ze druk, Dordrecht/Boston/London 1988

Plotkin, M A. Legal Status of Foreigners in the USSR Moscow 1934

Die in den Europäischen Staaten geltenden Gesetze über die Erwerbung und den Verlust der Staatsangehörigkeit unter Ausschlluss des Deutschen Reichsgesetzes vom 1. Juni 1870 Berlin 1898

Poljanskij, V.V. Principy sovetskogo grazdanstva SGiP $1980 / 5$, p. $123-129$

Pollyvios, P.-J. L'Albanie et la réunion d'ambassadeurs a Londres diss. Paris 1914

Popescu, S. Buts et méthodes de la comparaison dans le droit Revue roumaine des sciences sociales, Serie de sciences juridiques 1974, p. 63-71

Popovits, H. Die gesetzliche Regelung der Judenfrage in Rumänien

ZfoR 1940-41 p. $502-520$

Posch, M. bespreking van Riege, G. Staaltsbürgerschaft der DDR (Habilitationsverteidigung)

StuR 1964, p. 1968-1971

Potulicki, M. Constitution de la Republique de Pologne du 17 mars 1921

Varsovie 1921 
PRISCA

PROCHOROV

PUSYLEWITCH

\section{PUSYLEWTTSCH}

RABL

RADU

RAJSKI

RAMUS

RAMUS

RAMUS 1980

RECHTSLEXIKON

RESTRICTING

RIEGE

RIEGE

RIEGE

RIEGE

RIEGE
Prisca, N. Contributii la studul cetateniei romane

Analele Universitatii Bucuresti, Stïnte Juridice 1970/1, p. 47. S5.

Prochorov, A.M. Sovetskij enciklopediðeskij slovar Moskva 1983

Pusylewitch, T. Das neue Staatsangehörigkeitsgesetz der Sovjetunion

OER 1979 , p. $247-255$.

Pusylewitsch, T. Die Rechtsstellung des Ausländers in Polen Baden-Badem 1979.

Rabl, K.O. Zur jüngsten Entwicklung der slowakischen Frage ZäoRV 1939-40, p. 284-321

Radu, F. La reglementation de la citoyenneté en Rowmanie Revue roumaine des sciences sociales, Serie des sciences juridiques $1973 / 1$ p. 23-32

Rajski, J. Nowa ustawa o obywatelstwie polskim Palestra $1962 / 6$, p. $52-61$

Ramus, W. Prawo obywatelstwie polskim

Warszawa 1968

Ramus, W. Pojecie obywatelstwa

PiP $1977 / 6$, p. $35-45$

Ramus, W. Instytucje prawa o obywatelstwie polskim Warszawa 1980

Rechtslexikon (Brachmann, R. red.)

Berlin (Ost) 1988

Who may Leave: a Review of Soviet Practice Restricting Emigration on Grounds of Knowledge of "State Secrets" New York 1987

Staatsbürgerschaft und nationale Frage StuR 1964 p. $56-79$

Riege, G. Die Staatrechtliche Stellung des Burgers in der DDR Wiss. Zeitschrift Jena 1965 p. 563-569

Rüege, G. Das Staatsbiurgerschaftsgesetz der DDR StwR 1967, p. $701-715$

Riege, G. Staatliche Souveränität und Staatsbürgerschaftsrecht Neue Justiz 1978, p. 98-101.

Zum neuen sowjetischen Staatsbürgerschaftsgesetz

StuR 1979, p. 891-902 


\section{RIEGE/KULKE}

RIEGE

ROBINSON

ROGGEMANN

ROTHSTEIN

RUBANOV

RUSINOVA

RYMUSZKO

RZEPKA

SAFRONOV

SANDIFER

SCHÄTZEL

SCHEETZ

SCHILESER

SCHMID

SCHMID 1979
Riege, G. en Kulke, H. Nationalitär:s deutsch, Staattsbüngerschaft: DDR

Berlin (Oosit) 1980

Riege, $G$. Die Staatsbürgerschaft der DDR

2e druk, Berlin (Oost) 1986

Robinson, N. The Universal Declaration of Human Rights New York 1958

Roggemann, H. Die Verfassungen der sorialistischen Staaten Berlin 1980

Rothstein, A. The Soviet Constitution London 1923

Rubanov, A.A. Osnovnye kollizionye voprosy sovetskogo zakonodatelstwa o graždanstve

SGiP $1979 / 7$, p. $48-55$

Rusinova, S.I. Zakreplenie instituta graždanstwa $v$ poslevoennych konstitucijach buržoaznych stran

Pravovedenie 1962/4, p. 45-57

Rymuszko, M. O obywatelstwie polskim

Prawo i zycie 1985/25, p. 7

Rzepka, W. Sowjetische Gesetztechnik

ROW 1961, p. 177-180

Safronov, V.M. Konstitucija SSSR i sovetskoe graždanstwo Moskva 1984

Sandifer, D.V. Soviet Citizenship

AJIL 1936, p. 614-631

Schätzel, W. Entstehung und Verfassung der Polnischen Republik

JöR 1923-24, p. 289-310

Scheetz, E.C. Recent Soviet Law on Citizenship

Ukrainian Qwarterly 1982, p. 172-180

Schleser, W.Fr. Dile deutsche Staatsangehörigkeit, ein Leitfaden Frankfurt am Main 1980

Schmid, K. Die tschechoslowakische Staatsangehörigkeit. Einige offene Fragen in Vergangenheit und Gegenwart Friedens-Warte Deel 54, p. 267-314.

Schmid, K. Staatsangehörigkeitsprobleme der

Tschechoslowakei

Berlin 1979 
SCHMID 1982

SCHMID

SCHMIED

SCHMIED

SCHRÖDER

SCHULTZ

SCHULTZ

SCHULTZ

SCHULTZ

SCHULTZ

SCHWANKE

SCHWARTZ

SCHWEISSGUTH

SCHWEISSGUTH
Schmid, K. Die Verfassungssysteme der BundesRepublik Deutschland und der DDR, eine vergleichende Darstellung Berlin (West) 1982

Schmid, K. Das internationale Erbrecht der Tschechoslowakei unter besonderer Berücksichtigung der "Republikfluchtfälle" WGO 1986 p. 258-271

Schmied, E. Das neue tschechoslowakische Staatsbürgerschaftsgesetz von 1958

OER 1959, p. 119-121.

Schmied, E. Die Rechtsstellung der emigrierten und ausgebürgerten tschechoslowakischen Staatsbürger WGO 1977 , p. $351 \cdot 357$

Schröder, D. Die völkerrechtliche Wirkung des "Gesetzes über die Staatsbürgerschiaft der DDR"

ROW 1967, p. 233-239

Schultz, L. Die Verfassungsentwicklung Polens seit 1944 JöR 1954, p. 367-397

Schultz, L. Die Verfassungsentwicklung der Föderativen Volksrepublik Jugoslawien seit 1945

JöR 1958, p. 289-320

Schultz, L. Die Verfassung der Volksrepublik Bulgarien vom 18. Mai 1971

Jö $\mathbb{R} 1973$, p. 203-248

Schultz, L. Die meue Verfassung der Sozialistischen Föderativen Republik Jugoslawien vom 21. Februar 1974 JöR 1974 , p. 13-37

Schultz, L. Die neue Verfassung der Sowjetunion und die Entwicklung des Verfassungsrechts in den volksdemokratischen Ländern

ROW 1978 p. $207-213$

Schwanke, R. Chronik Juli-Dezember 1962: Albanien Osteuropa 1963 p. 346-350

Schwartz, M. Die Slowakei. Der jüngste Staat Europas Leiprig 1939

Schweissguth, E. Das Verfassungsrecht der ungarischen Rätenrepublik von 1919

JOR $1960 / 1$, p. $199-228$

Schweissguth, E.AVNOJ: Zur Entstehung des Jugoslawischen Staates

JOR $1967 / 2$, p. 184213 
SEELER:

SENIUTA

SGS deel 3

SGS deel 5

SGS deel 5a

SGS deel 9

SGS deell 17

SGS deel 18 le druk

SGS deel 18

SGS deel 22

SOS deel 25

SGS deel 30

SGS deel 35
Seeler, H.J. Die Staatsangehörigkeit der deutschen Aussiedler ans Polen

NJW 1978, p. 924-927

Seniuta, A. Obywatelstwo i jego regulacja prawna w PRL Wroclaw 1974

Meder, G. Das Staatsangehörigkeitsrecht von Sowjetunion und die Ballische Staaten, Sammlung geltender Staatsangehörig. keitsigesetze, deel 3

Frankfurt/Main-Berlin 1950

Beitzke, G. Das Staatsangehörigkeitsrecht von Albanien, Bulgarien und Rumänien, Sammlung geltender Staatsangehörigkeitsgesetze, deel 5

Frankfurt/Maim-Berlin 1951

Beitzke, G. Das Staatsangehörigkeitsrecht von Albanien, Bulgarien und Rumănien, Sammlung geltender Staatsangehörigkeitsgesetze, deel $5 \mathrm{a}$ (supplement bij deel 5)

Frankfurt/Mailn-Berlin 1956

Geilke, G. Das Staatsangehörigkeitsrecht von Polem, Sammlung geltender Staatsangehörigkeitsgesetze, deel 9

Frankfurt/Main-Berlin 1952

Seeller, H.-J. Das Staatsangehörigkeitsrecht von Jugoslawien, Sammlung geltender Staatsangehörigkeitsgesetze, deel 17 Frankfurt/Main 1956

Schmied, E. Dass Staatsangehörigkeitsrecht von Tschechoslowakei, Sammlung geltender Staatsangehörigkeitsgesetze, deel 18 1e druk, Frankfurt/Main-Berlin 1956

Schmied, E. Das Staatsangehörigkeitsrecht von Tschechosllowakei, Sammlung geltender Staatsangehörigkeitsgesetze, deel 18 2e druk, Frankfurt/Main-Berlin 1978

Szlezak, L. Das Staatsangehörigkeitsrecht von Ungarn, Sammlung geltender Staatsangehörigkeitsgesetze, deel 22 Frankfurt/Main-Berlin 1959

Geilke, G. Das Staatsangehörigkeitsrecht won Sowjetunion, Sammlung geltender Staatsangehörigkeitsgesetze, deel 25 Frankfurt/Main-Berlin 1964

Hecker, $\mathbb{H}$. Mehrseïtige wölkerrechtllichtliche Verträge zum. Staatsangehörigkeit. Sammlung geltender Staatsangehörigkeitsgesetze, deel 30

Frankfurt/Main-Berlin 1970

Das Staatsangehörigkeitsrecht in Deutschland (Bundesrepublik und BRD), Sammlung geltender Staatsangehörigkeitsgesetze, deel 35

Frankfurt/Main-Berlin 1975 


\section{SHARP}

SILAGI

STMONARD

SINAGRA

SIPKOV

SIPKOV

SKENDI

SLAPNICKA

SLAPNICKA

SOBOTA

SOVIET RUSSLA

SPASOV/ANGELOV

SPASOV/NACEVA

SSD

STAATSBURGERSCHAFT
Sharp, S.L. New Constitutions in the Soviet Sphere Washington D.C. 1950

Silagi, M. Staatsangehörigkeit im geteilten Deutschland. Zum Beschluss des Bundeswerfassungsgerichts wom 21.10.1987 StAZ 1988, p. 64-71

Simonard, A. Essai sur indépendance Albanaise diss. Paris 1942

Sinagra, A. Problemi di cittadinanza e di indennizzi nel trattato italo-jugoslavo di Osimo del 1975

Rivista di diritto internazionale 1977, p. 485-506

Sipkov, I. Settlement of Dual Nationality in European Communist Countries

AJIL 1962 , p. $1010-1019$

Sipkov, I. Bulgaria: Amendment to the Law of Citixensthip ILM 1987, p. 422-424

Skendi, S. The political evolution of Albania 1912-1944 New York 1954

Slapnicka, H. Die Werdegang der tchechoslowakischen. Föderation

JOR $1968 / 2$, p. 179-197

Slapnicka, H. Die neuere Verfassungsentwicklung in der Tschechoslowakischen Sozialistischen Repablik, in Verfassungs- und Verwaltungsreformen in den sozialistischen Staaten, Berlin, 1977, p. 149-178

Sobota, E. Das Tschechoslowakische Nationalitätenrecht (Duitse vertaling)

Prag 1931

A Description of the various Political Units Existing on Russian Territory Foreign Office, London 1924

Spasov, B. en Angelov, A. Duržavno pravo na marodna republika Bulgarija

2e druk, Sofija 1968

Spasov $_{n}$ B. en Načwa, S. Konstitucija na narodna republika Bulgarija

Sofija 1978

Soviet Citizenship Law, in:

Soviet Statutes and Decisions 1970-71

Staatsbürgerschaft der DDR, uitgave van de Friedrich-EbertStiftung

Bonn 1984 
STAINOW

STAINOV

STANIMIR OFP

STARGARDT

STOKOFF

STOPPEL

STRAUSS

STUCKART/GLOBKE

SUGA diss.

SUGA

SWIATKIEWICZ

\$ZABO

SZABO

SZABO /PETERII
Stainow, P. Das Staatsrecht Bulgariens nach dem Weltkrieg JöR 1937, p. 251-265

Stainow, P. Die neue Itudengesetzgebung in Bulgarien ZfoR 1940-41, p. $553-558$

Stanimiroff, S.S. De la nationalité d'origine et de l'acquisition de la nationalité diss. Paris 1909

Stargardt, M. Zur intersystemaren Rechtswergleichung, in: Die Rolle der Rechtsvergleichung in der Rechtswissenschaft, Rechtsausbildung und Rechtspraxis der DDR sowie in der ideologischen.Auseinandersetzung, Tagung des Nationallkomitees für Rechtswissenschaft der DDR am 7. Mai 1981 Potsdam-Babelsberg 1982, p. $25-29$

Stokoff, P.I. Modes et effets de l'acquisition de 1 nationalité Bulgare diss. Toulouse 1905

Stoppel, W. Die Rechtsquellen und juristische Publikationsorgane in Albaniem

JOR $1985 / 2$, p. $409-426$

Strauss, E. Die Entstehung der tschecoslowakischen Republik $2 e$ druk, Prag 1935

Stuckart, W. en Globke, H. Kommentare zur deutschen Rassengesetzgebung deel 1

München/Berlin 1936

Suga, A. Die völkerrechtliche Lage Bessarabiens in der geschichtlichen Entwicklung des Landes diss. Bonn 1958

Suga, A. Die Staatsangehörigkeit in der sozialistischen Republik Rumänien

OER 1973, p. 1-23

Swiatkiewicz, $\mathrm{J}_{\mathrm{x}}$ Nowa ustawa o obywatelstwie polskim Prawo i zycie 1962/6 p. 2 en 7

Szabó, I. Le droit comparé de nos jours

Acta Juridica Academiae Scientarum Hungaricae 1971, p. 131141

Szabó, I. La comparaison des institutions juridiques Acta Juridica Academiae Scientarum Hungaricae 1973, p. 131141

Szabó, I. en Péteri, L (red.) A socialist Approach to Comparative Law

Leyden/Budapest 1977 
SZIGETI

SZIRMAI

SEVCOV

SEVCOV

STURM

TÁBORSKY

TARACOUZIO

TARACOUZIO

TELEKI

TERZIEV

TOPP

TRATNIK

TRATNIK

TRATNIK
Srigeti, P. Note sur la loi hongroise $V$ de 1957 sur la nationalitế

Clumet 1961, p. $400-403$

Szirmai, Z. Das neue Staatsbürgerschaftsgesetz Ungarns won 1957

OER 1957, p. 112-117

Sevcov, V.S. sovetskoe grazdanstvo il gosudarstvennyj suverenitet

SGiP $1970 / 6$ p. $39-47$

Sevcov, V. S. Citizenship of the USSR (a Legal Study) vertaling van: Gratdanstvo SSSR (pravovoe issledovannic)

Moscow 1979

Sturm, L. Uprawnopravne institucije

Ge druk, Ljjubljama 1986

Taboorsky, E. The Crechoslowak Cause. An Account of the Problem of International Law in Relation to Czechosiovakia Lonndon 1944

Taracouzio, "TA. The Soviet Union and international Law New York 1935

Taracourzio, T.A. The Soviet Citizenship Law of 1938 AJIL 1939, p. 157-159

Teleki, P. The Evolution of Hungary and its Place in European History

New York 1923

Terziev, K.H. Prakticna uputstwa za izvrł̌enje zakona o državljanstvu

Beograd 1936

Topp, H.D. Der Konflikt zwischen Albanien und der VR China und Tiramas aussenpolitische Optionen

Berichte des BOIS 37/1979

Tratnik, M. Het Joegoslavische Huwelijksgoederen- en erfrecht, door A.J.Th.M. Gudde, boekbespreking WPNR 5708 (1984), p. $509-510$

Joegoslavie (Inleiding in het Joegoslavische recht) In: D. Kokkini-Iatridou e.a., Een inleiding tot het rechtsvergellijkend onderzoek

Deventer 1988, p. 420-439

Tratnik, M. Een ovierheid die spokem ziet. Opmerkingen met betrekking tot werkrijging van het Nederlanderschap door onwettige kinderen

NJB 1989, p. 296298 
TUNKIN

\section{UIBOPUU}

UTBOPUU

VERDOODT

VERDROSS

VERDROSS/SIMMA

VERWILGHEN

VESEL

VILKOV

VITRJUK

VOKOPOLA

VONDRACEK

VOORDUIN

VULKANOV

VULKANOV

WAEHLER
Turikini, Zakon o grazdanstwe SSSR

SGiP $1979 / 7$ p. $22-30$

Uibopuz, H.J. Soviet Nationality: Privilege of Burden?

Israel Yearbook of Human Rights 1977, p. 53-65

Uibopuu, HJ. Staatsamgehörigkeilt der UdSSR, Gleichberechtigung der Bürger

OER 1978 p. $63-69$

Verdoodt, A. Naissance et signification de la Declaration Universelle des droits de l'Homme

Louvain/Paris 1964

Verdross, A. Völkerrecht

Se druk, Wien 1964

Verdross, A. en Simma, B. Universelles Völkerrecht. Theorie und Praxis

3e druk, Berlin 1984

Verwilghen, M. Nationalité

Bruxelles 1984

Vesel, J. Zakon a drzavljanstvu kraljevine SHS od 21. septembra 1928

Ljubljana 1929

Vilkov, G.E. Zakonodatel'stvo SSSR i metdunarodinie suglašenija po voprosem grażdanstva. Sbornik

Moskva 1964

Vitrjuk, M. V. Gromadjanstvo w Radjans'kij federacii

Problemi prawoznanstva 1973, p. 49-59

Vokopola, K.A. The nationality Law of Albania

OER 1967, p. 242-260

Vondracek, Th.J. Sowjet-Staatsburgerschap

RM Themis 1966 , p. 71-85

Voorduin, J.C. Geschiedenis der Nederlandsche wetboeken deel II, Burgerlijk Wetboek

Utrechit 1937

Vulkanov, V. Bulgarskoto graždanstvo

Sofija 1978

Vulkanov, V. Zakonodatelnata uredba na graždanstwoto v NR Bulgarija

Pravna misul $1984 / 1$ p. $52-59$

Waehler, J.P. Das neue Staatsbürgerschaftsrecht der DDR JZ 1968, p. $776-779$ 
WAEHLER

WEIS, $\mathbf{P}$.

WEISS, $\mathbf{H}$.

WEYR

WIENER QUELLENHEFTE

WIERZBOWSKI

WILLEMS

WINTKLER

WOLLOCH

WYDUCKEL

ZAITZEFF

ZAKON

ZAKRZEWSKI

ZBIRKA

ZIEGER

ZIVS
Wachler, J.P. Das bulgarische Staatsbürgerschaftsgesetz vom Oktober 1968

StAZ 1969, p. 21

Weis, P. Natiomality and Statelessness in International Law 2e druk, Alphen aan de Rijn/Germantown 1979

Weiss, $H$. Das Heimatrecht

Wien 1906

Weyr, F. Der tschechoslowakische Staat. Seine Entstehung und Verfassung

JöR 1922, p. 351-375

Albanien: Authentische Interpretation des Statsbürgerschaftsgesetzes

Wiener Quellen zar Ostkunde, Reihe Recht, 1963 , p. 141

Wierzbowski, E. Sprawa obywatelstwa ludnosci b. Woj. Wschodnich Nowe prawo 1957/7-8, p. 144-145

Willems, De nationaliteitswetgeving van Albanië Bevolkingsboekhouding 1954, p. 9

Winkler, E. Die Tschehoslowakei im Spiegel der Statistik Karlsbad/Leipzig 1937

Wolloch, E. Die geschichtliche Entwicklung des Staatsangebörigkeitsrechts in Rumänien

Frankfurt am Main/Bern/New York/Paris 1988

Wyduckel, D. Anmerkung

Deutsches Verwaltungsblatt 1988 , p. $284-287$

Zaitzeff, L. Die Verfassungsentwicklung in Russland seit dem Sturz des Zarentums

JöR 1922, p. 275-303

Zakon o drŽavljanstwu sa pravilnikom za izvrక̌enje zakona 2e druk, Beograd 1954

Zakrzewski, W. Gründzüge der polnischen Verfassungsreform vom 10. Februar 1976

JöR 1978, p. 297-320

Zbirka predpisow o dræavljanstvu

Ljubljana 1947

Zieger, G. Das Staatsbürgerschaft der DDR Frankfurt am Main/Berlin 1969

Zivs, S.L. O metode spravitel'nogo issledovanija v nauke o gosudarstve i prave

SGiP $1964 / 3$, p. $23-35$ 
ZLATOPOLSKIJ

ZWEIGERT/KöTZ

ZOLGER
Zlatopol"skij, D.L. Gosudarstvennoe ustrojstvo SSSR Mosiliwa 1960

Zweigert, $K$, en Kött, H. Einführung in die Rechtswergleichung auf dem Gebiete des Privatrechts

$2 \mathrm{e}$ druk, Tübingen 1984

Zolger, I. Die Verfassung Jugoslawiens

JöR 1922, p. 182-217 


\section{CURRICULUM VTTAE}

Matjaž Tratnik werd op 1 mei 1957 in Ljubljana (Joegoslavië) geboren. Na het het behalen van het eindexamen op het gymnasium te Ljubljana in 1976, studeerde hij rechten aan de Universiteit van Ljubljana, waar hij in 1980 afstudeerde. $\mathrm{Na}$ enige tijd werkzaam te zijn geweest in het Joegoslavische bedrijfsleven, woont hij sedert 1982 in Nederland. Tussen 1983 en 1986 studeerde hij Nederlands Recht aan de Rijksuniversiteit Limburg te Maastricht, waar hij sedert 1 januari 1984 tevens werkzaam is als wetenschappelijk assistent voor privaatrecht en rechtsvergelijking. In 1986 publiceerde hij tezamen met Gerard-René de Groot het boek Nationaliteitsrecht (Zwolle 1986) en is auteur van meerdere artikelen op het gebied van het nationaliteitsrecht en rechtsvergelijking. 